Linguistik Aktuell Linguistics Today 242

\title{
Adjective Adverb Interfaces in Romance
}

Edited by

\author{
Martin Hummel \\ Salvador Valera
}

John Benjamins Publishing Company 
Adjective Adverb Interfaces in Romance 


\section{Linguistik Aktuell/Linguistics Today (LA)}

ISSN 0166-0829

Linguistik Aktuell/Linguistics Today (LA) provides a platform for original monograph studies into synchronic and diachronic linguistics. Studies in LA confront empirical and theoretical problems as these are currently discussed in syntax, semantics, morphology, phonology, and systematic pragmatics with the aim to establish robust empirical generalizations within a universalistic perspective.

For an overview of all books published in this series, please see http://benjamins.com/catalog/la

\section{Founding Editor}

Werner Abraham

Universität Wien / Ludwig Maximilian Universität München

\section{General Editors}

Werner Abraham

Elly van Gelderen

Universität Wien /

Arizona State University

Ludwig Maximilian Universität München

\section{Advisory Editorial Board}

Josef Bayer

University of Konstanz

Cedric Boeckx

ICREA/UB

Guglielmo Cinque

University of Venice

Liliane Haegeman

University of Ghent
Hubert Haider

University of Salzburg

Terje Lohndal

Norwegian University of Science and Technology

Christer Platzack

University of Lund
Ian Roberts

Cambridge University

Lisa deMena Travis

McGill University

Sten Vikner

University of Aarhus

C. Jan-Wouter Zwart

University of Groningen

\section{Volume 242}

Adjective Adverb Interfaces in Romance

Edited by Martin Hummel and Salvador Valera 


\section{Adjective Adverb Interfaces in Romance}

Edited by

Martin Hummel

University of Graz

Salvador Valera

University of Granada

John Benjamins Publishing Company

Amsterdam / Philadelphia 
The paper used in this publication meets the minimum requirements of the American National Standard for Information Sciences - Permanence of Paper for Printed Library Materials, ANSI z39.48-1984.

The editors and authors acknowledge the financial support by the University of Graz and the Hugo Schuchardt Foundation for the open access publication.
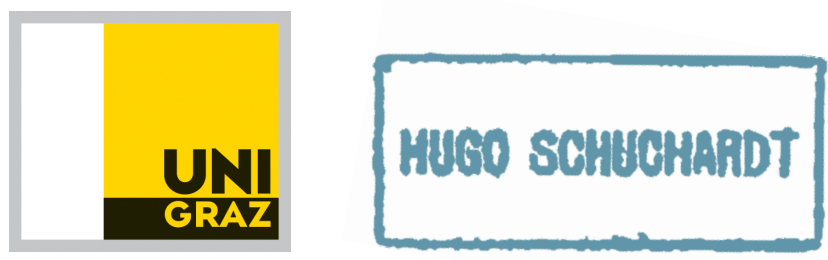

DOI 10.1075/la.242

Cataloging-in-Publication Data available from Library of Congress: LCCN 2017037246 (PRINT) / 2017047459 (E-BOOK)

ISBN 9789027257253 (HB)

ISBN 9789027264879 (Е-BOOK)

(C) 2017 -John Benjamins B.V.

The electronic edition of this book is Open Access under a CC BY-NC-ND 4.o license. https://creativecommons.org/licenses/by-nc-nd/4.0

This license permits reuse, distribution and reproduction in any medium for non-commercial purposes, provided that the original author(s) and source are credited. Derivative works may not be distributed without prior permission.

This work may contain content reproduced under license from third parties. Permission to reproduce this third-party content must be obtained from these third parties directly.

Permission for any reuse beyond the scope of this license must be obtained from John Benjamins Publishing Company, rights@benjamins.nl

John Benjamins Publishing Company $\cdot$ https://benjamins.com 


\section{Table of contents}

Introduction

Salvador Valera and Martin Hummel

Part I. General aspects of Romance languages

CHAPTER 1

Adjectives with adverbial functions in Romance

Martin Hummel

CHAPTER 2

Parameters in Romance adverb agreement

Adam Ledgeway

CHAPTER 3

Before the complementizer: Adverb types and root clause modification

Silvio Cruschina and Eva-Maria Remberger

\section{Part II. French}

CHAPTER 4

Adjectives and adverbs in the Grande grammaire du français

Anne Abeillé, Olivier Bonami, Danièle Godard

and Michèle Noailly

CHAPTER 5

Are intrapredicative adjectives adverbs?

Dan Van Raemdonck

\section{Part III. Italian}

CHAPTER 6

Adverb agreement in the dialects of the Lausberg Area 


\section{Part IV. Romanian}

CHAPTER 7

Historical overview of the Romanian adverb

\section{Adrian Chircu}

CHAPTER 8

Properties of Romanian adverbs and adjectives from a categorial status perspective

Carmen Mîrzea Vasile and Blanca Croitor

\section{Part V. Spanish}

CHAPTER 9

Adverbial adjectives and -mente adverbs face to face:

Diachronic evidence from Spanish

Concepción Company Company

CHAPTER 10

Descriptive and functional analysis of the solo-solamente

adverbial pair in spoken Mexican Spanish

Lorena Y. Medina Gómez and Luisa Josefina Alarcón Neve

CHAPTER 11

From adjective to adverbial modal locutions in Spanish

Rosa María Ortiz Ciscomani

CHAPTER 12

Adverbial adjectives and the decomposition of event predicates

Avel-lina Suñer

Language index

Subject index 


\title{
Introduction
}

\author{
Salvador Valera and Martin Hummel \\ University of Granada / University of Graz
}

The general topic of this volume concerns word-class based approaches to modifiers in Romance. Modification is a linguistic function that refers to a semantic change operated on a primary unit, e.g. a word or a sentence. It is hard to pursue this functional linguistic viewpoint without referring to word-classes. Adjective and adverb are major realizations of modifiers, at least if we refer to attributive adverbs, excluding circumstantial adverbs of time or space. It is precisely the interfaces of these word-classes and modifying functions where the difficulties of linguistic analysis arise.

A possible starting point in the clarification of this interface could be the canonical definition of adjectives as noun-modifying units as opposed to adverbs as verb-modifying units. Semantically, adjectives may therefore be defined as words denoting properties of entities, while adverbs refer to properties of events. Such radical semantic approaches encounter cases such as beautiful dancer, where beautiful can be read either as modifier of the person 'the dancer is beautiful' or as a modifier of the event 'the way he dances is beautiful'. But analysis also has to deal with cases such as She drives slow, where 'the adjective is used as an adverb', if we use a traditional expression. In addition, the same morphological and syntactic structure appears to modify the subject participant in She drives cool. To say that slow is an adverb and cool an adjective is not fully satisfactory, also because cool can be read as a modifier referring to both the attitude of the driver and her driving. This volume deals with problems word-class based approaches have to tackle if these categories are used as heuristic tools for the analysis of modification in Romance.

In view of the fact that English and Romance show similar problems at the functional interfaces of adjective and adverb, a conference on The Interfaces of Adjective and Adverb in Romance and English was held at the University of Graz in June 2014. As a product of this conference, the present volume concentrates on Romance. All major Romance languages but Portuguese are tackled in monographic papers. However, Portuguese and other Romance languages, such as Catalan or regional varieties, are also described, in papers focussing on Romance in general. In sum, the volume offers the first broad pan-Romanic discussion of the adjective 
adverb interface. Moreover, one of the editors being specialized in Romance linguistics and the other in English linguistics, we have tried to situate the debate in a broader context.

The problems outlined above are not limited to the clause level. If we look at the English language, modifiers of adjectives such as wide in wide-open or sentential modifiers such as More important(ly), this is dangerous can also be adduced. However, the verb phrase certainly displays the most complex scenario inasmuch as participants are part of the event. The main combinatorial possibilities in this area are graphically summarized in the following table:

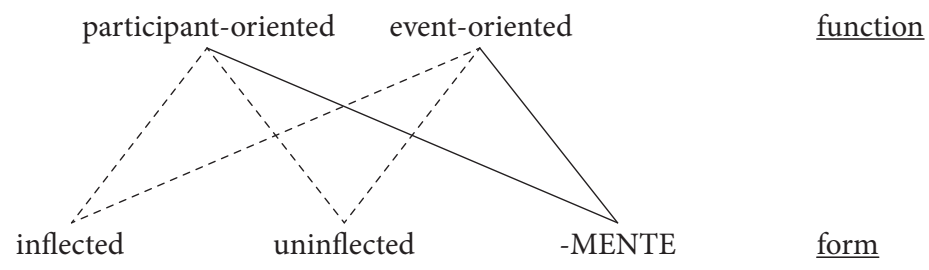

This chart illustrates that adjectives (or copulative, predicative or participantoriented elements) and adverbs (or adverbials, adverbial adjuncts or event-oriented elements) gain access to positions where the presumed or expected association between word-class and syntactic function is not found, but rather its opposite. Specifically, the emphasis is on what can be described as adjectival forms that perform (partly) adverbial functions at the clause level or, in other words, attributive forms that perform adverbial functions at the clause level. The opposite, i.e. adverbial forms that perform (partly) adjectival functions at the clause level are discussed elsewhere (e.g. Guimier 1991; Valera 1998). Other possible cases, such as adjectival forms that perform entirely adverbial functions at the clause level are discussed by Hummel (this volume). In the chart, the dotted lines foreground the structures discussed here (plus an additional paper on the interface at the phrase level by Medina Gómez \& Alarcón Neve).

One notable difference between English and Romance languages is that, in English, the inflectional morphology of the category that realizes the participantoriented function does not inflect for number or gender as in Romance languages (hence the emphasis on both options in the chart). The result of the description is, however, surprisingly similar in some cases despite the different conditions cited above and despite the different languages involved.

The book first considers Romance languages in general (in Hummel, in Ledgeway and in Cruschina \& Remberger) and then four languages: French (in Abeillé, Bonami, Godard \& Noailly and in Van Raemdonck), Italian and varieties of Italy (in Silvestri), Romanian (in Chircu and in Mîrzea Vasile \& Croitor) and 
Spanish and varieties of Spanish (in Company Company, in Medina Gómez \& Alarcón Neve, in Ortiz Ciscomani and in Suñer).

Hummel opens the book with a comprehensive review of the interface of adjectives and adverbs in Romance languages. The term 'comprehensive' applies here to the categories adjective and adverb in a range of structures and with a range of morphological realizations, and to their specificities in the languages considered in this book (Catalan, French, Italian, Portuguese, Romanian, Spanish, and in some of their dialects) in both the spoken and the written language, in the registers in which they may occur, and also diachronically and synchronically, referring as far back as the description of the structures of Latin and their influence on Romance languages (illustrated below with some of Hummel's examples for French):

(1) a. Les hommes travaillent $d u r$

'The men work hard'

b. Les hommes travaillent durement 'The men work hard'

(2) J'aime bien les traces dans la neige qui nous amène droits vers les maisons [sic] 'I like the tracks in the snow which bring us direct to the way home'

(3) Je suis sur le point d'arrêter nette ma conso de cannabis 'I'm about to stop cold my cannabis use'

The paper justifies its final argument for flexibility on account of the intricacy of interlocking variables that are at play here. More importantly, it insists in particular on the fact that the interfaces of adjectives and adverbs are not restricted to the clause level, and helps in understanding the intrinsic difficulty of this area of grammar by raising awareness of the complex variables that have affected not only the use but also the metalinguistic/grammaticographic description of adjectives and adverbs. Hummel presents data arranged as types of structures, and uses theory-neutral labels such as Type A, Type B, Type C and Type D for unbiased identification and also to avoid theoretical bias.

Like Hummel, Ledgeway (Parameters in Romance adverb agreement) takes a cross-linguistic approach for a review of adjectives in adverbial function at the clause level. This chapter starts with Italian but then takes into consideration both major Romance languages, such as French, Italian, Portuguese or Romanian, and Romance languages with a smaller speaking community, such as Catalan, Sicilian and smaller varieties in Italy. Ledgeway discusses concepts that have been described for some time for French and for English, such as orientation (Guimier 1991) and the type of small clauses that lie behind Allerton's (1982) account of what are much the same structures in English. This chapter thus also goes into the so-called 
adverbial inflection or adverbial agreement anticipated in the previous chapter by Hummel (here illustrated with Ledgeway's examples for Italian):

(4) Maria parla svelta/svelto

'Maria is a quick-talker/is talking quickly'

(5) (?)da Forgione pagherai queste scarpe salatamente/salate

'You'll pay for these shoes dearly at Forgione's'

The resulting overview brings to light a dissimilar spread of adverbial agreement across Romance, ranging from varieties where it is not recorded to others with varying degrees of morphological realization of agreement marks, all of which make up a system of four basic patterns labelled 'Pattern 1', 'Pattern 2', 'Pattern 3' and 'Pattern 4'. This chapter also remarks that languages that maintain forms with and without adverbial marks like -ment in French or -mente in Spanish appear to behave similarly to varieties where the so-called adjectival adverbs are in frequent use.

Cruschina and Remberger's chapter (Before the complementizer: Adverb types and root clause modification) widens the scope of the book to the sentence level and also to a contrastive approach in Romance. Set within a generative theoretical framework, it contrasts complemented sentence-initial adjectives and adverbs. The grammaticalization of these structures also affects the function of the complementizer, which can no longer be interpreted as a marker of subordination (here illustrated with examples from Italian, Spanish, English and French):

(6) (It.)

Certo che potevamo impegnarci un po' di più

'We could have certainly made a greater effort.'

(7) (Sp.)

Claro que no tiene ningún interés

'He clearly doesn't have any interest.'

(8) (En.)

Obviously that the Achilles was giving him a bit of a problem

(9) (Fr.)

Probablement que ce n'est pas leur faute

'It probably isn't their fault.'

The structures are classified as types (A, B) according to their adverbs. The generative approach offers a description of all these structures under one label, 'C-constructions', as root clauses consisting of an element displaying various degrees of grammaticalization and scoping over a sentence. The various degrees of grammaticalization entail various outcomes. In fact, the chapter carries further relevant implications beyond those that can arise from the study of these specific 
structures by examining grammaticalization not only in these structures in the languages considered but also in general. Grammaticalization may thus be interpreted, in some cases, as upward reanalysis along the syntactic tree.

Two chapters contribute towards the discussion of what happens in the interface between adjective and adverb in French. The first of these, Abeillé, Bonami, Godard \& Noailly's Adjectives and adverbs in the Grande grammaire du français, relies on examples taken from the grammar (in preparation) cited in the title to draw a strict division between adjectives and adverbs. This strict division is based on the inflectional capacity of adjectives for number and gender distinctions, on their structural capacity to take infinitival complements, and on the positional capacity of adverbs to occur between verbal operator auxiliaries and their lexical verbs, or before infinitival forms:

(10) a. Une réponse juste, des réponses justes 'a right answer', 'right answers'

b. juste un peu, juste amoureuses 'just a little', 'just in love'

This paper reviews the categories and functions contained in the abovementioned grammar and then goes into the formal, syntactic and semantic types of both adjectives and adverbs according to the grammar. This review of the standard identity of each of these categories may contribute a starting point for the identification of what happens when any of these standard conditions fail, e.g. when adjectives do not take inflection for gender or number agreement or when they occur in positions that the review ascribes typically to adverbs.

The latter is precisely the focus of Van Raemdonck's chapter Are intrapredicative adjectives adverbs? Van Raemdonck reviews the various uses of adjectives that, contrary to expectations, appear to be oriented towards the predicate rather than towards a participant - again, to cite an expression used for French by Guimier (1991):

(11) Pierre mourra vieux

'Pierre will die old'

(12) Il mange italien

'He eats Italian'

His model of genetic syntax concludes that, regardless of the possible variants that can be considered, these adjectives remain essentially adjectival in nature despite their apparent adverbial properties. This description is, therefore, close to the description presented by Allerton (1982) for English subject adjuncts, even if Van Raemdonck honestly admits limitations as regards some of the structures 
considered. Rather than hide these problems under the carpet, Van Raemdonck presents them openly, and the resulting picture, which is very similar to the picture in English (including the slippery ground that is also noted in English, starting with Matthews 1980), seems to point in the direction of inherent difficulties of this area of syntax.

The second language under study is Italian. Silvestri (Adverb agreement in the dialects of the Lausberg Area) pursues hints outlined in the chapter by Ledgeway in Southern Italian dialects. The chapter argues for empirical evidence of adverbial agreement in these dialects, such that manner adverbs agree for gender and number with preceding nominals, again as a result of orientation towards those nominals:

(13) Piətrəaggiustavəd a camməra pulita

'Pietro was tidying up the room nicely'

(14) Maria parla buənə/bòna

'Mary speaks well'

This chapter raises questions concerning the actual correspondence between syntactic functions and grammatical categories, especially if surface structure is given priority over the syntactic processes that may give rise to that surface structure. The chapter includes a semantic analysis of adverb agreement with respect to compound verb forms, and also of modifiers. The results of the latter bring up contrasts between the occurrence of (pseudo-)resultatives in the dialects under study in this chapter with respect to other varieties.

The third language under study is Romanian. In a paper that resembles Hummel's for the attention paid to extralinguistic and to diachronic variables and for its clarifying value, Chircu's contribution (Historical overview of the Romanian adverb) explains not only the separation between the use of older and newer forms across registers in present-day Romanian, but also why Romanian differs from other Romance languages as regards use of adverbial suffixes by reviewing the evolution of Romanian from the 16th to the 18th century in respect of the use - or rather, the lack of use - of the adverbial suffix -eşte:

(15) hrebor si dulcse me veszeleszk 'courageously and sweetly I frolic'

(16) 16 ani neprestan, cu o împărăţie mare 'continuously for 16 years, with a kingdom greater'

The chapter is an exhaustive attestation of simple and derived adverbs inherited from Latin in over 20 different sources, and relates the properties of the current use of adverbial forms to the dissimilar influences (Latin vs. Slavic) that have given shape to Romanian. Chircu's chapter has the added value that timelines can be 
extracted from the records listed, thus being a first step in studies of the same issue at a larger scale.

In their paper Properties of Romanian adverbs and adjectives from a categorial status perspective, Mîrzea Vasile and Croitor contribute a very different description of the adjective - adverb interface in Romanian. This description goes into the properties of adjectives inflected for agreement with nouns, adjectives that are not inflected for agreement (under the term 'adverbial configurations'), and adverbs, and lays emphasis on the formal identity between most adjectives and adverbs:

(17) După doi ani de practică, fetele dansează corect

'After two years of practice, the girls dance correctly'

(18) Lucrul corect este să își ceară scuze

'The correct thing for him would be to apologize'

This proves particularly relevant for the discussion of the separation of adjectives and adverbs as two categories vs. their merging as one category. Mîrzea Vasile and Croitor also lay emphasis on the contrast between the distribution of adjectives and that of adverbs. Like Hummel, Mîrzea Vasile and Croitor then discuss adverbial inflection as regards adverbs derived with -ește and adjectives derived with -esc. The conclusion is that neither the morphology nor the syntax of Romanian adjectives and adverbs allows clear and sufficient criteria for their identification or for their separation. Their orientation towards either a participant or an event appears a more relevant criterion, but again in general terms. Thus, unlike Abeillé, Bonami, Godard and Noailly for French, Mîrzea Vasile and Croitor conclude that no clear separation is possible for Romanian adjectives and adverbs even if tendencies can be identified at the syntactico-semantic level.

Four chapters discuss the interface between adjectives and adverbs in Spanish. Company Company's chapter (Adverbial adjectives and -mente adverbs face to face. Diachronic evidence from Spanish) discusses Spanish counterparts to the structures considered in several preceding chapters (Hummel and Ledgeway for Romance in general, Van Raemdonck for French, Silvestri for Italian dialects and Mîrzea Vasile and Croitor for Romanian). The diachronic approach is also present in this chapter by virtue of the comparison of the use of five minimal pairs of units with and without the suffix -mente in the 18th and 21st centuries (here illustrated with examples of only one of the pairs):

(19) ¡Váyase rápido!

'Go quick!'

(20) ¡Váyase rápidamente!

'Go quickly!' 
The comparison shows that the forms in -mente gain a wider access to contexts, to structures, and to event relationships than their non-affixal counterparts. The chapter puts these differences down to the traces of the original class that are still present in the non-affixal forms compared with the -mente forms: the former display a specialized syntax whereas the latter do not. Remarkably, this results in a markedness binomial where the morphologically unmarked term is the syntactically marked term, whereas the morphologically marked term is syntactically the unmarked term.

Similarly to Cruschina and Remberger for Italian, two papers expand the scope of the discussion in Spanish in two senses. In their chapter Descriptive and functional analysis of the solo-solamente adverbial pair in spoken Mexican Spanish, Medina Gómez and Alarcón Neve review syntactic, semantic and pragmatic properties of this adverbial pair as well as their use in two corpora of spoken Mexican Spanish:

(21) Solo María escucha discos de música clásica

'Only María listens to classical music discs'

(22) Solamente mis tres hermanos, ellos compran todo

'Only my three brothers, they buy everything'

The chapter ponders a number of possible variables and discards them as they do not turn out to be statistically significant. Those results which are statistically significant stand out not only for their attestation of near-synonymy in a number of respects (syntactic, distributional, and especially semantically with respect to the expression of exclusivity), except that the form without -mente shows a tendency towards exclusion, while the form with -mente shows a stronger tendency towards its use for nuancing. The results also support other relevant findings, e.g. the high frequency of solamente in spoken language compared with what is usually the case with other -mente forms.

Ortiz Ciscomani (From adjective to adverbial modal locutions in Spanish) also moves the discussion of the interface to the development of locutions in Spanish of the type $a \mathrm{Adj} / \mathrm{N}$-as:

(23) Dixo Moysen al Nuestro Sennor: "Non puedo a solas levar esta carga" 'Said Moses to Our Lord: "Not (I) can unaided/by myself carry this load"”

(24) y ahora hablamos a ciegas 'and now (we) speak unthinkingly/blindly'

A rather obscure formation, it is researched here both synchronically and diachronically (spanning from the 12th to the 20th century) based on corpus data. The synchronic research contributes both quantitative and qualitative data, especially on the semantic value of this type of structures. The diachronic side of the 
study reveals a range of types. The adverbial sense of these structures developed in the 15th century from prepositional phrases as a result of grammaticalization. In the process of grammaticalization, the original meaning of the prepositional phrase shifts in the adverbial locution in a number of directions: from referential to abstract, from objective features to subjective positions and from descriptive to evaluative meaning.

Suñer examines the same subject in her chapter on Adverbial adjectives and the decomposition of event predicates. Although the approach is cross-linguistic and considers comparable structures in Catalan, French, Italian, Portuguese and Spanish, the argumentation focuses on examples of European and American Spanish (here illustrated with examples of Mexican and Argentinian varieties, respectively):

(25) (Mex.)

Entrecierra los ojos y sonríe breve

'(S)he squints and smiles briefly'

(26) (Riopl.)

Durmió corto y profundo

'(S)he slept shortly and deeply'

Set in a framework of syntactic decomposition of event predicates, Suñer proposes a hierarchy of units termed adverbial adjectives according to their relation to levels of the argument structure of the predicate. In a second part of the chapter, Suñer discloses the conditions that govern the alternation between adverbial adjectives and secondary predicates, and weighs the arguments cited by the literature contra an analysis of adverbial adjectives as adverbs. Suñer closes the chapter with a description of the four types of modification found in these structures and highlights the role of subjects in the use of agreeing and non-agreeing forms.

\section{References}

Allerton, David J. 1982. Valency and the English Verb. London: Academic Press.

Guimier, Claude. 1991. Sur l'adverbe orienté vers le sujet. In Les états de l'adverbe, Claude Guimier \& Pierre Larcher (eds), 97-114. Rennes: Presses Universitaires de Rennes.

Matthews, Peter H. 1980. Complex intransitive constructions. In Studies in English Linguistics for Randolph Quirk, Sidney Greenbaum, Geoffrey Leech \& Jan Svartvik (eds), 41-49. London: Longman.

Valera, Salvador. 1998. On subject-orientation in English -ly adverbs. English Language and Linguistics 2(2): 263-282. doi:10.1017/S1360674300000885 

PART I

General aspects of Romance languages 



\title{
Adjectives with adverbial functions in Romance
}

\author{
Martin Hummel \\ University of Graz
}

\begin{abstract}
The adjective adverb interface is crucial for the analysis of adverbial modifiers: adjectives are used with adverbial function (Type A), adjectives are morphologically marked as adverbs (Type B) and adverbial paraphrases often contain adjectives (Type C). In the same 'local context' of VP, Type A, B and C may activate similar functions (to speak different/differently/in a different way) or different functions (to shine red $/{ }^{*}$ redly). However, even in the group with similar functions, register (formal/informal) and code (oral/written) account for variationist differences. The inflection vs. derivation debate for Type B adverbs and the recent discussion on 'adverbial agreement' adds more possible interfaces. This article provides a critical synthesis of these interfaces.
\end{abstract}

\section{Introduction: Adjective or adverb?}

Is the modifier an adjective or an adverb in a hard man, to work hard, hard worker, beautiful dancer, heavy smoker, etc.? This is the way teachers and linguists often state the alternative, thereby situating the problem at the level of word-classes (Valera Hernández 1996: 37). School trains the educated to see things this way. This secondarily favours the analysis of modifiers as instances of conversion defined as "same form and different word-class" (Valera Hernández 2004:20). But does this process systematically "create a new word", introducing "a change of meaning, however subtle" (ibid.: 33), to use a second criterion? Do we not simply use the same word slow in to drive slow and a slow turtle? The important point is that we have to take word-classes as heuristic tools. They are not (necessarily) objectively given categories. The linguist's task is not limited to the classification of usages, as we get used to at school, but to see to what extent we can explain things in this way.

Syntax plays a crucial role for differences in function and meaning. If we assume that slow is the same word in to drive slow and a slow turtle, its classification as an adverb in the first case and as an adjective in the second depends on its position in 
syntax. Hence, the analysis as one word-class used for different syntactic functions is possible as well. Adjectives are syntactically defined as modifiers of nouns, while adverbs are negatively defined as modifiers of 'everything else' (verbs, adjectives, adverbs, sentences). In Romance, these negatively defined adverbial functions go hand in hand with the assumption of invariability, that is, the usage of the unmarked masculine singular form of the adjective for adverbial functions (e.g. Sp. María habla rápido 'Mary speaks fast'). Secondary predicates fill the same syntactic slot as rápido. They syntactically belong to VP but semantically modify an argument of VP. Consequently, secondary predicates in Romance agree with a nominal argument (Sp. Ella $a_{i}$ vive contenta ${ }_{i}$ 'She lives happy $_{\mathrm{i}}$ '). In this sense, they are adjectives used in VP. In this case, the disambiguation is not a matter of syntax but of morphology and semantics. Hence, two constructions emerge in the same syntactic position involving specific interfaces between morphology and semantics.

In both Romance and English, adverbial functions may also be marked by a specific adverbial morpheme: Romance -mente and En. -ly. These morphemes are variously classified as endings (inflection, suffixes, derivation) or even an element of composition. ${ }^{1}$ In English, diachronic syncretism provides cases such as a friendly man vs. He speaks friendly. Word-formation comes into play via semantics. The noun modifying function in hard worker goes hand in hand with the underlying verb modifying semantics of to work hard, not to mention the well known ambiguity of beautiful dancer 'good-looking/good dancing'. All this complicates the analysis in terms of simple conversion as well as approaches based on word-class. Valera Hernández (2004) focuses on the variety of processes that underlie "apparent cases of conversion".

If we take into account that the same word-class may modify adjectives, adverbs and sentences, it clearly turns out that the interplay of syntax, morphology and semantics creates a manifold linguistic phenomenology. The complex playground that VP and sentences offer to modification allows for a rich variety of constructions. Usual subcategorizations of sentence adverbs mirror the complexity of modification in this field (attitude, point of view, epistemic value etc.). For their part, VPs refer to events that include participants and, roughly speaking, whole scenes and scripts. As a consequence, modifiers in VP differ with regard to scope. Moreover, a main scope may coexist with a secondary scope, e.g. subject-oriented adverbs

1. Adverbs in -mente are univerbations from Latin ablative constructions such as, e.g. sola mente. In Romance, they were first written as two words. In Spanish, coordinated adverbs still delete -mente in the first adverb (e.g. calma y tranquilamente 'calmly and peacefully'). Moreover, the adjective conserves the feminine form as a remnant of the agreement with the feminine noun Lat. mens 'mind'. Finally, -mente takes the primary stress: tran'quila"mente. Similar reflections can be made on Ger. -weise, which stems from the noun Weise 'way, manner' (Fábregas 2014). 
in -ly or -mente, or secondary predicates that modify both the argument and the change (manner). In Romance, agreement can be used to primarily or secondarily direct the scope of modification. Hummel (in print c) analyses the different types of modification from a cognitive linguistic point of view as emerging from baseline "verb + adjective structure". The range of modification includes, e.g. scenes, instrument roles, circumstances.

This all means that the apparent simplicity of the alternative Adjective or ad$v e r b$ ? masks a complex reality in terms of analysis. As a consequence of the basically negative definition of the adverb as a word-class, its internal heterogeneity is an obligatory introductory remark in all studies. Word-class systems traditionally use the adverb as a residual class for items that cannot be classified under one of the other classes. This explains the heterogeneity of this word-class (Pittner et al. 2015: 1; Ricca 2015), even in terms of prototypicality, since the possible members of the class cannot be reduced to a single prototype or close prototypes (Ramat \& Ricca 1994; Rauh 2015). It comes as no surprise that lists of functions included or excluded vary considerably (see overviews by Sonntag 2005: 1-41; Rauh 2015). French grammars often classify particles of affirmation and negation as adverbs (e.g. oui 'yes', non 'no', ne ... pas 'not'). The categorial status of discourse markers, possibly as adverbs (see 2.3), is also unclear, above all because oral syntax has long been neglected. The feature of invariability, which many grammars and linguists use as the only positive morphological criterion for the definition of this word-class, is essentially negative in nature since all inflected units are automatically classified as nouns, verbs or adjectives. The invariability criterion is called into question by the recent discussion on adverbial inflection and adverbial agreement (Section 6). Consequently, it is problematic to assume a change of word-class when we deal with adverbs, that is, an almost ill-defined word-class. It is therefore highly recommendable to place the first step of analysis at the level of function.

Given the complexity of the adjective adverb interfaces, one may be inclined to adopt Croft's (2001) "radical" claim that linguistic analysis should rely on distribution to the detriment of word-class (see also Telschow 2014). However, it should be clearly defined what distribution means. Traditionally, the term refers to a syntactic point of view, which is a legitimate one. Others may put function first, e.g. modification. The important point is that, regardless of the perspective, all relevant features have to be taken into account; this includes not only morphology and semantics, but also register, code, variety etc. If educated speakers tend to analyse language in terms of word-class, this is a relevant feature in the languages under scrutiny. The conscience of the educated may motivate their preference for drive slowly to the detriment of drive slow, for firstly vs. first (discourse organization). They may even prefer really good for writing and real good for speaking. The choice may also depend on regional preferences. In sum, analysis has to be complex. 
This article intends to provide a systematic account of these interfaces in Romance from the point of view of word-class taken as simple heuristic tools. This approach offers the advantage of a high degree of synthesis compared to distributional analyses, while running the risk of oversimplification. The focus lies on adverbial functions realized by adjectives and deadjectival adverbs, to the detriment of noun modification. Typological research and studies on variation in Romance provide evidence for a more flexible word-class based approach to adverbs (Section 2). The subsequent sections morphologically subcategorize attributive modification into Type A (adjectives used for adverbial functions in Section 3), Type B (adverbs in -mente ${ }^{2}$ in Section 4), Type C (adverbial paraphrases in Section 5) and Type D (lexical adverbs in Section 6). Syntactic aspects are discussed in these sections. Section 7 tackles the recent discussion on adverbial inflection (7.1) and adverbial agreement (7.2). Section 8 gives a short outlook on the functional transposition of modifiers to peripheral domains. If we except adjectival inflection, the adjective adverb interface is similar in English (Hummel 2014a). I therefore also use examples from this language in order to illustrate and to place the argumentation at a cross-linguistic level.

\section{Typology and variation}

\subsection{Attributive modification}

The term modification needs to be questioned and refined (Rauh 2015:21). ${ }^{3}$ Starting with the common meaning of the word, modification refers to a process whereby something undergoes a (minor) change. This, however, could even be used to vaguely describe predicate - subject or circumstance - sentence relations. In fact, each unit added to or deleted from an utterance 'modifies' the utterance or one of its constituents. Hence, a minimum requirement would be that of combining modification with a specifying quality, e.g. predicative modification. The term adverbial modification obviously inherits all the incoherence of the term adverb. As far as adverbs or adverbials using adjectives as their basis or syntactic nucleus are concerned, the term attributive modification (in short, attribution) specifies the

2. I use -mente as a dummy for all variants, e.g. Fr. -ment, Friulian -mentri/-menti, Old Spanish -mientre, etc.

3. See, for example, the vague definition in Crystal (2008: s.v.): "A term used in syntax to refer to the structural dependence of one grammatical unit upon another". 
relevant basic function (cf. Baker 2003). ${ }^{4}$ It means that the modification process attributes a property to another unit.

Attributive modification should not be understood in a traditional structural sense as referring to a language immanent relation. In a given utterance, the adjective red in a red house does not really modify the word house, neither morphologically nor semantically, but it attributes (in other terms: specifies, profiles, denotes) a concept (here 'red') to the extra-linguistic object denoted by the word house. By contrast, the lexical modification with the diminutive suffix in Sp. tornillo 'screw' indeed changes the word and its meaning. This is the reason why attributive modification comes close to (implicit) predication, at least in terms of linguistic tests: the red house $\rightarrow$ the house is red; Importantly, ... $\rightarrow$ It is important that; He drives fast $\rightarrow$ his driving is fast, etc. (cf. Fábregas 2014:291).

Not surprisingly, sentences may start with More importantly, ... or More important without relevant change in meaning (Erdmann 1997). This means that the assumption that - $l y$ changes the grammatical category is problematic from the functional point of view, at least in some of the heterogeneous functional domains covered by the word-class of adverbs. Following Marchand (1967: 16), we might classify the usage of sentential adverbs in - $l y$ that realize adjectival predicative functions as "transpositions", that is, "the use of a word in another than its normal function" (here: an adverb for a basically adjectival function) (see Hummel, submitted).

Attributive modification is prototypically realized by noun-modifying adjectives, but it can be transposed and adapted to other functions, e.g. verb modification. At the periphery, circumstantials can be included insofar as attributive modifiers may be used in order to state the circumstances which condition a given predication, e.g. previously (cf. Pittner 2015; see Section 8). The term 'circumstantial modification' will complementarily be used for this group. In such functions, the genuine attributive function is overruled by a major function. The overruling of the underlying attributive properties is particularly strong with PPs used as adverbials, e.g. in short with the discourse function 'to sum up, to reduce the previous arguments to the pertinent facts, to conclude'. In the first case, circumstantials are generally placed at the syntactic periphery; in the second, the preposition in is the head of the phrase. In more general terms, the distribution of adjectives and

4. The term may cause confusion when used for adjectival functions, which are traditionally subcategorized in terms of word-classes as attributive ( $a$ tall man) and predicative adjectives (The man is tall). From a strictly functional point of view, this basically useful distinction is unclear because predicative adjectives are not less "attributive" than those of the first group. Both groups attribute properties, the only difference being that in the second group the process of attribution is mediated by a predicative relation (He is tall). 
derived adverbs places them in manifold syntactic contexts which interact with their fundamental properties. Hence, functional interfaces are a general feature.

\subsection{Combining typology and variation}

According to the analysis of a sample of languages of the world characterized by maximal typological distance (Hengeveld 1992: 15, 20-1, 62-72; Hengeveld et al. 2004; Hengeveld \& van Lier 2010; see critical aspects discussed by Croft 2001:65-75), three morphological types of adverbial attributive modifiers can be distinguished. Languages such as English are "differentiated" since they separate adjective and adverb at the level of word-class, e.g. a slow (adj.) $m^{5} n^{5}$ vs. The man runs slowly (adv.). Danish, Dutch, German and Swedish (and Old English) are "flexible" since the unmarked form (German, Dutch) or a neuter form (Danish, Swedish, Old English) of the adjective is used for adverbial functions, that is, both adjectival and adverbial functions are assumed by the same word-class, e.g. Ger. der schnelle (adj.) Mann vs. der Mann rennt schnell (adv.). This presupposes the similarity of adjectival and adverbial functions. ${ }^{6}$ "Rigid" languages use verbs or nouns for adverbial functions. By extension, prepositional phrases may be used for this purpose (e.g. Sp. andar con rapidez 'to move with velocity'; cf. Štekauer et al. 2012:216). We thereby leave the domain of word-classes. This provides evidence for the limitations of analyses based on word-class. From a functional point of view, all adverbials competing for the same function have to be considered.

The common assumption of adverbs in Romance being derived from adjectives with the suffix -mente suggests their typological classification as differentiated languages, together with English. However, from a variationist point of view, most Romance languages combine differentiated techniques with flexible and even rigid ones (Salazar García 2007). To give an example, Sp. correr rápidamente 'to run quickly' coexists with correr rápido 'to run quick' and correr con rapidez lit. 'to run with speed/rapidity' (not to speak of the paraphrase de manera rápida 'in a quick manner'). If we further take into account the existence of lexical units specialized

5. Except if it is argued that a slow man still refers to the man's agility, which would be a semantic argument for the conservation of its adverbial function.

6. For different approaches to shared features of adjectives and adverbs see Pottier (1970:21720), Goes (1999: 215-26), van Raemdonck (2005, and in this volume), Eisenberg (2002), Langacker (2008: 116), Schäfer (2013), Schwenk (2015), Valera Hernández (1996), Telschow (2014), amongst others. While Radford (1988:137-45) tries to "conflate" the categories of adjective and adverb, Radford's (2004:36-7) minimalist approach considers categories as abstractions from distribution in syntax. 
for adverbial functions (e.g. Sp. bien 'well'), we can distinguish four morphosyntactic types:

Table 1. Morphosyntactic types of attributive modification

\begin{tabular}{ll}
\hline Type A & adjective (adjectival and adverbial functions) \\
Type B & $\begin{array}{l}\text { adjective (adjectival functions) } \\
\text { adjective + adverbial morpheme (adverbial functions) }\end{array}$ \\
Type C & paraphrase (e.g. prepositional phrases) \\
Type D & lexical adverbs
\end{tabular}

Simply using the adjective for adverbial functions (Type A) is the most common feature in Indo-European languages (Fortson IV 2004:211). It thus constitutes the most general tradition. This tradition is genuinely oral. By contrast, Type B adverbs are systematically preferred when languages develop standards of writing: Ancient Greek $(-\omega \varsigma)$, Classical Latin (- $\bar{e}$, -iter), Late Latin (-iter), Romance (-mente), English $(-l y)$. Consequently, Type B can be related to a cross-linguistic Western culture of "Sprachausbau" (Kloss 1967) in the domain of writing and educated oral communication (Hummel 2014a). Conversely, Type A is preferred where oral traditions prevail (e.g. American Portuguese and Spanish, English dialects, Louisiana French, many Italian dialects). For this reason, Hummel (2013a) argues that the diachrony and synchrony of attributive modification in Romance is basically determined by the competition between Type A and Type B adverbs in a socio-historical context of increasing discrepancy between, but also interdependence of, oral and written traditions.

The competition between Type A and Type B has also been discussed with regard to the typological division of Western and Eastern Romance, with Type A prevailing in the latter (overview in Hummel 2013a). However, Type A is used in all Romance languages and varieties. Hence, the opposite standpoint would argue that Western and Eastern Romance share the same oral tradition of using Type A, and while the latter tends to conserve this tradition (Renzi 2005), Western Romance has elaborated a tradition of writing where adverbs are morphologically marked with -mente. The exclusivity of Type A in (almost) Western Romance Sardinian and the selection of Type B for standardized Eastern Romance Italian support the latter analysis. 


\subsection{Parts of speech and syntax}

The typological and variationist coherence in Hengeveld's approach has its price. The first price to pay is its limitation to the verb phrase (secondary modification). ${ }^{7}$ This corresponds to the commonplace perception of manner adverbs as modifiers of the verb. However, while manner adverbs tend to prevail in written texts (e.g. Company Company 2014 with regard to Spanish), in spoken discourse sentential adverbial functions may be more frequent (Hummel 2013b), and only a few manner adverbs figure amongst the most frequent adverbs (Ramat \& Ricca 1994:317-9). This notwithstanding, there is no real obstacle to extending Hengeveld's approach to other syntactic contexts in Romance: the modification of adjectives and adverbs (tertiary modification) or of sentential units and of interactive discourse (discourse modification). The second price to pay is the exclusion of all adverbs of time and space, and, obviously, of all other functions (affirmation/negation particles, connectors, discourse markers, if not based on adjectives). The selection of 'attributive modification' provides analytical coherence, but it splits the putative word-class. Hengeveld's restriction to attributive modification matches with the perspective adopted in this paper, that is, the interfaces of adjective and adverb.

\section{Type A}

Type A means using adjectives for adverbial syntactic functions. Following the traditions of writing, grammars and manuals clearly underestimate the role of Type A adverbs in Romance. Type A is particularly salient in Italian and Italo-Romance varieties, but even the most detailed grammars hardly pay attention to them (half a page in Renzi et al. 2001:375 and Salvi \& Renzi 2010:1499).

7. This term follows Jespersen's theory of ranks (1992:96-107). 'Secondary modification' addresses primary word classes (verbs, nouns), whereas 'tertiary modification' means the modification of modifiers, if we simplify Jespersen's slightly different definition of this term. The distinction of three ranks requires further differentiation if all adverbials (see Section 8) are considered, e.g. discourse functions, which would justify the term 'quaternary modification'. Frey (2003) and Abraham (2013) suggest a more sophisticated analysis in terms of c-command. Cinque (1999:2004) proposes the analysis of adverbs in terms of syntactic hierarchy and scope, assuming about 40 different cross-linguistically attested projections (against their analysis as adjuncts; for discussion see Alexiadou 2013). 


\subsection{Pan-Romanic usage and oral tradition}

From both the diachronic and the variationist viewpoint, Type A is the primary form used for attributive modification. It is the form Latin inherits from its IndoEuropean tradition, transmitting it to Romance (Löfstedt 1967). Due to this tradition, Type A is the only pan-Romanic form of the deadjectival adverb. Witness the following equivalents for The men work hard:

Table 2. Type A adverbs in Romance

\begin{tabular}{ll}
\hline Cat. & Els homes treballen fort/dur. $<$ Lat. durus, dura, durum \\
Fr. & Les hommes travaillent dur. \\
It. & Gli uomini lavorano sodo/duro. \\
Pt. & Os homens trabalham duro. \\
Rom. & Oamenii lucrează greu. $<$ Lat. gravis, gravis, gravě \\
Sard. & Sos omine trabagliana folte. $<$ Lat. fortis, fortis, fortě \\
Sp. & Los hombres trabajan duro. \\
\hline
\end{tabular}

Two variationist facts show the long-term effects of this oral tradition in Romance. First, all New World varieties make a broader usage of Type A, as a consequence of the lower impact of linguistic education and linguistic norm in general. In American Spanish and Portuguese, Type A constitutes the default variant in informal oral communication. Second, geographically isolated French varieties such as Louisiana French or the rural varieties of Acadian French have a generalized usage of Type A in informal spoken language (Hummel 2000:430-1; data from New Brunswick):

(1) a. une fois que vous la vendez légal 'once you sell it legally'

b. on pourra en parler un petit peu plus profond 'we can talk about it more deeply'

c. ton animau grandissait naturel 'your animal grew naturally'

In contrast to standard European French, where Type A modifiers of verbs tend to lexicalization (e.g. Fr. couper court 'to interrupt/to cut short'), the examples quoted above are completely productive. The German or Romanian adjective would be used in exactly the same way as an adverb of manner. Now, informal spoken Acadian and Louisiana French are generally supposed to continue metropolitan oral traditions from the 17 th century. If this is the case, we can assume that in the 17th century spoken French basically used Type A. However, in the bibliography, the epoch from 1650 to 1750 in France is known not for the usage of Type A but as that of the apogee of adverbs ending in -ment (Glatigny 2005). This apparent 
contradiction is resolved if we differentiate the oral tradition of using Type A and the written tradition of Type B. There seems to have been a rather clear-cut division between oral usage of Type A and preference for Type B in written texts in this century. This is not as surprising as it may seem at first glance, since the same discrepancy opposes present-day informal oral usage and written standard in American Spanish and Portuguese. Similarly, Type B is used in formal written texts in Acadia. Standard British English and British dialects show similar contrasts (Hummel 2014a).

\subsection{Latin}

Almost the same as in modern English and Romance, manuals of Classical Latin unilaterally posit Type B as the standard form of the adverb (Hummel 2013a). However, a closer look at the data provides plain evidence for the coexistence with Type A, which is the only Latin adverb type to be conserved in Romance, since all Latin Type B forms disappear. Karlsson (1981:17) mentions Type A adverbs such as difficilĕ, celerĕ, dulcĕ, grandĕ, vilĕ. The underlying productive rule holds for the $i$-declension (see brevis in Table 3):

Table 3. Rule A in Latin

brevis, brevis, brevĕ (adj.) $\rightarrow$ brevĕ (adv. = adj.; nom.-acc., sg., n.)

tranquillus, - $a$, -um (adj.) $\rightarrow$ tranquillum (adv. = adj., nom.-acc., sg. n.)

In contrast to long $-\bar{e}$ (see Section 4), Type A uses the short - $\breve{e}$ of the neuter adjective for adverbial functions. School grammars also mention a long list of exceptions supposed to be learned as lexical adverbs or adverbials (e.g. Throm 1984:38). Interestingly, many of the lexical exceptions have a neuter ending morpheme: $m u l$ tum, paulum, primum, altum, rapidum, firmum, tranquillum, falsum, etc. This open list should, instead, be a reason to claim a Type A rule for the o/a-declension (see tranquillus in Table 3).

Romance followers ending in -o support the productivity of Rule A (cf. MeyerLübke 1972: §619). In fact, It. parlare alto, Pt. falar alto, Sp. hablar alto stem from Lat. altu $(m)$. The same holds for the $i$-declension, e.g. Sp. fuerte, suave, breve, fácil, grave used as adverbs. According to Rule A, Type A undergoes agreement in Latin when it modifies a noun, but adopts the neuter singular form ('weak form') when used with adverbial function. Supplementary evidence for Type A comes from the fact that the standard comparative form of the adverb in Classical Latin is identical to the neuter singular of the adjective's comparative (e.g. iustius, pulchrius, miserius, acrius, etc.). In the diachrony of Latin, the oral tradition of using Type A emerges as 
Classical Latin decays. Löfstedt (1967) gives a detailed account of Type A adverbs commonly used in Late Latin. Hence, there is evidence for the persistence of Type A, not only from the point of view of reconstruction (see Dardel 1995:2009) but also from the existent texts.

There is one important point to see within all this: In a certain sense, it is misleading to say that It. forte stems from Lat. fortĕ, or Sp. alto from Lat. altu $(m)$. We need not necessarily assume the direct continuity of single forms since we are dealing with the history of a rule, not the history of words. In Old French, for example, the loaned Germanic word isnel 'quick' was commonly used as the Type A modifier with adjectival and adverbial functions, as well as the Type B alternative isnelement (see Sandmann 1946:28). This means that a French rule was at work. Tracing back single forms only holds for lexicalized items. Hence, asking the question whether a form stems from Lat. $-\breve{e}$ or $-\bar{e}$, or Lat. -um or $-\bar{o}$, may occasionally be justified, but it is a pointless exercise if asked in general terms. Fr. parler haut 'to speak loud' is not necessarily a successor of Lat. alte, altum or altō, but simply the unmarked form of the French adjective used as a Type A adverb.

\subsection{The polyfunctionality of Type A}

Hummel (2000:461-70) argues that syntactic restrictions possibly explain the limited usage of Type A for adverbial functions in written Romance and, conversely, the expansion of the morphologically marked Type B. Witness the following examples from Spanish $(\mathrm{M}=$ modifier $)$ :

Table 4. Syntactic variants of Spanish Type A and Type B adverbs

\begin{tabular}{lll}
\hline Syntax & Type A & Type B \\
\hline VMN & a. Mirar rápido el coche. & b. Mirar rápidamente el coche. \\
VNM & a. Mirar el coche rápido. & b. Mirar el coche rápidamente. \\
MA & a. ?alto importante & b. altamente importante \\
MAdv & a. ?tremendo bien & b. tremendamente bien \\
M+ Sentence & a. Curioso, ella no lo hizo. & b. Curiosamente, ella no lo hizo. \\
& c. Curiosa, ella lo hizo. & d. - \\
\hline
\end{tabular}

The syntactic distribution VMN is unambiguous for Type A and B since in the former case the adverbial function is marked by the syntactic position of rápido, which is a member of VP, and may eventually be marked by the neuter-masculine with feminine or plural subjects (Ella mira rápido el coche 'She quickly looks at the car'). The adverbial function in Type B is marked by both syntax and morphology. In the distribution VNM, modifier and verb are separated by a noun. In this case, unlike 
(b), (a) is formally ambiguous since the adjective can be a modifier of NP (el coche rápido 'the fast car'), although in oral communication the adverbial interpretation is possible as well. Type $\mathrm{A}$ is ungrammatical or at least unusual with modifiers of adjectives (MA) and modifiers of adverbs (MAdv), whereas the corresponding Type $B$ sentences are perfect. At first glance, sentence modifiers ( $M+$ Sentence) look odd for uninflected Type A (a), but in informal oral communication it is currently used with the same meaning as (b), which is preferred in written texts. Note that the orality - literacy gap thereby clearly appears. Type A is not documented in grammars of Spanish. The inflected variant of ' $\mathrm{M}+$ Sentence' in (c) is almost exclusive for literary texts. Curiosa 'curious' refers to the subject ella 'she', so that it formally conforms to the standardized norm to use it as an inflected adjective, while the uninflected adverbial use of the adjective in (a) is considered incorrect. Sentence (c) cannot be equivalently replaced by Type B (d). In sum, it can be said that the polyfunctional usage of Type A creates disambiguation problems at the level of syntax, even if the examples should be further discussed for prosody, subsequent semantic effects and morphological variants, as with the use of the feminine rápida in Ella mira rápida al coche (see Section 7).

In a series of studies, Hummel (see synthesis in Hummel 2013b) has checked the hypothesis of syntactic restriction with data from semi-informal spoken Chilean Spanish. ${ }^{8}$ Against the hypothesis, Type A is more frequent than Type B in all syntactic functions, both coming close only in the case of sentence adverbs and only at the level of type frequency (witness Table 5):

Table 5. Type A and Type B adverbs in spoken Chilean Spanish

\begin{tabular}{lcccc}
\hline & \multicolumn{2}{c}{ Type A } & \multicolumn{2}{c}{ Type B } \\
\hline & Types & Tokens & Types & Tokens \\
\hline Verb modifiers & 26 & 40 & 5 & 5 \\
Adjective/adverb modifiers & 10 & 202 & 6 & 11 \\
Discourse modifiers 9 & 11 & 395 & 9 & 61 \\
Time adverbs & 12 & 40 & 5 & 12 \\
Total number & 59 & $\mathbf{6 7 7}$ & $\mathbf{2 5}$ & $\mathbf{8 9}$ \\
\hline
\end{tabular}

While the modification of VP ('manner adverb') is well known (e.g. pensar positivo 'to think positive') the relevance of the other types is underestimated. Qualitative modifiers of adjectives are rare in the corpus (e.g. típico sureño 'typical(ly)

8. Interviews with housemaids from Southern Chile, length: 10 hours, 70.000 words, collected by Bettina Kluge (cf. Kluge 2005).

9. Including adjectival discourse markers and sentence adverbs. 
meridional'), but Type A quantifiers are standard in speaking and writing, the most striking aspect being their polyfunctionality:

(2) demasiado importante

'too important'

demasiado bien

'too good'

pagar demasiado

'to pay too much'

demasiadas casas

'too many houses'

The only restriction is that Type A modifiers of adjectives generally are unproductive, that is, they build an almost closed paradigm. Type B adverbs may be used for productive purposes (Kaul de Marlangeon 2002; see Section 8). In substandard varieties, however, the modification of adjectives and adverbs by Type A modifiers is not unproductive: una película terrible mala 'a terribly bad movie' (adolescent speech Chile). Interestingly, the emergence of quantifiers or intensifiers from adjective - adjective structures is a cross-linguistic tendency. Qualitative adjectives such as En. terrible and typical adapt to these functions in both Type A and Type B (typical(ly) German 'very German', terribly bad 'very bad') (Hummel 2014a).

Similarly, discourse markers have been controversially discussed, especially with regard to the word-class of adverbs (Fuentes Rodríguez 2001; Martín Zorraquino 2010). Such studies generally conclude that "discourse marker" is a category in its own right. Recent grammars, consequently, often add a separate chapter for this category. The differentiated approach to word-classes pointed out in 2.2 allows for a more satisfactory analysis. Sp. claro, bueno, igual, total, etc. are indeed invariable. Their analysis as specific functions of polyfunctional Type A adjectives in (oral) syntax resolves the problems in the case of deadjectival discourse markers. The invariability of discourse markers follows from the fact that they modify (chunks of) discourse, that is, units that are always unmarked for gender and number. Discourse markers naturally emerge from polyfunctional Type A usage. The fact that they may share features of both adjectival and adverbial functions makes them the natural correlate of the monocategorial system.

To sum up, as the analysis of the Chilean corpus reveals, there are no principled syntactic restrictions for the use of Type $\mathrm{A}$ in any adjectival and adverbial positions. This comes as no surprise from a general linguistic point of view, since flexible languages such as German, Dutch or Romanian function in exactly this way. The important fact is that the flexible system prevails in the genuine oral tradition of Romance. If this is felt as a surprise, this is due to expectations biased by linguistic education preferring Type B. The fact that there is no principled obstacle for 
using Type A does not exclude restrictions in usage. In Table 4, MA (alto 'high') and MAdv (tremendo 'tremendous') are unusual, for whatever diachronic reason, but not ungrammatical since the examples respect the grammar of Type A. Consequently, analysis must clearly separate grammaticality from usage. Crucially, the standard usage of Spanish relies more on the formal discrimination of adjectival and adverbial functions by morphology and syntax (see Type B in Table 4), while informal spoken Spanish prefers monocategorial modification (Type A) without fully replacing the morphological ambiguity by syntactic marking. In the latter case, semantic and functional disambiguation basically depend on interpretation ad sensum and communicative experience. Consequently, the relevance of the semantic-syntactic-morphological interfaces depends on code and register.

\section{Type B}

\section{1 -mente as a correlate of standardization}

All standardized Romance languages except Romanian have canonized -mente for the formation of adverbs from adjectives. ${ }^{10}$ Since the focus of linguistic interest has been mostly directed to written texts belonging to the Western cultural pattern of standardization (French, Italian, Portuguese, Spanish), grammars and manuals tend to consider adverbs in -mente as the only relevant rule in word-formation, apparently in both the written and the spoken language. However, Type B is neither pan-Romanic, as shown in Table 6, nor does it always prevail in spoken language (see Section 3):

Table 6. Type B adverbs in Romance
Cat. ?Els homes treballen durament.
Fr. Les hommes travaillent durement.
It. Gli uomini lavorano duramente.
Pt. Os homens trabalham duramente.
Sp. Los hombres trabajan duramente.

10. In Romanian, the Type B suffix -eşte (< Lat. -iscēe, i.e. the adverbial case of adjectival -iscu, a suffix for adjectives denoting names of peoples or countries) covers a limited domain of adverbs (often denoting the origin of something) such as româneşte 'Romanian' or omeneşte 'human' (Lausberg 1972: $\$ 691$; cf. Chircu 2008: 104-5, 115-6, and the overview on adverbial suffixes in Vasile 2013: 11-44). 
Native speakers of Catalan do not easily accept Type B, but it can be found in the Diccionari català-valencià-balear with examples drawn from old written texts. Possibly, the general decrease in use of Type B in Catalan can be related to a less permanent normative pressure during history in comparison to French, Portuguese and Spanish. In line with this, Company Company (2012) analyses Sp. -mente as a "cultismo" arising with the development of written Spanish. Company Company (2014) shows that Spanish Type B adverbs have prevailed in written texts since their beginnings (cf. Hummel 2014b on Type A using the same corpus, and Kortschak \& Hummel in print). Furthermore, modification of verbs has also been the most frequent function in written texts from their beginnings until the 21 st century. Manuals and grammars reflect these facts. However, discourse functions are more frequent in present-day spoken language than verb modification (witness Type B frequencies in Table 5). This means that the usage of the oral code makes speakers change the practice of using Type B. The orality - literacy interface is thus marked by selective permeability (osmosis).

\subsection{Type B in Latin}

As mentioned in 2.2, Type B recurrently emerges as a correlate of writing and standardization in Old Greek, Latin, English and Romance. Witness Classical Latin:

Table 7. Rule B in Classical Latin

\begin{tabular}{llll}
\hline First declension & longus, longa, longum (adj.) & $\rightarrow$ & longē (adv.) \\
Third declension & fortis, fortis, fortě (adj.) & $\rightarrow$ & fortiter (adv.)
\end{tabular}

Long - $\bar{e}$ was used for the $a / o$-declension, -iter for the third declension. In Late Latin $-\bar{e}$ gives way to the generalized usage of -iter, even for the a/o-declension, e.g. $h u-$ maniter to replace humane (Karlsson 1981:31; Ramat 2008:15-6). Although -iter had been popular at some moment in the diachrony of Latin (e.g. in the graffiti of Pompei; Karlsson 1981:39; Löfstedt 1967:92-4), it has left no relevant traces in Romance. This means that -iter was out of use in common spoken language. The loss of -iter explains why religious discourse and the written tradition of Romance developed -mente. Type A could have been used, but it seems that the cultural tradition of marking the adverb in the written code was already powerful at that time. In this sense, the educated replaced-iter by-mente. This is an interesting fact, since it shows that diachrony needs an onomasiological framework (the succession of these items is not etymological but related with the same function) and that the practice of written Latin influenced written Romance. The replacement process explains the expansion of -mente. 
It is noteworthy that Romanian intellectuals tried to introduce -mente adverbs during the process of standardization in the 19th century, according to the French model (Chircu 2011:53-8). This was apparently too late, since the traditional oral use of Type A was well implemented, even for the new sentential functions, which followed French as far as the lexical base is concerned, using however Type A: Rom. normal, curios, logic, inadmisibil, evident, etc. Note the internationalization of many such lexical bases, e.g. the intensifier En. absolutely, Fr. absolument, Ger. absolut, It. assolutamente, Pt./Sp. absolutamente, Rom. absolut, Swed. absolut etc. (Hummel 2013c). The internationalization process obviously mirrors the intercultural dimension of the written tradition, or, in more general terms, the language of the educated.

Type B adverbs most easily penetrate spoken language in the domains of intensification (e.g. terribly initially loaned from Classical Latin) and discourse modification (e.g. naturally 'it goes without saying'). A paradigmatic case for this is En. real good which stems from spoken and written Late Latin realiter $>$ En. really $>$ real (adv.), not in terms of lexical-phonetic continuity, but as a calque from spoken Late Latin, firstly as really. The Type A adverb real later appears in 17th century English dialects, that is, really was adapted to the oral tradition of using Type A, which still prevails in many dialects (Hummel 2014a; Tagliamonte \& Ito 2002).

\section{Type C}

Manuals focus on adverbial paraphrases such as Fr. de manière/de façon + adjective 'in a adj.way/manner', It. in (un) modo/in (una) maniera + adj., or Lat. modo/ mente + adj. (e.g. Lausberg 1972: $\$ \$ 700-4)$. The very term 'paraphrase' means that speakers use these types instead of adverbs, e.g. when Type B has undergone grammaticalization, changing its basic meaning or creating polysemy (naturally 'obviously/in a natural way' vs. in a natural way). This seems to be a procedure mainly used by educated speakers for writing, especially in French, where adverbs in -ment have become almost unproductive because speakers adopt a strong normative attitude and tend to use established forms only (Bally 1965:247-8; Klein 1973; Company Company 2014; Hummel in print a).

By contrast, prepositional phrases with adjectives such as Sp. a las claras '(bring) to light', a medias 'half- (baked, won, etc.)', a solas 'alone' have been neglected by grammars, even more than Type A adverbs (cf. however Lapesa 2000; Ricós Vidal 2012; Rodríguez Molina 2014), basically because they are considered set phrases, that is, units of the lexicon to be studied within phraseology (García-Page 2008: 120-9; 2014). Most of them have indeed undergone lexicalization. However, the pattern was productive in the past. In a diachronic corpus analysis of Type A 
in Spanish, Hummel (2014b) observes that typical Type A adverbs, that is short and frequent adjectives in adverbial function, also occur in prepositional phrases:

Table 8. Type A, B and C variation in Spanish

\begin{tabular}{|c|c|c|}
\hline Type A & Type B & Type C \\
\hline $\begin{array}{l}\text { continuo } \\
\text { 'continuous' }\end{array}$ & continuamente & de continuo \\
\hline $\begin{array}{l}\text { extremo } \\
\text { 'extreme' }\end{array}$ & extremadamente & en extremo \\
\hline $\begin{array}{l}\text { fijo } \\
\text { 'fix' }\end{array}$ & fijamente & de fijo \\
\hline $\begin{array}{l}\text { ligero } \\
\text { 'light, small' }\end{array}$ & ligeramente & de ligero \\
\hline $\begin{array}{l}\text { ordinario } \\
\text { 'ordinary' }\end{array}$ & - & de ordinario \\
\hline $\begin{array}{l}\text { pronto } \\
\text { 'soon' }\end{array}$ & prontamente & de pronto \\
\hline $\begin{array}{l}\text { seguro } \\
\text { 'sure' }\end{array}$ & seguramente & de seguro \\
\hline $\begin{array}{l}\text { cierto } \\
\text { 'certain' }\end{array}$ & ciertamente & de cierto \\
\hline $\begin{array}{l}\text { solo } \\
\text { 'alone, only' }\end{array}$ & solamente & a solas \\
\hline
\end{tabular}

The relation between Types A and C is closer than that between Types B and C, insofar as Types $\mathrm{A}$ and $\mathrm{C}$ did not follow the enormous productive expansion of Type $\mathrm{B}$ adverbs. However, most Type $\mathrm{C}$ adverbials belong rather to the same everyday vocabulary as Type $\mathrm{A}$. Some Type $\mathrm{C}$ adverbials belong rather to the elaborated style (subir en alto 'go/climb high', en muy breve/muy en breve 'very soon', salir por bueno 'to turn out good', saber de cierto 'to know with certainty', por completo 'fully', en confuso 'confused', de continuo 'continuously', de diario 'daily', en especial 'especially', etc.), while others are popular in informal spoken language (a la buena 'in good terms', a ciegas 'blindly', a la continua 'continously', a derechas 'correctly', a la larga 'in the long run', a malas 'in bad terms', a medias 'incompletely, half-and-half', $a$ la mera 'only', a las malas 'in bad terms', a las buenas 'in good terms', a oscuras 'at night', a secas 'outright', en seguida 'at once', a solas 'alone', de veras 'truly, in fact', a las veras 'truly/in fact', etc.). 
The fact that there is no etymological construction in Classical Latin ${ }^{11}$ supports the hypothesis that these adverbials are a typical case of analytical innovation in Romance. Chircu (2008:56-7) provides a list of prepositional adverbials in Late Latin, e.g. a foras, in medio, de contra, ad satis (> Fr. assez). Only a few of these adverbials match with the adverbial Type $\mathrm{C}$ based on adjectives, but many of them survive in adverbials of time and space (e.g. in Romanian: Chircu 2008: 109-13, $118,121)$. According to Ortiz Ciscomani (in this volume), the Old Spanish core of these phrases has a directional semantics (e.g. a derechas), which was later extended to manner semantics (e.g. a solas, a secas). Another argument supporting the hypothesis of an analytical innovation is the pan-Romance character of these periphrases:

(3) (Cat.)

a les bones/males 'in good/bad terms'

a les seques 'outright'

(4) (Fr.)

au juste 'really'

en gros 'approximately'

(5) (It.)

di buono 'actually'

di sicuro 'certainly'

di certo 'surely'

da bon (Parmigiano) 'actually'

de bon (Milanese) 'actually'

alla larga 'in the long run'

alla fiorentina 'in Florentine style'

a poco a poco 'smoothly'

invano 'in vain'

d'ordinario 'usually'

di solito 'usually'

in generale 'in general'

alla grande 'on a large scale'

in grande 'enlarged'

davvero 'really, seriously'

in breve 'in short'

(Rohlfs 1969:246; Chircu 2008: 159; 2011)

11. Medias in res, or the later adapted in medias res, did not correspond to a commonly used pattern, not to speak of the fact that simple ${ }^{*}$ in medias is not documented. The construction with final $-s$ might be related to the so-called adverbial $-s$ in Romance, but the discussion of this phenomenon (Lausberg 1972: \$\$ 696-9) has not come to a conclusive result. 
(6) (Pt.)

às cegas 'blindly'

às escondidas 'secretly'

às boas 'in good terms'

às sabidas 'knowing full well'

em geral 'in general'

deveras 'actually, seriously'

(7) (Rom.)

cu greu 'hardly, with difficulty'

din greu '(work) hard'

(Chircu 2008: 129)

(8) (Sard.)

de seguru 'certainly'

(Ramat \& Ricca 1998:203)

Romanian and Spanish informants consider these adverbials as spoken substandard. It seems that the general preference of French for using prepositions converts, at least in some cases, the preposition into a 'particule de noblesse' (cf. au juste, en gros, etc.), which parallels Type A forms (dire juste 'to say it as it is', dire gros 'approximately'). Dire juste/gros indeed sound more informal or even incorrect, but the examples documented by Hummel and Stiegler (2005) provide clear evidence of their use. As mentioned above, Spanish offers a similar contrast between a more acceptable series for writing and a less acceptable one. Consequently, the written and the oral tradition might have developed analytical series of their own. All this provides evidence for a broad and productive usage of analytical adverbials based on prepositions. Today, the underlying rules seem to be rather unproductive according to some linguists (Chircu 2008: 177), but García-Page (2008:120, 126) states that it is almost impossible to provide a complete inventory of adverbial locutions because some patterns are still productive. Note that this process occasionally affected Type B, as in OSp. de buena mient $(r)$ e 'with good intentions'.

Type $\mathrm{C}$ has the advantage of not being restricted to adjectives, but to be used also with nouns, verbs (e.g. Fr. à reculons 'backwards') and adverbs as prepositional complements, especially those of time or space (cf. Meyer-Lübke 1972: \$621, and the above-mentioned authors). Analogy with nominals is one hypothesis for explaining the strange use of $-s$ with adjectives. The plural is indeed functional in Sp. a puertas cerradas 'with the doors closed', while it seems odd in a las buenas o a las malas 'in good or in evil', a secas 'directly, crudely, outright'. Both nominalization ('las buenas') and analogy provide explanations related to nominals.

In sum, Type $\mathrm{C}$ has crucial interfaces with adverbial functions also realized by Type A and Type B. Type C lacks thorough empirical investigation for both synchrony and diachrony, especially concerning its involvement in changes from synthetic to analytical constructions. The diachronic relevance of the morphosyntactic 
Type C questions the adequacy of a strictly word-class based approach to attributive modification.

\section{Type D}

Lexicalized manner adverbs such as Sp. bien 'well' and mal 'bad, wrong' are currently used. In this case, the Latin adverbs bene and male have become fossilized. Many others have undergone univerbation from Type C structures (Ramat \& Ricca 1998:241-3). Some of them have been documented in Section 5, e.g. Pt. deveras/ It. davvero 'in fact'.

\section{Adverbial inflection and adverbial agreement}

The morphological analysis of allegedly invariable units should be rather short and simple. However, two debates challenge the invariability criterion. The first one questions the traditional analysis of En. -ly, Romance -mente, Latin $-\bar{e}$ and -iter, etc. as derivational suffixes, claiming instead that they are inflectional morphemes of the adjective (7.1). The second concerns adverbial agreement with a nominal, which is ruled out in standard varieties but frequently used in varieties and registers of informal spoken discourse (7.2). In the following, the debate will be considered from the point of view of the adjective adverb interface.

\subsection{Adverbial inflection}

In contrast to other word-classes, there tends to be one main morpheme marking adverbial function in language, e.g. Romance -mente and En. -ly. These morphemes do not conceptually subcategorize adverbs (see however fn. 10 for Romanian and Ricca 2015: 1392), but simply mark the adverbial function as such. This is the precondition for considering the morpheme not as a suffix or a constituent of a compound but as an inflectional device.

Type B inflection has been discussed in terms of typology (e.g. Haspelmath 1996), from the perspective of functional linguistics (e.g. Plag 2003:195-6), in the tradition of Gustave Guillaume (Molinier 1963: 181), for Latin (e.g. Pinkster 1972:64-70), from a general linguistic point of view for Romance (Ramat \& Ricca 1998:202; Ricca 1998:2015), and for single Romance languages (e.g. Dal 2007 for French, Rainer 1996 for Portuguese and Spanish) as well as for English and German (e.g. Pittner 2015; Telschow 2014). The discussion has particularly focused on 
English adverbs in -ly (see Giegerich 2012 for a good state of the art). The relevant discussion is generally limited to synchrony in a structural linguistic framework, and mostly to verb modifiers (see a critical overview in Rainer 1993:35-43, 600-2). Since all criteria and arguments pointing in favour of or against inflection, derivation or composition have been thoroughly discussed in the above literature, I will only add some critical remarks from a more distant point of view without trying to answer the question of inflection vs. derivation.

The discussion has to be situated in broader contexts. The vivid debate resembles at times a storm in a teacup, that is, linguists trying to resolve problems created by linguists. Clearly, separating inflection from derivation divides a continuum into two different objects, at least if we do not consider the opposition of inflection and derivation as a theoretical and heuristic one, as we should do. In fact, both En. -ly and Romance -mente are long-term grammaticalizations of full nouns, the first one meaning 'body' in (Proto-) Germanic (Guimier 1985), the second one 'mind' in Latin. Hence, diachrony is marked by transitions including not only derivation, but also composition (Lat. tota mente 'entirely dedicated/totally', cf. Hüning \& Booij 2014). If inflection is the endpoint of diachronic grammaticalization, there is necessarily a transition from composition to inflection, possibly via derivation. Ger. -weise marks (some) sentential adverbs, conserving however its conceptual meaning related to the noun Weise 'manner'. Consequently, the existence of a morpheme sharing properties with inflection, derivation, and possibly composition comes as no surprise, even from synchronic points of view. Hence, attempts to clearly separate inflection from derivation at the level of object language run the risk of being a pointless exercise (cf. Štekauer 2015), if no nuancing devices are introduced (prototypicality, optimality etc.).

The tenants of the derivational hypothesis are not free from internal biases either. The derivational hypothesis follows tradition: the word-class of adverbs is taken as a fact, which includes the assumption of a word-class change from adjective to adverb, and -mente is considered a suffix. Hence, biases of grammatical traditions have to be taken into account. The main point is 'word-class obstinacy' (Maas 2010:82), that is, the intuition of the educated that the traditional word-class system works, even if it is clear that it does not work cross-linguistically (Croft 1990:13), e.g. for creole languages. In the domain under scrutiny here, Latin $-\bar{e}$ appears to be a clear example of a word-class bias created by traditional education. This morpheme was an instrumental case supposed to be already archaic in Classical Latin. However, to the extent that it was productive for adverbs, we might rather think that items such as alte were inflections of the adjective altus. The fact that grammars of Latin separate adjectives from adverbs is the reason why the inflectional status of $-\bar{e}$ is not discussed, the logic being that a change of word-class is incompatible with inflection (cf. Pittner 2015: 133). In modern terminology, it would be a case 
of indirect conversion, the same as En. highly (see Ricca 2004). Now, from the diachronic point of view, OE -lice (>-ly) was the neuter instrumental case of adjectives ending in -lic, that is, a case of the adjective, following the Germanic tradition. Hence, it was not an instance of conversion but one of inflection. The classification of forms ending in -lice as adverbs is a metalinguistic projection.

\subsection{Adverbial agreement}

Although invariability is the privileged positive morphological criterion for the word-class of adverbs, which is supposed to correlate with a series of so-called adverbial functions in syntax, "adverbial agreement" (Ledgeway 2011, and in this volume) with nouns referring to an argument of the verb is widespread in Romance, especially in older texts and in present-day spoken language. Adverbial agreement has long been overlooked. The landmark study by Ledgeway (2011) marks a turn in the discussion, tying up with older insights from Rohlfs (1969:241-4) on central and southern varieties of Italy. Ledgeway observes a systematic, rule-guided agreement of Type A with an argument of the verb. Roughly speaking, adverbial agreement correlates with low agentivity, and with undergoer roles in particular (see (12)-(14)). A series of similar studies on Italian dialects confirm this analysis (Cruschina 2010; Silvestri in this volume). While Ledgeway and others only consider VP modifiers, Hummel (2015) argues that adverbial agreement also concerns other syntactic functions. Portuguese has been analysed by Meier (1948), Martelotta (2012:31-2) and Hummel (in print b). Witness the following examples taken from the above-mentioned publications:

Secondary modifiers of VP

(9) (Fr.)

j'aime bien les traces dans la neige qui nous amène droits vers les maisons [sic] (Internet, informal)

'I like the tracks in the snow which bring us direct to the way home'

(10) (Fr.)

Je suis sur le point d'arrêter nette ma conso de cannabis (Internet, informal)

'I'm about to stop cold my cannabis use'

(11) (It.)

Ci sono bimbi che non nasceranno, e se ne vanno dritti in Paradiso

'There are children who will not be born, going direct to Paradise'

(12) (It.)

Gli anni passano veloci 'The years pass fast' 
(13) (It.)

Anna miscava bone 'i carte (dialect of Cosenza)

'Anna shuffled the cards well'

(14) (It.)

alla mia età la prostata non funziona bona (dialect of Ribera)

'At my age the prostate does not work well'

(15) (Sp.)

para ir directos al grano

'to go direct to the point'

(16) (Sp.)

[onbres de armas) que vengan justos a quien las a menester (16th c.)

'men-at-arms come together exactly to where they are needed'

(17) (Sp.)

vamos derechos a casa 'we go straight home'

(18) (Sp.)

las puertas cierran automáticas

'the doors close automatically'

(19) (Sp.)

llegamos puntuales

'we arrive punctually'

Tertiary modifiers

(20) (Fr.)

une femme toute contente

'a fully content woman'

fenêtres grandes ouvertes

'windows wide open'

fleurs fraîches écloses

'flowers freshly hatching'

fine bonne

'full good'

(21) (It.)

molti contenti

'full happy'

molte belle

'full nice'

bestie mezze selvaggie

'half-wild beasts' 
tutti pieni

'completely full'

tanta grande alterazione

'such a big change'

lunga distesa

'to extend over a long stretch'

(22) (Pt.)

ela é meia chata

'half annoying'

ela ficou toda contente

'she got full happy'

(23) (Rom.)

noi-născuţi

'newborn'

uşile erau largi deschise

'the doors were wide open'

studenţi puţini numeroşi

'only a few students'

(24) (Sp.)

muchachos medios perezosos

'half-lazy boys'

toda soñolienta

'full sleepy'

bastantes vagos

'quite lazy'

ciudadanos enfermos graves

'severely ill citizens'

una novela justa ganadora del premio Nadal

'a novel that just got the Nadal Prize'

mucha menos gente

'much less people'

iguales de difíciles

'as difficult as'

Modifiers in the determiner group

(25) (Fr.)

seules les femmes

'only the women' 
(26) (Sp.)

solos tres
'only three'
solos hombres
'only men'
solos los hombres
'only the men'
puros hijos de medicos
'only physicians' sons'
justos tres
'exactly/only three'

Adverbial agreement clearly is a tradition of Romance in general. The only exception seems to be Romanian, where the generalization of Type A goes hand in hand with invariability (Mîrzea Vasile \& Croitor, in this volume), but Chircu mentions cases of agreed adverbs (2008: 127; see (23)).

An important thing to observe is that agreement is not unmotivated or "illogical", as it would be called in French grammaticography. In Sp. medias tontas 'half crazy', Fr. toute contente, Sp. solos los hombres, etc., inflection follows the rule of agreement with the modified unit. The reason why Sp. medias tontas is rejected by linguistic norm is not the functional non-sense of agreement, which is indeed motivated by the modifier - modified relation, but the dogma of invariability.

Unmotivated inflection is a marginal phenomenon. To my knowledge, the only usual case of semantically unmotivated inflection is Pt. muita bom, which combines the feminine quantifier muita with the masculine form of the adjective bom for ludic emphasis in colloquial language. Fernández-Ordóñez (2015) mentions a similar noun-modifying usage in rural Spanish (e.g. mucha trabajo; see also Pato \& Fernández 2015). In such cases, the feminine morpheme - $a$ plays an intensifying role for the quantifier. Hence, the intentional violation of semantic agreement rules is pragmatically motivated.

Hummel (2015, in print a) shows that linguistic norms stigmatize adverbial agreement, imposing instead invariability as a major criterion for adverbs in 17 th-century purism. Hence, invariability is a strong natural tendency of adverbs, but the complete exclusion of agreement is a normative dogma. In a corpus covering the diachrony of Spanish, adverbial agreement abruptly disappears with upcoming purism and rationalism, continuing however in less norm-sensitive American Spanish (Hummel 2014b). In line with this, the new grammar of the Spanish Academies mentions Type A adverbs, recommending however to respect invariability (Real Academia-ASALE 2009: § 13.8d). 
At this point of the discussion, we may ask the question if the term 'adverbial agreement' conveys an adequate analysis of the data. It certainly reflects a widespread normative feeling in the above-mentioned sense. Traditionally, the Type A modifiers are termed 'adverbialized adjectives' or 'short adverbs'. However, in line with van Raemdonck (in this volume), we should question the assumption that adjectives are adverbialized in terms of word-class. Adverbial agreement can easily be explained if we claim that we still deal with adjectives and, consequently, adjectival agreement. Even if the syntactic function is primarily adverbial, adjectives maintain their capacity of secondarily modifying nominals. This explains both non-standard adverbial agreement and standard secondary predication. As shown by van Raemdonck (in this volume), Suñer (in this volume), and Hummel (in print $\mathrm{c}$ and $\mathrm{d}$, submitted), so-called adverbialized adjectives manifest a manifold series of modifications that fall into either adjectival or adverbial functions. Finally, this point of view coincides with Hengeveld's typological analysis (see 2.2). The only thing we have to add is that in the Western grammatical tradition strong normative efforts have been made in order to eradicate agreement whenever adjectives are used for adverbial functions ("used as adverbs", as this is generally called). In this cultural context, the adjectival agreement with adverbial functions is considered as adverbial agreement that violates the invariability rule.

Linguistic tests usually paraphrase attitudinal sentential adverbs as follows: Naturally, she thinks... = It is natural that she thinks... It is generally overlooked that this means that, semantically, the adverb naturally functions as a predicative adjectival modifier of the sentence, according to the scheme It is adj. that. As shown in Section 3, languages often simply use the adjective for this purpose. Diachronically, this strange expansion of adverbs to adjectival functions in Romance was probably a consequence of the 16th- and 17th-century fashion of excessively using Type B adverbs (Hummel, submitted). Emerging polyfunctionality and polysemy as a consequence of fashion and high frequency is well documented for oral discourse markers (Thompson \& Mulac 1991:314, 319). Interestingly, inflected parenthetical adjectives are used in the same position with a sentential focus: Sp. Furiosa, la chica se marchó 'Angry, the girl went away'. In VP, a similar situation can be observed for so-called subject-oriented adverbs (She entered furiously) and subject-oriented secondary predicates (She entered furious), the latter being inflected in Romance (Sp. Ella entró furiosa) (see e.g. Nakamura 1997; Valera 1998; Broccias 2011). This does not mean that the alternatives are fully equivalent, if the alternative exists, but it shows that they come close, up to the point that fashions or linguistic norms can favour one of the alternatives.

The fact that adverbs of time and space (tomorrow, here) are indeed invariable may be used to argue that things are more complicated. Indeed, adverbial inflection (7.1) and adverbial agreement (7.2) are not relevant for these adverbs of time and 
space which linguists consider core adverbs. However, as far as modifiers referring to a property/quality are concerned, both phenomena blur the nice normative picture of invariable adverbs and inflected adjectives. The interface of morphology, syntax and semantics turns into a playground for manifold emerging constructions sharing different sets of features (see Hummel, in print c).

\section{The expansion of attributive modification to peripheral functions}

The capacity of attributive modifiers to expand to contiguous linguistic functions seems to be a major property. However, only few authors emphasize the dynamics of "extension/transposition" (Ricca 2015).

For the sake of analytical coherence, I have argued in favour of separating attributive from circumstantial modification. Indeed, attributive modifiers do not belong to the lexical core of time or space adverbs. They nevertheless expand their functions to this domain as well. Witness the following examples for adverbial usage from spoken Chilean Spanish (Hummel 2013b; see also Company Company 2014:492 and Medina Gómez \& Alarcón Neve 2013):

Type A: actual 'now', anterior 'before', frecuente 'frequently', indefinido 'for an indefinite period', largo 'a long time', pronto 'soon', seguido 'frequently'

Type B: actualmente 'presently', eternamente 'eternally', mensualmente 'monthly', nuevamente 'newly', últimamente 'recently'

Type C: en seguida 'right afterwards', de nuevo 'again', por primero 'first of all', de repente 'suddenly'

These variants are all used as time adverbs at least in substandard, not only in Spanish (see attestations in Hummel 2013b). Since almost all of them are loanwords from Classical Latin, their usage in informal spoken languages presupposes a diachronic process of diffusion from educated language to common spoken language. The dynamics of expansion from attributive modification to time adverbials considerably increases in literary style, but only in favour of Type B. Most of the attested items never occur in informal oral communication. Witness Sp. desacompasadamente '(to beat) irregularly', entrecortadamente 'to have gasping breaths', incesantemente 'incessantly', presurosamente 'in haste', reiterativamente 'repeatedly', subrepticiamente 'surreptitiously', sincronizadamente 'synchronously', etc. Adverbs such as prontamente are variants used in elaborated style to replace common pronto, similar to (hypercorrect) En. firstly for first, etc. in discourse organization.

Elaboration may be defined as a special type of productivity tied to the architecture of language. The productivity of Type B adverbs has been widely discussed, some arguing that they are highly productive, others deny this property (see e.g. 
Goes 1999:217; Pittner 2015: 140). In fact, they are highly productive indeed. The restrictions are not driven by functional features but by communicative necessity or conceptual semantics (e.g. ?redly). To begin with the latter, redly can be formed without any problem, e.g. for poetic expressivity (see e.g. Meier 1948:107), but usage is very restricted. The underlying concept cannot easily be adapted to adverbial functions in common language. With regard to the former, everyday informal communication is soon saturated, but diachronically common written language has also reached saturation, that is, language has created enough Type B adverbs, even for literary style (Bally 1965:246-8; Company Company 2014). Type B adverbs can only be productive to the extent adjectives are. Technical language provides plain evidence. Once the adjective nanotechnical is created, the adverb nanotechnically is immediately available. This is what happened in diachrony: the lexical borrowing of the adjective Fr. rapide went hand in hand with rapidement (Hummel \& Kröll 2015). This fact is systematic in the diachrony of almost all English loan-adjectives (Hummel 2014a).

A second domain of expansion concerns functions in discourse. I have already mentioned the example of naturally and its equivalents in Romance expanding to the predicative discourse function 'It is natural that...' (7.2). This dynamics includes attributive modifiers such as Sp. bueno, claro, total, igual, fijo, etc. In sentences such as Yesterday, I went home and Tired, I went home attributive modification meets circumstantial modification since yesterday and tired refer to circumstances, although tired still functions as an attributive modifier of a unit in discourse (a tired person). Type A and Type B also expand to affirmative/negative (e.g. Fr. sûr, surement), connecting (e.g. Fr. sentence initial finalement 'finally') and discourse operating functions (e.g. Fr. apparemment 'apparently'). These functions are morphologically heterogeneous.

\section{Conclusion}

I have argued in favour of a more flexible approach to adjectives and adverbs in terms of coexisting word-class systems. The first word-class system consists in using a single word-class for both adjectival and adverbial functions (Type A). This explains why nominal agreement of Type A in adverbial functions still plays a role in Romance, in spite of the considerable efforts made during the cultural process of standardization to eradicate adjectival agreement from adverbial functions. The long Indo-European tradition of using Type A adverbs interacts in Romance and English with morphologically marked adverbs of manner (Type B), which are clearly favoured by linguistic norms. The expansion of Type B multiplies the interfaces between adjectives and adverbs, especially because both Type A and Type B are 
generally based on adjectives. Prepositional phrases (Type C) add more interfaces, especially those that also take an adjective as their lexical base. Linguistic research has traditionally concentrated on Type B adverbs. Therefore, the role played by Type $\mathrm{A}$ and Type $\mathrm{C}$ in diachrony and synchrony, in standard and varieties, and in registers requires further empirical investigation.

\section{References}

Abraham, Werner. 2013. Deutsche Syntax im Sprachenvergleich. Tübingen: Stauffenburg.

Alexiadou, Artemis. 2013. Adverbial and adjectival modification. In The Cambridge Handbook of Generative Syntax, Marcel den Dikken (ed.), 458-484. Cambridge: Cambridge University Press. doi: 10.1017/CBO9780511804571.017

Baker, Mark C. 2003. Verbs, Nouns and Adjectives. Cambridge: Cambridge University Press. doi: $10.1017 / C B O 9780511615047$

Bally, Charles. 1965. Linguistique générale et linguistique française, 4th edn. Berne: Francke.

Broccias, Cristiano. 2011. Motivating the flexibility of oriented -ly adverbs. In Motivation in Grammar and the Lexicon [Human Cognitive Processing 27], Klaus-Uwe Panther \& Günter Radden (eds), 71-87. Amsterdam: John Benjamins. doi:10.1075/hcp.27.06bro

Chircu, Adrian. 2008. L’adverbe dans les langues romanes. Cluj Napoca: Casa Cărţii de Ştiinţă.

Chircu, Adrian. 2011. Dinamica adverbului românesc. Ieri şi azi. Cluj Napoca: Casa Cărţii de Ştiinţă.

Cinque, Guglielmo. 1999. Adverbs and Functional Heads. Oxford: OUP.

Cinque, Guglielmo. 2004. Issues in adverbial syntax. Lingua 114: 683-710. doi: 10.1016/So024-3841(03)00048-2

Company Company, Concepción. 2012. Condicionamientos textuales en la evolución de los adverbios en -mente. Revista de Filología Española 92: 9-42. doi:10.3989/rfe.2012.v92.11.235

Company Company, Concepción. 2014. Adverbios en -mente. In Sintaxis histórica de la lengua española, Part III, Concepción Company Company (ed.), 457-611. México: Universidad Nacional Autónoma de México/Fondo de Cultura Económica.

Company Company, Concepción (ed). 2014. Sintaxis histórica de la lengua española, Part III. México: Universidad Nacional Autónoma de México/Fondo de Cultura Económica.

Croft, William. 1990. Typology and Universals. Cambridge: CUP.

Croft, William. 2001. Radical Construction Grammar. Oxford: OUP. doi:10.1093/acprof:oso/9780198299554.001.0001

Cruschina, Silvio. 2010. Aspetti morfologici e sintattici degli avverbi in siciliano. Caderni di Lavoro ASIt 11: 21-42.

Crystal, David. 2008. A Dictionary of Linguistics and Phonetics, 6th edn. Cambridge, MA: Blackwell. doi:10.1002/9781444302776

Dal, Georgette. 2007. Les adverbes de manière en -ment du français: Dérivation ou flexion? In Morphologie à Toulouse, Nabil Hathout \& Fabio Montermini (eds), 121-147. Munich: Lincom.

de Dardel, Robert. 1995. Le protoroman comme héritier de l'indo-européen (à propos de la construction clamare altum). In Latin vulgaire - latin tardif IV, Louis Callebat (ed.), 21-28. Hildesheim: Olms-Weidmann. 
de Dardel, Robert. 2009. La morphosyntaxe de l'adjectif-adverbe en protoroman. Vox Romanica 68: $1-22$.

Diccionari català-valencià-balear, Institut d'Estudis Catalans, <http://dcvb.iecat.net>

Eisenberg, Peter. 2002. Morphologie und Distribution. Zur Morphosyntax von Adjektiv und Adverb im Deutschen. In Das Adverb - Zentrum und Peripherie einer Wortklasse, Frederike Schmöe (ed.), 61-76. Wien: Präsens.

Erdmann, Peter. 1997. Supplementive adjective clauses in English. In Language history and linguistic modeling, Vol. 2: Linguistic modeling, Raymond Hickey \& Stanislaw Puppel (eds), 1433-1451. Berlin: Mouton de Gruyter.

Fábregas, Antonio. 2014. Adjectival and adverbial derivation. In The Oxford Handbook of Derivational Morphology, Rochelle Lieber \& Pavol Štekauer (eds), 276-295. Oxford: OUP. Fernández-Ordóñez, Inés. 2015. Mucha trabajo: Sincretismo femenino en los cuantificadores evaluativos de Cantabria. In Studium grammaticae. Homenaje al profesor José A. Martínez, Departamento de filología española (ed), 337-349. Oviedo: Universidad de Oviedo.

Fortson IV, Benjamin W. 2004. Indo-European Language and Culture. Oxford: Blackwell.

Frey, Werner. 2003. Syntactic conditions on adjuncts classes. In Modifying Adjuncts, Cathrine

Fabricius-Hansen, Ewald Lang \& Claudia Maienborn (eds), 163-209. Berlin: Mouton de Gruyter. doi: 10.1515/9783110894646.163

Fuentes Rodríguez, Catalina. 2001. Los marcadores del discurso, ¿una categoría gramatical? In Indagaciones sobre la lengua. Estudios de filología y lingüística españolas en memoria de Emilio Alarcos, Elena Méndez García de Paredes, Josefa Mendoza Abreu \& Yolanda Congosto Martín (eds), 323-348. Sevilla: Universidad de Sevilla.

García-Page Sánchez, Mario. 2008. Introducción a la fraseología española. Barcelona: Anthropos. García-Page Sánchez, Mario. 2014. Relaciones entre la morfología y la fraseología. In Fraseología y paremiología: Enfoques y aplicaciones, Vanda Durante (ed), 11-22. Madrid: Instituto Cervantes.

Giegerich, Heinz. 2012. The morphology of -ly and the categorial status of 'adverbs' in English. English Language and Linguistics 16(3): 341-359. doi:10.1017/S1360674312000147

Glatigny, Michel. 2005. L'éternel retour des adverbes en -ment. XVI ${ }^{\mathrm{e}}-\mathrm{XX}$ siècle. In L'adverbe: un pervers polymorphe, Jan Goes (ed.), 43-67. Arras: Artois Presses Université.

Goes, Jan. 1999. L'adjectif. Paris: Duculot.

Goes, Jan (ed.). 2005. L'adverbe: un pervers polymorphe. Arras: Artois Presses Université.

Guimier, Claude. 1985. On the origin of the suffix -ly. In Historical Semantics. Historical Wordformation, Jacek Fisiak (ed.), 155-170. Berlin: Mouton de Gruyter.

doi: $10.1515 / 9783110850178.155$

Haspelmath, Martin. 1996. Word-class-changing inflection and morphological theory. In Yearbook of Morphology 1995, Geert Booij \& Jaap van Marle (eds), 43-66. Dordrecht: Kluwer. doi:10.1007/978-94-017-3716-6_3

Hengeveld, Kees. 1992. Non-verbal Predication. Berlin: Mouton de Gruyter. doi: $10.1515 / 9783110883282$

Hengeveld, Kees, Rijkhoff, Jan \& Siewierska, Anna. 2004. Parts-of-speech systems and word order. Journal of Linguistics 40(3): 527-570. doi:10.1017/So022226704002762

Hengeveld, Kees \& van Lier, Eva. 2010. An implicational map of parts of speech. Linguistic Discovery 8: 129-156. doi:10.1349/PS1.1537-0852.A.348

Hummel, Martin. 2000. Adverbale und adverbialisierte Adjektive im Spanischen. Tübingen: Narr. Hummel, Martin. 2013a. Attribution in Romance: Reconstructing the oral and written tradition. Folia Linguistica Historica 34: 1-42. doi:10.1515/flih.2013.001 
Hummel, Martin. 2013b. Sincronía y diacronía de los llamados adjetivos adverbializados y de los adverbios en -mente. Anuario de Letras. Lingüística y Filología (UNAM) 1(2): 215-281.

Hummel, Martin. 2013c. La dimensión intercultural de la expansión diacrónica de los adverbios en -mente. In Los adverbios con función discursiva. Procesos de formación y evolución, María Pilar Garcés Gómez (ed), 5-41. Madrid \& Frankfurt: Iberoamericana \& Vervuert.

Hummel, Martin. 2014a. The adjective-adverb interface in Romance and English. In Adjectives in Germanic and Romance, Petra Sleeman, Freek Van de Velde \& Harry Perridon (eds), 35-71. Amsterdam: John Benjamins. doi:10.1075/la.212.02hum

Hummel, Martin. 2014b. Los adjetivos adverbiales. In Sintaxis histórica de la lengua española, Part III, Concepción Company Company (ed.), 613-731. México: Universidad Nacional Autónoma de México/Fondo de Cultura Económica.

Hummel, Martin. 2015. Los adverbios flexionados. In El discurso de la gramática, Carmen Galán Rodríguez, María Luisa Montero Curiel, José Carlos Martín Camacho \& María Isabel Rodríguez Ponce (eds), 205-233. Cáceres: Universidad de Extremadura.

Hummel, Martin. In print a. Éléments d'une diachronie grammaticographique de l'adverbe français. Accompagnés de trois méthodes pour mesurer son effet sur l'usage. Romanische Forschungen.

Hummel, Martin. In print b. Existe a concordância adverbial no português brasileiro? Considerações acerca de vamos diretos, todas contentes, bastantes grandes, muitas boas. In Funcionalismo linguístico - vertentes e diálogos, Mariangela Rios de Oliveira \& Maria Maura Cezario (eds). Rio de Janeiro: Eduff.

Hummel, Martin. In print c. Baseline elaboration at the adjective-adverb interface in French (and English).

Hummel, Martin. In print d. L'accord adverbial en français. In Cadrage sur la variation, le changement lexical et le changement grammatical en français actuel. Special issue of Revue de sémantique et pragmatique.

Hummel, Martin. Submitted. Romance sentence adverbs in -mente: epistemic mitigation in synchrony and diachrony.

Hummel, Martin \& Kröll, Andrea. 2015. Vite et vitement. Revue de Linguistique Romane 79: 39-91.

Hummel, Martin \& Stiegler, Karin. 2005. Dictionnaire historique de l'adjectif-adverbe. Database. $<$ http://languageserver.uni-graz.at/dicoadverbe/>

Hüning, Matthias \& Booij, Geert. 2014. From compounding to derivation. The emergence of derivational affixes through 'constructionalization'. Folia Linguistica 48(2): 579-604. doi:10.1515/flin.2014.019

Jespersen, Otto. 1992[1924]. The Philosophy of Grammar. Chicago IL: University of Chicago Press.

Karlsson, Keith E. 1981. Syntax and Affixation. The Evolution of MENTE in Latin and Romance. Tübingen: Niemeyer. doi:10.1515/9783111329017

Kaul de Marlangeon, Silvia. 2002. Los adverbios en -mente del español y su funcíon semántica de cuantificación. Madrid \& Frankfurt: Iberoamericana \& Vervuert.

Klein, Hans-Wilhelm. 1973. Courageusement - avec courage. Observations sur la structure de l'adverbe en français. Travaux de Linguistique et de Littérature 11: 407-414.

Kloss, Heinz. 1967. 'Abstand languages' and 'Ausbau languages'. Anthropological Linguistics 9: 29-41.

Kluge, Bettina. 2005. Identitätskonstitution im Gespräch: südchilenische Migrantinnen in Santiago de Chile. Frankfurt \& Madrid: Vervuert \& Iberoamericana. 
Kortschak, Carmen \& Hummel, Martin. In print. Los adverbios en -mente en el español hablado peninsular y mexicano: registros formal e informal. Nueva Revista de Filología Hispánica.

Langacker, Ronald W. 2008. Cognitive Grammar. Oxford: OUP.

doi:10.1093/acprof:0so/9780195331967.001.0001

Lapesa, Rafael. 2000. Sobre el adjetivo complementario circunstancial. In Estudios de morfosintaxis histórica del español, vol. 1, Rafael Lapesa (ed.), 272-287. Madrid: Gredos.

Lausberg, Heinrich. 1972. Romanische Sprachwissenschaft, Vol. 3. Berlin: Walter de Gruyter.

Ledgeway, Adam. 2011. Adverb agreement and split intransitivity: Evidence from Southern Italy. Archivio Glottologico Italiano 96: 31-66.

Löfstedt, Bengt. 1967. Bemerkungen zum Adverb im Lateinischen. Indogermanische Forschungen 72: 79-109.

Maas, Utz. 2010. Literat und orat. Grundbegriffe der Analyse geschriebener und gesprochener Sprache. Grazer Linguistische Studien 73: 21-150.

Marchand, Hans. 1967. Expansion, transposition, and derivation. La Linguistique 3(1): 13-26.

Martelotta, Mário. 2012. Advérbios - conceito e tendências de ordenação. In Adverbiais, Mariangela Rios de Oliveira \& Maria Maura Cezario (eds), 13-96. Niterói: UFF.

Martín Zorraquino, María Antonia. 2010. Los marcadores del discurso y su morfología. In Los estudios sobre marcadores del discurso en español, hoy, Óscar Loureda Lamas \& Esperanza Acín Villa (eds), 93-181, Madrid: Arco Libros.

Medina Gómez, Lorena \& Alarcón Neve, Luisa Josefina. 2013. El adverbio de manera corto en el español formal de México. Verba Hispanica 21: 55-74. doi:10.4312/vh.21.1.55-74

Meier, Harri. 1948. Adjectivo e advérbio. In Ensaios de filologia românica, Harri Meier (ed.), 55-114. Lisboa: Edição da Revista de Portugal.

Meyer-Lübke, Wilhelm. $1972\left(=^{1} 1894\right)$. Grammatik der romanischen Sprachen, Vol. 2. Hildesheim: Olms.

Molinier, Christian. 1963. L'incidence de l'adverbe et l'adverbialisation des adjectifs. Travaux de Linguistique et de Littérature 1: 175-194.

Nakamura, Wataru. 1997. A cognitive approach of English adverbs. Linguistics 35: 247-248. doi:10.1515/ling.1997.35.2.247

Pato, Enrique \& Viejo Fernández, Xulio. 2015. Mucho bien y mucho guapa: Mu(n)cho como cuantificador 'pleno' de adjetivos y adverbios en castellano y asturiano. <http://www.corpusrural. es/publicaciones/2015/2015_mucho_bien.pdf>

Pinkster, Harm. 1972. On Latin Adverbs. Amsterdam: North-Holland.

Pittner, Karin. 2015. Between inflection and derivation. Adverbial suffixes in English and German. In Pittner, Elsner \& Barteld (eds), 133-156. doi:10.1075/slcs.170.06pit

Pittner, Karin, Elsner, Daniela \& Barteld, Fabian (eds). 2015. Adverbs. Functional and Diachronic Aspects [Studies in Language Companion Series 170]. Amsterdam: John Benjamins. doi: $10.1075 /$ slcs.170

Plag, Ingo. 2003. Word-formation in English. Cambridge: CUP doi:10.1017/CBO9780511841323

Pottier, Bernard. 1970. Lingüística moderna y filología hispánica. Madrid: Gredos.

Radford, Andrew. 1988. Transformational Grammar. Cambridge: CUP. doi:10.1017/CBO9780511840425

Radford, Andrew. 2004. Minimalist Syntax. Cambridge: CUP. doi:10.1017/CBO9780511811319

Rainer, Franz. 1993. Spanische Wortbildungslehre. Tübingen: Niemeyer. doi:10.1515/9783110956054 
Rainer, Franz. 1996. Inflection inside derivation: evidence from Spanish and Portuguese. In Yearbook of Morphology 1995, Gert Booij \& Jaap van Marle (eds), 83-91. Dordrecht: Kluwer. doi:10.1007/978-94-017-3716-6_5

Ramat, Paolo. 2008. Les adverbes latins du point de vue de l'indo-européen. In Adverbes et évolution linguistique en latin, Michèle Fruyt \& Sophie van Laer (eds), 13-24. Paris: L'Harmattan.

Ramat, Paolo \& Ricca, Davide. 1994. Prototypical adverbs: On the scalarity/radiality of the notion of adverb. Rivista di Linguistica 6: 289-326.

Ramat, Paulo \& Ricca, Davide. 1998. Sentence adverbs in the languages of Europe. In Adverbial Constructions in the Languages of Europe, Johan van der Auwera (ed), 187-275. Berlin: Mouton de Gruyter. doi:10.1515/9783110802610.187

Rauh, Gisa. 2015. Adverbs as a linguistic category. In Pittner, Elsner \& Barteld (eds), 20-45.

Real Academia Española/Asociación de Academias de la Lengua Española. 2009. Nueva gramática de la lengua española, Vol. 1. Madrid: Espasa Libros.

Renzi, Lorenzo. 2005. Italiano e romeno. Quaderni del premio letterario Giuseppe Acerbi 6: 55-60.

Renzi, Lorenzo, Salvi, Giampaolo \& Cardinaletti, Anna (eds). 2001. Grande grammatica italiana de consultazione, Vol. 2. Bologna: Il Mulino.

Ricca, Davide. 1998. La morfologia avverbiale tra flessione e derivazione. In Ars linguistica, Giuliano Bernini, Pierluigi Cuzzolin \& Piera Molinelli (eds), 447-466. Roma: Bulzoni.

Ricca, Davide. 2004. Conversione in avverbi. In La formazione delle parole in italiano, Maria Grossmann \& Franz Rainer (eds), 550-553. Tübingen: Niemeyer.

Ricca, Davide. 2015. Adverbial categories. In Word-formation, Vol. 2 [HSK 40], Peter O. Müller, Ingeborg Ohnheiser, Susan Olsen \& Franz Rainer (eds), 1390-1406. Berlin: De Gruyter.

Ricós Vidal, Amparo. 2012. A reculas, a hotas, a sabiendas, a la deshilada, a la callada, a la sorda: Más sobre locuciones adverbiales. In Fablar bien y tan mesurado, Adela García Valle et al. (eds), 63-86. Valencia: Tirant.

Rodríguez Molina, Javier. 2014. Adverbios y locuciones adverbiales de manera. In Sintaxis histórica de la lengua española, Part III, Concepción Company Company (ed.), 733-937. México: Universidad Nacional Autónoma de México/Fondo de Cultura Económica.

Rohlfs, Gerhard. 1969. Grammatica storica della lingua italiana e dei suoi dialetti, Vol. 3. Torino: Enaudi.

Salazar García, Ventura. 2007. Flexibilidad categorial y adverbios de manera en español: Un enfoque functional. In Estudios lingüísticos, literarios e históricos. Homenaje a Juan Martínez Marín, Pedro Barros García, Gonzalo Águila Escobar \& Esteban Tomás Montoro del Arco (eds), 309-326. Granada: Universidad de Granada.

Salvi, Giampaolo \& Renzi, Lorenzo (eds). 2010. Grammatica dell'italiano antico, 2 Vols. Bologna: Il Mulino.

Sandmann, Manfred. 1946. On neuter adjectives determining verbs with special reference to French and Spanish. The Modern Language Review 41: 24-34. doi:10.2307/3717490

Schäfer, Martin. 2013. Positions and Interpretations. German Adverbial Adjectives at the SyntaxSemantics Interface. Berlin: De Gruyter. doi:10.1515/9783110278286

Schwenk, Hans-Jörg. 2015. Sind Adjektiv und Adverb verschiedene Wortarten? Frankfurt: Peter Lang. doi: 10.3726/978-3-653-06003-4

Sonntag, Eric. 2005. Lexeme, Morpheme und Kategoreme. Die Wortkategorie Adverb und die adverbialen Wortklassen des Französischen und Spanischen. Aachen: Shaker. 
Štekauer, Pavol. 2015. The delimitation of derivation and inflection. In Word-formation, Vol. 2 [HSK 40], Peter O. Müller, Ingeborg Ohnheiser, Susan Olsen \& Franz Rainer (eds), 218-235. Berlin: De Gruyter.

Štekauer, Pavol, Valera, Salvador \& Körtvélyessy, Lívia. 2012. Word-formation in the World's Languages. Cambridge: CUP. doi:10.1017/CBO9780511895005

Tagliamonte, Sali \& Ito, Rika. 2002. Think really different: Continuity and specialization in the English dual-form adverbs. Journal of Sociolinguistics 6: 236-266. doi:10.1111/1467-9481.00186

Telschow, Claudia. 2014. Die Adjektiv-Adverb-Abgrenzung im Deutschen: zu grundlegenden Problemen der Wortartenforschung. Berlin: De Gruyter. doi:10.1515/9783110341485

Thompson, Sandra A. \& Mulac, Anthony. 1991. A quantitative perspective on the grammaticization of epistemic parentheticals in English. In Approaches to Grammaticalization, Vol. 2: Focus on Types of Grammatical Markers [Typological Studies in Language 19], Elizabeth C. Traugott \& Bernd Heine (eds), 313-329. Amsterdam: John Benjamins. doi:10.1075/tsl.19.2.16tho

Throm, Hermann. 1984. Lateinische Grammatik. Düsseldorf: Schwann.

Valera, Salvador. 1998. On subject-orientation in English -ly adverbs. English Language and Linguistics 2(2): 263-282. doi:10.1017/S1360674300000885

Valera, Salvador. 2004. Conversion vs. unmarked word-class change. SKASE Journal of Theoretical Linguistics 1(1): 20-42.

Valera Hernández, Salvador. 1996. Adjetivos y adverbios en inglés: La relación de homomorfia. Granada: Universidad de Granada.

Van Raemdonck, Dan. 2005. L'adverbe, adjectif du verbe? Répartition des rôles. In L'adverbe: Un pervers polymorphe, Jan Goes (ed.), 23-42. Arras: Artois Presses Université.

Vasile, Carmen. 2013. Adverbul românesc între continuitate latină, specific balcanic şi evoluţie internă. Bucharest: Editura Muzeului Naţional al Literaturii Române. 


\title{
CHAPTER 2
}

\section{Parameters in Romance adverb agreement}

\author{
Adam Ledgeway \\ University of Cambridge
}

\begin{abstract}
Many Romance varieties are known to employ adjectives in adverbial function. This paper explores the parameters involved in the distribution of agreement of adjectival manner adverbs across Romance. Agreement is shown to be sensitive to specific structural configurations which can ultimately be retraced to the phenomenon of split intransitivity: agreement is typically controlled by nominals which at some level of representation are associated with the object relation, although some exceptions to this generalization are noted producing what appear to be ergative patterns. Looking at such evidence from within and beyond Italy, the paper sketches a typology of the differing licensing conditions on adjectival adverb agreement in Romance in an attempt to identify the precise semantico-syntactic parameters involved in the relevant patterns.
\end{abstract}

\section{Introduction: Narrowing the field}

Following Hummel (2000; 2011:4; 2014:36), Romance attribution may be expressed either by a bicategorial system (1a), where the categories of adjective and adverb are formally distinguished, or a monocategorial system (1b), in which the two categories fall together into a single syncretic class:

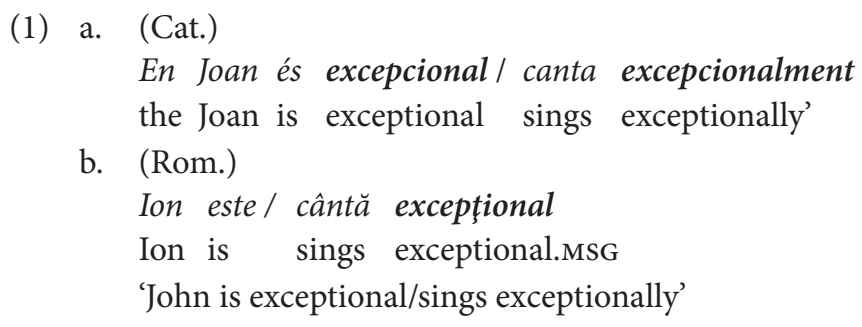

However, even standard varieties with bicategorial systems show monocategorial uses of specific adjectives (2a-e; cf. Chircu 2008: 106, 251f; Hummel 2011: 18; 2014:37f; 2013:226f): 
(2) a. (Sp.) Los hombres trabajan duro

b. (Pt.) Os homens trabalham duro

c. (Fr.) Les hommes travaillent dur

d. (It.) Gli uomini lavorano sodo

e. (Cat.) Els homes treballen dur

the men work.3PL hard.MSG.

'The men work hard'

The distribution of the two options appears to be subject to diachronic, diatopic, diamesic and diastratic variation, inasmuch as bicategorial attribution "appears to be a cultural phenomenon that recurrently occurs in socio-historical contexts of standardized literacy", whereas monocategorial attribution "is profoundly rooted in oral tradition(s) and consequently reemerges where the impact of literacy fails or weakens" (Hummel 2014:48). Unsurprisingly, then, adjectival adverbs prove most frequent in those periods and areas of Romance predating the rise of standardization (e.g. early Romance) or the establishment of a shared western literary tradition and the rise of -men $(t(e))$ adverbs (e.g. Daco-Romance; Hummel 2014:48), ${ }^{1}$ or where the effects of standardization have been less conspicuous (e.g. colloquial usage, Romània nova; Hummel 2011:13, 16;2015:\$5.2) or absent (e.g. dialects of Italy; Rohlfs 1969:243-5; Ledgeway 2000:272-5; 2003; 2009: 724-9; 2011a: § 6.2.4; 2011b; Manzini \& Savoia 2005: III, 211-13; Cruschina 2010).

Furthermore, we find variation across Romance between contexts and varieties in which the adjective in adverbial function may display agreement with an accompanying nominal, witness the contrast between (3) and (4): ${ }^{2}$

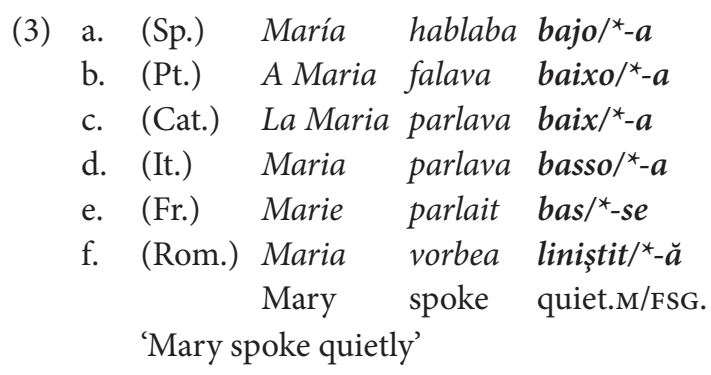

(4) a. (coll.Sp.) Vamos directos a la playa

b. (coll.Pt.) Vamos diretos à praia we.go direct.MPL to the beach

'We go directly to the beach'

1. Cf. Dinică (2012), Mîrzea Vasile (2012a; b), Dinică \& Mîrzea Vasile (2013).

2. In what follows we do not discuss the frequent agreement of so-called tertiary attributes (Chircu 2008: 127; Hummel 2011:22; 2014:40-2; $2015 \$ 3$; in press a). 


\section{c. (Leccese) A bui bu trattamu bueni \\ to you.PL you.PL = we.treat good.MPL}

'We treat you well'

d. (Catanzarese) Nèscia spontanea

it.comes.out spontaneous.FsG

'[The word.FsG] comes out spontaneously'

e. (Sic.) Basta ca ti mariti bedda pulita

it.suffices that you $=$ marry beautiful.FsG nice.FSG

'You simply need to marry well'

The structural conditions determining the agreement or otherwise of the adjectives in (3)-(4) will form the focus of the rest of this article, where we shall review the different parameters of adjectival adverb agreement observed across Romance. In the final section we shall briefly sketch how such agreement patterns may be interpreted in theoretical terms and in relation to current assumptions regarding parameters.

\section{Parameters of adverbial agr(eement)}

\subsection{Pattern 1: No agr}

We begin our survey with monocategorial systems in which the adjective proves totally inert for agreement, invariably occurring in the masculine singular default form irrespective of the presence of any potential nominal controllers. This is the situation found in Romanian (Mîrzea Vasile 2012a, b; Dinică \& Mîrzea Vasile 2013:437) and some northern Italian dialects (Rohlfs 1969:244; Manzini \& Savoia 2005:211), witness the following examples where the adjective fails to agree with the clausal object, be it a full DP (5a) or a clitic (6), or the clausal subject (5b):

(5) a. (Rom.)

Rezolv legal/*-ă problema

I.solve legal.MSG/FSG problem.F.the.FSG

'I solve the problem legally'

b. (Rom.)

Fetele răspund corect/-*e

girls.the reply.3PL correct.MSG/FPL

'The girls answer correctly'

(6) (Cerano, Piedmont)

0 'fatfa-l/-la / 'fatf-i pi'lit

I.have done $=i$ it.M $/=$ it.F done $=$ them clean.MSG

'I did it/them well' 
To conclude, we should recall that this pattern of zero agreement also characterizes those standard Romance varieties which, despite displaying a system of bicategorial attribution, allow adjectival adverbs in a small number of restricted contexts (cf. 3a-f).

\subsection{Pattern 2: Full active/stative split}

The second pattern we consider is widely found among southern Italian dialects (Ledgeway 2011b; 2012: Chapter 7), ${ }^{3}$ which systematically show agreement of adjectival adverbs under specific structural conditions. In these varieties agreement of the adjective cannot be controlled by an Agent/Actor subject $\left(\mathrm{A} / \mathrm{S}_{\mathrm{A}}\right)$, namely a transitive/unergative subject, but can be controlled by a transitive object $(\mathrm{O})$ or an Undergoer subject $\left(\mathrm{S}_{\mathrm{O}}\right)$, namely an unaccusative subject. The result is a classic active/stative split (7), where adverb agreement systematically discriminates between internal arguments generated as immediate constituents of the verb in the complement position, from which they can license agreement, and external arguments generated as modifiers of the verb+complement constituent from where they fail to license agreement.

(7) $\left[{ }_{\mathrm{VP}}\left[{ }_{\mathrm{NP}} \mathrm{A} / \mathrm{S}_{\mathrm{A}}\right]_{\mathrm{k}}\left[\mathrm{V}^{\prime} \mathrm{V} \operatorname{Adv}_{\mathrm{i}}\left[{ }_{\mathrm{NP}} \mathrm{O} / \mathrm{S}_{\mathrm{O}}\right]_{\mathrm{i}}\right]\right]$

This explains why in the following Cosentino examples the adverb fails to display agreement with the transitive/unergative subject in (8a), but does agree with the transitive object in $(8 b)$ and the unaccusative subjects in $(8 c-d)$.

(8) a. (Cos.)

Maria studia buonu/ *bona ('u libbru)

Maria studies good.MSG good.FSG the.Msg book.M

'Maria studies (the book) hard'

b. (Cos.)

Maria un' criscia buoni $\underline{a} \quad \underline{r i}$ figli

Maria not raises good.MPL to.ACC the children.MPL

'Maria does not bring the children up properly'

c. (Cos.)

Maria haddi cada bona

Maria will fall.INF good.FsG

'Maria will come down well and truly with a bump'

3. Where examples appear without references, they come from the author's own investigations with native informants. In some cases, examples have also been taken from published sources (e.g. plays by local playwrights). 
d. (Cos.)

Maria si lítica bona ccu ra suoru

Maria self $=$ argues good.FSG with the sister

'Maria argues fiercely with her sister'

Significantly, it is this same active/stative split that we find in the distribution of participle agreement in many Romance varieties such as Italian (Loporcaro 1998, 2016: § 49.2; Bentley 2006: 189ff.; Ledgeway 2012: \$ 7.3.1.2), where participle agreement is also controlled by transitive objects (9b) and unaccusative subjects ( $9 c-d)$, but never by transitive/unergative subjects $(9 a):^{4}$

(9) a. (It.)

Maria ha studiato $^{*}-a$ (il libro)

Maria has studied.MSG/FSG the.MSG book.M

'Maria studied (the book) hard'

b. (It.)

I figli, Maria non $\underline{\underline{i}}$ ha tirati ${ }^{*}{ }_{-}$o $\quad$ su bene

the kids Maria not them $=$ has pulled.MPL/MSG up well

'The kids, Maria didn’t bring them up properly'

c. (It.)

$\underline{\text { Maria }}$ è caduta $/{ }^{*}$ o male

Maria is fallen.FsG/MSG badly

'Maria came down well and truly with a bump'

d. (It.)

Maria si è litigata ${ }^{*}$-o bene con la sorella

Maria self $=$ is argued.FSG/MSG well with the sister

'Maria argued fiercely with her sister'

Given the presence of such adverb agreement, varieties such as Cosentino can readily discriminate between subject- and object-oriented readings (cf. event- vs participant-oriented attribution in Hummel 2011:26-7; 2013:246s). Thus, although both versions of (10) can both be translated as 'Anna shuffled the cards well', the non-agreeing buonu signals an eventive subject-oriented reading of the adverb (viz. 'Anna was adept at shuffling the cards'), whereas the agreeing feminine plural bone

4. The parallelism referred to here concerns the structural conditions under which both adverbial agreement and past participle agreement are licensed This does not imply, however, that a variety that displays participle agreement necessarily exhibits adverb agreement or vice versa (cf. independence of distribution of participle agreement and argument-driven have be auxiliary selection across Romance). On the contrary, the two phenomena represent separate parametric options, as highlighted by the absence of any reference to participle agreement in the adverb agreement parametric subhierachy in Figure 2. 
licenses an object-oriented reading in which the resultant state of shuffling the cards is emphasized ( $v i z$. 'Anna gave the cards a good shuffle').

(10) (Cos.)

Anna miscava buonu/ bone 'i carte

Anna shuffled good.Msg good.FPL the.PL cards.F

'Anna shuffled the cards well'

Indeed, as argued in Ledgeway (2011b), the agreeing form in examples such as (10) licenses a resultative reading of the adjective which functions as a predicative complement of the Undergoer argument whilst simultaneously specifying the manner in which the event is brought about. Consequently, the predicative resultative and manner readings fall together formally and semantically in monocategorial systems (at least in those licensing agreement), as in the Matinese example (11a), whereas in bicategorial systems like Italian the two readings are kept formally and semantically distinct through the distinctive use of the adjective (11b) and adverb (11c), respectively.



The same active/stative split is also attested in various diachronic and diatopic varieties of Spanish and French in those cases and registers in which they make recourse to an adjectival adverb. For instance, from an examination of the Spanish CNDE corpus (www-gewi.uni-graz.at/dicoadverbe), ${ }^{5} 298$ inflected forms (excluding ambiguous masculine singular forms) were identified. Excluding 36 probable cases of secondary predication and 3 inexplicable cases, ${ }^{6}$ the remaining 259 cases

5. I thank Martin Hummel for making this database available to me.

6. The relevant examples are: 
of adverb agreement were controlled either by a transitive object (12a-b) or an unaccusative subject $(12 \mathrm{c}-\mathrm{d}) \mathbf{:}^{7}$

(12) a. (Sp.)

Mandólos colgar altos

she.ordered=them.M hang.INF high.MPL

'She ordered that they be hung up high' (Libro de buen amor; 1330-43)

b. (Sp.)

Ofrecía baratos los iconos

he.offered cheap.MPL the.MPL icons.m

'He offered the icons cheaply'

(El escarabajo; 1982; Argentina)

c. (Sp.)

la noche que avanzaba lenta, pausada, numismática

the.FSG night.F that advanced slow.FSG unhurried.FSG numismatic.FSG 'the night which was advancing slowly, unhurriedly, gradually'

(El Señor Presidente; 1933-46; Guatemala)

d. (Sp.)

dirigióse rápida a su alcoba

she.directed=self quick.FSG to her bedroom

'She quickly went off to her bedroom'

(Tipos y paisajes; 1871)

An analogous distribution is found in the DICO-FR corpus, where out of 492 audible inflected forms (excluding masculine singular forms) 24 probable cases of secondary predication were identified leaving a residue of 468 cases of adjectival adverbs in which agreement is variously controlled once again either by a transitive
(1) a. (Sp.)
$\begin{array}{lllll}e & \text { asy dize alta en otro testo } \\ \text { and thus (s)he.says loud.FSG in other text }\end{array}$
'and thus it(?) is said explicitly(?) in another text'

b. (Sp.)

(Traducción y glosas de la Biblia de Alba, II; 1422-1433)

QUE Portugal mire humana al Rey que en la tumba yace that Portugal look.sBjv human.Fsg to.the king that in the tomb lies 'That Portugal should look upon the King humanly/as a human(?)who lies in the tomb'

(Descripción de las reales exequias de Carlos III que se hicieron en la ciudad de Guatemala; 1789; Guatemala)

c. (Sp.)

Vamos rápida, que se nos desangran we.go quick.FSG that self $=$ us= they.bleed

'Let's leave quickly, 'coz they're bleeding us dry'

(La fuente de la edad; 1986)

7. Martin Hummel (p.c.) points out that, in contrast to Latin America, such examples occur in the Iberian Peninsula only until around the 17 th century. 
object (13a-b) or an unaccusative subject $(13 c-d)$, but never by a transitive/unergative subject:

(13) a. (Fr.)

la coupe de cèdre que le bûcheron a creusée assez the.FSG cut.F of cedar that the woodcutter has hollowed quite profonde dans le bois

deep.FsG in the wood

'the cut in the cedar which the woodcutter cut deeply into the wood'

b. (Fr.)

la vie était abominable, comment pouvait-on la vivre the.FSG life.F was awful how could=one it. $\mathrm{F}=$ live.INF

paisible et heureuse?

peaceful.sG and happy.FSG

'life was awful, how could you live it peacefully and happily?'

c. (Fr.)

Même une feuille morte qui tombe toute légère

even a.F leaf.F dead.Fsg that falls all.FSG light.FsG

'Even a dead leaf which lightly falls'

d. (Fr.)

des colonnes de fumée s' élevant toutes droites some columns.F of smoke self= raising all.FPL straight.FPL 'columns of smoking rising straight up'

Returning now to the varieties of southern Italy, also of interest here are apparent counterexamples to the active/stative split. To all appearances, these involve agreement with an unergative subject, as in the Sicilian examples (14a-b):

(14) a. (Sic.)

Iddi sunu. Boni travagghianu

they are good.MPL they.work

'It's them. They are good workers'

b. (Sic.)

Mi pari ca a famigghia camina bona

$\mathrm{me}=$ it.seems that the.FSG family.FSG walks good.FSG

'I don't think, after all, that our family is so badly off'

Nonetheless, it is well known that some intransitives prove ambiguous, ${ }^{8}$ allowing both an unergative and unaccusative reading. Such is the case in $(14 a-b)$ where

8. Cf. Burzio (1986: 122-6), Lonzi (1986), Saccon (1992), Parry (2000), Cresti (2003), Bentley (2006:230-42, 267-8). It should be noted here for clarification that unaccusative readings of 
travagghiari and caminari are not being used with their canonical unergative activity/accomplishment interpretations 'to work' and 'to walk' with an Agent subject, but are being employed as unaccusatives with the respective stative readings 'to be a (good) worker' and 'to make (good) progress, function' with an Undergoer subject. This explains the observed adverb agreement in these examples.

A similar explanation accounts for the agreeing/non-agreeing forms of Italian svelta/svelto in (15) taken from Antrim (1994): in the former case the predicate functions as an unaccusative predicating an ongoing characteristic of the subject (namely, 'Maria is a quick-talker'), hence the observed agreement with the Undergoer subject, whereas in the latter case there obtains an unergative activity reading (namely, 'Maria is talking quickly') and agreement with the Agent/Actor subject proves impossible.

(15) (It.)

Maria parla svelta/ svelto $\quad\left(\right.$ Maria $\left.=\mathrm{S}_{\mathrm{O} / \mathrm{A}}\right)$

Maria speaks swift.FsG swift.MSG

'Maria is a quick-talker / is talking quickly'

A more telling case is provided by the Italian contrast with correre 'to run' in (16a-b) where, following Napoli (1975:423f.), we see that the adverb agreement facts correlate with the other canonical reflexes of the active/stative split manifested in the choice of auxiliary and the absence/presence of participle agreement:
a. (It.)
Maria ha corso * ${ }^{*}$ svelta/ svelto
Maria has run.MSG swift.FSG swift.MSG
$\left(\right.$ Maria $\left.=\mathrm{S}_{\mathrm{A}}\right)$
b. (It.)
Maria è corsa svelta/ ${ }^{*}$ svelto
Maria is run.FSG swift.FSG swift.MSG
'Maria ran fast'

To conclude, we summarize in Table 1 the distributional patterns of adverb agreement observed so far. Whereas in Romanian (together with other standard Romance varieties) and northern Italian dialects (NIDs) adjectival adverbs were shown to be entirely inert for agreement (Pattern 1) - presumably underlying a nominative/accusative alignment according to which all subjects are marked uniformly (albeit without further differentiation from objects) -, Pattern 2 was shown to instantiate a robust active/stative split in southern Italian dialects (SIDs) in which

\footnotetext{
unergative verbs in examples such as (14) and (15) are independent of the presence or otherwise of adjectival adverbs, inasmuch as adverb agreement in such examples is a consequence, and not the cause, of the relevant readings.
} 
adverb agreement is licensed solely by Undergoer/internal arguments, but never by Agent/external arguments.

Table 1. Distribution of Romance adverb agreement

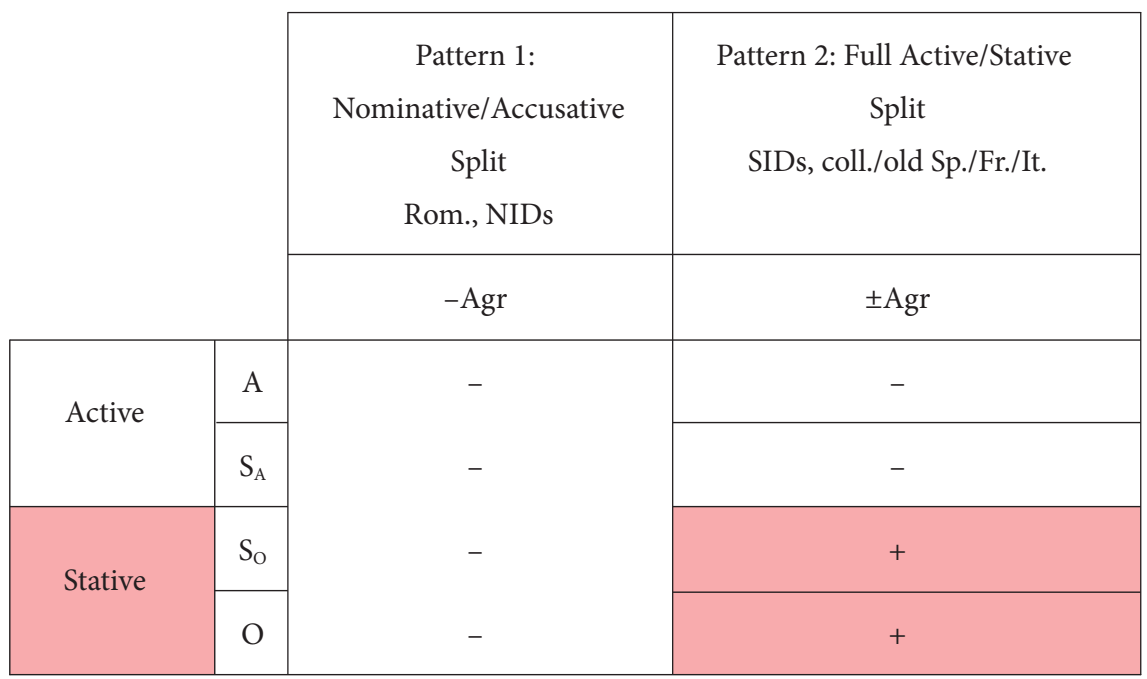

\subsection{Pattern 3: Restricted active/stative split}

Above we observed how the active/stative split witnessed in the distribution of Romance participle agreement is paralleled by the distribution of agreement with Romance adjectival adverbs. Thus, conservative Romance varieties like modern Lengadocien (Loporcaro 1998; Ledgeway 2012:300f., 317-19) robustly display past participle agreement with unaccusative subjects (17a) and all types of transitive object, irrespective of whether they surface as full DPs in postverbal (17b) or preverbal (17c) position or as clitic pronouns (17d). Similarly, numerous southern Italian dialects systematically display Pattern 2 agreement of adjectival adverbs with unaccusative subjects (18a) and transitive objects, be they full DPs in postverbal (18b) or preverbal (18c) position or clitics (18d):

(17) a. (Lgd.)

Ma maire era tombada

my.FSG mother was fallen.FSG

'My mother had fallen down'

b. (Lgd.)

Avèm visitadas fòrça vilas coma Lorda we.have visited.FPL many towns.F like Lourdes

'We have visited many towns like Lourdes' 
c. (Lgd.)

Los vilatges qu' avèm traversats

the.MPL villages.m that we.have crossed.MPL

'The villages we've passed through'

d. (Lgd.)

Vos ai menats a Lorda

you.PL I.have led.MPL to Lourdes

'I took you to Lourdes'

(18) a. (Leccese)

$\underline{\text { Ll }}$ affari ànu fiacchi

the matters.m go.3PL bad.MPL

'Business is going badly'

b. (Matinese)

Quannu faci $\underline{e}$ cose bone le faci

when you.do the.FPL things.F good.FPL them.F= you.do

a metà

at half

'When you do things well you don't finish them off'

c. (Cos.)

na canzuna ca saccciu sunà bona a ra chitarra

a.F song.F that I.know play.INF good.FSG at the guitar' 'a song that I can play well on the guitar'.

d. (Leccese)

$\underline{L} \quad \ddot{a} \quad$ uardata bona?

her= you.have looked.at good.FSG

'Did you take a good look at her?'

However, there are a number of less conservative Romance varieties where participle agreement reveals a more restricted active/stative split (Smith 1993, 1999; Loporcaro 1998, 2016: 804; Bentley 2006: 189ff., 242-7). Exemplary in this respect is modern Italian which has unrestricted agreement of the past participle with unaccusative subjects (19a), but displays a more restricted distribution of agreement with transitive objects. In particular, full DP objects, whether in postverbal or preverbal position, invariably fail to license agreement (19b), while object clitics invariably trigger agreement if third person (19c) and only optionally so if nonthird person (19d-e), with a growing tendency for non-agreement to obtain in this latter case.

(19) a. (It.)

I vicini sono partiti

'The neighbours have left' 
b. (It.)

(I vicini che) avevo visto ${ }^{*}-i \quad \underline{i v i c i n i}$

the.MPL neighbours.M that I.had seen.MSG/MPL the.MPL neighbours.M '(The neighbours which) I had seen the neighbours'

c. (It.)

$\underline{L}$ 'li/le avevano vist-o/-a/-i/-e

it.M/F=/them.M/F=they.had seen-MSG/-FSG//-MPL/-FPL

'They had seen him/her/them'

d. (It.)

$\underline{\mathrm{Mi}} \underline{\mathrm{ti}} \quad$ avevano vist-o/-a

$\mathrm{me}=/$ you.sG $=$ they.had seen-MSG/-FSG

'They had seen me/you (= FSG)'

e. (It.)

$\underline{\mathrm{Ci} /}$ vi avevano vist-o/-i/-e

$\mathrm{us}=$ /you.PL $=$ they.had seen $-\mathrm{MSG} /-\mathrm{MPL} /-\mathrm{FPL}$

'They had seen us/you (= M/FPL)'

Significantly, this restricted active/stative split found in the distribution of participle agreement in many Romance varieties such as Italian is paralleled in the distribution of adverb agreement in some southern Italian dialects. ${ }^{9}$ By way of illustration,

9. As Martin Hummel (p.c.) points, an interesting question which remains to be investigated is the robustness of agreement with secondary predication in French according to the structural conditions outlined in (19). For instance, we might expect agreement in examples such as (1.a) to be more resilient than in examples such as $(1 . b-c)$, a question we leave for future research.

(1) a. (Fr.)

La soupe que j'ai mangée chaud(e)

the.FSG soup.F that I have eaten(.FSG) hot.FSG

'The soup which I ate hot'

b. (Fr.)

Je $\underline{l}$ ai mangée chaud(e)

I it.FSG have eaten.FSG hot(.FSG)

'I ate it hot'

c. (Fr.)

J'ai mangé chaud(e) la soupe

I have eaten.MSG hot(.FSG) the.FSG soup.F

'I ate the soup hot'

While we have already seen an example of type (i.a) in (13a) above, an example of type (i.b) has been pointed out to me by M. Hummel (p.c.) and is exemplified in (2).

(2) (Fr.)

je l' ai tirée basse dans le ventre

I it.FSG $=$ have shot.FSG low.FSG in the belly

'I shot it [= harpoon arrow] in the lower belly [of the kingfish]' 
consider the following examples from the eastern Abruzzese dialect of Arielli (R. D’Alessandro, p.c.):

a. (Arielli)

$\underline{\text { Tutte }} \underline{\text { li }}$ cose a riscite bbune

all the.PL things.F have turned.out good.PL

'Everything has turned out well'

b. (Arielli)

Giorge pittineve bbone/*bbune li fije

Giorgia combed good.sG/good.PL the children

'Giorgia combed the children's hair well'

c. (Arielli)

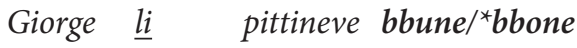

Giorgia them $=$ combed good.PL/good.sG

'Giorgia combed them well'

Whereas the adverb agrees freely with unaccusative subjects (20a), agreement with a transitive object proves more selective, inasmuch as it is excluded with a full DP object (20b), but proves obligatory if the object is cliticized (20c). Indeed, the parallels between Ariellese adverb agreement and Italian participle agreement extend even further, as illustrated by the following Ariellese examples where the transitive object is represented by various classes of pronominal clitic. In (21a) the clitic is third person and agreement with the adverb proves obligatory, just as in the case of Italian participle agreement (cf. 19c). However, if the clitic is first or second person (21b), then the acceptability of agreement is considerably degraded with speakers' judgments ranging from marginal to entirely ungrammatical (R. D'Alessandro p.c.), largely on par with the facts seen above for Italian (cf. 19d-e). A further distinction also arises in conjunction with third-person reflexives, where agreement proves robust with argumental reflexives (21c), but at best marginal or ungrammatical with non-argumental reflexives in accordance with their antipassive (21d) or middle (21e) function:

(21) a. (Arielli)

Falle bbune / *bbone!

do.IMP2sG=them good.PL good.sG

'Do them well!'

b. (Arielli)

Gianne $j^{\prime} / \underline{v}^{\prime}$ a mminite bbone/ ?bbune

Gianni us= you.PL has beaten good.sG good.PL

'Gianni gave us/you a good beating' 
c. (Arielli)

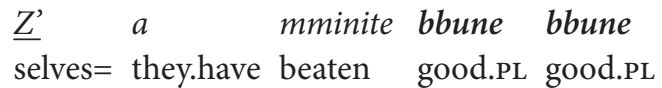

'They gave one another a good thrashing'

d. (Arielli)

$\underline{Z}$ a litte bbone/ *bbune lu giurnale

selves $=$ have read good.sG good.PL the newspaper

'They've read the newspaper'

e. (Arielli)

$\underline{Z}$ a 'ngazzite bbone bbone/ *bbune bbune

selves $=$ have got.angry good.sG good.sG good.PL good.PL

'They got really angry'

f. (Arielli)

Nin $\underline{z}$ avé ddurmite bbone / ‘bbune

not selves $=$ they.had slept good.sG good.PL

'They hadn't fallen asleep properly'

As summarized in Table 2, the adverb agreement pattern observed in varieties such as Ariellese exemplifies an active/stative split similar to Pattern 2, but with the difference that it further discriminates between different types of DP object controller in accordance with the nominal vs pronominal distinction.

Table 2. Distribution of Romance adverb agreement

\begin{tabular}{|c|c|c|c|c|}
\hline & & $\begin{array}{c}\text { Pattern 1: } \\
\text { Nominative/Accusative } \\
\text { Split } \\
\text { Rom., NIDs }\end{array}$ & $\begin{array}{c}\text { Pattern 2: Full } \\
\text { Active/Stative } \\
\quad \text { Split } \\
\text { SIDs, coll./old } \\
\text { Sp./Fr./It. }\end{array}$ & $\begin{array}{c}\text { Pattern 3: } \\
\text { Restricted } \\
\text { Active/Stative } \\
\text { Split } \\
\text { Ariellese }\end{array}$ \\
\hline & & -Agr & \pm Agr & - \\
\hline & A & - & - & - \\
\hline & $\mathrm{S}_{\mathrm{A}}$ & - & - & - \\
\hline & $\mathrm{S}_{\mathrm{O}}$ & - & + & + \\
\hline Stative & $\mathrm{O}_{\text {Pron }}$ & - & + & + \\
\hline & $\mathrm{O}_{\mathrm{DP}}$ & - & + & - \\
\hline
\end{tabular}




\subsection{Pattern 4: Ergative split}

The final pattern of adverb agreement that we have identified can be informally defined in terms of an ergative split. This pattern is found once again in a number of southern Italian dialects (cf. Manzini \& Savoia 2005: 211-13; Silvestri 2014), notably in Campania (Torre Orsaia, S. Giorgio del Sannio), Puglia (Minervino Murge), Calabria (Gizzeria, Iacurso), and Sicily (Mussomeli (S.Cruschina p.c.), Belmonte Mezzagno). On a par with other southern dialects, in these varieties adjectival adverbs systematically agree with Undergoer arguments, namely transitive objects (22a-b, 23a) and unaccusative subjects (22c-d, 23b):

a. (Muss.)

I sacciu fari bùani/ *bùanu $\underline{\text { spacchetti }}$

them= I.know do.INF good.PL good.MSG the.MPL spaghetti.m

'I know how to cook spaghetti well'

b. (Muss.)

$S^{\prime} \quad \underline{u}$ liggiaru bùanu/ *bùani u giornali

selves $=$ it.m they.read good.MsG good.PL the.MSG newspaper.m

'They read the newspaper thoroughly'

c. (Muss.)

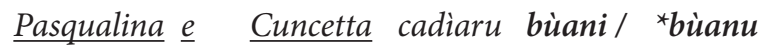

Pasqualina and Cuncetta fell good.PL good.MsG

'Pasqualina and Cuncetta took a great fall'

d. (Muss.)

Iddri un 's avivanu addrummisciutu bùani / *bùanu

they not selves $=$ they.had fallen.asleep good.PL good.MSG

'They hadn't fallen asleep well/deeply'

(23) a. (Gizzeria)

$\underline{\mathrm{u}} /$ a / $\underline{\mathrm{i}}$ 'lavu b'bonu / b'bona / b'boni

him $=$ her= them $=$ I.wash good.MSG good.FSG good.PL

'I wash him/her/them properly'

b. (Gizzeria)

'illu / 'illa s a 'llavatu b'bonu / b'bona

he/she self = has washed good.MSG good.FSG

'H/she washed thoroughly'

However, in contrast to dialects exhibiting the active/stative agreement Patterns 2 and 3, dialects of this group also permit agreement with an intransitive Agent/Actor subject, namely with the subject of an unergative predicate: ${ }^{10}$

10. For the behaviour of northern Calabrian dialects, see the discussion in relation to Figure 2 below and, in particular, the discussion in Silvestri (this volume). 
(24) a. (Muss.)

L' abbocati parlaru lianti

the lawyers spoke slow.PL

'The lawyers spoke slowly'

b. (Muss.)

Maria joca bona

Maria plays good.FsG

'Maria plays well'

c. (Muss.)

$\underline{\text { Iddra }}$ canta stunata

she sings off.key.FsG

'She sings out of tune/badly'

(25) a. (Gizzeria)

'illu/'illa a ddor'mutu b'bonu / b'bona

he/she has slept good.Msg good.FsG

'He/She has slept well'

b. (Iacurso)

a'via Sor'mutu b'buenu / b'bona

had.3sg slept good.MsG good.FSG

'He/She had slept well'

c. (Torre Orsaia)

a ddur'mutu 'tantu b'bellu / b'bella

has slept so pretty.MSG pretty.FSG

'He/She has slept so well'

d. (Minervino Murge)

o dər'muta b'bunə/ b'bonə

has slept good.m good.F

'He/She has slept well'

e. (S. Giorgio)

'isso/'essa 'rorme b'buono / b'bona

he/she sleeps good.MsG good.FSG

'He/She sleeps well'

f. (S. Giorgio)

'rormono b'buoni / b'buone

they.sleep good.MPL good.FPL

'They sleep well'

g. (Belmonte Mezzagno)

rur'mi b'bonu / b'bona // rur'meru b'bonə

slept.3sg good.MSG good.FSG they.slept good.PL

'He/She // They slept well' 
However, agreement with an unergative subject in such cases is not obligatory, but is subject to meaningful variation (see below), witness the possibility of apparently default masculine singular agreement (chiaru) alongside masculine plural agreement (chiari) with the subject in (26):

(26) (Muss.)

L' abbocati parlaru chiaru/ chiari

the lawyers talked clear.MSG clear.MPL

'The lawyers talked clearly'

To understand such variation, we propose, following classic proposals in Hale \& Keyser $(1993 ; 2002)$, that unergatives should be analysed as hidden transitives derived from underlying structures in which a null (light) verb selects for a cognate object, a nominal root, which raises to incorporate into the verbal root, as informally sketched in the simplified Figure 1 for talk:

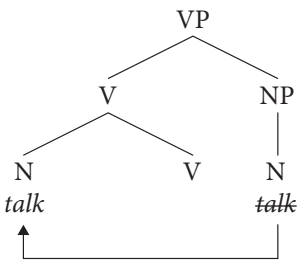

Figure 1. Structure of unergatives

On this view, the variation witnessed in examples such as (26) now finds a principled explanation: whenever the adverb agrees with the subject we obtain a subject-oriented reading (27a) which simultaneously implies an eventive reading (namely, 'the lawyers were clear, hence their talk was given clearly'), while the masculine singular form of the adverb (27b) does not signal a lack of agreement but, rather, highlights an overt agreement relation with the implicit cognate object, hence the so-called default masculine singular form assumed by the adverb (cf. also lexicalized cases of the masculine singular adjective in the standard varieties observed in $(2 \mathrm{a}-\mathrm{e})$ and $(3 \mathrm{a}-\mathrm{f})$ above). This analysis is further confirmed by the interpretation of such sentences where the adverb predicates a resultative reading of the implied complement, e.g. 'the lawyers gave a clear talk', albeit simultaneously implying an eventive interpretation (namely, 'the talk was given clearly by the lawyers').

(27) a. (Muss.)

$\underline{L}^{\prime} \quad$ abbocati $_{i}$ parlaru chiari ${ }_{i}$

the lawyers spoke clear.PL

'The lawyers spoke clearly (= the lawyers were clear, hence their point/talk made/given clearly)' 
b. (Muss.)

L' abbocati parlaru chiaru OBJECT $_{i}$

the lawyers spoke clear.MSG овJECT

'The lawyers made their point clearly/gave a clear talk (= point made clearly by the lawyers)'

The difference between the two structures in $(27 a-b)$ is further highlighted by the differing aspectual properties of their eventive interpretations (cf. Vendler 1967; Dowty 1979): while the subject-oriented reading of the adverb gives rise to an activity interpretation of the verb in (27a), the masculine singular agreement with the implied object in (27b) necessarily licenses an accomplishment reading of the verb. This is straightforwardly substantiated by standard diagnostics for activity and accomplishment readings such as the felicity of durative for-adverbials (activities) and time span in-adverbials (accomplishments), witness the ungrammaticality of the masculine singular form of the adverb in (28) with the durative adverbial pi uri 'for hours', as well as the contrasting minimal pair in (29a-b):

(28) (Muss.)

L' abbocati parlaru chiari/ *chiaru pi uri

the lawyers spoke clear.PL clear.MSG for hours

'The lawyers spoke clearly for hours' (*'The lawyers gave a clear talk for hours.')

(29) a. (Muss.)



Maria replies just.FSG just.MSG for hours

'Maria answers correctly for hours'

b. (Muss.)

Maria arrispunni giustu/ ${ }^{*}$ giusta ntra n' ura

Maria replies just.MSg just.Fsg in an hour

'Maria answers correctly (= finds/gives correct answer) in an hour'

Although adverb agreement with unergative subjects appears principally restricted to certain dialects of southern Italy, our Spanish CNDE corpus also provides two otherwise isolated early examples of agreeing claro 'clear' with hablar 'talk' (30a-b) surprisingly similar to examples such as (27a), although the examples in (31a-c) would appear to show, as in southern Italy (cf. 27b), that such agreements oscillate with the masculine singular form of the adverb:

(30) a. (OSp.)

$\begin{array}{ll}\text { hablemos } & \text { claros } \\ \text { speak.SBJv.1PL } & \text { clear.MPL }\end{array}$

'let us speak clearly' (= let us be frank in our speech?; Correo del otro mundo; 1725) 
b. (OSp.)

\section{Don Félix, hablemos claros}

Don Félix speak.SBJv.1PL clear.MPL

'Don Félix, let us speak clearly' (= let us be frank in our speech?; La petimetra; 1762)

(31) a. (OSp.)

\section{hablemos claro \\ speak.SBJv.1PL clear.MSG}

'let us speak clearly' (= let us put it frankly?; El viaje entretenido; 1603)

b. (OSp.)

Mire, Ascanio, hablemos claro

look Ascanio speak.sBJv.1PL clear.MSG

'Look, Ascanio, let us speak clearly' (= let us put it frankly?; Loa...; 1638)

c. (OSp.)

$\begin{array}{ll}\text { Hablemos } & \text { claro } \\ \text { speak.SBJv.1PL } & \text { clear.MPL }\end{array}$

'Let us speak clearly' (= let us put it frankly?; El siglo pitagórico...; 1644)

The synopsis of adverb agreement patterns presented in Table 3 highlights how the present pattern of agreement is not oriented towards an active/stative split distinguishing between Agent/Actor $\left(\mathrm{A} / \mathrm{S}_{\mathrm{A}}\right)$ and Undergoer $\left(\mathrm{O} / \mathrm{S}_{\mathrm{O}}\right)$ arguments but, rather, operates in terms of an ergative split. In particular, the Pattern 4 distribution of

Table 3. Distribution of Romance adverb agreement

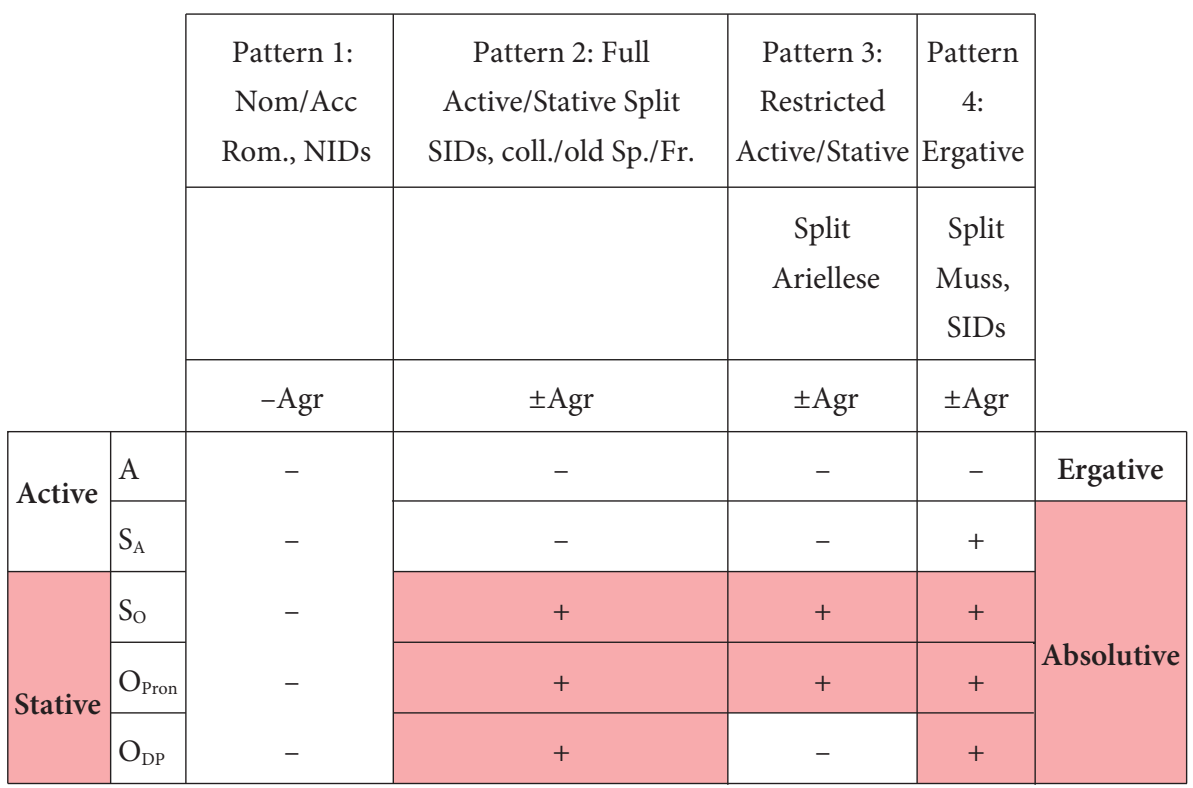


adverb agreement overtly discriminates on the one hand between transitive Agents/ Actors (A), which fail to control agreement, and all other arguments, namely intransitive subjects (be they Agents $\left(\mathrm{S}_{\mathrm{A}}\right)$ or Undergoers $\left(\mathrm{S}_{\mathrm{O}}\right)$ ) and transitive objects (O) on the other, which all systematically qualify as adverb controllers.

\section{Formal approach: A quick sketch}

Keeping the technical detail to a minium, in this final section we briefly sketch how the different parameters of agreement observed above can be accounted for in formal terms. The approach is based on recent analyses in Ledgeway (2011b:55ff; in press a: \$2.1.1.3) who, following Jackendoff (1972), Ramat \& Ricca (1998) and Cinque (1999: 19-28), argues that adverbs may occur in one of three positions within the clause: (1) a high position Adv1 associated with the Infl/T-domain licensing subject-oriented adverbs which may occur before or after auxiliaries; (2) a clausemedial position Adv2 associated with the pre- $v$-VP area licensing event-oriented (manner) adverbs that occur after the lexical verb; and (3) a low VP-final position Adv3 licensing resultative process-oriented (manner) adverbs that occur in clausefinal position. These three adverb positions and their distinct interpretations are exemplified in the Italian sentence (32) taken from Ledgeway (in press a), where all three positions are simultaneously lexicalized:

(32) (It.)

Ugo (ha) furbamente (ha) risposto sovversivamente alle loro Ugo (has) cunningly (has) replied subversively to.the their domande erroneamente questions erroneously

'Ugo was cunning by replying in a subversive manner to their questions with incorrect answers'

As revealed by the English translation, the so-called manner adverbs (characterized by their distinct -mente '-ly' ending) in (32) have different scopal properties, the first serving to modify the subject ('cunningly'), the second the manner in which the event constituted by the Infl-/T-domain was carried out ('subversively'), and the third the manner in which the process denoted by the lexical VP was completed ('incorrectly'). These readings are confirmed by their relative appropriateness as answers to the three questions in $(33 \mathrm{a}-\mathrm{c})$. 
(33) a. (It.)

Com'è stato Ugo nel rispondere alle loro domande? (Adv1) how is been Ugo in.the reply.INF to.the their questions

'How was Ugo in his answers to their questions?'

b. (It.)

Come ha risposto Ugo?

how has replied Ugo

'How did Ugo answer?'

c. (It.)

Come ha risposto alle loro domande, Ugo?

how has replied to.the their questions Ugo

'How did Ugo answer their questions?'

In relation to the low Adv3 position which licenses the resultative interpretation, we note that in many instances even in standard bicategorial Romance varieties adverbs can variously alternate in this position with adjectives, the formal category canonically employed to mark resultative predication. This is illustrated below with the following Italian alternations where the formal choice of adjective or adverb is for many speakers subject to free variation, although both options are often equally judged to be less than perfectly grammatical. ${ }^{11}$

(34) a. (It.)

(?)da Forgione pagherai queste scarpe

at Forgione's you.will.pay these.F shoes.F

salatamente / salate

expensively expensive.FPL

'You'll pay for these shoes dearly at Forgione's'

b. (It.)

(?)Ugo mi tagliava $\underline{i}$ capelli stranamente /

Ugo me $=$ cut.PST the.MPL hairs.M strangely

strani (strani)

strange.MPL strange.MPL

'Ugo left my hair looking (most) strange'

11. The resultative interpretation of the adverb/adjective in this position is further evidenced by the fact that many speakers strongly prefer reiteration of the adjective in such cases, a typical reflex of resultative predication in (Italo-)Romance (cf. Bentley 2006:340). 
c. (It.)

(?)D' estate Ida vestiva $\underline{i} \underline{\text { bimbi leggermente / }}$

of summer Ida dressed the.MPL kids.m lightly

leggeri (leggeri) (It.)

light.MPL light.MPL

'In the summer Ida would dress the children in light clothing'

d. (It.)

La ragioniera calcolerà $\underline{i}$ costi precisamente /

the accountant will.calculate the costs precisely

(?)precisi (precisi)

precise.MPL precise.MPL

'The accountant will calculate the costs (most) precisely'

If we now integrate the three adverb positions identified above with general assumptions about the structure of the clause, we can interpret the relevant Romance adverb facts in terms of the representation in (35):

$$
\text { [ } \left.{ }_{\mathrm{IP}} \operatorname{Aux} \operatorname{Adv1}\left[{ }_{v \mathrm{p}} \underline{\mathrm{ACTOR}}\left(\mathrm{A} / \mathrm{S}_{\mathrm{A}}\right) \mathrm{V}-v \operatorname{Adv} 2\left[\mathrm{VP} \underline{\mathrm{UNDERGOER}}\left(\mathrm{O} / \mathrm{S}_{\mathrm{O}}\right) \forall \mathrm{Adv} 3-\operatorname{ResultP}\right]\right]\right]
$$

We begin our analysis with the active/stative Pattern 2 where we noted that in these varieties the adverb agrees exclusively with Undergoers $\left(\mathrm{O} / \mathrm{S}_{\mathrm{O}}\right)$, inasmuch as it functions as a resultative predicative complement of the Undergoer argument whilst simultaneously specifying the manner in which the event is carried out. Taking Cosentino Example (36) as our model, ${ }^{12}$ we maintain that the adjectival adverb is first generated in the lower Adv3 position from where it enters into a local agreement relation with the object inside the VP licensing the observed resultative interpretation of the same. From this base position, however, we argue that the adjectival adverb raises to the clause-medial Adv2 position, a movement which crucially explains both the superficial linear order, whereby the adverb typically comes to precede the object, and the observed hybrid resultative-eventive reading of the adverb, which not only functions as a resultative predicative complement of the Undergoer argument (licensed in its base-position Adv3), but also specifies the manner in which the process was carried out (licensed in its derived position Adv2).

(36) (Cos.)

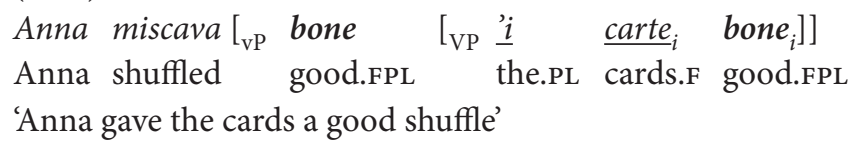

12. Note that for expository simplicity, we do not illustrate the movement of the lexical verb from within the VP in the following simplified structural representations. 
Turning to the minimally different example (37) where the adverb now fails to show agreement appearing in the default masculine singular form, here we argue that the adjectival adverb is directly inserted in the clause-medial position Adv2. This immediately explains why the adjectival adverb fails to agree with the object and license a resultative reading of the latter, since it does not enter into a local agreement configuration with the object in the VP at any point in the derivation. By contrast, being base-generated within the $v$ P naturally predicts the adverb's observed event-oriented reading, though, note, that in varieties displaying Pattern 2 the adverb does not agree with the Agent/Actor subject (viz. the external argument) also base-generated in the $v \mathrm{P}$.

(37) (Cos.)

Anna miscava ${ }_{\nu \mathrm{P}}$ buonu $\left[_{\mathrm{VP}}{ }^{\prime} \quad\right.$ carte $\left.]\right]$

Anna shuffled good.Msg the.PL cards.F

'Anna shuffled the cards well/competently/adeptly'

As for Pattern 3, we have observed that dialects such as Ariellese behave essentially like varieties displaying Pattern 2, with the difference that objects only trigger agreement under particular structural conditions. The relevant facts are illustrated again in (38a-b):

a. (Arielli)

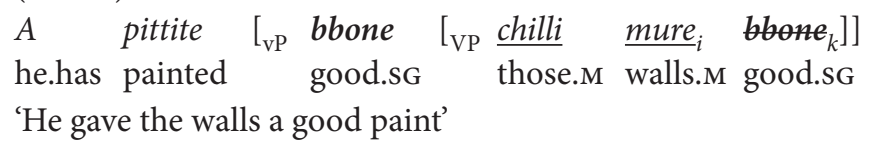

b. (Arielli)



them $=$ he.has painted them $=$ good.PL them $=$ good.sG

'He gave them a good paint'

As in Kayne's (1989) classic analysis of Romance participle agreement, the correct empirical generalization is that in these varieties a full DP in its base position within the VP is unable to control agreement of the adjective in Adv3 (cf. 38a), but must overtly raise through the potential agreement target (cf. $38 \mathrm{~b}$ ) to produce the required configuration that triggers agreement on the adverb. In short, the relevant locality configuration which licenses agreement in varieties displaying Pattern 2 proves insufficient in Ariellese. Rather, for agreement to obtain in Ariellese the adjective and the object must enter into a very specific local agreement configuration which can only obtain when the object passes through the left edge of the adverb (or, more precisely, through the adverb's associated specifier position), a movement which only arises when the object is represented by a pronominal clitic as in (38b). As a clitic, the latter is forced to raise (initially as a DP) from its base-position within 
the VP to cliticize as a head to the finite verb raised to the Infl/T-domain, passing en route through the adjectival adverb now raised to Adv2 from Adv3. Note that this equally explains the relevant agreement facts with unaccusative subjects (cf. 20a) which, in raising from their base-position within the VP to the canonical preverbal subject position within the Infl/T-domain, must also pass through the specifier of the adjectival adverb producing the required local specifier-head relationship that licenses the observed agreement. ${ }^{13}$

We now turn to the ergative Pattern 4, where we observed, in contrast to Patterns 2 and 3, unergative contrasts such as (39a-b) from the Sicilian dialect of Mussomeli.

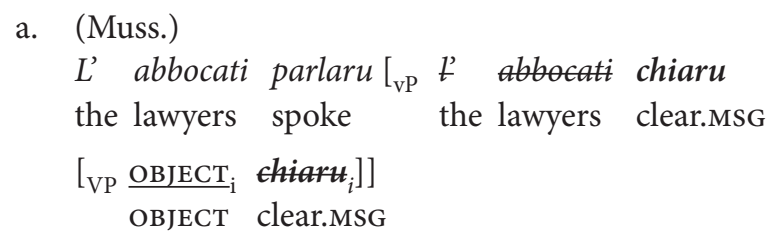

a. (Muss.)

$L^{\prime}$ abbocati parlaru $\left[_{\mathrm{vP}}{ }^{\prime}\right.$ becati chiaru

the lawyers spoke the lawyers clear.MSG

$\left[\mathrm{VP} \frac{\mathrm{OBJECT}_{\mathrm{i}}}{\text { chiaru }_{i}}\right]$ ]

OBJECT clear.MSG

b. (Muss.)

$L^{\prime} \quad$ abbocati $_{i}$ parlaru $\left[{ }_{\mathrm{VP}} t^{\prime}\right.$ chocati $_{i}$ chiari $_{i} \quad\left[{ }_{\mathrm{VP}}\right.$ OBJECT$\left.]\right]$ the lawyers spoke the lawyers clear.MPL овJECT

In (39a) we have a canonical case of the adjectival adverb base-generated in Adv3, from where it licenses a resultative interpretation of the implicit null object (овJECT) within the VP and with which it enters into a local agreement configuration, hence the apparent default masculine singular agreement on the adjective. As noted, however, in examples such as (39a) the adverb receives a hybrid resultative-eventive reading which we interpret once again as a direct consequence of adverb raising from Adv3 to Adv2, from where the scope of adverbial modification ranges over the event instantiated by the $\mathrm{vP}$ constituent (ultimately producing the observed accomplishment reading 'the lawyers gave a clear talk'). Crucially, this analysis explicitly excludes the possibility of the raised adverb entering into an agreement relation with the subject l'abbocati in its base-position within the vP, since it has already agreed with the implicit object in the VP such that its agreement features are no longer available for re-evaluation in its derived surface position.

13. Note that in many varieties such as Ariellese unaccusative subjects also frequently occur in situ within the VP, in which case any co-occurring adverbs continue to exhibit agreement. In such cases we assume that the postverbal subject establishes a long-distance dependency (e.g., a CHAIN) with a preverbal null argument (pro) in the canonical subject position (Cardinaletti 1997; 2004), a dependency which can only be established by the subject's features being copied into the intermediate specifier position of the adverb raised to Adv2. 
In (39b), by contrast, the adjective is directly inserted in Adv2, from where it licenses an event-oriented (but crucially not a resultative) reading of the adverb. Consequently, the adverb does not enter into a prior agreement relation with the object and is a priori free to agree with any other nominal in the structure. Indeed, unlike in the other southern varieties that we have seen, from this pre-VP position the adjectival adverb enters into a local agreement configuration with the subject, also base-generated in the $v \mathrm{P}$, giving rise to the reported subject-oriented activity reading 'the lawyers spoke clearly'.

\subsection{Parameter hierarchies}

Since the conception in early Government and Binding Theory of Universal Grammar in terms of a small set of abstract parameterized options, much work over recent decades has radically departed from this view with a focus on predominantly surface-oriented variation (cf. Borer 1984). This has led to the proliferation of a remarkable number of local, low-level parameters interpreted as the (PF-) lexicalization of specific formal feature values of individual functional heads in accordance with the so-called Borer-Chomsky Conjecture (Baker 2008b:353). While this approach may prove descriptively adequate in that it predicts what precisely may vary (cf. Kayne 2000; 2005a, b; Manzini \& Savoia 2005), it suffers considerably from explanatory inadequacy. Among other things, it necessarily assumes such microparameters to be highly local and independent of one another. This assumption seriously increments the acquisitional task of the child who has to set each value in isolation of the next on the basis of the primary linguistic data alone, and at the same time exponentially multiplies the number of parametric systems and, in turn, the number of possible grammars predicted by UG (cf. Kayne 2005b: 11-15; Roberts 2014).

One way to avoid the proliferation of grammatical systems that such a microparametric approach predicts, while still accommodating morphosyntactic variation like that witnessed for Romance adverb agreement, is to assume a theory that combines some notion of macroparameters alongside microparameters (Baker 1996; 2008a; b). Following ideas first proposed by Kayne (2005b: 10) and further developed by Roberts \& Holmberg (2010) and Roberts (2012), progress in this direction has recently been made by the Rethinking Comparative Syntax (ReCoS) research group based in Cambridge; ${ }^{14}$ their central idea is that macroparameters

14. Recent publications of the ReCoS project (http://recos-dtal.mml.cam.ac.uk/) include Biberauer, Holmberg, Roberts \& Sheehan (2012), Biberauer \& Roberts (2012, in press), Roberts (2012). See also Ledgeway $(2013,2015$, in press b). 
should be construed as the surface effect of aggregates of microparameters acting in unison, ultimately as some sort of composite single parameter. On this view, macroparametric effects obtain whenever all individual functional heads behave in concert, namely are set identically for the same feature value (e.g. in a consistently head-final language such as Japanese ${ }^{\star}$ all ${ }^{\star}$ heads will bear a movement feature of some kind guaranteeing uniform head-finality which invariably places complements to the left of their heads), whereas microparametric variation arises when different subsets of functional heads present distinct featural specifications (e.g. in mixed languages such as German where verbal heads bear the relevant movement feature, but nominal heads do not). Conceived in this way, parametric variation can be interpreted in a scalar fashion and modelled in terms of parametric hierarchies. Macroparameters, the simplest and least marked options that uniformly apply to all functional heads, are placed at the very top of the hierarchy, but, as we move downwards, variation becomes progressively less 'macro' and, at the same time, more restricted with choices becoming progressively more limited to smaller and smaller proper subsets of features (namely, no $F(p)>$ all $F(p)>$ some $F(p)$, for $F$ a feature and $\mathrm{p}$ some grammatical behaviour). More specifically, functional heads increasingly display a disparate behaviour in relation to particular feature values which may, for example, characterize: (1) a naturally definable class of functional heads (e.g. [+N], [+finite]), a case of mesoparametric variation; (2) a small, lexically definable subclass of functional heads (e.g. pronominals, auxiliaries), a case of microparametric variation proper; and (3) one or more individual lexical items, a case of nanoparametric variation.

In light of these assumptions, we may now reinterpret the distribution of Romance adverb agreement in terms of a small-scale parametric hierarchy along the lines of Figure 2, ultimately part of a larger hierarchy related to clausal alignment (for discussion, see Sheehan 2014, in press).

The gradual cascading effect produced by the options presented in Figure 2 highlights how variation in relation to the ability of the (functional projection hosting the) adjectival adverb to probe the person/number agreement features of specific nominals is not uniform but, rather, licenses differing degrees of surface variation in accordance with the growing markedness conditions that accompany the available parametric options as one moves down the hierarchy. The simplest and least constrained system is exemplified by Romanian and northern Italian dialects (Pattern 1), where the adverb quite simply never displays any agreement, failing to enter into an agreement relation with any DP. Its mirror image is the pattern of adverb agreement analysed by Silvestri, this volume (cf. also Silvestri 2014), for some northern Calabrian dialects such as those spoken in Verbicaro (Vb.), Santa Maria del Cedro (SM.) and Orsomarso (Om.), where the adverb simply agrees with any plural DP, be it the internal or external argument (with the expected concomitant 
Are Agr features of Adv controlled by DP arguments?


Figure 2. Parametric hierarchy for Romance adverb agreement

interpretive differences). Consequently, in these latter dialects the adverb can probe the person/number features of transitive (40a), unergative (40b) or unaccusative (40c) subjects, as well those of transitive objects (40d).

(40) a. (SM.)

Rita mèts svelta u grans
Rita reaps quick.FSG the.MSG wheat.m
'Rita quickly harvests the wheat'

b. (Or.)

Chira quatrara ha zumbata bona ppu scanto

that.FSG girl has jumped good.FSG for.the fear

'That girl jumped out of her skin out of fear'

c. (Vb.)

Maria no campado bòna

Maria not lives good.FsG

'Maria hasn't got an easy life'

d. (SM.)

Vito sta pattènno pulita sa parita

Vito stands painting clean.FsG this.FsG wall.F

'Vito's painting the wall accurately' 
In this respect, both groups of languages represent rather simple and relatively unmarked options, in that the adverb in these varieties either indiscriminately fails to probe all DP arguments or, on the contrary, systematically probes all DP arguments.

Slightly more constrained, though still liberal by general Romance standards is the pattern found in varieties such as Mussomelese (Pattern 4), where the adverb only probes a subset of DP arguments, namely intransitive subjects (whether $\mathrm{S}_{\mathrm{A}}$ or $\mathrm{S}_{\mathrm{O}}$ ) and transitive objects $(\mathrm{O})$, but not transitive subjects $(\mathrm{A})$, giving rise to an ergative split. This ergative pattern is further constrained in many southern Italian dialects (Pattern 2) by the further restriction that the adverb can only probe the person/number features of a subset of intransitive subjects, namely those bearing the Undergoer role $\left(\mathrm{S}_{\mathrm{O}}\right)$. The result is an active/stative split-S alignment in which the absence/presence of agreement on the adverb formally distinguishes between $\mathrm{S}_{\mathrm{A}}$ (aligned with $\mathrm{A}$ ) and $\mathrm{S}_{\mathrm{O}}$ (aligned with $\mathrm{O}$ ).

In all four cases considered so far we are dealing with mesoparametric variation, in that the four options can be subsumed within a naturally definable class insofar as they exclusively make reference to a single functional head [D], in turn further specified for an increasingly selective subset of this class, namely internal $\left(\mathrm{O}, \mathrm{S}_{\mathrm{O}}\right)$ and intransitive external $\left(\mathrm{S}_{\mathrm{A}}\right)$ arguments (Pattern 4$)>$ internal $\left(\mathrm{O}, \mathrm{S}_{\mathrm{O}}\right)$ arguments (Pattern 2).

We observe however a shift from meso- to microparametric variation as we move down the hierarchy to varieties such as Ariellese (Pattern 3), insofar as the relevant class of triggers for adverb agreement is no longer represented tout court by a naturally definable class of functional heads (viz. [D]), but now also includes reference to a small and lexically definable subclass of Ds, namely pronominals. In particular, the generalization that adverb agreement in Ariellese is controlled by internal arguments is subject to the additional restriction that the internal argument be overtly raised to the Infl/T-domain. This further restriction derives the observation that, apart from subjects of unaccusatives and passives displaced under object-to-subject raising, adverbs only display agreement with pronominal object clitics since this subclass of objects is systematically required under cliticization to vacate the VP and pass through the adverb en route to its surface position. However, we noted in $\$ 2.3$ that the relevant agreement facts with pronominal clitics are not uniform across all speakers of Ariellese, but show further microvariation. In particular, we can identify a more conservative Pattern 3 according to which agreement of the adverb holds with all types of pronominal object (41a), alongside a more innovative Pattern $3_{\mathrm{B}}$ where the adverb is further restricted to agreeing only with third-person pronominal clitics (41b). Arguably, in this latter case where this lexically definable subclass is broken down into the ever more marked pronominal categories of third-person vs first-/second-persons, we are entering nanoparametric 
territory where the relevant generalizations hold of just a handful of individual lexical items.
a. (Arielli $\left.i_{\mathrm{A}}\right)$ Gianne $l^{\prime} / j^{\prime} / v^{\prime}$
b. $\left(\right.$ Arielli $\left._{\mathrm{B}}\right)$
Gianne $l^{\prime} / *^{*} j^{*} *^{\prime}$
a mminite bbune
Gianni them $=/$ us $=/$ you.PL has beaten good.PL
'Gianni gave them/us/you a good beating'

Note, finally, that the hierarchy in Figure 2 also correctly predicts our previous observation regarding the agreement contrast between argumental (cf. 21c) vs non-argumental (cf. 21d-f) third-person reflexive clitics: the parametric restriction higher in the hierarchy that all internal arguments undergo raising excludes agreement with non-argumental reflexives since, unlike their argumental counterparts, these are base-generated directly in the Infl/T-domain and hence do not raise out of the VP to pass through the adverb whereupon adverb agreement is licensed.

\section{Conclusion}

We have seen that there is significant microvariation in the relevant patterns, ultimately to be understood in terms of locality conditions and structural domains, which yield adverb agreement across Romance. First, there are varieties (Pattern 1) such as Romanian and northern Italian dialects where apparently no configuration (however local) or domain is able to license agreement of the adverb with a potential nominal controller. Second, there are many southern Italian dialects which, despite all exhibiting the same underlying active/stative split, minimally differ in how the relevant locality domains are computed. In the most liberal varieties (Pattern 2), the relevant locality configuration can be broadly defined in terms of the confines of a simple VP configuration in which the Undergoer argument and the adjectival adverb enter into an agreement relation in their in situ positions locally within the VP, where the adjectival adverb qua resultative predicative complement directly modifies the Undergoer. In dialects of eastern Abruzzese such as Ariellese (Pattern 3), by contrast, the definition of the relevant locality condition proves much narrower in that it requires the controlling nominal to overtly pass through (the associated specifier position of) the adverb, an operation which, for independent reasons, can only obtain within the $v \mathrm{P}$ domain in conjunction with unaccusative subjects and object clitic controllers which are independently required to transit through the $v \mathrm{P}$ layer. Third, there are southern dialects with so-called ergative agreement (Pattern 4) where the broad locality configuration characteristic of the VP observed in dialects displaying Pattern 2 is extended to the $v \mathrm{P}$, such that 
intransitive external arguments (viz. Agent/Actor subjects) also enter into a local agreement relation with the adjectival adverb base-generated in Adv2.

Significantly, we have also seen how languages such as Spanish and French, despite predominantly employing bicategorial systems with -men $(t(e))$ adverbs since their earliest written attestations (Company 2014:495-8), seem to obey the same broad structural tendencies in those diachronic (viz. early) and diatopic (viz. Latin American) varieties which show productive uses of adjectival adverbs. In particular, we have observed how agreement in these varieties follows the active/ stative Pattern 2 and, in a small number of cases, may also show a distribution suggestive of ergative Pattern 4. Observations like these underline how the synchronic comparison of a number of conservative dialectal Romance varieties reveals how minimal differences among otherwise highly homogenous systems can be used to investigate microvariation along the diachronic axis to reconstruct facts of earlier stages of Romance which are only sporadically reflected in early texts and which have often been blurred, not to say filtered out, by the the diachronic and synchronic effects of standardization. It remains to be seen whether future investigations of diachronic and synchronic Romance variation will bring to light new patterns of adverb agreement in addition to the four patterns identifed in this study or further restictions on these same four patterns, but the evidence of Silvestri (this volume) and, in particular, the growing body of work by Hummel on diachronic, diamesic and diatopic Romance variation in this area suggest that the typology of adverb agreement is likely to be much larger.

\section{References}

Antrim, Nancy Mae. 1994. Italian adverbial agreement. In Issues and Theory in Romance Linguistics: Selected Papers from the Linguistic Symposium on Romance Languages XXIII April 1-4, 1993, Michael L. Mazzola (ed.), 129-140. Washington DC: Georgetown University Press.

Baker, Mark. 1996. The Polysynthesis Parameter. Oxford: OUP.

Baker, Mark. 2008a. The Syntax of Agreement and Concord. Cambridge: CUP. doi: $10.1017 / C B O 9780511619830$

Baker, Mark. 2008b. The macroparameter in a microparametric world. In The Limits of Syntactic Variation [Linguistik Aktuell/Linguistics Today 132], Theresa Biberauer (ed.), 351-374. Amsterdam: John Benjamins. doi: 10.1075/la.132.16bak

Bentley, Delia. 2006. Split Intransitivity in Italian. Berlin: Mouton de Gruyter. doi: $10.1515 / 9783110896053$

Biberauer, Theresa, Holmberg, Anders, Roberts, Ian \& Sheehan, Michelle. 2012. Complexity in comparative syntax: The view form modern parametric theory. Paper presented at the Formal Linguistics and the Measurement of Grammatical Complexity Workshop, Seattle, 24 March. 
Biberauer, Theresa \& Roberts, Ian. 2012. The significance of what hasn't happened. Paper presented at Diachronic Generative Syntax 14, Lisbon, 4 July.

Biberauer, Theresa \& Roberts, Ian. In press. Towards a parameter hierarchy for auxiliaries: Diachronic considerations. In Proceedings of the XII Diachronic Generative Syntax Meeting, Anthony Kroch (ed.). Oxford: OUP.

Borer, Hagit. 1984. Parametric Syntax. Dordrecht: Foris. doi:10.1515/9783110808506

Burzio, Luigi. 1986. Italian Syntax: A Government-binding Approach. Foris: Dordrecht. doi:10.1007/978-94-009-4522-7

Cardinaletti, Anna. 1997. Subjects and clause structure. In The New Comparative Syntax, Liliane Haegeman (ed.), 33-63. London: Longman.

Cardinaletti, Anna. 2004. Toward a cartography of subject positions. In The Structure of CP and IP: The Cartography of Syntactic Structures, Vol. 2, Luigi Rizzi (ed.), 115-165. Oxford: OUP. Chircu, Adrian. 2008. L'adverbe dans les langues romanes. Etudes étymologique, lexicale et morphologique. Cluj-Napoca: Casa Cărţii de Ştiinţă.

Cinque, Guglielmo. 1999. Adverbs and Functional Heads. A Cross-Linguistic Perspective. Oxford: OUP.

Company, Concepción. 2014. Adverbios en -mente. In Sintaxis histórica de la lengua española. Tercera parte: Adverbios, preposiciones y conjunciones. Relaciones interoracionales, Concepción Company (ed.), 459-614. Mexico: Fondo de Cultura Económica y Universidad Nacional Autónoma de México.

Cresti, Diana. 2003. Aspects of the syntax and semantics of ne. In The Syntax of Italian Dialects, Christina Tortora (ed.), 67-101. Oxford: OUP.

Cruschina, Silvio. 2010. Aspetti morfologici e sintattici degli avverbi in siciliano. In Studi sui dialetti della Sicilia [Quaderni di Lavoro ASIt n.11], Jacopo Garzonio (ed.), 21-42. Padua: Unipress.

Dinică, Andreea. 2012. Adverbul (în secolul al XIX-lea). In Studii de istoria limbii române. Morfosintaxa limbii literare în secolele al XIX-lea şi al XX-lea, Chivu Gheorghe, Gabriela Pană Dindelegan, Adina Dragomirescu, Isabela Nedelcu \& Irina Nicula (eds), 223-248. Bucharest: Editura Academiei Române.

Dinică, Andreea \& Mîrzea Vasile, Carmen. 2013. Adverbs and adverbial phrases. In The Grammar of Romanian, Gabriela Pană Dindelegan (ed.), 432-450. Oxford: OUP.

Dowty, David. 1979. Word Meaning and Montague Grammar: The Semantics of Verbs and Times in Generative Semantics and in Montague's PTQ. Dordrecht: Reidel.

doi:10.1007/978-94-009-9473-7

Hale, Kenneth \& Keyser, Samuel Jay. 1993. On argument structure and the lexical expression of syntactic relations. In The View from Building 20. Essays in Linguistics in Honor of Sylvain Bromberger, Kenneth Hale \& Samuel Jay Keyser (eds), 53-109. Cambridge MA: The MIT Press.

Hale, Kenneth \& Keyser, Samuel Jay. 2002. Prolegomenon to a Theory of Argument Structure. Cambridge MA: The MIT Press.

Hummel, Martin. 2000. Adverbale und adverbialisierte Adjektive im Spanischen. Konstruktionen des Typs Los niños duermen tranquilos und María corre rápido. Tübingen: Gunter Narr.

Hummel, Martin. 2011. The interfaces of adjective and adverb in Romance. Facts and arguments for discussion. <http://sites.google.com/site/rsgadjadv/> 
Hummel, Martin. 2014. The adjective-adverb interface in Romance and English. In Adjectives in Germanic and Romance [Linguistik Aktuell/Linguistics Today 212], Petra Sleeman, Freek Van de Velde \& Harry Perridon (eds), 35-71. Amsterdam: John Benjamins.

doi:10.1075/la.212.02hum

Hummel, Martin. 2015. Los adverbios flexionados. In El discurso de la gramática, Carmen Galán Rodríguez, María Luisa Montero Curiel, José Carlos Martín Camacho \& María Isabel Rodríguez Ponce (eds), 205-233. Cáceres: Universidad de Extremadura.

Hummel, Martin. 2013. Sincronía y diacronía de los llamados adjetivos adverbializados y de los adverbios en mente. Anuario de Letras I(2), 215-281. México: Universidad Nacional Autónoma de México.

Hummel, Martin. In press a. Existe a concordância adverbial no português brasileiro? Considerações acerca de vamos diretos, todas contentes, bastantes grandes, muitas boas. In Funcionalismo linguístico - vertentes e diálogos, Mariangela Rios de Oliveira \& Maria Maura Cezario (eds). Rio de Janeiro: Eduff.

Jackendoff, Ray. 1972. Semantic Interpretation in Generative Grammar. Cambridge MA: The MIT Press.

Kayne, Richard S. 1989. Facets of Romance past participle agreement. In Dialect Variation on the Theory of Grammar, Paola Benincà (ed.), 108-140. Dordrecht: Foris.

Kayne, Richard S. 2000. Parameters and Universals. Oxford: OUP.

Kayne, Richard S. 2005a. Movement and Silence. Oxford: OUP.

doi:10.1093/acprof:oso/9780195179163.001.0001

Kayne, Richard S. 2005b. Some notes on comparative syntax, with special reference to English and French. In Handbook of Comparative Syntax, Guglielmo Cinque \& Richard S. Kayne (eds), 3-69. Oxford: OUP.

Ledgeway, Adam. 2000. A Comparative Syntax of the Dialects of Southern Italy: A Minimalist Approach. Oxford: Blackwell.

Ledgeway, Adam. 2003. Linguistic theory and the mysteries of Italian dialects. In Multilingualism in Italy: Past and Present, Anna Laura Lepschy \& Arturo Tosi (eds), 108-140. Oxford: Legenda.

Ledgeway, Adam. 2009. Grammatica diacronica del napoletano [Beihefte zur Zeitschrift für romanische Philologie Band 350]. Tübingen: Max Niemeyer. doi:10.1515/9783484971288

Ledgeway, Adam. 2011a. Morphosyntactic typology and change. In The Cambridge History of the Romance Languages, Vol. 1: Structures, Martin Maiden, John Charles Smith \& Adam Ledgeway (eds), 724-734. Cambridge: CUP.

Ledgeway, Adam. 2011b. Adverb agreement and split intransitivity: Evidence from southern Italy. Archivio Glottologico Italiano 96: 31-66.

Ledgeway, Adam. 2012. From Latin to Romance. Morphosyntactic Typology and Change. Oxford: OUP. doi:10.1093/acprof:0so/9780199584376.001.0001

Ledgeway, Adam. 2013. Greek disguised as Romance? The case of southern Italy. In Proceedings of the 5th International Conference on Greek Dialects and Linguistic Theory, Mark Janse, Brian D. Joseph, Angela Ralli \& Metin Bağriaçik (eds), 184-228. Laboratory of Modern Greek Dialects, University of Patras. <http://lmgd.philology.upatras.gr/en/research/downloads/ MGDLT5_proceedings.pdf $>$.

Ledgeway, Adam. 2015. Parallels in Romance nominal and clausal microvariation. Revue roumaine de linguistique LX: 105-127.

Ledgeway, A. In press a. The verb phrase. In The Syntax of Italian, Giuseppe Longobardi (ed). Cambridge: CUP. 
Ledgeway, Adam. In press b. From Latin to Romance syntax: The great leap. In The Oxford Handbook of Diachronic and Historical Linguistics, Paola Crisma \& Giuseppe Longobardi (eds). Oxford: OUP.

Lonzi, Lidia. 1986. Pertinenza della struttura tema-rema per l'analisi sintattica. In Tema-rema in italiano, Hans Stammerjohann (ed.), 91-120. Tübingen: Gunther Narr.

Loporcaro, Michele. 1998. Sintassi comparata dell'accordo participiale romanzo. Turin: Rosenberg \& Sellier.

Loporcaro, Michele. 2016. Auxiliary selection and participial agreement. In The Oxford Guide to the Romance Languages, Adam Ledgeway \& Martin Maiden (eds), 802-818. Oxford: OUP. doi:10.1093/acprof:oso/9780199677108.003.0049

Manzini, Maria-Rita \& Savoia, Leonardo Maria. 2005. I dialetti italiani e romanci. Morfosintassi generativa, Vol. III. Alessandria: Edizioni dell'Orso.

Mîrzea Vasile, Carmen. 2012a. Eterogenitatea adverbului românesc: Tipologie şi descriere. Bucharest: Editura Universităţii din Bucureşti.

Mîrzea Vasile, Carmen. 2012b. Adverbul (în secolul al XX-lea). In Studii de istoria limbii române. Morfosintaxa limbii literare in secolele al XIX-lea şi al XX-lea, Chivu Gheorghe, Gabriela Pană Dindelegan, Adina Dragomirescu, Isabela Nedelcu \& Irina Nicula (eds), 597-626. Bucharest: Editura Academiei Române.

Napoli, Donna Jo. 1975. A global agreement phenomenon. Linguistic Inquiry 7: 413-435.

Parry, Mair. 2000. Accordo e soggetti posverbali in piemontese. In Congrès international de linguistique et pihlologie romanes, Bruxelles 1998. Vol. 6: De la grammaire des formes à la grammaire du sens, Annick Englebert, Michel Pierrard, Laurence Rosier \& Dan van Raemdonck (eds), 391-402. Tübingen: Niemeyer.

Ramat, Paolo \& Ricca, Davide. 1998. Sentence adverbs in the languages of Europe. In Adverbial Constructions in the Languages of Europe, Johann van der Auwera (ed.), 187-275. Berlin: Mouton de Gruyter. doi:10.1515/9783110802610.187

Roberts, Ian. 2012. Macroparameters and minimalism. A programme for comparative research. In Parameter Theory and Linguistic Change, Charlotte Galves, Sonia Cyrino, Ruth Lopez \& Juanito Avelar (eds), 320-354. Oxford: OUP. doi:10.1093/acprof:oso/9780199659203.003.0017 Roberts, Ian. 2014. Subject clitics and macroparameters. In Diachrony and Dialects. Grammatical Change in the Dialects of Italy, Paola Benincà, Adam Ledgeway \& Nigel Vincent (eds), 177201. Oxford: OUP. doi:10.1093/acprof:oso/9780198701781.003.0009

Roberts, Ian \& Holmberg, Anders. 2010. Introduction: Parameters in minimalist theory. In Parametric Variation. Null Subjects in Minimalist Theory, Theresa Biberauer, Anders Holmberg, Ian Roberts \& Michelle Sheehan (eds), 1-57. Cambridge: CUP.

Rohlfs, Gerhard. 1969. Grammatica storica della lingua italiana e dei suoi dialetti. Sintassi e formazione delle parole. Turin: Einaudi.

Sheehan, Michelle. 2014. Towards a parameter hierarchy for alignment. In Proceedings of WCCFL 31, Robert E. Santana-LaBarge (ed.), 399-408. Somerville MA: Cascadilla Press.

Sheehan Michelle. In press. Parametrising ergativity: An inherent case approach. In The Oxford Handbook of Ergativity, Jessica Coon, Diane Massam \& Lisa deMena Travis (eds). Oxford: OUP.

Silvestri, Giuseppina. 2014. Participle and adverb agreement: Split intransitivity in northern Calabrian dialects. Paper presented at meeting of the XLI Romance Linguistics Seminar, Trinity Hall, Cambridge, 3-4 January. 
Smith, John Charles. 1993. La desaparición de la concordancia entre participio de pasado y objeto directo en castellano y catalán: Aspectos geográficos e históricos. In Actas del primer congreso anglo-hispano, I: Lingüística, Ralph John Penny (ed.), 275-285. Madrid: Castalia.

Smith, John Charles. 1999. Markedness and morphosyntactic change revisited: The case of Romance past participle agreement. In The Emergence of the Modern Language Sciences: Studies on the Transition from Historical-comparative to Structural Linguistics in Honour of E. F. K. Koerner. 2: Methodological Perspectives and Applications, Sheila Embleton, John E. Joseph \& Hans-Josef Niederehe (eds.), 203-215. Amsterdam: John Benjamins.

Vendler, Zeno. 1967. Linguistics in Philosophy. Ithaca NY: Cornell University Press. 


\title{
Before the complementizer
}

\section{Adverb types and root clause modification}

\author{
Silvio Cruschina and Eva-Maria Remberger \\ University of Vienna
}

In this paper we investigate the distributional, morphosyntactic, and semantic properties of a particular construction found in Romance, as well as in other languages such as English. This construction involves a class of elements that appear in sentence-initial position and that are followed by a complementizer introducing a root clause (a $\mathrm{CP}$ in generativist terms). This class may comprise underived attributes (adjectives) and derived attributes (adverbs), depending on the specific language. We claim that these adverbial constructions, as a result of grammaticalization, can be analysed as structurally equivalent to other constructions with similar speaker-oriented meanings, such as quotative and reportative constructions. A further or alternative process of grammaticalization, instead, has yielded new adverbial forms which morphologically include the complementizer.

\section{Introduction}

The construction under investigation in this paper $^{1}$ is characterized by two main properties: (1) it features either an underived attribute (adjective) or a derived attribute (adverb) in sentence-initial position, and (2) this sentence-initial element is immediately followed by a complementizer introducing a root clause. This special construction is found both in Romance and in other languages such as English (cf. also López-Couso \& Méndez-Naya 2015). In the examples in (1), from Italian and Spanish respectively, the complementizer is preceded by an underived attribute which is morphologically identical to the corresponding adjective. The English and French examples in (2), by contrast, feature a derived attribute, namely an adverb

1. We would like to thank two anonymous reviewers for valuable insights into the use of the constructions under discussion here, as well as for the additional data provided. The following abbreviations will be used in this paper (standard glossing abbreviations are not included): $\mathrm{C}=$ complementizer $\mathrm{CP}=$ Complementizer Phrase; ForceP $=$ Force Phrase; $\mathrm{PrP}=$ Predicate Phrase; $\mathrm{S}=$ sentence; $\mathrm{SAP}=$ Speech Act Phrase. 
derived through the process of adverb formation that is productive in the relevant language: ${ }^{2}$

(1) a. (It.)

Certo che potevamo impegnarci un po' di più.

certain that could.1PL commit-us a little of more

'We could have certainly made a greater effort.'

b. (Sp.)

Claro que no tiene ningún interés.

clear that not have.3sg no interest

'He clearly doesn't have any interest.'

(2) a. (En.)

Obviously that the Achilles was giving him a bit of a problem.

(Radford 2013:42) $)^{3}$

b. (Fr.)

Probablement que ce n' est pas leur faute.

probably that it not be.3sg NEG their fault

'It probably isn't their fault.' (Grevisse \& Goosse 2008: \$1121b)

In some Romance languages, this construction may involve special adverbs derived by a process of univerbation between an adjective or a verb and the complementizer. Several pieces of evidence unambiguously indicate that we are dealing with single morphosyntactic units (Cruschina \& Remberger 2008), and that the

2. The alternation between underived attribute and derived adverb is not in complementary distribution, as observed by an anonymous reviewer. When both options are possible within the same language a lexical distinction might be at play, as for example for Spanish seguro (strong assertion) vs. seguramente (weak assertion).

Furthermore, underived attributes and derived adverbs can alternate in a VP-internal position like in (i):

(i) (Sp.)

Juan habló claro/claramente en la reunión.

J.speak.PST.3sg clear/clearly at the meeting. (Suñer \& Di Tullio 2014:24)

For an analysis of these types of adverb, see Suñer \& Di Tullio (2014). Our paper will only discuss higher (modal/evidential) speech act, evaluative, and epistemic adverbs, all of which are only referred to in Suñer \& Di Tullio (2014:30) as base generated in the higher functional field of the left periphery. Suñer \& Di Tullio (2014:fn. 9) also mention the use of claro as "a functional particle" in "holophrastic statements" as in answers to questions.

3. The English data reported in Radford (2013) are from recordings of unscripted British radio and TV broadcasts between May 2010 and July 2011, including discussion forums, phone-ins, interviews and sports commentaries. 
complementizer is thus a morphological segment of the adverb, as also reflected by the orthography (cf. 3).
(3) a. (Sic.)
Capacica
già partiru.
capable/possible-that already left.3PL
'They have probably already left.'
b. (Rom.)
Cică banul n-aduce fericirea.
say-that money-the not-bring.3sg happiness-the
'Allegedly, money doesn't give you happiness.'

Although the sentence-initial elements in (1) are morphologically identical to the corresponding adjectives in the given language, we believe that they are in fact underived adverbial forms occurring at the beginning of the sentence. The elements in (2), on the contrary, show adverbial morphology and can hence be unambiguously identified as adverbs derived from adjectives. Less morphologically transparent is the function of the elements in (3): these elements result from a process of grammaticalization and reanalysis that has led to the merger of a first element (an adjective or a verb) with the complementizer. Despite this morphological make-up, they synchronically behave like fully-fledged sentential adverbs (cf. Section 5).

For ease of exposition, we will use the term "C-construction" for the structures featuring an adverbial element before the complementizer, either in the sense of syntactic linear order (cf. 1, 2) or in terms of morphological composition (cf. 3). In the following sections, we will use the label "S-construction" (S for "sentential") to refer to sentences containing a canonical sentential adverb with no complementizer. More specifically, our analysis will focus on those $\mathrm{C}$-constructions in which the element preceding the complementizer conveys either an epistemic or an evidential value; ${ }^{4} \mathrm{~S}$-constructions will be referred to only for comparative and contrastive purposes. We will begin by outlining a typology of the adverbs that can appear before the complementizer (Section 2), and will then carry out an examination of the semantic and pragmatic functions associated with the C-constructions in which they occur (Section 3). In order to account for the special morphosyntactic and semantic properties of these structures, we will propose that in some cases they

4. For a typology of adverbs, see Jackendoff (1972), Bellert (1977), Ernst (2002), Laenzlinger (1996), Ramat \& Ricca (1998), Cinque (1999). The C-construction is quite common crosslinguistically (cf. Ramat \& Ricca 1998:212; Cinque 1999: 18-19; Ernst 2002: 427). The constructions under investigation could also be seen as cases of insubordination, namely, "the conventionalised main-clause use of what, on prima facie grounds, appear to be formally subordinate clauses" (Evans 2007:367). 
involve a silent truth predicate meaning something like "it is true that", "it is so that" or "it is the case that". This predicate can be modified by an evidential or epistemic element (Section 4). Our proposal builds a link between the C-constructions under investigation and the quotative/reportative structures found in some Romance languages: it will be shown that the properties of both constructions can be better understood under a unified analysis. Finally, in Section 5, the C-constructions involving a morphosyntactically autonomous complementizer will be compared with C-constructions characterized by the presence of a morphologically merged complementizer. Some final remarks conclude the chapter (Section 6).

\section{Typology of adverbs before the complementizer}

As for the types of adverb that can occur before the complementizer, our point of departure is Hummel's $(2012 ; 2013 ; 2014)$ distinction between underived or unmarked adverbs (Type A) and derived adverbs (Type B) (see also Ledgeway 2011). We then need to add a third category to this typology, namely, those adverbs formed through the morphological merger with the complementizer (Type C):

1. Type A: underived or unmarked adverbs. These adverbs are morphologically identical to adjectives or, in other terms, they correspond to an adverbial use of adjectives (cf. 1).

2. Type B: derived adverbs, i.e. adverbs derived through the language-specific productive suffix for adverb formation (-ment (e) in Romance, -ly in English) (cf. 2).

3. Type C: adverbs derived through a process of univerbation and grammaticalization whereby an adjective or an adverb merges with the complementizer, creating a single morphosyntactic unit (cf. 3).

These three types of adverb share an important property, namely the category they modify is a full proposition: Types A and B modify the sentential CP, while Type C takes an IP in its scope. ${ }^{5}$ We find significant differences, however, with respect to their distribution: while some languages admit both Type-A and Type-B adverbs in the C-construction, others have conventionalized specific choices:

5. The position of Type-C adverbs is actually more controversial than we are assuming here. In Cruschina \& Remberger (2008) we claimed that the positions occupied by these adverbs match up with Cinque's (1999) corresponding projections. The question of whether these adverbs are first-merged within the IP, as originally maintained in Cinque (1999), or within the CP, as suggested in other studies (Speas \& Tenny 2003; Hill 2007; cf. also van Gelderen 2004; 2011), remains unresolved. See also Section 5 below. 
(4) (Sp.)

a. ¡Claro que te lo voy a dar! clear that you it go.1sG to give.INF

'Of course I'll give it to you!'

b. ¡Evidentemente que va a ser declarado culpable! evidently that go.3sg to be.INF declared guilty 'Of course, he will be found guilty!'

(Gutiérrez-Rexach 2001:194)

(5) (It.)

a. Certo che te lo do! certain that you it give.1sG

'Of course I'll give it to you!'

b. Ovvio/*ovviamente che lo dichiarano colpevole! obvious $/{ }^{*}$ obviously that him declare.3PL guilty

'They will obviously find him guilty!'

c. Forse che ci aiuterà?

perhaps that us help.Fut.3sG

'Is it possible that he will help us?'

Both Type-A and Type-B adverbs can be used in a Spanish C-construction (cf. 4), while only Type-A adverbs are found in the Italian equivalent (cf. 5a, 5b). Since Type A consists of underived adverbs, it is not surprising that in a language such as Italian, in addition to Type-A adverbs that are morphologically identical to adjectives, we also find underived standard adverbs like forse in $(5 \mathrm{c})$ in the C-construction (Cinque 1999: 177 fn. 53; cf. also Lonzi 1991: 401). ${ }^{6}$ It is therefore clear that the choice between derived and underived adverbs across languages is not predictable on the basis of morphosyntactic, semantic or functional factors, but instead appears to be language specific and restricted to particular styles and registers. Hummel's $(2013 ; 2014: 37)$ account of the frequency and diamesic differences in English and across Romance explains the differences between Type A and Type B, and their language-internal rivalry: "In fact, these languages are characterized by the systematic coexistence and competition of Type A and Type B in synchrony and throughout their history." This competition has been seen as the result of the contrast between traditions of speaking (orality), favouring Type A, and traditions of writing (literacy), prescribing Type B.

6. Unlike the other Type-A adverbs in C-Constructions, Italian forse is not confined to informal registers, and is mainly found in interrogative sentences. 
Given that the origins of the C-construction must be related to oral traditions, ${ }^{7}$ we expect the colloquial Type-A adverbs to be more commonly used, although, as we have seen (cf. 4b), Type-B adverbs are not entirely excluded. Like Italian, other languages admit both "adverbial adjectives" (cf. 6), often in informal registers, and standard adverbs of Type A, including lexicalized adverbs like Fr. peut-être, En. perhaps, maybe and adverbials like Fr. sans doute (cf. 7, 8): ${ }^{8}$

(6) a. (En.)

Obvious that the Achilles was giving him a bit of a problem.

b. (Fr.)

Probable que ce n' est pas leur faute.

probable that it not be.3sg NEG their fault

'It probably isn't their fault.'

(7) (En.)

a. Yes, perhaps that they could do it.

b. Maybe that this is the season for Chelsea to find their form in the Champion's League.

(Radford 2013:34)

(8) (Fr.)

a. Peut-être qu' il vendra.

perhaps that he come.Fut.3sg

'He will probably come.'

b. Sans doute $q u$ ' il accepterait si vous insistiez.

without doubt that he accept.COND.3sG if you insist.PsT.2PL

'No doubt he would accept if you insisted.' (Grevisse \& Goose 2008: \$1121b)

The distinction of two subtypes within Type A (A1: adverbial adjectives vs. A2: standard adverbs) is also useful for describing another property of the C-construction: its complementarity with the S-construction. Despite representing the adverbial type that is expected to occur more frequently than others due to its oral character, substandard Type-A adverbial adjectives (A1) are almost never found instead of

7. However, nowadays the construction can also be found, to different degrees depending on the specific language and geographical variety, in the standard language and in written (e.g. journalistic) texts.

8. The examples in (6) are adaptations from those in (2) that have been judged as grammatical by our native speaker informants. Note that not all native speakers of English accept sentences like (2a) or (6a), which are restricted to a specific register and style, and only those who admit (2a) would also accept the variant in (6a). On the different behaviour of French adverbs in this construction with respect to subject inversion, see Rizzi \& Roberts (1989) and Laenzlinger (1996: \$2.11.3). 
higher sentential adverbs. ${ }^{9}$ Only Type-B adverbs and Type-A standard adverbs (A2) are in complementary distribution with (more canonical) structures where the adverb is sentence-internal and without complementizer, i.e. in S-constructions:

(9) (Sp.)
a. Evidentemente va a ser declarado culpable. evidently go.3sg to be.INF declared guilty 'Of course, he will be found guilty!'
b. ${ }^{\star}$ Evidente va a ser declarado culpable. evident go.3sg to be.INF declared guilty

As we will see below (cf. Section 4), the C-construction can be classified into semantic-pragmatic subtypes, depending on the epistemic value of the adverb and the discourse saliency of the propositional content of the modified clause.

9. This behaviour must be interpreted as a strong tendency rather than a strict generalization. Certain Type-A adverbs can indeed appear in the S-construction, although this exception seems to be limited to specific adverbs in some languages. We have not carried out a detailed investigation across languages, but note that Italian certo is one such adverb:

(i) Non possiamo certo ignorare questa eccezione. not can.1PL certain ignore.INF this exception 'We certainly cannot ignore this exception.'

Similar examples can be found in Spanish (here: Mexican Spanish), as pointed out by an anonymous reviewer:

(ii) Así como ya vería en Chihuahua en qué podría trabajar, y en dónde dejar mientras a Joaquín; seguro encontraría en quién confiar...

[CREA. Relatos. México] 'So he would also see what type of job he could get in Chihuahua, and where he could leave Joaquín in the meanwhile; he would surely find somebody to trust...'

(iii) No quiero ir a tu entierro, seguro me van a subir en el mismo coche que Rodolfo y lo voy a tener que aguantar todo el camino hasta Zacatlán. [CREA. Novela. México] 'I don't want to go to your funeral, they will surely make me sit in the same car as Rodolfo and I'd have to put up with him all the way to Zacatlán.'

We believe that, despite some apparent similarity, the Spanish structures like that in (iv) are in fact not monoclausal. The first element here is external to the main clause (as also confirmed by the comma intonation) and has an independent affirmative value with respect to the proposition that follows. As parentheticals, these elements can appear in any position where other parentheticals could appear, i.e. also in intermediate or final position.
(iv) Claro, no va a venir.
clear not go.3sg to come.INF
'Sure, he's not coming.'

Other examples that might appear to be instances of Type-A adverbial adjectives (A1) turn out, on closer inspection, to be either secondary predicates or VP-internal adverbs, such as those analysed by Suñer \& Di Tullio (2014). 
The Type-A split between substandard (adjectival) adverbs (A1) and standard adverbs (A2) (cf. Figure 1) has an important consequence. The traditionally assumed (and admittedly problematic) complementarity between adjectives and adverbs appears to be lost when substandard Type-A adverbs take a CP in their scope.

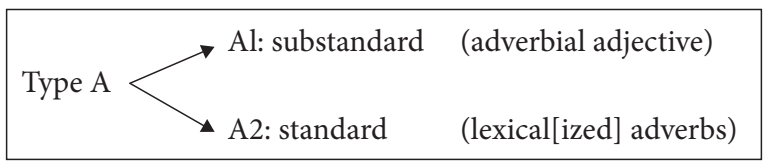

Figure 1. Two groups of Type-A adverbs

This means that $\mathrm{C}$-constructions do not always have an equivalent $\mathrm{S}$-construction, and that the complementizer is typically a necessary condition for the adjective to be used as a higher adverb. Compare (9a, 10a) with (9b, 10b): only the Type-B adverbs are allowed in the S-constructions without complementizer, while the adjective/Type-A1 adverb is ruled out. Italian appears to be more restrictive than Spanish, in that it does not admit a Type-B adverb in the C-construction (10d).

(10) (It.)

a. È probabilmente bloccato nel traffico. be.3sg probably stuck in-the traffic 'He's probably stuck in a traffic jam.'

b. ${ }^{\star} \mathrm{E} \quad$ probabile bloccato nel traffico. be.3sg probable stuck in-the traffic

c. Probabile che ̀̀ bloccato nel traffico. probable that be.3sg stuck in-the traffic 'He's probably stuck in a traffic jam.'

d. *Probabilmente che ̀̀ bloccato nel traffico. probably that be.3sg stuck in-the traffic

Let us now return to the contrast between Type A and Type B and to their distribution. As is well known, not all Romance languages have a Type A vs. Type B distinction (cf. Ledgeway 2011; Hummel 2013; 2014, among others). Is there still a distinction between C-construction and S-construction? It seems that in these varieties the two structures may be associated with slightly different meanings. In the examples below, from Romanian and Sicilian respectively, only the S-constructions (11a) and (12a) can have a punctual/impersonal (objective) reading in addition to the subjective, speaker-oriented interpretation, whereas the latter is the only interpretation available with the corresponding C-constructions in (11b) and (12b) (we will return to this interpretive distinction in Section 4). 
(11) (Rom.)
a. Sigur va veni.
sure will.3sg come
'Of course s/he's coming./'It is certain that s/he's coming.'
b. Sigur că va veni.
sure that will.3sg come
'Of course s/he's coming.'/*'It is certain that s/he's coming.'
(S-construction)

(Hill 2007: 61; Lupşa 2011:93-94)

(12) (Sic.)
sure left.PST.3PL left.PST.PL sure
(S-construction)
'Of course they left.'/It is certain that they left.'
a. Sicuru partiru. / Partiru sicuru.
b. Sicuru ca partiru.
sure that left.PST.3PL
'Of course they left.'/*'It is certain that they left.'
(C-construction)

To understand the difference between the two readings (e.g. between (11a) and (11b)), imagine the following context. Ioana asks Alexandru if Ion will attend the conference next week. Ioana has not heard from Ion, so she genuinely does not know his intentions. Alexandru, by contrast, has been in touch with Ion and is (objectively) aware of his willingness to attend the conference because Isopescu will give a talk on that occasion. Alexandru then replies to Ioana's question with (11a). Sentence (11b) would be infelicitous in this context, since it would imply that Ioana should have been able to infer or should have possessed the relevant information.

Suppose now that both Ioana and Alexandru know that Ion is a big fan of Isopescu and would never miss a conference where he is an invited speaker. The two interlocutors are therefore in the position to know, by inference, that Ion will attend the conference. In this scenario, as an answer to Ioana's question (i.e. Will Ion attend the conference next week?), sentence (11b) would be more appropriate, since such a reply would be based on a personal and subjective inference that relies on logical reasoning. By uttering (11b), Alexandru points out that they both have enough information, in the common ground as shared knowledge, to support certainty about the question under discussion. In this second context, (11a) would also be felicitous, most likely if the epistemic adverb is prosodically focalized. (We thank Ion Giurgea for his help with building this context contrast.)

The distribution of our Type A and Type B adverbs is summarized in Table 1, where the sub-distinction between Type-A standard adverbs and Type-A substandard (adjectival) adverbs is taken into consideration: ${ }^{10}$

10. Our observations are based on native speakers' judgements. Dealing with a construction that does not belong to the standard language, it was sometimes difficult to obtain clear-cut 
Table 1. Distribution of Type-A and Type-B adverbs

\begin{tabular}{llcc}
\hline & Example & C-construction & S-construction \\
\hline Type-A1 (substandard) & Sp. claro & + & - \\
Type-A2 (standard) & Fr. peut-être & + & + \\
Type-B & Sp./It. evidentemente & $+/-$ & + \\
\hline
\end{tabular}

This table shows that in general these types of adverb are found in both the C-and the S-construction. Two exceptions stand out (see the shaded cells in Table 1). First, unlike Spanish and other languages, Italian does not allow Type-B adverbs to occur in the $\mathrm{C}$-construction; this restriction may be seen as a consequence of the specific stylistic and register traits of the $\mathrm{C}$-construction, such that the corresponding adverbial type has been chosen and conventionalized for use in this construction. Second, substandard Type-A adverbs, i.e. those adverbs that are morphologically identical to adjectives, cannot occur in the S-construction. This second restriction is stronger and more generalized than the first, allowing only a small number of exceptions (cf. fn. 9), and is found in all languages under examination, although for obvious reasons it does not apply to languages that do not distinguish between Type-A and Type-B adverbs (cf. 11-12).

\section{Pragmatic adverbs: Grammaticalization towards discourse}

One may hypothesize that the C-construction is not an independent construction, but is in fact a biclausal structure characterized by the omission of the copula (either ser or estar, for Spanish). This hypothesis may appear appealing at first sight, especially for its apparent simplicity, but under closer scrutiny it turns out to be problematic in many respects: evidence and tests suggest that a copula-omission analysis is on the wrong track, and instead favour the hypothesis that the first item of the construction is a functional element that has undergone grammaticalization. First of all, while copula structures can be negated (cf. 13a), the first element of the

judgements from our informants. What we report here must be taken as robust generalizations, with the possibility of a certain degree of variation among native speakers. Indeed, further research that takes into account the variation among speakers from different areas is required in order to more accurately identify these aspects, which are surely an important issue in the highly dynamic system of adverbial sentence modification.

With regard to geographical variation, the use of C-constructions in Latin America seems to be much wider than we are able to describe here (see, e.g., NGLE 2009: $\$ 30.11 . r$ ). We thank one anonymous reviewer for pointing out to us $\mathrm{C}$-constructions such as posta que and others in Rioplatense Spanish. 
C-construction is incompatible with negation, be it morphologically or syntactically realized (cf. 13b), and cannot be modified by any adverb (cf. 14b) (Cruschina 2015; see also Hummel 2012; 2013; 2014 for other arguments against this hypothesis): ${ }^{11}$

(13) (It.)

a. Non ̀̀ probabile /È improbabile che sia ${ }^{12} / \grave{\mathrm{e}}$

not be.3sg probable be.3sg improbable that be.sBJv.3sg/be.3sg

bloccato nel traffico.

stuck in-the traffic

'It's not likely / it's unlikely that he's stuck in a traffic jam.'

11. We are not indiscriminately ruling out the possibility of copula omission with similar structures, nor are we assuming that modification is never possible when the copula is omitted. In the La Repubblica corpus, for example, we found ten instances of quasi certo che with no copula (out of 401 hits); a few examples with casi seguro que can be found for Spanish in CREA. It is important to note, however, that in all these occurrences the special epistemic or evidential meaning typical of the $\mathrm{C}$-construction does not emerge, and that the CP clearly functions as the subject of the adjectival predication (similarly to the "sentential adjectives" in the left periphery and without complementizer analysed by Erdmann (1997) for American English). We then conclude that these instances presumably represent the very first step of a process of grammaticalization which, from impersonal biclausal structures, leads to monoclausal C-constructions, and is characterized by the mere omission of the copula.

The copula omission analysis seems to be the view adopted by the NGLE (2009) which defines the que-constructions at issue as "subordinadas sustantivas de sujeto" that occur without a copula. Some of their examples could be viewed as counterexamples to our argument. As mentioned, we do not categorically exclude copula omission in all cases. Each possible counterexample, however, must be inspected carefully: Sentence (i) contains a morphologically negated adjective (i.e. imposible) but, crucially, in conjunction with a verb in the subjunctive mood. It is natural, then, to analyse this example as a biclausal construction with an elided copula (similar examples would be possible in Italian, too). By contrast, the constructions under examination in this paper do not involve a subjunctive verb; in fact, the subjunctive is not admitted in most cases. Example (ii) is an exclamative clause where the second (expletive) que is part of the exclamative syntax:

(i) ¡Imposible que no lo sepa!

'It's impossible that he doesn't know it!'

(ii) ¡Qué bien que salga el sol!

'How nice that the sun comes out!'

(NGLE 2009:3239, § 43.4j)

12. Whether there is an obligatory or optional subjunctive in the various types of constructions at issue (including the copula construction) is a complex topic that cannot be discussed in detail here. For the time being, we assume that the presence of a subjunctive verbal form signals the biclausal nature of the construction, which could possibly involve an elided copula (see also the previous footnote). 
b. ${ }^{\star}$ Non probabile chel ${ }^{\star}$ Improbabile che è bloccato not probably that improbable that be.3sg stuck nel traffico. in-the traffic

(14) (It.)

a. È del tutto/quasi certo che domani andiamo al mare. be.3sg totally almost certain that tomorrow go.1PL to-the sea 'We are definitely/most probably going to the seaside tomorrow.'

b. ${ }^{\star}$ Del tutto/ ${ }^{\star}$ quasi certo che domani andiamo al mare. totally almost certain that tomorrow go.1PL to-the sea

c. Quasi certamente domani andiamo al mare. almost certainly tomorrow go.1PL to-the sea 'We are almost probably going to the seaside tomorrow.'

By contrast, modification is possible in the copula construction (cf. 14a) as well as in the S-construction (cf. 14c). Moreover, the copula-omission analysis cannot be applied to structures with Type-B adverbs, given that they are independently excluded from the equivalent impersonal biclausal construction:

(15) (Sp.)
a. ${ }_{i}$ Es evidentemente que va a ser declarado culpable! be.3sg evidently that go.3sg to be.INF declared guilty
b. (Fr.)
${ }^{\star}$ Il est probablement que ce n' est pas leur faute.
it be.3sg probably that it not be.3SG NEG their fault
c. (En.)

${ }^{\star}$ It is obviously that the Achilles was giving him a bit of a problem.

On the basis of this evidence against a biclausal analysis, the starting point of our proposal is that $\mathrm{C}$-constructions are in fact monoclausal root structures. More specifically, we claim that the adverbs, Type A and Type B, that occur in this position have undergone a process of grammaticalization and are simple variants of the same functional category. As a result, they sit in the specifier of an empty head $\left(\mathrm{SA}^{\circ}\right.$ in the diagram) that modifies the root clause (CP or ForceP, cf. Rizzi 1997), ${ }^{13}$ promoting the speaker's point of view (see also Giorgi 2010 for a similar idea). This is illustrated in (16):

13. In Rizzi (1997), a seminal paper that marked the beginning of the Split-CP approach, i.e. the subdivision of the complementizer domain in the left periphery of the sentence into an ordered layer of syntactic positions with their corresponding functional tasks, ForceP corresponds to the functional category which encodes the illocutionary force. 
(16)

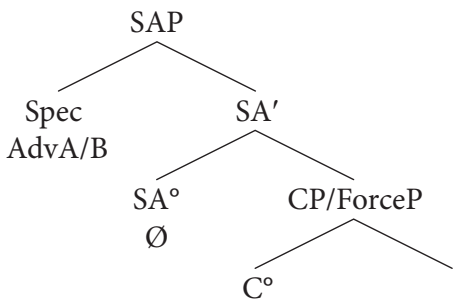

Following Speas \& Tenny (2003) and Hill (2007), we call the projection above the CP "Speech Act Phrase" (SAP), which encodes speaker-oriented discourse/pragmatic features (evaluative, evidential, epistemic values). Within this analysis, the complementizer $\mathrm{C}$ assumes a simple demarcation function: it signals the border between the pragmatic and the propositional domain:
$[\operatorname{AdvA} / B]$
[CP [C] [IP]]
pragmatic field border proposition

This proposal reflects the position and the linear order of the elements in the C-construction. It also captures the contrast between a C-construction and the equivalent impersonal biclausal construction as illustrated in (18):

(18) (It.)
a. Era
chiaro che erano disperati.
be.PST.3sg clear that be.PST.3PL desperate
'It was clear that they were desperate.'
b. Chiaro che erano disperati.
clear that be.PST.3PL desperate
'They were clearly desperate.'

In (18a) the CP che erano disperati 'that they were desperate' is the subject of the predicate era chiaro 'it is clear'. The propositional content of the sentence in (18b) is identical; what changes is the speaker's evaluation of this content. In (18a) the predication is presented as generic and objective: that they were desperate was clear to everyone or, at least, to the contextually relevant people, on the basis of the circumstantial facts, situation, and state of affairs. By contrast, in (18b) a similar assessment of the assertion conveyed by the $\mathrm{CP}$ is attributed to the speaker himself, as a subjective evaluation. This does not amount to saying that the situation described was clear to the speaker only, but rather that this evaluation is based on the genuine belief of the speaker about the truth of the proposition (cf. Section 4). Note also that the speaker's epistemic assessment of the proposition is not temporally anchored to the reference or topic time, namely, to the time the speaker refers to by describing a situation (cf. Reichenbach 1947; Klein 1994 for the notions of 
reference or topic time), but is necessarily bound to the speech time, that is, to the moment of speech. In (18a), by contrast, the time relation between reference time and speech time can be altered by modifying the tense of the copula.

Now that we have shown that C-constructions must be analysed as monoclausal root sentences, the next step is to provide an explicit characterization of the semantic and pragmatic import of this construction, in order to answer the following question: what are the differences between the C-construction and the S-construction? We saw that syntactically the elements sitting in the Spec of the SAP are (more) grammaticalized, in that they do not allow modification and negation (cf. 13-14). Semantically, the distinction may appear somehow blurred, in the sense that in some cases (mainly, with epistemic adverbs) the C-construction seems to express the same meaning as the ordinary S-construction. In some languages, however, a further step of grammaticalization has brought about a specialized function and meaning associated with the $\mathrm{C}$-construction. The next section will deal with such specialized meanings, focusing particularly on data from Romance.

\section{Pragmatic function and silent predicates}

In some Romance languages, at least in Spanish, Italian, Sicilian and Romanian, the C-construction has developed special functions via further stages of grammaticalization. As observed above, the adverbial C-constructions in Romanian and Sicilian might have a subjective, epistemic reading, whereas in the examples without $C$, only an objective adverbial reading is available (cf. 11-12). We repeat those examples here for convenience:

(19) (Rom.)
a. Sigur va veni.
sure will.3sg come
(S-construction)
'Of course s/he's coming.'/It is certain that s/he's coming.'
b. Sigur că va veni.
sure that will.3sg come
(C-construction)
'Of course s/he's coming.'/* It is certain that s/he's coming.'

(Hill 2007: 61; Lupşa 2011:93-4)

(20) (Sic.)
a. Sicuru partiru. / Partiru sicuru.
sure left.PST.3PL left.PST.PL sure
'Of course they left.'/'It is certain that they left.'
b. Sicuru ca partiru.
sure that left.PST.3PL
(S-construction) 
In general, we can conclude that, whenever the C- vs. S-construction opposition is possible, the C-construction tends to have a subjective epistemic function as in $(19 b, 20 b),{ }^{14}$ whereas adverbs in S-constructions like (19a, 20a) typically have an objective epistemic connotation, and their meaning corresponds to the English expressions 'it is certain that', 'it is possible that', 'it is likely that' (cf. Lyons 1977; Traugott 1995; see also Kocher 2014). The subjective epistemic function of the C-construction has often been characterized as evidential (e.g. Hill 2007; 2012; Gutiérrez-Rexach 2001; 2008). The distinction between epistemicity and evidentiality, especially in the domain of the speaker's inferences, is certainly problematic and controversial (van der Auwera \& Plungian 1998; Dendale \& Tasmowski 2001; Plungian 2001; Aikhenvald 2004; see also Cruschina \& Remberger 2008; Cruschina 2015 and references therein). However, we claim that this function of the C-construction is best described as epistemic. According to De Haan (2005:379), "evidentiality asserts the evidence, while epistemic modality evaluates the evidence". This means that "while evidentiality qualifies the source that justifies the assertion of a proposition, modality qualifies the genuine belief of the speaker about the truth of the proposition" (Pietrandrea 2005:33). Since the first element of the C-construction does not assert the source of information on which his assertion is based, but rather qualifies and evaluates the proposition as certain, obvious, (un)likely, possible or probable, we claim that epistemicity is at play here. More specifically, since the speaker's assessment is based on his own beliefs and knowledge, rather than on inferences built on the external context or factors, we assume that we are dealing with subjective epistemicity (cf. Lyons 1977; Traugott 1995).

A specialized use of the C-construction is characterized by an even greater interaction with the discourse level, since it involves the speaker's point of view on a sentential discourse topic. In this type, the presence of an adverb in the Speech Act Phrase (SAP) emphatically expresses the attitude of the speaker with respect to a sentence whose propositional content is already salient and active in the discourse. To illustrate these properties, in what follows we use examples from Spanish and Italian, but note that similar phenomena are also found in other Romance languages:

(21) (Sp.)
a. ¡Claro que te lo voy a dar! clear that you it go.1sG to give 'Of course I'll give it to you!'

14. See also the contrast between C-constructions and impersonal biclausal sentences described in the Section 3. 


\section{b. ¡Evidentemente que va a ser declarado culpable! evidently that go.3sg to be declared guilty 'Of course, he will be found guilty!' (Gutiérrez-Rexach 2001:194)}

In sentences like in (21) the presence of an adverb in the SAP has a specific effect: in (21a) the utterance ${ }_{j}$ Claro que te lo voy a dar! semantically expresses the attitude of the speaker with respect to the propositional content te lo voy a dar, namely, that it is obvious that $\mathrm{s} / \mathrm{he}$ is going to give the object at issue to the addressee, and this content is already salient and active in the discourse. In other words, in (21) the speaker asserts that it is obvious that $\mathrm{s} / \mathrm{he}$ is going to give the object at issue to the addressee (cf. 21a), or that it is evident that a verdict of guilty will be returned (cf. 21b). By using a C-construction the speaker also adds a "contextually determined emotive attitude towards this assertion" (e.g. doubts about the truth of the sentence, surprise or resentment because the addressee possibly does not share their view) (cf. Gutiérrez-Rexach 2001: 184f, who calls this type of structure "evidential exclamatives"). ${ }^{15}$

Thus, the complementizer que has two functions, namely, to introduce the topical proposition and to signal the border between the pragmatic and the propositional domain. This has also been observed by Etxepare (1997) and Hernanz (2007), who give the examples in (22):

(22) a. \{Evidentemente/ciertamente/desde luego\}, Julia está muy enfadada. Evidently certainly of course Julia is very angry

b. \{Evidentemente/ciertamente/desde luego\}que Julia está muy enfadada. Evidently certainly of course that Julia is very angry

The pragmatic difference between (22a) and (22b) is evident: while (22a) can be uttered in an out of the blue context, (22b) cannot. Evidentemente que Julia está muy enfadada is an emphatic sentence that can only be used to stress an already mentioned propositional content, i.e. the fact that Julia is angry. This discourse topic functions as "a linguistic antecedent" for our C-construction to be felicitous, so that the CP of the C-construction must be in a sense "anaphoric".

If we make reference to the dynamics of the conversation, and to the updating of the shared knowledge representing the Common Ground of the speakers, ${ }^{16}$ we may describe the pragmatic conditions and functions of this type of C-construction

15. An anonymous reviewer observes that this special C-construction is very often followed by "counter-argumentative schemas" in the discourse context following it. We agree with the reviewer, but we leave the full investigation of these pragmatic strategies to future research.

16. The Common Ground is a set of propositions which the conversational community shares and which is taken to be accepted by all the participants (Stalnaker 1978). 
as follows. The context includes an implicit or explicit 'question under discussion' as to whether a given assertion $p$ is true or not, and should be added to the Common Ground. The C-construction is a reaction to a polar question (23) or to a previous assertion (24) through which the speaker conveys precisely her high degree of confidence that $p$ is true and should thus update the Common Ground: ${ }^{17}$

(23) (It.)

A: Ma secondo te Gianni ha capito?

but according-to you Gianni has understood

'Do you think Gianni understood?'

B: Ha capito certamente.

has understood certainly

'He surely understood.'

C: Certo che ha capito!

certain that has understood

'Of course, he understood!'

(24) (It.)

A: Credo che Gianni non abbia capito.

believe.1sG that Gianni not have.sBJv.3sg understood

'I believe Gianni didn't understand.'

B: ?Ha capito certamente.

'He surely understood.'

C: Certo che ha capito!

'Of course, he understood!'

Both in (23) and in (24) speaker B can react to the antecedent provided by speaker A either with an S-construction (23B, 24B) or with a C-construction (23C, 24C), but only the latter conveys an emphatic assertion of the truth (or lack of truth) of the content of the propositional topic. In case of a contrast, the C-construction may even prove more natural than the S-construction (cf. 24B), which would require the aid of some extra lexical material in order to deny the truth of the previous assertion and express a correction.

Specific constraints follow from the anaphoric status of the $\mathrm{CP}$ of a $\mathrm{C}$-construction. The clause (i.e. the $\mathrm{CP}$ ) following the functional element, for instance, cannot contain new material that is not already given in the context:

17. See Poletto \& Zanuttini (2013) for the same characterization of emphatic answers with polarity particles. The tests that follow are adapted from their work. 
(25) (It.)

A: Gianni ha già presentato?

Gianni have.3sg already presented

'Did Gianni already present?'

B: Certo che ha presentato!

certain that has presented

'Of course, he already presented.'

$\mathrm{B}^{\prime}$ : \#Certo che ha presentato ieri!

certain that has presented yesterday

Speaker B's reply $\left(25 B^{\prime}\right)$ includes the temporal adverb ieri, which is not present in the discourse antecedent (25A): this results in the pragmatic infelicity of such a reply (marked with the symbol \#).

\subsection{Truth predicate and root clause modification}

In this section we propose an analysis of C-constructions. We assume that C-constructions originate from one of the two structures illustrated in (26). The diagram in (26a) represents a normal predication structure (cf. Bowers 1993), with a Predicate Phrase ( $\mathrm{PrP})$ comprising either of a copula plus adjective or of a verb; this predicate takes a $\mathrm{CP}$ as its complement. Since adverbs cannot enter a predicative structure like this, we suggest that an alternative source for the C-construction is that in (26b), which involves an implicit or silent truth predicate with a meaning roughly equivalent to expressions like 'it is true that', 'it is so that', 'it is the case that'. The head of this silent Predicate Phrase is modified by our adverb (contributing an objective epistemic/evidential function, e.g. it is evidently/of course true/the case that), which might be of Type A or Type B; this truth predicate takes as its syntactic argument and within its semantic scope the $\mathrm{CP}$ or ForceP, i.e. the propositional content introduced by the complementizer:

(26) a.

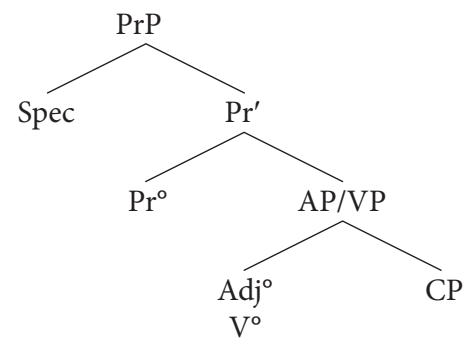


b.

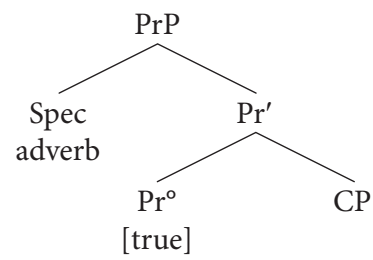

The structure in (26b) is independently needed to account for sentential adverbials used in fragments as answers to yes/no questions, as in the following example (cf. also Suñer \& Di Tullio 2014: fn. 9):

(27) A: Does he speak German?

B: Absolutely/Of course [(it is true/ the case that) he speaks German]

The optional ellipsis of the background material in the answer presupposes the presence of a silent truth predicate which the sentence initial adverb or adverbial modifies. When the C-constructions originally derived from structures like (26b) are simply marked through emphasis on the adverb, but with no other special meanings, we can simply postulate that the adverb is focussed, thus reflecting the binary articulation of the clause: a focalized adverb followed by the background, i.e. by the anaphoric CP. As soon as speaker-oriented meanings arise, however, a further step of reanalysis and grammaticalization must be posited: the adverbs move into a higher position and come to sit in the head or specifier of the SAP, which modifies the root clause $(\mathrm{CP} /$ ForceP) and which promotes the speaker's point of view:

(28)



This movement is meant to capture the speaker-oriented meaning and the scope of the C-construction, properties typically associated with the higher field of the sentence left periphery and not with the TP.

In the next section we extend this analysis to another set of constructions that have many features in common with $\mathrm{C}$-constructions, namely, evidential and quotative structures. 


\subsection{Hearsay, quotatives and reported speech}

The structure in (28) can specialize for the expression of hearsay or epistemic modality by hosting semi-grammaticalized elements such as Italian dice che, i.e. a verb of saying plus a complementizer (cf. 29a), or capace che (cf. 29b). ${ }^{18}$ Cruschina (2015) shows that these structures, typically found in a colloquial register of central and southern Italian, involve functional heads followed by the complementizer che. Adopting Hill's (2007) account for similar structures in Romanian, Cruschina claims that these functional elements occur in the SAP above the CP. This analysis implies that, once they have undergone a similar process of grammaticalization, originally different categories of elements such as adjectives and verbs can end up occupying the same head position of SAP. ${ }^{19}$

(29) (It.)
a. Dice che domani pioverà. say.3sg that tomorrow rain.FUT.3sG
'It will apparently rain tomorrow.'
b. Capace che sono già partiti. possible that be.3pL already left 'They might already have left.'

Demonte \& Fernández-Soriano (2014) apply a similar analysis to Spanish quotative que-constructions, also adopting the SAP hypothesis. This construction has been argued to involve a silent nominal element of saying which takes a reported speech act (utterance) within its scope (Etxepare 2008; 2010):

(30) (Sp.)
a. Oye, que el Barça ha ganado la Champions.
hear that the Barça have.3sg won the Champions
'Barça won the Champions League (somebody said).'
b. Si viene mi madre, que el tabaco es tuyo.
if come.3sg my mother that the tobacco be.3sg yours
'If your mother comes, (tell her that) the tobacco is yours.'

(Etxepare 2008:36)

18. See Rodríguez-Espiñeira (2014) on capaz que in Spanish.

19. We leave open here the issue of whether the Pragmatic Field should instead be conceived of as a series of functional projections, each associated with a specific meaning, as originally proposed by Speas \& Tenny (2003). Note that, following Hill (2007), Cruschina (2015) adopts a single SAP projection not only for descriptive simplicity, but also in order to offer a homogenous analysis in terms of grammaticalization. 
c. Tu padre que cuándo vas a visitarle.

your father that when go.2sG to visit him

'Your father (asked) when you are going to visit him.' (Etxepare 2008: 28)

(31) (Sp.)

a. ... de repente se oye detrás: oye, que Manolo puso

... suddenly one hears behind listen that Manolo put.Pst.3sG

la bandera.

the flag

'... suddenly one hears from behind: listen, (someone said) that Manolo put the flag.'

(CREA, ORAL Spain)

b. Que ha dimitido el decano.

that have.3sg resigned the dean

'The dean has resigned (someone said/I just heard)'.

(Demonte \& Fernández-Soriano 2014:229)

In the examples in (30) and (31), the quotative meaning derives from the fact that what is reported is indirect speech (with no deictic shift to another speaker, cf. $30 \mathrm{~b}$ and 30c), so that que now has the function of introducing reported speech (more precisely, an utterance, not a proposition; see the wh-interrogative following que in 30c). Starting from this observation, Demonte \& Fernández-Soriano (2014) argue that these structures are root clauses and that the semantic contribution of que is to encode the reference to a speech event reported by the speaker. The function of the complementizer que in this particular construction is thus that of an indirect reportative grammatical evidential. ${ }^{20}$ Note that in this type of structure the actual author of the original speech act is usually not explicitly expressed, but it could be (see $30 \mathrm{c}){ }^{21}$

Building on Etxepare (2010), we can say that Spanish evidential and quotative que-constructions involve an empty predicate of saying, whose complement is an utterance introduced by the special marker que; this marker is therefore no longer a complementizer proper (i.e. a complementizer introducing a sentential

20. For a different analysis, see Etxepare (2010), who through a series of tests shows that quotative que is not evidential, but only quotative (for this distinction, see also footnote 21).

21. Aikhenvald (2004: 177f) distinguishes between quotative and reportative evidentials stating that "if a language has two reported type evidentials, the most common distinction is that between reported (stating what someone else has said without specifying the exact authorship) and quotative (introducing the exact author of the quoted report)." The distinction between quotatives and indirect reportative evidentials is surely an important issue in the understanding of the ultimate function of Spanish que in the constructions under discussion. For reasons of space, however, we cannot discuss this further here. 
complement in the form of a proposition) but a marker of evidential or quotative values, since it introduces an utterance. ${ }^{22}$

In light of this analysis, the main differences between the Italian example in (29a) and the Spanish evidential quotative sentences in $(30,31)$ can be reduced, first, to the overt vs. covert realization of the predicate of saying (a decategorialized form of this predicate shows up in the Italian construction, while a silent or implicit predicate of saying must be assumed for the Spanish construction); and, second, the semantic nature of the element that the evidential/quotative adverb takes scope over, which is a proposition in the case of (29) and an utterance (a speech act) in (30, 31 ). Both constructions feature a complementizer in a root clause and express an evidential meaning related to reporting. Despite their specialized evidential meaning, we claim that these reportative evidential structures can be viewed as structurally equivalent to the other epistemic and evidential C-constructions discussed above, and can be best described under a homogenous analysis.

\section{Back to sentential adverbs: Type- $\mathrm{C}$ adverbs}

In several Romance varieties a further development is possible. In Sicilian, Sardinian, Galician, Romanian and Spanish, the univerbation between the speaker-related element before the complementizer with the complementizer itself has yielded new higher adverbs. This phenomenon is not limited to Romance; it has in fact also been attested for other languages (Ramat \& Ricca 1998). Most typically, in Romance this univerbation involves a verb of saying, although an adjective or adverb can also undergo a similar process of univerbation (cf. the epistemic Type-C adverb in 32) (see Kany 1944; Company Company 2004; Travis 2006; Olbertz 2007; Cruschina \& Remberger 2008; Cruschina 2010; Remberger 2015, among others): the elements dicica in Sicilian, nachi in Sardinian, disque in Galician, cică in Romanian, and dizque in Old and Latin American Spanish shall derive from the (impersonal) third person singular form of the verb 'to say' plus the complementizer. They are now fully-fledged adverbs that lend an evidential, reportative value to the sentence in which they appear. These are the adverbs that we have labelled Type-C adverbs (see also Cruschina \& Remberger 2008; Example (33d) is from Remberger 2015:36):

22. Etxepare (2010:619) calls this quotative que "a clausal Determiner", which makes the utterance (i.e. predicational relation between the saying predicate and the proposition) referable. 
(32) (Sic.)

Capacica dumani chiovi.

possible-that tomorrow rain.3sg

'It will probably rain tomorrow.'

(33) a. (Sic.)

Dicica dumani av' a chioviri.

says-that tomorrow have.3sg to rain.INF

'It will apparently rain tomorrow.'

b. (Srd.)

In custu castello nachi bi istaiada su fizu 'e su re.

in this castle says-that there stay.PST.3sG the son of the king

'The son of the king was apparently living in this castle.'

(Archivi del Sud 1996)

c. (Gal.)

- Entón Anxo vendeu o piso? - Disque (si).

so Anxo sell.PST.3sg the flat says-that yes

- 'So Anxo sold the flat?' - 'Apparently (so).'

d. (Rom.)

Cică individul a fost prins.

says-that individual-the have.3sg been arrested

'Allegedly the individual was arrested.'

e. (Sp.)

- ¿Cómo vivirá esa gente? - Dizque son artistas. how live.Fut.3sg this people says-that be.3PL artists

- 'How are these people going to live?' - 'Apparently, they are artists.'

Unlike Type-A and Type-B adverbs before the complementizer in C-constructions, in which the adverb and the complementizer are two distinct units, Type-C adverbs consist of single units with a morphologically merged complementizer at the end of the word. Cruschina \& Remberger (2008) show that the originally lexical element preceding the complementizer in this type of adverb has undergone a process of decategorialization and semantic bleaching, so that it has now lost all the grammatical properties as well as the lexical meaning typical of its original category, including the ability to inflect or to realize a partial or full argument structure. Lexical element and complementizer are now inseparable units which enjoy the true mobility of adverbs: although they tend to occur in sentence-initial position, they can also appear sentence-finally or in other positions of the clause when used parenthetically (cf. 34, 35). They can also stand alone in isolation, for example in fragment answers (cf. 33c above): 
(34) (Sp.)

Además sí subí, un día en un taxi, que me cobró una fortuna porque dizque vida no hay sino una...

'Moreover, one day I did enter a taxi which made me pay a fortune because they say there is one life only ...'

(CREA, Colombia; Fernando Vallejo: La virgen de los sicarios, 1994)

(35) (Srd.)

Tando ch'intrada e crobada, nachi, su pohu ipinu, da unu momentu a s'ateru, nachi, tottu offiadu, offiadu cun cuddos oios, nachi, abbaidendesila; ...

'Then she goes inside and finds, they say, the porcupine, from one moment to the other, they say, completely bloated, bloated with those eyes, they say, looking at her;...'

(Archivi del Sud 1996)

These examples provide strong evidence in favour of the hypothesis that Type-C adverbs now display the same distributional restrictions and mobility as sentential adverbs (cf. Cruschina \& Remberger 2008; Cruschina 2015, for more details). Even if they share, at least morphologically, the same composition as the C-constructions that feature Type-A and Type-B adverbs, it is important to emphasize that, being adverbs proper, the syntactic environment in which they now occur is in fact a canonical sentence.

\section{Conclusions and final remarks}

On the basis of synchronic data, we have demonstrated that a variety of structures expressing speaker-oriented properties may show different degrees or types of grammaticalization, and may involve different types of adverb: Type-A vs. Type B according to the specific language. We have grouped together all these structures under the common name 'C-constructions', and have offered a unified analysis according to which they are root clauses that consist of a semi-grammaticalized element in the so-called pragmatic field that takes a sentence within its scope (as opposed to canonical 'S-constructions', in which adverbs occur sentence-internally with no complementizer). C-constructions can have similar meanings to those of S-constructions: this may simply be the result of the omission of the copula in a biclausal structure, but could also represent a primary step towards grammaticalization. As a consequence of further grammaticalization, however, C-constructions develop specialized meanings related to the speaker's attitude and point of view with respect to the propositional content of the clause: they can emphasize the speaker's point of view with respect to a sentential discourse topic, or else they can instantiate epistemic, hearsay and other evidential strategies. Only when they 
become fully grammaticalized may C-constructions yield new adverbial forms (Type C) which, on a par with canonical sentential adverbs, are to be associated with Cinque's (1999) functional projections.

Further diachronic corpus-based studies, complemented by the synchronic investigation of the geographical variation concerning these and similar constructions, could certainly cast new light not only on the evolution of standard adverbs and their precise function within the sentence, but also on the development of our C-construction (cf. Kocher 2014; 2015; Killie 2015, among others). On the basis of the observation that different $\mathrm{C}$-constructions clearly involve varying degrees or stages of grammaticalization, we should now ask the question of whether or not Type-C adverbs should be seen as the outcome of the final stage of a gradual and unidirectional process of grammaticalization. Do the Type-C adverbs discussed in Section 5 presuppose an anterior phase in which the first element and the complementizer were identifiable as two distinct units? Would this intermediary stage be an essential step in the development of Type-C adverbs? In fact, no evidence is available to support the claim that the process of grammaticalization yielding Latin American Spanish dizque, for example, requires as a necessary antecedent or precondition a previous stage in which an alleged C-construction comprises a semi-grammaticalized verb form dice before the complementizer que. Even if the two structures co-exist in one language, this does not necessarily mean that one stage develops from the other. On the one hand, gathering diachronic evidence from corpora is not an easy task, since the orthographic rendition of this structure as two distinct words or as a single word is one of many potentially unreliable factors. On the other, it could well be the case that the evidential C-constructions and the evidential Type-C adverbs are two possible, parallel and independent grammaticalization developments from the same biclausal source. This hypothesis would predict different outcomes characterized by different degrees of grammaticalization (a potential problem for those analyses that treat grammaticalization as a gradual process; see the contributions to Traugott \& Trousdale 2010), but at the same time it would comply with the minimalist approach to grammaticalization put forward in Roberts \& Roussou (2003). According to this approach, grammaticalization is to be conceived of as upward reanalysis/movement along the syntactic tree. Type-A and Type- $\mathrm{B}$ adverbs in the pragmatic field are already the result of such a reanalysis, having been reinterpreted as elements occupying the SAP projection above the CP. A further reanalysis to Type-C adverbs, namely, to canonical adverbs, would imply downward reanalysis/movement, against Roberts \& Roussou's (2003) theory. If we assume that Type-C adverbs derive directly from a biclausal construction, this problem does not arise. 
A manifestation of the different degrees of grammaticalization is also reflected in the status of the complementizer depending on the specific structure. A complementizer proper introduces the propositional argument of a predicate, within the propositional domain. In the C-constructions, the complementizer that follows Type-A or Type-B adverbs, or a semi-grammaticalized functional element, has the function of marking the border between the pragmatic field and the propositional domain, and of introducing an antecedent proposition/speech act. Finally, when the complementizer has become lexically part of a Type-C evidential or epistemic adverb it is part of a process of sentence adverb formation.

\section{References}

Archivi del Sud. 1996. Contami unu contu. Racconti popolari della Sardegna, Vol. I: Logudoro. Alghero: Archivi del Sud.

Aikhenvald, Alexandra Y. 2004. Evidentiality. Oxford: OUP.

Bellert, Irena. 1977. On semantic and distributional properties of sentential adverbs. Linguistic Inquiry 8(2): 337-351.

Bowers, John. 1993. The syntax of predication. Linguistic Inquiry 24(4): 591-656.

Cinque, Guglielmo. 1999. Adverbs and Functional Heads. Oxford: OUP.

Company Company, Concepción. 2004. ¿̨ramaticalización o desgramaticalización? El reanálisis y subjetivización de verbos como marcadores discursivos en la historia del español. Revista de Filología Española 84(1): 29-66. doi:10.3989/rfe.2004.v84.i1.97

CREA - Real Academia española: Banco de datos (CREA) [online]. Corpus de referencia del español actual. <http://www.rae.es> (20 December 2014).

Cruschina, Silvio \& Remberger, Eva-Maria. 2008. Hearsay and reported speech: Evidentiality in Romance. Rivista di Grammatica Generativa 33: 95-116.

Cruschina, Silvio. 2010. Aspetti morfologici e sintattici degli avverbi in siciliano. In Studi sui dialetti della Sicilia [Quaderni di lavoro ASIt 11], Jacopo Garzonio (ed.), 21-42. Padua: Unipress.

Cruschina, Silvio. 2015. The expression of evidentiality and epistemicity: Cases of grammaticalization in Italian and Sicilian. Probus 27: 1-31. doi:10.1515/probus-2013-0006

De Haan, Ferdinand. 2005. Semantic distinctions of evidentiality. In The World Atlas of Language Structures, Martin Haspelmath, Matthew S. Dryer, David Gil \& Bernard Comrie (eds), 314317. Oxford: OUP.

Demonte, Violeta \& Fernández-Soriano, Olga. 2014. Evidentiality and illocutionary force. Spanish matrix que at the syntax-pragmatics interface. In Left Sentence Peripheries in Spanish: Diachronic, Variationist, and Typological Perspectives [Linguistik Aktuell/Linguistics Today 214], Andreas Dufter \& Álvaro S. Octavio de Toledo (eds), 217-252. Amsterdam: John Benjamins. doi: 10.1075/la.214.13dem

Dendale, Patrick \& Tasmowski, Liliane. 2001. Introduction: Evidentiality and related notions. Journal of Pragmatics 33(3): 339-348. doi:10.1016/S0378-2166(oo)0ooo5-9

Erdmann, Peter. 1997. Supplementive adjective clauses in English. In Language History and Linguistic Modelling. A Festschrift for Jacek Fisiak on his 60th Birthday, Vol. 2, Raymond Hickey \& Stanislaw Puppel (eds), 1433-1451. Berlin: Mouton de Gruyter. 
Ernst, Thomas. 2002. The Syntax of Adjuncts. Cambridge: CUP.

Etxepare, Ricardo. 1997. The Grammatical Representation of Speech Events. PhD dissertation, University of Maryland.

Etxepare, Ricardo. 2008. On quotative constructions in Iberian Spanish. In Crosslinguistic Studies of Clause Combining: The Multifunctionality of Conjunctions [Typological Studies in Language 80], Ritva Laury (ed.), 35-77. Amsterdam: John Benjamins. doi:10.1075/tsl.80.04etx

Etxepare, Ricardo. 2010. From hearsay evidentiality to samesaying relations. Lingua 120(3): 604-627. doi:10.1016/j.lingua.2008.07.009

Evans, Nicholas. 2007. Insubordination and its uses. In Finiteness: Theoretical and Empirical Foundations, Irina Nikolaeva (ed.), 366-431. Oxford: OUP.

Giorgi, Alessandra. 2010. About the Speaker. Towards a Syntax of Indexicality. Oxford: OUP. Grevisse, Maurice \& Goosse, André. 2008. Le bon usage, 14th edn. Brussels: De Boeck \& Larcier. Gutiérrez-Rexach, Javier. 2001. Spanish Exclamatives and the Semantics of the Left Periphery. In Romance Languages and Linguistic Theory 1999. Selected papers from 'Going Romance' 1999, Leiden, 9-11 December 1999 [Current Issues in Linguistic Theory 221], Yves de Hulst, Johan Rooryck \& Jan Schroten (eds), 167-194. Amsterdam: John Benjamins.

doi:10.1075/cilt.221.07gut

Gutiérrez-Rexach, Javier. 2008. Spanish root exclamatives at the syntax/semantics interface. Catalan Journal of Linguistics 7: 117-133.

Hernanz, María Luisa. 2007. From polarity to modality: Some (a)symmetries between bien and si in Spanish. In Coreference, Modality, and Focus: Studies on the Syntax-Semantics Interface [Linguistik Aktuell/Linguistics Today 111], Luis Eguren \& Olga Fernández-Soriano (eds), 133-169. Amsterdam: John Benjamins. doi:10.1075/la.111.08her

Hill, Virginia. 2007. Romanian adverbs and the pragmatic field. The Linguistic Review 24(1): 61-86. doi:10.1515/TLR.2007.003

Hill, Virginia. 2012. A main clause complementizer. In Main Clause Phenomena: New Horizons [Linguistik Aktuell/Linguistics Today 190], Lobke Aelbrecht, Liliane Haegeman \& Rachel Nye (eds), 279-296. Amsterdam: John Benjamins. doi:10.1075/la.190.12hill

Hummel, Martin. 2012. Polifuncionalidad, polisemia y estrategia retórica. Los signos discursivos con base atributiva entre oralidad y escritura. Berlin: De Gruyter. doi:10.1515/9783110281248

Hummel, Martin. 2013. Attribution in Romance: Reconstructing the oral and written tradition. Folia Linguistica Historica 34(1): 1-42. doi:10.1515/flih.2013.001

Hummel, Martin. 2014. The adjective-adverb interface in Romance and English. In Adjectives in Germanic and Romance [Linguistik Aktuell/Linguistics Today 212], Petra Sleeman, Freek Van de Velde \& Harry Perridon (eds), 35-71. Amsterdam: John Benjamins.

doi:10.1075/la.212.02hum

Jackendoff, Ray. 1972. Semantic Interpretation in Generative Grammar. Cambridge MA: The MIT Press.

Kany, Charles E. 1944. Impersonal dizque and its variants in American Spanish. Hispanic Review 12(2): 168-177. doi: $10.2307 / 469712$

Killie, Kristin. 2015. Secondary grammaticalization and the English adverbial -ly suffix. Language Sciences 47: 199-214. doi:10.1016/j.langsci.2014.10.003

Klein, Wolfgang. 1994. Time in Language. London: Routledge.

Kocher, Anna. 2014. Claro que son adverbios: Análisis de un proceso de gramaticalización. MA thesis, University of Vienna. 
Kocher, Anna. 2015. Epistemic and evidential adverbial constructions in Ibero-Romance. Talk at the International Conference on Linguistics of Ibero-Romance Languages, Ghent, 14-16 December.

La Repubblica - Corpus. <http://sslmit.unibo.it/repubblica> (31 January 2015).

Laenzlinger, Christopher. 1996. Adverb syntax and phrase structure. In Configurations: Essays on Structure and Interpretation, Anna-Maria di Sciullo (ed.), 99-127. Somerville MA: Cascadilla Press.

Ledgeway, Adam. 2011. Adverb agreement and split intransitivity: Evidence from southern Italy. Archivio Glottologico Italiano 96(1): 31-66.

Lonzi, Lidia. 1991. Il sintagma avverbiale. In Grande grammatica italiana di consultazione, Vol. 2:

I sintagmi verbale, aggettivale, avverbiale; la subordinazione, Lorenzo Renzi \& Giampaolo Salvi (eds), 341-412. Bologna: Il Mulino.

López-Couso, María José \& Belén Méndez-Naya. 2015. Epistemic/evidential markers of the type verb + complementizer. Some parallels from English and Romance. In New Directions in Grammaticalization Research [Studies in Language Companion Series 166], Andrew D. M. Smith, Graeme Trousdale \& Richard Waltereit (eds), 93-120. Amsterdam: John Benjamins. doi:10.1075/slcs.166.05lop

Lupşa, Cornelia Daniela. 2011. Deconstructing the "Adverb plus complementizer construction" in Romanian. Bucharest Working Papers in Linguistics 13(2): 91-98.

Lyons, John. 1977. Semantics. Cambridge: CUP.

NGLE - Real Academia Española. 2009. Nueva gramática de la lengua española, 2 Vols. Madrid: Espasa-Calpe.

Olbertz, Hella. 2007. Dizque in Mexican Spanish. The subjectification of reportative meaning. Italian Journal of Linguistics 19(1): 151-172.

Pietrandrea, Paola. 2005. Epistemic Modality. Functional Properties and the Italian System [Studies in Language Companion Series 74]. Amsterdam: John Benjamins. doi:10.1075/slcs.74

Plungian, Vladimir A. 2001. The place of evidentiality within the universal grammatical space. Studies in Language 12(1): 349-357.

Poletto, Cecilia \& Zanuttini, Raffaella. 2013. Emphasis as reduplication: Evidence from si che/no che sentences. Lingua 128: 124-141. doi:10.1016/j.lingua.2012.10.016

Radford, Andrew. 2013. The complementiser system in spoken English: Evidence from broadcast media. In Information Structure and Agreement [Linguistik Aktuell/Linguistics Today 197], Victoria Camacho Taboada, Ángel L. Jiménez-Fernández, Javier Martín-González \& Mariano Reyes-Tejedor (eds), 11-54. Amsterdam: John Benjamins. doi:10.1075/la.197.01rad Ramat, Paolo \& Ricca, Davide. 1998. Sentence adverbs in the languages of Europe. In Adverbial Constructions in the Languages of Europe, Johann van der Auwera (ed.), 187-275. Berlin: de Gruyter. doi:10.1515/9783110802610.187

Reichenbach, Hans. 1947. Elements of Symbolic Logic. New York NY: MacMillan.

Remberger, Eva-Maria. 2015. 'I didn't say it. Somebody else did.' - The Romanian hearsay marker CICĂ. In Redefining community in Intercultural context, Vol.4/1. Selection of papers presented within 4th RCIC Conference, Braşov, 21 May, 2015, 31-41.

Rizzi, Luigi. 1997. The fine structure of the left periphery. In Elements of Grammar, Liliane Haegeman (ed.), 281-337. Dordrecht: Kluwer. doi:10.1007/978-94-011-5420-8_7

Rizzi, Luigi \& Roberts, Ian. 1989. Complex inversion in French. Probus 1(1): 1-30. doi:10.1515/prbs.1989.1.1.1

Roberts, Ian \& Roussou, Anna. 2003. Syntactic Change: A Minimalist Approach to Grammaticalization. Cambridge: CUP. doi:10.1017/CBO9780511486326 
Rodríguez-Espiñeira, María José. 2014. Emergencia e historia de la construcción es capaz que. In Llaneza. Estudios dedicados al profesor Juan Gutiérrez Cuadrado, María Bargalló Escrivá, María Pilar Garcés Cómez \& Cecilio Garriga Escribano (eds), 205-218. A Coruña: Anexo de la Revista de Lexicografía.

Speas, Peggy \& Tenny, Carol L. 2003. Configurational properties of point of view roles. In Asymmetry in Grammar, Vol. 1 [Linguistik Aktuell/Linguistics Today 57], Anna-Maria di Sciullo (ed), 315-344. Amsterdam: John Benjamins. doi: 10.1075/la.57.15spe

Suñer, Avellina \& Àngela Di Tullio. 2014. Bare adjectives as syncretic forms. Borealis 3(1): 23-47. doi:10.7557/1.3.1.2751

Stalnaker, Robert. 1978. Assertion. In Syntax and Semantics, 9: Pragmatics, Peter Cole (ed.), 315-332. New York NY: Academic Press.

Traugott, Elisabeth Closs \& Trousdale, Graeme. (eds). 2010. Gradience, Gradualness and Grammaticalization [Typological Studies in Language 90]. Amsterdam John Benjamins. doi:10.1075/tsl.9o

Traugott, Elisabeth Closs. 1995. Subjectification in grammaticalization. In Subjectivity and Subjectivisation, Dieter Stein \& Susan Wright (eds), 37-54. Cambridge: CUP. doi:10.1017/CBO9780511554469.003

Travis, Catherine. 2006. Dizque: A Colombian evidentiality strategy. Linguistics 44: 1269-1297. doi:10.1515/LING.2006.041

van der Auwera, Johann \& Plungian, Vladimir A. 1998. Modality’s semantic map. Linguistic Typology 2(1): 79-124. doi:10.1515/lity.1998.2.1.79

van Gelderen, Elly. 2004. Grammaticalization as Economy [Linguistik Aktuell/Linguistics Today 71]. Amsterdam: John Benjamins. doi:10.1075/la.71

van Gelderen, Elly. 2011. The Linguistic Cycle. Language Change and the Language Faculty. Oxford: OUP. doi:10.1093/acprof:0so/9780199756056.001.0001 

PART II

French 



\title{
Adjectives and adverbs in the Grande grammaire du français
}

\author{
Anne Abeillé, ${ }^{\star}$ Olivier Bonami, ${ }^{\star}$ Danièle Godard ${ }^{\star}$ \\ and Michèle Noailly ${ }^{\star *}$ \\ * LLF, University Paris Diderot \& CNRS / \\ ** University of Bretagne Occidentale
}

The distinction between adjectives and adverbs is a traditional issue in French grammars:

1. many adverbs are derived from adjectives, usually with a -ment suffix (facile 'easy' > facilement 'easily') but not always (juste > juste 'just')

2. many adjectives may modify verbs without being inflected (voir clair 'see clear') with a manner or result interpretation.

We show how the principles of the Grande grammaire du français (Abeille \& Godard 2012, to appear) allows one to draw a strict division, based on morphosyntactic criteria, for modern French:

1. only adjectives may vary in gender and number

2. only adverbs may occur between the auxiliary and the past participle (a clairement ${ }^{*}{ }^{*}$ lair $v u$ 'has clearly seen'), or before the infinitive ( ${ }^{*}$ clair voir), with an integrated prosody.

\section{The distinction between French adjectives and adverbs}

The distinction between adjectives and adverbs is a traditional issue in French grammars (Moignet 1963; Noailly 1999 among others). Most adverbs are derived from adjectives by -ment suffix, but some authors have proposed that they belong to the same category, -ment being an inflexional rather than derivational suffix (Dal 2007). ${ }^{1}$

1. See Giegerich (2012) for a similar proposal for English -ly derived "adverbs". 
For simple adverbs, most French dictionaries distinguish homonyms such as fort ('strong', 'highly'), juste ('right', 'just'), soudain ('sudden', 'suddenly'). The adjective may vary in number and gender (1a), not the adverb (1b):

(1) a. Une réponse juste, des réponses justes

INDF.FSG answer.FSG right.FSG, INDF.FPL answer.FPL right.FPL 'a right answer,' 'right answers'

b. juste un peu, juste amoureuses

right.MSG a-little, right.MSG in-love.FPL

'just a little', 'just in love'

c. un homme fort, une femme forte

INDF.MSG man.MSG strong.MSG, INDF.FSG woman.FSG strong.FSG

'a strong man', 'a strong woman'

d. fort bien, fort belle

strong.MSG well, strong.MSG beautiful.FSG

'highly well', highly beautiful'

There may also be a meaning difference between both: the adjective juste means 'fair' or 'right' (1a), while the degree adverb means 'barely', 'just' (1b). Similarly, fort can be a degree adverb ('highly') (1c) or an adjective ('strong') (1d).

Further more, non agreeing adjectives may occur in the French verbal phrase, usually with a manner or a result interpretation (Guimier 1989).

(2) a. Elle travaille dur

3FSG works hard.MSG

'She works hard'

b. Marie mange chinois

Marie eats chinese.MSG

'Marie eats Chinese food'

Their status has been debated among linguists: Moignet (1963), for example, analyses them as adverbs (with a truncated -ment suffix), while Guimier (1989), Noailly (1994) analyse them as adjectives. After Sandmann (1942), Hummel (2014) proposes a continuum between adjectives and adverbs and sees the distinction in contemporary standard French as the result of standardization imposing adjectival invariability and -ment forms with verbs, quoting Vaugelas:

Monsieur de Malherbe dit, Allez tout beau. Cette façon de parler ne vaut rien pour dire tout doucement, tout bellement ('Mr de Malherbe says Allez tout beau, This way of speaking is worth nothing to say tout doucement, tout bellement').

(Vaugelas 1647, Remarques sur la langue françoise) 
He challenges the distinction for contemporary spoken (or informal) French (see Section 5 below).

We show how the redefinition of categories and functions in the Grande grammaire du français (Abeillé \& Godard 2012) allows one to draw a strict division between adverbs and adjectives, on the basis of morphosyntactic criteria for contemporary French:

1. only adjectives may vary in gender and number

2. only adverbs may occur between the auxiliary and the past participle, or before the infinitival verb, with an integrated prosody.

\section{Categories and functions in the Grande grammaire $d u$ français}

The Grande grammaire du français (GGF) is an international project, gathering more than 50 linguists, ${ }^{2}$ which has started in 2002 (Abeillé et al. 2007, 2012). It will be published in 2019 by Actes Sud, and similar to what exists for many European languages: the Gramática descriptiva de la lengua española (Bosque \& Demonte 1999), the Grande grammatica italiana di consultazione (Renzi et al. 2001), the Cambridge Grammar of the English language (Huddleston \& Pullum 2002), the Gramàtica del Català contemporani (Solà et al. 2008). Nothing of the sort exists for French, despite good descriptive grammars, such as Damourette \& Pichon (19111946), Grevisse \& Goosse (2008) or Riegel et al. (2014).

It aims at a comprehensive description of the syntactic phenomena of contemporary French (after 1950), while taking into account morphological, lexical, semantic, pragmatic and prosodic aspects.

As the focus is on "ordinary" French (Gadet 1989), the data come from a variety of sources, including sizable corpora, both written (newspapers, novels, internet) and spoken (radio, interviews), and constructed examples for simple cases and ungrammatical variants. They also include some regional variation (esp. Belgium, Switzerland, Quebec) and non standard data (Blanche Benveniste 1997).

\section{Syntactic categories in the GGF}

To ensure maximal coherence and readability, the GGF is based on a surfacist phrase structure grammar with a fixed set of categories and functions. It relies on eleven morphosyntactic parts of speech (see Table 1).

2. O. Bonami is coordinator of the Adverb chapter, and M. Noailly of the Adjective chapter. A. Abeillé and D. Godard are coordinators of the whole 
116 Anne Abeillé et al.

Table 1. The parts of speech in the GGF

\begin{tabular}{|c|c|}
\hline POS & Examples \\
\hline Adjective & $\begin{array}{l}\text { cardinal (trois 'three'...), ordinal (premier 'first'...), intensional (supposé } \\
\text { 'supposed'...), qualifying (rouge 'red'...), relational (national 'national'...) }\end{array}$ \\
\hline Adverb & $\begin{array}{l}\text { associative (aussi 'also'...), degree (très 'very'...), frequency (souvent } \\
\text { 'often'...), manner (bien 'well'...), negative (pas 'not'...)... }\end{array}$ \\
\hline Complementizer & comme 'as', quand 'when', que 'that', si 'if'... \\
\hline $\begin{array}{l}\text { Coordinating } \\
\text { conjunction }\end{array}$ & et 'and', mais 'but', ni 'nor', ou 'or'... \\
\hline Determiner & definite (le 'the'...), indefinite (un 'a'...), quantifier (chaque 'each'...)... \\
\hline Interjection & bravo 'congratulations', bon 'well'... \\
\hline Noun & common (table 'table'...), predicative (faim 'hunger'...), proper (Jean..) \\
\hline Participle & past (dormi 'slept'...), passive (aimé 'loved'...) \\
\hline Preposition & weak ( $\dot{a}$, de), locative (dans 'in'...), temporal (pendant 'during'...)... \\
\hline Pronoun & $\begin{array}{l}\text { demonstrative (ceci 'this'...), indefinite (quelqu'un 'someone'...), } \\
\text { interrogative (quoi 'what'...), negative (personne 'no one'...), personal (lui } \\
\text { 'him'...), quantifier (tout 'everything...), relative (lequel 'which...) }\end{array}$ \\
\hline Verb & $\begin{array}{l}\text { auxiliaries (avoir, être), intransitives (dormer 'sleep'...), transitive (laver } \\
\text { 'wash' ...), ditransitive (donner 'give' ...) }\end{array}$ \\
\hline
\end{tabular}

Past and passive participles are defined as a specific category with both verbal and adjectival properties: like verbs (3a), and unlike adjectives (3c), they may occur in an impersonal construction with a nominal complement (3b); like adjectives, and unlike verbs, they may agree in gender and number (3d). Present participles, on the other hand, are purely verbal (Abeillé \& Godard 2002).

(3) a. Il arrivera un accident

3.MSG arrive.FUT.SG INDF.MSG accident

'There will arrive an accident'

b. Il sera utilisé un sac en plastique

3.MSG AUX.FUT.SG used.PASS.MSGINDF. MSG bag in plastic

'One will use a plastic bag'

c. ${ }^{\star}$ Il sera utile un sac en plastique

3.MSG AUX.FUT.SG usefull. MSG INDF.MSG bag in plastic

d. une poire cuite, un abricot cuit

INDF.FSG pear.FSG cooked.PASS.FSG, INDF.MSG apricot.MSG cooked.PASS.MSG 'a cooked pear, a cooked apricot' 
For syntactic phrases, six phrasal categories are defined:

1. Adverbial phrase (AdP): très bien 'very well'

2. Adjectival phrase (AP): très content 'very happy'

3. Noun phrase (NP): un enfant 'a child'

4. Preposition phrase (PP): à Paris 'in Paris'

5. Verb phrase (VP): aller à Paris 'go to Paris'

6. Clause: Paul est là 'Paul is here'

Clauses may be headed by a verb (4a) or by some other part of speech (4b). They may be introduced by a complementizer (4c).

(4) a. Le soleil brille

ART.MSG sun.MSG shine.3sg.

'The sun is shining'

b. Tous dehors!

'Everyone outside!'

c. Qu' il vienne!

COMP 3.MSG come.sBJv.3sg.

'Let him come!'

We do not make use of determiner phrases: nouns are considered the head of the noun phrase, and so-called predeterminers are adjuncts to the whole NP (tous [les enfants] 'all the children') or to the numeral adjective ([jusqu'à trente] enfants 'up to thirty children').

\section{Syntactic functions in the GGF}

The GGF uses more syntactic functions than most French grammars (e.g. Grevisse \& Goosse 2008; Riegel et al. 2014). For instance, it introduces an explicit function "head", for nouns in NP, prepositions in PP, verbs in VP etc., and a specifier function for the determiner or another element introducing an NP. It relies on eleven syntactic functions for words and phrases (see Table 2).

Grammatical functions are defined by syntactic criteria, and carefully distinguished from semantic roles. The subject relation for example is characterized by verb agreement, canonical preverbal position, possibility of weak proforms such as $i$ and $c e$, and impossibility of others such as en. Direct complements, on the other hand, are defined by using different weak proforms (le, la, les for definite objects, en for indefinite objects) and canonical postverbal position. With this definition, NP subjects can play different semantic roles: agent for son fils in (5a), location for ce tiroir in (5b), goal for Paul in (5c). 
118 Anne Abeillé et al.

Table 2. The syntactic functions in the GGF

Syntactic function Examples

Adjunct

grand chien ('big dog'), très bien ('very well'), courir vite ('run fast')

Coordinate

Paul et Marie 'Paul and Marie', rouge et noir 'red and black'

Oblique complement J'habite à Paris 'I live in Paris', Paul va bien. 'Paul is doing fine'

Predicative Il est intelligent 'He is smart' Je trouve Paul intelligent. 'I find Paul smart' complement

Extract Un ami avec qui parler 'a friend with whom to talk'

Combien ça vaut? 'How much does it cost?'

Direct complement Paul regarde le ciel 'Paul watches the sky'

Head le livre 'the book', très bien 'very well', Paul viendra. 'Paul will-come'

Marker commencer à lire begin to read', Que Paul vienne! 'Let Paul come!'

Peripheral Tu le connais, Paul? 'Do you know him, Paul?'

Specifier le livre 'the book', trois questions 'three questions'

Subject Les enfants sont là. 'The kids are there'

(5) a. Son fils travaille

POsS.MSG son.MSG work.3sG

'His son works'

b. Ce tiroir contient del' argent

DEM.MSG drawer.MSG contains INDF.MSG money

'This drawer contains money'

c. Paul a reçu des livres

Paul AUX.3sg received.MSG INDF.PL book.MPL

'Paul has received books'

The postverbal NPs in $(6 \mathrm{a}, \mathrm{c})$ on the other hand, are analysed as direct complements, even though they correspond to the first semantic argument of the verb venir in (6a) and of travailler in (6c); they contrast with inverted subjects, which have non canonical placement properties but still agree with the verb and resist the use of object proforms $(6 e, f)$.

$\begin{array}{ll}\text { (6) a. } & \text { Il est venu des visiteurs } \\ & \text { 3.MSG AUX.SG come.MSG INDF.PL visitors.MPL } \\ \text { 'There came visitors' } & \end{array}$

b. Il en est venu

3.MSG PRO AUX.3SG come.MSG

'There came some' 

c. Paul fait travailler son fils
Paul makes work.INF POss.MSG son.MSG
'Paul makes his son work'

d. Paul le fait travailler

Paul PRO.3MSG makes work.INF

'Paul makes him work'

e. Quel livre ont lu deux étudiants?

Which book AUX.3PL read.MSG two student.MPL?

'Which book have two students read?'
f. ${ }^{\star} Q u e l$ livre en ont lu deux?
Which book PRO AUX.3PL read.MSG two?

\section{Adverbs in the Grande grammaire du français}

\section{The GGF definition of adverbs}

French adverbs have been studied extensively (cf. Schlyter 1977; Guimier \& Larcher 1991a, b; Guimier 1996; Molinier \& Lévrier 2000) but the category itself is not always well defined. Adverb definitions usually rely on the following criteria:

1. adverbs are not inflected, unlike adjectives

2. adverbs cannot take a direct nominal complement, unlike prepositions

3. adverbs adjoin to verbal categories

We follow the first two criteria and extend the third one: adverbs may adjoin to verbs (7a), but they may also adjoin to various categories. Degree (7b) and manner (7c) adverbs, for example, may adjoin to all major categories (Abeillé \& Godard 2003):
a. Dors
bien!
sleep.IMP.2sg well
'Sleep well !'
b. manger assez 'eat enough', assez gentil 'nice enough', assez facilement 'easily enough', assez peur 'enough fear'
c. réussir facilement 'succeed easily', facilement timide 'easily shy', facilement à l'heure 'easily on time', facilement ministre 'easily minister'


The distinction between prepositions and adverbs

French dictionaries usually split forms such as après ('after'), avant ('before'), depuis ('since') into adverbs (8a), prepositions (8b), and subordinating conjunctions (8c), depending on their complementation.

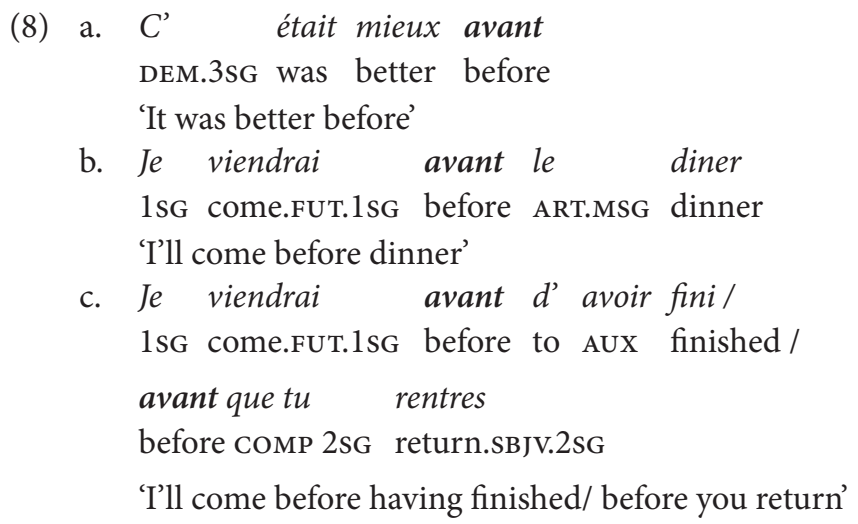

Following Piot (1995), we analyse them uniformly as prepositions with different complementations: just like verbs, they may have no complement (9a), a nominal complement (9b), an infinitival or a sentential complement in (9c).

(9) a. J' attendrai

1SG wait.FUT.1SG

'I'll wait'

b. J' attendrai le diner

1sG wait.FUT.1sG ART.MSG dinner

'I'll wait for the dinner'

c. J' attendrai d'avoir fini/ que tu rentres

1SG wait.FUT.1SG to AUX finished COMP 2SG return.sBJv.2SG

'I'll wait to have finished/ for you to return'

\section{A further test for French adverbs}

We follow Bonami (1999), Abeillé \& Godard (2004) who add a distributional test: adverbs may appear between tense auxiliary and past participle (10a, b, c), or before the infinitival (10d), without a prosodic break.
(10)
a. Paul est
souvent allé en Espagne
Paul Aux.3sg often gone.Msg to Spain
'Paul has often gone to Spain' 

b. Paul a facilement réussi ses examens
Paul AUX.3sg easily passed.Msg Poss.MPL exams
'Paul has easily passed his exams'
c. Paul s' est bien comporté
Paul RefL AUX.3sg well behaved.MSG
'Paul has well behaved'
d. Paul a décidé de bien se comporter
Paul AUX.3sg decided.MSG to well REFL behave.INF
'Paul has decided to well behave'

This test is usefull for distinguishing adverbs from NPs (11a) and PPs (11c). Plusieurs fois ('several times') cannot appear between the auxiliary and the past participle without a prosodic boundary, and is thus an NP (11c). Jusqu'à présent ('until now') cannot either and is thus a PP (11d).
(11)
a. Paul est allé plusieurs fois en Espagne
Paul AUX.3sg gone.Msg several times to Spain
'Paul has gone several times to Spain'
b. Paul est, plusieurs fois, allé en Espagne
'Paul has, several times, gone to Spain'
Paul AUx.3sg passed.Msg poss.mpl exams up to present
'Paul has passed his exams until now'
c. Paul a réussi ses examens jusqu'à présent
d. Paul a, jusqu’à présent, réussi ses examens
'Paul has, until now, passed his exams.'

Prosodic boundary, indicated here with commas, corresponds to an incidental prosody. It may have different phonetic realizations: a pause, lenghtening or higher register at the left edge... (Delais-Roussarie 2008).

As noted by Bonami and Godard (2007), this test does not apply to forms which always have a prosodic boundary such as speech act adverbs (12a, b). In (12c), without a prosodic boundary, it can only have a manner interpretation: 'really, and not 'frankly speaking'.
a. Franchement, Paul a 'Frankly, Paul has passed the limits'
b. Paul a, franchement, dépassé les bornes dépassé les bornes Frankly, Paul AUX.3sg passed.MSG ART.FPL limits
'Paul has, frankly, passed the limits'
c. Paul a franchement dépassé les bornes
'Paul has frankly passed the limits'


But it clearly sets apart forms which are often considered as adverbs in French dictionaries or grammars, such as prepositions with an implicit complement (13a, b).
(13)
Paul AUx.3sg Gone.Msg to Spain since
'Paul has gone to Spain since'
a. Paul est allé en Espagne depuis
b. Paul est, depuis, allé en Espagne
'Paul has, since, gone to Spain'
c. Paul a refusé d'aller en Espagne depuis
Paul Aux.3sg refused.Msg to go.INF to Spain since
'Paul has refused to go to Spain since'
d. ${ }^{*}$ Paul a refusé de depuis aller en Espagne
Paul AUX.3sg refused.Msg to since go.INF to Spain

As a consequence, we have no locative adverbs. Forms such as ailleurs, ici, là-bas... cannot appear between the auxiliary and the past participle (14a) nor before the infinitive (14b) without a prosodic boundary and are thus analysed as intransitive prepositions. $^{3}$
a. Paul est
allé
'Paul has gone elsewhere'
ailleurs/ *est
ailleurs allé
Paul AUx.3sg gone.Msg elsewhere/ AUx.3sg elsewhere gone.Msg
b. Paul a décidé d’aller là-bas/ *de là-bas aller
Paul AUX.3sg decided.MSG to go.INF there/ to there go.INF
'Paul has decided to go there'

\section{The subclasses of adverbs in the GGF}

Adverbs are an open class in French. Some are simple adverbs: bien ('well'), mal ('badly'), vite ('fast')... while most of them are -ment derived: dernièrement ('last'), gentiment ('kindly'), politiquement ('politically)... or compounds: quand même ('nethertheless'), un peu ('a little'), tout de suite ('right away')...

3. There may be some speakers variation in the respect: some may accept ici or ailleurs after the auxiliary without prosodic boundary, and thus treat them as adverbs: Nous sommes ici parvenus au dernier barreau de l'échelle des climatosceptiques. (23dd.fr/climat June 7th 2012). 'we have here reached the last bar of the climatosceptists' scale'. 
While most adverbs do not take complements, some may take a prepositional complement (15a) and some a sentential one $(15 b, c) .{ }^{4}$ In $(15 b, c)$, the adverb is the head of a verbless clause (Bonami \& Godard 2007). They do not take infinitival complements.

(15) a. relativement à votre demande ('regarding your request'), indépendamment de vous ('independently from you')

b. Peut-être que Paul viendra

Perhaps сомp Paul come.Fut.3sg

'Maybe Paul will come'

c. Cestemps-ci, il arrête pas de râler contre le

DEM.PL times DEM, 3MSG stops NEG to bitch.INF against the

plastique. Soi-disant qu' il y aurait

plastic. Alleged COMP 3MSG PRO have.COND.3sG

recrudescence

(Jean Vautrin, Bloody Mary, 1979: 103)

recrudescence

'These times, he keeps on bitching against plastic. There is supposed to be a recrudescence'

Adverbs also vary with respect to their syntactic function. Although most adverbs can be adjuncts, some may also be complements. Manner adverbs are obligatory complements with verbs like se comporter (16a). Comparative adverbs are also complements of some transitive verbs $(16 \mathrm{~b}, \mathrm{c})$ : they are obligatory and alternate with nominal complements (davantage d'argent 'more money' in 16b, quelque chose de mieux 'something better' in 16c).
a. Paul se comporte bien
Paul ReFL behaves well
'Paul behaves well'
b. On peut proposer davantage
'One can propose more'

4. As adverbs, they may occur between the auxiliary and the past participle without a prosodic boundary:

Paul a relativement perdu la face. ('Paul has relativey lost face')

Paul a soi-disant réglé le problème. ('Paul has allegedly solved the problem') 

c. il arrive souvent qu' on en ait assez de 3MSG arrives often COMP one PRO AUX.SBJv.3sG enough with sa première guitare $[\ldots]$, surtout si on a POSs.FSG first guitar.FSG [...], especially if one AUX.3sG acheté mieux parlasuite bought.MSG better.Msg by the following 'One may often have enough with his first guitar [...], especially if one has bought better therafter' (forum.zonemetal.com/, July 16th 2008)

Adverbs cannot be subjects ( ${ }^{\star}$ Mieux a été acheté. 'Better has been bought') but may introduce headless NP subjects (Davantage sera fait. 'More will be done').

The semantic subclasses of adverbs in the GGF

From a semantic point of view, adverbs are divided into eleven subclasses (Bonami et al. 2004):

1. Speech act adverbs: franchement 'frankly'...

2. Connective adverbs: pourtant 'nethertheless'...

3. Evaluative adverbs: heureusement 'fortunately'...

4. Modal adverbs: probablement 'probably'...

5. Agent-oriented adverbs: intelligemment 'cleverly'...

6. Aspectual adverbs: habitual (habituellement 'usually'), phase (déjà 'yet')

7. Domain adverbs: légalement 'legally'...

8. Temporal adverbs: duration (longtemps 'for a long time'), localisation (bientôt 'soon'), frequency (souvent 'often')

9. Manner adverbs: silencieusement 'silently', vite 'fast'...

10. Degree adverbs: beaucoup 'a-lot', trop 'too'...

11. Additive/restrictive adverbs: seulement 'only', aussi 'also'

The first five subclasses are often called "sentential adverbs" (Schlyter 1977; Molinier \& Lévrier 2000) because they may occur in the initial position of a negated clause (17). Semantically, they modify the proposition expressed by a clause $(17 \mathrm{a}, \mathrm{b})$ or the speech act associated to it (12a).

(17) a. Malheureusement, Pierre n' est pas parti à Rome Unfortunately, Pierre NEG AUX.3sg NEg gone to Rome 'Unfortunately, Pierre has not gone to Rome'

b. Peut-être Pierre n' est pas parti à Rome. Maybe Pierre NEg AUX.3sg NEg gone to Rome 'Maybe Pierre has not gone to Rome' 

c. Intelligemment, Pierre n' est pas parti à Rome Cleverly, Pierre NEg AUX.3sg NEg gone to Rome 'Cleverly, Pierre has not gone to Rome'

Semantically, agent-oriented adverbes (17c) modify both the situation and the agent ('Peter was clever not to go to Rome').

The monosyllabic manner and degree adverbs are the only ones which usually give rise to liaison forms:

(18) a. Paul est plus amusant que Jean [plyzamuzã]

'Paul is more amuzing than Jean'

b. Paul est très ami avec Jean [trezami]

'Paul is very friend with Jean'

\section{Adjectives in the Grande grammaire du français}

\section{The GGF definition of adjectives}

In the GGF, adjectives are defined with the following criteria (Noailly 1999):

1. adjectives may vary in gender and number

2. they agree in gender and number with their first argument

3. they cannot take a direct nominal complement, unlike participles

4. they cannot be subjects, unlike nouns

Most adjectives vary in gender and number in written French, although some, especially the recent ones (chic) do not.

When an adjective takes a complement, this complement can be a PP (19a), an infinitival VP or a subordinate clause (19b), but it cannot be an NP (19c). This last property differentiates adjectives from participles (19d):

(19) a. fier de lui 'proud of him', attentif à ses amis 'devoted to his friends'

b. fier d'avoir réussi 'proud of having succeeded', content que tout soit fini 'happy that all is finished'

c. un garçon amoureux de Mariel *amoureux Marie INDF.MSG boy.MSG in-love.Msg with Marie/ in-love Marie 'a boy in love with Marie'

d. un garcon aimant Marie INDF.MSG boy.MSG loving Marie 'a boy loving Marie' 


\section{The distinction between nouns and adjectives}

The distinction between nouns and adjectives is a traditional problem in French (Noailly 1990 among others), since many current adjectives come from converted nouns (chic, chouette, orange...). Usually, subjects are NPs (20a), but sometimes bare nouns can be subjects too (20b). Unlike nouns, adjectives cannot be subjects (20c):
(20) a. Une grosse somme a été risquée dans
INDF.FSG big.FSG sum.FSG AUX.3sG been risked.FSG in
cette affaire
DEM.FSG business
'a large sum has been risked in this business'
b. Hommage sera rendu aux victimes
Tribute MSG AUX.FUT.3Sg paid.MSG to.ART.PL victims
'Tribute will be paid to the victims'
c. ${ }^{*}$ Gros a été risqué dans cette affaire
big.MSG AUX.3sg been risked.MSG in DEM.FSG business
d. Les petites sont venues
ART.PL small.FPL AUX.PL come.FPL
'The small ones have come'

Adjectives can only occur in subject position when they belong to a nounless, anaphoric NP (20d).

Some nouns, such as color nouns, are renanalysed as adjectives when they agree (des bottes oranges 'orange boots') or when they may occur prenominally (un chic type 'a nice fellow').

But the ability to be used as a noun modifier does not automatically turn a noun into an adjective, since the noun + noun construction is productive in French (Noailly 1990). In (21), the first noun is the head and the second noun, an adjunct: contrary to an attributive adjective, it does not agree in number nor gender with the head noun (21a, b), and may be a proper name (21c).
(21)
a. un
passage
piétons
INDF.MSG crosswalk.MSG pedestrians.MPL
'a pedestrian crosswalk'
b. un gâteau maison
INDF.MSG cake.MSG home.FSG
'a home-made pie'
c. des lunettes Dior
INDF.PL glasses.FPL Dior
'Dior glasses' 


\section{Adjectives inside the Noun Phrase}

In the NP, adjectives are usually adjuncts, prenominal (22a) or postnominal (22b). They modify the head noun and agree with it in number and gender. Cardinal and similarity adjectives may also introduce the NP, with the same specifier function as determiners (22c).

(22) a. un nouveau type 'a new guy', un agréable voyable 'a pleasant journey'

b. une voiture rouge 'a red car', un voyage agréable 'a pleasant journey'

c. Pareille aventure arrive rarement

Similar.FSG adventure.FSG occurs seldom

'Similar adventure seldom occurs'

Prenominal adjectives usually give rise to a liaison form (23a). In the singular, the liaison form is generally assumed to be the same as the feminine form (23b), but a few adjectives (grand, gros...) have a special liaison form (23d), while others resist liaison (23f).
a. de bons_amis [bõzami]
INDF.PL good.MPL friend.MPL
'good friends'
b. un bon_ami [bonami]
INDF.MSG good.MSG friend.MSG
'a good friend'
c. une bonne_amie [bonami]
INDF.FSG good.FSG friend.FSG
d. un gros_ennui [grozãnyi]
INDF.MSG big.MSG trouble.MSG
'a big trouble'
e. une grosse_envie [grosãvi]
INDF.FSG big.FSG desire.FSG
'a strong desire'
f. un fort accent [foraksã] $/ *$ [fortaksã]
INDF.MSG strong.MSG accent.MSG
'a strong accent'

As proposed by Bonami \& Boyé (2005), the spoken prenominal form of the singular adjective is the masculine one if it ends with a phonetic consonant, like fort ('strong'), the feminine one, or a special one, if it ends with a phonetic vowel like bon ('good'), petit ('small') or gros ('big'). 


\section{Adjectives inside the Verbal phrase}

\section{Agreeing adjectives inside the VP}

In the VP, predicate adjectives are complements of verbs and agree with the subject (24a) or the object (24b). They are masculine singular when the object is omitted (24c), or when their argument is an infinitive or a subordinate clause (24d).
(24) a. Marie semble contente
Marie.FSG seems happy.FSG
'Marie seems happy'
b. Je trouve Marie heureuse
1sg find.1sg Marie.FsG happy.FSG
'I find Marie happy'
c. Cette musique rend sourd
DEM.FSG music.FsG makes deaf.MSG
'This music makes one deaf'
d. Je trouve important de continuer le projet
1SG find.1SG important.MSG to continue the project
'I find it important to continue the project'

Predicative adjectives which are not complements may also agree with the subject $(25 \mathrm{a}, \mathrm{e})$ or the complement (25b): semantically, they modify the subject or the object, but syntactically, they are adjuncts to the verb or the sentence and are optional (25c, d).
a. Marie vivait heureuse dans cet endroit
'Marie.FSG lived happy.FSG in DEM.MSG place.MSG'
'Mary was living happy in this place'
b. Ils ont coupé la jupe trop courte
3MPL AUX.PL cut.MSG ART.FSG skirt.FSG too short.FSG
'They cut the skirt too short'
c. Marie vivait dans cet endroit
d. Ils ont coupé la jupe
'They have cut the skirt'

Some agreeing adjectives may also occur in sentence initial position, thus outside the VP (26). They modify the subject but are often associated also with a clause-like interpretation: temporal ('when they were young' in 26a), conditional ('if she had been silent' in 26b). 
(26) a. Très jeunes, ils ont décidé de devenir cinéastes Very young.MPL, 3MPL AUX.PL decided to become filmmakers 'Very young, they decided to become filmmakers'

b. Silencieuse, elle les aurait mieux convaincus

Silent.FSG, 3FSG PRO.3PL AUX.COND.FSG better convinced.MPL

'Silent, she would have convinced them better'

Non agreeing adjectives inside the VP

Non agreeing adjectives can occur inside the VP (27a, d). Following Noailly (1994), Abeillé \& Godard (2004), Abeillé \& Mouret (2010), we analyse them as complements when they are obligatory $(27 b, e)$ and commute with an NP complement $(27 c, f)$.
(27)
a. Elle risque gros
3FSG risks big.MSG
'She risks a lot'
b. ${ }^{\star}$ Elle risque
3FSG risks
c. Elle risque sa place
3FSG risks POSS.FSG position.FSG
'She risks her position'
d. Ces livres coutent cher
DEM.MPL books.MPL cost.PL expensive.MSG
'These books are expensive'
e. ${ }^{*}$ Ces livres coutent
DEM.MPL books.MPL cost.PL
f. Ces livres coutent une fortune
DEM.MPL books.MPL cost.PL INDF.FSG fortune.FSG
'These books cost a fortune'

As noticed by Noailly (1993), comparative adjectives easily occur in this position $(28 \mathrm{a}, \mathrm{b})$. They are not reanalysed as NPs since they cannot occur in subject position (28c), unless they combine with a specifier (28d).
(28)
a. J' ai pris trop grand
1sG AUX.1sG taken.MSG too big.MSG
'I have taken one too big'
b. J'ai acheté plus petit
1sG AUX.1sg bought.MSG more small.MSG
'I have bought a smaller one'
c. ${ }^{*}$ Plus petit a été acheté récemment
More small.Msg AUx.3sg been bought recently




\section{d. Un plus petit a été acheté récemment INDF.MSG more small.MSG AUX.3sg been bought recently 'A smaller one has been bought recently'}

As complement, the adjective denotes a distinctive property of the unexpressed noun.

But non agreeing adjectives may also occur as verbal adjuncts (29a, b). In such contexts, they are optional (29c), and may sometimes cooccur with a complement (29d).
a. Marie travaille dur/ creuse profond
Marie works hard.Msg / digs deep.MsG
'Marie works hard/ digs deep'
b. L'Elysée apprécie moyen
The Elysee appreciates average.MsG
'Elysee does not appreciate this much'
(Libération, July 7th 1989:8)
c. Marie travaille / creuse
'Marie works / digs'
d. L'Elysée apprécie moyen cette initiative The Elysee appreciates average.MSG DEM.FSG initiative.FSG 'Elysee does not appreciate this iniative much'

They have a manner (travailler dur), a result (creuser profond), or a degree (29b) interpretation (Guimier 1989). They are masculine singular since they do not have any NP to agree with.

Many verbal collocations include such adjectives: boire sec ('drink heavily'), laver blanc ('wash clean'), filer doux ('toe the line'), refuser net ('refuse sharp')...

Depending on the verb, the same adjective may occur as a complement or as an adjunct.

Pareil ('similar') is a complement of faire ('do') in (30a) and an adjunct to the verb in (30b). Terrible ('awful') is a complement of risquer ('risk') in (30c) and an adjunct to the verb in (30d).

(30) a. Paul chante à tue-tête et moi, je faispareil

Paul sings at kill-head and me, 1sG do similar.MsG

'Paul sings loudly and I do the same'

b. I' ai l' impression que ma vie s'

1SG have ART.SG impression.FSG COMP POSS.FSG life.FSG REFL

est déformée pareil.

AUX.3Fs distorted.FSG similar.MSG

(Sébastien Japrisot, Un long dimanche de fiançailles, Paris: Gallimard: 76)

'I have the impression that my life has been distorted similarly' 
c. Les cours martiales n' existaient plus, il ART.FPL courts.FPL martial.FPL NE existed no-longer, 3MSG risquait pas terrible, il aurait un risked NEG awful-MSG, 3MSG have.COND.3SG INDF.MSG avocat.

lawyer.MSG

'The martial courts did not exist any more, he was not risking much, he would have a lawyer'

d. Ça canardait probablement terrible à la tombée DEM.MSG sniped probably awful.MsG at the fall du jour

of.ART.MSG day.MSG

'There was probably awful sniping at nightfall'

\section{The GGF distinction between adjectives and adverbs}

Adjectives and adverbs with adjectives and nouns

Typically adverbs modify adjectives and adjectives modify nouns (31a). But various adverbs may modify quantity or role denoting nouns (31b, c).

(31) a. excessivement chaud 'extremely hot', une chaleur excessive 'an extreme heat'

b. la presque totalité des participants 'the almost totality of participants'

c. le désormais ex-président de France Inter 'the now ex-president of France Inter'

d. un excellent départ 'an excellent start', un examen rapide 'a rapid examination'

However, only adjectives may modify event denoting nouns with a manner interpretation (31d). ${ }^{5}$

\section{The case of tout}

The quantifier tout is analysed as an adjective in predeterminer position (32a): it agrees in number and gender with the following noun or pronoun. The same form is sometimes analysed as an adverb when premodifying an adjective (32b). We

5. Bien as a manner adverb ( ${ }^{\star}$ un départ bien 'a departure well'), must be distinguished from its adjectival homonym restricted to human nouns: un homme bien ('a decent man'). 
also analyse tout as an adjective in this position, since it agrees in gender (32b). When it modifies an adverb or a PP (32c), it is not inflected and we analyse it as a degree adverb.
a. tout le
voisinage,
toute la
famille,
all.MSG ART.MSG neighourhood.MSG, all.FSG ART.FSG family.FSG,
tous ceux-là
all.MPL DEM.MPL
'the whole neighbourhood, the whole family, all of these'
$\begin{array}{lllll}\text { b. un avocat tout vert, une pomme } \\ \text { INDF.MSG avocado.MSG all.MSG } & \text { green.MSG, INDF.FSG apple.FSG }\end{array}$
toute verte
all.FSG green.FSG
'a completely green avocado, a completely green apple'
c. tout doucement 'all slowly', tout près de la rivière 'all near to the river'

According to the written norm (Gougenheim 1962; Grevisse \& Goosse 2008), tout only agrees with a feminine adjective starting with a consonant $(33 \mathrm{c}, \mathrm{d})$, and is not inflected before a vowel initial or masculine adjective $(33 a, b){ }^{6}$
a. un
couloir
tout petit,
un
couloir
INDF.MSG corridor.MSG all.MSG small.MSG, INDF.MSG corridor.MSG
tout étroit
all.MSG narrow.MSG
$\begin{array}{lll}\text { b. } & \text { des } & \text { couloirs } \\ \text { INDF.PL } & \text { corridor.MP } \\ \text { tout } & \text { étroits } \\ \text { all.MSG } & \text { narrow.MPL }\end{array}$

6. This norm, which violates the free phonology syntax principle (Miller et al., 1997), aims at blocking the combinations ${ }^{\star}$ tous_étroits et ${ }^{\star}$ toutes_étroites, since $[\mathrm{z}]$ liaison is not possible with such plural forms ( ${ }^{\star}$ tuzetrwat], ${ }^{\star}$ [tutzetrwat]). In spoken French, only two forms do exist: [tut] before a feminine (toute petite, toutes petites) or vowel initial masculine (tout_étroit, tout_étroits) adjective, and [tu] in all other cases (tout petit, tout petits). This is why Miller et al. propose to change the orthography and agree preadjectival tout in gender, not in number:
un couloir tout petit
un couloir tout étroit
des couloirs tout petits
des couloirs tout étroits
une galerie toute petite
une galerie toute étroite
des galeries toute petites
des galeries toute étroites 
c. une galerie toute petite, une galerie INDF.FSG gallery.FSG all.FSG small.FSG, INDF.FSG gallery.FSG tout étroite

all.MSG narrow.FSG

d. des galeries toutes petites, des galeries INDF.PL galleries.FPL all.FPL small.FPL, INDF.PL galleries.FPL tout étroites all.MSG narrow.FPL

Adjectives and adverbs with verbs

Adjectives which occur outside an NP but modify a subject or an object do agree (34a) (see above Section 4.1). Unlike adverbs, they cannot occur between the auxiliary and the past participle (34b), or before the infinitival (34c) without a prosodic break.
(34)
a. Marie a vécu heureuse dans cet endroit
Marie.FSG AUX.sg lived happy.FSg in DEM.MSg place.MSG'
'Mary was living happy in this place'
b. ${ }^{*}$ Marie a heureuse vécu dans cet endroit
Marie.FSG AUX.SG happy.FSG lived in DEM.MSG place.MSG
c. Marie voudrait vivre heureusel theureuse vivre
Marie.FSG want.COND.3sg live.INF happy.FSG/ happy.FSG live.INF
'Mary would like to live happy'

Non agreeing adjectives in the VP are not analysed as adverbs since they do not meet the distributional criterion (Abeillé \& Godard 2004): contrary to related -ment adverbs (35a, d), they do not occur between the auxiliary and the past participle with an integrated prosody $(35 \mathrm{~b}, \mathrm{c}) .^{7}$
a. Ma vie s' est pareillement déformée
POSS.FSG life.FSG REFL AUX.SG similarly distorted.FSG
'My life has similarly distorted'
b. ${ }^{\star} M a$ vie s' est pareil déformée POSS.FSG life.FSG REFL AUX.SG similar.MSG distorted.FSG

7. See Suñer in this volume for the same criteria applied to uninflected adjectives modifying verbs in Spanish. 

Marie AUX.SG worked hard.MSG/ AUX.SG hard.MSG worked
'Marie has worked hard'
c. Marie a travaillé dur/ ${ }^{*} a$ dur travaillé
d. Marie a durement travaillé
Marie AUX.SG hardly worked
'Marie has worked hard'

Similarly, the adjective net in (36a, b) contrasts with the adverb nettement, which may occur between the auxiliary and the past participle or before the infinitive without a prosodic boundary $(36 \mathrm{c}, \mathrm{d}){ }^{8}$
a. Paul a refusé net votre proposition/ ${ }^{*} a$
Paul AUX.sG refused sharp.Msg Poss.2sg proposal.FSG/ AUX.sG
net refusé votre proposition
sharp.MSG refused Poss.2sG proposal.FSG
'Paul has sharply refused your proposal'
b. Paul a décidé de refuser net votre
Paul AUX.SG decided to refuse.INF sharp.MSG POss.2sG
proposition/ *de net refuser votre proposition
proposal.FSG/ to sharp.MSG refuse.INF POSs.FSG proposal.FSG
'Paul has decided to sharply refuse your proposal'
c. Paul a nettement refusé votre proposition
Paul AUX.sG sharply refused Poss.2sG proposal.FSG
'Paul has sharply refused your proposal'
d. Paul a decidé de nettement refuser votre proposition
Paul AUX.sG decided to sharply refuse.INF POss.2sG proposal.FsG
'Paul has decided to sharply refuse your proposal'

The case of fort, juste, soudain

In case of homophonous forms (fort, juste, soudain...), the adjective may modify a verb (37a), but only the adverb may occur between the auxiliary and the past participle $(37 b, c)$ or before the infinitive $(37 d)$ :

$$
\begin{aligned}
& \text { a. Elle a visé juste } \\
& \text { 3FSG AUX.sG aimed right.MSG } \\
& \text { 'She aimed right' }
\end{aligned}
$$

8. As noted by Noailly (1994), some adjectives may premodify a passive participle (plutôt cher payé. 'rather expensive paid'). We analyse them as Adj-Part compounds, like raide mort ('stone dead') or court-vêtu ('short dressed'). 

b. Elle a juste visé
'She has only aimed'
$\begin{array}{llll}\text { c. Elle a soudain disparu } \\ \text { 3FSG AUX.SG sudden.MSG } & \text { disappeared.MSG }\end{array}$
'She has suddenly disappeared
d. Elle a décidé de soudain disparaitre
3FSG AUX.SG decided.MSG to sudden.MSG disappear.INF
'She has decided to suddenly disappear'

Similarly, the adjective fort can modify a verb (38a), but cannot occur between the auxiliary and the past participle (38b), contrary to the adverb (38c). In addition, the adverb (38c) can give rise to liaison ([fortapresye ]), but not the adjective (23f) (Bonami \& Boyé 2005).

Adjective and adverb distinction in contemporary informal registers

In informal registers $(39 \mathrm{a}, \mathrm{b})$, or in the media, many adjectives are used to modify verbs (voter utile 'to vote useful', laver plus blanc 'to wash whiter'...).
a. J' ai fait ça facile
1sG AUx.1sg done DEM.SG easy.MSG
'I did this easily'
b. Tu me dis ça sérieux?
2SG 1SG tell DEM.SG serious.MSG?
'Are you telling me this seriously?'

c. A partir de là, elle $s^{\prime}$ est
At starting from then, 3FSG REFL AUX.3SG
serious.MSG

énervée

(forum bladi.net, August 4th 2005)

become-upset.FSG

'From then, she got seriously upset' 
d. I' ai moyen avancé sur mes dossiers

1SG AUX.1sG average.MSG advanced on POss.1PL files

'I have mildly advanced on my files.' (BIBA, June 2007, p. 80)

Following our criteria, most are still adjectives (facile, sérieux...) but some (grave 'serious', moyen 'medium'...) are currently reanalysed as degree adverbs, with the criterial preverbal position (39c, d).

In the diachrony of French, verb modifying adjectives used to occur before the verb: Vil acheter et vendre chiar 'bad buying and selling expensive' (Anonyme, $\mathrm{La}$ Clef d'Amors, XII, quoted by Hummel \& Gazdik 2014). In informal registers, especially on the internet, Hummel and Gazdik 2014 notice cases where verb modifying adjectives are inflected (40a). ${ }^{9}$
a. [...] votre progression, qui va s'arrêter nette POss.2SG progression.FSG, which will REFL stop sharp.FSG http://egeria.overblog.com/faites-taire-votre-gremlin (Dec 6th.2013) 'your progression, which will stop short'
b. [...] votre progression, qui va net s' arrêter/ POss.2sG progression.FSG, which will sharp.MSG REFL stop/
*qui va nette s' arrêter
which will sharp.FSG REFL stop
'your progression, which will stop short'

c. Les discussions se sont vites élargies

ART.FPL discussions.FPL REFL AUX.PL fast.PL widened.FPL

'The discussions have widened fast'

(Les Echos, Feb 1st 2013) (Hummel \& Kröll 2015)

d. Les deux Russes étaient vraiment plus vites que moi

ART.MPL two Russian.PL were really more fast.PL than 1SG 'The two Russian were really faster than me'

(Le Droit, Feb, 12th 2014) (Hummel \& Kröll 2015)

In (40a), the adjective may be analysed as modifying the subject. In that case, we do not expect it to occur before the past participle or the infinitive, unless it is uninflected and modifies the verb (40b). But as such plural endings are not pronounced, spelling mistakes (or hypercorrections) are also possible as in (40c). As noticed by Hummel and Kröll (2015), vite ('fast') is for some speakers an adjective, especially in sports, and as such, may be a predicate agreeing with the subject (40d). According

9. A complete study is under way as part of the project Dictionnaire historique de l'adjectifadverbe (DHAA). See Hummel \& Gazdik (this volume). 
to the GGF criteria, it should not occur preverbally as an adjective. In (40c), no liaison is acceptable with the past participle ${ }^{\star}$ [vitzelarzi].

\section{Conclusions}

The distinction between adjectives and adverbs is often a hot debate for contemporary French since a lot of adjectives modify verbs (voter utile 'to vote useful') and some do not vary in number or gender even with nouns (chic 'hype'). In the Grande grammaire du français, we draw a strict division between adverbs and adjectives. They may share some common properties:

1. They may take prepositional or sentential complements; contrary to verbs and prepositions, they cannot take a direct nominal complement

2. They cannot be subjects

3. They may be complements of verbs (risquer gros 'risk a-lot', risquer davantage 'risk more')

4. They can be adjuncts: while adjectives commonly adjoin to nouns (un refus net 'a clear refusal'), nothing prevent them from adjoining to verbs (refuser net 'to refuse sharp'); likewise, while adverbs frequently adjoin to verbs (rire souvent 'often laugh'), most may also adjoin to other major categories as well (souvent malade 'often sick', souvent ministre 'often minister')

Three criterial properties distinguish adjectives from adverbs:

1. Only adjectives may vary in gender and number

2. Only adjectives agree with the category they modify

3. Only adjectives may take an infinitival complement

4. Only adverbs may occur between the auxiliary and the past participle, or before the infinitive, without a prosodic break

\section{References}

Abeillé, Anne \& Godard, Danièle. 2002. The syntactic structure of French auxiliaries. Language 78: 404-452. doi:10.1353/lan.2002.0145

Abeillé, Anne \& Godard, Danièle. 2003. The syntactic flexibility of French degree adverbs. In Proceedings of the 10th international conference on Head-Driven Phrase Structure Grammar. Michigan State University, Stefan Müller (ed.), 26-46. Stanford CA: CSLI.

Abeillé, Anne \& Godard, Danièle. 2004. Les adjectifs invariables comme compléments légers en français. In L'adjectif en français et à travers les langues, François Jacques (ed.), 209-244. Caen: Presses Universitaires de Caen. 
Abeillé, Anne, Delaveau, Annie \& Godard, Danièle. 2007. La grande grammaire du français: principes de construction. Revue roumaine de linguistique 52-54: 419-436.

Abeillé, Anne \& Mouret, François. 2010. Les compléments adjectivaux des verbes transitifs en français, in Les Tables. La grammaire par le menu, Cahiers du Cental 6: 1-10.

Abeillé, Anne \& Godard, Danièle. 2012. La grande grammaire du français et la variété des données. Langue Française 176: 47-68. doi:10.3917/lf.176.0047

Abeillé, Anne \& Godard, Danièle (eds). To appear. La grande grammaire du français. Arles:Actes Sud.

Blanche-Benveniste, Claire. 1997. Approches de la langue parlée en français. Gap: Ophrys.

Bonami, Olivier. 1999. Les constructions du verbe: Le cas des groupes prépositionnels argumentaux. Thèse de doctorat, Paris 7.

Bonami, Olivier \& Boyé, Gilles. 2005. Construire le paradigme d'un adjectif. Recherches Linguistique de Vincennes 34: 77-98. doi:10.4000/rlv.1370

Bonami, Olivier, Godard, Danielle \& Kampers-Manhe, Brigitte. 2004. Adverb Classification. In Handbook of French Semantics, Francis Corblin \& Henriette de Swart (eds), 143-184. Stanford CA: CSLI.

Bonami, Olivier \& Godard, Danielle. 2007. Quelle syntaxe, incidemment, pour les adverbes incidents? Bulletin de la Société de Linguistique de Paris CII: 255-284. doi:10.2143/BSL.102.1.2028206

Bosque, Ignacio \& Demonte, Violeta (eds). 1999. Gramática descriptiva de la lengua española. Madrid: Espasa.

Dal, Georgette. 2007. Les adverbes de manière en -ment du francais: Dérivation ou flexion? In Morphologie à Toulouse, 4e décembrettes. Nabil Hathout \& Fabio Montermini (eds), 121-147. Munich: Lincom.

Damourette, Jacques \& Pichon, Edouard. 1911-1946. Des Mots à la Pensée; essai de grammaire de la langue française. Paris: Editions Vrin.

Delais-Roussarie, Elisabeth. 2008. Prosodie incidente et structure prosodique. Verbum 30(1): 37-52.

Gadet, Françoise. 1989. Le français ordinaire. Paris: Armand Colin.

Giegerich, Heinz J. 2012. The morphology of - ly and the categorical status of 'adverbs' in English. English Language and Linguistics 16(3): 341-359. doi:10.1017/S1360674312000147

Gougenheim, Georges. 1962. Système grammatical de la langue française. Paris: Editions d'Artrey. Grevisse, Maurice \& Goosse, André. 2008. Le Bon Usage, 14th edn. Louvain-la-Neuve: DeBoeck-Duculot.

Guimier Claude. 1989. Sur l'adjectif invarié en français. Revue des Langues Romanes 93: 109-120. Guimier, Claude \& Larcher, Pierre (eds.) 1991a. Les états de l'adverbe. Travaux linguistiques du CERLICO, 3. Rennes: Presses universitaires de Rennes.

Guimier, Claude \& Larcher, Pierre (eds.) 1991b. L'adverbe dans tous ses états. Travaux linguistiques $d u$ CERLICO, 4. Rennes: Presses universitaires de Rennes.

Guimier, Claude. 1996. Les Adverbes du Français: Le Cas des Adverbes en -ment. Paris: Ophrys. Huddleston, Rodney \& Pullum, Geoffrey K. (eds) 2002. The Cambridge Grammar of the English Language. Cambridge: Cambridge University Press. doi: 10.1017/9781316423530

Hummel Martin. 2014. The adjective-adverb interface in Romance and English. In Adjectives in Germanic and Romance [Linguistik Aktuell/Linguistics Today 212], Petra Sleeman, Van de Velde, Freek \& Perridon, Harry (eds), 35-71. Amsterdam: John Benjamins.

doi:10.1075/la.212.02hum 
Hummel, Martin \& Gazdik, Anna. 2014. Le dictionnaire historique de l'adjectif-adverbe: De aimer haut à baiser utile. In Actes $d u 4^{e}$ Congrès Mondial de Linguistique Française, Berlin, 19-23 juillet. doi:10.1051/shsconf/20140801132.

Hummel, M. \& Kröll, Andrea. 2015. Vite et vitement. Etude diachronique variationnelle d'une exception. Revue de Linguistique Romane 313-314: 39-91.

Miller, Philip, Pullum, Geoffrey K. \& Zwicky, Arnold. 1997. The principle of phonology-free syntax: Four apparent counter-examples from French. Journal of Linguistics 33: 67-90. doi: $10.1017 /$ So022226796006305

Molinier, Christian \& Lévrier, Françoise. 2000. Grammaire des adverbes: Description des formes en -ment. Genève: Droz.

Moignet, Gérard. 1963. L'incidence de l'adverbe et l'adverbialisation des adjectifs. Travaux de Linguistique et de Littérature 1: 175-194.

Noailly, Michèle. 1993. Sur un étrange privilège des adjectifs au comparative. L'information Grammatical 58: 47-51. doi:10.3406/igram.1993.3155

Noailly, Michèle. 1994. Adjectif adverbal et transitivité. Cahiers de Grammaire 19: 103-114.

Noailly, Michèle. 1990. Le substantif épithète. Paris: PUF.

Noailly, Michèle. 1999. L'adjectif en français. Gap: Ophrys.

Piot, Mireille. 1995. Composition transformationnelle de phrases par subordination et coordination. Thèse d'Etat, University Paris 7. Lille: Presses du Septentrion.

Renzi, Lorenzo, Salvi, Giampaolo \& Cardinaletti, Anna (eds). 2001. Grande grammatica italiana di consultazione, nuova edizione, 3 Vols. Bologna: Il Mulino.

Riegel, Martin, Pellat, Jean-Christophe \& Rioul, René. 2014. Grammaire méthodique du français, 5th edn. Paris: PUF.

Sandmann, M. 1942. Remarques sur la genèse d'adjectifs en fonction d'adverbes. Revue de Linguistique Romane 14: 257-278.

Solà, Joan, Lloret, Maria Rosa, Mascaró, Joan \& Pérez Saldanya, Manuel. 2008. Gramàtica del català contemporani, last edition, 3 Vols. Barcelona: Empúries.

Schlyter, Suzanne. 1977. La place des adverbes en -ment en français. PhD Thesis, Konstanz. 



\title{
CHAPTER 5
}

\section{Are intrapredicative adjectives adverbs?}

\author{
Dan Van Raemdonck \\ Université Libre de Bruxelles, Vrije Universiteit Brussel, LaDisco, Gramm-R
}

Traditionally, the adjective/adverb opposition is part of a larger structural framework, where these parts of speech are differentiated by the type of parts of speech with which they have a relationship of dependency. The adjective is said to be related to the noun, and the adverb to the adjective, the verb or another adverb, and each time in relationships systematically described as $\mathrm{T} 1 \leftarrow \mathrm{T} 2$, where $\mathrm{T} 2$ is related to $\mathrm{T} 1$.

In this paper we investigate in French the case of intrapredicative adjectives, i.e. adjectives within the predicate which, counter to prevailing assumptions, appear to be related to the verb. We will try to shape a coherent functional system within which all the different uses of intrapredicative adjectives take place.

\section{Introduction $^{1}$}

The constructions of theoretical models remain often dependent on constant speech development since school which, following the example of Nos ancêtres, les Gaulois, becomes a constituent part of our culture and, therefore, of our mental plans. In the best case of grammatical memories, the adjective would hence be a variable word associated with the noun and the adverb an invariable word associated with the verb, the adjective or another adverb.

\section{Is there such a thing as adverbialized adjective?}

The traditional opposition adjective/adverb according to the above contrast belongs in a larger structural framework, where these parts of speech are differentiated in use by the type of parts of speech with which they have a relationship of dependency. The above association between adjectives and nouns, and adverbs and verbs,

1. We thank Maxence Delsaut (see 2013), whose questions and remarks ceaselessly made us refine our model. 
adjectives or other adverbs takes the form of relationships systematically described as $\mathrm{T} 1 \leftarrow \mathrm{T} 2$, where the term $\mathrm{T} 2$ is related to the term $\mathrm{T} 1$.

In this paper we investigate the case of intrapredicative adjectives in French, i.e. adjectives within the predicate which, counter to prevailing assumptions, appear to be related to the verb. We will try to shape a coherent functional system within which the range of uses of intrapredicative adjectives (not taking into consideration those within noun phrases) will find a place.

The initial hypothesis assumes that the adjective is not limited to the adnominal space assigned to it by traditional grammar. Indeed, adjectives can be related to other adjectives, as in the following examples:

(1) une porte bleu foncé

'a dark blue door' (the blue is dark)

(2) des fenêtres grandes ouvertes

'wide open windows'

(3) des enfants derniers-nés

'last born children'

More problematically, what is one to say of the following cases, where adjectives appear in relation with verbs:

(4) Pierre est gentil.

'Pierre is nice.'

(5) Il fait beau.

'The weather is nice.'

(6) Marie tombe enceinte.

'Marie becomes/gets pregnant.'

(7) Pierre mourra vieux.

'Pierre will die old.'

(8) a. Il mange italien.

'He eats Italian.'

b. Il vote utile.

'He casts a useful vote.' (intended as: 'He votes tactically.)

(9) Ça sent bon la rose.

'It smells good, like roses.'

(10) On dit Pierre amoureux.

'Pierre is said to be in love.'

(11) Pierre rend sa femme malheureuse.

'Pierre is making his wife unhappy'. 
(12) Sylvie a les yeux bleus.

'Sylvie has got blue eyes.'

(13) Pierre mange son steak saignant.

'Pierre eats his steak rare.'

(14) On l'a retrouvée morte.

'She has been found dead.'

The above examples illustrate not only the case of the predicative complement often described as "subject complement" (French traditionally labelled attribut du sujet, (4), cf. Van Raemdonck 2010) but also cases that are poorly described for French, ((5) and (6)), and others whose possible descriptions will be summarized in what follows, according to the interpretations available in the literature ((7) to (14)).

The counterpart to the subject complement, i.e. the objective predicative complement or object complement (French traditionally labelled attribut de lobjet), is illustrated in (10) to (13), and can be divided into three broad categories according to the type of relationship with the verb and/or the object:

1. Clausal nexus, actant of the verb (nexus propositionnel actant de verbe), as in (10) (cf. Riegel 1996; Muller 2000),

2. Obligatory object complement (attribut de l'objet obligatoire), as in (11) and (12) (Rémi-Giraud 1991; Riegel 1996; Noailly 1999; Muller 2000; Goes 2008; Wilmet 2010), and

3. Facultative object complement (attribut de lobjet facultatif), as in (13) and (14) (Rémi-Giraud 1991; Riegel 1996; Noailly 1999; Muller 2000; Goes 2008; Wilmet 2010; Havu \& Pierrard 2014).

The so-called uninflected adjectives (adjectifs invariés) in Examples (8) and (9) are usually explained in terms of the adverbialization of the adjective (Le Goffic 1993; Noailly 1999; Riegel, Pellat \& Rioul 2009; Wilmet 2010). Yet, some authors qualify the automatic adverbialization of all adjectifs invariés (Grundt 1972; Guimier 1989; Le Goffic 1993; Noailly 1999; Abeillé \& Godard 2005), but generally make the adjectival interpretation dependent on the identification of a noun within the verb. Damourette \& Pichon (1911-1940) even claim that there is a case of nominalization for all adjectifs invariés; Wilmet (2010) seems to agree, but for a subset of them (miser gros 'to bet a big bet').

The concept of adverbialization offers those who believe that the adjective can only be related to the noun a way out against the odds raised by the many attested examples. Related to a verb, the adjective would in fact be an adverb or work as such.

This discussion echoes the Hengeveld's typology (Hengeveld 1992; Hengeveld \& van Lier 2010), which divides languages between those with only adjectives and those with adjectives and adverbs. Some linguists (e.g. Hummel 2014) consider that 
the basic French system works with one word-class: the adjective. But, importantly, a solution is only possible if one separates the word class from syntactic function. Then, an adjective might have a syntactic function traditionally called "adverbial".

We'll try to show in our contribution that and how the adjective mostly remains an adjective with adjectival functioning. And hence register French within the set of languages with both adjectives and adverbs.

\section{Towards a genetic syntactic system: Incidence, determination and predication}

We designed a double system: ${ }^{2}$ a system of natures of word, system of parts of language, organized by the criterion of extension borrowed from Wilmet (1986), that doubles a system of parts of speech or functions organized by the criterion of incidence borrowed from Guillaume (1964) (see Van Raemdonck 1998; 2010 and 2011 for further details on the system).

In this first system, the parts of language are distinguished by the way the word gives access to its extension (the set of objects of the conceivable world to which the word can be applied). In this system, a noun, or a pronoun, gives a direct access to its extension (table can only be said of a table); adjectives and verbs give indirect access to their extension (they are normally said of something that can be used as their support (une belle chemise 'a nice shirt'; Cet homme mange 'this man eats'); adverbs are said of a relation processed between two terms (their support is double; Il range la liste alphabétiquement 'He arranges the list alphabetically': the arrangement of the list is alphabetical).

Secondly, as part of a syntax inspired by Gustave Guillaume (Van Raemdonck 2011), we have proposed to include the syntactic functions into a system where they are all defined using the same criterion, namely incidence (the relationship between import and support of signification). Besides the support/core of the sentence (French traditionally labelled sujet), characterized by internal incidence, and the imports to terms of the sentence (determiner of the noun, the verb, the adjective, the adverb...; predicate of a term), characterized by first-degree external incidence, one still distinguishes imports (determiner or predicate) to relations between two terms, imports that are unified by this common feature even if they are morphologically diverse (from the word to the clause): the second-degree external incidence.

Coupled with the pair of mechanisms determination vs. predication, the criterion of the incidence enables to define a complete systemic set of functions of the

2. This paper only contains the data of the model relevant to its purpose. 
sentence. These functions may take a range of realizations: determinative phrase, (nominal, verbal...), predicative phrase (primary, secondary).

By "determination", it is here meant that the general grammatical mechanism by which an element is related (imported) to another element or to a relation not only reduces the extension or gives an indication onto the extensité (effective quantity of elements (Wilmet 1986; 1997 and 2010 ${ }^{5}$ )) of the determined element, but also reduces the extension of the relation on which it is imported. We shall thus speak about determiners of the noun (la table de la cuisine, 'the kitchen table'), of the pronoun (celui qui part; 'the one who leaves'), of the verb (manger une pomme, 'to eat an apple'), of the adjective (plein d'espoir, 'full of hope'), of the adverb (loin d'ici, 'far from here'), of the subordinative connector (avec moi, 'with me'), as well as of determiner of a relation (predicative relation, À Paris, il pleut, 'In Paris, it rains'), relation between the determiner and the nominal core (une fille très jeune, 'a very young girl'), between the determiner and the verbal core (Il mange ses frites avec les doigts, 'He eats his fries with his fingers'). The hierarchical group of word(s) which gathers around a support/core its imports by means of relations of the determinative kind will be labelled "determinative phrase" (DXPh; nominal, if the core is a noun, $\mathrm{DNPh}$; verbal if the core is a verb, DVPh; etc.). ${ }^{3}$

By contrast, by "predication" it is here meant the general grammatical mechanism by which an element is related (imported) to another element or to a relation without reducing its extension. The predicate intervenes on a term or a relation of the sentence, and does so after all the operation of determination and the constitution of the phrase, that is after the closure of this one. To avoid the confusion with the primary predication which is essential because it is constitutive of the sentence, when the same mechanisms are implemented without the intervention of a verb conjugated to a finished tense (or personal mood), we shall speak of "secondary predication" (Melis 1988; Furukawa 1996; Cadiot \& Furukawa 2000; Havu \& Pierrard 2009). It will be in particular the case for the appositional phrase (French traditionally labelled "appositions", nominal or adjective, including the predicative relative clause: Philippe, roi des Belges, ... ('Philippe, King of Belgium'), La jeune fille, très jolie, ... ('The young girl, very pretty, ...'), Une très jeune fille, qui passait par là,... ('A very young girl, who passed by,...'), for certain adverbial imports, that predicate without an intervening verb (Heureusement, il est parti 'Fortunately, he's gone') and for the complements of the determiner of the verb or object complement (French traditionally labelled attributs de l'objet: Le bureau l'a élu Président 'The board elected him President'). The organized and hierarchical group of word(s)

3. The term 'determinative phrase' $(\mathrm{DPh})$ is used here for a clearer opposition with the term 'predicative phrase' ( $\mathrm{PPh}$ ) (see below). The relation of determination will be drawn in schemas by means of a simple arrow. 
which gathers around a support/core its imports by means of relations of predicative kind will be labelled "predicative phrase" (PPh1 for the sentence (main clause), organized around the primary predication (Pierre mange une pomme 'Pierre eats an apple'); $\mathrm{PPh} 1$ ' for the sub-clause (Je pense que Pierre viendra 'I think that Pierre will come'); $\mathrm{PPh} 2$ for the predicative group whose core's import is a secondary predicate (P2); PPh2 with core $\emptyset$ (PPh2 whose core's position is not saturated), integrative structure between the $\mathrm{PPh} 2$ and the $\mathrm{DNPh}$ or the $\mathrm{DAdjPH}){ }^{4}$

Refining their analysis, we agree, with the option of the "nexus" developed by Jespersen (1924), endorsed by Eriksson (1993), and Hanon (1989) ("absolute constructions"). The PPh2 concerns examples as the former propositions infinitive et participe ("infinitival or participial clauses"): J'entends les enfants chanter ('I hear the children singing'), Le chat parti, les souris dansent ('The cat's away, the mice will play'), or Il marche la tête haute ('He walks head high'), On dit Pierre amoureux ('Pierre is said to be in love'), ... We described this kind of structure (see Van Raemdonck, 2007) as an integrative structure, carrying a syntactic function, intermediary between the determinative phrase (DPh inside which determination operates) and the sentence, or the sub-clause (PPh1 or PPh1' inside which primary predication operates). In the binomial integrative structure $\mathrm{PPh} 2$, secondary predication operates. For there to be a PPh2 with core $\varnothing$ (Van Raemdonck 2011), the core of the PPh2 must be recoverable, either co-textually (referential identity of the core of the PPh2 and that of the sentence or the determiner of the verb: Je pense venir 'I think coming'), or con-textually (recovery by identification to one of the interlocutors or to an already evoked element: Enfant, la nourriture manquait 'When a child, food was missing'; memory recovery or recovery by generalization: L'appétit vient en mangeant 'Appetite comes with eating'; in the latter case, the core corresponds to whoever).

Finally, and more specifically for the question which is the main subject of study here, inside the DVPh ("determinative verbal phrase"), we distinguish three levels in the relation between a determiner of the verb and its verbal core: the valency corresponds to the scheme of the lexico-semantic comprehensiveness of the verb (the required element is a constitutive element of it: in Pierre range alphabétiquement la liste 'Pierre arranges the list alphabetically', Pierre and la liste are considered as required); the governed element is the one whose incidence, at the syntactic level, falls on(to) the verb (in Pierre range alphabétiquement la liste, la liste and alphabétiquement are governed; Pierre is not governed even if required; la liste is required and governed; alphabétiquement is governed but not required); and the selected element is the one whose form, construction and/or meaning are

4. The relation of predication will be drawn in schemas by means of a double arrow. 
commanded by the verb (in Marie tombe enceinte 'Marie becomes pregnant', the verb tomber means 'devenir' 'to become' only when followed by few selected adjectives: enceinte, malade, amoureuse,...) (Van Raemdonck 2010).

This model is part of a genetic syntax. Therefore, we claim the existence of two types of incidence (Van Raemdonck 2002): "effective incidence" (in solid line in schemas), which connects the import of signification to its support, and "prospective incidence" (in dashed line in schemas) which prefigures and thus precedes, in the genesis of the sentence, the actual incidence prior to its implementation. Every term or every constituted group, before being actually put in relation with other elements, can be declared to expect either a support, or an import (by determination or predication). For instance, the verb ranger 'to arrange', just out of the dictionary, before being actually put in relation with other elements of the sentence (e.g. the core of the sentence and its determiner), can be declared to expect either a support (this future core, e.g. Pierre), or an import (this future determiner, e.g. la liste), both of these elements being part, in this case, of its valency. As Figure 1, where $\mathrm{T}$ is a functional term of the sentence:

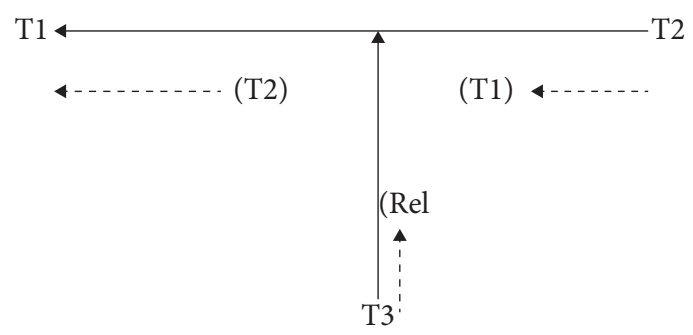

Figure 1. Microsystem of relations

We propose here to system(at)ically register in this frame all the cases cited above in Examples (4) to (14). The resulting description is thus intended to contribute to a redefinition of the respective roles of the categories adjective and adverb, in their identity as parts of speech just as in their syntactic function.

\section{Description of items}

4.1 Determiner of the verb (= determiner of the core of the DVPh)

(15) Pierre est gentil. 'Pierre is nice.' 
The verb (manger 'to eat') is always susceptible to receiving a determiner (une pomme 'an apple') as an import of information (Van Raemdonck 2002; 2010), and the determiner fulfils this functional position. When no element saturates the functional position of determiner, this position is said to be "non-saturated", the determiner is represented as "determiner $\varnothing$ ", and the verb is declared to be in intransitive use (Pierre mange $\varnothing$ 'Pierre eats $\varnothing$ ').

The function determiner of the verb appears, in our system, as a function positively characterized by an external incidence of the first degree on the governing verb: it is a term of the verbal term. It proceeds by determination of the verb as far as it reduces its extension. Indeed, there are fewer occurrences of manger (V) une pomme (Det) ('to eat an apple') than of manger ('to eat').

This view of the determination and the function of determiner of the verb makes the question of the kind of governing verb (which is no more to be seen as a quasi-nature of verb, but as a subclass of uses) be of secondary importance. There are thus no ontological (and insoluble in a clear-cut way) questions any more on to the copulative, transitive or intransitive nature of the verb.

As far as we conceive the adjective as the prototype of the term of a term, it is hence necessary to consider the subject complement (attribut du sujet) as a determiner of the verb in copulative use. Its normal basis is adjectival, but it can also be taken care by a noun. In this case, we are usually in the presence of an article $\varnothing$, sign of the link between the noun and the adjective. Thus, for the example in (4), the DVPh (determinative verbal phrase) can be represented as Figure 2:

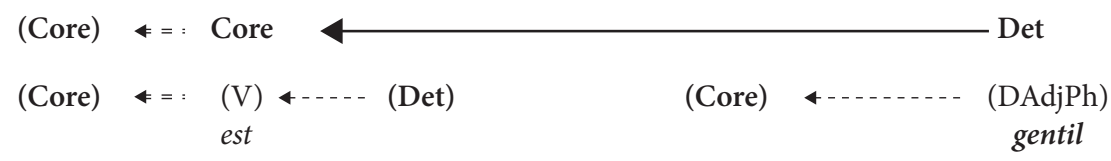

Figure 2. (Pierre) est gentil

The intrapredicative adjective displays the following characteristics here:

1. it is under the scope of the negation (Pierre n'est pas gentil),

2. its anteposition is possible, but not frequent (Gentil Pierre est; Gentil est Pierre); its interposition between the auxiliary and the participle is not possible ( ${ }^{\star}$ Pierre a gentil été),

3. it is an import to the core of the sentence (Pierre) through its relation to the verb in copulative use (it is not selected by the verb, except that être 'to be' in copulative use accepts as determiner a DAdjPh),

4. it is governed by the verb and is part of its valency,

5. it is, from the above, not deletable, otherwise être 'to be' would lose its copulative use and would take on an existential meaning (Pierre est), 
6. it agrees with the core of sentence (Pierre, masculine singular),

7. despite the above, it pronominalises in the neutral (it has in fact no direct contact with the core of the sentence; the pronominalization intervenes before there was any contact with the core of sentence) (Pierre l'est), and

8. there is no set phrase nor lexicalization with the verb.

4.2 Determiner of the relation [Dét (or Dét $\varnothing) \rightarrow$ CoreDVPh], not included in verbal valency

(16) Pierre kiffe fort/grave cette fille; je le termine juste.

'Pierre likes very much/badly this girl; I just end it.'

Some intrapredicative adjectives are really in adverbial use. They have a particular characteristic: the possibility of taking the position between the auxiliary and the participle, this being the exclusive defining criterion of the adverb in Abeillé, Delaveau \& Godard (to appear). If this defining criterion says nothing of what is an adverb, it allows all the same to bound a class of commutation which includes the adverbs (almost all: $s i$ and très, for example, will not fit in) and certain pronouns, but in any case no adjectives. We can hence infer that there is an adverbial use of the adjective as determiner of the relation between the determiner of the verb and the core of the DVPh. As Figure 3:

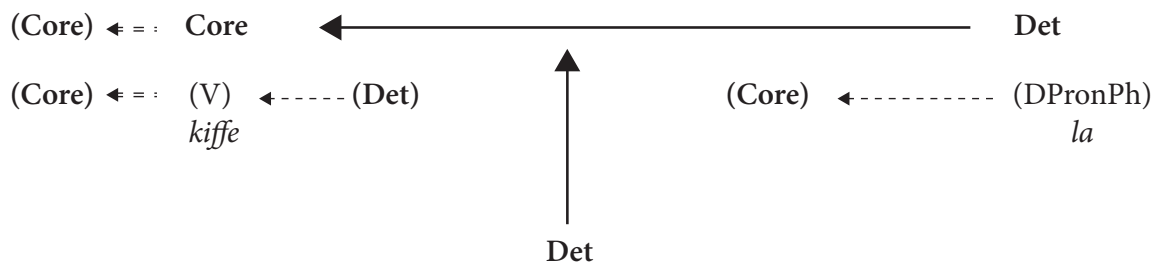

(DAdjPh)

grave

Figure 3. (Pierre) la kiffe grave

We find the same kind of examples with a determiner $\varnothing$ of the verb:

(17) Ça déchire fort/grave; ça a fort/grave déchiré; ça a déchiré fort/grave; je termine juste; jai juste terminé. ${ }^{5}$

'That tears badly; that has badly torn; that tore badly; I just end; I just ended.'

The intrapredicative adjective has here the following characteristics:

5. J'ai terminé juste would have a different meaning: 'just in time'. 
1. It is under the scope of the negation (Ça ne déchire pas grave),

2. its movement is possible, as its interposition between the auxiliary and the participle (Ça a grave déchiré),

3. it is an import to the relation [Dét (or Dét $\varnothing$ ) $\rightarrow$ Core of theDVPh],

4. it is not selected by the verb, apart from the selection of a quantifying, intensive meaning: we do not find any characterization,

5. it is governed by the verb but is not part of its valency,

6. there is no agreement because the import is related to a relation,

7. pronominalization is not possible (it is therefore not a determiner of the verb) $\left({ }^{*}\right.$ Ça le déchire, with le = grave $)$,

8. there is no set phrase nor lexicalization with the verb, and

9. it is deletable (Ça déchire).

\subsection{The secondary predicates}

Inside the predicate, only the determiners of the verb appear to have the possibility to receive an import characterized by an external incidence of the first degree of predicative kind. This kind of predicative incidence characterizes, in particular, the imports traditionally described as object complement (attribut de l'objet, even attribut du complément d'objet direct (COD), labels which cover examples as Il a rendu sa voiture cabossée 'He returned his car dented'). Some analysts have joined this structure to examples as (18), (19) and even (20) below:

(18) Il a rendu sa femme malheureuse.

'He has made his wife unhappy.'

(19) On le dit pressé.

'They say he is in a hurry.'

(20) Il mourra vieux.

'He will die old.'

However, these examples do not react in the same way to various morphosyntactic tests. To report these differences, we shall distinguish these structures by using the abovementioned notion of prospective relation as well as that of valency.

4.3.1 Secondary predicate of the core inside a PPh2 determiner of the verb

(21) On dit Pierre amoureux.

'We say Pierre is in love.'

(22) Pierre trouve la situation sérieuse.

'Pierre finds the situation serious.' 
(23) On l’a jugé coupable.

'We considered him guilty.'

(24) Pierre veut son steak saignant.

'Pierre wants his steak rare.'

In (21), amoureux is hardly deletable, and yet it will not be object complement or secondary predicate of the determiner of the verb, whether prospected or effective. In fact, the determiner of the verb is here the whole PPh2 'Pierre + amoureux'. In this case, the whole $\mathrm{PPh} 2$ is indeed the determiner of the verb (the predication is that 'he is in love'). The internal structure of this PPh2 can be described as a secondary predication of amoureux onto the core Pierre. As Figure 4:

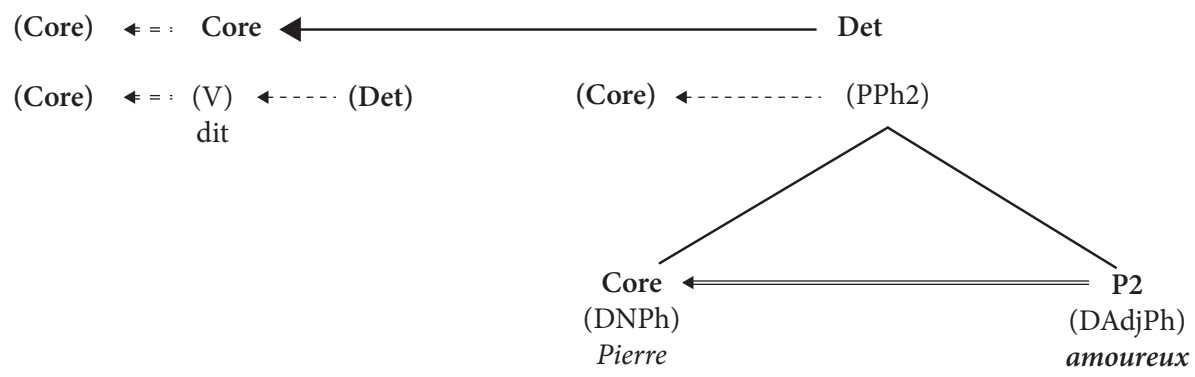

Figure 4. (On) dit Pierre amoureux

The intrapredicative adjective has here the following characteristics:

1. it is under the scope of the negation (On ne dit pas Pierre amoureux),

2. its movement is possible but with difficulty (?'On dit amoureux Pierre et Marie),

3. its interposition between the auxiliary and the participle is impossible $\left({ }^{*} \mathrm{On} a\right.$ amoureux dit Pierre),

4. it is an import to the core of the PPh2 (Pierre),

5. it is not selected by the verb,

6. the global group $\mathrm{PPh} 2$ is governed by the verb and part of its valency $\left({ }^{\star} \mathrm{On}\right.$ dit),

7. the adjective agrees with the core of the $\mathrm{PPh} 2$ (Pierre, masculine singular),

8. there is no pronominalization of the adjective alone $\left({ }^{\star} \mathrm{On}\right.$ le dit Pierre), but the pronominalization in the neutral of the global PPh2 (as for a sub-clause 'On le dit') is possible, as well as the pronominalization of the core alone with preservation of the secondary predicate (On le dit amoureux),

9. there is no set phrase nor lexicalization with the verb, 
10. it is not deletable (?? On dit Pierre) ${ }^{6}$ The PPh2 appears as the reduction of a sub-clause (PPh1') in que ('that': On dit que Pierre est amoureux).

4.3.2 Secondary predicate of the core $\varnothing$, inside a PPh2 determiner of the relation [Dét $\rightarrow$ Core DVPh]

(25) Pierre mange son steak saignant. 'Pierre eats his steak rare.'

(26) Pierre rend sa voiture cabossée. 'Pierre returns his car dented.'

(27) Pierre mourra vieux.

'Pierre will die old.'

(28) Pierre vote utile.

'Pierre casts a useful vote.'

The first three examples have often been labelled secondary predicate on the object or the subject (attribut du complément dobjet direct (COD) ou du sujet). For (28), the role of quasi-adverb of the adjective is often highlighted, and some descriptions use the term "adverbialized adjective" (adjectif adverbialisé). We suggest here taking advantage of the structure $\mathrm{PPh} 2$ with core $\varnothing$ to explain how, from the schema describing the DVPh, we can refine the analysis and establish differences within some of the cases of the use of the intrapredicative adjective.

\subsubsection{Pierre mange son steak saignant ('Pierre eats his steak rare')}

In the case of (25) Pierre mange son steak saignant, the rare character of the meat appears as a condition for ingestion by Pierre: the sentence can be glossed as 'Pierre eats his steak provided that it is rare'. There is a determination of the relation between the verb and its determiner. The $\mathrm{PPh} 2$ with core $\varnothing$, as reduction of a sub-clause, sets a clear example to explain this sequence: the core of the PPh2 is referentially identical to the determiner of the verb (steak; moreover saignant shows concordance with it), and can thus be the subject of ellipsis. As Figure 5:

6. Deletion of the adjective is possible, but it causes a change of meaning (for dire, trouver et vouloir, for example). For juger, deletion changes the meaning less markedly, but still relates to another analysis that is proposed below. 




Figure 5. (Pierre) mange son steak saignant

The intrapredicative adjective displays the following characteristics here:

1. it is under the scope of the negation (Pierre ne mange pas son steak saignant),

2. its movement is possible (Pierre mange saignant son steak),

3. its interposition between the auxiliary and the participle is impossible ( ${ }^{\star}$ Pierre a saignant mangé son steak),

4. it is an import to the core $\varnothing$ of the PPh2 (the core is not saturated, because its reconstruction is possible from the immediate context (steak)), with PPh2 being determiner of the relation [Dét $\rightarrow$ Core of the DVPh], so as to mark that it is the frame of the current process (the steak must be rare so that Pierre can eat it),

5. it is not selected by the verb,

6. it is governed by the verb and is not part of its valency,

7. it agrees with the non saturated core of the $\mathrm{PPh} 2$, which would be referentially equivalent to the determiner of the verb (steak, masculine singular),

8. there is no pronominalization of the adjective alone, but the pronominalization of the determiner of the verb alone with preservation of the secondary predicate is possible (Pierre le mange saignant),

9. there is no set phrase nor lexicalization with the verb,

10. it is deletable (Pierre mange son steak), and

11. it has a rather process meaning.

4.3.2.2 Pierre a rendu sa voiture cabossée ('Pierre returned his car dented: non processual meaning')

In this Example (26), the explanation seems appreciably the same: the core of the $\mathrm{PPh} 2$ is referentially identical to the determiner of the verb (its car; and cabossé also shows concordance with it); it can therefore be the subject of ellipsis. Things being 
what they are, we can imagine that, from the structure above, P2 shifts towards the position of $\mathrm{P} 2$ of the determiner of the verb.

This typical case of object complement corresponds in fact to a secondary predication of cabossée on the Determinative Nominal Phrase (DNPh) determiner of the verb sa voiture, after shifting from the position described previously. This secondary predicate is not obligatory: it is deletable without substantial modification of the meaning of the verb. It intervenes, from the previous schema, as a supplement of meaning on the determiner of the verb (it agrees with it) and is related to it once this determiner is constituted as a DNPh (that is, once the operations of determination inside the $\mathrm{DNPh}$ are complete). Inside the predicate, it is the non processual meaning, which is different from the former case, that allows this movement: dented denotes a characteristic of the restituted car but is not a condition for its restitution. Apart from these differences with regard to the former case, the intrapredicative adjective displays the same characteristics. As Figure 6:

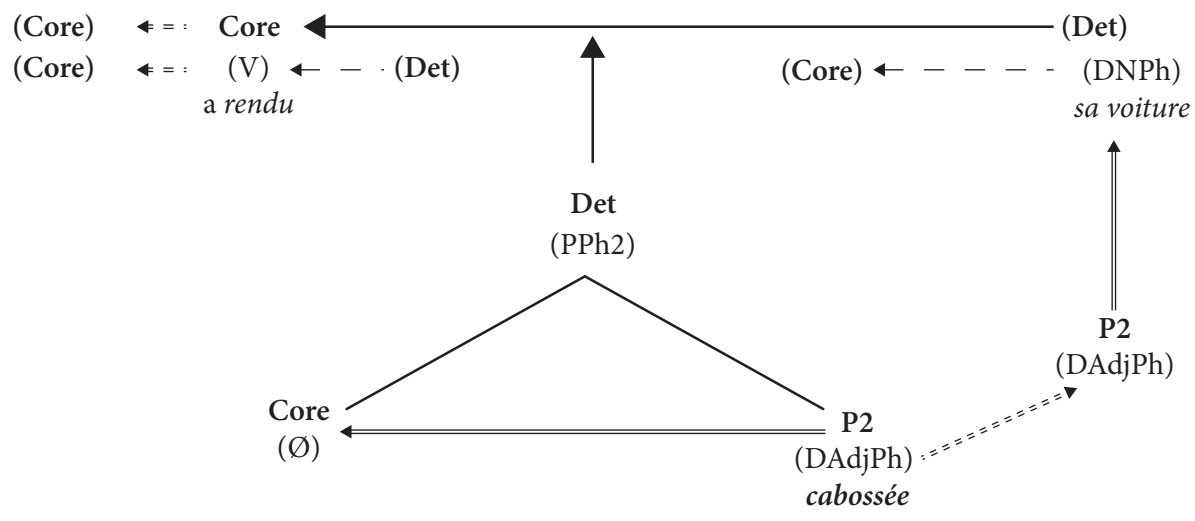

Figure 6. (Pierre) a rendu sa voiture cabossée

From there, the following reduction follows, as Figure 7:



Figure 7. (Pierre) a rendu sa voiture cabossée 


\subsubsection{Pierre vote utile}

(28) Pierre vote utile; mange sain, italien; mise gros; roule japonais; bronze idiot; parle net.

'Pierre casts a useful vote; eats healthy, Italian; bets a big amount; drives in a Japanese car; tans stupidly; speaks clear.'

In Example (28), there is no determiner of the verb, no possible cotextual co-referentiality. In this and in the other examples of this set, some linguists have seen an adverbial use of the adjective, while specifying that a potential support could be found inside the verb (the "internal object", or the idea contained in the verb). Thus, Pierre eats an Italian meal, votes a tactical vote, drives in a Japanese car and tans in a way which makes stupid (the last two items being in French under intransitive construction).

The absence of real determination of a support leaves the adjective invariable. Still, we do not see an adverbial meaning, except maybe in bronze idiot. The analysis in PPh2 with core $\varnothing$ allows to explain these examples. A more explicit gloss, but undoubtedly somewhat unnatural, would use another integrative structure (the PPh2) with complete predication (including core and P2):

1. 'Pierre eats, his meal being Italian'

2. 'vote, his vote being useful'

3. 'tans, his tanning making stupid'

4. 'drives, his car being Japanese'

The PPh2 with core $\varnothing$ (recoverable from the verb) would be determiner of the relation between the verbal core and the not saturated position of determiner of the verb. Because of the recurrence of these constructions where the position of determiner of the verb is not saturated, the absence of saturation of this position can result in a reading where the PPh2 with core $\varnothing$ would shift from its position of determiner of relation to that of determiner of the verb, in order to function as such, ${ }^{7}$ this occurring more easily as the verb has transitive uses (manger, voter, miser...). As Figure 8, for vote utile:

7. According to a mechanism described in Van Raemdonck (2003) for structures with 'obligatory adverbial phrase':

1. Pierre va à la mer

2. 'Pierre goes to the sea' 


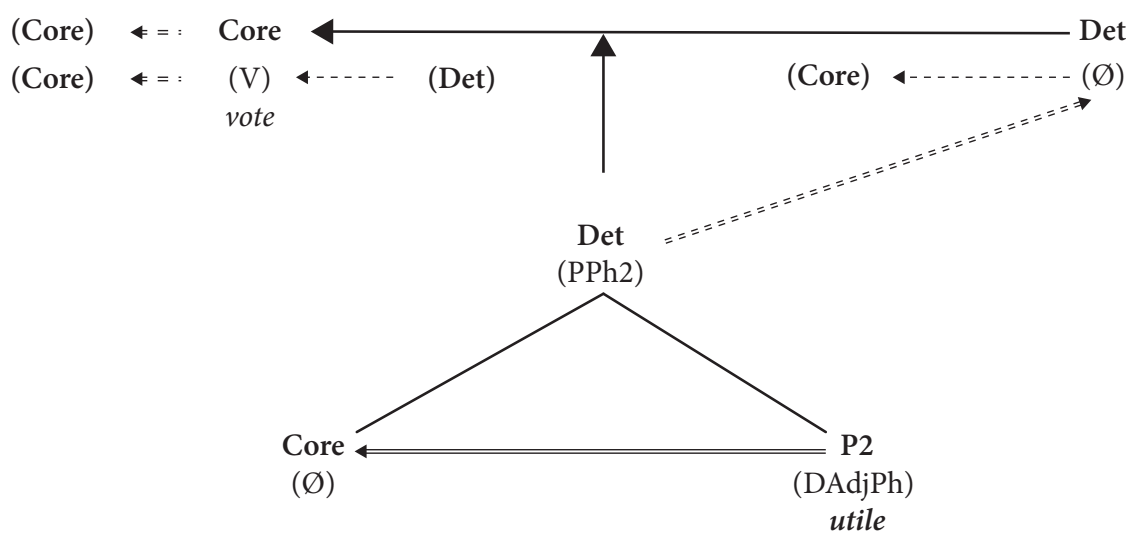

Figure 8. (Pierre) vote utile

Consider now the following pair:

(29) Il parle clair.

'He speaks clear.'

(30) Il parle clairement.

'He speaks clearly'.

In order to see if we can really speak, in the first case, of an adverbialization of the adjective and if the answer to this question is positive, both sentences must be synonymic. In our system, in (29), clair would relate syntactically to the verb after shifting towards the position of determiner of the verb. Its semantic import would be related to the word contained in the verb parler (its internal object). The invariability of the adjective would result from the fact that this hypothetical internal object is not marked for gender or for number, as a usual nominal support would be. There are hence no marks to be passed on the adjective. We could paraphrase it as:

(29) a. Il parle un langage clair; ses paroles sont claires.

'He speaks a clear language; his words are clear.'

In (30), it is not the word (internal object) that is characterized, but the relation (and the process of which it is the sign) between the verb parle and its determiner $\varnothing$ of the verb. We could paraphrase it as:

(30) a. Il parle de manière articulée.

'He speaks in a articulated way.' 
The differences between the glosses clearly highlight that the implemented mechanisms are different, cannot be likened or confused and, therefore, cannot be analyzed as if the two constructions were identical. In the first case (clair), it is the result which is targeted by the characterization, which clearly corresponds to the idea of determiner of term, even if this term is not saturated ( $\varnothing$ ), it being recoverable from the verb (its internal object). In the second (clairement), it is the process which is targetted, represented by the relation characterized by the adverb. In this description, the analytical structure clearly highlights the semantic differences between both constructions. Why go without such a profit, if it is not because it strikes the grammatical fairy tales which rocked our schooling? ${ }^{8}$

The intrapredicative adjective has the following characteristics here:

1. it is under the scope of the negation (Pierre ne vote pas utile),

2. its anteposition is difficult (?? Utile Pierre vote; Utile vote Pierre),

3. its interposition between the auxiliary and the participle is impossible ( ${ }^{\star}$ Pierre a utile voté),

4. it is an import to the internal object of a verb usually in transitive use (manger, voter),

5. it is not selected by the verb,

6. it is governed by the verb and is not part of its valency,

7. it can however also be found with a verb in intransitive use (bronzer, rouler),

8. it does not show any concordance because it is an import to a core $\varnothing$, the reconstruction of which involves, apart from co- or con-textual element explicitly available, either the internal object in the verb (without any mark for gender or number), or the idea contained in the verb in intransitive use,

9. it is not pronominalizable ( ${ }^{*}$ Pierre le vote),

10. there is no set phrase nor lexicalization with the verb, and

11. it is deletable (Pierre vote, mange...).

\subsubsection{Pierre la coupe net}

(31) Pierre la coupe net, s'arrête net, porte haut les couleurs, discute ferme la vente; le gouvernement creuse profond la dette; ça sent bon la rose.

'Pierre cuts it net, stops dead, carries proudly the colours, discusses hard(ly) the sale; the government digs deep the debt; that smells good, like roses.'

8. Moignet (1974) defended this point of view, but still preferred to keep an adverbialized view of the adjective in these structures. 
In these examples, the occurrence of a determiner of the verb changes the situation compared with the cases discussed above. Besides, adjectives are semantically strongly selected by the verb (almost at the dictionary level). This explains the inscription at the level of the valency of the verb and of the system of prospective relations. Nevertheless, as the adjective is deletable without modification of the meaning of the verb, the $\mathrm{PPh} 2$ will not be a part of the aforementioned valency (we draw it in solid lines). As Figure 9:

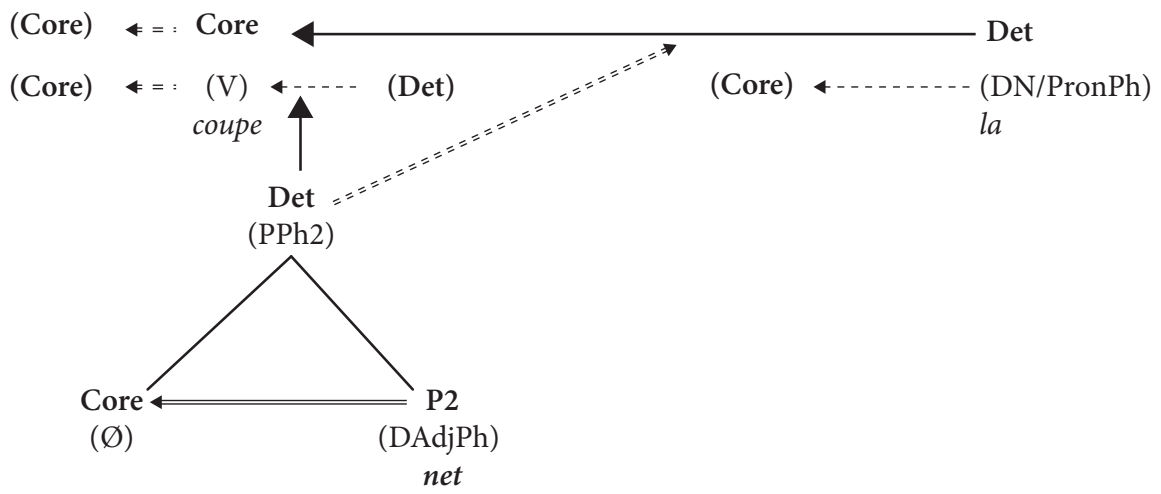

Figure 9. (Pierre) la coupe net

The intrapredicative adjective displays here the following characteristics:

1. it is under the scope of the negation (Pierre ne la coupe pas net),

2. its movement is possible, but its position before the determiner of the verb seems more natural (Pierre coupe net la discussion/la discussion net),

3. its position between the auxiliary and the participle is impossible ( ${ }^{*}$ Pierre l' $a$ net coupée),

4. it is $\mathrm{P} 2$ of the determiner expected by the verb (discussion/elle),

5. it is selected by the verb, with final government by the verb, and is not part of its valency,

6. it does not agree with the determiner of the verb, because the import is made onto the verb because of the selection (to its internal object: in Pierre la coupe net, it is the cut that is clear, not the referent of the pronoun la),

7. there is no pronominalization of the adjective alone, but the pronominalization of the determiner of the verb alone with preservation of the secondary predicate is possible (Pierre la coupe net), 
8. there is a set phrase/lexicalization with the verb (couper net): the selection of the adjective by the verb is very strong (not much freedom in the choice of the possible adjectives), ${ }^{9}$ and

9. it creates with the verb as a new lexical item (couper net).

Nevertheless, we cannot speak about a necessary integration in the valency of the verb, as the adjective appears to be deletable. In case of non-saturation of the position of determiner of the verb ((32) Ça sent bon), the shift is possible from the position in the schema above towards this position of determiner of the verb. As Example (32) and Figure 10:

(32) Ça sent bon.

'It smells good.'

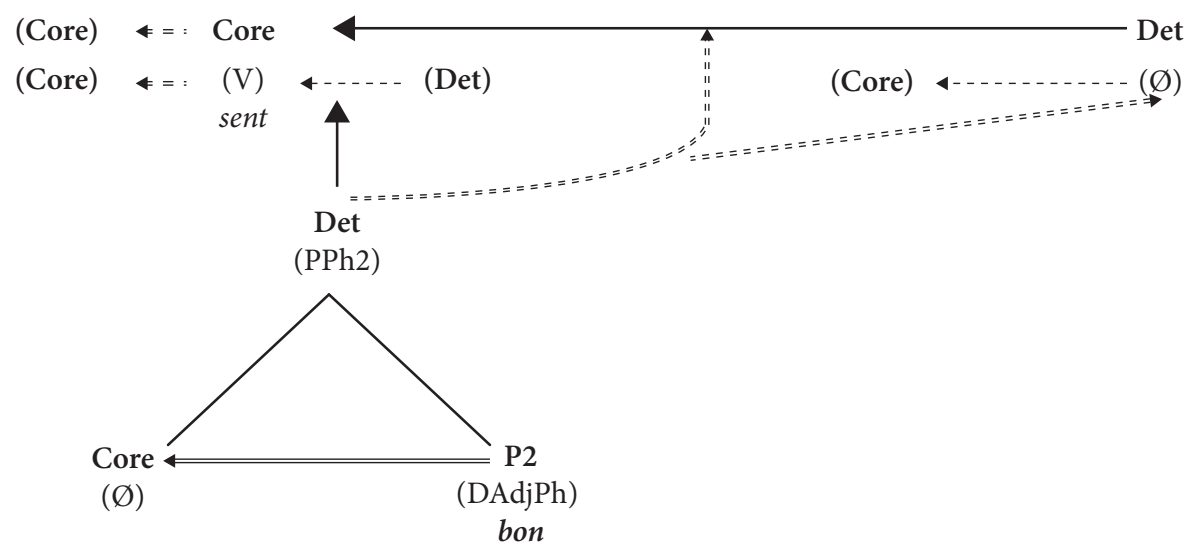

Figure 10. (Ça) sent bon

\subsubsection{Il fait beau}

(33) Il fait beau

'The weather is nice.'

This case, in impersonal voice, is close to the former, apart from the fact that the adjective is not deletable (?? Il fait) without modification of the meaning of the verb (faire is here 'meteorological'). From then on, it will be considered as being part of

9. In some cases, the link verb/adjective may seem even stronger: postposition of the adjective seems very difficult, even impossible, in the following example:

Ça sent bon la rose.

'That smells good, like roses.' 
the valency of the verb (and, thus, the whole PPh2 determiner will be represented as dashed lines). Given the non-saturation of the position of the determiner of the verb, a shift towards this position is possible as above. As Figure 11:

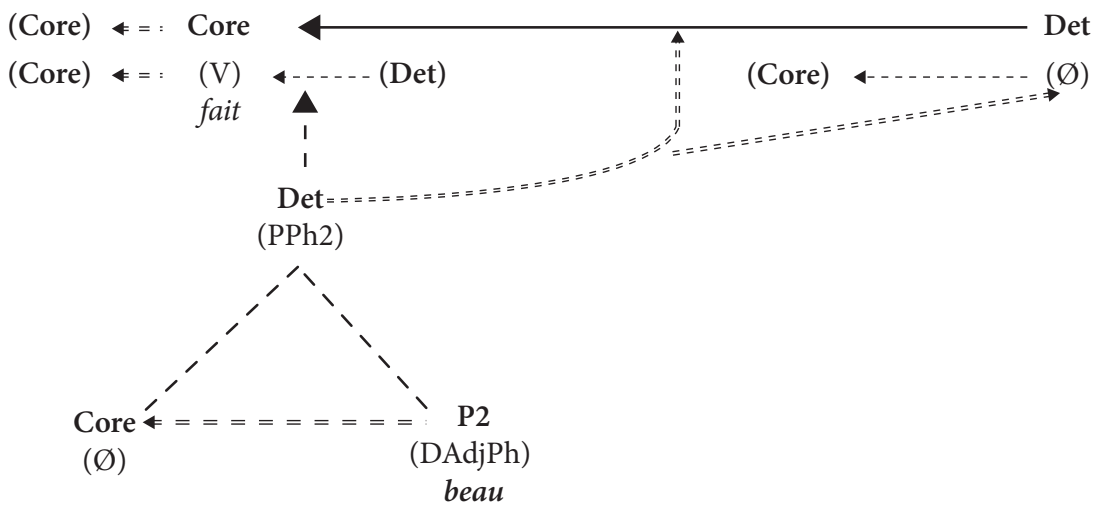

Figure 11. (Il) fait beau

This adjective is not deletable, the same way that the determiner of the verb in the copulative use is not deletable. Still, significant differences can be found: the agreement with the core of the sentence or the pronominalization is impossible here.

\subsubsection{Pierre mourra vieux}

(27) Pierre mourra vieux.

'Pierre will die old.'

Sometimes considered as subject complement, sometimes as secondary predicate of the subject or as adjective in adverbial use as manner phrase, vieux is described by Riegel (1996) by means of an underlying structure of the following kind:

(27) a. Pierre mourra [et il sera vieux].

'Pierre will die [and he will be old].'

Here vieux appears as a subject complement in the underlying sentence. Goes (2008), in the same vein, speak about a completive extension (extension attributive). But, to the latter, the syntactic anchoring is not explained.

Vieux could not be used adverbially as it concords for gender and number:
b. Marie mourra vieille.
'Marie will die old.' 
Vieux could not be a secondary predicate of the subject because, in a negative sentence, it would be under the scope of the negation, and would thus be integrated in the predicate:

(27) c. Pierre ne mourra pas vieux.

'Pierre will not die old.'

A real secondary predicate of the subject would stay out of scope of the negation:

\section{d. Cardiaque, Pierre ne mourra pas vieux.}

'Having a heart condition, Pierre will not die old.'

The option of subject complement is not possible given that mourir is an intransitive verb: it never appears in copulative use.

In linguistics it is usually preferred to follow the marks which guide the linguist rather than to try to guess what could be behind an implicit structure. The tests available indicate that vieux has to find a syntactic anchoring in the predicate, and to be at the same time in touch with the subject, with which it shows concord. This position exists in our system: We consider that the description of this case corresponds to Example (25), Pierre mange son steack saignant, except that the not saturated core of the PPh2 determiner of the relation [Dét $\varnothing \rightarrow$ Core DVPh] refers not to the determiner of the verb (which is in any case missing), but to the core of the sentence, support of this verb. The non-saturation of the position of the core of the PPh2 is allowed due to the easy reconstruction of the missing sequence by means of the immediate context.

Taking those features into account, and by following the arrows which indicate the direction of the imports towards their support, and hence the dynamics of the construction of the meaning, we can refine our analysis and describe vieux as a secondary predicate which would be incidental to the core expected by the verb.

The intrapredicative adjective displays here the following characteristics:

1. it is under the scope of the negation (Pierre ne mourra pas vieux),

2. its movement is difficult (??Vieux Pierre mourra),

3. its interposition between the auxiliary and the participle is impossible ( ${ }^{*}$ Pierre est vieux mort),

4. it is an import to the core $\varnothing$ of the PPh2 (the core is not saturated: the ellipsis results from the possible reconstruction from the immediate context (Pierre), with $\mathrm{PPh} 2$ determiner of the relation [Dét $\varnothing \rightarrow$ Core DVPh], marking that it is about framing the current process (Pierre will die while he is old),

5. it is not selected by the verb,

6. it is governed by the verb and is not part of its valency, 
7. it agrees with the not saturated core of the $\mathrm{PPh} 2$, which refers here to the core of sentence (Pierre, masculine singular), support of the verb,

8. there is no pronominalization of the adjective ( ${ }^{*}$ Pierre le mourra, which differentiates it from the determiner of the verb in copulative use (Il est gentil; Il l'est)),

9. there is no set phrase nor lexicalization with the verb, and

10. it is deletable (Pierre mourra).

The adjective secondary predicate relates to an expected core. But this P2, which cannot be moved, falls in reality onto a component of the verb (the component "core expected by the verb", which is inside the predicate). Hence we choose to conclude that vieux is also a part of the verbal government.

However, vieux is not required nor selected and will hence not be a part of the valency of the verb (and is hence represented by a solid line). Indeed, numerous verbs in intransitive use can be found in this type of construction:
a. Il est né riche
'He was born rich'
b. a vécu adulé
'lived adulated'
c. et est mort couvert d'honneurs.
'and died covered with honor.'

Deletion of the secondary predicates, if it can sometimes give the impression of improper constructions, does not alter the meaning of the verb, or at least does not substantially. As Figure 12:

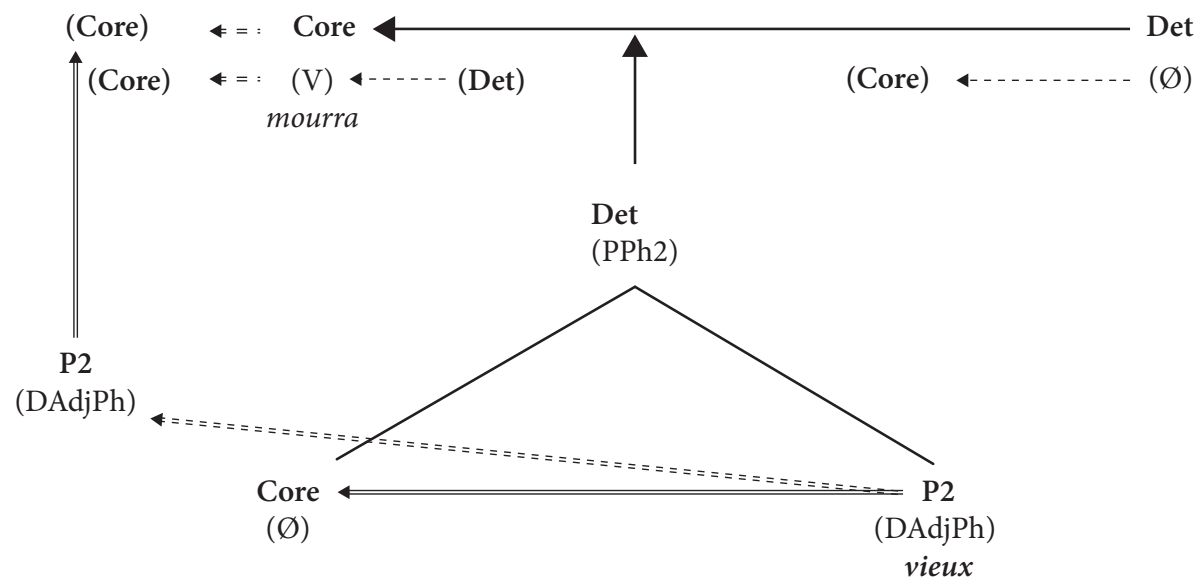

Figure 12. (Pierre) mourra vieux 
4.3.3 Secondary predicate of the determiner expected by the verb, not included in the verbal valency

Let us consider now the following examples:

(35) On l'a jugé coupable. (for the second reading, see Example (23))

'We considered him guilty.'

(36) On l'a nommé Directeur.

'We appointed him General Manager.'

(37) On l’a étiqueté incapable.

'We labelled him unable.'

In these cases, the adjective has the function of $\mathrm{P} 2$ of the determiner expected by the verb, without being a part of its valency: it can be deleted. This type of structure is close to the one illustrated by (26), Pierre Pierre rend sa voiture cabossée, except that the shift towards the position of $\mathrm{P} 2$ of the determiner of the verb that can be seen here does not proceed from a processual structure of the kind "PPh2 determiner of relation": it proceeds from a position where $\mathrm{P} 2$, selected by the verb of judgment or label, reaches prematurely, because of this selection, the determiner expected by the verb (and is thus represented by solid lines). As Figure 13:

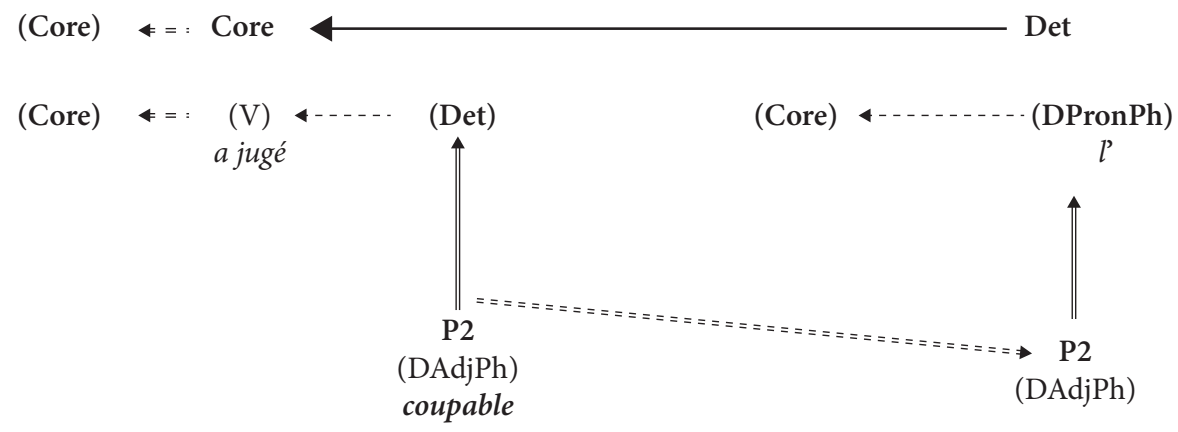

Figure 13. (On) l’a jugé coupable

The intrapredicative adjective displays here the following characteristics:

1. it is under the scope of the negation (On ne l'a pas jugé coupable),

2. its movement is possible (On a jugé coupable cet homme),

3. its position between the auxiliary and the participle is impossible $\left({ }^{*} \mathrm{On}\right.$ l'a coupable jugé),

4. it is $\mathrm{P} 2$ of the determiner expected by the verb,

5. it is selected (wide selection: adjective with meaning of judgment or label) by the verb, with final government by the verb, and is not part of its valency, 
6. it agrees with the determiner of the verb $\left(l^{\prime}\right)$, because it relates to it,

7. there is no pronominalization of the adjective alone, but the pronominalization of the determiner of the verb alone with preservation of the secondary predicate is possible (On l'a jugé coupable),

8. there is no set phrase nor lexicalization with the verb, and

9. it is deletable (On l'a jugé).

4.3.4 Secondary predicate of the determiner expected by the verb, included in the verbal valency

The following case is illustrated by:

(38) Pierre rend sa femme malheureuse.

'Pierre is making his wife unhappy'.

In this case, malheureux cannot be deleted without altering substantially the meaning of the verb: from 'faire devenir' ('to make become'), it would shift to 'restituer' ('to return'). We hence observe a closer solidarity between the verb and the secondary predicate, as if, to maintain the intended meaning of the verb, the secondary predicate had to be a part of its valency. Hence rendre in this meaning of a word would not have the same valency profile as rendre meaning 'to return'. ${ }^{10}$ To account for this, we suggest an analysis of this structure where malheureux is secondary predication on the determiner expected by the verb, this secondary predicate being included in the valency of the verb (and is thus represented by dashed lines). As Figure 14:

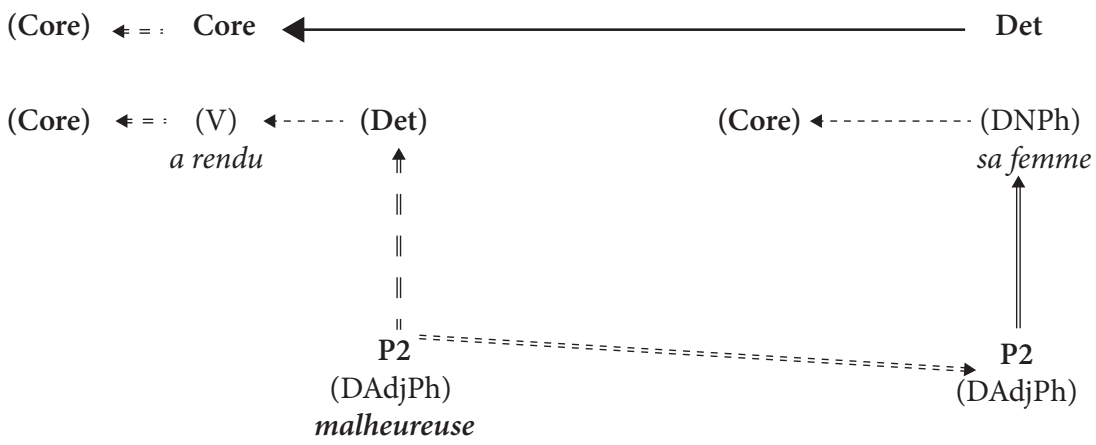

Figure 14. (Pierre) rend sa femme malheureuse

10. We can find L'amour rend fou ('Love drives crazy'), with determiner $\varnothing$ of the verb, which seems to confirm the constitution of a quasi-lexical item of the verb 'rendre + adjective'. 
The intrapredicative adjective displays here the following characteristics:

1. it is under the scope of the negation (Pierre ne rend pas sa femme malheureuse),

2. its movement is possible but unusual (?Pierre rend malheureuse sa femme),

3. its position between the auxiliary and the participle is impossible ( ${ }^{\star}$ Pierre $a$ malheureuse rendu sa femme),

4. it is $\mathrm{P} 2$ of the determiner expected by the verb,

5. it is selected (wide selection: adjective with potentially resultative meaning) by the verb, with final government by the verb, and is not part of its valency,

6. it agrees with the determiner of the verb (sa femme, feminine singular), because it relates to this determiner,

7. there is no pronominalization of the adjective alone, nor altogether with the determiner of the verb, but pronominalization of the determiner of the verb alone with preservation of the secondary predicate is possible (Pierre la rend malheureuse),

8. there is a set phrase/lexicalization with the verb, which changes the verb meaning or sets a particular meaning (rendre $X$ has the particular meaning to 'make become $\mathrm{X}^{\prime}$ and forms a lexical item from then on), and

9. it is not deletable without modifying the meaning $\left(\left(^{*}\right)\right.$ Pierre rend sa femme, would have another meaning of restitution).

\subsubsection{Secondary predicate of the core inside a PPh2 determiner expected} by the verb, included in the verbal valency

The following type is a is well-known case of meronymical avoir (see in particular Furukawa 1987 and Hanon 1989):

(39) Marie a les yeux bleus, le cheveu rare, la main leste.

'Marie has blue eyes, rare hair, agile hand.'

This is analyzed here as a verb selecting for this particular meaning a determiner of PPh2's kind with, as core, the part (les yeux 'the eyes') semantically and referentially connected to the core of sentence (Marie, support of $a$, and which represents the whole to which the part is connected), and a $\mathrm{P} 2$ relating to it. This $\mathrm{PPh} 2$ is as a whole a part of the valency of the verb: its absence would modify the meaning of the verb. As Figure 15: 


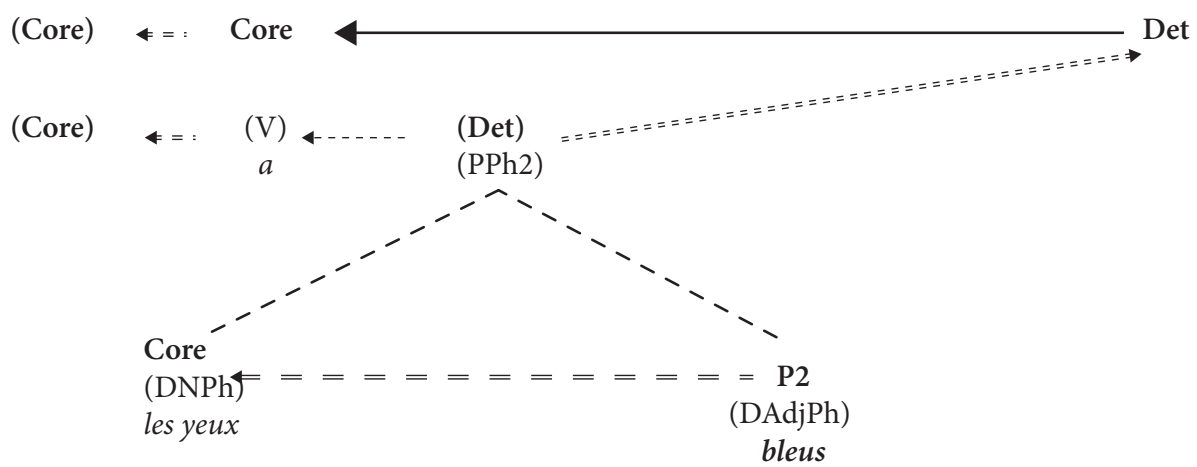

Figure 15. (Marie) a les yeux bleus

The intrapredicative adjective displays here the following characteristics:

1. it is under the scope of the negation (Marie n'a pas les yeux bleus),

2. its movement is possible but unusual ('Marie a bleus les yeux),

3. its interposition between the auxiliary and the participle is impossible ( ${ }^{*}$ Marie a bleus eu les yeux),

4. it is $\mathrm{P} 2$ of the core inside a $\mathrm{PPh} 2$ determiner expected by the verb, included in the verbal valency,

5. it is selected by the verb (wide selection of the determiner (part + free P2)), with final government by the verb, and is part of its valency,

6. it agrees with the core of the PPh2 (yeux, masculine plural),

7. there is no pronominalization of the adjective alone, but the pronominalization of the global PPh2 (Les yeux bleus, ça, pour sûr, Marie les a, 'Blue eyes, that, for sure, Marie has it'), or of the core alone with preservation of the secondary predicate is possible (Marie les a bleus, 'Marie has them blue'),

8. there is a set phrase/lexicalization with the verb, which changes the verb meaning or sets a particular meaning, and

9. it is not deletable ( ${ }^{*}$ Marie a les yeux $)$.

4.3.6 Secondary predicate of the core expected by the verb, included in verbal valency

The last type of structure considered here is illustrated as follows:

(40) Marie tombe enceinte.

'Marie gets pregnant.' 
This case is similar to (27), Pierre mourra vieux, apart from the fact that the absence of the secondary predicate would radically change the meaning of the verb. There is no preliminary transit by a structure of $\mathrm{PPh} 2$ with core $\varnothing$ : it would mean that the verb tomber would have at first its meaning 'chuter' ('to drop'). The secondary predicate, incidental to the component "core expected by the verb", is required and is hence not only part of the verbal government, but also of the valency of the verb, so that the figurative meaning of tomber can be generated, as in (38), Pierre rend sa femme malheureuse, (and is thus represented by a dashed line). As Figure 16:

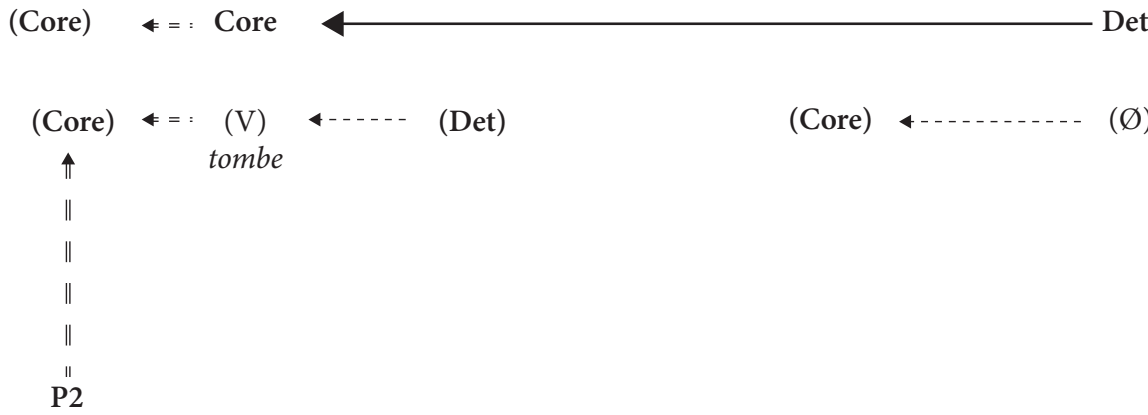

(DAdjPh)

enceinte

Figure 16. (Marie) tombe enceinte

The intrapredicative adjective displays here the following characteristics:

1. it is under the scope of the negation (Marie ne tombe pas enceinte),

2. its movement is impossible ( ${ }^{\star}$ Enceinte Marie tombe),

3. its position between the auxiliary and the participle is impossible ( ${ }^{\star}$ Marie est enceinte tombée),

4. it is an import to the core expected by the verb,

5. it is selected by the verb (tomber + some selected adjectives),

6. it is governed by the verb and is part of its valency,

7. it agrees with the core of sentence (Marie, feminine singular),

8. there is no pronominalization of the adjective ( ${ }^{*}$ Marie le tombe), which differentiates this case from that of the determiner of the verb in copulative use ( $I l$ est gentil; Il l'est)),

9. there is a set phrase/lexicalization with the verb (tomber enceinte), and

10. it is not deletable without modifying the meaning $\left(\left(^{*}\right)\right.$ Marie tombe, would have another meaning of falling). 


\section{Conclusion}

All in all, and in the theoretical framework of the genetic syntax outlined here, the intrapredicative adjective sees its adjectival integrity strengthened and secured. We have mapped the various uses of intrapredicative adjectives, and have hence indexed each of them to a specific functional position, participating in that way to a redefinition of the limits of the class.

The result is that in all the examples we analyzed, the adjective is almost always used in compliance with the features that define its class: the fact of being a term of a term, characterized by an external incidence of the first degree. If we except the very few examples in 4.2 , all the items can find a description within the scope of this definition. What has sometimes been considered as an adverbial use, can be analized more finely in considering that the adjective is used as a secondary predicate of a core within a $\mathrm{PPh} 2$ structure, this core being saturated or not. The $\mathrm{PPh} 2$ structure on the whole can be used as an import determining a relation, which is the characteristic of an adverbial use. Hence, our two-level analysis allows to give full account of the features observed and the meanings generated: the adverbial use of the phrase ( $\mathrm{PPh} 2)$ which entails the meaning of frame of the relation; within this phrase, the adjective in predicative use keeps all the features of its class.

\section{Key to abbreviations}

DAdjPH: determinative adjectival phrase

DNPH: determinative nominal phrase

DPronPH: determinative pronominal phrase

DVPH: determinative verbal phrase

Det: determiner

$\mathrm{PPH}(1 / 2)$ ： (primary/secondary) predicative phrase

P2: $\quad$ secondary predicate

Rel: $\quad$ relation

T: $\quad$ term

$\mathrm{V}: \quad$ verb

\section{References}

Abeillé, Anne, Delaveau, Annie \& Godard Daniele. Forthcoming. La grande grammaire du français.

Abeillé, Anne \& Godard, Danielle. 2005. Les adjectifs invariables comme compléments légers en français. In L'adjectif en français et à travers les langues, Jacques François (ed.), 209-224. Caen: Presses universitaires de Caen. 
Cadiot, Pierre \& Furukawa, Naoyo. 2000. Présentation. Langue Française 127: 3-5.

Damourette, Jacques \& Pichon, Edouard. 1911-1940. Des mots à la pensée: Essai de grammaire de la langue française. Paris: Editions d'Artrey.

Delsaut, Maxence. 2013. La tradition obère-t-elle la question de l'adjectif invarié jusqu'à un point de non-retour? Travaux de linguistique 67: 25-60. doi:10.3917/tl.067.0025

Eriksson, Olof. 1993. La phrase française: Essai d'un inventaire de ses constituants syntaxiques. Göteborg: Acta Universitatis Gothoburgensis.

Furukawa, Naoyo. 1987. Sylvie a les yeux bleus: Construction à double thème. Lingvisticae Investigationes XI(2): 283-302. doi:10.1075/li.11.2.03fur

Furukawa, Naoyo. 1996. Grammaire de la prédication seconde. Louvain-la-Neuve: Duculot.

Goes, Jan. 2008. Les prédications secondes à prédicat adjectival. Travaux de Linguistique 57:

23-41. doi:10.3917/tl.057.0023

Grundt, Lars Otto. 1972. Études sur l'adjectif invarié en français. Bergen: Universitetsforlaget.

Guillaume, Gustave. 1964. Langage et science du langage. Paris and Québec: Nizet/Presse de l'Université de Laval.

Guimier, Claude. 1989. Sur l'adjectif invarié en français. Revue des Langues Romanes 93(1): $109-120$.

Hanon, Suzanne. 1989. Les constructions absolues en français moderne. Louvain: Peeters.

Havu, Eva \& Pierrard, Michel. 2009. La prédication seconde: Essai de mise au point. Travaux de Linguistique 57: 7-21. doi:10.3917/tl.057.0007

Havu, Eva \& Pierrard, Michel. 2014. Les co-prédicats adjectivants: Propriétés et fonction des adjectifs et des participes adjoints. Bern: Peter Lang.

Hengeveld, Kees. 1992. Non Verbal Predication. Theory, Typology, Diachrony. Berlin: Mouton de Gruyter. doi:10.1515/9783110883282

Hengeveld, Kees \& van Lier, Eva. 2010. An implicational map of parts of speech. Linguistic Discovery 8(1): 129-156. doi:10.1349/PS1.1537-0852.A.348

Hummel, Martin. 2014. The adjective-adverb interface in Romance and English. In Adjectives in Germanic and Romance [Linguistik Aktuell/Linguistics Today 212], Petra Sleeman, Freek Van de Velde \& Harry Perridon (eds), 35-71. Amsterdam: John Benjamins. doi:10.1075/la.212.02hum

Jespersen, Otto. 1924. The Philosophy of Grammar. Chicago IL: University of Chicago Press.

Le Goffic, Pierre. 1993. Grammaire de la phrase française. Paris: Hachette supérieur.

Melis, Ludo. 1988. La prédication seconde: Présentation. Travaux de Linguistique 17: 7-12.

Moignet, Gérard. 1974. Sur la "transitivité indirecte" en français. Travaux de Linguistique et de Littérature XII(1): 281-299.

Muller, Claude. 2000. Les constructions à adjectif attribut de l'objet, entre prédication seconde et complémentation verbale. Langue Française 127: 21-36. doi:10.3406/lfr.2000.996

Noailly, Michèle. 1999. L'adjectif en français. Paris: Ophrys.

Rémi-Giraud, Sylvianne. 1991. Adjectif attribut et prédicat: approche notionnelle et morpho-syntaxique. In À la recherche de l'attribut, Marie-Madeleine De Gaulmyn \& Sylvianne RémiGiraud (eds), 151-207. Lyon: Presses universitaires de Lyon.

Riegel, Martin. 1996. Les constructions à élargissement attributif: Double prédication et prédicatifs complexes? In Dépendance et intégration syntaxique: Subordination, coordination, connexion, Claude Muller (ed.), 189-197. Tübingen: Max Niemeyer.

Riegel, Martin, Pellat, Jean-Christophe \& Rioul, René. 2009. Grammaire méthodique du français, 7th edn. Paris: Presses Universitaires de France. 
Van Raemdonck, Dan. 1998. Sous mon arbre, volait un esthète. In La Ligne claire. De la linguistique à la grammaire. Mélanges offerts à Marc Wilmet, Annick Englebert, Michel Pierrard, Laurence Rosier \& Dan Van Raemdonck (eds), 237-252. Louvain-la Neuve: Duculot.

Van Raemdonck, Dan. 2002. En attendant l'incidence: La relation d'attente. In Le système des parties du discours. Sémantique et syntaxe, Ronald Lowe (ed), 408-419. Québec: Presses de l'Université Laval.

Van Raemdonck, Dan. 2003. COI: Complément Objectivement Inutile. In Actas del XXIII Congreso Internacional de Lingüistica y Filologia Romanica, Salamanca 2001, II/2, Seccion 3: Sintaxis, semantica y pragmatica, Fernando Sanchez Miret (ed.), 473-486. Tübingen: Max Niemeyer.

Van Raemdonck, Dan. 2007. Syntaxe de la phrase et structures intégratives: L'exemple par T et $\Theta$. In Psychomécanique du langage et linguistiques cognitives. Actes du XIe Colloque international de l'Association internationale de Psychomécanique du langage, Jacques Brès, Marc Arabyan, Thierry Ponchon, Laurence Rosier, Renée Tremblay \& Henriette Vachon-L'Heureux (eds), 311-320. Limoges: Lambert-Lucas.

Van Raemdonck, Dan. 2010. La rection verbale à l'aune de l'incidence: L'incidence autour et alentour du verbe. Travaux de Linguistique 60: 45-64. doi:10.3917/tl.060.0045

Van Raemdonck, Dan. 2011[2015]. Le sens grammatical. Référentiel à l'usage des enseignants, with M. Detaille and L. Meinertzhagen, 2nd edn. Bern: Peter Lang.

Wilmet, Marc. 1986. La détermination nominale. Paris: Presses Universitaires de France.

Wilmet, Marc. 1997[2010]. Grammaire critique du français, 5th edn. Paris, Louvain-la-Neuve \& Bruxelles: Hachette, Duculot \& De Boek. 
PART III

Italian 



\title{
Adverb agreement in the dialects of the Lausberg Area
}

\author{
Giuseppina Silvestri \\ University of Cambridge
}

\begin{abstract}
This paper brings uncharted evidence to the phenomenon of adverb agreement in Italo-Romance. Among southern Italian dialects, manner adverbs are not morphologically distinguished from adjectives and, in certain varieties, may agree with a referring nominal. The patterns of agreement are discussed and analysed by assessing and describing novel data retrieved from the upper southern Italian dialects of north-western Calabria. In these varieties adverbs agree with Undergoer/Patient arguments. The semantic entailments of the adverb agreement in transitive and unaccusative clauses disclose the availability of true and pseudo-resultative predicates. Moreover, agreeing adverbs influence the past participle agreement, which normally displays alternative patterns depending of the morpholexical properties of the participle ( \pm metaphonic).
\end{abstract}

\section{Introduction}

The aim of this paper is exploring the morphosyntactic distribution as well as some semantic entailments of agreeing adverbs within the Italian dialects of northwestern Calabria (1), wherein adverbs are formed with the masculine singular form of the corresponding adjectives, as no adverbial suffix -mente (and allomorphs) is productively used.

(1) a. (N.Cal.)

Piətrə aggiustavəd a camməra pulita

Piətrə fixed.3sg the.FsG room.FsG nice.FSG

'Pietro was tidying up the room nicely'

b. Maria parla buənə/bòna

Maria speaks good.M/FSG

'Mary speaks well' 


\section{c. Maria cada sempə sbèrna \\ Maria falls always inadvertent.FSG \\ 'Maria always falls down inadvertently'}

After including the issues posed by the evidence from northern Calabrian within a crosslinguistic picture (Section 2), the relevant data will be discussed in the light of the syntactic configurations driving the agreement patterns (Section 3). Moreover, the availability of both resultatives (of the type 'The river froze solid') and pseudo-resultatives (like 'John cut the meat thin') among these varieties will be corroborated (Section 4). Finally, unnoticed patterns of the past participial agreement due to the co-occurrence with agreeing adverbs are presented (Section 5) and analysed altogether with the syntactic nature of the adverb agreement (Section 6).

\section{Adjectival adverbs}

Other than the straightforward morphological process for which adverbs are productively derived from adjective stems throughout the insertion of a suffix (e.g. -mente and allomorphs for most Romance, veloce > velocemente (Italian); -ly for English, bad > badly; - $a$ for Greek, grígoros > grígora), (manner) adverbs and adjectives show other crucial similar properties (Hengeveld 1992).

In terms of distribution, adverbs and adjectives display different morphosyntactic behaviour only regarding the category they modify, i.e. verbs and nouns, respectively. Readily accessible evidence proves that the points of similarities between adverbs and adjectives are quantitatively and qualitatively more significant.

Notably, both adverbs and predicative adjectives can take complements (Alexiadou 1997:2-6). Furthermore, it has been noted that the placement of adverbs in clauses (Jackendoff 1972; Cinque 1999) corresponds to interpretative strategies of adjectives modifying event nominals (Crisma 1996; Cinque 2010).

Two further points of affinity between adverbs and adjectives are particularly significant for this contribution, i.e. that in some languages adjectives and adverbs display no morphological difference (e.g. Dutch, German, Romanian, southern Italian dialects) and, more crucially, that in Romance adverbs may exhibit agreement with an associated nominal (Zagona 1990; Ledgeway 2000, 2003, 2011; Cruschina 2010; Hummel 2014). Crosslinguistic evidence based on standard and non-standard Romance varieties enhances empirical observations on the structural correspondences between adverbs and adjectives, not only in terms of morphological derivation of the former from the latter or the total lexical overlap of the masculine singular form of the adjective and the corresponding adverb, but also 
for the property shown by verb modifiers of agreeing in gender and number with a nominal functioning as a verb argument.

Recently Hummel $(2014,2015)$ extended the investigation about the adjectiveadverb interface to several Romance varieties and pointed out that two morphosyntactic types of manner adverbs are to be defined, both derivationally based on adjectives and conveying a common attributive (ATT) function, as they express a manner type of adjectives/adverbs: Type A which uses the unmarked masculine singular form of the adjective, and Type B which is formed from the lexical basis of the adjective with the dedicated suffix -mente and its Romance allomorphs. With a particular attention addressed to the historical development, Hummel (2014) provides a reconstruction of the first type developed within a shared context between oral and written traditions. Romance examples with masculine singular (MSG) morphology is shown in (2):

(2) a. (Pt.) Os homens trabalham duro.

b. (Fr.) Les hommes travaillent dur.

c. (Rom.) Oamenii lucrează greu.

d. (Srd.) Sos omine trabagliana folte.

'The men work hard'

(Hummel 2014:38)

In Hummel's (2014) analysis, the evidence that modern Romanian, Sardinian and the southern Italian dialects use Type A can be explained by the continuance of the spoken Latin tradition and the exclusion from the early implementation of a written norm, as conversely was the case of French, Portuguese, Spanish and to a lesser extent for Italian.

\subsection{Adverbs in southern Italian dialects}

In modern dialects of southern Italy (SIDs), in particular south of the isogloss Gaeta-Rieti-Teramo (Rohlfs 1969:243-5), manner adverbs form a morphological syncretic class with adjectives, except for a list of lexicalized forms belonging not exclusively to the manner class (e.g. francamente, veramente, appos(i)tamente...). It was noted that the adverbs of the syncretic type present productive patterns of agreement with a referring nominal. In particular, Cruschina (2010) and Ledgeway (2011) provided direct evidence of a robust adverbial agreement in several southern Italian dialects and Sicilian varieties, respectively.

In this contribution, it will be shown that across SIDs manner adverbs and adjectives, although identical in terms of morphological makeup, still fulfil two distinct functions: adjectival and adverbial. The possibility for manner adverbs to agree with a related nominal represents a striking point of similarity with manner 
adjectives. However, the activation of specific syntactic positions and consequent interpretations on the modifiers unambiguously suggest that the category of adverbs in SIDs is robust and includes agreeing adverbs.

Relevant data newly collected from a handful of SIDs of north-western Calabria will be discussed and analysed under the light of the generalisations advanced in Ledgeway (2011) who argues that the agreement patterns found among SIDs undergo specific structural constraints which reflect the structural conditions driving the past participle agreement in Romance, ultimately signalling split intransitivity. ${ }^{1}$ The agreement patterns are essential for the SIDs investigated in this contribution in order to reveal a different behaviour of the two intransitive classes (unergative and unaccusative). Namely, two of the major diagnostic tests are not applicable in the varieties at issue, i.e. auxiliary selection, which homogeneously results in 'have' among the north-western Calabrian (N.Cal.) dialects (3a), and past participle agreement, almost totally neutralised due to the loss (or convergence in schwa) of the distinctive vocalic morphemes (3c):

(3) a. (N.Cal.)

I littərə hanə arrivatə

the.PL letters.F have.3PL arrived.PL

b. (Standard It.)

Le lettere sono arrivate

the.FPL letters.F be.3PL arrived.FPL

'The letters have arrived'

c. (N.Cal.)

I çurə hanə crəsciutə

the.PL flower.MPL have.3PL grown.PL

d. (Standard It.)

I fiori sono cresciuti

the.MPL flower.mpl be.3PL grown.MPL

'The flowers have grown'

1. Given that the class of intransitives is not homogenous (Perlmutter's 1978 'Unaccusative Hypothesis' implemented within the 'Government and Binding' syntactic theory by Burzio 1986), 'split intransitivity' refers to the discrepant behaviour that distinct intransitive configurations (i.e. unaccusatives $v s$ unergatives) display. In particular, the subject plays different semantic roles (Van Valin 1990): Agent/Actor in transitives and unergatives $\left(\mathrm{S}_{\mathrm{A}}\right)$ and Undergoer/Patient in unaccusatives $\left(\mathrm{S}_{\mathrm{O}}\right)$. For the implications of Perlmutter's (1978) hypothesis and the language-specific diagnostic for standard Italian, which can be applied for other Italo-Romance varieties, cf. Burzio (1986), Loporcaro (1998, 2016), Bentley (2006). 


\subsection{The dialects of the so-called Lausberg Area}

The varieties discussed throughout this contribution include the dialects of Buonvicino, Orsomarso, S. Maria del Cedro, and Verbicaro, all located in northwestern Calabria (see Map 1 in Appendix). Geo-linguistically they all belong to the so-called Lausberg Area, due to Lausberg's (1939) work of assessment, description, and internal classification of non-standard Italo-Romance. Based on phonomorphological characteristics Lausberg (1939) identified a linguistic strip encompassing, from the Tyrrhenian to the Ionian Sea, northern Calabria and southern Basilicata.

Several facts related to the phonological diachronic change from Latin into Romance, such as notably the development of different tonic vowel systems ('Sardinian' and 'Romanian' types, among others; Fanciullo 1997) or the retention of original endings within verb paradigms, are nowadays still attested among the dialects of this area. On the one hand, the unique characteristics of this group of varieties, which single out the dialects of Basilicata and northern Calabria from the rest of Italo-Romance have been extensively described (Alessio 1954; Parlangeli 1960, 1971; Rohlfs 1966-1969, 1972; Rensch 1973; Trumper 1980; Fanciullo 1988; 1997; Martino 1991; Romito 2006, among others). On the other hand, their morphosyntactic makeup has barely received specific attention from scholars. ${ }^{2}$

The relevant evidence was collected through fieldwork in loco. A morphosyntactic questionnaire was administrated by means of interviews to native speakers, which were carried out face-to-face in order to unambiguously elicit judgments of (un)grammaticality. A male and a female informant were chosen based on three age groups (25-45, 46-65 and 66-85), for a total of six informants for each dialect. Unless stated otherwise, all the examples in this paper come from the dialect of Verbicaro.

\subsection{Adjectives or adverbs}

A question might naturally arise about the referring category of the modifiers under examination and the consequent possible practical problem of which label to apply, i.e. (adverbial) adjectives or (agreeing/adjectival) adverbs. The question may be far from irrelevant, if the adoption of one label rather than another entails a specific point of observation on the very nature of the related linguistic phenomena.

2. Exceptions in this sense can be the works on some syntactic aspects of the nominal phrase, such as non-prepositional genitive (Silvestri 2013) and the adnominal possessives (Silvestri 2016) as well as the macro-phenomenon of agreement (Loporcaro \& Silvestri 2011). For relevant data and interpretations on some morphosyntactic facts cf. also Manzini-Savioia (2005). 
For instance, Hummel (2014) terms these cross-categorical adjectival and adverbial items as adverbial adjectives, since their core adjectival nature is expanded with syntactic functions typical of adverbs. ${ }^{3}$ Hummel (2014) adopts Hengeveld's (1992) conclusion that SIDs lack the word-class of manner adverbs, as the wordclass of adjectives entails both relevant functions of adjectives and (manner) adverbs. Levinson (2010), in discussing (true and pseudo-)resultative predicates in Catalan, which are comparable with the modified predicates in SIDs (see 4.2), claims that they are deeply adjectives due to their crosslinguistic morphosyntactic properties. In Catalan pseudo-resultatives show adjectival morphology which is distinct from adverbial marks.

In SIDs adverbs and adjectives share a fundamental property, i.e. the possibility of agreement with a nominal, under specific conditions. In other words, a vocabulary item with masculine singular (MSG) exponence needs to be specified for its function in the grammar of native speakers either as MSG adjective or a nonagreeing adverb or an adverb agreeing with a MSG nominal. Likewise, a feminine singular (FSG) marked vocabulary item may perform the function of either an adjective or an adverb agreeing with a FSG nominal.

For instance, if one takes into account the examples in (4)-(5), what emerges is that in the northern Calabrian a neat semantic difference between the adjectival (adj) and the adverbial (adv) value of the same lexical item, though surfacing in the same position, is evident within the unaccusative construction in (4), whereas it might be blurred elsewhere, e.g. in transitive sentences with a non-resultative reading (5), where the agreeing modifiers can convey an adjectival function (predication of a quality of the noun) or an adverbial function of predication on the event and its effects on the individuals involved.

(4) (N.Cal.)

A quatrara crescia svèlta ${ }_{\text {adj/adv }}$

the girl grows.up quick.FSG

i. 'The girl is growing up quickly'

ii. 'The girl is growing up (to be) witty'

(5) a. Pietrə tenədə na giacchetta traviərsə ${ }_{\text {adv }}$ Pietro holds a jacket.FSG oblique.MSG

'Pietro holds a jacket crookedly'

3. "Preferimos el término adjetivos adverbiales a adjetivos adverbializados, porque este sugiere una trasformación categorial a la clase de adverbios, mientras que aquel parece más compatible con la idea de emplear los mismos adjetivos con funciones sintácticas" (Hummel 2014). 
b. Pietrə tenədə na giacchetta traversa ${ }_{\text {adj }}$

Pietro holds a jacket.FSG oblique.FSG

'Pietro holds a malformed jacket'

c. Maria tenədə na giacchetta traviersə ${ }_{\text {adv }}$

Maria holds a jacket.FsG oblique.MSG

'Maria holds a jacket crookedly'

d. Maria tenədə na giacchetta traversa $a_{a j / a d v}$

Maria holds a jacket.FSG oblique.FSG

i. 'Maria wears/holds a malformed jacket'

ii. 'Maria sits crooked(ly) holding a jacket'

iii. 'Maria, sitting crookedly, holds a jacket'

In (5b) traversa functions as an attributive adjective predicating a physical property of the jacket. The adverbial value of this modifier is null as the interplay with the semantics of the verb does not allow it. However, in (5d) with the insertion of a FSG noun as a subject of the transitive, traversa simultaneously conveys two distinct interpretations, either as a noun modifier like in (5b) or as a modifier taking scope on the subject, not only as a nominal attribute, but also expressing a quality of the manner in which the subject carries on the action of holding the jacket.

The picture might prove even more complicated by including a resultative reading triggered by a creation verb ${ }^{4}$ (e.g. to sew $)^{5}$ and the modifier's scope on the verb or on a nominal. The placement of the modifier in one of the possible positions does not always help disambiguate. ${ }^{6}$ More specifically, other than the noun modification function (adj), the agreeing modifier can take scope on the event only (adv) or convey a specific subject-oriented reading (adv.S-or) as well as an object-oriented interpretation (adv.O-or) which systematically licenses a resultative predication.

4. Creation verbs (or explicit creation verbs in Levinson 2007: 17) entail an individual is realised as a DP argument, such as in 'Mary built a sand castle'. Implicit/Root creation verbs entail the creation of an entity which is not expressed by the verb argument 'Mary grouped the students (by age)'.

5. In these dialects 'to sew' is a creation (i) and a non-creation (ii) verb:

(a) Maria cusa na cammisa

Maria sows a.FSG shirt.FSG

i. 'Maria is making a shirt'

ii. 'Maria is darning/altering/repairing a shirt'

6. In SIDs the prenominal position is mostly unavailable for adjectives (Ledgeway 2009 for Old Neapolitan; Silvestri 2013; Guardiano-Stavrou 2015; Andriani 2016 for Barese). 
(6) a. Pietrə cusa na giacchetta traviersə ${ }_{\text {adv/adv.S-or }}$

Pietro sews a.FSG jacket.FSG crooked.MSG

i. 'Pietro is sewing a jacket haphazardly' (adv)

ii. 'Pietro, sitting crookedly, is sewing a jacket' (adv.S-or)

b. Pietrə cusa na.FSG giacchetta traversa ${ }_{\text {adj/ adv.O-or }}$

Pietro sews a.FSG jacket.FSG crooked.FSG

i. 'Pietro sews a malformed jacket' (adj)

ii. 'Pietro sews a jacket crooked(ly)' (adv.O-or)

c. Maria cusa na giacchetta traviers ${ }_{\text {adv }} /$ traversa $_{\text {adj/adv.S-or/adv.O-or }}$

Pietro sews a.FSG jacket.FSG crooked.MsG/FSG

i. 'Mary haphazardly sews a jacket'(adv)

ii. 'Maria sews a crooked jacket' (adj)

iii. 'Maria sews a jacket while sitting crookedly' (adv.S-or)

iv. 'Maria sews a jacket crooked(ly)' (adv.O-or)

In (6a) the MSG form bears two distinct functions: denoting the manner in which the action is carried out (mere adverbial value) and qualifying a property of the subject in conveying the action (subject-oriented reading).

Instances such as (6b) show that a resultative reading on the direct object is possible due to the semantics of the creation verb. Yet, within the greatly wealthy variation across SIDs, in transitive constructions the modifier agreeing with the direct object licenses two functions which, although being kept distinct in other Romance varieties, here are realised through exactly the same strategy: an objectoriented reading, be the predicate either true or of pseudo-resultative type, and manner predication taking scope on the event itself. To sum up, a lexical item such as traviersa/traversa is able to bear at least three different functions in the grammar of the southern Italian varieties:

1. attributive adjective;

2. (pseudo-)resultative predicate;

3. adverb taking jointly scope on both the verb arguments and the event.

The complexity of Italo-Romance varieties only exhibiting one morphological adverb-adjective syncretic class suggests that a debate about the category status of agreeing modifiers which can take scope on the action conveyed by the verb and, at the same time, a verb argument (Agents vs. Patients, namely) is not to be reduced to a discussion about terming them (adjectival/agreeing) adverbs or (adverbial) adjectives. An ostensibly sharp definition in favour of one label or another would probably only tackle the most superficial issue and leave out a more profound consideration about their core modification property which turns to be \pm adverbial or \pm adjectival based on the interplay between the semantic-syntactic value of the 
verb, the role of verbal argument involved, and the semantic-syntactic properties of the modifiers.

Empirical evidence from the dialects of north-western Calabria will prove that the agreeing modifiers at issue disclose an adverbial semantic-syntactic behaviour so that a label such as "agreeing adverbs" or "adjectival adverbs" is not to be ruled out.

It is crucial to point out, in definitive terms, that the aim of the discussion carried out throughout this contribution is not to introduce a new category or word class, i.e. a third option other than adverbs and adjectives, which is not borne out according to the data under examination. What the pieces of evidence from southern Italian dialects prove is that morphological settings do not disambiguate between adjectives and adverbs: indeed, agreeing modifiers are able to take scope on the verb arguments and the event denoted by the verb itself, expressing morphological agreement.

\section{Adverb agreement in southern Italian dialects}

Right at the outset of a detailed discussion of the agreement patterns, it is worth mentioning that the morphological exponence on adjectives, adverbs, and past participles is encoded also by metaphonic outcomes of the tonic vowels. In other words, the morphological marks of agreement may be particularly robust at the articulatory-perceptual phonetic level due to the alternation between presence and absence of metaphonic diphthong for Verbicaro (Table 1) or a rised metaphonic vowel for Buonvicino, Orsomarso, and S. Maria (Table 2): ${ }^{7}$

Table 1. Metaphonic adjectives and participles in the dialects of Verbicaro

\begin{tabular}{llclr}
\hline & M & F & M & F \\
\hline SG & a'piərtə & a'perta & 'kuettə & 'kotta \\
PL & & a'pertə & & 'kottə \\
& & 'copened' & & 'cooked' \\
\hline
\end{tabular}

7. For an extensive description of inputs and outputs of metaphony in Italo-Romance see Savoia \& Maiden (1997). 
Table 2. Metaphonic adjectives and participles in the dialects of Buonvicino, Orsomarso and S. Maria del Cedro

\begin{tabular}{lllll}
\hline & M & F & M & F \\
\hline SG & a'pirtə & a'pertə & 'kuttə & 'kəttə \\
PL & & a'pertə & & 'kəttə \\
& & 'opened' & & 'cooked' \\
\hline
\end{tabular}

\subsection{Patterns of adverb agreement}

The patterns of adverbial agreement shown by these dialects can be based on the syntactic-semantic transitive/non-transitive configurations, i.e. transitives (3.1.1), unaccusatives (3.1.2), and unergatives (3.1.3).

\subsubsection{Transitives}

The agreement patterns concerning the transitive configuration display three options:

1. the adverb may agree with the object;

2. the adverb may exhibit a default MSG morphological marking;

3. the adverb may (apparently) agree with the subject.

As for pattern 1, let us consider the following cases:

(7) a. Vitə sta sfrantumennə sa parita proprjə fina $/^{*}$-ə Vito stays shattering this.FSG wall.FSG very thin.FSG $/{ }^{*} M$ 'Vito is breaking this wall into tiny pieces'

b. Fratəma non aggiustədə bona/ *buənə a mota brother-my not fixes good.FSG ${ }^{*} M$ the motorcycle.FSG 'My brother does not how to fix the motorcycle well'

Evidence in (7) witnesses that the agreement with the object intransitive constructions is obligatorily selected when the function of the agreeing adverb is depicting the effects of the action conveyed upon the object. ${ }^{8}$

As for the pattern in 2, the MSG form of the adjective serves as the unmarked or default adverb that seems to take scope over the entire event by expressing the manner in which the process was carried out:

8. In Levinson's (2010) terms, (7a) is an instance of pseudo-resultative (cf. 4.1). 
(8) a. Maria tagghiava quidda chianta prəcisə

Maria cut.PST that.FSG plant.FSG precise.MSG

'Maria was cutting that plant precisely'

b. A nonna stadə aggiustenn a stanza (tuttə) mbrugghiatə the granma stays fixing the room.FsG all confused.MSG 'Granma confusedly is cleaning the room.'

c. Maria guarda stuərtə a nəputa

Maria looks.at oblique.MsG the.FsG niece

'Maria looks.at the niece threateningly'

The adverbial agreement may fail if the adverb only predicates the manner in which the action is carried out by the subject (Agent).

A FSG form of the modifier in the structures in (8) would give a subject-oriented reading or take scope on the object with a resultative value. ${ }^{9}$ The adverbial nature of these modifiers is grasped through a comparison with standard Italian, wherein the same sentences in (9) have to or may be expressed with adverbial prepositional phrases or canonical adverbial forms:

(9) a. Maria tagliava quella pianta con precisione

Maria cut.3sG.PST that.FSG plant.FSG with precision

'Maria was cutting that plant precisely'

b. Nonna riassettava la stanza confusamente

Grandma tie.3sG.PST the.FSG room.FsG confusingly

'Grandma tied the room confusedly'

c. Maria guarda sua nipote minacciosamente

Maria watches her niece menacingly

'Maria looks at her niece menacingly'

The adjectival adverb enters into an agreement relation with the direct object, and qualifies the manner in which the latter is affected by the activity carried out upon it and giving rise to a type of resultative reading.

If the adverb agreement does not take scope on the object, the modifier exhibits a default MSG exponence. On this ground, it emerges that adverb agreement affects the Patients. According to the facts noted so far, the dialects of the Lausberg Area seem to go along with the evidence collected in Ledgeway (2011) and, furthermore, provide peculiar cases in which adverbs morphologically match with subject $\left(S_{A}\right)$.

9. Namely, Maria tagghiava ( pracisa $_{\text {adv.S-or/adv.O-or }}$ ) quidda chianta pracisa $a_{\text {adv.S-or/avd.O-or }}$ allows the two types of adverbial orientations, so that, if S-oriented, the modifier refers to a quality of the subject in cutting plants, whereas if $\mathrm{O}$-oriented, it depicts the manner in which the plant appears after the cutting, i.e. precisely/geometrically/sharply shaped. 
For pattern 3 (subject-adverb agreement) native speakers provided more than one modifier position, which in fact appears in preverbal position or at the end of the sentence. In both placements, the modifier conveys a reading on how the Actor/ Agent is carrying out the action. Yet, the two positions entail different interpretations concerning the information structure of the sentence. The modifier occurs in sentence-final position in a non-marked word order, where all the information is new. If the agreeing modifier surfaces on the right of the verb, anyway before the direct object (DO), it marks a specific word order in which the DO is the information focus of the sentence.

In (10b) the preposition mark for the DO cooccurs with the focalisation of the DO. From preliminary surveys on this further puzzle, it emerges that the phenomenon of the Differential Object Marking, which is widespread among central and southern Italian varieties (Ledgeway 2000; Guardiano 2010; Iemmolo 2010, among others), seems to have been reinterpreted as a focalisation strategy in the presentday Lausberg dialects. Namely, these varieties exhibit an only apparent optionality between a prepositional and a non-prepositional marking of the DO which denote human or humanised beings (i.e. elements with maximum degree of agentivity), which comes to disambiguation when the DO represents the Focus/New of the utterance and requires a prepositional mark:
a. Vitə had ammazzat u
sinnəkə
Vito has killed the.Msg mayor.MsG
[trigger question: what has Vito done?]
b. Vitə had ammazzat allu sinnəkə
Vito has killed to.the.Msg mayor.MsG
[trigger question: who has Vito killed?]

The agreement of the modifier with the transitive subject, as given in (10), raises the issue of to what extend instances of this type of predication are to be reduced to secondary predicates, i.e. the syntactic realisation of resultative states (Roberts 1988; Napoli 1992; Bentley \& Ledgeway 2014). In our opinion the attempt to assimilate this pattern of agreement, as well as the other agreement configurations found among SIDs, would take into account only one of the modification properties of these peculiar modifiers, i.e. the property of qualifying the individual(s) which the 
predication is about (adjectival function), and would leave aside the entailment that such a qualification exists only in relation to the action/event (adverb function).

\subsubsection{Unaccusatives}

In intransitive clauses of unaccusative type, the evidence collected from the dialects under examination shows that the adjectival adverbs systematically agree with the subject/Patient of unaccusatives (12) with no exception, including reflexives (13) and passives (14).

(12) a. Quidda mònəca campədə affritta/ ${ }^{*}-\partial$ that.FSG nun lives poor.FSG $/{ }^{*} \mathrm{M}$

'That nun lives wretchedly'

b. Zijata no sta bòna $/{ }^{*}$ buənə

Aunt.your not stays good.FsG $/{ }^{*} \mathrm{M}$

'Your aunt is not well'

(13) a. Jidda sə vesta sempo spugghiata/-*a

she self $=$ dresses always naked.FSG $/{ }^{*} M$

'She always dresses succinctly'

b. Maria sə piəttəna brutta $/{ }^{*}$-ə

Maria self $=$ combs ugly.FSG $/{ }^{\star} \mathrm{M}$

'Maria combs (her hair) ugly'

(14) Dd'acina non ha stata còta bona/*buənə the grapes.FSG not has been.FSG harvested.FSG good.FSG $/{ }^{*} \mathrm{M}$ 'The grapes have not been harvested accurately'

The value of the adverb can be interpreted by means of a resultative predicative reading on the subject, presumably of the same type occurring at a deep level with the object/Patient. ${ }^{10}$

According to Mateu (2000), unaccusative resultative predicates of the type in (15), perfectly productive in English, are not available in Romance (Catalan, d):

(15) a. The toast burned black.

b. The gate swung shut.

c. The river froze solid.

10. As pointed out by Ledgeway (2011:41): "In intransitive clauses of the unaccusative kind (...), the adjectival adverb (...) conveys a resultative reading of the surface subject, ultimately functioning as a predicative complement of the same and specifying at the same time the manner in which the situation, accomplishment or achievement comes about." 
d. (Cat.)

${ }^{\star}$ El riu es congelà sòlid.

(Mateu 2000:73)

the river $\mathrm{REFL}=$ froze solid.MSG

In the dialects of north-western Calabria the same unaccusative predicates are possible and realised with agreement of the modifier with the subject $\left(\mathrm{S}_{\mathrm{O}}\right)$ :

(16) a. (N.Cal.)

A fərita ruppa brutta

the.FSG wound.FSG breaks ugly.FSG

'The wound breaks badly'

b. A sajìma quagghia tòsta u viərnə

the lard.FSG solidifies hard.FSG the winter

'The lard solidifies hard during the winter'

\subsubsection{Unergatives}

As for unergatives, adjectival adverbs may agree with the subject (17) or exhibit a default MSG exponence (18):

(17) a. Quidda quatraredda parla citta

that.FSG little-girl speaks silent.FsG

'That little girl is speaking quietly' (i.e. she is a quiet speaker')

b. Maria parlava segreta

Maria talked secret.FsG

'Maria spoke enigmatically' (i.e. she was an enigmatic interlocutor)

(18) a. Quidda quatraredda parla citta

that little-girl speaks silent.MSG

'That girl is speaking quietly'

b. Maria parlava segretə

Maria spoke secret.MsG

'Maria was speaking secretly' (i.e. her talking was secret)

The optionality shown in (17) and (18) can be analysed following from some generalisations. First of all, in (18) the non-agreeing modifier conveys an adverbial value: the subject initiates, controls or determines the action, to some extent, and the modifier conveys a predication on the event.

What is more controversial is the interpretation of the sentences in (17) which allow for two different readings. The first is tied up with a predication upon the subject. In this case, the modifier denotes permanent qualities or skills of the subject, who is directly involved in the realisation of action. As a matter of fact, the semantic scope of the sentence is on the condition of the subject in being quiet (17a) or enigmatic (17b). Therefore, the resulting reading corresponds to a stative 
predicate, where the agreeing modifier has a [+adjectival] connotation, as shown in the translations.

Yet, the native speakers' neat intuitions allow for another interpretation of the sentences in (17) which is fundamentally identical to the only reading available for (18), i.e. the modifier denotes the manner of carrying on the action, therefore meeting the value [+adverbial].

\subsection{Interim summary}

Given the empirical evidence above, it emerges that the split between Undergoers (unaccusative subjects- $\mathrm{S}_{\mathrm{O}}$ and transitive objects-O) and Actors (transitive and unergative subjects- $\mathrm{S}_{\mathrm{A}}$ ) is disclosed by the selection of the adverb agreement patterns. In particular, the north-western Calabrian dialects are consistent with the patterns singled out by Ledgeway (2011) for the rest of the SIDs, as the adverbs agreeing with the Undergoers but showing no agreement with the Actors are detectable among the dialects of north-western Calabria, too.

Moreover, the adverbial agreement with the objects bears a resultative-type reading upon the Undergoer/Patient. In the next section, a finer-grained classification of the semantic macro-class of resultative predicates will be tackled, especially in the light of Mateu (2000) and Levinson (2010).

\section{Notes on resultatives and pseudo-resultatives}

The adverbial agreement with the direct object of transitives or the subject of unaccusatives is of a resultative type. Nevertheless, a thorough examination of the semantic conditions triggering the agreement reveals that the label "resultative" might function as a loose hyperonym of objectively distinct (sub-)classes of modification-related phenomena.

The issue posed by the semantics and the syntax of resultatives across Romance occupies a long debate (Napoli 1992; Hale \& Keyser 1993, 2002 among others). Notably, the opposition between pseudo-result(atives) and true result(atives) has been thoroughly discussed in Mateu's work (2000) for Catalan and Horrocks \& Stravrou's (2003) for Greek. More recently, Levinson (2010) proposed a more extensive account including Finnish and Norwegian.

Mateu (2000), in the light of a lexical-syntactic approach to resultative constructions, argues that some Romance varieties lack (true) resultative constructions. The availability in English of both true resultative (19a) and pseudo-resultative $(19 b, c)$ predicates is found among Romance, which seems to lack the true/nonadverbial resultatives: 
(19) a. John hammered the metal flat [true result]

b. John cut the meat thin [pseudo-result]

c. Do not lay milk flat. It leaks! [pseudo-result]

Both English and Catalan display pseudo-resultatives but only English has true transitive, unergative and unaccusative resultatives. ${ }^{11}$

Thus, the supposed divide between resultatives and pseudo-resultatives emerges from the empirical evidence of English, a few Romance languages, as well as from the analysis of Finnish and Norwegian adverbial case markings. According to Mateu (2000) and Levinson $(2007,2010)$, even though Romance resultatives have been classified as "canonical" resultatives (cf. Napoli 1992: $88^{12}$ for standard Italian), it emerges that they behave as adverbial modifiers.

Yet, in Catalan (20) the same modifiers in the same clauses agree with the referring nominal:

(20) (Cat.)

M' he lligat els cordons de les sabates ben estrets me.DAT have.1sG tied the laces of the shoes well tight.PL

'I tied the laces of my shoes very tight'

(Mateu 2000:90, fn. 21)

11.
(a) i. The waiter wiped the dishes dry
ii. (Cat.) ${ }^{\star}$ El camber fregà els plats secs
(b) i. The dog barked the chickens awake
ii. (Cat.) ${ }^{\star} \mathrm{El}$ gos bordà els pollastres desperts
(c) i. The river froze solid
ii. $\quad$ El riu es congelà sòlid

(Mateu 2000: 79)

12. According to Napoli (1992), the difference between (a) and (b) below is due to the fact that resultatives are generally combined with the change of state verbs (a) but not with process verb (b):

(a) (Standard It.)

Gli operai hanno caricato il camion pieno al massimo

The workers loaded the truck full to the brim

(b) ${ }^{\star}$ Gianni ha martellato il metallo piatto

'Gianni hammered the metal flat'

(Napoli 1992:77)

This view is not incompatible with Morimoto's (2001) key observation that resultative phrases in Romance can only specify or intensify the result already present and encoded into the main verb. Morimoto (2001) yet does not accept the label of "resultative" for such modifiers.

According to Mateu's (2000:91) terms of discussion, standard Italian shows pseudoresultatives of the type The butcher slices meat thin or John painted the wall white, but lacks the true type such as The river froze solid or The dog barked the chickens awake. 
In Mateu's (2000) analysis estrets is a pseudo-resultatives. Since resultative predicates are licensed by the semantic entailment of the verb conveying the transformation of the object individual through the action carried out upon it (21a), a diagnostics to prove a resultative as true, is the 'cause' paraphrase $\left(21 \mathrm{a}^{\prime}\right),{ }^{13}$ used by the proponents of the lexical subordination approach. Crucially the "cause" paraphrase is incompatible with pseudo-resultatives $\left(22 \mathrm{a}^{\prime}\right)$ :

(21) a. He cut the meat thick

$a^{\prime} . \quad \neq$ He caused the meat to become thick by cutting it

(22) a. He hammered the metal flat

$\mathrm{a}^{\prime}$. = He caused the metal to become flat by hammering (on) it

However, this account includes within the class of pseudo-resultatives also those modifiers that take scope on the event denoted by the verb phrase. Conversely, according to Geuder (2000) and Levinson (2010), pseudo-resultatives are semantically distinct from predicates of events, even though pseudo-resultatives can sometimes occur with -ly morphology.

\section{1 (Pseudo-)resultatives in SIDs}

Levinson (2010) refines the definition of the semantic-syntactic properties of true/ canonical resultatives in contrast with pseudo-resultatives. As mentioned, resultatives and pseudo-resultatives, though morphologically equivalent in some languages, are semantically different: the final modifier tight in (23a) does not modify the object, whereas in (23b) flat does.

13. The cause test is transferable to the SIDs under analysis as the 'fare' test, i.e. a paraphrase of the sentence with the clause 'make it X', where $\mathrm{X}$ is the modifier. This paraphrase is only compatible with a resultative (a) and ruled out with pseudo-resultatives (b):
(a) Fratəma tagghiavədə a tavəla fina ${ }^{*}$-ə brother-my cut.PST the board.FSG thin.FSG $/{ }^{*} \mathrm{M}$ 'My brother was cutting the board thin'
(a') Fratəma faciva a tavəla (tutta) fina $/{ }^{*}-\partial$ brother.my made the board.FSG all.FSG thin.FSG $/{ }^{*} \mathrm{M}$ 'My brother made the board thin' (i.e. he caused the board to be thin)
(b) Maria affiddijavədə a pitta mənuta ${ }^{*}$-ə Maria sliced the cake.FSG tiny.FSG ${ }^{*} \mathrm{M}$ 'Maria sliced the cake tiny' (i.e. not as 'Maria facivədə a pitta (tutta) mənuta') 'Maria made the cake in tiny slices' (i.e. not as 'Maria caused the cake to be thin by slicing it') 
(23) a. Janet braided her hair tight [pseudo-result]

$a^{\prime}$. $\neq$ Janet caused her hair to be tight by braiding it (i.e. the braid created was tight) ${ }^{14}$

b. Rhoda hammered the metal flat [true result]

$\mathrm{b}^{\prime}$. Rhoda caused the metal to become flat by hammering it

(Levinson 2010: 135)

The type in (23a) is an instantiation of pseudo-resultatives, as the individual argument modified is syntactically active and denoted by the lexical root of the verb, clearly a (root) creation verb (Levinson 2010: 136). ${ }^{15}$ In these terms, pseudoresultatives do not modify the direct object of the verb. On the opposite, canonical and depictive resultatives do modify DPs by denoting the resultative state of the object at the end of the event ('Mary hammered the metal $_{\mathrm{i}}$ flat $_{\mathrm{i}}$ ' $=$ the metal is/ became flat = the metal is flat at the end of the event).

The dialects of Lausberg Area exhibit pseudo-resultatives which systematically display a morphological agreement with the objects:
a. N.Cal.
Maria ha mpilijat i
pipə
stòrtə/*stuərtə
Maria has piled the.FPL peppers.FPL twisted.FPL ${ }^{\star}{ }^{\star} M$
'Maria has piled the peppers crooked'
b. Rita ha stuzziat a carna spara $/{ }^{*}$-ə
Rita has chopped the.FSG meat.FSG uneven.FSG/ ${ }^{*} \mathrm{M}$
'Rita has chopped the meat uneven'
c. Rita had allazzat a scarpa stritta/ ${ }^{*}$-a
Rita had laced the.FSG shoe.FSG tight.FSG $/{ }^{*} \mathrm{M}$
'Rita has laced the shoe tight'
d. Maria had affiddiat a panetta para/*-a
Maria has sliced the.FSG loaf.FSG even.FSG $/{ }^{*} \mathrm{M}$
'Maria has sliced the loaf even'

These cases are consistent with the evidence from Catalan and Spanish. Yet, SIDs do not confirm the lack of agreement, which is realised through a default singular neuter, as in Norwegian. ${ }^{16}$

Both Mateu (2000) and Levison (2010) argue that normally Romance languages lack true/canonical resultatives. Nevertheless, Levinson (2010: 148, fn. 9) points

14. The root of the verb 'braiding' entails a nominal-type object ('braid').

15. More specifically, it entails the creation of an entity denoted by the root of the verb (Hale \& Keyser 1993, 2002; Pesetsky 1995; Marantz 1997).

16. In Norwegian the agreement occurs with true resultatives. 
out that some Romance varieties do seem to permit a restricted array of resultatives with explicit creation verbs (25a). Italo-Romance varieties of north-western Calabria behave accordingly (25b):

(25) a. Cat.

La meva filla va cosir la faldida estreta

the my daughter go.3sg sew.INF the skirt.FSG estreta.FSG

'My daughter sewed the skirt tight'

b. N.Cal.

Mia figlia ha cusutə na gonna (troppa) stritta/*-a

my daughter has sewed a skirt.FSG too.FSG tight.FSG $/{ }^{*} \mathrm{M}$

'My daughter sewed a skirt (too) tight'.

However, crucially SIDs from the Lausberg Area exhibit (true) resultative predicates as well, even with no creation verbs: ${ }^{17}$
a. Rita sta cunzennə a massa para ${ }^{*}$-ə
Rita stays fixing the.FSG dough.FSG flat.FSG $/{ }^{*} \mathrm{M}$
'Rita is stretching the dough flat' (i.e. 'Rita caused the dough to be flat by stretching it')
b. Vitə pattavədə a parita brutta/*-ə
Vito has painted the.FSG wall.FSG ugly.FSG ${ }^{*} \mathrm{M}$
'Vito has painted the wall awful'

\subsection{The agreement of (pseudo-)resultatives}

In Levinson's (2010) terms, resultatives and pseudo-resultatives represent two different classes, which are in turn distinct from predicates of event, implicit object modifiers and resultative adverbs. ${ }^{18}$ In the north-western Calabrian dialects

17. In standard Italian adjectives expressing a (true) resultative reading on the object are ruled out as ungrammatical or on the edge of acceptability. The same instance is fully grammatical in English:

(a) *l? Gianni ha martellato il metallo piatto

'Gianni has hammered the metal flat'

The sentence meets grammaticality if, and only if, piatto is interpreted as an attributive adjective.

18. Contra Geuder (2000) who proposes that, in compositional semantics, resultative adverbs are predicates of events, but that ultimately they are oriented towards an individual and thus receive an interpretation which is found also in other adjectival contexts. In Geuder's account, this individual is not realised directly by any constituent in the syntax, but is accessed as part of the semantic contribution of the verb: 
these classes are robustly represented and the agreement patterns distinguish the predicates of event (27) as well as the implicit object modifiers (28), which do not exhibit agreement with nominals and show a default MSG, from the resultatives and pseudo-resultatives that, as discussed in (4.1), do display agreement with the nominal they modify:

(27) A gatta jiva musciə

the.FSG cat.FSG went slow.MSG

'The cat was walking slowly' (i.e. the going event was slow)

(28) a. Pəttavənə quidda stanza pricisə/*a

painted.3PL that.Fs room.F precise.MSG

'They painted that roomfsG precisely'

b. Ncartavənə a scatəla mbrugghiatə/*-a

wrapped.3PL the.FSG box.FSG messy.MSG $/{ }^{*} \mathrm{~F}$

'They wrapped the box untidily'

The overt adverbial agreement functions as a strategy of predication of an individual which expresses the accomplishment of the action which is conducted upon it. Hence, a resultative and a pseudo-resultative readings are semantically fulfilled if the referring individual is a Patient/Undergoer, i.e. a transitive object and an unaccusative subject. Therefore, the mechanism of predication upon the objects is logically connected with a resultative and a pseudo-resultative value.

Levinson (2010: 149ff) claims that pseudo-resultatives are in fact syntactically adjectives due to their adjectival morphology and the evidence that in some languages, such as Catalan and Finnish, pseudo-resultative predicates bear distinct adjectival morphology. In other words, since adverbial morphology in Catalan is overtly expressed (-ment) and distinct from adjectival morphology, pseudoresultative predicates are not simplistically adverbs which lack adverbial suffix and possibly agree with a referring argument.

The structures found in the 'Lausberg' dialects display some crucial differences: adjective-adverb system of SIDs allows no productive adverbial formation in -mente, but a very few, and the normal adverbial class exhibits no distinct morphology from MSG form of adjectives. Therefore, no semantic or morphological difference occurs between pseudo-resultatives and resultative adverbs across SIDs. Furthermore, in the northern Calabrian dialects resultatives and pseudoresultatives are not morphosyntactically distinct from resultative adverbs, as all show agreement with objects (cf. Table 4 in the Appendix for a synoptic crosslinguistic variation of Romance and English).

a. They decorated the room beautifully $\approx$ beautiful decoration

b. She wrapped the gift nicely $\approx$ nice wrapping 


\section{Effects on past participle agreement}

The peculiar type of agreement between an adverbial modifier and a noun phrase among the SIDs seems to be consistently triggered by semantic-syntactic conditions ultimately conveying an ergative/absolutive split, as the modifier agrees with verb arguments with a Patient/Undergoer role and, under specific conditions, with the subject $\left(S_{A}\right)$ of unergatives (Agent; Ledgeway 2011; Ledgeway \& Silvestri 2016).

Concerning the agreement patterns, other implications are to be noted, in particular when the verb is a compound form: the past participle behaves differently depending on its morphophonological makeup.

\subsection{The general picture}

It has been pointed out that as for the dialects of north-western Calabria the past participial agreement is realised according to two different patterns depending on the morphological exponence of the metaphonic or (strong and weak) non-metaphonic past participle (Loporcaro \& Silvestri 2011 for the dialect of Verbicaro).

In particular, non-metaphonic participles display agreement patterns responding to an active/stative split, like in standard Italian. In particular, participles systematically agree thus with unaccusative subjects ( $\mathrm{S}_{\mathrm{O}}$, Patients) (29) and, conversely, never show agreement with transitive subjects $\left(S_{A}\right.$, Actor) $(30)$, regardless of its morpholexical nature:

(29) a. A niva s'ha squagghiata $/{ }^{*}$-a

the snow.FSG self=has melted.FSG $/{ }^{*} M$

'The snow melted'

b. Maria ha bənuta $/{ }^{*}-\partial$

Maria has come.FsG $/{ }^{*} \mathrm{M}$

'Maria has come'

c. A pasta ha còtta $/{ }^{*}$ cuəttə

the pasta.FSG has cooked.FSG/MSG

'the pasta's cooked'

(30) a. A gatta ha bistə $/{ }^{*}$-a na gaddina

the.FSG catFSG has seenMSG $/{ }^{*} \mathrm{~F}$ a.FSG hen

'The cat has seen a hen'

b. Mamma ha puləzzatə $/{ }^{\star} a$ sa stanza

Mom has cleaned.MSG $/{ }^{*} \mathrm{~F}$ this.FSG room.FSG

'Mom has cleaned this room' 
The participial agreement never occurs with transitive objects (Patients) (31a), except when the participle (Prt) is metaphonic (31b):
(31)
a. Fratəma ha cuciutə $/^{*}$-a na cassarola i pasta
Brother.my has cooked.MSG $/{ }^{\star} \mathrm{F}$ a.FSG pot.FSG of pasta.FSG
b. Fratəma ha cuəttə/ còtta na cassarola i pasta Brother-my has cooked.M/ FSG a.FSG pot.FSG of pasta 'My brother has cooked a pot of pasta'

If the object is a preverbal clitic, both types of participle agree with it.

Same divide between metaphonic and non-metaphonic participles is evident within unergative clauses, inasmuch as unergative subjects $\left(\mathrm{S}_{\mathrm{A}}\right)$ display agreement with metaphonic participles (29a), but fail to concord in gender and number with non-metaphonic participles (32b):
a. Rita non ha rəspòsa / rəspuəsə
Rita not has answered.F / MSG
'Rita has not replied'
b. Rita non ha rəspunnutə $/{ }^{*}$-a
Rita not has answered.MSG $/{ }^{*} \mathrm{~F}$
'Rita has not replied'

The participial agreement in the dialects of north-western Calabria is, thus, subject to a syntactic and morpholexical generalization, which states that:

(33) 'In the dialects of north-western Calabria the agreement of non-metaphonic participle is ruled out with transitive objects and unergative subject'.

\subsection{Adjectival adverbs affect participle agreement}

The syntactic and morpholexical rule in (33) proves descriptively inadequate when an agreeing adverb is inserted within the structure:
a. Vitə ha stritta/-ə/stringiuta/-ə quidda corda ferma/*-ə
Vito has tightened.F/MSG that.FSG rope.FGs firm.FSG ${ }^{*} \mathrm{M}$
'Vito has tightened that rope firmly'
b. Rita non ha rospunnuta /-a cuntenta $/{ }^{*}$-ə
Rita not has answered.F /MSG happy.FSG/ ${ }^{*} \mathrm{M}$
'Rita has not replied cheerfully'

The agreement patterns as exemplified in (34) are possible only with the insertion of adjectival adverbs which show overt agreement with the semantically and 
syntactically selected verb argument. Given these conditions, the generalization in (33) needs a further specification:

(35) 'In the dialects of north-western Calabria the agreement of non-metaphonic participle is possible, not obligatory, with transitive objects and unergative subject iff these arguments are overtly modified by adjectival adverbs'.

\section{Outline of a structural interpretation}

\subsection{Adverb placement}

A structural account for the agreement of manner adverbs as shown in the dialects of the Lausberg Area and the rest of the SIDs enhances the assumptions that distinct semantic interpretations of modifiers correspond to as many different positions in the architecture of the sentence (Jackendoff 1972; Cinque 1999 for adverbs; Crisma 1996 and Cinque 2010 for adjectives).

As for transitive configurations, there is evidence for three distinct positions for the adverbs to be placed: a high position close to the subject area, a mid position laying within the verb syntactic complex and a low one which is placed in proximity of the direct object. In SIDs adverbs behave differently depending on the position they occupy at the time of the derivation of the syntactic structure.

Based on recent analyses (in particular, Ledgeway 2011 and this volume, who follows Jackendoff 1972; Ramat \& Ricca 1998 and Cinque 1999: 19-28), the positions in which manner adverbs can occur arguably correspond to the following: (1) a high position which is associated with the T domain (that concerns tense, aspect and mood features of the verb) and able to license a subject-oriented adverb; (2) a mid-clause adverb placement related to the (pre-)light verb $(v)^{19}$ or verb phrase (VP) area, licensing event-oriented adverbs; (3) a low VP-final position allowing resultative process-oriented modifiers (ResultP, in Ledgeway's 2011 terms), normally placed in clause-final position (Radford 2009:353).

Under these assumptions, the three adverb positions can be integrated in a simplified structure of the clause as in (36):

${ }_{\mathrm{TP}}$ AuxAdv1 ${ }_{\nu \mathrm{P}}$ Agent/ActorV-vAdv2 [ ${ }_{\mathrm{VP}}$ Theme/Undergoer V Adv3-ResultP]] Ledgeway (2011, this volume), based on instances of adverb agreement from Cosentino, which exhibits an active/stative split as the adverb agrees exclusively

19. Roughly, the light verb $(v \mathrm{P})$ projection of the structure entails properties related to the verb voice. 
with Undergoers, argues that the adjectival adverb is generated in Adv3 position from where it agrees with the object within the VP thus licensing the observed resultative interpretation. Evidence from the dialects of the Lausberg Area supports this structural interpretation (see Silvestri 2016):
a. (N.Cal.)
Maria pattava quidda stanza pulita
Maria painted that.FSG room.FSG nice.FSG
b. $\quad\left[_{\mathrm{VP}}[\mathrm{DO}\right.$ quidda stanza $]$ pəttava $[/$ pulit/- $\left.]\right]>\ldots\left[_{\mathrm{VP}}\left[{ }_{\mathrm{DO}}\right.\right.$ quidda stanza $]$ pəttava [pulita]]

Nevertheless, from this base position, given the superficial linear order, the adjectival adverb might end occupying the mid-clause Adv2 position, whereby the adverb comes to precede the object, and allows a resultative-eventive reading of the adverb.

Cases of northern Calabrian such as (38) would fail in revealing the tight correlation between a functional position of Adv2 and its resultative value. One could argue that what triggers agreement between the manner adverb and the object when the predicate takes scope on the action is the syntactic proximity. Evidence from north-western Calabria dialects shows that the adverb, generated in the same position in the structure (Adv3), does not have to bear a resultative value, which would contrast the semantics of the verb. Even though the adverb does not take scope on the object, it is placed close to the DP and the agreement realised:
a. (N.Cal.)
Pətruzzə guardavədə a nəputa stòrta
Pətruzzo watched.3sg the.FSG niece twisted.FSG
b. $\quad \ldots\left[_{\mathrm{VP}}[\mathrm{DP}\right.$ a nəputa $]$ guardava $[/$ stort/- $\left.]\right]>\ldots\left[_{\mathrm{VP}}\left[{ }_{\mathrm{DP}}\right.\right.$ a nəputa $]$ guardava [storta]]

Adverbs exhibiting a default MSG morphology (i.e. mark of non-agreement) usually occur when the adjectival adverb surfaces between the verb and the object (39). The base position of this adverb must be definitely higher than the Manner position licensing the patterns in (37) and (38). The lack of agreement could be due to the possibility for the adverb to be base-generated in the mid-clause position (Adv2). In this place the non-agreement of adverb primarily conveys one piece of information: that the scope of the modification is the event. A resultative reading of the adverb can ultimately be grasped but local agreement configuration with the object in the VP is neither possible nor semantically sustained. 
(39) a. (N.Cal.)

Rita pittava buənə i paritə

Rita painted good.Msg the.PL walls.FPL

b. $\quad \ldots\left[_{\mathrm{vP}}\left[{ }_{\mathrm{DP}}\right.\right.$ Rita [buənə] $]$ pittava $\left[_{\mathrm{VP}}\left[{ }_{\mathrm{DP}}\right.\right.$ i paritə] $\left.]\right]$

Finally, instances such as (40) suggest that a third higher position of the adverb is to be assumed, which is correlated with a subject-oriented interpretation. According to Ledgeway's account (2011), this position (called ModP-volitional in Cinque 1999 and identified as Adv1 in (36)) is to be defined outside the $v \mathrm{P}$, thus higher that the position associated with verb's voice and transitivity:
a. (N.Cal.)
Rita traversa pittavədə i paritə bònə
Rita oblique.FsG painted the.PL walls.FPL good.FPL
b. $\quad \ldots\left[_{\mathrm{TP}}\right.$ Rita traversa $\left[_{\mathrm{vP}}\left[{ }_{\mathrm{DP}}\right.\right.$ Rita $]$ pittava $\left[_{\mathrm{VP}}\left[{ }_{\mathrm{DP}}\right.\right.$ i paritə] $\left.\left.]\right]\right]$
'Rita, standing crookedly, painted the walls accurately'

\subsection{Adverb and participle agreement}

Unlike for the previous descriptions and theoretical accounts regarding the patterns of adverb agreement, evidence offered by the dialects of Lausberg Area poses the puzzle of the patterns of past participle agreement with the direct object (DO) within transitives. In particular, only metaphonic (past) participles can show agreement with the DO:
a. (N.Cal.)
Maria ha scuciutə $/{ }^{*}-\mathrm{a}$ pur a pasta gojə
Maria has overcoocked.MSG ${ }^{*} \mathrm{~F}$ also the pasta.FSG today
'Maria today has also overcooked the pasta'
b. Maria ha scòtta $/{ }^{*}$ scuəttə pur a pasta
Maria has overcooked.FSG $/{ }^{*} \mathrm{M}$ also the pasta.FSG
'Maria has also overcooked the pasta'

One can argue that the opposite syntactic behaviour of the two types of participle is connected to their different morpholexical nature. The metaphonic participles are able to express the formal features of gender and number more robustly if compared with the non-metaphonic ones (see Table 3). In particular, the distinction between masculine and feminine plural survives the merging of final non-tonic vowels in schwa and it is encoded trough the different outcome of the original tonic vowel, namely diphthong for MSG and full vowel for FSG. 
Table 3. Metaphonic vs. non-metaphonic past participles in the dialect of Verbicaro

\begin{tabular}{lllll}
\hline & \multicolumn{2}{l}{ Metaphonic PtP } & \multicolumn{2}{l}{ Non-metaphonic PtP } \\
\cline { 2 - 5 } & M & F & M & F \\
\hline SG & cuəttə & còtta & & cuciuta \\
PL & & còttə & cuciutə & \\
& & & 'cooked' & \\
\hline
\end{tabular}

I assume that the more distinctive morphophonological makeup of the metaphonic participles makes them capable of overtly realizing the agreement with the structurally closer DP, i.e. the DO. This assumption is also supported by the evidence that some (strong) metaphonic participles are not (morphologically) distinct from the corresponding adjective. In (42) apiarta/apèrta 'opened' conveys an adjective function (a) and it is also able to act as a participle (b), whereas the corresponding non-metaphonic participle raputz/- $a$ (a) has no chance to function as adjective (a), but only as a participle (b).
a. S'ha misə na cammisa tutta apèrta/ ${ }^{? / *}$ raputa self=has put.PRT.MSG a.FSG shirt.FSG all.FSG opened.FSG 'He is wearing a low-necked shirt'
b. A porta s'had aperta/raputa da sula
the.FSG door.FSG self=has opened.FSG by alone.FSG 'The door has opened by itself'

It follows that, in a representation of the morphosyntactic properties of past participles as [ \pm adjective] and [ \pm verb], metaphonic participles are specified as [+adjective, + verb], whilst non-metaphonic participles are marked as [-adjective, +verb]. The adjectival nature of the metaphonic participle is overtly expressed through the realisation of the agreement with the DO.

As a definition of the mechanism of morphophonological agreement between two syntactic items $\alpha$ and $\beta$, we adopt the view for which agreement is the result of an Agree operation occurring between $\alpha$ and $\beta$ (D'Alessandro \& Roberts 2008: 482, following Chomsky 2000, 2001):

(42) Agree $(\alpha>\beta)$, where $\alpha$ is the Probe and $\beta$ is the Goal, and $\alpha$ c-commands ('>') $\beta$.

More specifically, agreement proceeds in two steps, i.e. Match and Agree proper (Chomsky 2001): the Probe searches its c-command domain to find a Goal with matching features. Match is finalised when the featural content is identical. Once Match has taken place, Agree copies the feature value of the Goal into the Probe. 
In the representation of the transitive structure in (43), adopted from D'Alessandro \& Roberts (2008:481), the Agree relation between the past participle (Prt) and the DO (external argument) obtains iff the Prt is [+adjective, +verb].

$$
\left[\left[_{\mathrm{TP}} \mathrm{T}\left[{ }_{v \mathrm{P}}\left[{ }_{v} \operatorname{Aux}\left[{ }_{v \mathrm{PrtP}} \mathrm{EA}\left[{ }_{v \mathrm{Prt}^{\circ}} \operatorname{Prt}\left[\mathrm{VP}_{\mathrm{VP}} \mathrm{DP}\right]\right]\right]\right]\right]\right]\right.
$$

Therefore, we have to assume that, even if Match takes place between both types of participles and the DO, the Agree operation can be finalised only with metaphonic Prt, which can realise the full copying of unvalued gender and number features of the DO. Non-metaphonic participles are unable to receive the featural content of the Goal, ${ }^{20}$ due to their almost null distinctive morphology. Therefore, no morphophonological agreement is realised.

The discrepant behaviour between metaphonic and non-metaphonic transitive participles with regard to the agreement with DO is not longer given if an agreeing adverb intervenes in the structure, as stated in (35), quoted here as (44):

(44) 'In the dialects of north-western Calabria the agreement of non-metaphonic participle is possible, not obligatory, with transitive objects and unergative subjects iff these arguments are overtly modified by adjectival adverbs'.

The agreement process with the related DP pervasively affects the non-metaphonic past participle, regardless of its morpholexical makeup, and the agreeing adverb.

If we set apart the agreement between the DP and the adverb which follows its own semantic-syntactic requirements, the full optionality of the agreement pattern of the non-metaphonetic participle suggests that it is more than plausible that these instances are the outcomes of a superficial morphological matching.

\section{Concluding remarks}

The dialects of the Lausberg Area provide neat empirical evidence for the reality of adverbial agreement: manner adverbs productively exhibit agreement with a referring nominal in order to satisfy specific semantic and syntactic requirements. Adverbs consistently agree with Patients, i.e. transitive objects and unaccusative subjects, conveying interpretations of resultative types. Adverbs may also display

20. In terms of syntactic derivation by phases (Chomsky 2000, 2001), the agreement between a transitive Prt and the internal argument contradicts the assumption that vPrt be a phase head (D'Alessandro \& Roberts 2008, 2010). Given that the Prt raises to vPrt and the DO is left within the DP, vPrt heads a non-defective phase so that the Phase Impenetrability Condition may apply. However, in north-western Calabrian the non-metaphonic transitive participles seem to override this condition. 
superficial morphological concord with Agents, i.e. unergative and transitive subjects, which is arguably licensed by structural proximity between the modifier and the related nominal. The empirical evidence witnesses that, even when the modifier activates its adjectival properties, i.e. agreement in gender and number with a noun as well as predication on the resultative state of an individual, it does not nullify its adverbial function of predicating upon the event/action.

Furthermore, the minute semantic analysis of the modifying relation between adverbs and nominals, which necessarily involves the semantics of the verb, reveals that in the dialects of north-western Calabria both resultatives and pseudoresultatives are productively available in transitive and unaccusative constructions, whilst among the Romance varieties investigated so far only pseudo-resultatives are found (Mateu 2000; Levinson 2010); a fact that, in our opinion, is of a certain degree of relevance for the challenging debate on the semantic and syntactic architecture of these predicates and the parametric variation that Romance and Germanic display.

Finally, the agreeing adverbs interact with the past participle of compound verb forms: the patterns of adverb agreement overcome the settings of the participle agreement, therefore showing a superficial involvement of the participle into the adverb-noun agreement mechanism.

\section{Acknowledgements}

I owe Adam Ledgeway a great debt for fruitful discussions about this topic and valuable information, comments and criticism. I also would like to thank Norma Schifano for first pointing out to me the possibly valid contribution of upper southern Italian dialects to this issue. Previous versions of this paper have been presented at Cambridge University and at the University of Trento, and I am in debt to the members of the respective conferences for their comments and suggestions. Finally, special and warm thanks go out to the native speakers of the northern Calabria villages where I often conducted linguistic interviews: their patience, generosity and hospitality always reward my work. All errors, misrepresentations and omissions, that the reader will find in spite of the meticulous work of two anonymous reviewers, are entirely my own responsibility.

\section{References}

Alessio, Giovanni. 1954. Concordanze lessicali tra i dialetti rumeni e quelli calabresi. Taranto: Cressati.

Alexiadou, Artemis. 1997. Adverb Placement. A Case Study in Antisymmetric Syntax [Linguistik

Aktuell/Linguistics Today 18]. Amsterdam: John Benjamins. doi:10.1075/la.18

Andriani, Luigi. 2016. Morphosyntax of Barese. PhD dissertation, University of Cambridge. 
Bentley, Delia. 2006. Split Intransitivity in Italian. Berlin: Mouton de Gruyter. doi: $10.1515 / 9783110896053$

Bentley, Delia \& Ledgeway, Adam. 2014. Manciati siti? Les constructions moyennes avec le participles résultatifs statifs en italien et dans les variétés italo-romanes méridionales. Langages 194(2): 63-80. doi:10.3917/lang.194.0063

Burzio, Luigi. 1986. Italian Syntax: A Government-Binding Approach. Dordrecht: Reidel. doi:10.1007/978-94-009-4522-7

Chomsky, Noam. 2000. Minimalist Inquiries: The framework. In Step by Step: Essays On Minimalist Syntax in Honor of H. Lasnik, Roger Martin, David Michaels \& Juan Uriagereka (eds), 89-155. Cambridge MA: The MIT Press.

Chomsky, Noam. 2001. Derivation by phases. In Ken Hale: A Life in Language, Michael J. Kenstowicz (ed.), 1-52. Cambridge MA: The MIT Press.

Cinque, Guglielmo. 1999. Adverbs and Functional Heads. A Cross-Linguistic Perspective. Oxford: Oxford University Press.

Cinque, Guglielmo. 2010. The Syntax of Adjectives. A Comparative Study. Cambridge MA: The MIT Press. doi:10.7551/mitpress/9780262014168.001.0001

Crisma, Paola. 1996. On the configurational nature of adjectival modification. In Grammatical Theory and Romance Languages [Current Issues in Linguistic Theory 133], Karen T. Zagona (ed.), 59-71. Amsterdam: John Benjamins. doi:10.1075/cilt.133.06cri

Cruschina, Silvio. 2010. Aspetti morfologici e sintattici degli avverbi in siciliano. In Studi sui dialetti della Sicilia, Jacopo Garzonio (ed.), 21-42. Padua: Unipress.

D’Alessandro, Roberta \& Roberts, Ian. 2008. Movement and agreement in Italian past participles and defective phrases. Linguistic Inquiry 39(3): 477-491. doi:10.1162/ling.2008.39.3.477

D’Alessandro, Roberta \& Roberts, Ian. 2010. Past participle agreement in Abruzzese. Split auxiliary selection and the null-subject parameter. Natural Language and Linguistic Theory 28: 41-72. doi:10.1007/s11049-009-9085-1

Fanciullo, Franco. 1988. Lucania. In Lexikon der Romanistischen Linguistik 4, Günter Holtus, Michael Metzeltin \& Christian Schmitt (eds), 669-688. Tübingen: Max Niemeyer.

Fanciullo, Franco. 1997. Basilicata. In The Dialects of Italy, Martin Maiden \& Mair Parry (eds), 349-354. London: Routledge.

Geuder, Wilhelm. 2000. Oriented Adverbs: Issues in the Lexical Semantics of Event Adverbs. $\mathrm{PhD}$ dissertation, Universität Tübingen.

Guardiano, Cristina. 2010. L'oggetto diretto preposizionale in siciliano. Una breve rassegna e qualche domanda. In Quaderni di lavoro ASIt 2010. Studi sui dialetti della Sicilia, Jacopo Garzonio (ed.), 95-115. Padova: Unipress.

Hale, Ken \& Keyser, Samuel J. 1993. On argument structure and the lexical expression of syntactic relations. In The View from Building 20. Essays in Linguistics in Honor of Sylvain Bromberger, Ken Hale \& Samuel J. Keyser (eds), 53-109. Cambridge MA: The MIT Press.

Hale, Ken \& Keyser, Samuel J. 2002. Prolegomenon to a Theory of Argument Structure. Cambridge MA: The MIT Press.

Hengeveld, Kees. 1992. Non-verbal Predication. Theory, Typology, Diachrony. Berlin: Mouton de Gruyter. doi: $10.1515 / 9783110883282$

Horrocks, Geoffrey \& Stavrou, Melita. 2003. Actions and their results in Greek and English: the complementarity of morphologically encoded (viewpoint) aspect and syntactic resultative predication. Journal of Semantics 20: 297-327. doi:10.1093/jos/20.3.297 
Hummel, Martin. 2014. The adjective-adverb interface in Romance and English. In Adjectives in Germanic and Romance [Linguistik Aktuell/Linguistics Today 212], Petra Sleeman, Freek Van de Velde \& Harry Perridon (eds), 35-71. Amsterdam: John Benjamins. doi:10.1075/la.212.02hum

Hummel, Martin. 2015. Los adverbios flexionados. In El discurso de la gramática. Estudios ofrecidos a José Manuel González Calvo, Carmen Galán Rodríguez, María Luisa Montero Curiel, José Carlos Martín Camacho \& María Isabel Rodríguez Ponce (eds) 205-233. Cáceres: Universidad de Extremadura.

Iemmolo, Giorgio. 2010. Topicality and differential object marking. Evidence from Romance and beyond. Studies in Language 34(2): 239-272. doi:10.1075/sl.34.2.01iem

Jackendoff, Ray. 1972. Semantic Interpretation in Generative Grammar. Cambridge MA: The MIT Press.

Lausberg, Heinrich. 1939. Die Mundarten Südlukaniens. Halle: Max Niemeyer.

Ledgeway, Adam. 2000. A Comparative Syntax of the Dialects of Southern Italy: A Minimalist Approach. Blackwell: Oxford.

Ledgeway, Adam. 2003. Linguistic theory and the mysteries of Italian dialects. In Multilingualism in Italy: Past and present, Anna Laura Lepsky \& Arturo Tosi (eds), 108-140. Legenda: Oxford. Ledgeway, Adam. 2009. Grammatica diacronica del Napoletano. Tübingen: Max Niemeyer. doi: $10.1515 / 9783484971288$

Ledgeway, Adam. 2011. Adverb agreement and split intransitivity: Evidence from Southern Italy. Archivio Glottologico Italiano 96: 31-66.

Ledgeway, Adam \& Silvestri, Giuseppina. 2016. L'accordo degli avverbi aggettivali e del participio passato nei dialetti meridionali. Proceedings of the IV Conferenza Internazionale di Dialettologia 'Dialetti: per parlare e parlarne', Università della Basilicata, 3-5 novembre 2014. Levinson, Lisa. 2007. Roots of Verbs. PhD dissertation, New York University.

Levinson, Lisa. 2010. Arguments for pseudo-resultatives predicates. Natural Language \& Linguistic Theory 28: 135-82. doi:10.1007/s11049-010-9089-x

Loporcaro, Michele. 1998. Sintassi comparata dell'accordo participiale romanzo. Turin: Rosenberg \& Sellier.

Loporcaro, Michele. 2016. Auxiliary selection and participle agreement. In The Oxford Guide to the Romance Languages, Adam Ledgeway \& Martin Maiden (eds), 802-818. Oxford: OUP. doi:10.1093/acprof:oso/9780199677108.003.0049

Loporcaro, Michele \& Silvestri, Giuseppina. 2011. Vocalismo finale atono e morfosintassi dell'accordo participiale in due varietà generazionali del dialetto di Verbicaro (Cosenza). Revue de Linguistique Romane 75: 325-356.

Manzini, Maria R. \& Savoia, Leonardo M. 2005. I dialetti italiani e romanci. Morfosintassi generativa, Vol. III. Alessandria: Edizioni dell'Orso.

Marantz, Alec. 1997. No escape from syntax: Don't try morphological analysis in the privacy of your own lexicon. In Proceedings of the 21st Annual Penn Linguistics Colloquium, Alexis Dimitriadis, Laura Siegel, Clarissa Surek-Clark \& Alexander Williams (eds), 201-225. Philadelphia PA: University of Pennsylvania.

Martino, Paolo. 1991. L'“area Lausberg”. Isolamento e arcaicità. 'Biblioteca di ricerche linguistiche e filologiche' del Dipartimento di Studi glottoantropologici dell' Università di Roma 'La Sapienza', 31. 
Mateu, Jaume. 2000. Why can't we wipe the slate clean? A lexical-syntactic approach to resultative constructions. Catalan Working Papers in Linguistics 8: 71-95.

Morimoto, Yuko. 2001. Los verbos de movimiento. Madrid: Visor.

Napoli, Donna Jo. 1992. Secondary resultative predicates in Italian. Journal of Linguistics 28: 53-90. doi:10.1017/Soo22226700014997

Parlangeli, Oronzo. 1960. Storia linguistica e storia politica nell'Italia meridionale. Firenze: Le Monnier.

Parlangeli, Oronzo. 1971. La nuova questione della lingua. Brescia: Paideia.

Perlmutter, David M. 1978. Impersonal passives and the unaccusative hypothesis. In Proceedings of the 4th Annual Meeting of the Berkeley Linguistics Society, 157-190. Berkeley CA: Linguistic Society of America's digital platform, UC Berkeley.

Pesetsky, David. 1995. Zero Syntax: Experiencers and Cascades. Cambridge MA: The MIT Press.

Radford, Andrew. 2009. Analysing English Sentences. A Minimalist Approach. Cambridge: Cambridge University Press. doi:10.1017/CBO9780511801617

Rensch, Karl Heinz. 1973. Nordkalabrischer Sprachatlas anhand der Parabel vom verlorenen Sohn. The Hague: Mouton.

Roberts, Ian. 1988. Predicative APs. Linguistic Inquiry 19(4): 703-710.

Rohlfs, Gerhard. 1969. Grammatica storica della lingua italiana e dei suoi dialetti. Sintassi e formazione delle parole. Torino: Einaudi.

Rohlfs, Gerhard. 1972. Studi e ricerche su lingua e dialetti di Italia. Firenze: Sansoni.

Romito, Luciano. 2006. Uno studio degli esiti metafonici nei dialetti dell'area Lausberg: un'introspezione sulla natura della sillaba. In Analisi prosodica. Teorie, modelli e sistemi di annotazione, Atti del II convegno nazionale dell'Associazione italiana di scienze della voce, Renata Savy \& Claudia Crocco (eds), 538-565. Fisciano: EDK.

Savoia, Leonardo \& Maiden, Martin. 1997. Metaphony. In The Dialects of Italy, Martin Maiden \& Mair Parry (eds), 15-25. London: Routledge.

Silvestri, Giuseppina. 2013. The Nature of Genitive Case. PhD dissertation, University of Pisa.

Silvestri, Giuseppina. 2016. Adverb and participle agreement: For a parameter hierarchy in Italo-Romance microvariation. In Thorethical Approaches to Linquistic Variation, E. Bidese, F. Cognola, \& M. C. Moroni (eds), 89-118. Amsterdam/Philadelphia: John Benjamins.

Trumper, John. 1980. La zona Lausberg e il problema della frammentazione linguistica. In I dialetti e le lingue delle minoranze di fronte all'italiano, Federico Albano Leoni (ed.), 267-303. Roma: Bulzoni.

Van Valin Jr., Robert D. 1990. Semantic parameters of split intransitivity. Language 66(2): 221260. doi: $10.2307 / 414886$

Zagona, Karen. 1990. Mente adverbs, compound interpretation and the projection principle. Probus 2(1): 1-30. doi:10.1515/prbs.1990.2.1.1 


\section{Appendix}

Table 4. Cross-linguistic distribution of agreeing adverbs and pseudo-/resultatives (English, Catalan, Spanish, French, standard Italian, southern Italian dialects, Romanian)

\begin{tabular}{lccccccc}
\hline & ENG & CAT & SP & FR & St. IT & SIDs & ROM \\
\hline adverbial suffix & + & + & + & + & + & - & - \\
agree features spread on Adj & - & + & + & + & + & + & + \\
agree features spread on Adv & - & + & + & - & - & + & - \\
true resultatives & + & - & - & - & - & $+{ }^{(a g r)}$ & $?$ \\
pseudo-resultatives & + & $+^{(\text {agr })}$ & $?$ & + & $+{ }^{(\text {agr })}$ & $+^{(\text {agr })}$ & + \\
\hline
\end{tabular}

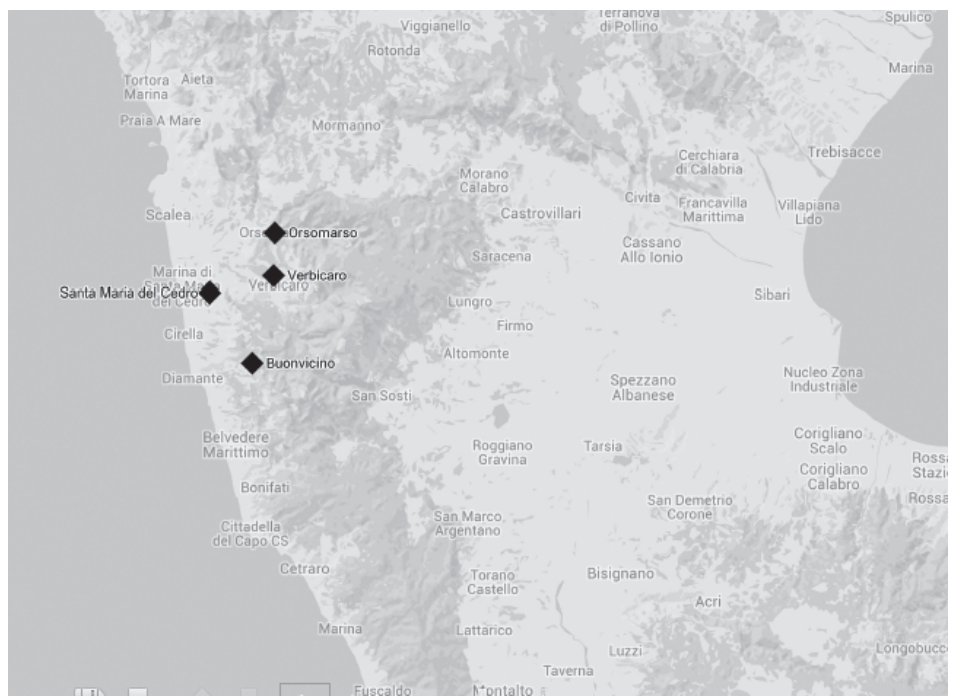

Map 1. Buonvicino, Orsomarso, Santa Maria del Cedro, Verbicaro (north-western Calabria) 
PART IV

Romanian 



\title{
CHAPTER 7
}

\section{Historical overview of the Romanian adverb}

\author{
Adrian Chircu \\ Babeş-Bolyai University, Cluj-Napoca
}

\begin{abstract}
This paper provides an overview of adverbs in the diachrony of the Romanian language with data from the 16th-18th century. The analysis starts from the stock of adverbs inherited from Latin: primary adverbs, adverbs derived from other parts of speech, especially adjectives, or borrowed adjective-adverbs. The striking fact is the lack of adverbs ending in -mente. The presence of this suffix in Western Romance languages is due to the influence of Late Latin. Being only influenced by Slavic languages at the beginning of its existence, the Romanian language started to use the suffix -eşte, the equivalent of -mente. However, short adverbial forms rarely combine with suffixes. This indicates that old forms are resistant to derivation, which differentiates Romanian from other Romance languages.
\end{abstract}

\section{Introduction}

Over the past few years, Romanists have focused their attention on the diachronic study of language issues, particularly on the way in which certain classes of words have evolved and developed (Ledgeway 2012). Among the uninflected parts of speech, special emphasis has been placed on the adverb. Taking into account these preliminary findings, we undertake to point out the way in which the class of Romanian adverbs developed along the centuries. It differs from the other Romance languages because it had to appeal to borrowings from the languages with which Romanian came into contact or it had to create new types of adverbs with the help of certain Latin derivative bases or affixes. Romanian was isolated for a long time from the other Romance languages because of the Slavic population settled in the territories surrounding the regions inhabited by the Romanians (Densusianu 1997:230-72; Pană Dindelegan 2013:2-3). Romanian succeeded in founding a particular adverbial system, which reflects the multiple external influences, but also the internal developments (Chircu 2012; Vasile 2013:22).

In our article we will focus, on the one hand, on aspects regarding the origin of Romanian adverbs and, on the other hand, on the way in which adverbs developed 
on the Romanian territory. In this latter case, we will talk about derivation, conversion, composition, and the adverbial phrases created or taken from the linguistic patterns the Romanian language came into contact with throughout the centuries. The first two sections are meant to underline the Latin adverbial heritage and the reorganization of the adverbial class, which justifies, to a certain extent, the further developments from the oriental part of Latinity. The diachronic perspective itself starts with the borrowed lexical units (Section 3) and continues with the innovations up to the present.

We extracted an important part of the examples from texts which are representative for the evolution of the Romanian language (see bibliography). The great majority of the examples of this study have been quoted from the texts in the References and the Corpus electronic (2014). We also excerpted data from texts which were not taken into account by specialists carrying out research on Romanian adverbs in the past. Thus, some of them are presented for the first time.

\section{Latin adverbs in Romanian}

The Romanian language inherited from Latin a relatively low number of primary adverbial forms. A great number of Latin compounds have been preserved in the language until today as part of the Romanian bulk vocabulary. They have a simple structure and rarely form the derivative lexical basis of other adverbs. By contrast, as it will be seen below, they are members of compound adverbs, which are quite numerous, and, therefore, compensate for the losses suffered by the class of adverbs of Latin origin (Chircu 2008; Popescu-Marin 2007: 260-4; Vasile 2013).

In what follows, we shall list the inherited forms, varying across texts, regions and epochs: au 'or' (< Lat. aut), bine 'well' (< Lat. bene), ca 'as ... as/how' (< Lat. quam), călare 'horseback' (< Lat. caballaris), cătelin 'slowly' ( $<$ Lat. ${ }^{*}$ cautelinus), chiar 'exactly' (< Lat. clarus), când 'when' (< Lat. quando), cât 'how/what' (< Lat. quantus), cum 'how' (< Lat. quomodo), d(e)rept 'directly' (< Lat. directus), foarte 'very'(< Lat. forte), ieri 'yesterday' (< Lat. heri), io 'where' (< Lat. ubi), încă 'still/yet' (< Lat. unquam), (în)cet 'quietly' (< Lat. (in +) quietus), înde 'where' (< Lat. inde), jos 'down' (< Lat. deorsum), mai 'more' (< Lat. magis), mâne 'tomorrow' (< Lat. mane), mult 'much'(< Lat. multus), nici 'not/no more' (< Lat. neque), nu 'no' ( $<$ Lat. non), puţin 'little' (< Lat. * putinus), repede 'rapidly' (< Lat. rapide), sus 'up' (< Lat. sursum), şi 'also' (< Lat. sic) (see Iliescu 2008:253-63), tare 'strong(ly), loud(ly)' ( $<$ Lat. talis), târziu 'late' (< Lat. tardivus), tot 'all' (< Lat. totus), unde 'where' (< Lat. unde), vârtos 'strongly/vigorously' (< Lat. virtuosus). These adverbs are encountered in most Romanian texts: 
(1) a. io viermii o ŗa putredeaşte where worms.DEF CL.ACC.F.3Sg find.PRES.3PL and rot.PRES.3SG şi io furii 0 sapă and where reavers.DEF CL.ACC.F.3SG dig.PRES.3PL 'where it can be found by worms and can rot and where the reaver digs for it and steals it.' (TEMR, 179v, p. 142)

b. ascundeţi-vă puţintel, cîtinel, cîtinel, pănă hide.IMP.2PL=CL.ACC.2PL a while slowly slowly until când va treace mîniia Domnului (D, Pî, 200r, p. 679) it fades.away wrath.DEF God.DEF.gen 'go into hiding for a while, a little, slowly, slowly, until God's wrath fades away.'

c. încinge-veri armele sale pre coapsele sale tare gird=will weapons.DEF his to thigh his strongly 'for he would tightly gird himself up his weapons to the thigh.'

(PH, 38r, p. 125)

d. pusă pre fičroriŭ săĭ călare, şi-i

put.PS.3SG DOM sons.DEF his on.horseback and=CL.ACC.M.3PL trimisă, zicăndu-le send.PS.3SG say.GER $=$ CL.DAT.3PL

'he had his sons mount the horses, and then sent them away, saying.'

Alongside the primary forms, Romanian also inherited an important number of Latin adverbial compounds (especially compounds attested in Vulgar Latin), which reflect their importance in the Romanian language. The number is sensibly larger than that of the simple forms, which illustrates a tendency towards analysis, rather than synthesis (Ciompec 1985: 101-3).

Their structure comprises either specialized presentatives (of the eccum type) (Grandgent 1958:25-6), or lexical units (ad + similis), which were initially autonomous. For objective reasons, linguists (Väänänen 2006: 123; Bourciez 1967:257) included the presentatives in the deictics category, claiming that they were not construed later on, but were taken over from Latin as such: abia 'barely' ( $<$ Lat. $a d+v i x)$, aici 'here' (< Lat. $a d+h i c+c e)$, acmu 'now' (< Lat. eccum + módo), acum 'now' (< Lat. eccúm + modo), acolo 'there' (< Lat. eccum + illoc), adevăr 'truthfully' (< Lat. ad + de + verum), afară 'outside' (< Lat. ad + foras), ainte 'forward' (< Lat. ad + ante), mainte 'forward' (Lat. magis + ante), aiureal air 'elsewhere Lat. ali $+(u b i)+r e$, aimintre 'otherwise' (< Lat. alia + mente), amu 'now' $(<$ Lat. $a d+$ modo), aorea 'now' (< Lat. $a d+$ horam $)$, apoi 'then' $(<$ Lat. $a d+$ post $)$, aproape 'close, almost' (< Lat. ad + prope), asemenea 'alike' (< Lat. ad + similis), 
asupra 'thereon' (< Lat. ad + supra), aşa 'thus' (< Lat. eccum + sic), atât 'enough' $(<$ Lat. eccum + tantum), atunce 'then' ( $<$ Lat. ad + tunc $+c e)$, deneauri 'just before' (< Lat. de + in + illa + ora), dănăoară 'before' (< Lat. de + una + hora), îndărăpt 'backwards' (< Lat. in + de + recto), lăuntru 'inside' (< Lat. illac + intro), nemică 'nothing' ( $<$ Lat. + nec + mica), nicăuril nicăieri 'nowhere' $(<$ Lat. nec + aliubi + re $)$, neşchit 'any' (< Lat. nescio + quantum), numai 'only' (< Lat. non + magis), poimâ( $i)$ $n e$ 'the day after tomorrow' (< Lat. post + mane) (see in southern Italy dialects, pusticras. In Latin, mane 'morning'), utrinde 'therefore' (< Lat. ultra + inde):

(2) a. acicea să înceapă rugăciunea derept prunc here $\breve{A}_{\text {SUBJ }}$ start.SUBJ.3sg prayer.DEF for child 'the prayer shall start here for a child.'

(TEMR, 255v, p. 194)

b. au aicea învăţătură toţi creștinii (TEMR, 23v, p. 47) have here teaching all Christians.DEF 'for here all Christians received the teachings.'

c. fericiţi-s morţii carii mor de acmu în Domnul blessed=are the dead.PL who die from now in God.DEF 'blessed are the dead who die in the Lord from now on.'

(IZV, SA, 4r, p. 14)

The adverbs presented in the first part of this paper prove that, in the beginning, Romanian has preserved many meanings also present in Latin. The innovations are minor and in agreement with the evolution tendencies in both Vulgar Latin and the Romance languages. As a result of linguistic contact, the adverbs were reconfigured as a class, and they not only multiplied, but also diversified semantically.

Generally speaking, compound adverbs are not modal, but rather deictic: local and spatial. Unlike in current Romanian, in the old language, compounding was one of the major ways of forming adverbial units (Densusianu 1997: 586-609). In modern times, some Romanian linguists have noticed that this means of enriching the vocabulary is in permanent regression and is no longer a characteristic of this class (Ciompec 1985: 101), as borrowings and derivation are now prioritized (Chircu 2008: 123-6).

\section{Borrowed adverbs}

As a result of language contact, several adverbial units entered the Romanian language, many in their primary forms, which were at times associated with elements of Latin origin (preposition, suffix or particle), and consequently generated new adverbial units. 
Romanian borrowed from languages of Slavic origins primary adverbs, such as: da 'yes' (< Bg., Rus. Scr. da), ba 'no' (< Bg., Scr., Pol., Ucr. ba), baş 'just about' (< Scr. baš), grozav 'more, amazing' (< Bg. grozav), hrăbor 'courageously' $(<\mathrm{Sl}$. chraboru), iute 'quickly' (<Sl. ljute), prea 'so' $(<\mathrm{Sl}$. prě), razna 'astray' $(<\mathrm{Sl}$. ražno), tocma 'just, only, precisely' (<Sl. tukuma), molcom 'slowly' (<Sl. mlŭkomŭ), hojma 'always' (< Ucr. hozma), prisne 'completely, wholly' ( $<$ Sl. prisinu), lesne 'cheap, easy' (< Bg. lesno), neprestan 'continuously, always' (< v. Sl. neprestanŭ).

Some of these forms were used in the old language and in regional varieties:

(3) a. hrebor si dulcse me veszeleszk
courageously and sweetly CL.REFL.1sG frolic
'courageously and sweetly I frolic.' (P, PsH, Ps. IV, 38-39, p. 179)

b. 16 ani neprestan, cu o împărăţie mare (CC, IŢR, 13v, p. 154) 16 years countinuously with a kingdom great 'continuously for 16 years, with a kingdom greater'.

The adverbial elements of Hungarian origin are not as numerous as the Slavic elements. They are rather used in regional varieties, the exception being, maybe, mereu 'continuously' (< Hun. merö 'fix').

We can also mention: batăr 'although, in vain, at least' (< Hun. bátor), musai 'by all means, certainly, necessarily so' (< Hun. muszáj), urichiş 'forever' (< Hun. örökös), sichiş 'gradually, hardly, avariciously' (< Hun. szükös) or meghiş 'still' (< Hun. mégis), some of them have limited use, such an example is şohan 'never' (< Hun. soha nem) or măgan 'alone, single-handedly, accordingly' (< Hun. magán).

There is a large number of adverbs from Greek or Turkish in the Romanian language. From Greek come adverbs such as: aplos 'simply' (< NGr. aplós), agale 'slowly' (<NGr. agália), alandala 'randomly' (<NGr. alla and'alla 'on in place of the other'), anapoda 'topsy-turvy, upside down' (<NGr. anápoda), sigur 'surely' (<NGr. síghuros), măcar 'at least' (< NGr. makári), serta-ferta 'aimlessly' (< NGr. sirta férta), cu/ de prisos 'needless' (< NGr. perissós), cu/ de folos 'efficaciously' $(<\mathrm{NGr}$. ófelos), fără frică 'fearlessly' (< Gr. phrikē).

From Turkish, we can mention: başca 'particulary' (<Tk. başka), avan 'fiercely, venomously, cunningly' (<Tk. havan), buluc (<Tk. bölük), taman (<Tk. taman), berechet 'abundantly' ( $<$ Tk. bereket), sadea 'completely, entirely' ( $<$ Tk. sade), doldora 'plenty' (Tk. doldur), peşin 'in cash, effectively' (< Tk. peşin):

(4) că sufletul au săturat deşert / Şi de bunătăţi berechiet that soul.DEF have filled desert and of sweets abundantly 'for the soul was abundantly filled with sweets and goods.' 
The presence of Turkish and Greek adverbs is explained by borrowings from the Phanariot period.

With the Modern Romanization (during the 19th century) process, the Romanian vocabulary diversified as well, while some old words were discarded (Graur 1967: 52-72). The language of music was dominated by the Italian influence. The Italian adverbs from the musical language did not manage to enter the vocabulary of the literary Romanian language, but remained outside it. The scientific language was under Latin and French influence, and in the political, social and cultural fields, French came to the fore, mainly due to translations (Chircu 2008: 123).

All these changes in society led to borrowings. We can mention some adverbs that were borrowed from Italian, such as: agile 'lively' ( $<$ It. agile), agiato 'quietly, rarely' (< It. agiato), a giorno 'as a day' (< It. a giorno), allegretto 'happily' $(<$ It. allegretto), allegro 'lively' ( $<$ It. allegro), altissimo 'with high notes' ( $<$ It. altissimo), andantino 'moderately' ( $<$ it. andantino), appassionato 'passionately' $(<$ It. appassionato), a cappella 'without musical accompaniment' ( $<$ It. a cappella), accelerando 'more and more quickly' (< It. accelerando), adagio 'slowly' (< It. adagio), descrescendo 'less intense' (< It. descrescendo) diminuendo 'diminished intensity' $(<$ It. diminuendo), furioso 'powerfully, passionately' (< It. furioso), fortissimo 'loudly' ( $<$ It. fortissimo), lento 'quietly' ( $<$ It. lento), tardo 'slowly' ( $<$ It. tardo).

From French, there came the following adverbs or adverbial phrases: apropo 'by the way' (< Fr. à propos), vizavi 'across' (< Fr. vis-à-vis), viceversa 'vice-versa'

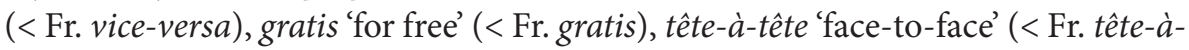
tête), expre(s) 'especially' (< Fr. exprès), angro 'wholesale' (< Fr. en gros), incognito 'incognito' (< Fr./It. incognito), deja 'already' (<Fr. déjà). Romanian borrowed deja from the French déjà when it already had a word for 'already', namely the still used şi (A venit deja. / A şi venit. 'He has already come.').

The majority of the French qualifying adjectives are used as adverbs in Romanian, following a model already established in earlier stages of the language: automat 'automatically', absolut 'absolutely', penibil 'embarrassingly', gratuity 'gratuitously', eficient 'efficiently', spectaculos 'spectacularly', dificil 'in a difficult manner', normal 'normally', oficial 'officially', spiritual 'spiritually', fizic 'physically', legal 'legally' etc. (see also infra Section 6.).

\section{Adverb derivation in -ește}

Romanian is a derivative language (Graur 1967:32-3; Pană Dindelegan 2013:599), and the class of adverbs is no exception. Although Romanian did not inherit from Latin a derivative means of adverb formation (aimintre is an isolated case), it nevertheless managed to create its own derivative system, continuously innovating and 
borrowing affixes from languages it had direct contact with. Generally speaking, Romanian compensated for the loss suffered, by creating a derivational system which, for centuries, proved to be functional in many respects, and survived until today, thus demonstrating its viability. Romanian, as in the case of other Romance languages, lost some of the adverbial primary forms from Latin, but it did not derive the ones it preserved (Chircu 2008: 106).

The first step in this direction was the use of the suffix -ește, which still has questionable origins. Some authors claim that its origin is Latin $(<-i s c u s+e)$. Bourciez (1967:260) states: "seulement en Orient que s'est développée une nouvelle formation organique -isce, répondant ici à la diffusion des adjectifs en -iscus: de misselus, barbatus, sortirent * misellisce, ${ }^{\star}$ barbatisce (roum. mişeleşte, bărbăteşte), etc.". Others, such as Graur (1927:552), claim that its origin is Thracian:

il est plus vraisemblable qu' on ait affaire ici à une survivance thrace: comme le latin $[\ldots]$ et le vieux slave [...] ont connu des adverbes tirés d'instrumentaux en $-\bar{e}$, le trace a dû connaître lui aussi ce procédé pour former des adverbes, procédé qui survit en roumain dans les mots en -eşte.

The truth lies, perhaps, in the middle. Probably, the Latin people in the eastern part of the empire adopted a Thraco-Dacian suffix, developed and lent it adverbial force $(-e$ : see bene), thus marking, as in Classical Latin, its adverbial value.

The addition of the particle $-\bar{e}$ to adjectives $\bar{e}$ (Lat. miser 'ugly' > misere 'in an ugly way', intensus 'intensively, attentively' > intensē 'in an intense way', considerātus 'tamely, prudently' > considerātē 'with judgment, with prudence', praeproperus 'in a hurry' > praepropere 'in a great hurry', tranversus 'obliquely, transversally' > tranverse 'across') or of suffixes (for instance, -iter, -im: conspiranter 'comonly agreeing', pressim 'squeezing tightly') implicitly led to the formation of adverbs of manner (De Carvalho 2008: 153-63).

The use of the particle $-e$ with adverbs was helped along by the fact that a series of primary adjectives (ending in $-e$ ) were used in Latin in the eastern territories of the Empire only as adverbs (repede, dulce, tare, moale, rece). The analogy was effective and the particle started being attached to other adjectives as well.

At first, the particle was attached to adjectives ending in -esc (bărbătesc > bărbăteşte), but later, it shifted to nouns as well (stăpân > stăpâneaşte). We consider this to be the evolution of the adverbial suffix in Romanian. Graur's observation (1927; see above), without a doubt, has to be taken into consideration.

On closer scrutiny of Albanian, we can note an adverbial specialized function of the suffix -isht, with origins that are not foreign to the Thracian -isk, the latter with adverbial use in Thraco-Dacian, and no longer found in Romanian: verbërë 'blind' + -isht > verbërisht 'blindly', besnikërisht 'faithfully', bukurisht 'beautifully', burrërisht 'manly', fatkequësisht 'near, close, around', hollësisht 'fully', kriesisht 
'especially, chiefly', trimërisht 'corageously', vllazërisht 'brotherly', vafërisht 'poorly'. In Albanian, this suffix is attached to neological adjectives (absolutisht 'absolutely', naturysht 'normally, naturally'), as it once happened in Romanian (doctoreşte 'medically', filozofeşte 'philosophically' etc.).

Therefore, in Romanian the suffix - $e$ marks the class of adverbs and strengthens it. This is facilitated by the development of the suffix - eşte, from -esc (<-isk), already used adverbially with primary adjectives.

Once present in the language, the suffix is attached to derivative noun and adjective bases (and rarely to adverbs călare (adv.) 'meaning' + -eşte > călăreşte), leading to the construction of forms in -ește, which gain in time wide usage. The suffix also has variants (-eaşte, -aşte, -iaşte), on the one hand due to the bases it is attached to, on the other, to the places/regions where the texts were edited (Vasile 2013:13-18).

Ciompec (1985:70-2) recorded some forms in a monograph dedicated to adverbs (apostoleşte 'apostolically', bărbăteşte 'manly', îngereşte 'angelically', copilăreşte 'childishly', curveşte 'depravedly', dumnezeieşte 'godly', frăţește brotherly', mireneşte 'in a lay way' etc.), to which we add from our corpus: arhiereaşte 'like bishops do' (TC, PV, Ps. 9, 131-132, p. 157), cucereaşte 'piously' (TC, PV, Ps. 118, 77-78, p. 235), cereaşte 'heavenly' (TC, PV, Ps. 101, 67-68, p. 342), drăceaşte 'in a demonic way' (TC, PV, Ps. 9, 119-20, p. 157), jidoveşte 'like Jews do, in the Jewish Language' (NTB, p. 119), fariseiaşte 'like a hypocrite' (V, RCC, 4r, p. 104), făţărnicéşte 'hypocritically' (IZV, SA, 104v, p. 116), fiiaşte 'brotherly' (TC, PV, Ps. 47, 17-18, p. 231), învredniceaşte 'favouringly' (PP, 96v, p. 89), meşterşugeaşte 'in an artisan manner' (TC, PV, Ps. 57, 19-20, p. 250), necurăteşte 'devilish' (CR, 87r, p. 111), robeaşte 'like servants do' (Ê̂,, p. 285), slujitoreaşte 'like slaves do' (TC, PV, Ps. 89/65-66, p. 322), stăpâneaşte 'like a ruler' (TC, PV, Ps. 93, 27-28, p. 328), veseleaşte 'happily' (Ê̂,, p. 246), tătăraşte 'like a Tatar' (TC, PV, Ps. 118, 77-78, p. 235), ticăloşeaşte 'meanly' (TC, PV, Ps. 67, 7-8, p. 267), vicleneaşte 'cunningly' (PP, 144r, p. 129), vredniceaşte 'deservingly' (TC, PV, Ps. 72, 69-70, p. 278):

(5) a. lui Dumnezău de slavă tu jârtvă jârtveaşte / Şi lui.DAT God of glory you sacrifice sacrifice.PREs.2sG and lui rugile tale le dă cucereaşte him.DAT prayers.DEF yours CL.ACC.3PL give.IMP.2sG piously 'you should praise God and bring him sacrifice / And send your prayers to him piously.

(TC, PV, Ps. 49/45-46, p. 235) 
$\begin{array}{llll}\text { b. ni-or } & \text { arăta } & \text { zapcii } & \text { mării } \\ \text { CL.DAT.1PL=will show sale } & \text { taxmen.DEF } & \text { Majesty.DEF.GEN }\end{array}$ cîte o colibă ce să chiamă tătăriaşte "aran" his each a hut which CL.REFL.3sg calls in.Tatar aran 'for his Majesty's taxmen will show to us a hut that is called "aran" in Tatar.' (CAM, 315v, p. 154)

c. că de are fi fost jidoveaşte scrisă, dară cine o that if would be been in.Jewish written.F but who CL.ACC.F.3sg are fi întors greceaşte would be translated in.Greek

'for if it were written the Jewish way, who would have translated it into Greek.'

(NTB, p. 119)

The derivative bases are "selected" from all semantic fields, but mainly from nouns marked [+animate], which suggests a special means of action and modal qualification, adapted to the communicative situation. Such adverbs help characterize verbs rather than other parts of speech.

We believe that during the 18th century, -iceşte was not only in a transitional stage, as stated by Ciompec (1985:104) and Haneş (1960:142-5), but could be attached to almost any neological adjective that ended in -ic, as proven by its occurrence in the work of authors influenced in their writing by the Western cultural tendencies, as in the case of the representatives of Școala Ardeleană (The Transylvanian School).

The claim is sustained by Samuil Micu Clain's Loghica (1799). The examples with -iceşte are far from sporadic. For a short presentation, the incidence of adverbs ending in -icește is quite high, replacing the suffix -mente: analiticeaşte 'analytically' (p. 99), istoriceaşte 'historically' (p. 40), metafiziceaște 'metaphysically' (p. 87), sistematiceaşte 'systematically' (p. 112), loghiceaşte 'logically' (p. 78), sintheticeaşte 'synthetically' (p. 99):

(6) a. omul să socoteaşte loghiceaşte, adecă în cît man.DEF CL.REFL.IMPERs thinks logically that.is in how.much

în minte are ideea omului (SMC, L, p. 78) in mind has idea man.DEF.GeN

'the man thinks logically, which means that in his mind is his idea.' 


\section{b. această spunere şi sintheticeaşte şi analiticeaşte this statement and synthetically and analytically \\ o voiu arăta \\ (SMC, L, p. 99) \\ CL.ACC.F.3sg will show \\ 'this statement I will present both synthetically and analytically.'}

During the 19th, 20th and the 21st centuries, no major shifts can be observed in the use of the suffix -ește (-iceşte). We can notice that the tendency is rather to attach it to neological bases, whether recorded or not in our main works on lexicography (Ion Coteanu et al. 2016) (americăneşte 'the American way', arhitectoniceşte 'architecturally', avocăţeşte 'lawyerly', banditeşte 'like a bandit', camaradereşte 'friendly', cavalereşte 'knightly', comiceşte 'jokingly', culturaliceşte 'culturally', economiceşte 'economically', europeneşte 'in an European way', gazetăreşte 'journalistically', intelectualiceşte 'intellectually', judecătoreşte 'judiciary', juridiceşte 'judicially', marinărește 'nautically', milităreşte 'militarily', soldăţeşte 'soldierly', studenţește 'student-like', tehnicește 'technically', teoreticeşte 'theoretically', etc.).

The Romanian language also knows adverbs derived in -iş, which we analysed in a previous study (Chircu 2006; see also Mîrzea Vasile 2013:45-71 and Popovici 2006: 137-89).

\section{Adverbs ending in -mente}

The adverbs ending in -mente are a feature common to all Romance languages (Bauer 2003; Posner 1998:117-9), except for Romanian (also southern Italy and Sardinian), which created its own alternative means for the adverbial system. With the exception of the two morphologically opaque forms altminteri and aimintre (and their allomorphs), in Romanian almost all the adverbs ending in -mente are later borrowings. Interestingly enough, we discovered a third example in a dialectal glossary printed years ago in Iași, namely bunăminte 'for instance'. This form has not been discussed yet. We expected it to be registered in a literary text, but the fact that it is used in a dialect/variety (Vișeu de Sus, Maramureș) raises questions. Similar forms are found in other Romance languages. For example in Spanish, there is buenamente 'easily, without much effort, in an unsolicited manner'; in Catalan, bonament 'stress free, with pleasure'; in Sardinian, bonamente (Lug.) / bonamenti (sth., nth.) 'with pleasure'. These observations help us reach the conclusion that this type of word formation initially existed. The lack of productive forms in -ment(e) in the Romanian language has to be related to the fact that in the Western Romance languages these forms were relatively late creations that managed to gain admittance through the agency of learned Latin (Hummel 2013: 18-30). Prior to the 
19th century, Romanian did not have forms in -mente for it was isolated from the Roman world.

The presence of the so-called -mente adverbs in Romanian is due to French (but we must not neglect the Italian influence as well) (Ciompec 1985: 106-7) which allowed for these forms to enter the written standard language, but not the spoken language: absolutamente 'absolutely', actualmente 'actually', accidentalmente 'accidentally', probabilmente 'probably', generalmente 'generally', excepţionalmente 'exceptionally', exactamente 'exactly', literalmente 'literally', loialmente 'loyally', oficialmente 'officially', spiritualmente 'spiritually', psihicamente 'psychologically', forţamente 'strongly' (< Fr. forcément, It. forzatamente):

(7) Biserica ne face servitiu natiunale conservativu numai The church CL.DAT.1PL makes service national conservative only accidentalmente, numai intru catu stiu respandi lumina accidentaly only into how.much know spread.INF light.DEF 'The church only accidentally pays national conservative service to us, only because they can spread the light.'

(Transilvania, 1875, nr. 5, p. 52)

Analogical forms such as colegialmente 'collegially', documentamente 'as documented', exhaustiveminte 'exhaustively', hellenicamente 'Hellenistically', instintualmente 'instinctually', neproductivamente 'unproductively', posibilmente 'possibly', principalmente 'principally', simţualmente 'simultaneously', usufructuarmente 'resultingly' etc., were formed in Romanian through imitating the Western Romance models, but starting from the masculine form (principal +-mente > principalmente).

\section{Adverbialized adjectives}

Conversion of adjectives was possible in Latin. Therefore its development in Romanian was not difficult, and the examples of other lexical and grammatical evolutions are at hand. Up to a point (Proto-Romance), all Romance languages used the adverbial adjective (Hummel 2013), which confirmed the presence of some common structures with adverbialized adjectives.

The conversion of adjectives is present from the first Romanian texts (the 16th century) and it can be seen also in the case of borrowed adjectives. Lat. carus 'expensive, dearly' did not exist in Romanian and the language had to innovate. Consequently, it used with the same value the adjective: Sl. skonpŭ (> Rom. scump): Fr. vendre cher, It. vendere caro, Sp. vender caro, Pt. vender caro, Cat. vender car, Prov. vendre car, Corsican vende caru. 
Today, the phenomenon is almost general in the language and became the standard form in oral and written communication. It was present in the old language as well, but they were in serious competition with the adverbs ending in -ește and with the numerous adverbial phrases which assigned different nuances to the text. The contact with the Slavic people and their cultural influence (especially in writing) strengthened the adverbial use of the adjective (with the appropriate translation of religious texts). In the first texts, one can encounter adjectives of Latin origin and of Slavic origin used adverbially, which proves that in the beginning common structures cohabited, joined later on by adjectives from Turkish, NeoGreek, Hungarian, which, too, in time, were adverbialized:
a. cel ce cu vedearea şi cu audzul Dereptu
$\mathrm{H}$ who with sight.DEF and with hearing.DEF rightfully
viia
întru ei
(CV, 86v/7-8, p. 400)
leave.IMPERF.3sg in them
'he who with the sight and with the hearing rightfully live in them.'
b. adecă acmu ce ebinre sau ce e frumos, numai se that.is now what is well or what is beautifully only S $\breve{A}_{\text {sUB }}$
vie ca fraţi depreunră? (PH, 114r/19, p. 199)
Come.PRES.3PL like brothers together
'is it that only what is good and what is beautifully presented should be merged?'
c. Moisi grăiia şi Domnedzeu chiaru-i
Moses speak.IMPERF.3sg and God rightly=CL.DAT.3sG
răspundea lui (PO, 19/19, p. 179)
answer.IMPERF.3sg him
'Moses asked God, and He rightly so answered him.'

The generalization of the adverbialization of adjectives via conversion was laid on solid ground when the Modern Romanization process of the Romanian language was resumed and when several borrowings from other Romance languages and from Latin were accepted. In the texts of the classic, modern and contemporary writers we find numerous examples that reinforce our statements.

Today, the number of neological adjectives that are adverbialized exceeds the number registered during the old stages of the language (Ciompec 1985: 98-100). This is due to the refusal to accept neological forms in -mente: abil 'aptly', actual 'actually', anterior 'previously', anticipat 'anticipatively', aparent 'apparently', automat 'automatically', brusc 'suddenly', real 'really', categoric 'categorically', corect 'correctly', elegant 'elegantly', elocvent 'eloquently', mecanic 'mechanically', modern 
'modernly', periodic 'periodically', personal 'personally', serios 'seriously', sincer 'sincerely', subtil 'subtly', etc.

\section{Adverbialized participles}

Participles have high incidence in Romanian. In the past, the inventory of adverbialized participles was far from limited, as considered in the specialized literature. Today, we can ascertain that several participles can be used with an adverbial value, transiting into (participial) adjectives and then into adverbs (as in the case of the old language stages) (Vasile 2013:33-7). Ciompec maintains that these adverbs are given less importance, for several studies consider the adverbialization of the participles "less common than that of the adjectives" (1985:75). However, a close study of the texts consulted by us reveals that the adverbialization of the participles is frequent across texts and centuries. The origin of the verbs being used as a source of such participles is diverse. This shows their natural adaptation to the Romanian language system. The adverbial use of the participles concords with the analogous use of the Latin participles, an aspect that facilitated future developments.

Ciompec (1985: 75-6) recorded adverbs of participial origin for the old language (prelinsu 'neatly', amânatu 'extendedly', alesu 'the one elected', neopritu 'inexorably', osăbit 'distinctively', desăvârşit 'completely', acoperit 'covertly', neapărat 'necessarily' neîncetat 'neîncetat', nepărăsit 'forsakenly', negreşit 'certainly'), to which we add other identified forms that support the importance of this tendency, often considered minor: neoprit 'unstoppable, inexorably' (Ê̂, p. 315), deşchis 'openly' (Ê̂, p. 314), necurmat 'relentlessly' (Ê̂,, p. 403), netocmit 'shapeless' (Ê̂I, p. 453), neţinut 'decently' (Ê̂, p. 455), luminat 'brightly' (SMC, L, p. 50), întins 'neatly' (IC, PARC, p. 104), întunecat 'dimly' (SMC, L, p. 50), nemutat 'still' (SMC, L, p. 60), neclătit 'steadily' (V, RCC, 31v, p. 228), nepărăsitŭ 'continually' (CR, 19r, p. 97), smeritŭ 'humbly' (CR, 61r, p. 106), netăgăduit 'undeniably' (MAB, p. 195):

(9) a. prea svintelor lui cuvinte glasu/ Auziţi necontenit în tot too holly his words voice hear.PREs.2PL continually in all

ceasul

(TC, PV, Ps. 102, 77-78, p. 345)

time.DEF

'we continually hear/The holy words in his voice.'

b. această Evanghelie, dragii miei, arată noao deschis doao this Gospel dear.PL.voc my shows us openly two

firi întru Hristos

(Ê̂, p. 314)

natures in Christ

'this Gospel, dearly beloved, openly reveals to us Christ's two natures.' 


$$
\begin{aligned}
& \text { c. şi-i dă, Doamne, netăgăduit să } \\
& \text { and=CL.DAT.3sg give.IMPER.2SG God.vOc undeniably să } \breve{\text { SUBJ }} \\
& \text { petreacă spre el numele Tău cel Svânt } \\
& \text { bear.sUBj.3sg towards him name.DEF your DEF holly } \\
& \text { 'and tell him Lord, to undeniably bear with him Your Holy name.' }
\end{aligned}
$$

(MAB, p. 195)

It is interesting that many adverbialized participles were preserved in the language. The vitality of the process also involves participles of neological origin: calculat 'cautios', diversificat 'diversified', divizat 'divided', multiplicat 'multiplied', echilibrat 'balanced', etc.

There are a series of semantic and/or syntactic restrictions which impede the generalization of the adverbial use of participles (mâncat $>{ }^{*}$ Noi plecăm mâncat. 'We leave after eating', lit. 'he leaves eaten'). In the last example, mâncat cannot be used with an adverbial function like in the case of calculat, in the example $E i$ acţionează calculat. 'They act rationally', but not ${ }^{\star} E i$ acţionează calculaţi. 'They act rational'.

\section{Adverbial phrases}

The number of studies dedicated to adverb phrases is not very large (Ciompec 1985; Vasile 2013), in spite of their common use in Romanian. Adverbial phrases were not numerous in Latin, but over time, their number grew significantly in Romance. Today, adverbial phrases are difficult to account for. Romanian, as well as the other Romance languages, has managed to create a rich inventory of phrases originating in the spoken language. From a grammatical standpoint, they behave like adverbs and bear, in most of the cases, syntactic or discursive functions. The number is quite high, and their origin can be diverse (Chircu 2008: 128-31). The adverb phrase system varied across the centuries, but in time it gained stability. Still, if we were to compare the old centuries to the modern ones, we must admit that in the old language the number of phrases was larger and more diversified (Densusianu 1997:586-609).

The majority of the adverb phrases belonging to this type were formed in Romanian through preposition(s) + noun. Many nominal elements that were part of adverbial structures had origins other than Latin. The origin of the constitutive elements (nouns) can be traced, as in the case of primary adverbs, in the language strata overlapping Romanian in the course of time (Ciompec 1985: 82-5). Different prepositions could be used in the same phrase, which once more certifies that the phrase units had not yet become definitive (întru deşert, pre deşertu 'in vain' / de 
alean, in alean 'yearningly'. Borrowed prepositions were rare. They were used as calques in phrases (contra cost 'in exchange for money'). Over time, losses prevail over innovations. Adverbial phrases were lost for being considered obsolete in comparison to neological borrowings, the latter contributing to the Romanization of the Romanian language.

Examples for traditional adverbial phrases: $c u$ adevăr 'indeed, sincerely speaking' (PAB, p. 1049), cu alnicie 'cunningly' (IZV, SA, 93r, p. 96), cu amar 'bitterly', cu ascuns 'secretly', cu cale 'naturally, directly' (IC, PARC, 7r, p. 4), cu degrabă 'quickly' (PAB, p. 1069), cu nevoie 'hardly', cu îndrăzneală 'daringly' (TC, PV, Ps. 3, 28-29, p. 148), cu îndrăznire 'courageously' (Ê̂, p. 336), cu ogoadă 'pleasantly, fearfully' (TC, PV, Ps. 93, 3-4, p. 327), cu grăbire 'hastily' (GC, ISG, p. 52), cu osârdie 'ardently' (TUTR, 438v, p. 30), cu sârguială 'hastily' (CAM, 274v, p. 87), cu stajă 'hastily', cu zăbavă 'slowly' (H, 184, p. 176), cu linişte 'quietly' (CAM, 258, p. 60), cu tocmală 'understandingly' (H, 60, p. 24), de alean 'against' (IZV, SA, 94v, p. 106), de faţă 'presently' (IZV, SA, 93v-94r, p. 105), de iznoavă 'again' (CAM, 297v, p. 125), de pripă 'immediately' (Ê̂, p. 213), de sârg 'soon, quickly' (H, 209, p. 87), din vecie 'for a long time, anciently' (TEMR, 4r, p. 33), fără de veaste 'immediately, surprisingly' (GC, ISG, p. 128), fără de vraşbă 'peacefully' (GC, ISG, p. 154), fără zăbavă 'quickly' (TC, PV, Ps. 49, 77-78, p. 236), în alean 'against' (PP, 76r, p. 69), în taină 'secretly' (TC, PV, Ps. 102, 1-2, p. 343), în zădar 'in vain' (PÎ, 40r, p. 359), în vază 'at sight' (TC, PV, Ps. 100, 51-52, p. 340), într-agiutoriu 'supportively' (IZV, SA, 42v, p. 52), în deşert 'in vain' (PÎ, 40r, p. 359), într-o clipală 'immediately, right away' (Ê̂, p. 246), la ivală 'at sight' (H, 185, p. 77), pre adevăr 'indeed' (Ê̂I, p. 254), pe adevărat 'truthfully' (GC, ISG, pp. 164-165), pe direptate 'correctly' (GC, ISG, p. 221), pe înţeles 'clearly' (SAM, L, p. 112), pre rând 'in turn' (PAB, p. 85), întru ascunsu 'secretly' (NTB, 114r, p. 280), pre ascuns 'secretly' (NTB, 4r, p. 123), supt cumpăt 'prudently, undecidedly' (IZV, SA, 93r, p. 106):

(10) a. şi iarăş de acolo să de cu vasăle în iazăru, şi and again of there SĂ $_{\text {SUBj }}$ give.SUBJ with ship.DEF in lake and aşă să fie foarte cu zăbavă mărsul (H, 184, p. 176) like.this $\mathrm{S}_{\text {SUBJ }}$ be.SUBJ very slowly course.DEF and again from there he would sail with the ship on water, and slowly sailed away.'

b. şi să periţ cu degrab din calea dreaptă and $\breve{s}_{\text {SUBJ }}$ leave.SUBJ.2PL hastly from path.DEF right Nesocotindu-vă voi strâmba voastră faptă disregard.GER=CL.ACC.2PL you wrong your doing 'and you shall hastily leave the righteous path/ For you go back on to your wrong doings.'

(TC, PV, Ps. 2, 29-30, p. 147) 

c. care să face într-ascuns şi pre supt cumpăt which CL.REFL.IMPERS makes secretly and undecidedly 'which is secretly and undecidedly done.'
d. cînd cu alnicie sfîrşeşte unul viaţa altuia (IZV, SA, 93r, p. 106) when cunningly ends one life.DEF other.DAT 'when cunningly one ends another's life.'

Although language productivity has decreased, adverbial phrases have emerged in different registers as there were no correspondents in Romanian for the meanings of the borrowed words. The majority of the neological adverb phrases are, in essence, the result of borrowings from French in the 19th century (Pană Dindelegan 2013:5), which led to restructuring the adverbial system and its dynamics. From among the new phrases we can mention the following: $c u$ aproximaţie 'approximately', cu atenţie 'attentively', cu forţă 'forcefully', cu intenţie 'intentionally', cu intermitenţe 'intermittently', cu nonşalanţă 'nonchalantly', în aparenţă 'apparently', in detaliu 'particularly', în esenţă 'essentially', în fond 'basically', în principiu 'virtually', în speţă 'chiefly', în totalitate 'completely', fără discuţie 'undoubtedly', din start 'offhand', din oficiu 'ex officio', din principiu 'virtually', din abundenţă 'abundantly', la discreţie 'unlimited', la perfecţie 'perfectly', la termen 'on time', pe parcurs 'in the course of', prin excelenţă 'principally':

(11) câte secunde are cu aproximaţie un secol?
how.many seconds has with approximation a century
'how many seconds does a century approximately have?' (www.calificativ.ro)

Roughly speaking, the phrases that have old elements as constituents are specific to everyday language, while the phrases with neological elements are characteristic of the educated, such structures being acquired most likely in school or in other environments.

\section{Conclusions}

In Romanian, language change has led to the semantic and functional development of some suffixes (-esc, -eşte, -iş, -mente), by borrowing some lexemes or phraseological units from contact languages (the Slavic language, Greek, Turkish, French, Italian, etc.) and by conferring new values to some parts of speech already present in language. These changes occurred according to the possibilities of the Romanian language system. As a result, the Romanian language occupies a special place among Romance languages. The changes involved both inventory change and structure change. Today, the Romanian adverb with its old types has been relegated 
to regional speech, and the new tendencies in usage, including borrowings, are a characteristic of highly educated people.

\section{References}

Bauer, Brigitte L. M. 2003. The adverbial formation in mente in vulgar and late latin. A problem in grammaticalization. In Latin vulgaire, latin tardif, VI, Heikki Solin, Martti Leiwo \& Hilla Halla-aho (eds), 439-457. Hildesheim: Olds-Weidmann.

Bourciez, Édouard. 1967. Éléments de linguistique romane. Paris: Éditions Klincksieck.

Chircu, Adrian. 2006. Adverbele româneşti în -iş (-âş). In Limba română. Aspecte sincronice şi diacronice (Actele celui de-al 5-lea Colocviu al Catedrei de limba română, Bucureşti, 8-9 decembrie 2005), Gabriela Pană-Dindelegan, 57-66. Bucureşti: Editura Universităţii din Bucureşti.

Chircu, Adrian. 2008. L'adverbe dans les langues romanes. Études étymologique, lexicale et morphologique (français, roumain, italien, espagnol, portugais, catalan, provençal). Cluj-Napoca: Casa Cărţii de Ştiinţă.

Chircu, Adrian. 2012. L'adverbe roumain dans la perspective romane. Revue Roumaine de Linguistique 55: 293-300.

Ciompec, Georgeta. 1985. Morfosintaxa adverbului românesc. Sincronie şi diacronie. Bucureşti: Ştiinţifică şi Enciclopedică.

Coteanu, Ion et al. 2016. Dicţionarul explicativ al limbii române. Bucureşti: Univers Enciclopedic Gold. (DEX).

De Carvalho, Paulo. 2008. Morphologie adverbiale, morphologie nominale: -ter vs. $\bar{e}(\breve{e})$. In Adverbes et évolution du latin, Michèle Fruyt \& Sophie Van Laer (eds), 149-164. Paris: L'Harmattan.

Densusianu, Ovide. 1997. Histoire de la langue roumaine. Bucureşti: Grai şi Suflet \& Cultura Naţională.

Grandgent, Charles Hall. 1958. Introducere în latina vulgară. Cluj: Universitatea Victor Babeş.

Graur, Alexandru. 1927. Le suffixe roumain -escu et le suffixe thrace -isk. Romania 53: 539-552. doi: 10.3406/roma.1927.4324

Graur, Alexandru. 1967. The Romance Character of Romanian. Bucharest: The Academy of Romania.

Haneş, Gheorghe. 1960. Sufixele adverbiale -eşte şi -iceşte. In Studii şi materiale privitoare la formarea cuvintelor, II, Alexandru Graur \& Jacques Byck (eds), 139-147. Bucureşti: Academia Română.

Hummel, Martin. 2013. Attribution in Romance: Reconstructing the oral and written tradition. Folia Linguistica Historica 34: 1-42. doi:10.1515/flih.2013.001

Iliescu, Maria. 2008. Miscellanea Romanica (1956-2007). Cluj-Napoca: Clusium \& Scriptor.

Ledgeway, Adam. 2012. From Latin to Romance. Oxford: OUP.

Pană Dindelegan, Gabriela. (ed) 2013. The Grammar of Romanian. Oxford: OUP.

Popescu-Marin, Magdalena. (ed) 2007. Formarea cuvintelor în limba română din secolele al XVIlea - al XVIII-lea. Bucureşti: Academia Română.

Popovici, Victoria. 2006. Sprachkontakt und Wortbildung. Das rumänische Suffix -iş. In Lexikalischer Sprachkontakt in Südosteuropa [Romanistisches Kolloquium XII]. Wolfgang von Dahmen, Günter Holtus, Johannes Kramer, Michael Metzeltin, Wolfgang Schweickard \& Otto Winkelmann (eds), 137-189. Tübingen: Gunter Narr. 
Posner, Rebecca. 1998. Las lenguas romances. Madrid: Cátedra.

Väänänen, Veikko. 2006. Introduction au latin vulgaire. Paris: Klincksieck.

Vasile, Carmen. 2013. Adverbul românesc între continuitate latină, specific balcanic şi evoluţie internă. București: Muzeul Naţional al Literaturii Române.

\section{Sources}

CAM = Pseudo-Amiras. 1975. Cronica anonimă a Moldovei (1661-1729), studiu şi ediţie critică de D. Simionescu. Bucureşti: Academia Română.

CC, IŢR = Cantacuzino, Constantin. 2006. Istoriia Ţărâi Rumâneşti, ediţie critică, studiu filologic, studiu lingvistic, glosar şi indice de nume proprii de O. Dragomir. Bucureşti: Academia Română.

Corpus $=2014$. Corpus electronic de limba română veche, modernă şi actuală. Bucureşti: Institutul de lingvistică „Iorgu Iordan - Al. Rosetti”.

CR = 1939. O tipăritură munteană necunoscută din secolul al XVII-lea: cel mai vechiu Ceaslov Românesc, studiu istoric, literar şi de limbă de Şt. Paşca. Bucureşti: Monitorul Oficial şi Imprimeriile Statului \& Imprimeria Naţională.

CV = 1981. Codicele Voroneţean, ediţie critică, studiu filologic şi studiu lingvistic de M. Costinescu. Bucureşti: Universitatea Bucureşti \& Minerva.

D, PÎ = Dosoftei. 2007. Psaltirea de-nţăles, text stabilit şi studiu lingvistic de M. Cobzaru. Iaşi: Demiurg.

EÎ = 2011. Evanghelie învăţătoare (Govora, 1642), ediţie, studiu introductiv, note şi glosar de A.-M. Gherman. Bucureşti: Academia Română.

GC, ISG = Cotore, Gheorghe Gherontie. 2006. Istoria despre schismăticia grecilor (Trnavia, 1746), ediţie de I. Gabor şi A.-M. Gherman, note şi studiu filologic de A.-M. Gherman, studiu introductiv, bibliografie selectivă, indici L. Stanciu, studiu teologic (rezumat) E. Christoph Suttner, prefaţă de I. Mârza. Cluj-Napoca: Argonaut.

H = 2003. Herodot, traducere românească publicată după manuscriptul găsit la Mănăstirea Coşula de N. Iorga. Bucureşti: Artemis.

IC, PARC = Cantacuzino, Ioan. 2010. Patru apologii pentru religia creştină şi Patru oraţii, traduse în limba română la mijlocul secolului al XVII-lea de N. Spătarul (Milescu), ediţie critică, studiu introductiv, notă asupra ediţiei, note şi comentarii, glosar de E. Dima. Iaşi: Universitatea „Alexandru Ioan Cuza”.

IZV, SA = Zoba din Vinţ, Ioan. 1984. Sicriul de aur, ediţie îngrijită şi studiu introductiv de A. Goţia. București: Minerva.

MAB = 2009. Molităvnic (Bălgrad, 1689), ediţie îngrijită, studiu introductiv şi glosar de A.

Dumitran, A.-M. Gherman şi D. A. Vanca. Alba-Iulia: Reîntregirea.

NTB = 1988. Noul Testament (Bălgrad, 1648). Alba-Iulia: Episcopia Ortodoxă Română.

$\mathrm{PAB}=2001$. Psaltirea de la Alba-Iulia (Bălgrad, 1651). Alba-Iulia: Reîntregirea.

$\mathrm{PH}=2005$. Psaltirea Hurmuzaki, vol. I-II, studiu filologic, studiu lingvistic şi ediţie de I. Gheţie

şi M. Teodorescu, indice de cuvinte de Rovena Şenchi. Bucureşti: Academia Română.

PO = 1968. Palia de la Orăştie (1581-1582). Text - facsimile - Indice, ediţie îngrijită de V. Pamfil.

Bucureşti: Academia Română. 
PP = 2008. Pânea pruncilor sau Învăţătura credinţii creştineşti strînsă în mică şumă, ediţie îngrijită de F. Ilis, studiu istoric de Ovidiu Ghitta, studiu filologic de Florina Ilis. Cluj-Napoca: Argonaut.

P, PsH = Pantaleoni, Daniele. 2008. Texte româneşti vechi cu alfabet latin: Psalterium Hungaricum, în traducere anonimă din secolul al XVII-lea. Timişoara: Universitatea de Vest.

SMC, L = Micu Clain, Samuil. 2007. Loghica (1799), ediţie îngrijită şi studiu introductiv de A.-M. Gherman. Cluj-Napoca: Argonaut.

TC, PV = Corbea, Teodor. 2010. Psaltirea în versuri, ediţie, studiu introductiv, note şi glosar de A.-M. Gherman. Bucureşti: Academia Română.

TEMR = Coresi. 1998. Tâlcul evangheliilor şi Molitevnic rumânesc, ediţie critică de V. Drimba, cu un studiu introductiv de I. Gheţie. Bucureşti: Academia Română.

Transilvania $=1875$. Transilvania, 8, 5: 49-56.

TUTR $=2002$. Texte uitate, texte regăsite (Viaţa Sfântului Hristofor, Pentru fulgere şi pentru tunete cum să fac, „Omul ca iarba, zilele lui...”, Manuale şcolare ca pregătire a orizontului de aşteptare pentru cititorii români din secolul al XVIII-lea, I. Maiorescu „Retorica”), ediţii şi studii introductive de S. Marin-Barutcieff, C. Velculescu, A. Mitu, M. Anton şi A. Nestorescu, cuvânt înainte de C. Velculescu. Bucureşti: Fundaţia Naţională pentru Ştiinţă şi Artă.

V, RCC = Varlaam. 1984. Opere. Răspunsul împotriva catihismusului calvinesc, ediţie critică, studiu filologic şi studiu lingvistic de M. Teodorescu. Bucureşti: Minerva. 



\title{
Properties of Romanian adverbs and adjectives from a categorial status perspective
}

\author{
Carmen Mîrzea Vasile and Blanca Croitor \\ University of Bucharest / The "Iorgu Iordan - Al. Rosetti" \\ Institute of Linguistics, Bucharest
}

In this article we discuss some properties of Romanian adverbs and adjectives from the perspective of their categorial status and, as part of this issue, the distinction between inflection and derivation within the subclass of derived adverbs. In Romanian the majority of adverbs are homonymous to their adjectival counterparts, a possible argument in favour of the single category claim. Romanian adjectives display agreement with the nouns, while adverbs remain invariable (with some exceptions, considered incorrect by normative grammars). However, it is possible to use non-agreeing adjectives in postverbal positions (usually described as adverbial configurations). We examine the distributional properties of adverbs, non-agreeing adjectives and variable (agreeing) adjectives and also the inflectional vs. derivational nature of the adverbial suffix -ește.

\section{Introduction}

Whether adjectives and adverbs are two different categories or form one major category is an ongoing debate (see Payne et al. 2010 and the references therein; Pinkster 1972:64-70; Hengeveld 1992; Giegerich 2011; Hummel 2014, among others). The arguments in favour of the single category hypothesis are generally related to their distributional properties: typically, adjectives modify nouns, while adverbs modify other categories: verbs, sentences, other adverbs, etc. (see Payne et al. 2010 for an introductory review of these arguments).

In the first part of the article, we present some properties of Romanian adverbs and adjectives that are related to the issue of the categorial status, especially distributional properties and agreement. Romanian data may be of interest to this topic as most Romanian adverbs are homonymic to their adjectival counterparts and adjectives agree in gender, number and, sometimes, in case with the noun. In the final part of the article we discuss whether the formation of adverbs with the 
suffix - ește (the most productive one) is an inflectional or a derivational process. Even though the mixed, inflectional and derivational, features of derived adverbs are a common topic in the literature (for English, Zwicky 1995; Haspelmath 1996; Ciszek 2002; Payne et al. 2010:60-5; for Italian, Scalise 1990; for French, Dal 2007; for Spanish, Torner 2005, etc.), the case of Romanian adverbs in -eşte has been discussed only briefly (Van Eeden 1985; see also Chircu in this volume).

This article is organised as follows: a general presentation of Romanian adverbs from a formal point of view in Section 2, a presentation of non-typical patterns of adverbialisation in Section 3, an analysis of the distributional properties of homonymic adverbs and adjectives in Section 4, a presentation of the contexts with adverbs as noun modifiers in Section 5, a note on parenthetical positions in Section 6, a presentation of the suffixes -ește and -esc and the properties of the adverbs derived with -ește with respect to the inflectional vs. derivational distinction in Section 7; in Section 8, we make some final remarks and draw some conclusions.

\section{Types of Romanian adverbs}

Most Romanian adverbs are morphologically non-analysable, from a derivational or inflectional point of view (see 2.1), and some of them are analysable as formed with a suffix from a noun, adjective, verb or adverb (see 2.2). We make a short description of these types below.

\subsection{Non-analysable adverbs}

We could divide this class into two main types, according to the origin of the adverbs and the relation to the adjectival counterparts:

1. adverbs identical to their adjectival counterparts, traditionally described in Romanian grammars as obtained by conversion of adjectives (see 2.1.1);

2. primary adverbs, which are neither derived nor converted from (homonymous with) adjectives (see 2.1.2 below; GALR 2008, I: 585-605):

\subsubsection{Adverbs homonymous to adjectives}

Most Romanian adverbs (1a) are formally identical with the adjective (1b, c), in the masculine/neuter singular form: 
(1) a. După doi ani de practică, fetele

after two years of practice, girl.F.PL.DEF

dansează corect.

dance.PRES.3PL correct.ADV $\equiv \mathrm{ADJ}$.M.SG

'After two years of practice, the girls dance correctly'.

b. profesorul corect

teacher.M.SG.DEF correct.M.sG

'the correct teacher'

c. Lucrul corect este să își

thing.N.SG.DEF correct.N.SG is S $\breve{A}_{\text {SUBj }}$ CL.REFL.3SG

ceară scuze.

ask.suBj apologies

'The correct thing for him would be to apologize.'

In Romanian, the adjective inflects for gender, number and case. The nouns have three genders: masculine, feminine, and neuter (with inflectional endings for each gender in the plural). The neuter forms of the adjective are homonymous to the masculine in the singular, and to the feminine in the plural (for the Romanian neuter, see Croitor \& Giurgea 2009; Maiden 2015). The masculine singular form of the adjective is also used as an unmarked (default) form, in various situations when the agreement controller does not have gender and number features (Croitor 2012), for instance when it is a clause, as in (2a), or an anaphoric pronoun whose semantic antecedent is non-nominal, as in (2b); in the second sentence, the semantic antecedent of the pronoun asta 'this' is a clause; although it is morphologically a feminine singular pronoun, asta does not trigger feminine agreement on the adjective; the adjectives agrees in gender in (2c), as the subject is a feminine singular noun:

(2) a. Este corect să muți calul. vs.



'It is correct to move the knight.'

b. Am văzut că ai mutat calul, AUX.PERF.1sg see.PPLE that AUX.PER.2SG move.PPLE knight.DEF nu știu dacă asta este corect. not know.Pres.1sg if this.F.SG is correct.M.sG

'I saw you that you moved the knight, I don't know if this is correct.'

c. Mutarea este corectă.

move.F.SG.DEF is correct.F.SG

'This move is correct.' 


\subsubsection{Primary adverbs}

Primary adverbs are inherited from Latin (or based on elements inherited from Latin), borrowed from Slavic, Turkish, Greek, etc.:

1. from Latin: acolo 'there' (< ECCUM ILLŌC), acum 'now' (< ECCUM MODo), aşa 'this way' (< ECCUM SIC), atunci 'then' ( $<{ }^{*}$ ad-tuncce), azi 'today' (probably $<{ }^{\star}$ hadie (= HODIE)), bine (< BENE), chiar 'really' (< CLARUS), şi 'also' (< SIC), unde 'where' (< UNDE);

2. from Slavic: da 'yes' $(<d a)$, lesne 'easily' (<lesno);

3. from Hungarian: mereu 'always' (<merö), musai 'necessarily' (<muszáj);

4. from Turkish: başca 'separately' (< bașka), taman 'just' (<tamam);

5. from Greek: agale 'slowly' $(<\alpha \gamma \alpha \dot{\alpha} \lambda \iota(\alpha))$, anapoda 'topsy-turvy' $(<\alpha v \alpha \dot{\alpha} \pi o \delta \alpha)$;

6. late borrowings from other Romance languages: deja 'already' ( $<$ Fr. déjà), eventual 'likely' (< Fr. éventuel), vizavi 'opposite; across from...' (< Fr. vis-à-vis) (GR 2013:432).

Members of this class are mainly spatial and temporal adverbs, deontic, relative, or focus adverbs.

\subsection{Suffixed adverbs}

Some Romanian adverbs are analysable as composed of a stem and a suffix (Mîrzea Vasile 2012:92-112). In some cases, the derivational process did not take place in Romanian; the analysable adverb was borrowed as such, but the speakers recognize the base (which exists as an independent word in Romanian), so from a synchronic point of view, the adverb appears to be a derived formation. All the adverbs in -mente fall into this category, as they are neological borrowings found only in the literary language. The adverbial suffixes are -eşte/-iceşte, -iş (-âş), and -mente (examples below). For some of these analysable adverbs, their use is rather limited and tends to become idiomatic.

Among the suffixed forms, -eşte and -iceşte adverbs are the most numerous: over 550 units in a thesaurus inventory (DI 1957), which takes into account all the words from old Romanian and from regional varieties, as well as from modern standard Romanian. In standard contemporary language, there are about 200 formations. The bases are nouns or adjectives:

1. frăţeşte adv. 'like a brother, fraternally' < frate n. 'brother' or < frăţesc adj. 'brotherly';

2. nebuneşte adv. 'like a fool; foolishly' < nebun n. 'mad' or < nebunesc adj.'foolish';

3. sufleteşte adv. 'spiritually' < suflet n. 'soul' or < sufletesc adj. 'spiritual';

4. numericește adv. 'numerically' < număr n. 'number' or numeric adj. 'numerical'. 
The suffix $-i s ̧(-\hat{a} s ̧)$ is less productive: 25 adverbs in current dictionaries (and 88 in a thesaurus inventory; see Rădulescu Sala 2015:523-32). The suffix is no longer productive in contemporary language. Usually, $-i s ̧ ~(-\hat{a} s ̧)$ adverbs are adjuncts to verbs of motion, localization, and intentional visual perception. The bases are nouns or verbs:

1. cruciş adv. 'crosswise; slantwise, aslant; obliquely' < cruce n. 'cross';

2. târâş adv. 'crawling, on all fours' < (a se) târî vb. 'to crawl'.

The suffix -iș is not exclusively used to derive adverbs; it is also used for the derivation of adjectives and nouns. Some derivatives can have both adverbial and adjectival uses (i.e. they can modify verbs or nouns), as in (3).

1. făţiş adj., adv. 'outright; frank(ly)' < faţă n. 'face' (from idiomatic phrases like pe faţă 'straight forwardly, frankly', literally 'on face');

2. acoperiș n. 'roof' < (a) acoperi vb. 'to cover';

3. mărunțiş n. 'change; coins' < mărunt adj. 'small'.
(3)
a. Ion a
criticat
fățiş
guvernul.
Ion AUX.PERF.3SG criticise.PPLE outright government.DEF
'Ion criticised the government openly'.
b. agresiune fățișă împotriva țării
aggression.F.SG outright.F.SG against country.DEF.GEN
'outright aggression against the country' (www.facebook.com)

The adverbs in -mente are borrowed from the Romance languages (especially French and Italian) starting with mid-19th century. There are about 20-35 adverbs with -mente recorded in the current modern dictionaries of Romanian. The bases are adjectives found in Romanian, but the derivational process took place in French or Italian, where these words are borrowed from.

1. actualmente 'at present', realmente 'actually', literalmente 'literally', finalmente 'finally', moralmente 'morally', necesarmente 'necessarily', etc.

\section{Non-typical adverbialisation}

In addition to the conversion of the adjectives (the prototypical pattern of adverbialisation in Romanian), other lexical-grammatical classes of words may be a source of adverbs: the participial or the supine verbal forms and some nouns. 


\subsection{Participial or supine forms}

A special type of adverbialisation by conversion or zero derivation is that of the participial/supine forms (the participial and the supine forms are homonymous in Romanian, therefore the categorial status of the form is ambiguous). The main verbs which occur in these structures are transitive (see $a$ intreba 'to ask' in (5b)) or intransitive (a merge 'to walk', a vorbi 'to speak'). There are several types of contexts:

1. after motion verbs:
(4) Pisica
merge
șchiopătat.
cat.F.SG.DEF walk.PRES.3sG limp.PPLE/suP
'The cat limps when she walks.'

2. after verbs denoting types of speaking:
a. Maria a
vorbit
răstit
$\mathrm{cu}$ el.
Maria AUX.PERf.3SG speak.PPLE shout.PPLE/sup with him 'Maria spoke harshly to him.'
b. Ea m- a întrebat deschis...
she CL.1SG.ACC AUX.PERF.3SG ask.PPLE open.PPLE/SUP 'She asked me openly...'
c. ${ }^{*}$ Maria a vorbit zâmbit cu el.
Maria AUX.PERF.3SG speak.PPLE smile.PPLE/sup with him
'Maria talked to him and smiled.'

There are semantic and syntactic restrictions on the type of participial/supine forms which can undergo adverbialisation (Vasile 2013:32-37). They must be semantically related to the main verb ('to walk' - 'to limp' in (4), 'to speak' - 'to shout' in (5a)), otherwise the sentence is ungrammatical ('to speak' - 'to smile' in (5c)). The participial/supine form occurs in postverbal position, adjacent to the main verb.

3. in a type of intensifying structures, denoting the highest degree; the participle/ supine is preceded by the negative prefix ne- and, optionally, the adverbial clitic mai 'more':
a. țară
nespus
de frumoasă
country.F.SG not-tell.PPLE/sup of beautiful.F.SG
'very beautiful country' (literally: 'unmentionably beautiful')
b. Această prăjitură este nemaipomenit de bună.
this.F.SG cake.F.SG is not-more-mention.PPLE/SUP of good.F.SG
'This cake is very good.' (literally, 'unmentionably good')

In the three structures above the participial/supine is homonymous to the masculine, singular (the unmarked/default) form. The fact that agreement in (4 to 6) is 
ungrammatical is considered in Romanian grammars as an argument in favour of the adverbial interpretation (for the contrast with the variable, agreeing adjective in postverbal position, see 4 below). Agreement is the most widely used criterion in Romanian grammatical tradition in order to distinguish adverbs from adjectives, but it could not be used for a language like German; in German adjectives inflect, but inflection does not appear in predicative use, in both copula constructions and secondary predication, even if the modification concerns a noun.

4. after the preposition pe 'on' (Mîrzea Vasile 2012:121-8); the participial/supine form denotes the manner in which the event is performed (or, more rarely, the time); the forms employed are either homonymous to the feminine/neuter plural (7) or the masculine singular form (8):
a. Dimineața
citesc
presa pe sărite.
morning.F.SG.DEF read.PRES.1sG press.DEF on jump.PPLE/sUP
'In the morning I read the newspapers selectively.'
b. Băiatul mănâncă pe alese.
boy.M.SG.DEF eat.PRES.3SG on choose.PPLE/SUP
'The boy eats what he wants.'

(8) Am plecat la bunica pe înserat.

AUX.1sG leave.PPLE to grandmother.DEF on dusk.PPLE/suP

'I went to my grandmother's [house] when it was getting dark.'

\subsection{Nouns}

There are two general types of noun adverbialisation: different types of singular bare nouns and temporal nouns. In the colloquial registry, single bare nouns are used in postverbal modifier positions, with an "adverbial value" according to Romanian grammars (GA 1966 I: 302); they express comparison (9a), intensity or degree (9b).
(9)
a. Pisica doarme covrig.
cat.F.SG.DEF sleeps pretzel.M.sG
'The cat sleeps in a curved shape [like a pretzel].'
b. Maria e frumoasă $f o c{ }^{1}$
Maria is beautiful.F.sG fire.N.sG
'Maria is very beautiful.'

1. Other examples of nouns that can express intensification: beton 'concrete', trăsnet 'thunder', tun 'cannon', etc. (GALR 2008, I: 603-4). Their grammaticalization as intensity markers is facilitated by their meaning (their semantics comprise a feature of the type "strong/powerful" or "high degree"). 
In standard language, the nouns which denote temporal units can acquire an 'adverbial' meaning when they modify a VP (GALR 2008, I: 603-4; Vasile 2013:37, 72-86). If they have the definite article, they may denote iteration or duration of events $(10 \mathrm{a}, \mathrm{b})$. If they are used as plural bare nouns, they have a quantitative meaning (10c):
a. Verile
merg
la mare.
summer.F.PL.DEF go.PRES.1SG to sea

'Every summer I go to the seaside.' / 'Usually in the summer I go to the seaside.'

b. Iau

mic-dejunul la cafenea

dimineața.

take.PREs.1sG breakfast.DEF at coffee-shop morning.F.SG.DEF

'Usually, I have breakfast at the coffee-shop in the morning.'

c. Am așteptat ore până am

have.AUX.1sG wait.PPLE hours until have.AUX.1sG

luat formularul.

take.PPLE form.DEF

'I waited for hours to take the form.'

Analysable (derived) adverbs (see above, 2.2) cannot be used in "adjectival contexts"; they can modify nouns only if the latter are derived from verbs, as in (11); therefore, the ability of these nouns to be modified by an adverb is an indication of their verbal properties and it is not a "diagnostic" context for the categorial status of the adverbial form. Notice that in (11a) the adverbial form remains morphologically invariable, it does not mark agreement with the noun:

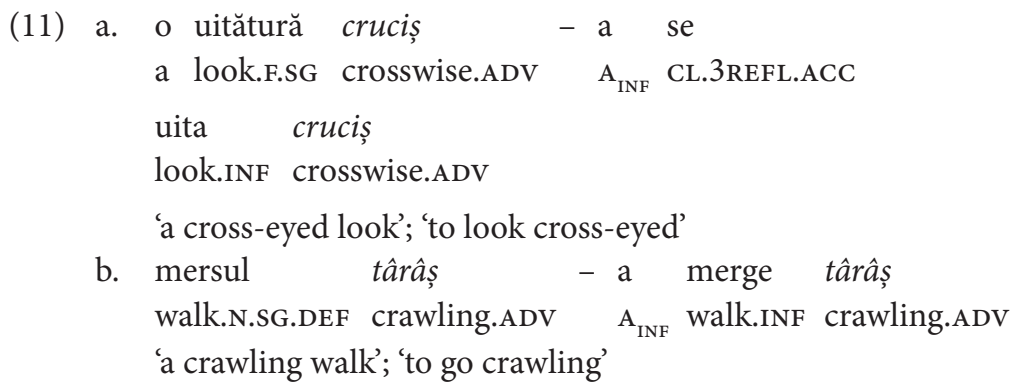

In Sections 2 and 3 above, we examined adverbs in Romanian from a morphological and etymological point of view. We showed that most adverbs are homonymous to adjectives, an argument in favour of a single adverb-adjective category. In Section 4 we will present the distributional properties of homonymous adverbs and adjectives. 


\section{Homonymic adverbs and adjectives and their distributional properties}

The most productive class of adverbs in Romanian is the one described in 2.1.1 above, with forms homonymous to adjectives (in the masculine, singular form, described as the unmarked or the default form). From the traditional class of "proper" adjectives (those which are not obtained by conversion from other categories, like nouns), almost all of them can be converted into adverbs, be they qualifying or classifying adjectives (GR 2013:417-20; see also Examples (1)-(2) above). The adjectives which cannot be converted into adverbs generally are: semantically defective adjectives (bondoc 'dumpy'), prenominal adjectives which are non-restrictive, non-intersective, non-predicative (fost 'ex-, former', see GR 2013:427-8) or adjectives derived with the suffix -esc (but many of these have a corresponding adverb in -ește, see 7.1 below).

Traditionally, in Romanian grammars the adverbs which are homonymous with the adjectives are labelled as adverbs solely based on their distributional properties: generally speaking, adjectives modify nouns (12) and adverbs (13) refer to VPs, AdjP, AdvPs, PPs, or sentences (therefore, anything else but a noun; the same observation was made for other languages, e.g. English, in Payne et al. 2010:34). Adjectives agree in gender, number and case with the head noun in (12), the markers of these three categories being fused into one inflectional ending (e.g. - $\breve{a}$ in $12 b$ ):
a. munte frumos
mountain.M.sG beautiful.M.sG
'beautiful mountain'
b. o dată sigură
a.F.SG.NOM $\equiv$ ACC date.F.SG.NOM $\equiv A$ ACC sure.F.SG.NOM $\equiv A C C$
'a sure date'
a. Fata vorbește sigur.
girl.F.SG.DEF speak.PRES.3sG surely
'The girl speaks confidently.'
b. o fată sigur frumoasă
a.F.SG girl.F.SG surely beautiful.F.SG
'a surely beautiful girl'
c. Ion pleacă sigur departe.
John leave.PREs.3sg surely far
'John goes surely far away.'
d. Ion e sigur împotriva deciziei.
Ion is surely against decision.DEF.F.SG.GEN
'Ion is surely against the decision.'
e. Sigur Maria va cânta diseară.
Surely Maria AUX.FUT.3sg sing.INF tonight
'Surely Maria will sing tonight.'


In the tradition of Romanian grammars (GA 1966, I: 301-2; GALR 2008, I: 585$605)$, these adverbs are described as obtained from their homonymous adjectives through conversion or zero derivation with a null, non-visible suffix (for this type of word formation process, see Bauer \& Valera 2005). In Romanian, conversion is not very productive, with the exception of adverbs. The conversion of the adjective (in the masculine singular form) to an adverb is the most common, productive and regular pattern. Other types of zero derivation or conversion include:

1. nouns derived from adjectives, quite frequently (muncitor 'worker', roşu 'red', român 'Romanian', petrecăreţ 'someone who loves to party'), especially with the adjunction of the definite article;

2. some locative and temporal prepositions are derived from adverbs with the addition of an ending which is homonymous with the definite article: inaintea < inainte 'before', înăuntrul < înăuntru 'inside', împrejurul < împrejur 'around', dedesubtul < dedesubt 'under'; for conceptual reasons, the grammars hesitate to label this ending as 'definite article' (GR 2013:463-4);

3. more rarely, common nouns can be converted from proper nouns ("secondary word class conversion", see Leech 1974), with an extension of the meaning (Xerox 'copy machine' < Xerox [company], adidași 'sport shoes' < Adidas [sports brand], converşi 'sport shoes' < Converse [shoe brand], etc.);

4. a few nouns can be converted from pronouns ( $e u$ 'I' > 'the nucleus of someone's personality; the conscious part of someone's psychology', nimeni 'nobody' > 'an unimportant person').

Unlike in Romanian, where the conversion adjective to adverb is very frequent and regular, in the standard variety of other Romance languages these homonymic forms are used only in some restricted contexts (for instance, after verbs meaning 'to cost', 'to sell', 'to fly'):
a. French: vendre cher
Italian: vendere caro
Spanish: vender caro
Portuguese: vender caro
Catalan: vender car
Provençal: vendre car
'to sell expensively'

b. Romanian: a vinde scump (see Vasile 2013:31 and the references therein)

However, in dialectal or in non-standard varieties of Romance languages, the homonymy adverb-adjective is more extended (in centre-meridional dialects of Italy, Sardinian, Louisiana French, informal oral American Spanish and Portuguese). It was shown that the standards of the written language privileged derived adverbs, 
while the homonymic forms were more frequent in spoken varieties (for more on this issue, see Hummel 2013). As Romanian did not have a strong written tradition, it is perhaps not surprising that in standard language the conversion of adverbs from adjectives is more productive than derivation.

The use of invariable adjectives as adverbs in French has been related to the existence of a (hidden) complement. Goes (1999:219-24) distinguished 4 groups: (1) adverbial adjectives after a transitive verb which has a direct object (les cheveux noués lâche), (2) adverbial adjectives after an intransitive verb (tourner court), (3) adverbial adjectives after a transitive verbs without an overt direct object (écrire gros et lisiblement) and (4) adjectives which are 'adverbal' rather than adverbial (acheter beau). The adjectives in (1) to (3) qualify especially a semantic feature of the verb, while in (4) the adjective has a function close to a direct object (see also Mîrzea Vasile 2012:63).

The Romanian grammars are unanimous in considering that, if the form is invariable, it should be considered an adverb and, if it is variable (agreeing with a noun which is an argument or an adjunct of the verb), it is an adjective.

In Romanian, invariable adjectives are rarely used in postverbal ('adverbial') contexts in the absence of an overt (explicit) object. By 'invariable adjectives' we refer to non-agreeing adjectives which are morphologically variable, but do not mark agreement in certain syntactic configurations (therefore, they appear with the unmarked, masculine singular form). From a morphological point of view, Romanian has four classes of adjectives, according to the number of specific ending for gender and number, and some of them have only one form for all genders, all number (i.e. they are morphologically invariable). Some grammatical contexts are given in (15) below, with verbs meaning 'to eat', 'to cook', 'to sell', 'to buy', and 'to drink':
a. Maria mănâncă gras.
Maria eat.PREs.3sg fat.M.sG
'Maria eats her food fat.'
b. Ana gătește sărat.
Ana cook.PREs.3sg salted.M.SG
'Ana cooks her meals very salted.'
c. Producătorii locali vând scump.
Producer.M.PL.DEF local.M.PL sell.PRES.3PL expensive.M.SG 'Local producers sell their products expensively'.
d. Bunicul
a
făcut
avere cumpărând
Grandfather.DEF AUX.PERF.3sg make.PPLE fortune buy.GER ieftin toamna și vânzând scump primăvara. cheap.M.SG autumn.DEF and sell.ger expensive.M.sG spring.DEF 'My grandfather made his fortune by buying cheap in the autumn and selling expensive(ly) in the spring.' 


\section{e. $\mathrm{Nu}$ bea rece, te va not drink.IMPER.2SG cold.M.SG CL.2SG.ACC AUX.FUT.3SG durea gâtul! hurt.INF throat.DEF}

'Don’t drink cold drinks, you'll have a sore throat!'

The invariable adjectives in the contexts from (15) denote a property associated with the direct object, they do not characterize the event; therefore, they could be interpreted as adjectives. However, the logical reference to the inner object does not exclude a manner interpretation at a more general level.

The agreement is allowed only when the direct object is overt / explicit (16):
a. *Producătorii locali vând scumpe.
Producer.M.PL.DEF local.M.PL sell.PRES.3PL expensive.N.PL
'Local producers sell their products expensively.'
b. Producătorii locali vând produsele
Producer.M.PL.DEF local.M.PL sell.PRES.3PL product.N.PL.DEF
lor scumpe.
their expensive.N.PL
'Local producers sell their products expensively'.

There are postverbal contexts in which both the variable (agreeing) and the invariable form can be used, with different interpretations. The invariable form is interpreted as a verbal modifier (an adverb), while the variable form is interpreted as an attributive modifier of the noun in subject or in object position (an adjective).
a. Ana merge grăbit.
Ana walk.PREs.3.sG hasty.M.SG
'Ana walks hastily'.
b. Ana merge grăbită.
Ana walk.PREs.3.sG hasty.F.SG
'Ana walks and she is hasty'.
a. Feliile
le
Slices.F.PL.DEF CL.3F.PL.ACC
tai subțire.
'I cut the slices thinly'
b. Feliile le tai subțiri.
Slices.F.PL.DEF CL.3F.PL.ACC cut.PRES.1SG thin.F.PL
'I cut the slices thin.'

The adjective in Examples (17) and (18) are secondary predications with a descriptive (17b) or a resultative (18b) reading. Secondary predications occur in various contexts, and the argument they predicate about is usually the subject or the direct 
object of the main verb (see (17) and (18) above, respectively); more rarely, they predicate about the indirect object, the prepositional object, a subjective predicative complement, a committative adjunct or a by-phrase (see GR 2013:497-503).

With respect to the adverb/adjective in postverbal position, two important distinctions should be made: between secondary predication adjectives and invariable adjectives on the one hand, and between the invariable adjective and the adverb on the other hand (for other Romance languages, see Ledgeway, in this volume). Secondary predication adjectives should be distinguished from the invariable adjectives in postverbal contexts from (15) above. The former agree in gender and number with the noun they predicate about and this noun is overt, whilst the latter are non-agreeing (invariable). The distinction between invariable adjectives and adverbs is based on their semantics: adjectives predicate about an entity (an implicit noun), while adverbs predicate about the event.

So far, we have made some remarks regarding the distribution and interpretation of variable adjectives, invariable adjectives and adverbs from the class of homonymous lexemes. As we have shown, not all adjectives can be converted into adverbs, for various semantic or contextual reasons. In other cases, there are different lexical forms for the adverb - adjective pair: bine 'well' vs. bun 'good' (both inherited from Latin). The qualifying adjectives are the typical class which undergoes adverbialisation (by conversion or zero-derivation). In addition, some relative adjectives (which have an identificational or a classifying function, see GR 2013:418-9) can be converted into adverbs:
a. Această procedură nu este legală.
this.F.SG procedure.F.SG not is legal.F.sG
'This procedure is not legal.'
b. Asociația nu a fost
association.F.SG.DEF not AUX.PERF.3SG be.PPLE
legal constituită.
legal.M.sG constituted.F.sG
'The association was not legally constituted.'

The distributional properties of adjectives and adverbs described above concern the postverbal position, where we can place adverbs, agreeing adjectives or nonagreeing adjectives. There are other syntactic positions where both adverbs and adjectives can occur, thus making difficult to use distributional properties as a criterion for categorial distinction: noun modifiers and parenthetical positions. 


\section{Adverbs as noun modifiers}

We have mentioned above that the distributional properties of adverbs and adjectives is an issue generally discussed in relation to their categorial status. Adjectives typically modify nouns, while adverbs modify everything else. However, this generalization should be amended with two observations:

1. Invariable adjectives can appear in postverbal position in the absence of an overt direct object noun (see above, (15)) and adjectives can modify other adjectives (20a, b). The modifier adjectives in (20) are invariable. Moreover, the compound adjectives they form with the adjective they modify are also invariable, as we see in (20b). Nouns can also modify adjectives in this type of chromatic contexts, with a comparative interpretation (20c):
a.
red.M.sG dark.M.sG light.M.sG
'dark red / light red'
b. rochie galben fosforescent
dress.F.sG yellow.M.sG phosphorescent.M.sG
'phosphorescent yellow dress'
c. rochie verde praz
dress.F.SG green.M.sG leek
'a dress green like the leek'

2. Some adverbs can occur as noun modifiers, in some configurations (21). They are non-analysable primary adverbs (the class in 2.1.2) which maintain their morphological invariability (i.e. they do not show agreement with the noun they modify). Notice that the nouns in $(21 \mathrm{a}-\mathrm{c})$ are not verb-related, the one in (21d) is a nominalized supine and the one in (21e) is a long infinitive converted into a noun:
(21)
a. un eseu anapoda
a.N.SG essay.N.SG topsy-turvy.ADV
'a badly construed essay'
a.F.SG trip.F.SG slowly
'a slow trip'
b. o drumeție agale
c. o femeie bine
a.F.SG woman.F.SG well
'a good looking woman' / 'a woman who looks well'
d. mersul agale
walk.N.SG.DEF slowly
'the slow walk'




\section{e. plecarea devreme \\ leaving.F.SG.DEF early \\ 'the leaving early'}

However, most non-analysable primary adverbs cannot have adjectival uses (they cannot modify nouns), such as deja 'already', mâine 'tomorrow', acum 'now', când 'when', etc. This restriction does not include postverbal nouns, which retain some combinatorial properties of the verb they are derived from (see, for instance, the postverbal nouns in $21 \mathrm{~d}, \mathrm{e})$.

In English, place and time adverbs can modify nouns, in contexts like the concert tomorrow; the room upstairs; the use temporarily of Australian troops to defend Ceylon; with the addition soon of an indoor riding and show arena (the last two examples are attested in the British National Corpus, from Payne et al. 2010:42). According to Payne et al. (2010), the semantic classes of adverbs which can occur as postnominal modifiers, according to the quantitative data provided by the corpus, are: (1) temporal, location and extent, frequency, aspectual and serial order; (2) spatial; (3) domain adverbs; (4) distributional; (5) maximal degree. In Romanian, examples like the concert tomorrow, the room upstairs are not possible: the preposition $d e$ 'of, from' intervenes between the noun and the adverb (concertul de mâine 'the concert tomorrow').

\section{Parenthetical positions}

In parenthetical, left-dislocated positions both adverbs and adjectives can be used. The adverb (the non-agreeing form) has an event related interpretation, while the adjective has an entity related reading:
a. Politicos, Dana a
vorbit
$\mathrm{cu}$ toți invitații.
polite.M.sG Dana AUX.PERF.3sg speak.PPLE with all.PL guest.PL.DEF 'As it was the polite thing to do, Dana spoke to all the guests.'
b. Politicoasă, Dana a vorbit cu toți invitații. polite.F.SG Dana AUX.PERF.3sg speak.PPLE with all.PL guest.PL.DEF 'Since she is polite, Dana spoke to all the guests.'

In Sections 4 to 6 we have described the overlapping distributional properties of homonymic adverbs and adjectives in Romanian. In Section 7, we take a look at derived items. 


\section{Derived adverbs and adjectives}

In this section we will examine the properties of derived adverbs and adjectives, from the categorial perspective. As we have mentioned in 2.2 above, two suffixes are productive to derive adverbs in Romanian: -ește and -iș. The suffixes which derive adjectives are more numerous: in GR (2013:603), approximately 20 suffixes are listed, with numerous formations. We will discuss in more detail the relation between the adverbs in -ește and their adjectival counterparts in -esc, since the adverbs in -ește are sometimes analysed as derived from their adjectival counterparts in -esc. We discuss the possibility that the adverbial suffix -ește be considered as an inflectional suffix (under the single category hypothesis) or a derivational one (under the complementarity hypothesis).

\subsection{The adverbs derived with -ește}

The adverbs in -eşte are derived from a noun or an adjective (see the examples in 2.2 above). The etymology of the suffix -ește is not entirely clear; two main hypotheses were advanced:

1. from the Romanian adjectival suffix $-e s c+$ the adverbial suffix $-e$ (Pascu 1916: 197; Haneș 1960: 141); the suffix - $e$ is not productive in Romanian, but it was preserved in some Romanian adverbs inherited from Latin, such as: bine 'well' (< BENE), limpede 'clearly' (< LIMPIDE), repede 'quickly' (< RAPIDE), mâine 'tomorrow' (<MANE), foarte 'very' (< FORTE), etc. The Latin adverbial suffix -e is derived from the adjectival ablative ending $-e$.

2. from the Latin suffix -ISCE (Meyer-Lübke 1900: 686; Mendeloff 1969: 89), which itself is derived from the adjectival suffix -ISCUS + the adverbial suffix -E (see Vasiliu 2009:2717).

As one can see, in any of the two hypotheses summarized above, the adverbial suffix can be traced back to the adjectival suffix (either the Latin-ISCus or the Romanian counterpart -esc).

The Romanian variant -iceşte resulted from a reinterpretation of the final part of adverbs derived with -ește from adjectives ending with the suffix -ic. In contemporary Romanian, many adverbs in -iceşte, that emerged as early as the 19th century, are obsolete and can be replaced by non-derived adverbs, homonymous to the adjectives:

Juridiceşte/ juridic, cazul este rezolvat. juridically juridical.M.sG case.N.SG.DEF be.PREs.3sG solved.N.SG 'From a juridical point of view, the case is solved.' 
Many adverbs ending in -ește express, basically, comparison and related meanings developed from the meaning of the base noun (see 2.2 and also: iepurește 'like a rabbit' < iepure 'rabbit'; mișelește 'meanly' < mișel 'villain'; păgânește 'like a heathen, ruthlessly' < păgân 'heathen'; sălbăticește 'wildly, cruelly' < sălbatic 'savage').

Most of the adverbs ending in -iceşte and some of those ending in -eşte express the point of view or the domain:
a. Stă prost băneşte.
be.PRES.3Sg bad.M.SG money-ește.ADV
'He's badly off, money-wise.'
b. Istoriceşte, evenimentul este important. historical-ește.ADV event.N.SG.DEF be.PRES.3sg important.N.SG 'From a historical point of view, the event is important.'

The modal-evaluative function of -ește adverbs in contexts like $(25 \mathrm{a}, \mathrm{b})$ is found in old Romanian (16th to 18th centuries) as well as in contemporary language:
a. Este
omenește
să greșești.
be.PRES.3SG human-ește.ADV Să $\breve{S U B J}_{\text {J }}$ err.SUBJ.PRES.2SG
'To err is human.'
b. fată drăcește de frumoasă
girl.F.SG devil-ește.ADV of beautiful.F.SG
'devilishly beautiful girl'

The derivatives with -eşte based on ethnic adjectives or nouns (e.g. englez(esc) 'English', evreu 'Jew', român(esc) 'Romanian') can fill the direct object position of verbs like a vorbi 'to talk', a înţelege 'to understand', a şti 'to know', a învăţa 'to learn', etc.; in these contexts, the adverbs denote the language:
a. El învaţă
româneşte.
he learn.PREs.3sg Romanian-ește
'He learns Romanian.'
b. El vorbeşte corect româneşte.
he speak.PRES.3sG correctly Romanian-ește
'He speaks Romanian correctly.'

In contemporary Romanian, these ethnic adverbs denoting language can be headed by prepositions, mostly în 'in', pe 'on', and din 'from':
(27) Secretara traduce documentul in / din turceşte. secretary.DEF translates document.DEF in from Turkish-ește 'The secretary translates the document into / from Turkish.'


Romanian resembles Latin with respect to the possibility of employing a derived adverb denoting languages:

(28) quod loqui Graece et Osce et Latine sciret

(Aulus Gellius, 17.17.1, in Ricca 2010: 133)

'because he (Ennius) was able to speak Greek and Oscan and Latin'

Other languages have this type of structure: Albanian, Old Church Slavonic and other Slavic languages, with a similar suffix, like Czech, Upper and Lower Sorbian (Mëniku, Campos, 2011: 19; Lunt 2001: 80; Short 1993:478; Stone 1993:631).

The prepositional use of ethnic adverbs is also found in Slavic languages like Russian, Polish, Sorbian (Rothstein 1993: 705; Stone 1993:631; Wade 2011:396). Therefore, this type of use in Romanian (see (27)) could be the result of Slavic influence. Romanian was influenced by Slavic languages to some extent, by language contact and via Old Church Slavonic, especially in the vocabulary, but also in grammar to some extent (mostly in old religious texts, many of them translated from Old Church Slavonic).

\subsection{The adjectives in -esc}

The suffix -esc is one of the most productive adjectival suffixes in Romanian (see FCLRV 2007: 104-11). It can be traced back to the Thracian isk- (Graur 1936:84)

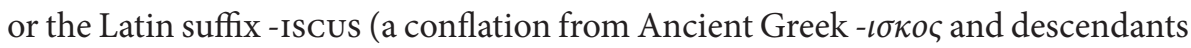
of Proto-Germanic-iskaz). This suffix is also present in Aromanian (-escu) and in other Romance languages (Italian -esco, Spanish -(e)sco, Catalan -esc, French -esque and partially -ais and -ois). In Romanian, it attaches to nominal bases, very rarely to adjectival ones:

$$
\begin{aligned}
& \text { a. prietenesc < prieten } \\
& \text { 'friendly' 'friend' } \\
& \text { b. înțălepțesc < îțălepț } \\
& \text { 'wise' 'wise (man)' }
\end{aligned}
$$

(FCLRV 2007: 107)

As we have already mentioned, Romanian adjectives agree for gender (masculine, feminine, neuter), number (singular, plural) and case (Nominative $\equiv$ Accusative, Genitive $\equiv$ Dative). Taking into account the homonymies, there are four morphological classes of adjectives: with four forms (the richest class), with three, with two and with one form. The adjectives in -esc have three forms:

(30) românesc românească românești

Romanian.M./N.SG Romanian.F.SG Romanian.M. $\equiv$ F./N.PL 
The adjectives formed with -esc express the type / nature (câinesc 'dog's, doggish' $<$ câine 'dog'), comparison (vulpesc 'sly' < vulpe 'fox'), possession (țara românească 'Romanian country' < român 'Romanian'), the origin (cai turcești 'Turkish horses' $<$ turc 'Turkish'), destination or purpose (manual școlăresc 'textbook (for pupils)' $<$ școlar 'pupil'), conformity (pravilnicesc 'legal, according to the law' < pravilnic 'legal, according to the law') or the constitutive elements (mediul judecătoresc 'in judicial circles' < judecător 'judge').

7.3 The properties of the adverbs with -ește, between inflection and derivation

There is an extremely rich bibliography on the relation between inflection and derivation (Plank 1994; Stump 1998: 14-19; Plag 2002: 18-22; Haspelmath \& Sims 2010:90-9, among others). A general distinction would be that inflection is claimed to be relevant to syntax, whereas derivation is not. The main criteria pertaining to the differences between derivation and inflection are: lexical category, productivity and paradigmaticity, obligatoriness and replaceability, affix ordering, and meaning.

\subsubsection{Lexical category}

In inflectional operations, the lexical category of the word does not change, whereas in derivational operations it does. We have shown that the adverbs in -ește can be derived from nouns or from adjectives. Most adverbs in -ește have an adjectival counterpart in -esc, ${ }^{2}$ but there are adverbs clearly derived from nouns: fânește 'like the hay (to the ground)' < fân 'hay' (there is no adjectival counterpart in -esc); morțește (obsolete) 'as you do around dead people, at a funeral' < mort 'dead' (the adjective morțesc is attested later than the adverb and is rarer), among others. Therefore, the suffix -ește can change the category of the derivative. As regards the derivation of adverbs in -ește from adjectives, especially from those with the suffix -esc, we cannot really say whether it changes the categorial status of the words since the categorial status of adverbs and adjectives is controversial.

\subsubsection{Productivity and paradigmaticity}

Inflection is very productive, and it gives rise to words of the same type, expressing the same concept as the base. Derivation is less productive, and it can give rise to words of a different category, expressing a new concept as compared to the base.

2. It is difficult to say whether every adverb with -ește has a correspondent adjective with -esc, as the current dictionaries do not register all the forms, exclusively. In the thesaurus inventory from DI (1957), there are approximately 550 adverbs with -ește and 950 adjectives with -esc. 
Inflection forms paradigms, derivation does not. It is hard to say whether the process of forming -ește adverbs is productive or not in modern Romanian. There are about 550 forms in DI (1957), a dictionary which contains a thesaurus inventory, including old language and regional varieties; some words even have only one attested occurrence in the texts. Therefore, this number is very questionable with respect to the productive potential. In current dictionaries of standard contemporary Romanian there are about 200 forms, some of them rare or found only in idiomatic contexts (DEX). The number of adjectives with -esc is considerably higher. Dictionaries of neologisms (some of them very recent), such as MDN and DCR, do not list any words with -ește. This means that the suffix is not productive in contemporary language (leaving aside some accidental-expressive contexts), and existing formations are from older stages of the language.

\subsubsection{Obligatoriness and replaceability}

This criterion pertains to the complementary distribution of the adverbs in -ește and the corresponding adjectives in -esc (one of the arguments discussed in relation to the categorial status of adverbs and adjectives). In general, the derivatives with -ește cannot occur in typically adjectival contexts, i.e. as noun modifiers (31); the nouns in (31) cannot accept the forms with -esste (the adverbial form), even if the meaning is verb-related, like mers 'walk(ing)' (a nominalized supine of (a) merge 'to go'), and inot 'swim' (a back-formation from (a) înota 'to swim'). The adjectival derivatives with -esc cannot occur in the verbal domain, as verb modifiers ((32), (33a)). Compare (32), where the inflected verb takes an adverbial modifier in -ește, with $(31 c)$, where the related noun takes an adjectival modifier in -esc:
a. un stil câinesc/ *âinește
a.M.SG style.N.SG dog-esc.ADJ.N.SG dog-ește.ADV
'a paddling style'
b. mersul voinicesc/ *voinicește
walk.N.SG.DEF sturdy.ADJ.N.SG sturdily
'a sturdy walk'
c. (un) înot câinescl *âinește
a.M.SG swim.N.sG dog-esc.ADJ.N.SG dog-ește.ADV
'a swim like a dog'

$(32)$
Copilul înoată
câinește / *câinesc.
child.M.SG.DEF swim.IND.PREs.3SG dog-ește.ADV dog-esc.ADJ.M.SG
'The child swims like a dog (paddling).'

Similar examples are given in (33). The verb can only take as a modifier the form with -ește, and the noun can only be modified by the form with -esc (the suffix has the form -ească in the feminine, singular): 

a. El a luptat vitejește/ *vitejesc.
he AUX.PERF.3sg fought bravely/ brave.M.SG
'He fought bravely.'
b. o luptă vitejească / *vitejește
a.F.SG fight.F.SG brave.F.sG/ bravely
'a brave fight'

This complementary distribution is present in many contexts; specific forms are required in specific syntactic contexts, therefore we could say that the adverbial affix resembles inflectional morphemes rather than derivational ones. However, the distributional distinction between the two types of forms is not so clear-cut. The adverbial forms with -ește can be replaced by the adjectival forms ending in -esc in several situations:

1. in the verbal contexts, when they express evaluation, in constructions with the copula a fi 'to be':
a. E tipic
românește
să dai
10.000 euro (...) pe is typically Romanian-ește să $\breve{s U B j}_{\text {J }}$ give.2sG 10.000 euros on
o mașină.
$<$ vwforum.promotor.ro $>$
a car

'To pay ten thousand euro on a car is typically Romanian / is typical of Romanian people.'

b. Etipic românesc să dai vina pe alții.

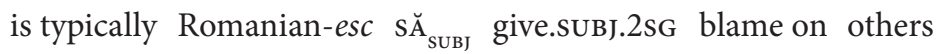
'Blaming others is typically Romanian / is typical of Romanian people.' $<$ www.designerul.ro $>$
a. $\mathrm{Nu}$ e creștinește
să
spui aşa ceva. not is Christian-eşte S $\breve{A}_{\text {SUB }}$ say.sUBJ.2sG this something 'It is not a Christian thing to say something like this.'
b. Lia, nu e creștinesc să ai superstiții. Lia.voc not is Christian-esc s $\breve{A}_{\text {SUB }}$ have.sUBJ.2SG superstitions 'Lia, being superstitious is not a Christian trait.' $<$ https://books.google.ro>

$<$ forum.desprecopii.com $>$

There are exceptions: some derivatives with -ește cannot appear in this post-copular, evaluative position. With the pair firesc 'natural' / firește 'naturally', derived from fire '(human) nature; character; being', the form in -esc (the "adjectival" form) is allowed in this position, but not the form in -ește (the "adverbial" form): 
(36) Nu e firesc / *firește să aștepți atât. not is natural naturally S $\breve{A}_{\text {SUB }}$ wait.sUBJ.2sG so long 'It is not normal to wait for so long.'

2. in intensifying structures, expressing a high degree:

a. echivalentul unei poșete prostește de mare equivalent.DEF a.GEN purse.GEN stupidly of big 'the equivalent of a stupidly big bag'

$<$ www.eva.ro $>$

b. Casa Poporului, prostesc de mare

house.F.SG people.GEN stupid-esc of big.ADJ.F.sG

'The People's House [monument in Bucharest], stupidly huge'

a. Țara e drăcește de frumoasă sub zăpezile de country.F.SG is devil-ește of beautiful.F.SG under snow.PL of

spumă.

$<$ www.informatiahd.ro $>$

foam

'The country is devilishly beautiful under the foamy snow drifts.'

b. Amândouă scriu drăcesc de bine. <cafegradiva.ro> both.F.PL write.PRES.3PL devil-esc of well

'They both write devilishly well.'

\subsubsection{Affix ordering}

Nothing can follow inflectional morphemes. By contrast, a derived form can undergo another derivational operation or/and can be inflected. The adverbs with -ește do not allow further affixation; neither do adjectives with -esc. ${ }^{3}$ Therefore, these suffixes seem to behave, with respect to affix ordering, as inflectional endings.

The test of affix ordering may be used in languages that express the comparative and the superlative by affixes, such as English (-er for comparative, -est for superlative), Italian (-issimo/a/i/e for the "absolute superlative" - il superlative assoluto), Spanish (-ísimo and its variants), French (-issime), etc. In Romanian, the comparative and the superlative markers are adverbs, not suffixes: mai 'more', foarte 'very' (e.g. mai inalt 'taller', foarte inalt 'very tall'). A few derived superlative adverbs exist, but they are borrowed from Neo-Latin or Romance: rarisim 'very rare' $(<$ French rarissime), clarisim 'very clear' (< Latin clarissimus), etc.

There are some diminutive suffixes, usually adjoined to nouns, which can attach to non-analysable adjectives and adverbs in order to express a lower degree of intensity ('a little...): -i(ş)or, -(ic)el, -leţ, -ţ.

3. Unless we accept the hypothesis that the adverbial suffix -ește is derived from -esc followed by an adverbial suffix - $e$ inherited from Latin, but unproductive in Romanian (see 7.1). 


\begin{tabular}{|c|c|c|c|}
\hline (39) & $\begin{array}{l}\text { bine } \\
\text { 'well' }\end{array}$ & $>$ & $\begin{array}{l}\text { binișor } \\
\text { 'pretty well' }\end{array}$ \\
\hline & uşor & $>$ & uşurel \\
\hline & 'light/not heavy' & & 'not very heavy' \\
\hline & greu & $>$ & greuleţ \\
\hline & 'difficult(ly)' & & 'a little difficult' \\
\hline
\end{tabular}

Neither of these diminutive suffixes can attach to the adverbs in -ește or to the adjective in -esc.

\subsubsection{Meaning}

The meaning of inflectional affixes is abstract, grammatical (number, gender, etc.), and syntactically conditioned. The meaning of derivational affixes is lexical, relatively 'concrete'. The meaning of inflectional affixes is regular, whereas the meaning of derivational affixes is often not. The broad, general meaning of the adverbs with the suffix -ește is not different from the meaning of their adjectival counterparts with -esc. Both types of forms express manner or relation. Some lexemes (both in -esc and -ește) can undergo a semantic evolution to a modal-evaluative meaning.

We consider both suffixes (-esc, -ește) to be derivational/lexical, as they have a concrete meaning (manner, point of view, modal-evaluative, etc.), unlike inflectional suffixes which typically express abstract, grammatical notions (gender, number, aspect, tense, etc.). This is the main criterion which can distinguish between derivational and inflectional affixes, along with the one pertaining to the lexical category of the formations.

\section{Conclusions}

We have shown that in Romanian the great bulk of adverbs are homonymous to their adjectival counterparts. In this respect, Romanian differs from other languages which prefer derivation to formation of adverbs from other types of words. For instance, in English a large number of adverbs are derived by -ly from their adjectival counterparts; in French, many adverbs are derived with -ment from the corresponding adjectives, but in non-standard varieties, the homonymy adverb/ adjective is more extended.

A smaller amount of Romanian adverbs are 'primary adverbs', non-homonymous with adjectives (e.g. acum 'now', mâine 'tomorrow') and most of them without an adjectival counterpart (an exception would be bine 'well' vs. bun 'good'). Some Romanian adverbs are derived, with the suffixes - ește and -iș (the ones in -ește 
have an adjectival counterpart with the suffix -esc), generally denoting manner and point of view.

Extensive homonymy between adverbs and adjectives could be an argument in favour of the single category hypothesis. We have examined the distributional properties of adverbs, invariable adjectives and variable (agreeing) adjectives in Romanian, as distribution is the main issue generally discussed in relation to the categorial status of adverbs and adjectives. We have shown that adjectives can appear in postverbal contexts (typical adverbial contexts), in certain configurations, and that, in restricted contexts, adverbs can appear as noun modifiers. Therefore, the frequently mentioned generalization that adjectives modify nouns and adverbs modify verbs and other categories must be nuanced. The overlapping distributional properties of homonymic adjectives and adverbs (Sections 4 to 6 above) show us that syntactic distribution cannot be used as a clear-cut criterion for differentiating between the two categories. What really differentiates the two classes in similar syntactic environments is agreement, but again, this criterion does not help us make clear-cut distinctions. We have shown that sometimes adjectives do not agree, if the noun they predicate about is covert (implicit), as in (15). Note that there are NPinternal adverbs which agree, in non-standard language (as normative grammars reject adverbial agreement in all environments):
a. copii noi-născuți
child.M.PL new.M.PL=born.M.PL
'new(ly) born children'
$\begin{array}{llll}\text { b. lângă ușile largi } & \text { deschise } \\ \text { near door.F.PL } & \text { wide.F.PL } & \text { open.F.PL }\end{array}$
'near the wide(ly) open doors' (see Chircu 2008: 127)

For homonymous pairs of adverbs and adjectives, agreement is a consequence of the semantic properties (event related vs. noun-related). Non-homonymous adverbs cannot agree even if they modify nouns (Section 5 above), but this can be more of a morphological restriction than a consequence of their categorial status.

In the last part of the paper we examined the relation and contrast between the adverbs derived with -ește and the adjectives derived with -esc, and the derivational vs. inflectional nature of the adverbial suffix - ește. We have shown that often there are pairs of derivatives with -ește and derivatives with -esc (with the same base) and their distributional properties as well as semantic properties overlap. The other suffix used to derived adverbs, -iş, can also derive adjectives and nouns (often, the derived items can have both adverbial and adjectival uses) and is not really productive (see 2.2 ).

We can conclude that the syntactic, morphological and semantic criteria we can use to distinguish adverbs from adjectives in Romanian are not so clear-cut. 
Their distributional properties overlap, both for homonymic adverbs and nonhomonymic (suffixed) ones. Agreement can be found with adverbs in non-standard varieties, if they modify a noun or an adjective inside a NP (see (40) above), whilst adjectives may not agree (see (15)). Intuitively, what distinguishes adverbs from adjectives is their semantics, as adjectives predicate about nouns (entities), while adverbs predicate about events, very generally speaking, but we have seen that adverbs can modify nouns as well (Section 5 above).

In this paper, we have brought some Romanian data into the on-going debate about the categories of adverbs and adjectives, from a syntactic and morphological perspective, and we have seen that their properties overlap. This general description could be completed with a systematic research of a corpus, in order to reveal the extent of some phenomena (like the agreeing adverbs in (40) or the non-agreeing adjectives in (15), among others).

\section{Acknowledgements}

This work was supported by a grant of the Romanian Ministry of Education, CNCS - UEFISCDI, project number PN-II-RU-PD-2012-3-0490.

\section{References}

Bauer, Laurie \& Valera, Salvador. 2005. Approaches to Conversion / Zero-derivation. Münster: Waxmann.

Chircu, Adrian. 2008. L'adverbe dans les langues romanes. Études étymologique, lexicale et morphologique. Cluj-Napoca: Casa Cărții de Știință.

Ciszek, Ewa. 2002. ME -lich(e)/-ly. Studia Anglica Posnaniensia 38: 105-129.

Croitor, Blanca \& Giurgea, Ion. 2009. On the so-called Romanian neuter. Bucharest Working Papers in Linguistics 11(2): 21-39.

Croitor, Blanca. 2012. Acordul în limba română. București: Editura Academiei Române.

Dal, Georgette. 2007. Les adverbes de manière en -ment du français: dérivation ou flexion? In Morphologie à Toulouse (Actes du colloque international de morphologie $4^{\text {ème }}$ Décembrettes), Nabil Hathout \& Fabio Montermini (eds), 121-147. Munich: Lincom.

DCR $=$ Dimitrescu, Florica. 1997. Dicționar de cuvinte recente, 2nd edn. București: Logos.

DEX = Academia Română, Institutul de Lingvistică 'Iorgu Iordan - Al. Rosetti' din București. 2009. Dicționarul explicativ al limbii române, 2nd edn. București: Univers Enciclopedic Gold. DI 1957 = Academia Republicii Populare Române, Institutul de Lingvistică din București. 1957.

Dicționar invers. București: Editura Academiei Republicii Populare Române.

FCLRV = Magdalena Popescu Marin (ed.). 2007. Formarea cuvintelor în limba română veche. București: Editura Academiei Române.

GA 1966 = Graur, Alexandru, Avram, Mioara \& Vasiliu, Laura (eds). 1966. Gramatica limbii române. București: Editura Academiei Române. 
GALR 2008 = Guțu Romalo, Valeria (ed). 2008. Gramatica limbii române, Vol. I - II. București: Editura Academiei Române.

Giegerich, Heinz J. 2011. The morphology of -ly and the categorial status of 'adverbs' in English. English Language and Linguistics 16(3): 341-359. doi:10.1017/S1360674312000147

Goes, Jan. 1999. L'adjectif. Entre nom et verbe. Paris: Duculot.

GR 2013 = Pană Dindelegan, Gabriela (ed). 2013. The Grammar of Romanian. Oxford: OUP.

Graur, Alexandru. 1936. Mélanges linguistiques, 1. Paris: Droz.

Haneş, Gheorghina. 1960. Sufixele adverbiale -eşte şi -iceşte. In Studii şi materiale privitoare la formarea cuvintelor în limba română, II, Alexandru Graur \& Jacques Byck (eds), 139-149. Bucureşti: Editura Academiei Republicii Socialiste România.

Haspelmath, Martin. 1996. Word-class-changing inflection and morphological theory. In Yearbook of Morphology 1995, Geert Booij \& J. van Marle (eds), 43-66. Dordrecht: Kluwer. doi:10.1007/978-94-017-3716-6_3

Haspelmath, Martin, \& Sims, Andrea D. 2010. Understanding Morphology, 2nd edn. London: Hodder Education.

Hengeveld, Kees. 1992. Non-verbal Predication: Theory, Typology, Diachrony [Functional Grammar Series 15]. Berlin: Mouton de Gruyter. doi:10.1515/9783110883282

Hummel, Martin. 2013. Attribution in Romance. Reconstructing the oral and written tradition. Folia Linguistica Historica 34: 1-42. doi:10.1515/flih.2013.001

Hummel, Martin. 2014. The adjective-adverb interface in Romance and English. In Adjectives in Germanic and Romance [Linguistik Aktuell/Linguistics Today 212], Petra Sleeman, Freek Van de Velde \& Harry Perridon (eds), 35-71. Amsterdam: John Benjamins.

doi:10.1075/la.212.02hum

Leech, Geoffrey. 1974. Semantics. Harmondsworth: Penguin Books.

Lunt, Horace G. 2001. Old Church Slavonic - Grammar, 7th rev. edn. Berlin: Mouton de Gruyter. doi: $10.1515 / 9783110876888$

Maiden, Martin. 2015. Morfologia flexionară a pluralului românesc și așa-zisul „neutru” în limba română și în graiurile românești. In Lucrările celui de-al cincilea simpozion internațional de lingvistică. Marius Sala, Maria Stanciu Istrate \& Nicoleta Petuhov (eds), 32-45. București: Editura Academiei Române.

MDN = Marcu, Florin. 2000. Marele dicționar de neologisme. București: Saeculum.

Meyer-Lübke, Wilhelm. 1895-1900. Grammaire des langues romanes, II: Morphologie; III: Syntaxe. Paris: H. Welter.

Mendeloff, Henry. 1969. A Manual of Comparative Romance Linguistics: Phonology and Morphology. Washington DC: Catholic University of America Press.

Mëniku, Linda \& Campos, Héctor. 2011. Discovering Albanian, 1: Textbook. Madison WI: University of Wisconsin Press.

Mîrzea Vasile, Carmen. 2012. Eterogenitatea adverbului românesc. Tipologie și descriere. București:

Editura Universității din București.

Pascu, Giorge. 1916. Sufixele româneşti. Bucureşti: Ediţiunea Academiei Române.

Payne, John, Huddleston, Rodney \& Pullum, Geoffrey K. 2010. The distribution and category status of adjectives and adverbs. Word Structure 3(1): 31-81. doi:10.3366/E1750124510000486 Pinkster, Harm. 1972. On Latin Adverbs. Amsterdam: North-Holland.

Plag, Ingo. 2002. Word-formation in English. Cambridge: CUP.

Plank, Frans. 1994. Inflection and derivation. In The Encyclopedia of Language and Linguistics, III, Robert E. Asher (ed.), 1671-1678. Oxford: Pergamon. 
Rădulescu Sala, Marina (ed). 2015. Formarea cuvintelor în limba română, IV: Sufixele. Derivarea nominală și adverbială, Partea 1. București: Editura Academiei Române.

Ricca, Davide. 2010. Adverbs. In New Perspectives on Historical Latin Syntax, Vol. 2: Constituent Syntax: Adverbial Phrases, Adverbs, Mood, Tense, Philip Baldi \& Pierluigi Cuzzolin (eds), 109-191. Berlin: Mouton de Gruyter.

Rothstein, Robert A. 1993. Polish. In The Slavonic Language, Bernard Comrie \& Greville G. Corbett (eds), 686-758. London: Routledge.

Scalise, Sergio. 1990. Constraints on the Italian suffix -mente. In Contemporary Morphology, Wolfgang U. Dressler, Hans C. Luschützky, Oskar Pfeiffer \& John R. Rennison (eds), 87-98. Berlin: Mouton de Gruyter. doi:10.1515/9783110874082.87

Short, David. 1993. Czech. In The Slavonic Language, Bernard Comrie \& Greville G. Corbett (eds), 455-532. London: Routledge.

Stone, Gerald. 1993. Sorbian. In The Slavonic Language, Bernard Comrie \& Greville G. Corbett (eds), 593-685. London: Routledge.

Stump, Gregory T. 1998. Inflection. In The Handbook of Morphology, Andrew Spencer \& Arnold M. Zwicky (eds), 13-43. Oxford: Blackwell.

Torner, Sergi. 2005. On the morphological nature of Spanish adverbs ending in -mente. Probus 17: 115-144. doi:10.1515/prbs.2005.17.1.115

Van Eeden, Willem. 1985. Édition et étude linguistique. In Willem Van Eeden (ed.), Învățături preste toate zilele (1642), Vol. 2. Amsterdam: Rodopi.

Vasile, Carmen. 2013. Adverbul românesc între continuitate latină, specific balcanic și evoluție internă. București: Editura Muzeului Național al Literaturii Române.

Vasiliu, Laura. 2009. Histoire interne du roumain: formation des mots. In Romanische Sprachgeschichte / Histoire linguistique de la Romania, 3. Teilband / Tome 3. Martin-Dietrich Gleßgen, Christian Schmitt \& Wolfgang Schweickard (eds), 2710-2721. Berlin: Walter de Gruyter.

Wade, Terence. 2011. A Comprehensive Russian Grammar. Oxford: Blackwell.

Zwicky, Arnold M. 1995. Why English adverbial -ly is not inflectional? In Papers from the 31st Regional Meeting of the Chicago Linguistic Society, Vol. 31(1). Audra Dainora, Rachel Hemphill, Barbara Luka, Barbara Beed \& Sheri Pargman (eds), 523-535. Chicago IL: Chicago Linguistic Society. 

PART V

Spanish 



\title{
Adverbial adjectives and -mente adverbs face to face
}

\section{Diachronic evidence from Spanish}

\author{
Concepción Company Company \\ Universidad Nacional Autónoma de México
}

\begin{abstract}
The paper compares five minimal pairs of adverbial adjectives (AA) and -mente adverbs in two periods of Spanish, the 18th and the 21st centuries. The hypothesis is that AA keeps "traces" or "memory" of its original adjective category, and for that reason, to recategorize as an adverb, AA needs to exhibit more cohesion with the verb, a rigid relative $\mathrm{V}$-AA order, appearing in contexts having a greater number of nominals than -mente, and appearing in sentences or paragraphs with lesser event complexity, as compared to -mente forms. -Mente has surpassed the NP status from old times, it is a true adverb, able to enter in more contexts than $\mathrm{AA}$, and able to enter in more complex sentences and event relationships.
\end{abstract}

\section{Introduction: An intriguing relation}

In Spanish, as in many Romance languages, adverbial adjectives (e.g., hable claro 'speak clear(ly)', literally 'speak clear') (hence AA) and -mente adverbs (e.g., hable claramente 'speak clearly') (hence -mente) have an intriguing relation to one another, because they have both remarkable similarities, and, at the same time, remarkable differences, leading to the idea that they are the "same category", but are "not the same category".

On the one hand, they seem to be the same category for several reasons. First, both are formed from Latin adjectives, but each one selects a different Latin case: AA comes, basically, from the nominative-accusative neuter case; it is known as adverbial accusative in Latin grammatical tradition (Bassols 1956 I: 174-5): multum te amamus 'we love you very much', dulce ridere 'to smile sweetly', while -mente comes from an ablative construction: ille traversa mente mihi hodie tradidit repagula 'he with surprising attitude/ surprisingly gave me the keys today' (Cicero, apud Company 2014a). Second, syntactically, both may enter in very similar or, even, the same contexts, forming strict minimal pairs, as examples in (1) to (3) below show. 
Third, semantically, both fill the category "adverb", coding the same functional space of manner-modality. Fourth, both have lived together in the history of Spanish from very old times, as (4) and (5) below show, and continue to live in synchronic variation in all dialects of Spanish up to now. The resemblances are so considerable that some linguists assert that "no hay ninguna diferencia sustancial entre 'los invitados regresaron alegres a sus casas' y 'los invitados regresaron alegremente a sus casas'” 'There is no substantive difference between 'the guests went back happy to their homes' and 'the guests happily went back to their homes'” (Bassols 1956 I: 176).

(1) a. Váyase rápido

'go quick.'

b. Váyase rápidamente 'go quickly.'

(2) a. Entremos directo al problema 'go direct to the problem.'

b. Entremos directamente al problema 'go directly to the problem.'

(3) a. Cierto, no me había percatado 'certain(ly), I was not aware of it.'

b. Ciertamente, no me había percatado 'certainly, I was not aware of it.'

(4) a. que por ningun casso dexe venir en esta flota, especial por venir en conpañia de nuestra hermana

[Venezuela, 16th c., 1584, CORDIAM) 'don't let any obstacle, and come in this [Spanish] fleet, special(ly) to come accompanied by our sister.'

b. no se le ponga ninguna cossa por delante, specialmente haviendo agora tan vuena occasion

[Mexico, 16thc., 1568, CORDIAM] 'don't let any obstacle, especially having a very good occasion at this moment.'

(5) a. digalo Francisco Marchel que actual se hallaba en dicho parage cuando llegamos

[Venezuela, 18th c., 1787, CORDIAM] 'and also Francisco Marchel confirms it because he was actual(ly) / current(ly) in that place when we arrived.'

b. declaro por mis bienes las casas en que actualmente bibo en este dicho valle

[Bolivia, 18th c., 1709, CORDIAM] 'I declare that the houses where I currently live in this valley are my goods.'

On the other hand, they do not seem to be the same category, for various reasons. First, in many contexts, they cannot fill the same structural syntactic slots, as examples in (7) to (9) below show. Second, they have different functional capacities 
at the discourse level: AA, in general, has more flexibility than -mente to become a discourse marker (6a). Third, in some cases they do not have the same meaning, even when displaying the same distribution, as in (9). In (9a) seguro 'sure' means 'complete certainty', while in (9b) seguramente 'surely' means 'probability'. Fourth, each one is specialized for different textual and register traditions: AA is more used in orality and popular speech, and -mente is more used in writing and learned speech (Hummel 2000: Chapter 3; 2012: Chapter 2, 2014: \$ 7.2).

(6) a. Listo, ya está agendado 'ready, it is already scheduled.'

b. ${ }^{\star}$ Listamente, ya está agendado *'readily, it is already scheduled.' 'All right, it is already scheduled.'

(7) a. Respire hondo 'breathe deep.'

b. ${ }^{*}$ 'Respire hondamente 'breathe *?deeply'

(8) a. Hable (más) alto 'speak loud(er).'

b. ${ }^{\star}$ Hable (más) altamente 'speak ${ }^{\star}$ (more) loudly'.

(9) a. Seguro te haces con ello en unos cuantos días 'sure, you may control the situation in a few days.'

b. Seguramente te haces con ello en unos cuantos días 'probably, you will control the situation in a few days.'

In sum, they seem exchanging adverb forms, as in (1) to (5), but, at the same time, they do not seem exchanging adverb forms, as in (6) to (9).

The aim of this paper is to compare five pairs of AA and -mente in two periods of Spanish: the 18th and the 21st centuries and to examine some of the causes for such an intriguing, even puzzling, functioning between the two classes. The paper is focused on the internal, syntactic conditions which are responsible for similarities and differences between AA and -mente, leaving aside external and textual variables, such as the Spanish dialect, the textual genre, the degree of elaboration of text, the origin of writers, etc. There is no work, as far as I know, comparing internally these two adverb classes, confronting minimal lexical pairs of AA and -mente, pair by pair, and analyzing their distribution, syntax, and selection of contexts, in a strict 
comparison. ${ }^{1}$ Such a strict comparison may shed light on the adverbial adjective / -mente adverb interface.

The five pairs are the following: claro 'clear' claramente 'clearly'; firme 'firm' I 'strong' firmemente 'firmly' / 'strongly'; igual 'equal' igualmente 'equally' / 'anyway'; infinito 'infinite' / 'immense' infinitamente 'infinitely' / 'immensely', and rápido 'quick' rapidamente 'quickly'. They are exemplified in (10) to (14).

(10) a. Bolívar no tiene claro con qué equipo afrontará el clásico de mañana

[La Prensa, 01-02-2003, Bolivia, CREA]

'Bolivar does not have clear(ly) the team formation for tomorrow.'

b. La publicidad de la época habla claramente de la irrupción de la oferta del ocio [Ángel Bahamonde, El Real Madrid en la historia de España, 2002, Spain, CREA]

'the publicity of that time speaks clearly about the breaking of leisure culture.'

(11) a. para conservar el respeto y mantener firme la representación

[Conde de Superunda, Relación de los principales sucesos de su gobierno, 1745-1756, Peru, CORDE] 'in order to preserve respect and to maintain firm(ly) the [government's] representation.'

b. Baxaron todos las cabezas al tiránico decreto, y empezaron a creer firmemente muchas máximas

[Benito Jerónimo Feijoo, Theatro crítico universal, 1730, Spain, CORDE] 'everybody bowed the tyrannical law, and they begun believing firmly many [popular] maxims.'

(12) a. Los árbitros le piden a la Liga que realice una reunión con todos los réferis para interpretar igual las reglas [El Deber, 24-09-2003, Bolivia, CREA] 'Referees ask the League to call for a meeting to interpret equal(ly) the rules.'

b. Es razonable suponer que este desarrollo, ..., ocurrirá igualmente en otro sitio donde resida vida inteligente [Daniel Roberto Altschuler, Hijos de las estrellas. Nuestro origen, evolución y futuro, 2002, Uruguay, CREA] 'this development will take place equally in another place where there is intelligent life.'

1. The only exception is the pair solo-solamente 'only', of which a long section in Hummel (2014) is dedicated. It has been also studied by Medina, Alarcon and De la Mora (2014). Medina and Alarcón (2013) have compared some adverbial adjectives and -mente adverbs in Mexican formal speech. In these two last works the analysis basically controls quantitative differences of external sociolinguistic variables, with no syntactic-semantic analysis of the contrast. 
(13) a. Holgárame infinito de tener el libro que escribió

[Benito Jerónimo Feijoo, Theatro crítico universal, 1730, Spain, CORDE] 'I will enjoy infinite(ly) to have the book that you wrote.'

b. mas quando se desembarca, y se comiensa á vér la mierda, y porqueria que cubre las calles, casas \&c... la idea disminuie infinitamente

[Francisco de Miranda, Diario de viajes, 1785-1786, Venezuela, CORDE] 'when one sees the dirty streets, the idea lessens infinitely'.

(14) a. Mi madre decía que los hijos de los pobres comen más y crecen más rápido que los de los ricos

[Gabriel García Márquez, Vivir para contarla, 2002, Colombia, CREA] 'my mother said that the poor men's sons grow up more quick(ly) than the rich ones.'

b. El gobierno francés de Jospin es el que más rápidamente se dio cuenta de que la economía moderna multiplica el destino del trabajo

[Carlos Fuentes, En esto creo, 2002, Mexico, CREA] 'the Jospin's French Government more quickly realized that the modern economy multiplies.'

I chose these pairs because they are very different in adjective nature, forming a kind of continuum from adjective to quasi noun: (1) The pairs claro claramente 'clear-clearly' and rápido rápidamente 'quick-quickly' are very adjectival in nature; for instance, they easily allow gradation: muy claro 'very clear', muy claramente 'very clearly', muy rápido 'very quick', muy rápidamente 'very quickly', más rápido que... 'more rapid than...', más rápidamente que... 'more rapidly than.... (2) The pairs firme $\sim$ firmemente 'firm-firmly' and igual igualmente 'equal-equally' are less adjectival: firme $\sim$ firmemente resist gradation: ??consideralo tan firme / tan firmemente como te sea posible '?? consider it as firm / as firmly as you can', and igual igualmente reject gradation in most cases, because the forms themselves are a kind of quantifier: *admitió su culpa muy igual / muy igualmente ‘*(s)he accepted her/ his guilt very equal(ly) / very equally'. (3) Finally, the pair infinito / infinitamente 'infinite-infinitely' is quasi non-adjective, it does not allow gradation: ${ }^{\star}$ muy infinito, * muy infinitamente “*very infinite', *very infinitely', and, even, the word infinito 'infinite' behaves nowadays more as a noun than as an adjective (RAE-ASALE 2013: s.v. infinito).

The paper is organized in five sections besides this Introduction. Section 2 is a brief state of the art devoted to revise the general findings and major problems related to AA and -mente, as a starting point to identify the specific contribution of this paper. Section 3 contains the corpus and the quantitative criteria to construe it. In Section 4, I draw up the research questions and the hypothesis which guide the analysis. Section 5, the largest one, is the analysis of corpus, controlling four independent variables. Section 6 contains the conclusions. 


\section{State of the art}

In the abundant specialized literature about AA and -mente, it is possible to set four main perspectives of analysis with various major problems inside each of them: (1) Synchronic grammar, (2) diachrony, (3) sociolinguistics, text genre and register, and (4) dialectology.

\subsection{Synchronic grammar}

The following eight differences are probably the major topics on AA and -mente, being identified by almost all synchronic grammars and by synchronic and diachronic specialized works.

\subsubsection{Category}

With no doubt, the greatest problem concerns which grammatical category AA belongs to. It is not clear whether it is an adverb, an adjective, a special kind of adjective, or a special kind of adverb. A direct consequence of this problem is that AA has received many category labels, at least fourteen: "adjective" (Hummel 2015), "adjectival adverb” (Kovacci 1999:707-19; RAE-ASALE 2009: \$13.4; Ledgeway 2011:35), "adverbial adjective" (Hummel 2012: Chapter 2; 2014: \$ 7.1), "adverbialized adjective" (Hummel 2007; 2014; Medina \& Alarcón 2013), "adjective for adverbial function” (Kühner \& Stegmann 1912-1914 I: 234; Bassols 1956 I: 174; Hengeveld 1992:62-5; Tarriño 2009), "bare adjective" (Suñer \& Di Tullio 2001), "deadjectival adverb" (Medina, Alarcón \& De la Mora 2014), "invariable adjective” (Abeillé \& Godard 2004; Abeillé \& Mouret 2010); "simple adverb” (Medina, Alarcón \& De la Mora 2014), "short adverb" (RAE-ASALE 2009: \$13.8f; Medina \& Alarcón 2013), "underived adverb" (Giegerich 2012:344), "uninflected adverb” (Hummel 2013a; 2014), "uninflected adjective" (Giegerich 2012:343); "weak complement" (Abeillé $\&$ Godard 2004). So many names are a symptom of uncertainty or ambiguity about the word class of this class of word.

On the contrary, -mente does not have problems of category adscription. It has always been analyzed as 'adverb', having reached the status of manner adverbs par excellence in Spanish grammars and specialized works. It has received four labels only: "derived adverbs" (Medina, Alarcón \& De la Mora 2014), 2 "long adverb" (Company, 2014a; Medina, Alarcón \& De la Mora 2014), "manner adverb” (Kovacci 1999: 700ff; Katz 2008; RAE-ASALE 2009: $\$ 30.7$; Company 2014a, and many other authors because is the most usual label), -mente adverb (Company 2014a: $\$ 6.3$ ).

2. This label is specially used in the non-Romance tradition. 
The scarce number of category names is a symptom of no uncertainty about its word class. In sum, there is uncertainty for AA vs. certainty for -mente in category adscription, as evidenced by 14 labels vs. 4 labels, respectively.

\subsubsection{Types of adverbial adjective}

Some works identify two subtypes of AA. One of them functions as an adverb properly, modifying the verb, as in ver claro 'to see clear(ly)', correr rápido 'to run quick(ly)', a manner of seeing / a manner of running. The other one basically functions as a predicative adjective of a non-explicit direct object, a kind of internal accusative, as in comer picante 'to eat spicy', vivir sano 'to live healthy', where spicy and healthy would be a secondary predication of an internal accusative: 'to eat something which is spicy' / 'to live a healthy life'. The borderline between these two subtypes are fuzzy as regards their adverbial properties, and the specialized literature recognizes that ambiguity exists when applying tests to distinguish them (Abeillé \& Godard 2004; Abeillé \& Mouret 2010; Hummel 2015).

\subsubsection{Scope}

A main grammatical difference between AA and -mente is that AA has basically two scopes: intrapropositional over the verb and extrapropositional over the discourse, functioning in this case as a discourse marker, ${ }^{3}$ while -mente has more flexibility in scope, because it may modify other word classes besides the verb, such as the noun, the adjective, the adverb, or the whole verb phrase, and it may also function as a discourse marker (Kovacci 1999; Rodríguez 2003; Company 2014b). Related to discourse scope, all works describe AA as more flexible than -mente when filling discourse functions. Authors that analyze AA as simple adjectives (Hummel 2015) consider that AA may modify any word and function.

\subsubsection{Cohesion and distribution}

AA usually shows strong cohesion with the verb and frequently forms lexicalized constructions: respirar hondo 'to breathe deep', saltar alto 'to jump high'. It easily forms formulaic or fixed expressions of generic, atemporal reading: votar libre es la clave de la democracia 'to vote free is the key of democracy' (Hummel 2015). As for -mente, it does not form collocations or constructions with such a strong degree of lexicalization (Company 2014a). The relative order with the verb is more rigid in the case of AA (almost always behind the verb), than in the case of -mente. They also function differently in extraction and focalization tests (Suñer \& Di Tullio 2001; Abeillé \& Godard 2004).

3. I will use the label "discourse marker" as a general operative term, without entering into the various discourse and connective functions that both AA and -mente may fill (Company 2014b). 


\subsubsection{Grammaticality}

Judgments about grammaticality are very variable in the case of AA; instead, -mente does not usually generate problems about grammaticality. For instance, in Suñer \& Di Tullio (2001), the use of AA is ungrammatical in the following sentences, but the use of -mente is grammatical: ¿Citaste aquellos párrafos? ${ }^{\star} S i ́$, textual/Sí, textualmente 'Did you quote those paragraphs? 'Yes, ${ }^{\star}$ literal/Yes, literally'; ${ }^{\star} T e$ estoy agradecido infinito/Te estoy agradecido infinitamente 'I am grateful *infinite/I am grateful infinitely'. However, the above AA, and others, are completely grammatical in many American Spanish dialects. Indeed, in Mexican Spanish, agradecer infinito 'to be grateful infinite(ly)' is a very learned, almost formulaic use, while agradecer infinitamente 'to be grateful infinitely' is less frequent.

\subsubsection{Lexical restrictions}

Both AA and -mente are heavily restricted by the lexical basis of their adjective etymon, and because of that, not all adjectives allow recategorization as AA nor generate -mente adverbs. Also, the complex internal classifications of AA and -mente are determined by the lexical and aspectual meaning of the adjective basis and by the lexical and aspectual verb classes co-occurring with AA and -mente (Moreno 1998; Kovacci 1999; Rodríguez 2003; Katz 2008, among many others).

\subsubsection{Basic meaning, polysemy and the role of context}

There is a strong disagreement in the specialized literature regarding whether AA and -mente have a basic, abstract, general meaning (separately AA and -mente), and polyfunctionality comes from the context (Hummel 2012, 2013a; Company 2014a, 2014b), or whether the various meanings of each one of these forms are a case of polysemy (Kovacci 1999; Rodríguez 2003). In consequence, for the authors defending a basic, general meaning, the internal classification of each adverb relies on context, exclusively or, at least, to a great extent (Hummel 2012, 2014; Company 2014a). For the authors postulating polysemy, the context plays a minimal role in the classification of these two forms.

\subsubsection{Morphological and semantic problems}

As for -mente ending, there are various morphological and semantic disagreements: whether it has lexical meaning, grammatical meaning or does not have any meaning at all; whether it is a derivational affix or it is functioning as a compound formative; whether it is a true affix or a phrase affix (Torner 2005; Company 2014a: $\$ 6.5$ for a status quaestionis of these aspects). ${ }^{4}$

4. The English bound form -ly displays very similar morphological problems; $\mathrm{cf}$. Giegerich (2012) for an extensive discussion on it. 


\subsection{Diachrony}

In diachronic perspective, there is less research about these two forms, however, many aspects of the evolution of these forms are already well known.

\subsubsection{Historical depth}

In Latin, adjectives in accusative case, recategorized as adverbs in certain contexts, that is, AA, are the oldest and the most common strategy to code manner adverbs (Karlsson 1981; Ricca 2010; Hummel 2013b, 2014; Company 2014a). This strategy was inherited by all Romance languages and continues to have great vitality in all of them. On the contrary, -mente is a Romance innovation; almost all Romance languages created -mente, except old vernacular Romanian, and other non-standard Italian dialects. Nevertheless, the historical depth of -mente is also very old: there are some bridge contexts (NP with mens-mentis in ablative having two readings, as noun and as adverb) from Plautus; there are some adverbial occurrences of mente in Virgilius and Seneca; there are many bridge contexts and switch contexts in Patristic texts. The first attestation of -mente as adverb appears in Reichenau Glosses, France, from the 8th century (Company 2014a).

\subsubsection{Status of -mente adverbs}

In Spanish, the affix - mente is a learned form, phonologically and morphologically. In this language, -mente was attested in very learned texts at first (sapient-moral textual genre), and was spread over less learned texts quickly (Company 2012, 2016).

\subsubsection{Type of change}

The creation of -mente is a paradigmatic case of grammaticalization with a very complex process intervening several reanalysis. Nevertheless, there is still discussion about the degree of grammaticalization of -mente adverbs in Ibero Romance languages, especially in Portuguese and in Spanish.

\subsubsection{Capacity to subjectivize}

Both AA and -mente are prone to undergo subjectification via metonymic inferential processes, giving rise to discourse markers and other forms of epistemic modality from the Middle Ages to current times.

\subsection{Sociolinguistics, text genre and register}

Numerous papers from Hummel $(2012,2013 c, 2014)$ have shown that AA and -mente construe a binomial complementary system in Spanish and in other Romance 
languages. Firstly, both forms display a quite neat sociolectal distribution: AA is much more frequent in popular speech whereas -mente is more frequent in learned speech. Secondly, AA and -mente have a quite separated register distribution: the first one is much more frequent in oral language/-mente is more frequent in written language; in written language, the first form usually appears in dialogue-oral textual zones. In sum, AA and -mente form a complementary specialized system: AA for oral and popular registers/-mente for written and learned ones.

\subsection{Dialectology}

There is a consensus in the specialized literature that AA is much more frequent in American than in European Spanish. In Latin America, the farther south one goes, the more frequently a dialect uses AA, both in oral and written texts, and both in popular and learned speech also (Company 2008, 2012; Hummel 2012, 2014).

\subsection{Summary}

Summing up, AA and -mente have been traditionally studied separately in the Spanish grammar, both synchronically and diachronically. The comparison, whenever is made, has been made usually from an external perspective: by dialect, by register or by grade of literacy.

There are no works comparing AA and -mente from an internal, grammatical point of view. This internal comparative analysis is the proposal of this paper. As for the label AA, I decided to use 'adverbial adjective', because the adjective-attributive etymological nature of AA, partly, determines the syntax and context selection of these forms, as we will see below $(\$ 6)$.

\section{Corpus}

The electronic corpora on which the analysis is based on are the Corpus Diacrónico del Español (CORDE) for the 18th century and the Corpus de Referencia del Español Actual (CREA), for the 21st century, both from Real Academia Española (www.rae. es). Occasionally, I have taken examples from the Corpus Diacrónico y Diatópico del Español de América (CORDIAM) from Academia Mexicana de la Lengua <www. cordiam.org $>$, in order to get some additional American evidence. The quantitative analysis was made on the first two corpora, CORDE and CREA, only.

I chose only adjectives with no agreement, recategorized as adverbs (15), and attestations of -mente as adverb with any scope (16). It is important to note that 
it is very difficult, almost impossible in some cases, to attest AA unambiguously. Often it had two potential readings, as a predicative adjective or as a true adverb. This was particularly true in the case of firme 'firm(ly)' 'strong(ly)'. Two readings are possible for many examples of almost all AA, the context deciding the best possible interpretation. Hummel (2000: Chapter 2, 2013a, 2013b, 2014: § 7.3) has mentioned repeatedly that this kind of ambiguity is intrinsic to AA, because the original attributive adjective meaning is present. Even, Hummel (2015) analyzes AA as true adjectives, recategorized via the context.

(15) a. Los versos que leí en el gabinete bien claro manifiestan que yo soy el desgraciado objeto de su amor [Ignacio García Malo, Voz de la naturaleza. Memorias o anécdotas curiosas e instructivas. 1787, Spain, CORDE] 'lyric verses that I read so clear(ly) manifest that I am....'

b. Amor las cuerdas de oro/ me dio, y el plectro, / porque cante en ellas/ a la que firme adoro/ dulcísimas querellas

[Leandro Fernández de Moratín, Poesías completas, 1778, Spain, CORDE] 'Love gave me the instruments to sing with them the woman who I firm(ly) adore.

c. Ved por las cumbres del cielo cuál alzándose camina rápido el sol

[Leandro Fernández de Moratín, La derrota, 1789, Spain, CORDE] 'the sun walks quick(ly).'

(16) a. como los acreedores eran muchos y cada uno se consideraba en mas alto grado de merito que los demás, no haviendo con que poderlos remunerar á todos igualmente, era indispensable huviessen de quedar muchos quexosos [Conde de Superunda, Relación ... de los principales sucesos de su gobierno, 1745-1756, Peru, CORDE] 'not having a way to remunerate equally everybody, it was indispensable....'

b. Este método de reproducción asexual permite a las salpas reproducirse rápidamente y en grandes cantidades cuando el alimento abunda

[Aquanet. Revista Virtual de Buceo, 34, 04-2002, Spain, CREA] 'this method allows salpas [sea fish] to reproduce quickly'.

The sample was construed as follows: I took any country and any textual genre in the two periods, but only written texts for the 21 st century in CREA, to allow a comparison under "similar" register conditions in the two centuries. ${ }^{5}$ I selected the complete 18th century, 1700-1799, and only two years for the 21 st century,

5. Written texts in the 21st century reproduce dialogue and oral speech very frequently; the 18 th century texts only occasionally reproduce dialogue. This is an external variable which rests equilibrium to the strict diachronic comparison that I am intending to do in this paper. It must be controlled in a future work. 
2002-2003, because CREA has more than 30,000 attestations of these adverbial pairs in the 20th-21st centuries (1976-2004). The sample was formed with all AA attested in the 18th and 21st centuries, except claro 'clear', rápido 'quick', and igual 'equal' in the 21st century, because there are 2095 forms of these three adverbs in CREA in 2002-2003. I took 100 examples of each one by random sampling. There is no attestation of infinito 'infinite(ly)' as adverb in CREA in 2002-2003, confirming the nominal nature that most dictionaries attest in present-day Spanish for this word. As for -mente, the corpus was formed with 75 examples in each century for each lexical pair, by random sampling also, except infinitamente 'infinitely' in the 21 st century, because CREA only has 72 occurrences of this adverb in 2002-2003. The analysis is based on 1723 examples, constituting a strong empirical base to explore similarities and differences between these two kinds of adverb forms.

Table 1 displays the corpus, showing important quantitative differences in AA: 657 occurrences in a whole century (1700-1799) and 319 in only two years (20022003), even with the quantitative restriction for claro 'clear(ly)', rápido 'quick(ly)' and igual 'equal(ly)' in this period, mentioned above. That is, the number of cases in two years is equal to half of the cases in one hundred years, signifying that diachronically AA has increased extensively in the Spanish written language. However, it is necessary to keep in mind that CREA contains many more documents and countries for the 20th-21st centuries than CORDE for the 18th century.

Table 1. Corpus

\begin{tabular}{lllr}
\hline & AA & -mente & Total \\
\hline 18th & 657 & 375 & 1032 \\
21st & 319 & 372 & 691 \\
Total & $\mathbf{9 7 6}$ & $\mathbf{7 4 7}$ & $\mathbf{1 7 2 3}$ \\
\hline
\end{tabular}

\section{Research questions and hypothesis}

The research questions guiding the analysis are the following: (1) What is the grammatical motivation for a speaker-writer to choose AA on some occasions and -mente on others at the same stage of language? (2) Do AA and -mente construe grammatically a complementary system, and which kind of it? (3) Are there significant diachronic changes in 200 years? (4) Why does -mente, generally, need more context than AA to display the complete function of the constituents and the complete meaning of its sentence? This last question was motivated by the data of corpus, while I was collecting them. I realized that the context I needed for -mente was (very) long, but much shorter in the case of AA. Examples in (17) and (18) 
present typical contexts for AA and -mente, respectively. They show that the AA context is, in general, much shorter than the -mente one: one line vs. three or more lines, respectively. The dot at the end of the example means that the whole sentence finishes there. Reduced contexts of AA may be a consequence of the reduced valency effect associated to this adverbial form (Hummel 2015) (see below $\$ 6.4$ ).

(17) a. Ni su ijo Salomon pudo dezirlo mas claro.

[Francisco Garau, El sabio instruido de la Gracia, 1703, Spain, CORDE] 'not even his son, Solomon, could tell it more clear(ly).'

b. He subido rápido, pero este puerto tiene lo que tiene.

[As, 22-09-2003, Spain, CREA]

'I have climbed [the mountain pass] quick(ly), but this height has its difficulties.'

(18) a. No como que reciva de Vuesa Señoría la Real Audiencia en esa entrega alguna cosa que ya no tenía antes, por lo que mira á Vuesa Señoría, sino como en voluntaria demostración que quiera hacer con aquella material entrega del bastón, vervigracia, para que todos vengan á entender más claramente que ya no está en Vuesa Señoría solo como aora la Superior authoridad, que tan á Gloria de Dios, veneficio universal havía estado Vuesa Señoría hasta aquel entonces exerciendo, como lo está aora.

[Simón de Anda y Salazar, Carta-circular al Provincial de dominicos, 1763, Philippines, CORDE] 'in order that everybody comes to understand more clearly that your lordship is not alone.'

b. El público está totalmente desorientado y a los que se acercan por primera vez a los toros, les captan rápidamente para que nunca lleguen a conocer realmente los cánones del toreo clásico, el puro, verdadero y a la postre, eterno.

[La Voz de la Afición, 19, 05-2002, 2002, Spain, CREA] 'they attract them rapidly in order that they[the last ones]never know the art of classic bull fighting.'

My starting point in diachronic analysis is that any linguistic form maintains its basic, general, and abstract meaning for centuries. Forms also retain traces of their original category values. In general, current synchronic grammatical behaviour reflects earlier patterns, because continuity plus discontinuity, together, are inherent to language change. It is the context which allows diversity of functions, which in turn leads to weakening of the etymological referential meaning, and which allows that the form slowly acquires new functions along its diachrony. That is, polyfunctionality comes from the context and not from the form itself (Company 2012, 2014a, 2014b; Hummel 2012, 2013a; Trousdale 2012; Waltereit 2012). 
This approach to diachrony allows me to pose the following hypothesis: AA will keep "traces" or "memory" of its original adjective category. For that reason, to recategorize as an adverb, AA will need to exhibit more cohesion with the verb and a rigid relative $\mathrm{V}$-AA order, the non-marked position of a manner adverb (Company 2014: $\$ 6.5)$. Because of that adjective "trace", it will appear in contexts having a greater number of nominals than -mente, because an adjective is typically related to nominals. Because of that adjective "trace", its ability to appear in complex sentences/events will be (somewhat) restricted, and it will appear in sentences or paragraphs with lesser event complexity, as compared to -mente forms, because AA is focused on nominals.

In its turn, -mente has surpassed the noun phrase (NP) status from old times, it is not a nominal anymore, it is an adverb, able to enter in more contexts than AA, and able to enter in more complex event relationships.

The speaker-writer will opt for AA when (s)he wants to focus on some relevant nominal in an event, and such a focalization requires less event complexity and less complex distribution. -Mente will be chosen for any type of event, complex or not, and for any kind of nominal, relevant or not. In sum, both forms, AA and -mente, construe a binominal complementary system in terms of markedness: AA is the marked form, having syntactic-semantic restrictions, because it is not an adverb when it lacks the appropriate context. -Mente will function as the unmarked or indifferent form, with no restrictions as to the relative order with the verb, as to the selection of nominals, or as the complexity of the event. In sum: AA = restrictions / -mente $=$ no restrictions.

\section{Analysis}

The dependent variable for the analysis is AA vs. -mente. I analyzed the frequency of four independent variables, seeking to test the hypothesis: (1) Adjacency to the verb; (2) Relative order verb-adverb; (3) Nominal binding, and (4) Structural event complexity.

Z-Scores ${ }^{6}$ were then computed on the frequency of each variable in order to measure whether the differences between AA and -mente were significant or not. Z-scores were applied both synchronically for each century separately and diachronically comparing the proportions of each type of adverb between centuries.

The data of the corpus show some interesting general findings, when comparing AA and -mente, on the one hand, and, on the other hand, the five AA among them

6. In $<$ http://www.socscistatistics.com/tests/ztest/Default2.aspx $>$ 
and the five -mente among them, separately. I will discuss these general findings before entering into the specific analysis of variables.

1. In the corpus, the only absolute difference between AA and -mente is that AA takes prepositions, while -mente does not: ${ }^{7}$ racione pampangos $y$ tagalos por igual 'ration out those tribes equal(ly)' (1763, Philippines, CORDE); las personas que allí habitaban de firme 'people lived there of firm' (1789, Ecuador, CORDE); un cóndor que de rápido se levanta un cabrito 'a condor thatof quick picks up a small goat' (1762, Peru, CORDE). The only AA that never takes preposition is infinito 'infinite(ly)'.

2. In the corpus, there are no strict minimal pairs, with the same contexts and the same distribution, like those exemplified in (1)-(3) above, so many times repeated in the specialized literature. Obviously, there are attestations of AA and -mente with the same lexical basis and the same verb (ver claro 'to see clear(ly)' I ver claramente 'to see clearly'; decir igual 'to say [it] equal(ly)' / decir igualmente 'to say [it] equally'; mantenerse firme 'to remain firm(ly)' / mantenerse firmemente 'to remain firmly'), but they appear in different contexts, dealing with different topics or themes and different communicative or textual situations. Therefore, the potential-abstract system of the language gives us different information than the language in its actual use, or, in other words, Corpus Linguistics provides new insights of the interface between AA and-mente.

3. As expected, there are important grammatical differences according to lexical meaning, but grammatical differences among AA are greater than those among mente. For instance, igual 'equal(ly)' behaves in a very different way from rápido 'quick(ly)' and from claro 'clear(ly)', but the five -mente adverbs behave in a similar way grammatically, in spite of their semantic differences. The reason is, in my opinion, that -mente is morphologically marked as adverb and thus internal differences must be lesser.

4. The well-known diachronic adverbial cline: verb scope $>$ sentential-intrapropositional scope > discourse particle (V-ADV > IP-ADV > DP) (Traugott 1995; Hummel 2013b) is not filled by every aA. For example, claro 'clear(ly)' and firme 'firm(ly)' never appear in the corpora as a sentential-intrapropositional adverb, IP-ADV. Both work as VADV in the two centuries, and claro 'clear(ly)', but not firme 'firm(ly)', emerges as a discourse particle, DP, of evidentiality in modern Spanish, without passing by IP-ADV. Infinito 'infinite(ly)' never functions as DP. Rápido 'quick(ly)' and igual 'equal(ly)' run along the three stages of the cline.

7. In Early Medieval Spanish, some -mente adverbs took preposition: "quantas liebres veya, prendié de buena mente" (Arcipreste de Hita, Libro de buen amor, 14th c., apud Company, 2014a] '[the wolf] took all hares of willingly'/'the wolf caught so many hares as he could'. 
5. Infinito 'infinite(ly)' is almost completely lexically specialized with psychemotion verbs; the constructions agradecer + infinito 'to be grateful infinite(ly)' and alegrar + infinito 'to be glad infinite(ly)' are quite fixed, almost completely lexicalized in the 21 st century, but infinitamente 'infinitely' is not lexicalized. Claro 'clear(ly)' co-occurs with ver 'to see' and other perception verbs more times than claramente 'clearly'. Rápido 'quick(ly)' and rápidamente 'quickly' are not lexicalized, they co-occur with very different semantic classes of verbs.

\subsection{Adjacency}

By adjacency, I mean that there is no interruption between the verb and the adverb. The adjacent adverb may be a pre- or a, more frequently, postverb. The adverb is also considered adjacent when it stands between the constituents of a verb periphrasis. In (19) the three possibilities of adjacency are exemplified: preverb (19a), postverb (19b) and between the auxiliary verb and the auxiliated verb (19c). By non-adjacency, I mean cases in which one or more constituents interrupt the syntagmatic sequence of verb and adverb, as in (20). Clitics do not interrupt adjacency.

(19) a. ¿Cómo no?, dice Taydor, bien claro lo dije

[Pedro Montengón, Eusebio, 1786, Spain, CORDE] 'what do you mean? Taylor says, clear(ly) enough I said it.'

Tan firme pisa el pie izquierdo, como el derecho

[Benito Jerónimo Feijoo, Cartas eruditas y curiosas, en que por la mayor parte se continúa el designio de el Theatro Crítico, 1742, Spain, CORDE] 'So firm(ly) he walks the left foot like the right one.'

b. Atendíase al gusto, y se escusaba el gasto. Ahora todo se atropella. Se aumenta infinito el gasto, aun sin contemplar el gusto

[Benito Jerónimo Feijoo, Theatro crítico universal, 1728, Spain, CORDE] 'nowadays everything is in chaos. The spending increases infinite(ly).' Queda muy claro que al estamento taurino no le interesa

[La Voz de la Afición, 19, 05-2002,Spain, CREA] 'it is very clear that authorities of bullfighting are not interested in.' porque vamos a cenar como la gente normal, la que trabaja de firme, tiene los pies en la tierra y vive como Dios manda

[Alfonso Rojo, Matar para vivir, 2002, Spain, CREA] 'let's go to dinner like normal people, she works firm(ly) having her feet on the ground.... 
c. Durante el proceso digestivo, las bacterias intestinales separan la molécula de carbohidrato de la isoflavona, que es rápidamente absorbida

[José Antonio Argente, Frutoterapia y sojaterapia. Frutas y soja para la energía y la salud, 2003, Argentina, CREA] 'during digestion, isoflavona is quickly absorbed.'

(20) a. me he valido de ellas en varios pazmos rectos, ótotales, que son los que rectamente embaran todo el cuerpo por igual, dejandole inmoble y tenso [Pedro Montenegro, Materia médica misionera, 1710, Argentina, CORDE] 'spasms make stiff the body equal(ly) [totally].'

b. ¿Lo ve usted claro? Me alegro, Pepe

[Ramón de la Cruz, La niñería, 1768, Spain, CORDE] 'do you see clear(ly)? I am glad.'

c. cada individuo busca la manera de hacerse rico rápido, a la buena o a la mala [Listín Diario, 31-12-2003, República Dominicana, CREA] 'everybody seeks the way to become rich quick[ly].'

d. por lo cual nos arrimamos a la otra costa de donde vimos la dicha casa mas claramente [Martín Fernández de Navarrete, Itinerario de la armada del rey católico a la isla de Yucatán, 1793, Mexico, CORDE] 'we saw the aforementioned house more clearly'.

e. porque no hay madera ni aun resina alguna que haga detonar el salitre tan rápidamente como el carbon puro [Luis Proust, Anales del Real Laboratorio de Química, 1791, Spain, CORDE] 'there is no wood nor resin which make to explode the nitre so quickly'.

f. Los primeros árboles eran de variedades de fruto muy áspero y astringente, por lo que rápidamente el juicio popular los dejó condenados

[C. Donoso, Fruticultura ecológica, 2002, Spain, CREA] 'quickly, popular opinion condemned those trees.'

Specialized literature about AA postulates adjacency as a definitory feature of AA: "la unidad que forma el verbo con el adjetivo desnudo no se puede romper" ([verb and bare adjective form an unbreakable unit], my translation, Suñer \& Di Tullio 2001; for French, the same opinion in Abeillé \& Godard 2004). However, corpus linguistics shows that AA allows flexibility when regarding cohesion $\mathrm{V}-\mathrm{AA}$, as Examples (20a)-(20c) above show. ${ }^{8}$

8. Non-adjacency with AA is not uncommon in CREA: "Si hacemos el diagnóstico rápido y le suministramos la medicación correspondiente, podemos reducir este porcentaje" ( $A B C$ Color, 31-10-2000, Spain, CREA) 'if we make the diagnosis quick(ly), and we give her / him the corresponding medication, we can.... 
Table 2 measures adjacency. ${ }^{9}$ It shows that both in the 18 th and in the 21 stcenturies, AA and -mente are almost categorically adjacent to the verb, being more than $90 \%$ the average of adjacency, although -mente has some more freedom to be non-adjacent. It means that the basic position of an adverb having scope on the verb is adjacent to this one.

Table 2. Proportion of sentences containing verb adjacency

\begin{tabular}{lll}
\hline & AA & -mente \\
\hline 18 th & $.93(611 / 657)$ & $.90(337 / 375)$ \\
21 st & $.98(312 / 319)$ & $.89(331 / 372)$ \\
\hline
\end{tabular}

Statistic results are diachronically very interesting: the hypothesis does not work for the 18th century, but works for the 21st one. It means that aA became more different from -mente over time in regards to adjacency. In the 18th century, the proportion of AA with adjacency (.93) is not significant compared to the proportion of -mente with adjacency $(.90), z=1.69, p=.089$. On the contrary, in the 21 st century the difference in proportion is statistically significant (.98 vs. .89, $\mathrm{z}=4.67, p<.001$ ). Diachronically, AA increased notably, 93\% > 98\%, while -mente did not change. Z-test confirms the significance of that change when comparing AA in the 18th and 21 st centuries, $z=3.25, p<.001$. Therefore, the hypothesis that AA is required to be closer to the verb than -mente is supported diachronically and for the last century.

In case of non-adjacency, transitive verbs allow some more interruption than intransitive ones. The constituents interrupting the adjacency between the verb and -mente may be both argument and non-argument; direct object is more common than other constituents, as examples in (20a, d, e) show. The corpus also shows that the lexical meaning of adjective basis impacts distribution: claramente 'clearly' and rápidamente 'quickly' have much more freedom in position than firmemente 'firmly' or igualmente 'equally'; the least flexible adverb is infinitamente 'infinitely', which always is adjacent and postverb. Clear 'clear(ly)' and rápido 'quick(ly)' are more flexible in adjacency than the other AA.

\subsection{Relative order of verb and adverb}

There are also important differences between AA and -mente in regards to the relative position of the verb, AA being more rigid than -mente across the two centuries. AA prefers the postposition in more than $90 \%$ of occurrences, while -mente only

9. Tables are given in proportions (.93) and not in percentages (93\%), because z-test calculates proportions. 
occupies a postverbal position in $75 \%$ of cases. That means that almost categorically AA needs to keep the non-marked position of a manner adverb (Company 2014a) in order to function as an adverb, because it is not marked as an adverb morphologically, while -mente is morphologically marked, and because of that it has more arrangement freedom. Examples (19) and (20) above show the possibilities of relative order of AA and -mente.

Table 3 below shows the quantitative differences between these adverbs in relative position; $\mathrm{V}-\mathrm{v}$ means that the adverb is between the constituents of a periphrasis. Table 3 indicates that both adverbs may stand in pre- and postverbal order, but that AA is excluded from $\mathrm{V}-\mathrm{V}$, a position where -mente may easily appear in the corpus, even in the 21st century: debe claramente consignarse (El Salvador, 2002, CREA), está firmemente decidida (Spain, 2003, CREA). The table also shows significant differences in preverbal position, where -mente amply doubles the proportion of AA.

Table 3. Proportion of sentences containing each relative order

\begin{tabular}{|c|c|c|c|c|}
\hline & \multicolumn{4}{|l|}{$\mathbf{A A}$} \\
\hline & V-ADV & ADV-V & $\mathbf{v}-\mathbf{v}$ & Total \\
\hline 18th & $.92(611)$ & $.08(46)$ & - & 657 \\
\hline \multirow[t]{3}{*}{$21 \mathrm{st}$} & $.95(303)$ & $.05(16)$ & - & 319 \\
\hline & \multicolumn{4}{|l|}{-mente } \\
\hline & V-ADV & $A D V-V$ & $\mathrm{v}-\mathrm{V}$ & Total \\
\hline 18 th & $.75(281)$ & $.20(75)$ & .05 (19) & 375 \\
\hline $21 \mathrm{st}$ & $.76(282)$ & $.11(41)$ & $.13(49)$ & 372 \\
\hline
\end{tabular}

Statistic results confirm the proposed hypothesis. In the 18th century, the proportion of AA in the non-marked position $\mathrm{V}$-ADV (.92) was much higher than the proportion of -mente in that position $(.75, z=7.53, p<.001)$, suggesting that AA needs to maintain the non-marked position of manner adverbs in order to function as a true adverb. This was also true in the 21 st century (.95 vs. .76, $z=6.92, p<.001$ ), meaning that relative order is also a significant variable in the second century. Diachronically, AA increased V-ADV order very slightly, .92 > .95, while -mente actually did not change, $.75>.76$. Z-test indicates that both increases were not significant (AA: $z=1.72, p=0.085$; -mente: $z=0.31, p=0.748$ ). On the contrary, the increase of $5 \%>13 \%$ of -mente in $\mathrm{v}-\mathrm{v}$ position is statistically significant, $z=3.82$, $p=.085$. However, this increase, in my opinion, does not reflect a new capacity of -mente but a general increase of periphrastic constructions in the Spanish of 21st century as compared to the 18 th one. 


\subsection{Nominality binding}

By nominality binding I mean that in the sentence where the adverb is (AA or -mente), there is a relevant noun and usually other nouns related to it. By relevant noun, I mean, operatively, an important or a main entity that constitutes the theme on which the story is focused on. That entity usually has referential persistence. This definition is akin to that of "topic" in the literature, ${ }^{10}$ but I use the term "relevant noun" to make explicit the relation of AA to nominality. The concept "nominality binding" is taken here in a very similar sense to "nominality boundedness" from Paradis (2001).

The expected fact is that there will be more relevant nouns in a sentence with AA than with -mente, and there will be more nominal persistence with AA than with -mente, because, according to the hypothesis, AA "attracts" nominals, inasmuch as it keeps "traces" of its adjective original category. The corpus shows that AA appears more frequently in examples where there is a topical noun as well as other nominals related semantically to it, creating a kind of nominality binding in the sentence where AA is.

The Example (21), with rápido 'quick(ly)', displays the typical nominality binding associated to AA. The main nominal in (21) is a singular personal pronoun, él 'he', which is the theme of that text section. It is also the grammatical subject of the verb modified by the AA, travesando 'crossing', and also is the subject of the other verbs, tendió 'applied' and vio 'saw'. Therefore, the main nominal él 'he' persists referentially across three sentences. It is important to notice that the pronoun él 'he' is linked semantically to two nominals: one body part, experta vista 'his expert eyes', and one coreferential possessive pronoun, los suyos 'his men' (literally 'the his'), and there is another nominal, las armadas filas 'his army' which contextually is the army possessed by the pronounn él 'he'. In sum, there are three nominals related to the subject-topic of the verb modified by the AA rápido 'quick(ly)'. The adverb is subject-topic oriented, ${ }^{11}$ because rápido 'quick(ly)' refers a quality or a capacity of the topic él 'he': 'he is rapid crossing a place.'

10. Cf. Givón (1988), Büring (1999), and Jacobs (1999), among many others, for bibliographical revisions and definitions of "topic".

11. By subject-oriented adverb I mean the same concept of traditional grammar of an adverb that predicates some property or capacity of the nominal functioning as subject (Kovacci 1999). 
(21) Entonces él por las armadas filas tendió la experta vista, y travesando rápido los inmensos batallones, vio el orden de los suyos

[Gaspar Melchor de Jovellanos, Traducción del primer canto, 1768-1778, Spain, CORDE] 'then, he, along the army lines, applying his expert sight (eyes), and crossing quick(ly) the immense army, saw the military disposition of his men.'

Similar features are displayed in the Example (22) with infinito 'infinite(ly)'. Again, there is a main nominal fuego 'fire' that is the theme of the text, and is the subject of the verb modified by the AA, enardeció 'to inflame', and is also the subject of the other two verbs fue dirigido '[fire] was directed' and se hizo '[fire] was made'. The nominal fuego 'fire' has referential persistence because it appears twice in the form of two anaphors: éste 'this [fire]' and el poco 'the little [fire]'. The adverb infinito 'infinite(ly)' refers to the psychological impact of the fire, mentioned previously in three different ways. Therefore, AA appears in a context with nominal relevance and nominality binding.

(22) tuvieron que hacer fuego. Aunque éste fue dirigido de modo que más sirviera de espanto que de daño, el poco que se hizo enardeció infinito al pueblo

[Conde de Fernán Núñez, Vida de Carlos III, 1790, Spain, CORDE] 'they had to make fire, this was directed more as fear than as damage; the little [fire] which was made inflamed [psychologically] infinite(ly) (to) the people.'

In turn, -mente adverb is indifferent both to nominal binding and to nominal relevance; that is, -mente may or may not appear in those marked contexts. Usually, the sentence where -mente appears has more than one nominal, even many nominals interacting in the event, but they are separated nominals, not linked to a main nominal only. Example (23) displays the interaction of various nominals that are not semantically related. In the context there are two different buckets, dos cubos de cobre 'two copper buckets', and one person, Christoval, who is trying to drink from them. Each bucket is placed at different heights, one of them is empty, the other one is being filled rapidly with water, the water is poured out, and the other bucket unbalances and falls down quickly, se hundió rápidamente 'it sank so quickly', knocking out the person who was trying to drink. As it occurs in this example, as in many sentences with -mente adverb, it is not possible to set up clearly a relevant nominal or referential persistence of one entity. In some cases, it is possible of course, because, as it was said above, -mente is unmarked or indifferent to nominality binding. 
(23) para lo cual tenía dos cubos de cobre, puesto cada uno al extremo de la soga; sucedió que quiso beber de uno de ellos, para lo cual le supesó un poco, y en este tiempo se llenó de presto el de abajo y se hundió tan rápidamente que, arrebatando el cubo de arriba, le dió tal golpe a Christoval en la garganta con el borde [Palomino y Velasco, El Parnaso español pintoresco laureado, 1724,

Spain, CORDE]

'[two nominals slightly related between them...] one of them sank so quickly that it hit a person...'

Examples in (24) and (25) confirm the very different relationship to nominals that AA and -mente have. Examples (24a) and (24b) exemplify rápido and rápidamente, 'quick(ly)'and 'quickly', respectively; (25a) and (25b), claro and claramente, 'clear(ly)' and 'clearly', respectively. In (24a), with AA, all nominals in italics are semantically linked to a main noun, confirming the nominality binding effect of sentences with AA. Furthermore, the various nominals in italics of (24a) are different ways to refer to the same entity, the god Apollus. Rápido 'quick(ly)' is a subject-oriented adverb, which predicates properties or capacities of nominals referring to the god Apollus, who is similar to éter 'ether' in lightness. On the contrary, in (24b), with -mente, there are so many different nominals in the context (santones 'blessed men', rotaciones del cuerpo 'body's rotations', estatuas 'statues') that it is impossible to establish any direct relation of any of the nominals to the verb and to the -mente adverb; for that reason, there are no italics in the example.

(24) a. El numen belígero, embrazando el égida sobre cruento plaustro, vagaba iracundo, fatigando los ejes férvidos y agitando, flagelifero, cuadriga indómita. No de otra manera, fulgurando el éter, se precipita rápido. - Calla, calla, maldita criatura - dijo Apolo [Leandro Fernández de Moratín, $\mathrm{La}$ derrota de los pedantes, 1789, Spain, CORDE]

'in the same way [as the previous nominals qualifying the god Apollus], the ether shines and falls down quick(ly).'

b. donde refiere innumerables prodigios de algunos de estos santones, como son violentas y dilatadas rotaciones del cuerpo, inimitables a todos los demás hombres, girando rápidamente y a compás por mucho tiempo, como si fuessen estatuas maquinalmente movidas [Benito Jerónimo Feijoo, Theatro crítico universal, 1729, Spain, CORDE]

'[many entities with a slight semantic relationship between them...], some of them spinning quickly and with rhythm...'

In (25a) below, the nominality binding is again very clear with the AA claro 'clear'. The nominals in italics establish a kinship relationship between Jesús 'Jesus', the God-son, and his father, God, both being the same person in Catholic religion. 
At the same time, there is a whole-part relationship, Jesús 'Jesus', the whole, and sus manos 'his hands', the part, confirming the nominality binding effect in a sentence with AA. In turn, in (25b) there are so many separated nominals (licenciado Arias 'lawyer Arias', disturbios 'riots', derramamientos de sangre 'bloodsheds', dichos autos 'aforementioned writings', etc.), that it is impossible to establish any direct relationship of any specific nominal to the verb and the -mente adverb; again, for that reason, there are no italics in the example. The adverb claramente 'clearly' does not have scope on any specific entity, but it is event-oriented, modifying all actions occurring in the complex sentence.

(25) a. Mas claro reconoce Jesús, que todo se lo a puesto en sus manos su Padre

[Francisco Garau, El sabio instruido de la Gracia, 1703, Spain, CORDE] 'more clear(ly) Jesus recognizes that his Father has left everything in his hands.'

b. Por el dicho Licenciado Arias de Aponte se conoce claramente haber habido en el mes de marzo de este sobredicho año mayores disturbios y derramamientos de sangre que el pasado, porque en dichos autos está una rigurosa sentencia contra Don Julián de Cupide, Sancho de Aristi, Antonio de Oporto... [Bartolomé Arzans de Orsúa y Vera, Historia de la villa imperial de Potosí, 1702-1736, Peru, CORDE]

'by Arias it is known clearly that in March of this year there were riots, bloodsheds, because in the aforementioned writings....

Specialized literature has affirmed that a distinctive feature of AA is that it frequently co-occurs with imperative verbs, respire hondo 'breathe deep', coma lento 'eat slow' (Suñer \& Di Tullio 2001; Abeillé \& Godard 2004; Hummel 2015). Although imperative lacks an overt subject nominal, it is always directed to a hearer-reader, the second person being highly prominent, topical, and actually present in the event, and because of that the second person has pragmatic relevance. Then, the nominality binding associated to AA works even with imperative utterances.

Table 4 below measures the nominality binding with the two adverbs. It shows that both types of adverbs are associated with a high percentage of nominality. This is expected, because almost any event (except purely impersonal ones) has nominal arguments and nominal complements. However, the percentile differences between AA and -mente are significant in the 18th century: AA appears $14 \%$ more than -mente in contexts with greater nominality in the 18 th century (.94 vs. .80, $z=6.88, p<.001$ ). Diachronically, AA weakens its relationship to nominality and gets closer to -mente, but the difference between the two types of adverb in the proportion of nominality continues being significant in the 21 st century (.86 vs. $.79, z=2.39, p=.016)$. 
Table 4. Proportion of sentences containing nominality binding

\begin{tabular}{lll}
\hline & AA & -mente \\
\hline 18 th & $.94(616 / 657)$ & $.80(300 / 375)$ \\
$21 \mathrm{st}$ & $.86(274 / 319)$ & $.79(294 / 372)$ \\
\hline
\end{tabular}

Diachronically, AA significantly decreased nominality binding, .94 >.86 $(z=4.17$, $p<.001$ ), while -mente did not change, $.80>.79$, and, in consequence, the statistic result is not significant, $z=0.33, p=0.727$. It means that over time AA weakens its presence with relevant nominals becoming more adverbial.

There are slight differences based on lexical meaning in regards to nominality binding. As I said before, there are more discrepancies among AA than among -mente. Claro 'clear(ly)' and rápido 'quick(ly)' are more easily related to relevant nominals than igual 'equal(ly)' and firme 'firm(ly)', whereas infinito 'infinite(ly)' is the AA least associated to relevant nominals. This continuum is logical, because clear 'clear(ly)' and rápido 'quick(ly)' have more adjectival properties than the other examples, and infinito 'infinite(ly)' is quasi non-adjectival in its properties. -Mente (claramente 'clearly', firmemente 'firmly', igualmente 'equally', rápidamente 'quickly' and infinitamente 'infinitely') does not show significant contrasts among them.

In sum, AA is usually associated to one main nominal and there may be other nominals related to that one in the sentence, whereas - mente usually lacks association with specific nominals. For that reason, AA is frequently a subject-oriented adverb, while -mente is frequently an event-oriented adverb. Subsequently, a sentence having AA is usually less complex and shorter than a sentence containing -mente (cf. below $\$ 6.4$ ). And, finally, for that same reason, AA has additional semantic complexity, because it is a form simultaneously associated to both to a verb and to a nominal; that is, nominality binding causes, in many cases, an ambiguous reading in AA between attribute and adverb. ${ }^{12}$ In contrast, -mente is not restricted to such a specific dual focalization.

\subsection{Complexity of the event}

Complexity of the event is defined by two related features: how many sentences are syntactically related to the sentence where the adverb appears (AA or -mente), and the grammatical type of those sentences. Following the hypothesis of this paper, AA is predicted to appear in less complex sentences because it is not focused on the event per se, but, instead, on some relevant nominal of that event. In contrast,

12. Hummel (2015) has pointed out the special semantic complexity of AA because the adjective nature of this kind of adverb generates two readings almost permanently. 
-mente is predicted to appear in both simple and complex sentences. The criteria for less and more complexity are the following: by less complexity, I consider one simple sentence, juxtaposition, or coordination. By more complexity, I take complex sentences, either with a completive subordinate sentence or sentences linked by a subordinating nexus of any kind.

Table 5 below measures the degree of event complexity, focusing on less complexity. The table shows that this independent variable has the highest quantitative percentile differences between AA and -mente: $25 \%$ favoring less complexity in AA. Diachronically, AA decreases its presence in less complex events slightly: $87 \%>85 \%$; -mente also decreases complexity in the same percentage: $62 \%>60 \%$.

Table 5. Proportion of examples with less complexity

\begin{tabular}{lll}
\hline & AA & -mente \\
\hline 18 th & $.87(572 / 657)$ & $.62(232 / 375)$ \\
$21 \mathrm{st}$ & $.85(271 / 319)$ & $.60(223 / 372)$ \\
\hline
\end{tabular}

Statistic results are very interesting, because synchronically the $z$-test is significant in both centuries but diachronically there were no changes, meaning that the complexity of the event is a very stable variable, yielding a high difference between the two adverbs in the two periods. The hypothesis is supported in the 18 th century $(z=9.31, p<.001)$, and the same is true in the 21 st century $(z=7.26$, $p<.001)$. Diachronically, neither AA nor -mente changed; for AA, $z=0.85, p=.395$; for -mente, $z=0.56, p=.575$. In sum, AA prefers appearing in very simple sentential constructions, while -mente usually selects complex events. ${ }^{13}$

Examples in (26) and (27) display the typical contexts where AA and -mente, respectively, usually appear. The very different degree of structural complexity is remarkable. Generally, AA is present in very short sentences: vuela rápido Idomeneo 'Idomeneo flies quick(ly)', amanecio claro 'it got light clear(ly)', padezco infinito en el verano 'I suffer infinite(ly) in the summer', etc. The dot at the end of the examples with AA means that the example really ends there, and another theme, related or not to the previous one, begins in the text. Instead, -mente usually appears in long and complex sentences, with various sentences related to it or embedded in other phrases, as all examples of (27) show. -Mente may appear also in simpler sentences, as $(27 \mathrm{a}, \mathrm{b})$ show, because it is an unmarked adverb compared to AA.

13. The very different way of writing Spanish in the 18 th and in the 21 st centuries is probably a conditioning factor crossing the significance of this variable. In fact, in the 18th century, written language was generally construed with much longer paragraphs and longer sentences than in present-day Spanish. 
(26) a. Dia 30, amaneció claro y con viento por el SE fresco.

[Máximo Rodríguez, Relación diaria que hizo el intérprete Máximo Rodríguez de la ysla de Amat, alias Otagiti, 1774-1776, Peru, CORDE] 'it got light clear(ly) in the morning.'

b. Los resultados anteriores señalan la importancia del estudio de la infección, y deja bien claro que esta enfermedad no discrimina entre hombre y mujer.

[Revista Vitae, 10-2002, 2002, Venezuela, CREA] 'it puts very clear(ly) that this disease does not discriminate...'

c. y creo se ven oy, varios sugetos, que con manejar grandes y importantíssimos negocios mantuvieron firme su fervorosa passión.

[Benito Jerónimo Feijoo, Teatro Crítico Universal, 1736, Spain, CORDE] 'some persons stood firm(ly) in their fervent passion.'

d. Truenos, y vuela rápido Idomeneo. [Eusebio Vela, Comedia nueva de Si el amor excede al arte, 1713, Mexico, CORDE]

'thunders [sound], and Idomeneus flies quick(ly).'

e. Luego rápido vuelve, y alegre por los valles no hay planta que no toque.

[Juan Meléndez Valdés, Poesías, ca. 1786, Spain, CORDE] 'then [the river] comes back quick(ly), and...'

f. mis nervios me quieren mal, y aun con el gran cuidado que tengo, padezco infinito en el verano.

[Leandro Fernández de Moratín, Cartas, 1796, Spain, CORDE] 'my nerves love me badly,... I suffer infinite(ly) in the summer.'

(27) a. José Luis es claramente uno de los hombres de futuro en el PSOE y terminará por irse a vivir a Madrid. [Gonzalo López Alba, El relevo. Crónica viva delcamino hacia el II Suresnes del PSOE, 2002, Spain, CREA]

'Jose Luis is clearly one of the main men of the future PSOE.'

b. A Santiago Álvarez no le pude dar la sorpresa, pero le pedí igualmente que escuchase el himno que iba a sonar a continuación.

[Eduardo Sotillos Palet, 1982. El año clave, 2002, Spain, CREA] 'I ask equally him to listen to the national anthem.'

c. y hinchadas las aguas de aquel rio con la cantidad que recibió de la mucha nieve y liquidada con las llamas corriendo rápidamente por el mismo rio Napo, destruyessen el pueblo llevando entre sus ondas las cosas que lo formaban. [Antonio de Ulloa, Viaje al reino del Perú, 1748, Peru, CORDE] '[a lot of events] flames running quickly along the Napo river.'

d. Pero lo que me importa infinitamente más es que las Sagradas Letras nos insinúan lo mismo que en el assumpto dixeron los antiguos philósophos.

[Benito Jerónimo Feijoo, Cartas eruditas, 1753, Spain, CORDE] 'for me, it matters infinitely more that Holy Writings...'

Differences inside AA are lesser for this variable than in the three variables previously analyzed. Differences among -mente adverbs are really non-significant also, 
although claramente 'clearly' frequently appears in shorter and less complex sentences than the other-mente adverbs.

The simplicity of the event in AA motivates fixed VP, fixed constructions V-AA, diachronically routinized as (quasi) formulae: respire hondo 'breathe deep'; váyase derecho 'go straight', hable más alto 'speak louder', etc. Very probably, the simplicity of the event of AA created a kind of structural pattern along the history of Spanish, promoting more AA with more simpler sentences, acquiring even the character of fixed constructions, as I described above. At the same time, this textual tradition blocked -mente for those simplest structural sentential patterns.

Summing up, there are two routines for choosing AA or -mente in context selection, well differentiated in the history of Spanish: the speaker-writer chooses AA when (s)he desires to emphasize or profile a specific relevant nominal into a structurally simple event. In all other cases, (s)he usually chooses -mente, although the latter adverb may appear in simpler syntactic contexts.

A circular problem arises at this point, related to the external factors textual genre and sociolinguistics. Do the simpler grammatical conditions of AA cause that AA appears preferably in oral, low level of education, and popular speech?, or vice versa, is it the popular and oral speech which causes a tradition or a pattern of simpler grammatical complexity in AA? That is, what causes what? Given that the corpus is construed from written texts, I think, by now, that the internal grammatical simplicity of AA motivates its use in oral and popular speech, and not vice versa. The same issue, obviously, can be raised for the bigger complexity of texts where -mente appears: is bigger complexity a property of -mente adverbs, or is it a consequence of the inherent complexity of those texts? Probably, it is a reciprocal attraction, but I do not yet have a definitive answer. More analysis is needed, crossing this internal independent variable with external ones, like the textual genre, the textual support (oral vs. written), the writer-speaker's degree of literacy, etcetera.

\section{Conclusions}

We have postulated that AA retains "memory" or "traces" of its original word class, and that fact determines the syntactic selection that it makes. AA is specialized for a certain kind of syntax while -mente is not. AA has more cohesion with the verb, a quasi-fixed postverb order, it is focused on important nominals, and the sentences where it appears are simpler in complexity, both qualitatively (simple sentences, juxtaposition or coordination) and quantitatively (fewer linked sentences). In contrast, the -mente adverb usually has more distributional freedom and it appears in more complex syntax constructions (compound sentences), although it may appear also in simpler sentences. 
Both adverbs make up a complementary system, construing a markedness binomial: AA is the marked member of the pair, -mente is the unmarked one. That is, AA and -mente are not actually disputing the "same" functional-distributional space, but they are specialized to profile, perspectivize, different grammatical aspects.

We have analyzed four independent variables, measuring statistically the quantitative differences between AA and -mente. For each variable, the results were statistically significant, confirming that AA is a very specialized adverb and -mente is not specialized for a certain type of syntax. Our results also suggest that, in general, AA changed more than -mente comparing the two centuries.

\section{Acknowledgements}

An abbreviated version of this paper was given as lectures at the Universidad de la República in Montevideo, Uruguay, in July, 25th, 2014, and in the "Working group on Romance languages", at the University of California Berkeley, in December, 10th, 2014. I am indebted to the assistants to those lectures. I am especially indebted to Virginia Bertolotti, Marisa Malcuori, and to two anonymous reviewers for their critical and insightful comments. I am also indebted to Laura Shneidman for her stylistic review. Any content or formal error is obviously mine.

\section{References}

Abeillé, Anne \& Godard Danielle. 2004. Les adjectifs invariables comme compléments légers en français. In L'adjectif en français et á travers les langues, Jacques François (ed.), 209-224. Caen: Presses Universitaires de Caen.

Abeillé, Anne \& Mouret, François. 2010. Les compléments adjectivaux des verbes transitifs en français, in Les Tables. La grammaire par le menu, Cahiers du Cental 6: 1-10.

Büring, Daniel. 1999. Topic. In Focus. Linguistic, Cognitive and Computational Perspectives, Peter Bosch and Rob van der Sandt (eds), 142-165. Cambridge: CUP.

Bassols de Climent, Mariano. 1956. Sintaxis Latina, 2 Vols. Madrid: Consejo Superior de Investigaciones Científicas.

Company Company, Concepción. 2008. Gramaticalización, género discursivo y otras variables en la difusión del cambio sintáctico. In Sintaxis histórica del español y cambio lingüístico. Nuevas perspectivas desde las tradiciones discursivas, Johannes Kabatek (ed.), 17-52. Frankfurt \& Madrid: Iberoamericana \& Vervuert.

Company Company, Concepción. 2012. Condicionamientos textuales en la formación de los adverbios en -mente. Una tensión diacrónica del español. Revista de Filología Española 92(1): 9-42. doi: 10.3989/rfe.2012.v92.11.235

Company Company, Concepción. 2014a. Adverbios en -mente. In Sintaxis histórica de la lengua española. Tercera parte: Adverbios, preposiciones y conjunciones. Relaciones interoracionales, Concepción Company (ed.), 457-612. México: Universidad Nacional Autónoma de MéxicoFondo de Cultura Económica. 
Company Company, Concepción. 2014b. Principios teóricos vs. datos de corpus: ¿diálogo o enfrentamiento? Los adverbios en -mente como marcadores de discurso. In Marcadores de discurso. Perspectivas y contrastes, María Marta García Negroni (ed.), 13-34. Buenos Aires: Santiago Arcos.

Company Company, Concepción. 2016. Sintaxis histórica y tradiciones discursivas. El género textual como macrolocus del cambio sintáctico. In El español a través del tiempo. Estudios ofrecidos a Rafael Cano Aguilar, Araceli López Serena (ed.), 385-415. Sevilla: Publicaciones de la Universidad de Sevilla.

Givón, Talmy. 1988. The pragmatics of word order. In Topic Continuity in Discourse: A Quantitative Cross-language Study [Typological Studies in Language 3], T. Givón (ed.), 1-43. Amsterdam: John Benjamins.

Giegerich, Heinz J. 2012. The morphology of -ly and the categorial status of 'adverbs' in English. English Language and Linguistics 16(3): 341-359. doi:10.1017/S1360674312000147

Hengeveld, Kees. 1992. Non-Verbal Predication. Theory, Typology, Diachrony. Berlin: Mouton de Gruyter. doi:10.1515/9783110883282

Hummel, Martin. 2000. Adverbale und adverbialisierte Adjektive im Spanischen. Tübingen: Gunter Narr.

Hummel, Martin. 2007. Adjetivos adverbializados y otros atributos directos del verbo en el habla oral informal de Chile. In Vernetzungen. Bedeutung in Wort, Satz und Text. Festschrift für Gerd Wotjak zum 65. Geburtstag, Juan Cuartero \& Martina Emsel (eds), 221-233. Frankfurt: Peter Lang.

Hummel, Martin. 2012. Polifuncionalidad, polisemia y estrategia retórica. Los signos discursivos con base atributiva entre oralidad y escritura. Acerca de esp. bueno, claro, total, realmente, etc. Berlin: De Gruyter. doi:10.1515/9783110281248

Hummel, Martin. 2013a. Polyfunctionality, polysemy, and rhethorical strategy. The functional, semantic and pragmatic motivation of discourse functions. Grazer Linguistische Studien 79: 63-91.

Hummel, Martin. 2013b. Attribution in Romance: Reconstructing the oral and written tradition. Folia Linguistica Historica 34: 1-42. doi:10.1515/flih.2013.001

Hummel, Martin. 2013c. La dimensión intercultural de la expansión diacrónica de los adverbios en -mente. In Los adverbios con función discursiva: Procesos de formación y evolución, María Pilar Garcés (ed.), 15-41. Frankfurt \& Madrid: Vervuert \& Iberoamericana.

Hummel, Martin. 2014. Adjetivos adverbiales. In Sintaxis histórica de la lengua española. Tercera parte: Adverbios, preposiciones y conjunciones. Relaciones interoracionales, Concepción Company (ed.), 613-732. México: Universidad Nacional Autónoma de México y Fondo de Cultura Económica.

Hummel, Martin. 2015. Baseline elaboration at the adjective-adverb interface in French and English: The event-modification-structure of the structure 'verb + adjective'. Ms.

Jacobs, Joachim. 1999. Informational autonomy. In Focus. Linguistic, Cognitive and Computational Perspectives, Peter Bosch \& Rob van der Sandt (eds), 56-81. Cambridge: CUP.

Karlsson, Keith E. 1981. Syntax and Affixation. The Evolution of -mente in Latin and Romance. Tübingen: Max Niemeyer. doi:10.1515/9783111329017

Katz, Graham. 2008. Manner modification of state verbs. In Adjectives and Adverbs. Syntax, Semantics and Discourse, Louise McNally \& Christopher Kennedy (eds), 220-248. Oxford: OUP.

Kovacci, O. 1999. El adverbio. In Gramática descriptiva de la lengua española, Ignacio Bosque \& Violeta Demonte (eds), 705-786. Madrid: Espasa Calpe. 
Kühner, Raphael \& Stegmann, Carl. 1912-1914. Ausführliche Grammatik der lateinischen Sprache, 2 Vols. Hannover: Hahnsche.

Ledgeway, Adam. 2011. Adverb agreement and split intransitivity: Evidence from Southern Italy. Archivo Glottologico Italiano 96: 31-66.

Medina Gómez, Lorena \& Alarcón Neve, Josefina. 2013. El adverbio de manera corto en el español formal de México. Verba Hispánica 21: 55-74. doi:10.4312/vh.21.1.55-74

Medina Gómez, Lorena, Alarcón Neve, Josefina \& De la Mora Gutiérrez, Juliana. 2014. Descriptive and functional analysis of the pair sólo and solamente in oral Mexican Spanish. Paper read in the International Conference The interfaces of adjective and adverb in Romance and English, Universität Graz, June, 5-7.

Moreno Cabrera, Juan Carlos. 1998. Adverbial quantification in the languages of Europe: Theory and typology. In Adverbial Constructions in the Languages of Europe, Johann van der Auwera (ed.), 147-185. Berlin: Mouton de Gruyter, doi:10.1515/9783110802610.147

Paradis, Carita. 2001. Adjectives and boundedness. Cognitive Linguistics 12(1): 47-65. doi:10.1515/cogl.12.1.47

Real Academia Española-Asociación de Academias de la Lengua Española. 2009. Nueva gramática de la lengua española. Madrid: Espasa.

Real Academia Española-Asociación de Academias de la Lengua Española. 2013. Diccionario de la lengua española. Madrid: Planeta.

Ricca, Davide. 2010. Adverbs. In New Perspectives on Historical Latin Syntax, 2: Constituent Syntax: Adverbial Phrases, Mood, Tense, Philip Baldi \& Pierluigi Cuzzolin (eds), 109-191. Berlin: De Gruyter Mouton.

Rodríguez Ramalle, Teresa María. 2003. La gramática de los adverbios en -mente o cómo expresar maneras, opiniones y actitudes a través de la lengua. Madrid: Universidad Autónoma de Madrid.

Suñer, Avel-lina \& Di Tullio, Angela. 2001. Los adjetivos desnudos y la cuantificación adverbial. Paper read at the $11^{\circ}$ Coloquio de Gramática Generativa, Universidad of Zaragoza.

Tarriño Ruiz, Eusebia. 2009. El adjetivo. In Sintaxis del latín clásico, José Miguel Baños Baños (coord), 251-272. Madrid: Liceus.

Torner, Sergi. 2005. On the morphological nature of Spanish adverbs ending in -mente. Probus 17: 115-144. doi:10.1515/prbs.2005.17.1.115

Traugott, Elizabeth Closs. 1995. The role of the development of discourse markers in a theory of grammaticalization. Paper read at the 12th International Conference on Historical Linguistics, Manchester.

Trousdale, Graeme. 2012. Grammaticalization, constructions and the grammaticalization of constructions. In Grammaticalization and Language Change. New Reflections [Studies in Language Companion Series 130], Kristin Davidse, Tine Breban, Lieselotte Brems \& Tanja Mortelmans (eds), 167-198. Amsterdam: John Benjamins. doi:10.1075/slcs.130.07tro

Waltereit, Richard. 2012. On the origins of grammaticalization and other types of language change in discourse strategies. In Grammaticalization and Language Change. New Reflections [Studies in Language Companion Series 130], Kristin Davidse, Tine Breban, Lieselotte Brems \& Tanja Mortelmans (eds), 51-72. Amsterdam: John Benjamins. doi:10.1075/slcs.130.03wal 


\title{
Descriptive and functional analysis of the solo-solamente adverbial pair in spoken Mexican Spanish
}

\author{
Lorena Y. Medina Gómez and Luisa Josefina Alarcón Neve \\ Universidad Autónoma de Querétaro, México
}

This study analyzes the solo-solamente adverbial pair's syntactic, semantic, and pragmatic distribution and frequency. The data stem from two sociolinguistic corpora of spoken Spanish, the Corpus Sociolingüistico de la Ciudad de México (CSCM) and the Corpus del Habla de Monterrey (CHDM). The objective is to determine the different meanings that this adverbial pair has regarding to information structure and pragmatic implications. It is shown that both units are used as focus operators. Both units come close to synonymy, but solo tends to mark exclusion, while solamente is more often used for simply nuancing.

\section{Introduction}

The Spanish language often disposes of apparently synonymous and thus competing adverbs with the same stem, such as rápido-rápidamente as seen in (1) and (2). The first is an adverbialized adjective or short adverb (rápido), and the second is a deadjectival adverb by affixation of -mente or long adverb (rápidamente).

(1) La mujer corre rápido.

'The woman runs quickly.'

(2) La mujer corre rápidamente.

'The woman runs quickly.'

Throughout this text, the terms long adverb and short adverb will be used to refer to the derivative adverb and the simple adverb, respectively. The existence of two such forms has been attested in a variety of languages, for example in English: slow-slowly, quick-quickly. This phenomenon is especially evident in Romance languages, as seen in the following examples: lento-lentamente ('slow'-'slowly') and 
rápido-rapidamente ('quick'-'quickly'), in Portuguese; lent-lentement and rapiderapidement, in French; lento-lentamente and rápido-rápidamente, in Spanish.

The purpose of this paper is to analyze the behavior of solo-solamente in order to assess whether these two forms fulfill the same discursive function and whether these two forms tend to appear in specific contexts according to semantic, syntactic, functional and pragmatic criteria. For Hummel (2013:12-14) adverbialized adjectives are the standard option in informal oral communication in the Spanish speaking regions of America, whereas the -mente forms are standard for correct writing (see also Karlsson 1981:35; De Mello 1992: 239; Hummel 2001:34; 2002: 17; Medina \& Alarcón 2013:65). However, in Mexican Spanish it has been observed that the long adverb solamente is unexpectedly recurrent in oral discourse. The extensive use of the long adverb solamente in oral register, in contrast to the relatively limited use of other long adverbs in this register, creates a desire to more closely observe the behavior of this element to determine if linguistic factors (i.e. semantic, syntactic, functional and pragmatic) influence its appearance, as it seems that each adverbial form appears under certain conditions or circumstances that have yet to be studied. It is also of interest to investigate if the short adverb solo appears in interface with the adjective solo, as recent research studies (Hummel 2008: 130; Hummel 2012:3) have found occurrences of this phenomenon of interface with other short adverbs and adjectives, particularly in Romance languages.

Specifically, the objectives of this paper are the following:

I. To observe the semantic, syntactic, functional and pragmatic behavior of the two forms in the adverbial pair solo-solamente in the role of focus operator in order to corroborate if these forms have similar or different meanings in the linguistic structure.

II. To observe the different syntactic positions in which the two forms in the adverbial pair solo-solamente appear in order to determine if position is a criterion that regulates the presence of one form or the other.

III. To observe if an interface between the adverbial and the adjectival uses of solo is present, and if so, in which contexts and under which circumstances it appears.

The next section will provide a review of the related literature, followed by a description of the methodology of the study. Then the results of the study are presented and analyzed. Finally, concluding remarks are given in response to the findings of this research study. In this research paper we omit the diacritical mark on sólo according to the RAE (2010); for this reason diacritical marks given in transcriptions and in the examples from other authors have also been left out. 


\section{Literature review}

\subsection{Solo-solamente as focus operators}

Some authors argue that the adverbial pair solo-solamente expresses exclusivity (Ferrari Giammatteo \& Albano 2011:30), restriction (Martínez 2006: 1438; Hummel 2012:143) or uniqueness (Seco 2002:417; Lara 2011:1524), as in (3).

(3) Juan solo miró.

(Gutiérrez 2010:626)

'Juan only saw'

(Juan only sees, and does nothing else)

These adverbs have also been classified as "focus operators" by Gutiérrez Bravo (2008:378), "evaluation focus markers" by Hummel (2012:145) or "focus markers" by Gutiérrez (2010:628). The term focus operator will be used henceforth. The function of these focus operators is to highlight, emphasize, or make an entity prominent within a discourse structure. "The adverb only, $[\ldots]$ is called a focus adverb, because it requires a focus constituent in its environment" (Hoeksema \& Zwarts 1991:52). The element under focus is labeled the "focus", and syntactically it is located under the domain or scope of the focus operator. From here on out the "focus" in example sentences will appear in bold italics.

Ladd (1979, apud in Veliz 2010:61) classifies the focus as either wide or narrow, while Face (2002:31) and Gutiérrez Bravo (2008:380) categorize the focus as either informative/presentational or contrastive. The terms wide and narrow will be used throughout this study. A wide focus distinguishes new information from previously given information (cf. Gutierrez Bravo 2008:377) while a narrow focus indicates and highlights a specific entity among a set of possible alternatives (cf. Gutierrez Bravo 2008: 376). Moreover, one of the qualities of a narrow focus seems to be related to the usage patterns of solo-solamente to signal exclusivity: "Los focos contrastivos [...] tienen la propiedad de aparecer con un 'operador de foco', que típicamente es un elemento adverbial que implica exclusividad o exhaustividad” ${ }^{1}$ (4 and 5) (Gutiérrez Bravo 2008:378).

(4) Solo Pedro se rindió.

(Gutiérrez Bravo 2008)

'Only Pedro gave up.'

(Nobody else gave up. The narrow focus is Pedro.)

1. 'A contrastive focus [...] has the property of appearing with a 'focus operator', which typically is an adverbial element that implies exclusivity or exhaustivity". 
(5) Pedro solo se rindió.

(Gutiérrez Bravo 2008)

'Pedro only gave up.'

(He did nothing else; he didn't struggle or escape. The narrow focus is the act.)

\subsection{Syntactic and pragmatic aspects of solo-solamente}

From a syntactic perspective, these focus operator adverbs can place any element in a clause under focus; for this reason, these adverbs have positional liberty. As it can be observed below, solo is not restricted to the subject, the predicate, or the direct object position; in fact, it is compatible with any one of these positions (6 to 8).

(6) Solo María escucha discos de música clásica.

'Only María listens to classical music discs.'

(and no one else)

(Ferrari et al. 2011:33)

(7) María solo escucha discos de música clásica.

'María only listens to classical music discs.'

(and does nothing else)

(Ferrari et al. 2011:33)

(8) María escucha solo discos de música clásica.

'María listens only to classical music discs.'

(and no other kind of discs)

(Ferrari et al. 2011:33)

In addition, in the majority of communicative interactions, the speaker does not openly manifest his/her agreement or disagreement with a situation, but instead makes use of tools or strategies so that the interlocutor may infer or interpret his/ her intention. In this sense, pragmatically, the adverbial pair solo-solamente is used strategically by the speakers with the purpose of exteriorizing their attitude or value judgment (9) (Barrenechea 1977:313; Di Tullio 2010: 141; RAE \& ASALE 2010:593; Hummel 2012:145). Moreover:

En lenguas entonativas, como las lenguas románicas, las variaciones melódicas no se usan para distinguir palabras [...] sino para manifestar una serie de sentidos pragmáticos que afectan generalmente a todo el enunciado. ${ }^{2}$

(Prieto 2003: 13)

Thus, these adverbs are used in conjunction with melodic variations in order to further clarify the pragmatic meaning of the utterance.

2. "In intonational languages, like Romance languages, melodic variations are not used to distinguish words [...] but to manifest a series of pragmatic meanings that generally affect the entire utterance". 
(9) Beatriz solo trabaja cuarenta horas semanales.

'Beatriz only works forty hours a week.'

(In their opinion, that amount is scant or insufficient)

\subsection{The adjective-adverb interface of solo-solamente}

Regarding the phenomenon of interface between adverb and adjective (Hummel 2008: 130; 2012:3), it has been found that a word acquires distinct meanings according to the position that it occupies within a linguistic group. Cárdenas (2010:24189) performs an analysis of the order of the discourse and the meaning of the units and the relation between them, while Costa (2008:13-25) makes a distributional proposal of adverb use according to the domains of semantics, prosody and categorical studies. Given that the research on this phenomenon is recent, no studies were uncovered that address interface between adverb and adjective.

\section{Methodology}

The examples were collected from two representative Mexican Spanish corpora, comprised of samples of spontaneous oral speech: the Corpus Sociolingüistico de la Ciudad de México (CSCM) (Sociolinguistic Corpus of Mexico City) (Lastra \& Butragueño 2011), and the Corpus del Habla de Monterrey (CHDM) (Corpus of Speech in Monterrey) (Rodríguez, Flores \& Pérez 2012). Both corpora, the CSCM and the CHDM, were compiled in response to the need for an oral, urban, local, contemporary Spanish Mexican language corpus.

Each corpus contains 108 interviews with the same characteristics (i.e. same number of participants, same number of men and women, similar ages and similar educational level). Furthermore, the corpora's sizes are comparable as the CSCM has $1,377,133$ words and the CHDM has 1,416,540 words. All language samples in the corpora were collected from interviews conducted in natural contexts: the participants were at home, at work or at school for a freer, more natural and authentic production. The focus of the interviews is everyday life, including topics such as childhood, school, work, stress, relationships, money, free-time activities, customs, television, books, food, etc.

These two corpora were selected because both represent the spoken language patterns of two of the largest and most important cities of the Mexican Republic and because the materials have discursive variety as they include expository, narrative, argumentative, descriptive and conversational fragments. This discursive variety allows an observation of the behavior of the solo-solamente adverbial pair in the 
Spanish spoken in these two important Mexican cities. Currently, the material of the $C S C M$ is available on the webpage $<$ http://lef.colmex.mx $>$ and the $C H D M$ is available on the webpage $<$ http://www.filosofia.uanl.mx/posgrado/hablamty/index.html .

In order to corroborate the results, all of the following variables were submitted to the chi-squared statistical test: the semantic function (exclusivity value vs. the nuancing values of attenuation and intensification); the type of focus (narrow or wide focus) and function of the focus (functional characteristics: argument, adjunct, phrase); and the syntactic position (location of the focus operator with respect to the focus element: adjacent, to the left or to the right).

\section{Results}

\subsection{Frequency of the solo-solamente adverbial pair}

In order to properly analyze the usage patterns of the solo-solamente adverbial pair in spoken language, all clauses or phrases in which these adverbs appeared in the corpora were considered. A total of 416 examples were found. Of these, 133 were discarded because they were reformulations, false beginnings, crystallized phrases or formed part of other combinations, such as tan solo 'only', no tan solo 'not only', no solo... sino 'not only... but also', no solo que... sino 'not only that... but also', solo que 'only that', no solo... también 'not only... but also'. These collocations with solo could be considered in a wider study, since they cross-reference another kind of information: inclusion, condition, explanation, etc. The final database for this study was made up of 283 examples of both forms of the adverbial pair: 177 (63\%) instances of the short form and 106 (37\%) instances of the long form.

\subsection{Semantic function of solo-solamente}

The results of the semantic analysis are consistent with what other authors have observed before, that the solo-solamente adverbial pair expresses exclusivity, uniqueness, limitation or restriction ((10) and (11)) (Ferrari, Giammatteo \& Albano 2011:30).

(10) la Universidad Autónoma de Nuevo León es una institución educativa que no persigue fines de lucro, dedicado solamente a la investigación

$(C H D M)$ 'The Autonomous University of Nuevo León is an educational institution that does not pursue financial gains, dedicated only to research'

(The University is dedicated only to $\mathrm{X}$, where $\mathrm{X}=$ to the research, and nothing more than to $\mathrm{X}$ [it shall not obtain financial gains, etc.]) 
(11) los oyes hablando en un dialecto que solamente ellos entienden

$(C H D M)$ 'You hear them speaking in a dialect only they understand' (they only $\mathrm{X}$, where $\mathrm{X}=$ understand, and nobody else than $\mathrm{X}$ )

In all of the examples found, solo-solamente carries a semantic value of exclusivity; nevertheless, in many of these examples this meaning is diluted or blurred, and another unspoken, nuanced meaning arises which is understood from the context (12) (Barrenechea 1977:313; Di Tullio 2010: 141; RAE \& ASALE 2010: 593; Hummel 2012: 145). This pragmatic meaning is deliberately promoted by the speaker with the purpose of revealing his/her point of view and of including the interlocutor in the communicative interaction.

(12) es que solo falta que esté ahí/ en la plaza

$(\mathrm{CSCM})$

'All we need now is that he/she is there/ in the square'

(In their opinion, it would be unbelievable that he/she is there; he/she would not be ashamed to be/go there)

Moreover, it is observed that with the use of these adverbs, the information can be attenuated ((13) to (15)) or it can be intensified ((16) to (17)); that is to say, it is possible to increase or decrease the importance of what is enunciated. In such cases, Hummel (2012:145) identifies these adverbs as elements with subjective and pragmatic effects.

(13) si yo te hubiera, dejado sin revisar, la respuesta, por una falta ortográfica, critica mi trabajo, pero si solamente, estoy diciendo, aquí va una uve aquí es ese ce o aquí va con hache, tómalo como un valor agregado a mi trabajo

$(C H D M)$ 'if I had decided not to check your answer because of spelling mistakes, that criticizes my work, but if I'm only saying a "u" goes here, this is a "c", and this goes with an " $h$ ", take it as added value of my work"

( $\mathrm{X}$ thinks it is not bad show writing mistakes)

(14) E: pero yo solo le conté a Concepción

$($ CSCM $)$

'But I only told Concepción'

I: pero ya lo sabe todo el mundo

'But the whole world already knows'

(X thinks it is not that bad, he/she did not tell everyone, he/she only told one person)

(15) I: de ellos sí dejamos a dos tres, un poco golpiados y ellos nomás un, amigo de nosotros porque, solo se resbaló y se cortó contra el suelo (CHDM) 'Of them we left two or three, a little beaten and only them a, friend of ours because, only/alone he slipped and cut himself against the ground' (X thinks nothing serious happened to his friend; he turned out to be injured because he slipped, not because he was beaten) 
(16) Y ahora ni el litro ¡chin!, ahora solo un litro de leche cuesta más de lo que costaba una caja anteriormente

$(C H D M)$

'And now not even a liter, damn!, now only a liter of milk costs more than what a box cost previously'

( $\mathrm{X}$ thinks it is inadmissible that now it is paid more for a litter tan before for a box)

(17) me acuerdo qué me enfermé, y me recetaron un antibiótico bastante fuerte, y venían solo ¡dos pastillas! en la cajita y costaba trescientos pesos, la medicina, mmhh, dije "híjole"

(CSCM)

'I remember I got sick, and I was prescribed a very powerful antibiotic, and only two pills were in the small box; it cost three hundred pesos, the medicine, mmh, I said "oh, boy"

(X thinks the price paid for two pills was excessive)

It is important to mention that when the enunciation acquires a nuancing value, the exclusivity value is not lost, only weakened; the quality of exclusivity is always latent and can be easily recuperated. In many occasions, the semantic load of these elements depends on the context of the communicative interaction and the interpretation will be inherent to the idiosyncrasies and the culture of the interlocutors.

The results (Table 1) show that 93 examples, in addition to carrying a meaning of exclusivity, carry the nuancing value, either to attenuate or to intensify. Furthermore, the data reveal that when there is an exclusivity value, it is more likely that the short adverb solo is used $\left(X^{2}=7.4218\right.$, g.l. $\left.=2, p \leq 0.02\right)$ and when there is a nuancing value it is more likely that the long adverb solamente is used $\left(X^{2}=5.3349\right.$, g.l. $\left.=1, p \leq 0.02\right)$, as is confirmed by statistical analysis.

Table 1. Semantic value frequency of solo-solamente

\begin{tabular}{lcc}
\hline Semantic value & Short solo & Long solamente \\
\hline Exclusivity & $110(62 \%)$ & $80(75 \%)$ \\
Attenuation & $46(26 \%)$ & $22(21 \%)$ \\
Intensification & $21(12 \%)$ & $4(4 \%)$ \\
Total & $\mathbf{1 7 7}(\mathbf{1 0 0 \% )}$ & $\mathbf{1 0 6}(\mathbf{1 0 0 \% )}$ \\
\hline
\end{tabular}

\subsection{Type of focus and syntactic function of the focus}

Due to the fact that the two forms in the adverbial pair solo-solamente function as focus operators, they require a focus (Hoeksema \& Zwarts 1991:52) that is always under the control of the operator. In relation to this, it has been observed that the focus is not always narrow as Gutierrez Bravo (2008:378) claims. The data in this 
analysis also show focus elements that are wide. Out of 283 examples (Table 2), 159 present a narrow focus ((18)), while 124 present a wide focus ((19) and (20)); thus, it is clear that the narrow focus is indeed prominent.

(18) ¿Qué fiestas acostumbra celebrar?

'Which holidays do you usually celebrate?'

Pos solo Navidad

$(C H D M)$

'Well only Christmas'

(and they do not celebrate anything else)

(19) normalmente cada quien escribe por separado, el baterista no escribe [...] (CSHM) de hecho, solamente tiene una canción, o al menos, una letra, que él aportó

'usually each one writes separately, the drummer does not write [...] (CSHM) in fact / he only has one song, or at least, one letter, that he contributed' (and he does not write anything else)

(20) ¿No invitan 'amigos?

'Don't you invite friends?

¡N'hombre tá muy caro!, no, solo nos, nos juntamos, por ejemplo..., mis hermanas, sus esposos, sus hijos, mi mamá, y nosotros, mi esposo y yo (CHDM) 'No, man, it's too expensive!, no, we only..., we get together, for example..., my sisters, their husbands, their children, my mother, and us, my husband and I' (and they invite no one else)

Table 2. Type of focus

\begin{tabular}{lcc}
\hline Focus & Short solo & Long solamente \\
\hline Narrow & $102(56 \%)$ & $57(54 \%)$ \\
Wide & $75(42 \%)$ & $49(46 \%)$ \\
Total & $177(100 \%)$ & $106(100 \%)$ \\
\hline
\end{tabular}

The results illustrate that the type of focus does not determine the presence of one or another operator (i.e. solo or solamente); this is confirmed in the statistical analysis $\left(X^{2}=0.3997\right.$, g.l. $\left.=1, p=.81\right)$.

Likewise, the data confirmed that the focus operators solo-solamente can focus on any element in a clause (Ferrari et al. 2011:33); however, the elements in focus are not only arguments ((21) and (22)), but also adjuncts ((23) and (24)), phrases ((25)) or clauses ((26)) (García Miguel 1995:20-1).

(21) Solamente mis tres hermanos, ellos compran todo

$(C H D M)$ 'only my three brothers, they buy everything' (Subject focuser) 
(22) [...] ellas hablan solamente el español ¿verdad?

(CHDM)

'They speak only Spanish, right?'

(Object focuser)

(23) ¿ha vivido en otro lugar, aparte de Monterrey?

(CSHM)

no, no, solamente aquí

Have you lived in anyother place, besides Monterrey?'

'no, no, only here'

(Place adverbial complement focuser)

(24) yo creo que solamente así nos pudo sacar adelante.

'I think that only like this could he/she make us prosper'

$(\mathrm{CSCM})$

(Manner adverb focuser)

(25) puede parecer algo muy exclusivo, de algunos muy conocedores, sólo para expertos

(CSCM)

'it may seem rather exclusive, to people who have knowledge about this, only for experts'

(Phrase focuser)

(26) solo estuvimos tu mamá y yo ¿no?

$(C S C M)$

'Only your mother and I were there, right?'

(Clause focuser)

The data demonstrate that both focus operators have great frequency focusing on clauses; nonetheless, arguments and phrases are also quite frequent as objects of focus (Table 3). Even so, it is important to mention that the syntactic function of the focus does not determine the presence of the short or long focus operator according to the statistical analysis $\left(X^{2}=3.2711\right.$, g.l. $\left.=3, p=0.35\right)$.

Table 3. Syntactic function of the focus of solo-solamente

\begin{tabular}{lcc}
\hline Focus & Short solo & Long solamente \\
\hline Argument & $57(32 \%)$ & $28(26 \%)$ \\
Adjunct & $13(7 \%)$ & $14(13 \%)$ \\
Phrase & $42(24 \%)$ & $27(26 \%)$ \\
Clause & $65(37 \%)$ & $37(35 \%)$ \\
Total & $177(100 \%)$ & $106(100 \%)$ \\
\hline
\end{tabular}

\subsection{Syntactic position of solo-solamente}

With regard to the syntactic position of the focus operators, all examples were located adjacent to the focus ((21) to (26)). 
It was noted that focus operators are usually located to the left of the focus ((21) to (26)). Although there were cases in which the focus operator appeared on the right of the focus $((27))$ (Table 4$)$, such cases were almost nonexistent as they represent a mere $1 \%$ of the sample.

(27) $[. .$.$] y ver pues, lo que pasaba en la tele solamente$ 'and to see what was on TV only'

$(\mathrm{CSCM})$

Table 4. Syntactic position of the focus operator as right or left

\begin{tabular}{lcc}
\hline Position & Short solo & Long solamente \\
\hline Left & $177(100 \%)$ & $104(98 \%)$ \\
Right & $0(0 \%)$ & $2(2 \%)$ \\
Total & $177(63 \%)$ & $106(100 \%)$ \\
\hline
\end{tabular}

As it can be seen, both operators (i.e. short and long) appear more prominently to the left of the focus. The long adverb solamente appears in 104 instances (37\%) on the left and only 2 instances (1\%) on the right ((28)) of the element under focus.

(28) Tú has hecho primaria solamente ¿no?

$(C H D M)$

'You have studied elementary school only, right?'

The short adverb appears without exception on the left of the focus. It is important to mention that when solo occurs on the right of the focus, it functions as an adjective and not as an adverb ((29) to (31)). When comparing Example (29) with Examples (30) and (31), it can be noticed that the adjective solo (i.e. 'alone') must formally maintain concordance with the subject or object which it modifies, otherwise it is ungrammatical (as in (29)). When used as an adjective, solo can function as an attribute or as a depictive secondary predicate (cf. Schultze-Berndt \& Himmelmann 2004:59).

(29) ${ }^{*}$ María escucha discos de música clásica solo

'María listens to CDs of classical music alone'

${ }^{*}$ Solo is not in agreement with María (a feminine noun), so it is ungrammatical in Spanish.

(30) y cada quien se atiende y se sirve solo

$(C H D M)$

'And everyone attends and serves themselves alone'

(31) me da miedo dejar lo solo porque orita hay mucho peligro

$(C H D M)$ 'It scares me to leave him alone because it's too dangerous' 


\subsection{The adverb-adjective interface of solo}

According to what was observed in some examples taken from the corpora, semantic ambiguity between the adverb and the adjective solo does occur in the corpora's transcriptions. While in some cases the double reading of this semantic ambiguity is disambiguated by the surrounding context of the utterance, in other cases it is not. It would be necessary to observe how such examples would be transcribed in the written register according to the application of the New Orthographic Reform of the RAE \& ASALE (2010), in which the omission of the diacritical accent in the adverb solo could cause confusion in meaning. Thus, solo could easily be understood as an adjective instead of an adverb or vice versa if there is not enough context to clarify the message.

In Example (32), ambiguity can be perceived because solo could be considered either an attribute of the pronoun uno or a modifier of the subordinate clause que trabaje; both interpretations are possible.

(32) la madre es para cuidar los hijos ¿verdad?, que aunque pos ya ahorita ya están cambiando mucho las cosas porque pos si, con uno solo que trabaje no le alcanza a uno

$(C H D M)$ 'a mother is meant to take care of children, right?, and even though things are changing a lot because, well, when there's one alone/only who works, it's difficult to make ends meet'

This structural ambiguity has been called "interface", and it refers to the lack of a semantic, formal or functional distinction between two categories; that is, there is the possibility for one structure to be understood in two different ways. The existence of two possible interpretations is caused by the functional and morphological indistinctness inherent to certain elements in the sentence (cf. Rodríguez Díez 1997:97). Moreover, Hummel (2008: 130) proposes the mono-categorical system, which identifies only one morphological category, without making a distinction between an adverb and adjective at the language level.

Furthermore, certain contexts exist in which an adverb-adjective interface is favored as seen in the following Examples ((33)-(35)).

(33) [focos] en la lavandería hay dos, son siete, aquí son dos, son nueve, bueno es uno solo porque es el candil pero vamos a ponerlo como nueve

(CDHM) '[light bulbs] in the laundry room there are two, that's seven, here there are two, that's nine, well it's one alone/only because it's the lamp, but we're going to put like nine'

(34) [yo] Estaré solo hasta las tres

$(\mathrm{CSCM})$

'I will be (here/there) alone/onlyuntil three' 
(35) pero yo solo oí dije ¡híjole!

$(C H D M)$

'but I only/alone heard and said "oh boy!"

Similar to Example (32), in Example (33) the location of solo causes ambiguity, as solo can refer to uno or it can refer to the following subordinate clause. If it refers to the former, then it is an attribute; but if it refers to the latter, then it is focus operator. In Example (34) the copulative verb requires the presence of an attribute; however, solo has the capacity of projecting itself in order to modify the adverbial phrase hasta las tres, in which case it becomes a focus operator. A similar case can be seen in (35), where the presence of the pronoun yo could give adjectival semantics to solo; even so, solo can also project itself to the predicate and focalize the most prominent element, which in this case would be the verb oir.

In order to delve deeper into the topic of interface, the following example was manipulated and mapped out with the objective of better observing how certain syntactic positions and context elements produce cases of interface.

+ adverb

A

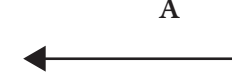

adverb-adjective interface

B

(A) E: ¿y todas las noches lees?

'Do you read every night?'

I: sí solo cuando me voy allá

'Yes, only when I go there'

(X reads only when he/she goes to that place)

(B) I: sí cuando solo me voy allá

'Yes, when I only go there'

'Yes, when I go there alone'

(when $\mathrm{X}$ only goes to that place or when $\mathrm{X}$ goes in a state of aloneness)

(C) I: sí cuando me voy allá solo

'Yes, when I go there alone'

(when $\mathrm{X}$ is in a state of aloneness)
(CHDM)

C

\section{Figure 1. Interface adjective-adverb internal position}

In Figure 1, it can be observed that when solo is at the extreme left (A), it conveys adverbial semantics, whereas if it is to the right of the phrase or clause, it acquires adjectival semantics (C). Thus, there is no doubt between (A) and (C) when solo has abandoned adverbial semantics and has acquired adjectival semantics. In contrast, in (B) there is ambiguity, as both interpretations are possible.

As it has been observed, in certain contexts and with certain surrounding grammatical elements, interface is produced. When this occurs, solo exhibits 
ambivalence and is thus inclined to modify either the most restricted element or the most prominent element of a clause or enunciation.

The following examples, (36) and (37), are given in order to illustrate that an adjective with noun concordance appears in the same position in which interface normally occurs (as seen in Figures 1 to 3 above).

(36) Yo sola tengo que aprender por mí misma.

$(\mathrm{CSCM})$

'I alone have to learn by myself.'

(In this state of aloneness)

(37) ¿Y usted sola empezó [algo]?

$($ CSCM $)$

'And did you start [something] alone?'

(In this state of aloneness)

In these examples it is observed that a double predication is given which includes a principal predication and a secondary predication (Schultze-Berndt \& Himmelmann 2004). In (36), the principal predication is tengo que aprender por mí misma ('I have to learn by myself') and the secondary predication is tengo que hacerlo sola ('I have to do it alone'). In (37), the principal predication is usted empezó ('you started') and the secondary predication is lo hizo sola ('you did it alone'). In these cases there is no ambiguity as the adjective with feminine noun concordance has no semantic ambiguity.

However, as mentioned before, if the gender of the adjective is masculine, then another meaning can be understood, as seen in the following: Yo solo tengo que aprender por mí mismo ('I only have to learn by myself') or ¿Y usted solo empezó? ('And you only started?'). These examples now present clear cases of interface because of the positioning of solo and because the masculine adjective solo has the same form as its short adverbial counterpart.

Out of the 373 total instances of the element solo, 177 examples have adverbial semantics (of which only six show this double reading) and 196 have adjectival semantics. The frequency of use of the adjective is similar to that of the adverb, $47 \%$ and 53\% respectively. However, of the 177 instances of the adverb solo, only $6(3 \%)$ presented ambiguity and were thus considered cases of interface.

\section{Final considerations}

The results of the present study corroborate what several authors have indicated regarding the use of the short adverb or the adverbialized adjective solo: that it exhibits a high frequency of use in oral register. On the other hand, it is important to highlight that the long adverb or deadjectival adverb solamente also had a high 
frequency in the oral register corpora, which is not common for other long adverbs. The reason for the high frequency of solamente seems to be due to the fact that both forms of the adverbial pair solo-solamente belong to the classification of focus operators, and thus are more frequently used in the oral register because of their discursive function.

Semantically, all the examples of both forms of the adverbial pair have an exclusivity reading; however, in 93 examples this exclusivity value is diluted and another meaning is activated that nuances the information. Thus, the findings of this study confirm that these adverbial elements do indeed help clarify the speaker's communicative intention. It is noteworthy that the variable for semantic function of solo-solamente was the only statistically significant variable. The results show that when there is primarily an exclusivity value indicated, it is likely that the short focus operator solo is utilized, whereas when there is a nuancing value present, it is more likely that the long adverb solamente is employed.

It is important to highlight that the nuancing value is perceived in $33 \%$ of the examples, which was an unexpected tendency, particularly for the long form solamente. Perhaps this tendency is evidence that these elements are in the process of bleaching, in which they are converting themselves into discourse markers.

In relation to the analysis of syntactic function, it was confirmed that both forms of the adverbial pair solo-solamente function as focus operators and introduce narrow focuses. Nevertheless, the results show that wide focuses also occur. However, this variable was not statistically significant.

On the other hand, the results reveal that these focus operators place focus on arguments, adjuncts, phrases or clauses. Even so, neither focus operator (i.e. solo or solamente) exhibited preference for any of these particular types of focus. This variable was also not significant.

According to the syntactic position results of the solo-solamente adverbial pair, focus operators were found in the adjacent position and to left of the element in focus. In a few cases, the long adverb also appeared to the right of the focus. When the short adverb solo appeared to the right of the focus, its reading was not of an adverb, but of an adjective. However, when solo appeared in the middle position or on the border of a non-delimited phrase, then interface was present. With this, it is observed that interface between the adverb solo and the adjective solo occurs in the syntax, for that is where functional differences are indicated. Even so, the number of examples of interface in the data was scarce: of the 177 cases of the short adverb, only 6 cases were ambiguous, which barely represents 3\%. Thus, it is necessary to continue searching for ambiguous cases in order to provide a wider and more decisive conclusion in this respect.

In accordance with this descriptive approach, it is observed that the two forms of the adverbial pair behave in a similar manner: both provide a meaning 
of exclusivity and both appear with a nuancing value. Moreover, the two forms are interchangeable; that is, the meaning of the sentence does not change if one is substituted for the other, except for the case when the long adverb is at the end of the clause. With respect to syntactic position, both focus operators can head clauses or phrases; both can place focus on arguments, adjuncts or phrases; and both can appear with either a narrow or a wide focus.

Therefore, it has been determined that these two linguistic forms, solo and solamente, have the same discursive function. This conclusion suggests that a complementary distribution does not exist between the two forms since they compete in the same linguistic variables and consequently are synonyms. However, it is important to emphasize that it is more likely that the short form solo will appear if there is a semantic value of exclusivity, while it is more likely that the long form solamente will appear if there is a semantic nuancing value.

\section{Acknowledgements}

We would like to thank Mónica Sanaphre Villanueva and E. Haydee Carrazco Ortiz for their valuable comments and feedback. Any errors found within this paper are the sole responsibility of the authors.

\section{References}

Barrenechea, Ana María. 1977. Operadores pragmáticos de actitud oracional: Los adverbios en -mente. In Estudios sobre el español hablado en las principales ciudades de América, Juan M. Lope Blanch (eds), 313-332. México: UNAM.

Cárdenas, Viviana. 2010. La relación entre semántica y sintaxis desde la perspectiva de la producción de lenguaje escrito. Tópicos del seminario 23: 241-289.

Costa, João. 2008. Adverbs and the syntax-semantics interplay. Linguistic Studies 2: 13-25.

De Mello, George. 1992. Adjetivos adverbializados en el español culto hablado de diez ciudades. Lingüística del Español Actual 14: 225-242.

Di Tullio, Ángela. 2010. Manual de gramática del español. Buenos Aires: Waldhuter.

Face, Timothy L. 2002. El foco y la altura tonal en español. Boletín de Lingüística 17: 30-52.

Ferrari, Laura, Giammatteo, Mabel \& Albano, Hilda. 2011. Operadores de foco: El caso de incluso, hasta, solo y aun. Cuadernos de la ALFAL 3: 30-41.

García Miguel, José María. 1995. Las relaciones gramaticales entre predicado y participantes. Colección Lalia, Series Maior 2: 11-39.

Gutiérrez Bravo, Rodrigo. 2008. La identificación de los tópicos y los focos. Nueva Revista de Filología Hispánica 56: 362-401.

Gutiérrez, Yurena María. 2010. Sobre foco nomás. In La renovación de la palabra en el bicentenario de la Argentina 77: 625-632, Víctor M. Castel \& Liliana Cubo de Severino (eds), Barcelona: Universidad Autónoma de Barcelona. 
Hoeksema, Jack \& Zwarts, Frans. 1991. Some remarks on focus adverbs. Journal of Semantics 8: 51-70. doi:10.1093/jos/8.1-2.51

Hummel, Martin. 2001. Adjetivos adverbiales flexionados y adjetivos adverbializados invariables en castellano contemporáneo. Construcciones del tipo Los niños duermen tranquilos y María corre rápido. Lengua 12: 9-52.

Hummel, Martin. 2002. Sincronía y diacronía del sistema atributivo de las lenguas románicas. Revista Lengua 13: 9-48.

Hummel, Martin. 2008. La predicación secundaria en el habla oral informal de Chile. Revista Elua 22: 129-149. doi:10.14198/ELUA2008.22.07

Hummel, Martin. 2012. Polifuncionalidad, polisemia y estrategia retórica. Los signos discursivos con base atributiva entre oralidad y escritura. Berlin: Walter de Gruyter. doi: $10.1515 / 9783110281248$

Hummel, Martin. 2013. Attribution in Romance: reconstructing the oral and written tradition. Folia Linguistica Historica 34: 1-42. doi:10.1515/flih.2013.001

Karlsson, Keith E. 1981. Syntax and Affixation. The Evolution of MENTE in Latin and Romance. Tübingen: Max Niemeyer. doi:10.1515/9783111329017

Lara Ramos, Luis Fernando. 2011. Diccionario del español de México. México: El Colegio de México.

Lastra, Yolanda \& Martín-Butragueño, Pedro. 2011. Corpus sociolingüístico de la ciudad de México. México: El Colegio de México.

Martínez Marín, Juan. 2006. Los adverbios en -mente y los diccionarios modernos del español: Perspectiva pragmático-discursiva. In Análisis del discurso: Lengua, cultura y valores, Actas del I Congreso Internacional, II, Manuel Casado Velarde, Ramón González Ruiz \& María Vitoria, Romero Gualda (eds), 1433-1444. Madrid: Arco/Libros.

Medina Gómez, Lorena \& Alarcón Neve, Luisa Josefina. 2013. El adverbio de manera corto en el español formal de México. Journal Verba Hispánica XXI: 55-74. doi:10.4312/vh.21.1.55-74 Prieto, Pilar. 2003. Teorías de la entonación. Barcelona: Ariel.

Real Academia Española (RAE) \& Asociación de Academias de la Lengua Española (ASALE). 2010. Madrid: Espasa.

Rodríguez Alfano, Lidia, Flores Treviño, María Eugenia \& Pérez Aguirre, Tzitel. 2012. Corpus Monterrey-PRESEEA. México: Facultad de Filosofía y Letras, UANL.

Rodríguez Díez, Bonifacio. 1997. El recurso a la neutralización en lingüística. León: Universidad de León.

Schultze-Berndt, Eva \& Himmelmann, Nikolaus P. 2004. Depictive secondary predicates in crosslinguistic perspective. Linguistic Typology 8: 59-130. doi:10.1515/lity.2004.004

Seco, Manuel. 2002. Diccionario de dudas y dificultades de la lengua española. Madrid: Espasa.

Véliz, C. Mauricio. 2010. La Fonología del Foco Contrastivo en la variedad de inglés denominada RP y español de Chile. Literatura y lingüística 21: 61-73. 



\title{
From adjective to adverbial modal locutions in Spanish
}

\author{
Rosa María Ortiz Ciscomani \\ Universidad de Sonora, Mexico
}

\begin{abstract}
This paper focus on an issue at present not well-known, neither in the synchronic nor in the diachronic perspective, that is, the adverbial modal locutions in Spanish with an adjective lexical base - a nominalized adjective or a nominal phrase - displaying the ending - as, in a prepositional phrase with the preposition $a$. The paper offers a diachronic analysis of these locutions from the 12th to 20 th centuries. It describes the adjectives entering in this construction and provides evidence to support the emergence of an adverbial scheme with a specific, expressive or subjective, function. It also aims to show that the adverbial modal scheme arose relevant to the fifteenth century from the original prepositional phrase by a constructional grammaticalization change.
\end{abstract}

\section{Introduction}

In Spanish, there is a sort of Adverbial Modal Locution, characterized by its lexical base: a noun or an adjective ending in - as, in a prepositional phrase with the preposition $a$, as in a gatas in Example (1), and in a solas, a ciegas, a tontas y a locas, in Example (2):

(1) no podía andar paso ninguno por el peso de las cadenas y por el ' $(\mathrm{He})$ could not walk a full step because of the weight of the chains and because quebrantamiento de sus piernas y cuerpo, sino iba a gatas y como podía the pain in his legs and body, rather (he) moved on all fours and as (he) could' (Alonso Maldonado, Hechos del Maestre de Alcántara don Alonso de Monroy, c. 1492, CORDE)

(2) a. Dixo Moysen al Nuestro Sennor: "Non puedo a solas levar esta carga" (Almerich, La fazienda de Ultramar, c. 1200, CORDE) 'Said Moses to Our Lord: "Not (I) can unaided/by myself carry this load"' b. y ahora hablamos a ciegas (Juan Orozco, Vejamen, a 1650, CORDE) 'and now (we) speak unthinkingly/blindly' 
c. porque a lo poeta hablas a tontas y a locas
'because as a poet (you) speak haphazardly'
(Miguel de Barrios, Contra la verdad no hay fuerza, a 1672, CORDE)

This paper will focus on locutions with an adjective base (2), locutions with a nominalized adjective base (3), and nominal phrases with an adjective displaying the same ending (4):

(3) y esto que andas mostrando como por resquicios, acaua de mostrarlo a las claras

'and this that (you) are showing as by chinks, (he) just showed it openly'

(San Juan de la Cruz, Cántico espiritual, 1578-1584, CORDE)

(4) Y si alguno quisiere decir que hay palabras maliciosas, digo que no quiera 'And if any man wanted to say that there are malicious words, (I) say that not want

nadie glosar malicias imputándolas a mí, porque yo no pensé poner anynone gloss malice imputing them to me, because I did not think to put nada que no fuese claro y a ojos vistas anything that not was clear and obviously/visibly clear'

(Francisco Delicado, La lozana andaluza, 1528, CORDE)

The locutions in (3) and (4) have a similar modal meaning to the locutions in (2) and a similar structure to the preposition and the adjective ending.

This issue falls in the scope of the adjective and adverb interface in Spanish grammar at present not well-known, neither in the synchronic nor in the diachronic perspective.

Diachronically, this subject is a particularly thought-provoking and challenging area, as there is little information on the origin of the aforementioned locutions. It is not known which adjectives can occur or which adjectives were documented historically in the locutions. There isn't enough evidence to support the aforesaid ending - as in an adjective without an agreeing noun. Furthermore, we don't know how the modal meaning arises.

This paper offers a diachronic analysis of adverbial modal locutions with an adjective ending in -as (between the 12th and 20th centuries). It describes the adjectives entering in this construction and provides evidence to support the emergence of an adverbial scheme with a specific function, different from the one of the adverbial adjective as solo in (5), and both from the long adjective with -mente and from the short adjective in (6); that is, from the attributive system in Romance Languages (Hummel 2013). 
(5) a. legose allas puertas del castillo el solo

'(he) arrived to the doors of the castle he alone'

(Anónimo, Cuento de don Tristán, c1313-c1410, CORDE)

b. si el juyz non lo puede prender por sí solo, demande al sennor

'if the judge not him can capture by himself alone, (he should) ask the lord que.l aiude

(Anónimo, Fuero Juzgo, 1250-1260, CORDE)

for help'

(6) a. e alli se tirauan ... tantos dardos que non osauan los armados 'and there were thrown ... so many arrows that non dare the armed people descobrir los ojos solamente (Anónimo, Historia troyana, c 1270, CORDE) to uncover the eyes only'

b. fue vençido dellos no solo / de dolor mas de enojo 'was defeated by them not only because of pain but because of anger'

(Pero López de Ayala, Caída Príncipes,1402, CORDE)

This chapter aims first, to point out that the main difference between a locution with adjective ending in -as (as the ones in (2), (3) and (4)), and long and short adverbs (as the ones in (5) and (6)), is the expressive, or subjective, meaning of the locution; and second, that an adverbial modal productive scheme - with a diachronically increasing amount of adjective types (derechas 'correctly', medias 'imperfectly', hurtadillas 'furtively' / 'on the sly' / 'stealthily', escondidas 'secretly', secas 'plainly', among many others) and tokens - arose relevant to the fifteenth century from the original prepositional phrase. Additionally, the paper will present evidence for a constructional grammaticalization change, via a process of schematization, as well as contextual data that supports the singular expressive function of that scheme.

The subject matter of the chapter is divided into five sections. Section 2 provides information concerning the source of analyzed data and its general quantitative characteristics. Section 3 is an overview of the topics mentioned herein. Section 4 includes the main results of the qualitative analysis and offers an explanation for the change from a Prepositional Phrase to an Adverbial Locution as an example of constructional grammaticalization. Section 5 summarizes the findings.

\section{Corpus and methodology}

The corpus of this research consists of 7,808 tokens from two different sources. The first is a base corpus made up of 13 texts written between the 12th and 20th centuries from Spanish language (see Corpus in Bibliography), comparing Mexican Spanish and Peninsular Spanish from 17th century onwards. This corpus yielded 162 tokens. The second is a complementary corpus from all documents in Books 
Section for Spain in the Corpus Diacrónico del Español (CORDE), excluding those of the base corpus, which yielded 7646 tokens, to confirm or reject the results of the base corpus. Table 1 contrasts the outcomes of the base and complementary corpus. It shows a low frequency of use of the locutions between the 12th and 15th centuries; a fluctuating frequency between the 16th and 18th centuries; and high frequency of use in the 19th and 20th centuries.

Table 1. Total of types and frequency of use: Base corpus vs. Complementary corpus

\begin{tabular}{lccccccccccc}
\hline Base corpus & & 12 th & 13 th & 14 th & 15 th & 16 th & 17 th & 18 th & 19 th & 20 th & \\
& tokens & 0 & 7 & 1 & 1 & 6 & 10 & 11 & 95 & 31 & 162 \\
& $\%$ & & 4 & .6 & .6 & 3.7 & 6.1 & 7 & 59 & 19 & \\
Complementary & tokens & 67 & 296 & 332 & 444 & 1329 & 1174 & 234 & 1502 & 2268 & 7646 \\
corpus & $\%$ & 1 & 4 & 4 & 6 & 17 & 15 & 3 & 20 & 30 & \\
\hline
\end{tabular}

Figure 1 contrasts how often types were used in both the base corpus and the whole corpus (base and complementary). The frequency is similar in both sources; however, there is a difference in the 19th century, which appears to be more related to the topic of the texts in the base corpus (specifically with the peninsular text), than with the genre (See Table 3). ${ }^{1}$

An additional search of all adjective locutions was conducted using a historical dictionary - Nuevo Diccionario Histórico de la Lengua Española (NDHE) - in order to confirm the reliability of the results. This dictionary provided not only the absolute number of tokens (1648) but also the normalized frequency (calculated over a million words). Table 2 shows the outcome of the search, which is consistent with the information in Table 1, regarding absolute frequency (low until the 15th century, fluctuating between 16th and 18th centuries and high in the 19th and 20th centuries) and norm frequency behavior (increased in the 19th and 20th centuries).

Table 2. NDHE: Absolute and normalized frequency of use (tokens per million words) ${ }^{2}$

\begin{tabular}{lcccccccccc}
\hline & 12th & 13th & 14th & 15th & 16th & 17th & 18th & 19th & 20th & Total \\
\hline Absolute & 2 & 85 & 41 & 102 & 172 & 212 & 174 & 296 & 564 & 1648 \\
Normalized & 0.00 & 0.19 & 0.08 & 0.21 & 0.33 & 0.43 & 0.41 & 0.69 & 1.29 & \\
\hline
\end{tabular}

1. La Regenta criticizes moral and social aspects of the Restoration period in Spain such as adultery, religion and politics.

2. The frequency data in this table only includes the nuclear CDE corpus (XII-XX) for Spain. 


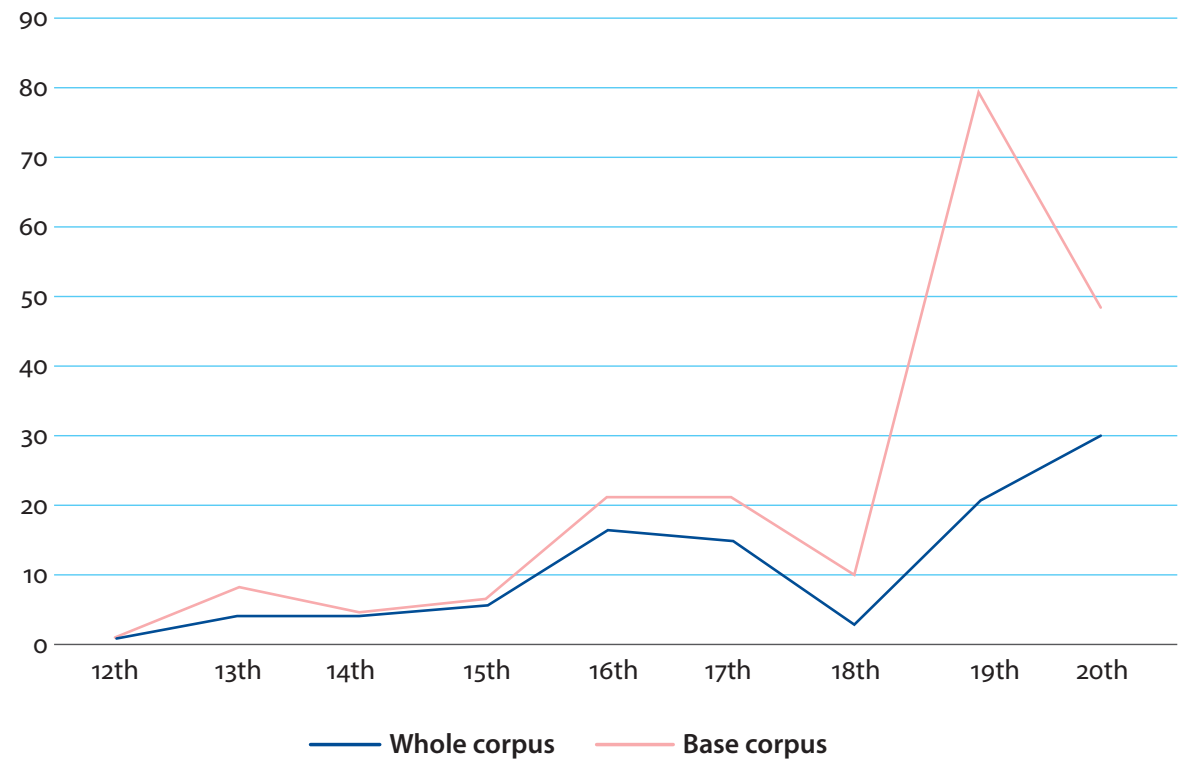

Figure 1. Frequency of type use: Base corpus vs. Whole corpus

Figure 2 shows the normalized frequency of use in the historical dictionary and confirms the increase during the 19th and 20th century.

The base corpus contrasts data from Peninsular and Mexican Spanish from the 17 th century onwards to see if there is a similar behavior between the varieties. Table 3 shows the distribution of types and tokens in the base corpus per century and region. It demonstrates that the adjective types are few, and that their frequency of use is low (most of them $<10 \%$ ), except for a solas and a oscuras, which gather almost half of the tokens (48\% (78/162)). Table 3 also shows that the frequency of type use in Peninsular Spanish is higher than in Mexican Spanish.

The collection of locutions identified above is not exhaustive. I began by looking at the group of previously defined examples and later added the locutions found in the base corpus texts to the items list. 


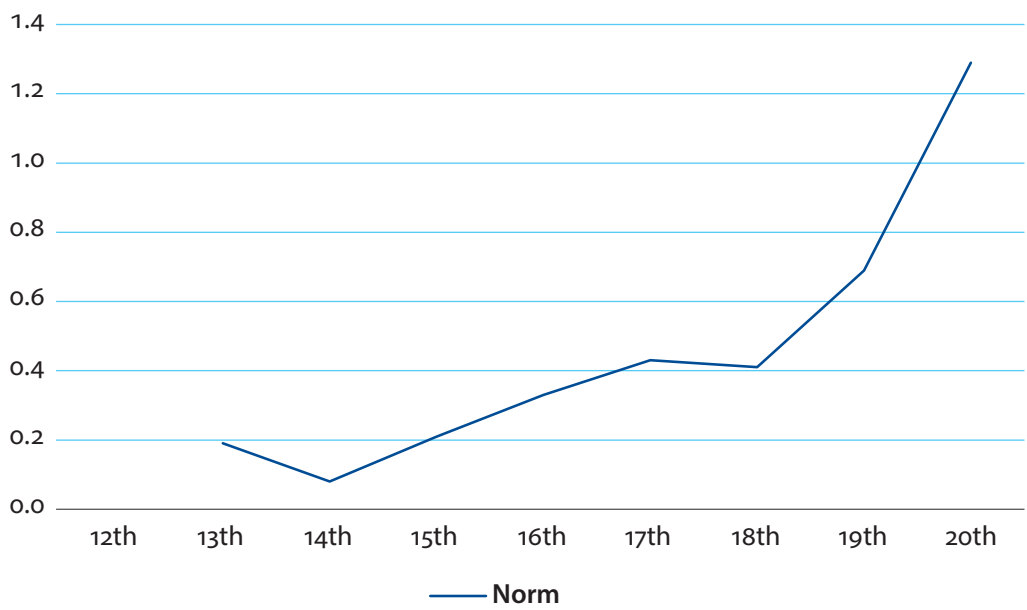

Figure 2. Normalized frequency of type use in NDHE

Table 3. Types and tokens in the base corpus

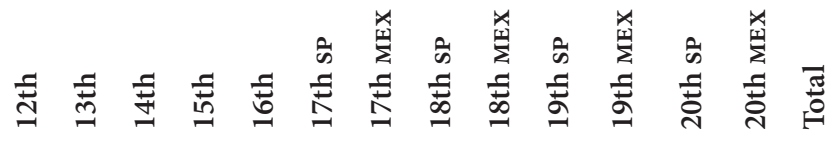

A primas

'firstly, originally'

A osadas

'boldly'

A derechas

'correctly, rightly'

A medias

'half, faultily'

A sabiendas

'knowingly, consciously'

A las derechas

'honestly'

A escondidas

'secretly'

A ojos vistas

'obviously'

A duras penas

'with great difficulty'

A secas

'plainly'
1

3

3

2

1

4

1

$\begin{array}{llll}1 & 5 & 2 & 7\end{array}$

16

1

1

3

21

3

1

12

26

31

2

6

1

$\begin{array}{lll}3 & 1 & 2\end{array}$

1

2

13 


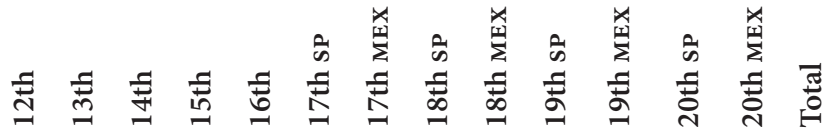

\begin{tabular}{|c|c|c|c|c|c|c|c|c|c|c|c|c|c|c|}
\hline $\begin{array}{l}\text { A solas } \\
\text { 'alone, in private' }\end{array}$ & & & & & & & 4 & 1 & & 34 & 5 & 5 & 1 & 50 \\
\hline $\begin{array}{l}\text { A o(e)scuras } \\
\text { 'in the dark' }\end{array}$ & & & & & & & & 5 & & 20 & & 3 & & 28 \\
\hline $\begin{array}{l}\text { A hurtadillas } \\
\text { 'furtively' }\end{array}$ & & & & & & & & 3 & & 2 & 1 & 1 & & 7 \\
\hline $\begin{array}{l}\text { A ciegas } \\
\text { 'blindly' }\end{array}$ & & & & & & & & & & 1 & & 1 & & 2 \\
\hline $\begin{array}{l}\text { A tientas } \\
\text { 'gropingly, uncertainly' }\end{array}$ & & & & & & & & & & 6 & 4 & 3 & 1 & 14 \\
\hline $\begin{array}{l}\text { A las malas } \\
\text { 'by force' }\end{array}$ & & & & & & & & & & & 2 & & & 2 \\
\hline $\begin{array}{l}\text { A las claras } \\
\text { 'openly' }\end{array}$ & & & & & & & & & & & 1 & & & 1 \\
\hline $\begin{array}{l}\text { A las primeras } \\
\text { 'suddenly, all of a sudden' }\end{array}$ & & & & & & & & & & & 1 & & & 1 \\
\hline $\begin{array}{l}\text { A tontas } \\
\text { 'thoughtlessly, carelessly' }\end{array}$ & & & & & & & & & & & & & 1 & 1 \\
\hline Total & 0 & 7 & 1 & 1 & 6 & 6 & 4 & 10 & 1 & 77 & 18 & 23 & 8 & 162 \\
\hline$\%$ & & 4 & .6 & .6 & 4 & 4 & 2 & 6 & .6 & 48 & 11.1 & 14.1 & 5 & \\
\hline
\end{tabular}

\section{The state of the art}

In general, Spanish historical linguistics has neglected the field of adverbial grammar. Nevertheless, it is well known that there are two ways an adverb is formed from an adjective: (i) an adjective that functions as an adverb without formal change (adverbial adjective or short adjective) (Hummel 2014), and (ii) an adverb with an adjective base and the suffix -mente or long adverb (Company 2014). But the knowledge about adverbial locutions with adjectives ending in -as is still scarce in both synchronic and diachronic perspectives.

Synchronically, the categorical status of the prepositional locutions we are dealing with, namely $a$ and a lexical basis ending in -as, is not controversial for grammars and grammarians who mention them. These locutions are considered adverbial modifiers, unanalyzable or indecomposable syntactic units with a non-compositional meaning (Corpas 2003; RAE-ASALE 2009: \$\$1.10c, 12.91), or 
phraseological units (García-Page 2008; Pavón 1999; Ruiz Gurillo 1997); however, it is unknown how they reached their current morphosyntactic features.

In diachronic perspective, there is no information regarding the origin of the ending - as in the locution; however, three aspects related to the vowel, to the consonant of the ending $-a$, and to the missing noun in the locution are pointed out in linguistic literature. As for the vowel, it has been said that the vowel $a$ not only characterized the feminine of Latin nouns 1st declension, but also the plural neuter nouns; it has been related with the evolution of this neuter gender class (Mariner 1968; Spitzer 1941) - the proper gender for the indeterminate, according to Mariner (1968). It has been suggested that some collective neuter nouns developed a feminine doublet so Latin had pairs such as bracchia - bracchias, labra - labras (documented in defixionum tabellae) (Väännänen 1968). The $a$ of -as functioning as a singular feminine marker has been considered as an effect of the complex history of the neuter in Romance languages (Mariner 1968: 1298). ${ }^{3}$ Spitzer (1941:347) affirms that it codifies a mental feminization of collectives and that its feminine feature is reflected in the elements it agrees with. For this author, the vowel is a subjective marker that reveals a speaker's feeling.

Concerning the final consonant $s$, typical of the Latin Plural Accusative, most of the authors who mention this matter assess it as an $s$ analogical with final /s/ of some other Latin adverbs such as the comparative magis 'more', laxius 'more loose', foras > español antiguo fueras 'outside’ (Lausberg 1966: \$\$ 696-698; Menéndez Pidal 1904/1940: \$ 128; Penny 1991/2002: 131). Lausberg (1966: \$ 699) claims that the explanation of adverbial -as remains obscure.

Finally, it has been explained that the missing noun in the locution (i.e., the missing noun head with which an adjective agrees, like solas in (2)) is an example of an ellipsis (García Calvo 1964; Mariner 1968; Spitzer 1941).

In this paper, I assume that the ending -as in the locution has a concomitant explanation, a subjective motivation; namely, it corresponds to one of the devices that the Spanish language created to encode expressiveness. ${ }^{4}$ As for the ellipsis hypothesis, it is a plausible explanation for early locutions, as we will see in Section 4, but not for all of the locutions in the corpus.

3. This phenomenon is known as "the feminization of neuter" (la feminización del neutro).

4. Our explanation covers locutions with nominal basis as a gatas (Example (1)). See Ortiz Ciscomani (2014) for details. 


\section{Adjectives documented in the locution: Types and tokens}

Table 4 includes all of the locutions found in the whole corpus and their development from the twelfth century until the twentieth century. The corpus documented a total of twenty-five adjective types: sixteen adjective types as the term of the Prepositional Phrase, three as modifiers of a noun, and six more as nominalized adjectives. The frequency of use in the whole corpus was low in the early centuries; it went oscillated and then tended to increase in the last two centuries.

Table 4. Adjectives types and tokens in locutions in the whole corpus (basic and complementary)

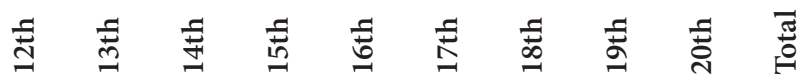

\begin{tabular}{|c|c|c|c|c|c|c|c|c|c|c|}
\hline $\begin{array}{l}\text { A primas } \\
\text { 'firstly, originally' }\end{array}$ & & 25 & 2 & & & & & & & 27 \\
\hline Primas & 50 & 72 & 12 & & & & & & & 134 \\
\hline $\begin{array}{l}\text { A certas } \\
\text { 'truly' }\end{array}$ & 1 & 3 & 1 & 1 & & & & & & 6 \\
\hline Certas & & 33 & 204 & 23 & & & & & & 260 \\
\hline $\begin{array}{l}\text { A derechas } \\
\text { 'correctly, rightly' }\end{array}$ & 5 & 18 & 4 & 39 & 24 & 39 & 5 & 23 & 66 & 223 \\
\hline $\begin{array}{l}\text { A medias } \\
\text { 'half, faultily' }\end{array}$ & 10 & 18 & 24 & 51 & 58 & 39 & 21 & 162 & 391 & 774 \\
\hline $\begin{array}{l}\text { A paladinas } \\
\text { 'openly, clearly' }\end{array}$ & & 4 & & 2 & & & & 6 & 1 & 13 \\
\hline $\begin{array}{l}\text { A sabiendas } \\
\text { 'knowingly, consciously' }\end{array}$ & 1 & 97 & 77 & 249 & 339 & 30 & 13 & 77 & 140 & 1023 \\
\hline Ad sabiendas & & 2 & 1 & & & & & & & 3 \\
\hline Sabiendas & & 2 & & & & & & & & 2 \\
\hline $\begin{array}{l}\text { A solas } \\
\text { 'alone, in private' }\end{array}$ & & 15 & 2 & 30 & 550 & 796 & 85 & 457 & 618 & 2553 \\
\hline $\begin{array}{l}\text { A osadas } \\
\text { 'boldly' }\end{array}$ & & 14 & 6 & 28 & 59 & 7 & 2 & 1 & & 117 \\
\hline $\begin{array}{l}\text { A ciegas } \\
\text { 'blindly' }\end{array}$ & & & & 1 & 50 & 83 & 27 & 74 & 129 & 364 \\
\hline $\begin{array}{l}\text { A escondidas } \\
\text { 'secretly' }\end{array}$ & & & & 6 & 25 & 24 & 10 & 43 & 128 & 236 \\
\hline $\begin{array}{l}\text { A oscuras } \\
\text { 'in the dark' }\end{array}$ & & & & 2 & 107 & 32 & 22 & 212 & 237 & 612 \\
\hline $\begin{array}{l}\text { A secas } \\
\text { 'plainly' }\end{array}$ & & & & & 39 & 50 & 19 & 49 & 101 & 258 \\
\hline $\begin{array}{l}\text { A tientas } \\
\text { 'gropingly, uncertainly' }\end{array}$ & & & & & 5 & 4 & 21 & 106 & 133 & 269 \\
\hline
\end{tabular}


Table 4. (continued)

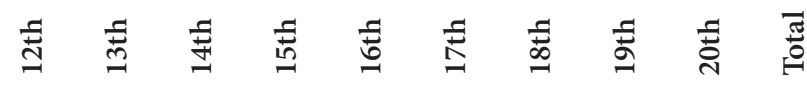

A tontas y a locas

'haphazardly'

A tontas

'thoughtlessly, carelessly'

A hurtadillas

'furtively'

A pie(s) juntillas

'firmly'

A duras penas

'with great difficulty'

A ojos vistas

'obviously'

A las duras

'in the hard situations'

A las claras

'openly'

A las derechas

'honestly'

A las calladas

$\begin{array}{llllll}2 & 26 & 1 & 27 & 11 & 67\end{array}$

2

1

'on the sly'

A las primeras

'suddenly, all of a sudden'

A las malas

$\begin{array}{lllllll}7 & 10 & 10 & 3 & 116 & 102 & 248\end{array}$

$\begin{array}{llllll}14 & 6 & 3 & 70 & 76 & 169\end{array}$

$\begin{array}{llllll}2 & 4 & 2 & 10 & 20 & 38\end{array}$

$\begin{array}{llllllll}6 & 30 & 10 & 3 & 8 & 17 & 74\end{array}$

'by force'

\begin{tabular}{lrrrrrrrrrr} 
Total & 67 & 303 & 333 & 445 & 1335 & 1184 & 245 & 1597 & 2299 & 7808 \\
$\%$ & 1 & 4 & 4 & 6 & 17 & 15 & 3 & 20.5 & 29.5 & 100 \\
\hline
\end{tabular}

The fixedness or non-compositionality of the expressions in Table 4 can be seen as variable to some degree, according to the gradual nature of the notion. ${ }^{5}$ Thus, early locutions - a solas 'alone, in private', a sabiendas 'knowingly, consciously' - tend to be perceived more as motivated and linked to the literal meaning - especially out of its context of use -, than some of the locutions from the 15th or 16th century

5. Non-compositionality is a complex notion often mentioned as a criterion in the definition of fixed expressions. Four properties are associated with non-compositionality: motivation/non motivation; transparency/opacity; analyzability/unanalyzability and literal/figurative meaning which, although referred to as dichotomies, as Langacker (1987:449) points out, lend more easily to a claim of partial rather than a full or clearcut compositional/non compositional dichotomy. See Svensson (2008) for a detailed account of the complexity of non-compositionality. 
onwards such as a pie juntillas 'firmly' or a tontas y a locas 'haphazardly', which are also motivated, but unanalyzable, figurative and opaque.

The frequency data provided by the NDHE in Table 5 yielded a total of less adjective types than the whole corpus did; however, the tokens behavior was similar in both the dictionary and the whole corpus. The total normalized frequency confirms and supports the diachronic increased use of these locutions.

Table 5. Adjectives types and tokens in locutions in the NDHE: Absolute and normalized frequency (tokens per million words)

\begin{tabular}{|c|c|c|c|c|c|c|c|c|c|c|}
\hline & 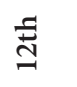 & $\stackrel{=}{\text { c }}$ & $\stackrel{\ddagger}{ \pm}$ & 营 & $\underset{⿱ 乛}{0}$ & $\stackrel{5}{ \pm}$ & $\underset{\infty}{-\infty}$ & 咅 & 苂 & 胥 \\
\hline A derechas & 0 & 11 & 2 & 6 & 4 & 10 & 2 & 2 & 7 & 44 \\
\hline 'correctly, rightly' & & 0.02 & 0.00 & 0.01 & 0.00 & 0.02 & 0.00 & 0.00 & 0.01 & 0.06 \\
\hline A medias & 0 & 3 & 7 & 2 & 3 & 11 & 16 & 22 & 79 & 143 \\
\hline 'half, faultily' & & 0.00 & 0.01 & 0.00 & 0.00 & 0.02 & 0.03 & 0.05 & 0.19 & 0.30 \\
\hline $\begin{array}{l}\text { A paladinas } \\
\text { 'openly, clearly' }\end{array}$ & 0 & $\begin{array}{l}2 \\
0.00\end{array}$ & 0 & $\begin{array}{l}1 \\
0.00\end{array}$ & 0 & 0 & 0 & 0 & 0 & $\begin{array}{l}3 \\
0.00\end{array}$ \\
\hline A sabiendas & 0 & 50 & 25 & 60 & 14 & 11 & 2 & 6 & 7 & 175 \\
\hline 'knowingly, consciously' & & 0.12 & 0.06 & 0.14 & 0,03 & 0.02 & 0.00 & 0.01 & 0.01 & 0.21 \\
\hline A solas & 0 & 10 & 0 & 9 & 98 & 123 & 65 & 93 & 173 & 571 \\
\hline 'alone, in private' & & 0.03 & & 0.02 & 0.23 & 0.30 & 0.22 & 0.27 & 0.42 & 1.49 \\
\hline A osadas & 2 & 9 & 5 & 19 & 6 & 5 & 0 & 0 & 0 & 46 \\
\hline 'boldly' & 0.00 & 0.02 & 0.01 & 0.04 & 0.01 & 0.01 & & & & 0.09 \\
\hline A ciegas & 0 & 0 & 1 & 0 & 8 & 10 & 17 & 12 & 33 & 81 \\
\hline 'blindly' & & & 0.00 & & 0.01 & 0.02 & 0.04 & 0.02 & 0.08 & 0.17 \\
\hline A escondidas & 0 & 0 & 0 & 0 & 3 & 3 & 3 & 4 & 34 & 47 \\
\hline 'secretly' & & & & & 0.00 & 0.00 & 0.00 & 0.00 & 0.08 & 0.08 \\
\hline A oscuras & 0 & 0 & 0 & 1 & 3 & 7 & 15 & 48 & 72 & 146 \\
\hline 'in the dark' & & & & 0.00 & 0.00 & 0.01 & 0.03 & 0.11 & 0.17 & 0.32 \\
\hline A secas & 0 & 0 & 1 & 0 & 9 & 8 & 10 & 14 & 15 & 57 \\
\hline 'plainly' & & & 0.00 & & 0.02 & 0.01 & 0.02 & 0.03 & 0.03 & 0.11 \\
\hline A tientas & 0 & 0 & 0 & 0 & 0 & 4 & 16 & 23 & 57 & 100 \\
\hline 'gropingly, uncertainly' & & & & & & 0.00 & 0.03 & 0.05 & 0.13 & 0.21 \\
\hline A tontas y a locas & 0 & 0 & 0 & 0 & 0 & 4 & 0 & 3 & 2 & 9 \\
\hline 'haphazardly' & & & & & & 0.00 & & 0.00 & 0.00 & 0.00 \\
\hline A hurtadillas & 0 & 0 & 0 & 0 & 5 & 0 & 8 & 14 & 15 & 42 \\
\hline 'furtively' & & & & & 0.01 & & 0.01 & 0.03 & 0.03 & 0.08 \\
\hline A pie juntillas & 0 & 0 & 0 & 0 & 0 & 4 & 2 & 7 & 2 & 15 \\
\hline 'firmly' & & & & & & 0.01 & 0.00 & 0.02 & 0.00 & 0.03 \\
\hline A pie(s) juntillas & 0 & 0 & 0 & 0 & 2 & 1 & 0 & 7 & 12 & 22 \\
\hline 'firmly' & & & & & 0.00 & 0.00 & & 0.01 & 0.02 & 0.03 \\
\hline A duras penas & 0 & 0 & 0 & 4 & 1 & 2 & 9 & 17 & 38 & 71 \\
\hline 'with great difficulty' & & & & 0.00 & 0.00 & 0.00 & 0.02 & 0.04 & 0.09 & 0.15 \\
\hline
\end{tabular}


Table 5. (continued)

\begin{tabular}{|c|c|c|c|c|c|c|c|c|c|c|}
\hline & $\stackrel{\Xi}{ \pm}$ & ले & $\underset{\exists}{\ddagger}$ & 点 & $\stackrel{0}{0}$ & 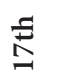 & $\underset{\infty}{-5}$ & ప & 풍 & సٓ \\
\hline A ojos vistas & 0 & 0 & 0 & 0 & 12 & 1 & 3 & 9 & 6 & 31 \\
\hline 'obviously' & & & & & 0.02 & 0.00 & 0.00 & 0.02 & 0.01 & 0.05 \\
\hline A las claras & & 0 & 0 & 0 & 1 & 2 & 5 & 14 & 12 & 34 \\
\hline 'openly' & & & & & 0.00 & 0.00 & 0.01 & 0.03 & 0.02 & 0.06 \\
\hline A las derechas & & 0 & 0 & 0 & 3 & 6 & 1 & 0 & 0 & 10 \\
\hline 'honestly' & & & & & 0.00 & 0.01 & 0.00 & & & 0.01 \\
\hline A las calladas & & & & & & & & 1 & & 1 \\
\hline 'on the sly' & & & & & & & & 0.00 & & 0.00 \\
\hline Absolute & 2 & 85 & 41 & 102 & 172 & 212 & 174 & 296 & 564 & 1648 \\
\hline Normalized & 0.00 & 0.19 & 0.08 & 0.21 & 0.33 & 0.43 & 0.41 & 0.69 & 1.29 & \\
\hline
\end{tabular}

\subsection{First adjective in the locutions}

Just a handful of adjectives were documented in the early locutions from the twelfth to the thirteenth century, as can be seen in Table 4 (above): a primas 'firstly', a certas 'truly', a paladinas 'openly, clearly', a derechas 'correctly', a medias 'half, faultily', a solas 'alone, in private', a sabiendas 'knowingly' 'consciously', a osadas 'boldly, with audacity'

The total of tokens in the eight early locutions tends to increase from the 12th through the 14th century. Types also increased from 5 in the 12th century to 8 in the 13th and 14th centuries. Most of them (6) recur until the 20th century. Just $a$ primas and a certas ceased to be used before the 16th century.

Semantically, the adjectives in these locutions are restricted to two etymological meanings:

1. spatial orientation (or location) and sequential order in space, and

2. cognitive, mental or intellectual position.

As to the 'spatial/locative-orientation' adjectives, two expressions were documented: a derechas 'to the right'/ 'correctly' and a medias 'half'/ 'faultily'; both of them accounted for the direction or position assumed by an entity from a reference point; that is, involving deictic values. The examples in (7) with a derechas, used from the 12 th through the 20 th century, are clear cases of referential-deictic meaning. ${ }^{6}$ They

6. Ad derechas is an orientational-directional locution, corresponding to Deixis am Phantasma (deixis in the imagination or deixis to refer to absent referents) (Bühler 1990). Its use implies that the speaker is situated in a virtual space and that he locates a referent based on their own laterality 
specify the orientation or direction from a reference point: aqua de Becedas in (7a), the back of the hill in (7b). In both examples, an elliptic locative noun as pars, partis, feminine, is attainable. See that a derechas in ( $7 \mathrm{~b})$ is preceded by derechamientre 'in straight line; without deviation', without any deictic value.

(7) a. et deinde ad derechas usque ad aquam de Becedas, 'and from there to the right continuously to water of Becedas, et de aqua de Becedas a derechas usque ad illam cabecam an from water of Becedas to the right continuously to that source'

(Anónimo, Fernando III confirma a la ciudad de Avila los límites meridionales, 1219, CORDE)

b. Aqui parte Lerma con Vra e torna a la calçada de los molinos 'Here splits Lerma with Vra and come back to the roadway of the mill de Abre, entre Vascones e Ramosa, e salle al moion que está entre of Abre, between Vascones and Ramosa, and (it) goes to the landmark that is between

Villaquella e Vascones e derechamientre a la vina bragada, e por lomo del Villaquella e Vascones

and directly to the sacred vineyard, and by the side of the cerro a derechas a valde taias

hill to the right to valde taias' (Anónimo, Carta-puebla y fueros dados á la villa de Lerma por el emperador Alfonso VII, 1148, CORDE)

The referential deictic meaning of a derechas occurs in characteristic linguistic contexts as setting verbs or nouns denoting places and physical space.

In the 12th and 13th centuries we also found tokens of a derechas 'rightly' with not a deictic but a modal value $(61 \%(14 / 23))$, as the one in (8). Unlike the examples in (7), the topic is a moral one in (8), an act that caused harm and pain to a man in his right foot, symbolizing the righteousness or rectitude that must guide one's actions. This token involves not a setting but a cognitive verb, da a entender 'to make somebody understand something'.

(8) La terçera plaga que le fezieron / fue quando le atrauesaron el clauo 'The third wound which him was made / was when him (they) pierced the nail por el su pie derecho commo quier que amos gelos atrauesaron pero antes el / through his right foot although both (feet) to him (they) pierced but first the /

(de Ferran Petrel 2008: 112), assuming that a virtual addressee does the same. As Fillmore (1975) points out, the deictic use of locating expressions involving notions like (left and) right implies the speaker to be aware of his addressee's point of view, and that speaker and hearer are oriented toward the object in the same way also (Fillmore 1975). 
derecho en que nos da a entender que los pasos que nos otros / andamos que los right (foot) which make us understand that the steps we / walk that (we) andamos a derechas \& en buenas obras walk rightly and in good works' (Anónimo, Castigos, 1293, CORDE)

The new meaning is embodied in a descriptive context which mentions Jesus' feet, but foregrounding his right foot so that a derechas 'rightly' emerges with some expressive force when referring to the correct way of walking in life. This locution is documented in the first centuries in moral, legal texts.

As to the emergence of the locution with a new modal meaning, in (8), it is difficult to delimit their constituents as we do with the two clear constituents of the expression in (7). In the context in Example (8), the two elements integrate into one unit seemingly similar to (7), but functionally and semantically different from it.

Other adjectives in these locutions, such as primas (< primus, prima, primum 'first, prime'), involve a sequential order. This adjective refers to sequentiality and, by extension, to hierarchy. It has been documented in moral texts as Fueros, in (9), which set behavioral rules or laws in a region; a primas emphasizes or stresses the first or foremost step to consider or take in a particular situation; see the example below.

(9) Tod omme que colmenas ouiere et a primas poblare / corral con sus 'Every man who hives had and firstly settled / in ground whit his colmenas, nenguno non sea osado de meterly hy otras colmenas hives, no one dare to introduce there other hives'

(Anónimo, Fuero de Cáceres, 1234-1275, CORDE)

Por esto mandamos defender e firmar al que a primas labro en ella;

'Because of this (we) order to defend and to affirm who firstly/originally worked in it;

ca quien entrare en lauor agena a de pechar $\mathrm{X}$ morabedis because whoever enter into field not owned must pay X morabedis'

(Anónimo, Fuero de Véjar, 1234-1275, CORDE)

Both expressions, a derechas and a primas, that involving deixis and that involving sequential order, undergo semantic change to a new abstract meaning comprising a modal perspective, in specific texts, from objective-locative meaning to modal-positive (evaluative) meaning.

The second semantic domain is that of the cognitive, mental or intellectual position, or modal adjectives. Four adjectives ending in -as were documented in the locution. The realm can be divided into two groups: those referring to externalized attitudes (external signs) or visible attitudes as a paladinas 'openly' and $a$ solas 'alone', and those referring to internal attitudes, as in a osadas 'boldly' and $a$ sabiendas 'consciously'. 
A paladinas 'openly' in (10) is emphasized by using it in contrast with en proverbios 'in proverbs', not directly, and preceded by an adversative nexus suggesting that the motivation of its use is to highlight a different way of acting, generally not a common one.

(10) Pedit e tomaredes, porque el uuestro gozo sea complido. Estas cosas uos dix 'Ask and will receive, for your enjoyment be fulfilled. These words to you (I) said en prouerbios..., mas a paladinas uos dire del Padre in proverbs... but openly to you (I) will speak about the Father' (Anónimo, Nuevo Testamento, 1260, CORDE)

The adversative context of a paladinas 'openly' is not an isolated case. Indeed, most of the locutions involving external position occur in contrast contexts, using different textual strategies in linguistic contexts that raise interpretations contrary to the expected situations, and lead to modal-expressive effects.

A solas in (11) underlines the difficulty of the task that Moises was trying to achieve alone and without help. The context is highly modal, introduced by a question: que es esto que fazes? 'what is this that you are doing?', followed by a negative adverb and a modal epistemic verb, non podras 'you cannot'.

(11) Vio Getro el grant afan que traya Moisen e dixo: "Que es esto que fazes?

'Saw Jethro the huge responsibility which had Moses and said: What is this (you) are doing?

Non lo podras fer a solas

Not it (you) can do without help'

(Almerich, La fazienda de Ultra Mar, c.1200, CORDE)

Regarding the internal adjective group, it includes a certas, a osadas, a sabiendas. We have a case of this sort with a certas in (12), talking about punishment for those who deceive people and take advantage of them. The use of the locution at the beginning of the sentence, preceded by et, emphasizes the rejection of deception used in selling a book.

(12) Et a certas, si alguno, queriendo conprar el ailleno libro de fueros, dió a entender a

'and truly, if someone, willing to buy the alien book of fueros, hinted to qui era el libro [que podía comprar el libro] por poco pretio, en guisa que non lo

who had the book [who could buy the book] at a cheap price, knowing that (he) not 
auía de uender aqueill libro por aqueill pretio, ad aqueill qui'l mentió no ha dubda

will sell that book at that price, to the one to whom (he) lied no will have doubt que aqueilla uéndida deue ser reuocada, that the sale must be revoked'

(Anónimo, Vidal Mayor, 1250, CORDE)

The use of a osadas and a sabiendas (in 13) presuppose previous knowledge contrasting with the context of the clause they introduce. A osadas 'boldly' refers to the Peter's fearless manner of speaking or preaching in the presence of Nero, which differs from his previous attitude when denying the Lord. The locution's expressive meaning enhances the unexpected behavior of Peter. Likewise, a sabiendas 'knowingly' highlights the undesirable, blameworthy behavior of a son that hurts and disrespects his parents while being fully aware of his misconduct and his corresponding punishment. As we can see, as the construction expands it incorporates derived adjectives that imply counter-expectations.

(13) Quánto fue el esfuerzo en Peidro se provava,/el que por la voz ante de la 'How big was the effort in Peter proved/(he) who by the voice in front of the fembra negava;/después, delante Nero, a osadas fablava,/todas sus amenazas woman denied;/later, in front of Nero, boldly preached/ all his (Nero's) threats un pan non las preciava

a bit not appreciate' (Berceo, Loores de Nuestra Señora, 1236-1246, CORDE) Fjllo qui a sabiendas feriere al padre o a la madre, et mayorment si lo trayere 'A son who knowingly hurts his father or his mother, and mainly if (he) grabs them

por los cabeillos o lo esmentiere ante omnes bonos ... por dreito deue ser by the hair or (he) disproves them in front of good man ... by law must be desheredado tal fillo

disinherited that son'

(Anónimo, Vidal Mayor, 1250, CORDE)

In sum, the adjectives in early locutions that etymologically refer to visible spatial features, or to internal or attitudinal features, evolved to account for a different, but modal meaning such as righteousness, certainty, consciousness or awareness, boldness, and something to be highlighted or emphasized in modal contexts.

\subsection{Adjectives entering in the Adverbial Modal Locution: Fifteenth-twentieth centuries}

From the 15th century onward (see Table 4), the Adjective types diversified diachronically; new types appeared every century and the frequency of use also increased, especially during the 19th and 20th centuries in modal contexts of use. 
We have two tokens of a ciegas, 'blindly', in (14). The locution is used in both examples in highly subjective contexts; the first, regarding the effects of envy in human being, is underlined by the negative judgment expressed by of other previous modal elements as malamente 'badly' and la ciega fortuna 'the blind fortune', rising expressiveness; in the second instance, talking about the ignorance reflected by the words of doctor Sepúlveda, the subjective perspective is strengthened by the interrogative clause itself.

(14) si ellos no alcançan tanto poder, y les despojan de aquello que justa o 'If they not reach much power, and (they) were plundered from what rightly or injustamente poseen y tienen recibido de mano de la ciega fortuna, wrongly (they) possess and had receveid from the hand of the blind fortune, cuya enemiga y contraria yo soy, porque lo que ella distribuye malamente a ciegas,

whose enemy and contrary I am, because what she distributed badly blindly ..., yo los quito de aquellos injustos poseedores ...,

I remove it from those unjust owners' (Pedro Hernández de Villaumbrales, Peregrinación de la vida del hombre, 1552, CORDE)

Éstas todas son palabras del doctor Sepúlveda. ¿Qué más claro puede mostrar el

'These all are words from doctor Sepúlveda. How much clearly can show the doctor lo poco que entiende cerca del hecho desta materia en que tanto ha querido

doctor how little (he) understands about this matter in which so much (he) wanted

a ciegas zahondar?

blindly to deepen?

(Fray Bartolomé de las Casas, Controversia entre Las Casas y Sepúlveda, 1552, CORDE)

In (15) we have examples with a tientas 'groping' and a tientas 'groping' y a tontas 'foolishly', both referring to an inconvenient or unsuitable behavior. The context in both instances accounts for the subjective perspective. In the first example, they considered that crazy people, answering even with teasing and groping, prevail over the wisest and top writers in discussions. In the second example, Andrenio considers the behavior of blind people guiding others a tientas as oblivious behavior.

(15) nuestros locos, hasta burlando i respondiendo a tientas (véase que harían 'Our crazy men, until mocking and answering groping (see what (they) would do

de veras), en cualquier género de disputas vencen i vienen a concluir a los más sabios

really) in any type of dispute (they) overcome and defeat the wisest 
i maiores letrados que tiene el mundo

and top writers that are in the world' (Jerónimo de Mondragón, Censura de la locura humana y excelencias della, 1598, CORDE)

Yo-dixo [Andrenio]-no me espanto que el ciego pretenda guiar a los otros, que, I-said [Andrenio]- I am not fearful that the blind wants to guide others, that, como él no ve, piensa que todos los demás son ciegos y que proceden del because he does not see, thinks that the rest are blind and that (they) proceed in the

mismo modo, a tientas y a tontas same way, groping and foolishly'

(Baltasar Gracián, El Criticón. Primera parte, 1651, CORDE)

Table 6 shows the diachronic type frequency. The Adjective type doubles from the12th to thirteenth and fourteenth centuries, increasing to thirteen in the 15th century and to twenty-one and twenty-two in the subsequent period. ${ }^{7}$

Table 6. Type frequency: Diachronic increasing

\begin{tabular}{lllllllll}
\hline 12th & 13th & 14th & 15th & 16th & 17th & 18th & 19th & 20th \\
\hline $4 \rightarrow$ & 8 & $8 \rightarrow$ & $13 \rightarrow$ & 21 & 21 & $21 \rightarrow$ & 22 & 22 \\
\hline
\end{tabular}

Table 6 also demonstrates that the number of adjective types remained almost the same from the sixteenth century onwards. However, some resources were added during that period to intensify/strengthen the inherent expressive meaning of the locution: (i) the diminutive suffi $\mathrm{x}^{8}$-ill affixed to the adjective base as in a hurtadillas in (16), (ii) a nominal phrase with an adjective with the ending - as and without agreement as a pies juntillas in (17); (iii) and a nominal phrase with the definite article $^{9}$ and an adjective nominalized as a las claras in (18). ${ }^{10}$

7. As we pointed out (Section 2), the collection of locutions identified is not exhaustive.

8. The diminutive suffix, which is multifunctional when added to a deverbal (participle) adjective as the base of the locution, shows the subjective function that Reynoso Noverón (2005: 81) calls centralizing function and that increased or intensified the base meaning. Indeed, this property of the locutions evokes the Latin diminutive with the expressive effect mentioned by Meillet (1928/1972: 108) and the inner geminate consonants, specially -ll-, inherently expressive (Meillet 1928/1972: 104).

9. The definite article functions here as expressiveness intensifier (Ortiz Ciscomani 2009: $\$ 3.9 .3 .1)$.

10. Adverbial expressions as a la brava, without the plural, are hardly documented in CORDE in the late sixteenth century. The adjective is a negative value adjective, lexically-semantically relatable to the undesirable or counter-expected value of the locution with -as. It deserves a separate study. 
(16) Y dice que le recibió como a hurtadillas, porque así como lo que se hurta 'And (he) says that (he) received him as stealthily, because as well as what is stolen

es ageno, así aquel secreto era ageno del hombre is foreign, as well that secret was foreign to men'

(San Juan de la Cruz, Cántico espiritual, 1578-1584, CORDE)

(17) Al tomarla el escribano/confesión de lo que ha hecho/ella niega a pies juntillas/ 'When receveid the writer/(the) confession of what she had done/she deny blindly/

lo que pecó a pies abiertos

that which (she) sinned ...'

(Francisco de Quevedo y Villegas, Poesías, 1597-1645, CORDE)

(18) Como si más claro digera: esto, Señor mío, Esposo mío, que andas dando de ti a mi

'As if clearer (she) said: this, my Lord, my Husband, which (you) give from you to my

alma por partes, acaua de darlo del todo; y esto que andas mostrando como por soul in parts, finish to give it entirely; and this that (you) are showing as at resquicios, acaua de mostrarlo a las claras chinks, (you) finish showing it clearly/openly'

(Francisco de Quevedo y Villegas, Poesías, 1597-1645, CORDE)

All of the characteristics mentioned herein, such as the increase of types and tokens; the semantic opacity of the directional meaning of the preposition, which is parallel to the new modal meaning; and the ambiguous limits of the constituents of the Prepositional Phrase are features shared by the locutions. They suggest that a new mechanism for adverbial modal function emerged. This new syntactic pattern arose for a specific semantic purpose: to underline or to magnify an atypical circumstance to carry out an event. That condition is generally related to the total absence of a quality associated with a behavior: a ciegas, a oscuras, and a tientas refer to absence of light and, by extension, to a rare behavior; a secas, without any ornament or kindness; a tontas y a locas, without common sense or reasonableness; a escondidas, a hurtadillas, out secretly, out of sight.

The change that comprises the Preposition $a$ and an Adjective base ending in -as in an Adverbial Locution capable of accounting for expressive meaning involves a process of schematization or constructional grammaticalization (Gisborne \& Patten 2011). Grammaticalization is understood here as a process that affects, or applies to, constructions (Goldberg 1995) more than to individual items (Bybee 2003; Himmelmann 2004:31); a process by which a construction, in specific contexts, acquires a new grammatical function (Company 2003; Kuryłowicz 1965; Hopper \& 
Traugott 1993/2003; Lehmann 1982/1995; among many others). Constructions are "pieces of grammar" (Kay \& Fillmore 1999:2), conventional form-function pairings (Goldberg 1995) originated in actual utterances; they are abstracted from a large number of utterances (Bybee 2010; 2011), whereas constructs are utterance-tokens that instantiate constructions.

The construction or scheme that emerged with this grammaticalization change has some fixed elements: the initial vowel $a$ and the ending -as, and a slot which is filled with variable lexical material, as illustrated in Figure 3.

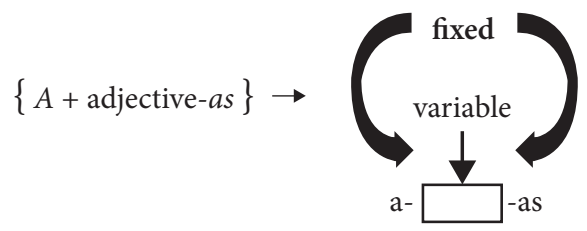

Figure 3. From Prepositional Phrase to Modal Locution Scheme

In other words, grammaticalization is concerned here, as suggested by Fried (2013:422), with changes in the relationship between form and function within a particular linguistic pattern or construction, a change in the constituent internal structure (Bybee 2008).

\section{Concluding remarks}

In this paper, with a large corpus as support, I showed quantitative and qualitative information about the historical development of Adverbial Modal Locutions with a preposition and an adjective characterized by the ending - as. The analysis showed that the adjectives in the locutions are semantically restricted to those referring to polar semantic values (counterparts positive vs. negative, presence or absence of a quality or property), generally highlighting unexpected or atypical features. Diachronically, the adjectives diversify regarding types but also increase in tokens, suggesting that an Adverbial Modal Locution scheme (a new adverbial formation pattern) emerges from the original prepositional phrase as of the fifteenth century with a specific function: accounting for an expressive or subjective meaning. The semantic and syntactic features of the original Prepositional Phrase blur or fade, promoting an interpretation as a unit with modal value, changing from referential to abstract meaning; from objective features in space to moral/mental/subjective/ positions; from descriptive to evaluative meaning. As we saw, the context is crucial; the locution occurs in particular modal contexts, which collaborates for the 
emergence of the new meaning. The whole feature suggests a change involving a process of schematization; that is to say, it can be considered as a sample of constructional grammaticalization.

\section{Bibliography}

\section{a. Corpus}

Cid = Anónimo. 1944-1945. Cantar de mio Cid. Texto, gramática y vocabulario, Vol. 3: Texto, Ramón Menéndez Pidal (Paleographic edition). Madrid: Espasa Calpe. GEI = Alfonso, X. 2002. General estoria, Primera parte, Pedro Sánchez Prieto-Borja (Edition). Alcalá de Henares: Universidad de Alcalá de Henares.

GEII = Alfonso, X. 2002. General estoria, Segunda parte, Pedro Sánchez-Prieto Borja (Edition). Alcalá de Henares: Universidad de Alcalá de Henares.

Lucanor = Don Juan Manuel. 1969/1971. El conde Lucanor o Libro de los enxiemplos del conde Lucanor et de Patronio, José Manuel Blecua (Edition). Madrid: Castalia.

Celestina $=$ Fernando de Rojas. 2000. La Celestina . Tragicomedia de Calisto y Melibea, Francisco

J. Lobera, Guillermo Serés, Paloma Díaz-Mas, Carlos Mota, Î́nigo Ruiz Arzálluz y Francisco Rico (Edition). Barcelona: Crítica.

Bernal = Bernal Díaz del Castillo. 1989. Historia verdadera de la conquista de la Nueva España,

Carmelo Sáenz de Santamaría (Edition). Madrid: Alianza.

Quijote = Miguel de Cervantes Saavedra. 2004. Don Quijote de la Mancha, Edición del IV

Centenario, Francisco Rico (Edition). España: Real Academia Española-Asociación de

Academias de la Lengua Española-Alfaguara.

DLNE = Concepción Company Company. 1994. Documentos lingüísticos de la Nueva España.

Altiplano central. México: Universidad Nacional Autónoma de México.

CN/sí = Leandro Fernández de Moratín. 1975. La comedia nueva. In La comedia nueva. El sí de

las niñas, John Dowling y René Andioc (Edition). Madrid: Castalia.

Vida $=$ Diego de Torres Villarroel. 1972. Vida, ascendencia, nacimiento, crianza y aventuras. Guy

Mercader (Edition). Madrid: Castalia.

Regenta $=$ Leopoldo Alas "Clarín". 1988. La Regenta, Juan Oleza (Edition) and Josep Lluis Sirera

y Manuel Diago (collaborators). México: REI.

Bandidos = Manuel Payno. 1979. Los bandidos de Río Frío. México: Clásicos de la Literatura

Mexicana,

Tabla = Arturo Pérez-Reverte. 1990. La tabla de Flandes. Madrid: Alfaguara.

Suerte $=$ Luis Miguel Aguilar. 1992. Suerte con las mujeres. México: Cal y Arena.

CORDE = Real Academia Española. Corpus Diacrónico del Español. www.rae.es.

NDHE = Instituto de Investigación Rafael Lapesa de la Real Academia Española. 2013-. Nuevo

Diccionario histórico de la lengua española. [en línea]. <http://web.rfl.es/DH> 


\section{b. References}

Bühler, Karl. 1990. Theory of Language: The Representational Function of Language, translation by Donald Fraser Goodwin. Amsterdam: John Benjamins. doi:10.1075/fos.25

Bybee, Joan. 2003. Mechanisms of change in grammaticalization: The role of frequency. In The Handbook of Historical Linguistics, Brian Joseph \& Richard Janda (eds), 602-623. Oxford: OUP. doi:10.1002/9780470756393.ch19

Bybee, Joan. 2008. Formal universals as emergent phenomena: The origins of structure preservation. In Linguistic Universals and Language Change, Jeff Good (ed.), 108-124. Oxford: OUP. doi:10.1093/acprof:0so/9780199298495.003.0005

Bybee, Joan. 2010. Language, Usage and Cognition. Cambridge: CUP. doi:10.1017/CBO9780511750526

Bybee, Joan. 2011. Usage-based theory and grammaticalization. In The Oxford Handbook of Grammaticalization, Heiko Narrog \& Bernd Heine (eds), 69-78. Oxford: OUP.

Company Company, Concepción. 2014. Adverbios en -mente. In Sintaxis histórica de la lengua española, tercera parte: Preposiciones, adverbios y conjunciones. Relaciones intraoracionales, Vol. 1, Chapter 6, Concepción Company (ed.), 457-611. México: FCE/UNAM.

Company Company, Concepción. 2003. La gramaticalización en la historia del español. In Gramaticalización y cambio sintáctico en la historia del español, Concepción Company Company (ed.), 1-62. México: UNAM.

Corpas Pastor, Gloria. 2003. Diez años de investigación en fraseología: Análisis sintácticos semánticos, contrastivos y traductológicos. Madrid: Vervuert-Iberoamericana.

De Ferran Petrel, Jaqueline. 2008. Cambio semántico en derecho e izquierdo en español y francés. In Memorias del IX Encuentro Internacional de Lingüística en el Noroeste, Vol. 2, Rosa María Ortiz Ciscomani (ed.), 111-130. Hermosillo: Universidad de Sonora.

Fillmore, Charles J. 1975. Santa Cruz Lectures on Deixis 1971. Bloomington IN: Indiana University Linguistics Club.

Fried, Miriam. 2013. Principles of Constructional Change. In The Oxford Handbook of Construction Grammar, Thomas Hoffmann \& Graeme Trousdale (eds), 419-437. Oxford: OUP.

García Calvo, Agustín. 1964. La feminidad del camino. Emerita 32: 49-56.

García-Page Sánchez, Mario. 2008. Introducción a la fraseología española: Estudio de las locuciones. Barcelona: Anthropos.

Gisborne, Nikolas \& Amanda Patten. 2011. Construction grammar and grammaticalization. In The Oxford Handbook of Grammaticalization, Heiko Narrog \& Bernd Heine (eds), 92-104. Oxford: OUP.

Goldberg, Adele. 1995. Constructions: A Construction Grammar Approach to Argument Structure. Chicago IL: The University of Chicago Press.

Himmelmann, Nikolaus. 2004. Grammaticalization and lexicalization: Opposite or orthogonal? In What makes grammaticalization. A look from its components and its fringes, Walter Bisang, Nikolaus P. Himmelman \& Björn Wiemer (eds), 21-42. Berlin: Mouton de Gruyter.

Hopper, Paul \& Elizabeth Closs Traugott. 1993[2003]. Grammaticalization. Cambridge: CUP.

Hummel, Martin. 2014. Adjetivos adverbiales. In Sintaxis histórica de la lengua española, tercera parte: Preposiciones, adverbios y conjunciones. Relaciones intraoracionales, Vol. 1, Chapter 7, Concepción Company (ed.), 613-731. México: FCE/UNAM. 
Hummel, Martin. 2013. Sincronía y diacronía de los llamados adjetivos adverbializados y de los adverbios en -mente. Anuario de Letras. Lingüística y Filología I(2): 217-281.

Kay, Paul \& Charles Fillmore. 1999. Grammatical constructions and linguistic generalizations: The What's X Doing Y? construction. Language 75: 1-34. doi:10.2307/417472

Kuryłowicz, Jerzy. 1965. The evolution of gramatical categories. Diogenes 55: 55-71. doi:10.1177/039219216501305105

Langacker, Ronald W. 1987. Foundations of Cognitive Grammar: Theoretical Prerequisites. Stanford CA: Stanford University Press.

Lausberg, Heinrich. 1966. Lingüística Románica. Segunda parte. Morfología. Madrid: Gredos. Lehmann, Christian. 1982/1995. Thoughts on Grammaticalization. Munich: Lincom.

Mariner, Sebastián. 1968. El femenino de indeterminación. In Actas del XI Congreso Internacional de Lingüística y Filología Románicas, Antonio Quilis, Ramón B. Carril \& Margarita Cantarero (coords), 1297-1314. Madrid: Consejo Superior de Investigaciones Científicas.

Meillet, Antoine. 1928[1972]. Historia de la lengua latina. Reus: Avesta.

Menéndez Pidal, Ramón. 1904/1940. Manual de gramática histórica española. Madrid: Espasa Calpe.

Ortiz Ciscomani, Rosa María. 2014. Locuciones adverbiales con a y base léxica en -as. In Sintaxis histórica de la lengua española, segunda parte: La frase nominal, Chapter 10, Concepción Company (ed.), 1117-1192. México: FCE/UNAM.

Ortiz Ciscomani, Rosa María. 2009. La creación y generalización del artículo definido. In Sintaxis histórica de la lengua española, segunda parte: La frase nominal, Chapter 3, Concepción Company (ed), 271-386. México: FCE/UNAM.

Pavón Lucero, María Victoria. 1999. Clases de partículas: Preposición, conjunción y adverbio. In Gramática descriptiva de la lengua española, Ignacio Bosque \& Violeta Demonte (eds), 565-656. Madrid: Espasa Calpe.

Penny, Ralph. 1991[2002]. A History of Spanish Language. Cambridge: CUP.

RAE-ASALE = Real Academia Española-Asociación de Academias de la Lengua Española. 2009. Nueva gramática de la lengua española. Madrid: Espasa Libros.

Reynoso Noverón, Jeanett. 2005. Procesos de gramaticalización por subjetivización: El uso del diminutivo en el español. In Selected Proceedings of the 7th Hispanic Linguistics Symposium, David Eddington (ed.), 79-86. Somerville MA: Cascadilla Proceedings Project.

Ruiz Gurillo, Leonor. 1997. Relaciones categoriales de las locuciones adverbiales. Contextos 15: 29-30: 19-31.

Spitzer, Leo. 1941. Feminización del neutro: rumano oasele, italiano le ossa, ant. francés ces brase, español las vísceras. Revista de Filología Hispánica 3: 339-371.

Svensson, María Helena. 2008. A very complex criterion of fixedness: Non-compositionality. In Phraseology. An interdisciplinary perspective, Sylvianne Granger \& Fanny Meunier (eds.), 81-93. Amsterdam: John Benjamins. doi:10.1075/z.139.10sve

Väänänen, Veikko. 1967/1968. Introducción al latín vulgar. Madrid: Gredos. 



\title{
Adverbial adjectives and the decomposition of event predicates
}

\author{
Avel.lina Suñer \\ University of Girona
}

This article provides an analysis of the so-called "adverbial adjectives" in Romance on the basis of a theory of syntactic decomposition of the event predicate by using Hale \& Keyser's Configurational Theory of Argument Structure. The first part establishes a hierarchy of adverbial adjectives according to the different levels of the argument structure of the predicate they are related to. The last section analyses the structural conditions determining the alternation between adverbial adjectives and secondary predicates. The article claims that the non-agreeing properties and the particular semantic interpretation of adverbial adjectives are the result of the interaction between their own lexical and semantic features and the portion of the internal structure of the event predicate they are associated with.

\section{Introduction}

A well-known fact is that in some Romance languages, the masculine singular default form of the adjective may appear as a VP-internal modifier as shown in (1).

(1) a. (Sp.)

Ella duerme profund-o.

She sleeps deep-MSG

'She sleeps deeply'.

b. (Cat.)

La meva filla condueix ràpid.

My daughter drives fast-MSG

'My daughter drives fast.'

c. (Fr.)

Elle a parlé clair

She spoke clear-MSG

'She spoke clearly.' 
d. (It.)

Anna labora dur-o.

Anna works hard-Msg

'Anna works hard.'

e. (Pt.)

A Maria trabalha dur-o.

The Maria works hard-MsG

'Maria works hard.'

These elements have received different names such as "bare adjectives" (Bartra \& Suñer 1997; Di Tullio \& Suñer 2001, 2011, 2013; Suñer \& Di Tullio 2014), "invariable adjectives" (Abeillé \& Godard 2003, 2004) and "adverbial adjectives" (Luján 1980: Chapter V; Noailly 1994), all of them suggesting that these elements are the default base form of the corresponding adjective.

In Romance languages, where adjective secondary predicates morphologically agree with their controller nominals, these default forms have sometimes been ascribed to the extensive category of adverbs, ${ }^{1}$ which has been no doubt reinforced by the possibility for many of them to be replaced by adverbs productively forged through suffixation of the Latin feminine noun -mente (< MENS 'mind-ABL-FSG') to the feminine form of the predicative adjective, as we can see in (2).

(2) a. (Sp.)

Ella duerme profundamente.

'She sleeps deeply.'

b. (Cat.)

La meva filla condueix ràpidament.

'My daughter drives fast!'

c. (Fr.)

Elle a parlé clairement.

'She spoke clearly.'

d. (It.)

Anna labora duramente.

'Anna works hard.'

e. (Pt.)

A Maria trabalha duramente.

'Maria works hard.'

However, the selection of examples such as (1) and (2) suggest a biased vision of equivalence between adverbial adjectives and -mente adverbs. In fact, the distribution of the two options depends on multiple factors. From a diachronic perspective,

1. See RAE-ASALE (2009: $\$ 30.3)$ for additional information. 
the former are the result of a productive syntactic pattern in all spoken Romance languages, while the latter emerged with the establishment of a shared written tradition, see Grevisse $(2008: \$ 963)$, Company $(2012,2014)$ and Hummel $(2014 \mathrm{a}$, 2014b).

Furthermore, each form often specializes in a different meaning. Take the case of the adjective profundo 'deep' in Spanish, which produces the adverbial adjective profundo and a derived adverb profundamente. The first one is used when denoting the physical dimension of "deep" and combines with actions that can define measures in that dimension (cavar 'to dig', sembrar 'to sow', enterrar 'to bury', aspirar 'to inhale', respirar 'to breathe', among others, see REDES 2004, s.v. profundo), while the second one has a metaphorical meaning and tends to combine with mental processes (sentir 'to feel', lamentar 'to regret', deplorar 'to deplore', enamorarse 'to fall in love', implicarse 'to get involved', conmoverse 'to be moved/to be touched', pensar 'to think', amar 'to love', respetar 'to respect', among others, see REDES 2004: s.v. profundamente). ${ }^{2}$

(3) a. (Sp.)

cavar \{profund-ol??profund-a-mente\}

to dig deep-MsG /deep-ly

'to dig deep'

b. sentir \{ ${ }^{*}$ profund-o /profund-a-mente\}

to feel deep-Msg /deep-ly

'to feel deeply'

Conversely, some adverbial adjectives are lexically restricted to specific verbs. Thus, the Spanish adjective adverb sano 'healthy' can be associated to the verb comer 'to eat' as shown by (4a), but the same form is rejected when combined with verbs such as alimentarse 'to feed on' and nutrirse 'to nourish', which are very similar from a semantic point of view but display various syntactic configurations. In contrast, the corresponding -mente adverb sanamente 'healthy' does not show the same restrictions.

2. A similar explanation accounts for the Italian examples in (i), where the adverbial adjective forte is equivalent to 'loud' whereas fortemente is interpreted as 'vehemently' (see Migliorini 1952).

(i) a. (It.)

parlare forte

'to speak loudly'

b. parlare fortemente

'to speak vehemently' 
(4) a. (Sp.)
comer sano
vs. comer sanamente
'to eat healthy'
b. ??alimentarse sano vs. alimentarse sanamente
'to feed on healthy'
c. ${ }^{*}$ nutrirse sano
$v s$. nutrirse sanamente
'to nourish healthy'

Main differences are also found with regard to the degree of syntactic cohesion that these elements establish with the verb. While the traditional assumption has long been that -mente adverbs are adjuncts, ${ }^{3}$ adverbial adjectives behave similarly to verbal arguments. ${ }^{4}$ Therefore, the unit formed from a verb and some adverbial adjectives cannot be broken by the presence of an object nor by applying grammatical processes like extraction or focalization (Bosque 1989: §6.3; Abeillé \& Godard 2003, 2004; Di Tullio \& Suñer 2001, 2011, 2013), witness the contrast between lourdement and lourd in the following French examples.

(5) a. (Fr.)

Cette incertitude pèse lourdement sur l'économie.

'This uncertainty weighs heavily on the economy.'

b. Cette incertitude pèse sur l'économie lourdement.

c. C'est lourdement qu'elle pèse sur l'économie.

(6) a. (Fr.)

Cette incertitude pèse lourd sur l'économie.

'This uncertainty weighs heavily on the economy'

b. ??Cette incertitude pèse sur l'économie lourd.

c. ??C'est lourd qu'elle pèse sur l'économie. [apud Abeillé \& Godard 2003: 17]

3. This is assumed to be consistent with their iterability, optionality, and restrictions on their extraction. We refer the reader to Cinque (1999 and subsequent work) for an alternative analysis of adverbial phrases as Specifiers of functional projections.

4. Significantly, the existence of idioms consisting of a verb and an adverbial adjective rather than a verb and a -mente adverb, is a strong argument in favor of the idea that there is a strict local relationship between adverbial adjectives and the verbal form (Sp. hilar fino 'to draw it fine', Sp. picar alto 'to set yourself ambitious plans', Cat. jugar net 'to fair play', Cat. fer curt 'to calculate below expectations', Fr. chanter faux 'to sing a wrong note', Fr. filer doux 'to keep a low profile', It. giocare sporco 'to behave dishonestly, specially by cheating in a game', It. parlare schietto 'to talk without mincing words'). In contrast, the only interpretation accepted by -mente adverbs is the compositional one. 
Abeillé \& Godard $(2003,2004)$ account for these facts by proposing that all (integrated) adverbs in post-verbal position should be analysed as complements of the verbal head. Indeed, as they observe, adverbs (especially manner adverbs) can be subcategorised for by a verb, as shown by the Spanish examples in (7).

(7) a. (Sp.)

Mi perro se porta ${ }^{*}($ bien/horrible) .

'My dog behaves well/horrible.'

b. Ana viste ${ }^{*}$ (bien/elegante).

'Ana dresses well/elegantly.'

Abeillé \& Godard implement their analysis in the Head-driven Phrase Structure Grammar (HPPS) framework. In particular, they propose that a lexical rule can extend the argument structure to include a number of adverbs, if the verbal head has the same features and key relation that such adverbs require of the verbal projection they modify.

On the basis of the Configurational Theory of Argument Structure (Hale \& Keyser 1993, 2002 and related work), Bartra \& Suñer (1997), Di Tullio \& Suñer (2011) and Suñer \& Di Tullio (2014) relate the degree of syntactic cohesion that adverbial adjectives establish with the verbal head with their lack of agreement. More specifically, Bartra \& Suñer (1997) argue that the default agreement can be derived from the fact that these elements are predicates of an empty category selected by the V at Lexical Conceptual Structure. Di Tullio \& Suñer (2011) and Suñer \& Di Tullio (2014), in turn, suggest that the lack of agreement is due to the fact that adverbial adjectives cannot check their agreement features against the gender and number features of their respective subjects before Spell-Out. ${ }^{5}$

The aim of this article is to argue that the distribution of adverbial adjectives within the VP domain displays a hierarchical order, which correlates with the different levels of the argument structure of the predicate they are related to. ${ }^{6}$ Hence, the alleged adverbial behavior that adverbial adjectives show, i.e. their lack of productive agreement, can be syntactically derived from the relationship they establish with different portions of the subeventive structure in which the main verbal predicate is decomposed.

The structure of the paper is as follows. In the second part of this article, it is argued that adverbial adjectives follow similar structural patterns than those

5. In Minimalist Theory, Spell-Out is the operation that removes material from the syntax and feeds it to the interpretive components of Logical Form and Phonetic Form.

6. In this article we do not discuss sentential adverbial adjectives and "tertiary attributes" (modifiers of adjectives and adverbs). See Hummel (2012) for a detailed description of sentential adverbial adjectives in Spanish. 
suggested by Bosque \& Masullo (1998) for adverbial quantifiers. Section 3 is devoted to analysing some cases of ambiguity when different adverbial adjectives co-occur in a single clause. In the fourth section some of the syntactic and interpretive differences between secondary predicates and adverbial adjectives will be accounted for. The final section provides an overview of the main points put forward in this paper.

\section{Adverbial adjectives and the syntactic decomposition of event predicates}

As has been claimed by Hale \& Keyser $(1993,2002)$, Mateu $(2002,2014)$ and Ramchand (2008), among others, argument structure and event structure can be represented in a layered syntactic structure of the VP. According to these proposals, VP heads are light (cf. CAUSE, DO, CHANGE, etc.) and always select a complement. Take for example the case of the denominal verb trabajar 'to work'. Its initial lexical projection contains an empty verb which selects the nominal root Trabajo. Hence, the verbal form trabajar is obtained by copying the relevant set of features of the nominal root TRABAjo into the null verb, as illustrated in (8). ${ }^{7}$

(8) a. $\left[{ }_{\mathrm{V}}\left[{ }_{\mathrm{V}} \varnothing\right]\left[{ }_{\mathrm{N}} \mathrm{V}_{\text {Trabajo }}\right]\right.$

b. $\left[{ }_{\mathrm{V}}\left[\mathrm{V}_{\mathrm{V}}\right.\right.$ trabaj $\mathrm{i}_{\mathrm{i}}$-ar $]\left[{ }_{\mathrm{N}} \sqrt{\text { TRABAJO }}\right]$

Following Hale \& Keyser's work, Bosque and Masullo (1998) argue that the ambiguity of the Spanish quantifier mucho 'a lot' in (9) can be accounted for by using a layered VP structure. Indeed, the Spanish sentence in (9) can convey four possible readings, illustrated by the paraphrases in (10), where mucho expresses an inherent quantification in (10a), an eventive quantification in (10b), a temporal or durative quantification in (10c) and, finally, an argumental quantification in (10d).

(9) (Sp.)

\#Corrió mucho.

Ran a lot-MSG

'(S/he) ran a lot.'

(10) a. Corrió a mucha velocidad. IQ

'(S/he) ran very fast.'

b. Corrió muchas veces.

'(S/he) ran many times.'

7. The verbal form is obtained via incorporation conceived as a head-movement (Baker 1998; Hale \& Keyser 1993, 2002). 
c. Corrió mucho tiempo.

'(S/he) ran for a long time.'

d. Corrió mucha distancia.

'(S/he) ran a long distance.'

In short, the different interpretations that the sentence in (9) can express are due to the fact that the quantifier mucho 'a lot' may be systematically associated to different scalar arguments or dimensions of a predicate susceptible to being quantified. ${ }^{8}$ In the following sections, I will propose that similar semantic nuances can be established by using adverbial adjectives, although they have a much more restricted distribution than quantifiers because they express a lexically governed predication. ${ }^{9}$

\subsection{Adverbial adjectives and inherent modification}

According to Bosque and Masullo (1998:31-8), the inherent quantification (IQ) is systematically allowed in Spanish when a quantifier such as mucho 'a lot', poco '(a) little' or demasiado 'too much' has scope over a predicative element in the verb's sublexical structure.

As the examples (11) to (13) illustrate, most unergative verbs are I-quantifiable

(11) (Sp.)

Pablo trabaja/piensa/camina/ríe/duerme mucho.

Activity verbs

'Paul works/thinks/walks/laughs/sleeps a lot.'

(12) Su herida sangraba/olía/supuraba un poco.

Emission verbs

'His/her wound bled/smelled/oozed pus a little.'

(13) Está lloviendo/nevando/granizando demasiado. Weather verbs 'It is raining/snowing/hailing too much.' [apud Bosque \& Masullo 1998:43]

This is to be expected if we assume, following Hale \& Keyser's work, that unergative predicates are obtained by incorporating a non-delimited noun into the light verb, as illustrated in (8).

In the case of adverbial adjectives, the inherent reading may be obtained when a dimensional adjective (Bierwisch 1989; Kennedy 1999; Demonte 1999: §3.4.2.2)

8. Some adverbial modifiers such as again can also convey multiple interpretations that arise because of differences of scope, see von Stechow (1995).

9. Additional information about the differences between quantification and modification in Doetjes (1997: Chapter 5). 
predicates a relevant dimension of the mass noun that has been previously incorporated into the light verb. ${ }^{10}$

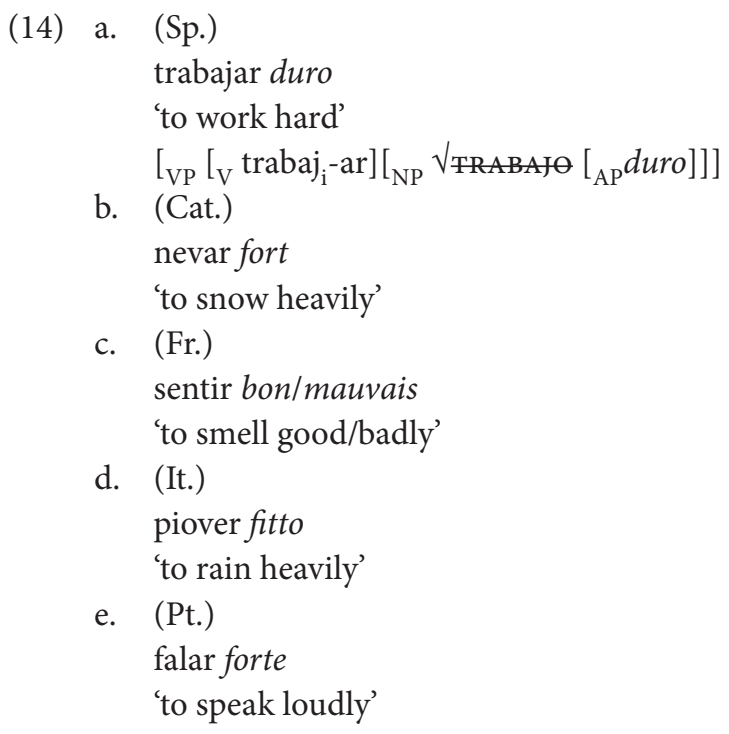

In this way the default agreement (masculine singular) that these forms display can be derived from the fact that they cannot check their gender and number features against the mass noun because it has been previously incorporated into the light verb. Significantly, the same adjective shows productive agreement under the scope of the corresponding mass noun in a nominal domain (15).

10. In addition, Bosque and Masullo (1998:35) argue that the implicit mass noun that unergative verbs contain must be a QP instead of being an NP. Thus, the head Q can function as a variable whose value can be determined by the adjunct quantifier mucho as seen in (i):

(i) (Sp.)

$$
\begin{aligned}
& \text { sangrar mucho } \\
& \left.{ }_{\mathrm{VP}}\left[{ }_{\mathrm{V}} \mathrm{V}+\text { sangre }_{\mathrm{i}}-\operatorname{ar}\right]\left[\mathrm{QP}_{\mathrm{QP}}\left[\mathrm{Q}^{\circ}\left[_{\mathrm{NP}} \mathrm{t}_{\mathrm{ij}}\right]\right]\right] \text { mucho }_{\mathrm{j}}\right] \\
& \text { 'to bleed } \text { lot }^{\prime}
\end{aligned}
$$

[adapted from Bosque \& Masullo 1998:35]

Postulating a Q as the head of an unbounded mass NP complement can justify, according to Bosque and Masullo (1998: 35), the fact that nominalizations of unergative verbs denoting products or results as (iia) are I-quantifiable, as shown in (iib).

(ii) a. (Sp.)

trabajar mucho, sangrar poco, nevar demasiado

'to work a lot', 'to bleed a little', 'to snow too much'

b. mucho trabajo, poca sangre, demasiada nieve

'a lot of work', 'a little blood', 'too much snow' 
(15) a. (Cat.)

nevada forta

snowfall-Fs heavy-Fs

'heavy snowfall'

b. (Fr.)

bonne/mauvaise odeur

good-Fs/ bad-Fs smell-Fs

'good/bad smell'

c. (It.)

pioggia fitta

rain-FS thick-FS

'heavy rain'

It is common ground that some transitive verbs behave like unergative predicates when used as intransitives. Therefore, they can also be combined with different adverbial adjectives conveying an inherent modification of the noun included in the verbal predicate (16) to (19).

(16) a. (Sp.)

saltar alto

$\left[{ }_{\mathrm{VP}}\left[\mathrm{V}\right.\right.$ salt $\mathrm{i}_{\mathrm{i}}$-ar $]\left[{ }_{\mathrm{NP}} \sqrt{\text { sALTO }}_{\mathrm{i}}\left[{ }_{\mathrm{AP}}\right.\right.$ alto $\left.\left.]\right]\right]$

'to jump high'

b. golpear fuertelflojo

'to hit hard/softly'

(17) a. (Cat.)

comptar curt/llarg

'to underestimate/to overestimate'

b. cavar fondo

'to dig deep'

(18) a. (Fr.)

viser haut

'to aim high'

b. frapper fort

'to hit hard'

(19) a. (It.)

tagliare corto

'to cut short' 'to come straight to the point'

b. colpire forte

'to hit hard' 
Notice that in the previous examples the adverbial adjective expresses a degree usually relatively high but sometimes also low - on a certain property that can be predicated of the noun that has been incorporated into the light verb. This is what occurs, for example, with the Spanish adjective alto 'high, loud', which expresses a positive value of a dimensional property (high/low, loud/quiet) but this value is interpretable according to two different parameters (height or loudness) depending on the meaning of the verb it modifies, cf. REDES (2004: s.v. alto).

(20) a. volar alto

$\left[\mathrm{VP}\left[\mathrm{V}\right.\right.$ vuelo $_{\mathrm{i}}$-ar $]\left[\mathrm{NP}_{\mathrm{NUE \perp O}}\left[\mathrm{V}_{\mathrm{AP}}\right.\right.$ alto $\left.\left.]\right]\right]$

'to fly high'

b. cantar alto

$\left[{ }_{\mathrm{VP}}\left[{ }_{\mathrm{V}}\right.\right.$ canción $\left._{\mathrm{i}}-\mathrm{ar}\right]\left[_{\mathrm{NP}} \sqrt{ }\right.$ eANCiÓN $_{\mathrm{i}}\left[{ }_{\mathrm{AP}}\right.$ alto $\left.\left.]\right]\right]$

'to sing loudly'

Similar contrasts can be observed in Catalan (21), and Italian (22).
a. (Cat.)
llaurar fondo
'to plow deep'
b. respirar fondo
'to breathe deeply'

(22) a. (It.)

andare piano

'to walk slowly'

b. parlare piano

'to speak in a low voice'

The most relevant properties of inherent adverbial adjectives are described below.

In the first place, as the inherent interpretation is obtained from the incorporation of the object into the light verb, strict adjacency between the $\mathrm{V}$ and the adverbial adjective is required, as shown by the Examples (23) to (25). ${ }^{11}$

11. Notice that, although some adverbial adjectives generally require strict adjacency with the verb, they can be split out when their relative weight increases, usually with elements that express degree, as diminutive suffixes (Spanish: hablaban entre ellos bajitol?? bajo, 'talked among themselves quiet/??little quiet, in a low voice'), superlatives (Sp.: hablaban entre ellos muy alto/?alto o gritó lo más fuerte que pudo' they talked among themselves loudest/?as loud as he could') or comparative codas (Sp.: En este súper me venden los yogures más barato que en el otro 'In this supermarket they sell yogurts cheaper than in the other one'). 
(23) a. (Sp.)

Habló claro en la reunión.

Spoke-3sg clear-ms at the meeting

'(S)he spoke clearly at the meeting.'

b. *Habló en la reunión claro.

Spoke-3sg at the meeting clear-Ms

'(S)he spoke at the meeting clearly'.

(24) a. (Cat.)

Lavió vola alt sobre la selva amazònica.

The plane flies-3sg high-ms over the Amazon jungle

'The plane flies high over the Amazon jungle'.

b. *'Lavió vola sobre la selva amazònica alt.

The plane flies-3sg over the Amazon jungle high-ms

'The plane flies over the Amazon jungle high.'

(25) a. (It.)

Nicola parla chiaro con i suoi superiori.

'Nicola speaks-3sg clear-Ms with his superiors.'

'Nicola speaks clearly with his superiors.'

b. ${ }^{*}$ Nicola parla con i suoi superiori chiaro.

Nicola speaks-3sg with his superiors clear-Ms

'Nicola speaks with his superiors clearly'.

Secondly, since adverbial adjectives express the extension of the event, they are in complementary distribution with delimited objects of transitive predicates (26), which also measure the time interval where the action takes place, as shown in the Spanish examples in (26). ${ }^{12}$

(26) a. (Sp.)

Saltó $\quad$ la valla/alto $\}$.

Jumped \{the fence/high-MSG

'(S)he jumped \{(over) the fence/high\}.'

b. Cantó \{un bolero/bajo\}.

Sang \{a bolero/soft-MSG

'(S)he sang \{a bolero/softly\}.'

c. Corrió \{la maratón/lento\}.

Ran $\quad$ the marathon/ slow-MSG\}.

'(S)he ran $\{$ the marathon/ slowly\}.'

12. The idea that some arguments of verbs (also known as "Incremental Themes") are used to show to what extend the event denoted by the verb progresses dates back to Tenny $(1987,1992)$, Dowty (1991) and Krifka (1992). 
The same restriction holds for QP phrases measuring the time span where the event is carried out (27).
(27) a. (Sp.)
Saltó $\quad$ dos metros/alto\}.
Jumped \{two meters/high-MsG
'(S)he jumped \{two meters/high\}.'
b. Cantó $\{$ diez minutos/bajo\}.
Sang $\{$ ten minutes/soft-MSG
'(S)he sang \{(for) ten minutes/softly.\}'
$\begin{array}{ll}\text { c. Corrió } & \{\text { cinco horas/lento }\} . \\ \text { Ran } & \text { five hours/slow-MSG }\} \text {. }\end{array}$
'(S)he $\operatorname{ran}\{$ (for) five hours/slowly.\}'

Finally, despite the incompatibility with internal arguments in (26) and measure phrases in (27), inherent adverbial adjectives do not alter the aspectual character of the activity. For this reason, their constructions do not admit temporal expressions with en 'in' which are only compatible with telic predicates, in sharp contrast to structures with delimited internal arguments which denote telic accomplishments, as seen in (28) and (29).

(28) a. (Sp.)

${ }^{\star}$ Cantó

bajo en tres minutos.

Activity (Non telic)

Sang-3sg soft-ms in three minutes

'(S)he sang soft in three minutes.'

b. Cantó un bolero en tres minutos.

Sang-3sg a bolero in three minutes

Accomplishment (Telic)

'(S)he sang a bolero in three minutes.'

(29) a. (Sp.)

${ }^{*}$ Corrió lento en cinco horas.
Ran-3sg slow-Ms in five hours

Activity (Non telic)

'(S)he ran slow in five hours.'

b. Corrió la maratón en cinco horas. Accomplishment (Telic)

Ran-3sg the marathon in five hours

'(S)he ran the marathon in five hours.'

Conversely, structures containing inherent adverbial adjectives can be associated to temporal expressions with durante 'for' which delimit a portion of the temporal extent of an atelic event. 
(30) a. (Sp.)

Cantó bajo durante diez minutos. Activity (Non telic)

Sang-3sg soft-Ms for ten minutes

'(S)he sang soft for ten minutes.'

b. "Cantó un bolero durante diez minutos. ${ }^{13}$ Accomplishment (Telic) Sang-3sg a bolero for ten minutes

'(S)he sang a bolero for ten minutes.'

(31) a. (Sp.)

Corrió lento durante cinco horas. Activity (Non telic)

Ran-3sg slow-Ms for five hours

'(S)he ran slowly for five hours.'

b. *Corrió la maratón durante cinco horas. Accomplishment (Telic)

Ran-3sg the marathon in five hours

'(S)he ran the marathon in five hours.'

\subsection{Adverbial adjectives and eventive modification}

According to Bosque and Masullo (1998:25), eventive quantification is obtained when a quantifier is combined with an event predicate as in (32), where quantifiers such as mucho 'a lot', demasiado 'too much' and poco '(a) little' express repetition or iteration.
a. (Sp.)
Pablo viaja mucho.
Pablo travels a lot-Ms
'Pablo travels a lot (= many times).'
b. Julio va poco al cine.
Julio goes rare-Ms to the cinema
'Julio rarely goes to the cinema'
c. Eva telefonea demasiado a los amigos.
Eva phones too much-Ms to the friends
'Eva phones her friends too often.'

In these cases, the quantifier is supposed to extend the scope over the hidden eventive argument $<\mathrm{e}>$ in the sense of Higginbotham (1985) and others. ${ }^{14}$

13. The iterative reading must be excluded.

14. The idea that verbs have an argument corresponding to a spatio-temporal location (eventive argument) where the event takes place has been argued for by Davidson (1967). This idea reemerged in neo-davidsonian hypotheses, see Higginbotham (1985) and Parsons (1990), among others. In accordance with these approaches, in the sentence in (i), the verbal head cut selects 
(33) a. (Sp.)

viajar mucho (= viajar muchas veces)

Eventive quantification

'to travel a lot (= to travel many times)'

b. $\left[_{\mathrm{vP}}\left[{ }_{\mathrm{v}} \mathrm{v}\left[{ }_{\mathrm{VP}}\left[\mathrm{V}_{\mathrm{V}}\right.\right.\right.\right.$ viaje $\left.\left.\left._{\mathrm{i}}+\mathrm{V}\right]{\sqrt{\text { HAfF }_{\mathrm{i}}}}\right]\right]<\mathrm{e}>$ mucho $]$

Similarly, some eventive adjectives (Demonte 1999: \$ 3.6.4) such as Sp. seguido ${ }^{15}$ 'often', Mex. mensual 'monthly', Riopl. salteado 'on and off', Mex. constante 'constantly', Riopl. tupido 'often', Mex. frecuente 'frequently', Mex. diario 'daily' or Mex. occasional 'occasionally/from time to time' have an iterative interpretation when they are predicated of the eventive argument of action verbs (34).

(34) a. (Riopl.)

Laburan salteado.

'They work on and off.'

b. (Sp.)

Juegan a cartas seguido.

'(They) often play cards.'

c. (Riopl.)

Habla tupido de él.

'(She) often talks about him.'

d. (Mex)

Visito frecuente este restaurante.

'(I) often go to this restaurant.'

e. (Mex)

¿Qué es lo máximo que puedes pagar mensual por tu casa nueva?

'What is the most you can afford to pay monthly for your new home?'

its external and internal arguments (Seymour and the salami, respectively) as well as an eventive argument $<\mathrm{e}>$ which can be modified by an (optional) adverbial or PP adjuncts, such as instrumentals (with a knife), locatives (in the kitchen), temporal or manner expressions, among others.

(i) a. [[ $\underline{\text { Seymour }}$ cut the salami $]<e>$ with a knife in the kitchen] Agent Theme

b. $\quad \theta$-grid cut $(\mathrm{x}, \mathrm{y}, \mathrm{e})$

where, $\mathrm{x}=$ external argument (Seymour)

$\mathrm{y}=$ internal argument (the salami)

$\mathrm{e}=$ eventive argument (modified by the predicates with a knife (instrumental) and in the kitchen (locative).

For further information we refer the reader to Bosque and Gutiérrez-Rexach (2009: \$5.5.2) and Mendikoetxea (2009).

15. As we will see in the next section $(\$ 3)$, the adverbial adjective seguido 'often/constantly' may express both eventive and durative readings depending on the aspectual properties of the predicate with which it is combined. 
If this analysis is appropriate, the default agreement that the adverbial adjectives in (34) display can be derived from the fact that the eventive argument lacks gender and number features.

The most relevant properties of eventive adverbial adjectives are described below:

First, since eventive modification is obtained when an eventive adjective is predicated of the (hidden) eventive argument, all types of events (activities, accomplishments and achievements) are expected to license this interpretation, unlike stative predicates (35).

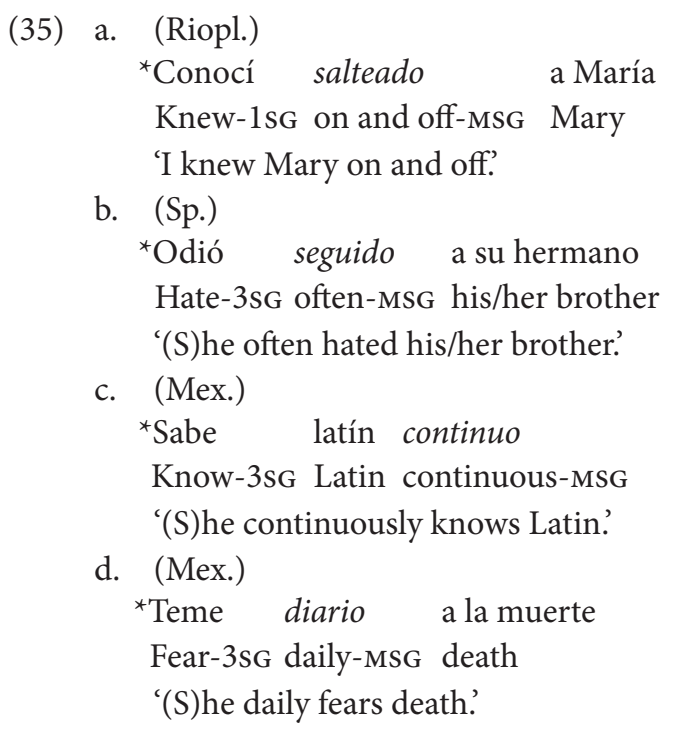

Secondly, as the eventive adverbial adjective modifies the whole event, strict adjacency between the verbal head and the adjective is not necessarily required (36), unlike what happens with inherent modification.
a. (Sp.)
viajar (seguido) a Graz (seguido)
to travel (often) to Graz (often)
b. (Mex.)
ir (frecuente) al baño (frecuente)
to go (often) to the toilet (often)

Finally, given that eventive adverbial adjectives express an iterative interpretation, it is expected that these forms be in complementary distribution with frequentative expressions such as $x$ veces 'x times' (see Doetjes 1997: Chapter 5) or otra vez 'again' (see von Stechow 1995). 
(37) a. (Sp.)

viajar \{seguido/dos veces/otra vez\} a Graz

to travel \{often/two times/again\} to Graz

b. ir $\{$ seguido/muchas veces/otra vez $\}$ al baño

to go $\{$ often/many times/again $\}$ to the toilet

\subsection{Adverbial adjectives and durative interpretation}

According to Bosque and Masullo (1998:26), adjunct quantifiers such as mucho 'a lot', poco 'a little', bastante 'enough' can also convey a durative interpretation. Durative interpretations are licensed whenever the quantifier has scope over a part of the internal development of an activity (38).

(38) a. (Sp.)

esperar bastante

'wait long enough'

b. dormir un poco

'sleep a little bit'

c. no permanecer mucho en un lugar

'not to stay in a place for too long' (apud Bosque \& Masullo 1998:26)

A similar semantic effect is obtained when an adverbial adjective denoting spatial or temporal length such as Sp. largo 'long', Mex. constante 'constantly', Mex. corto 'shortly', Sp. largo y tendido 'at length', Old Sp./Am. Sp. breve 'briefly' modifies the temporal extension in which an activity is carried out.

(39) a. (Sp.)

Hablaron largo $y$ tendido.

Talked-3PL long-ms and lying-ms

'(They) talked at length.'

b. (Riopl.)

Mateaba largo sobre un tronco.

Drank-3sg mate long-Ms on a log

'(S)he drank mate long on a log.'

c. (Mex.)

Entrecierra los ojos y sonríe breve.

Half-close-3sg the eyes and smiles brief-ms

'(S)he squints and smiles briefly.'

d. (Riopl.)

Durmió corto y profundo.

Slept-3sg short-ms and deep-ms

'(S)he slept shortly and deeply'. 
e. (Mex.)

El actual gobierno federal habla constante de seguir The current Federal Government speaks constant-Ms about moving con paso firme hacia adelante.

resolutely forward

'The current Federal Government is constantly speaking about moving forward resolutely.' [url:<http://www.notasdelmedioambiente.com>]

The most salient properties of durative adverbial adjectives are described below.

First, durative readings can only appear when durative adjectives modify atelic predicates. For this reason, some semantically-related verbs such as attention verbs (which denote atelic activities) and perception verbs (which denote telic achievements) display an asymmetric behaviour, as shown by the contrasts between examples $\mathrm{a}$ and $\mathrm{b}$ in (40) and (41), see Bosque \& Masullo (1998:26).

(40) a. (Sp.)

La miró largo.

Activity (Atelic)

'(S)he looked at her long enough.'

b. ${ }^{\star}$ La vio largo.

'(S)he saw her long enough.'

(41) a. (Sp.)

La escuchó largo.

Achievement (Telic)

'(S)he listened to her long enough.'

b. ${ }^{\star}$ La oyó largo.

'(S)he heard her long enough.'

Secondly, in contrast with quantifiers such as mucho, which can be systematically associated with different aspectual types of predicates, some durative adjectives are lexically restricted to a particular class of verbs. This is the case for largo $y$ tendido 'at length' which can only be combined with speech verbs such as hablar 'to talk', charlar 'to chat', conversar 'to converse', responder 'to reply' etc., see Alcina \& Blecua (1975: 709), Bosque (1989: \$ 6.3.) and REDES (2004: s.v. largo 'long').

Finally, given that durative adjectives express the temporal extent in which an atelic event is carried out, they cannot co-occur with durative complements denoting the same concept (42a) nor with QPs measuring the time in which the event takes place (42b), see Bertinetto (1986:273-85).

(42) a. (Sp.)

*/??Hablaron durante dos horas largo y tendido.

(They) talked for two hours at length

b. *Sonrió breve tres segundos.

(S)he smiled briefly for three seconds 


\subsection{Adverbial adjectives and argumental interpretation}

According to Bosque and Masullo (1998), argumental quantification is obtained when the internal argument of a transitive verb is lexicalized by a quantifier such as mucho 'a lot' or poco 'little' as in (43).
a. (Sp.)
Comió $\left[{ }_{\mathrm{QP}}\right.$ mucho $\left.\left[_{\mathrm{NP}} \varnothing\right]\right]$.
'S(he) ate a lot (of Ø).'
b. Bebió $\left[{ }_{\mathrm{QP}}\right.$ poco $\left.\left[_{\mathrm{NP}} \varnothing\right]\right]$.
'(S)he drank little $(\varnothing)$.'

Notice that the empty noun in (43) can be semantically recovered through two different grammatical procedures. On the one hand, by establishing an anaphoric relation with an antecedent previously mentioned in discourse as in (44).
a. (Sp.)
Luis come $\left[{ }_{\mathrm{QP}}\right.$ poco $\left[{ }_{\mathrm{NP}}\right.$ chocolate $\left.\left.\mathrm{i}_{\mathrm{i}}\right]\right]$ pero Julio come $\left[\mathrm{QP}_{\mathrm{QP}}\right.$ mucho $\left.\left[{ }_{\mathrm{NP}} \varnothing_{\mathrm{i}}\right]\right]$.
'Luis eats little chocolate but Julio eats a lot.'
b. Yo bebí $\left[{ }_{\mathrm{QP}}\right.$ mucho $\left[{ }_{\mathrm{NP}}\right.$ vino $\left.\left._{\mathrm{i}}\right]\right]$ pero el conductor bebió $\left[{ }_{\mathrm{QP}}\right.$ poco $\left.\left[{ }_{\mathrm{NP}} \varnothing_{\mathrm{i}}\right]\right]$. 'I drank a lot of wine but the driver drank little.'

On the other hand, sentences such as (43) can also be uttered out-of-the-blue. In these cases, quantificational complements are interpreted as partitive neuter forms which can be paraphrased as 'a big part of something eatable' in (45a) and 'a small part of something drinkable' in (45b).
a. (Sp.)
Come $\left[_{\mathrm{QP}}\right.$ much-o (de) $\left[_{\mathrm{NP}}\right.$ algo comible $]$.
'S(he) eats a lot of something eatable'
b. Bebe $\left[{ }_{\mathrm{QP}}\right.$ poco $(\mathrm{de})\left[_{\mathrm{NP}}\right.$ algo bebible $]$.
'(S)he drinks little of something drinkable'

As a result, the default agreement (masculine singular) that the Spanish quantifiers in (44) display can be derived from the fact that they surface as neuter forms. By contrast, since the empty noun can be contextually recovered in (46), quantifiers may emerge displaying productive gender and number agreement.

(46) a. (Sp.)

$$
\begin{aligned}
& \text { Luis come }\left[\begin{array}{l}
\mathrm{QP} \\
\text { poc-a }
\end{array} \begin{array}{l}
\left.\left[_{\mathrm{NP}} \text { carne }_{\mathrm{i}}\right]\right] \\
\text { Luis eats pero Julio come } \\
\left.{ }_{\mathrm{QP}} \text { much-a }\left[{ }_{\mathrm{NP}} \varnothing_{\mathrm{i}}\right]\right] \\
\quad \text { a lot-FSG }
\end{array}\right. \\
& \text { 'Luis eats little meat but Julio eats a lot.' }
\end{aligned}
$$


b. Yo bebí $\left[{ }_{\mathrm{QP}}\right.$ much-a $\quad\left[{ }_{\mathrm{NP}}\right.$ cerveza $\left.\left._{\mathrm{i}}\right]\right]$ pero él bebió I drank a lot-FSG of beer-FSG but he drank

$\left[{ }_{\mathrm{QP}}\right.$ poc-a $\left.\left[{ }_{\mathrm{NP}} \varnothing_{\mathrm{i}}\right]\right]$ little-FSG

'I drank a lot of beer but he drank little.'

Similar contrasts can be obtained when an implicit internal argument is modified by an adjectival adverb under its scope. Unsurprisingly, when the meaning of the implicit internal argument can be anaphorically recovered from the previous context, adjectives show productive agreement (47).

(47) a. (Sp.) [Context: A group of friends are in a pub]

A: ¿Te apetece una Guinness?

'Do you fancy a Guinness?'

B: No, yo solo bebo rubi-a.

No, I only drink blond-FSG

'No, I only drink lager (beer).'

b. A: ¿Quieres leche?

'Do you want some milk?'

B: No, yo solo bebo desnatad-a.

No, I only drink skimmed-FSG (milk)

'I only drink skimmed (milk)'.

Conversely, the adjectives directed to the implicit object in (48) manifest default agreement in masculine singular.

(48) a. (Sp.)

comer sano/ligero/sabroso/graso/salado/picante

'to eat healthy/light/savoury/fatty/salty/spicy (food)'

b. beber tinto/blanco

'to drink red/white (wine)'

c. bailar clásico/moderno

'to dance classical/modern (dance)'

d. votar socialista/demócrata/verde

'to vote socialist/democrat/green (vote)'

e. fumar negro/rubio

'to smoke black/Virginian (tobacco)'

The syntactic nature of the non-agreeing adjectives in (48) is a controversial issue. To begin with, the adverbial adjectives described in the previous sections denote dimensional properties whereas the ones in (48) are classifying adjectives and they do not usually admit gradation (49), nor can they be replaced by adverbs with -mente (50): 


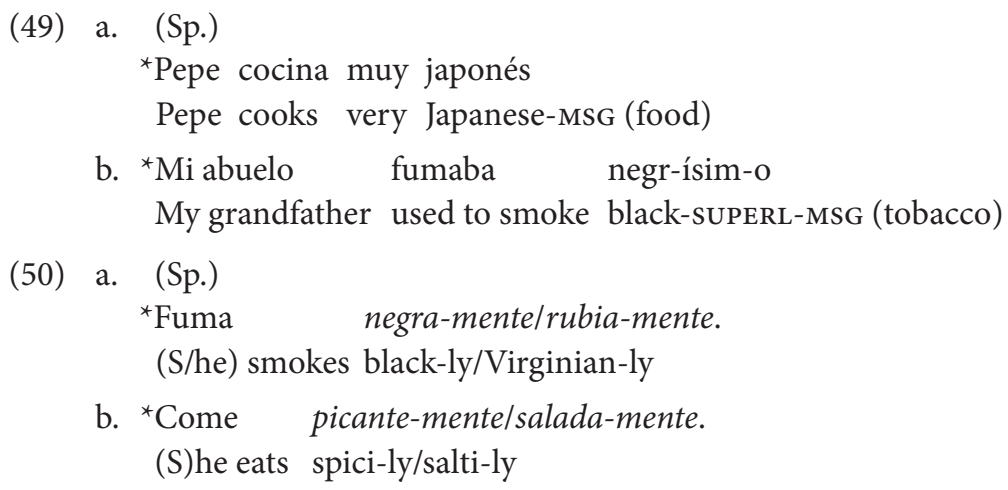

Interestingly enough, these adjectives modify bivalent transitive verbs such as comer 'to eat' and other verbs of consumption, creation, execution and excretion in their absolute use (without overt direct objects). However, they cannot be combined with other transitive verbs such as zamparse 'to gobble down' or tragar 'to swallow' (51), which are very similar from a semantic point of view but always require an overt direct object, as shown in (52).

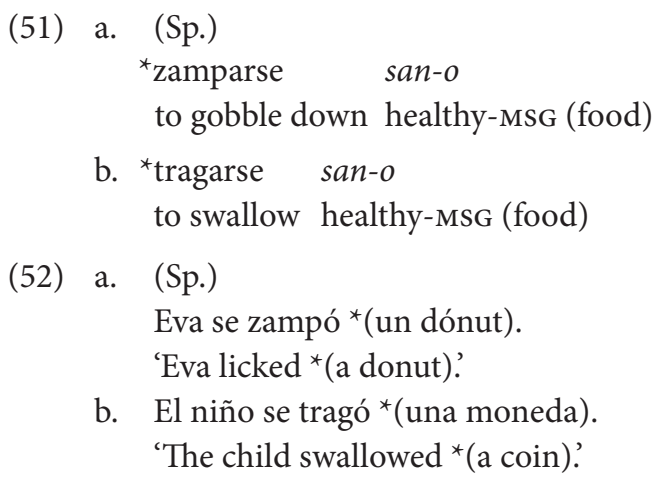

As we have seen above, absolute transitive verbs such as bailar 'to dance', comer 'to eat' and leer 'to read' have been analysed as a result of the incorporation of a cognate object into a light verb. ${ }^{16}$ In fact, they are all "false" transitive verbs since, if they

16. Cognate object constructions have received widespread attention in lexical-semantics literature. Indeed, there is a traditional disagreement on the question whether the cognate object must be seen as an argument or an adjunct. In general terms, three proposals have been put forth: (i) those who analyse cognate objects as arguments (Massam 1990; Hale \& Keyser 1997; among others), (ii) those who argue that they are adjuncts (Jones 1988; Zubizarreta 1987; Mittwoch 1998) and, finally, those who consider that there are both argumental and adjunct cognate objects (Pereltsvaig 1999a, 1999b; Nakajima 2006). We will not pursue here in such debate, but we refer the reader to Real Puigdollers (2008) for detailed information about it. 
admit objects, they morphologically reiterate the content that is expressed by the verb (53), or they are hyponyms of such nouns (Jones 1988: 89), as illustrated in (54).

(53) (Sp.)
a. bailar (baile) to dance (dance)
Cognate Object Construction
b. comer (comida) to eat (food)
c. leer (lectura) to read (reading)

(54) (Sp.)
a. bailar (tango) to dance (tango) Hyponymic Object Construction
b. comer (galletas) to eat (cookies)
c. leer (novela) to read (novel)

As pointed out by Baron (1971), Jones (1988), Massam (1990), Pereltsvaig (1999a, 1999b) and Real Puigdollers (2008), argumental cognate objects do not have a referential ability, nor do they have a lexical meaning independent from the verb. Furthermore, they can be interpreted as a variable categorized for a range of entities defined by the meaning of the verb. Let us suppose that this nominal variable lacks specific gender and number features and can be lexicalized by a neuter pronoun such as algo 'something' in (55).

(55) a. (Sp.)
Lee algo (legible).
Read something-MSG (readable-MSG)
'(S)he reads something (readable)'.
b. Come algo (comible).
Eats something-MSG (eatable-MSG)
'(S)he eats something (eatable).'

If this assumption is correct, adverbial adjectives predicated to the (covert) neuter object will emerge showing default agreement as illustrated in (56).

(56) a. (Sp.)
Baila (algo) lent-o.
Dances (something-MSG) slow-MSG
'(S)he is dancing (some) slow dance.'
$\begin{array}{lll}\text { b. Comió (algo) } & \text { salad-o. } \\ \text { Ate } & \text { (something-MSG) } & \text { salty-MSG }\end{array}$
'(S)he ate something (salty).'

By contrast, when they are under the scope of a hyponym, they manifest productive agreement (57). 
(57) a. (Sp.)

Baila una rumb-a lent-a.

Dances a rumba-FSG slow-FSG

'(S)he is dancing a slow rumba'.

b. Comió dos galletas salad-a-s.

Eats two cookie-FPL salty-FPL

'(S)he ate two salty cookies.'

These inflectional differences are related to semantic nuances: whereas the NP objects in (57) refer to individualized entities, the neuter pronoun in (56) denotes a set of uncountable elements that cannot be put in one-to-one correspondence with the set of natural numbers. Interestingly enough, in these cases the main contrast is linked to the number feature: while number has the ability to individualize entities, neuter is unable to express plurality.

Moreover, despite being portions of the internal argument, adjectives directed to the neuter cognate object differ from full overt objects in some respects:

First, they can never function as the grammatical subject of a passive clause (58a).

(58) a. (Sp.)

*Primero fue comido san-o.

First was eaten healthy-MSG

'Healthy (food) was eaten first.'

b. Primero fue comida la comida san-a.

First was eaten the food-FSG healthy-FSG

'Healthy food was eaten first.'

Similarly, they cannot be topicalized (59a), pronominalized (60a) nor replaced by an interrogative pronoun (61a). ${ }^{17}$

(59) a. (Sp.)

*Sano-MSG, nadie comió.

Healthy-MSG, nobody ate

17. Nevertheless, in certain contexts argumental adjectival adverbs may behave as true internal arguments, namely they can be coordinated with singular mass nouns or plural count nouns:

(i) a. (Sp.)

Fuma negr-o y puros.

Smokes black-MSG and cigars

'S/he smokes black (tobacco) and cigars.'

b. Bebe tinto y coñac.

Drinks red-MSG and brandy

'S/he drinks red (wine) and brandy'. 
b. La comida san- $a$, nadie la comió.

The food-FSG healthy-FSG, nobody it-CL-FSG ate

'Healthy food, nobody ate it.'

(60) a. (Sp.)

${ }^{*}$ Laura comió sano y su hermano lo comió también.

Laura ate healthy-MSG and her brother it-MSG ate too

'Laura ate healthy (food) and her brother ate it, too.'

b. Laura comió comida san-a y su hermano la

Laura ate food healthy-FSG and her brother it-FSG

comió también.

ate too

'Laura ate healthy (food) and her brother ate it, too.'

(61) a. (Sp.)
A: ¿Qué come Laura?
What eats Laura
'What does Laura eat?'

B: *San-o.

Healthy-MSG

'Healthy (food).'

b. A: ¿Qué come Laura?

What eats Laura

'What does Laura eat?'

B: Comid-a san-a.

Food-FSG healthy-FSG

'Healthy food.'

From an aspectual perspective, argumental adverbial adjectives do not delimit the temporal extent of the predicate as incremental themes do. Consequently, temporal expressions with en 'in', which are only compatible with telic predicates (62b), cannot be added (62a).

(62) a. (Sp.)

Comió salad-o ( ${ }^{*}$ en dos minutos).

Atelic

Ate salty-MSG in two minutes

'(S/he) ate salty (things) ( ${ }^{*}$ in two minutes).'

b. Comió dos gallet-as salad-as en dos minutos.

Telic

Ate two cookies-FPL salty-FPL in two minutes

'(S/he) ate two salty cookies in two minutes.'

Unsurprisingly, argumental adverbial adjectives can co-appear with durative complements (63a), whereas full overt objects cannot (63b). 
(63) a. (Sp.)

Comió salad-o durante dos minutos. Atelic

Ate salty-Msg for two minutes

'(S/he) ate salty (things) for two minutes.'

b. Comió dos gallet-as salad-as (*durante dos minutos). Telic Ate two cookies-FPL salty-FPL in two minutes

'(S/he) ate two salty cookies ( ${ }^{\star}$ for two minutes).'

Additionally, as non-delimited processes, sentences with argumental adverbial adjectives such as (64a) reject the aspectual operator se in sharp contrast with overt objects (64b). ${ }^{18}$
a. (Sp.)
${ }^{*}$ Se comió salad-o.
She-Asp ate up salty-MSG
'(S/he) ate salty (food).'
b. Se comió dos galletas salad-as.
Se-ASP ate up two cookies salty-FPL
'(S/he) ate up two salty cookies.'

To sum up, in this section several arguments have been provided to support the hypothesis that the distribution of adverbial adjectives within the VP domain follows a hierarchical order which correlates with the four different portions of the subeventive structure of the predicate they can be related to.

\section{Some ambiguities}

As seen in the previous sections, adverbial adjectives may be predicates of different portions of the sub-lexical structure of an event predicate. On the basis of this premise, it may be expected that some adverbial adjectives may convey multiple interpretations according to differences in scope. It is also predictable that more than one adverbial adjective may co-occur in the same sentence provided that they are associated to different structural levels. As we shall see below, these predictions hold true.

Accordingly, the sentence in (65) is ambiguous: in the first reading, the adverbial adjective expresses a type of dance (66a), whereas in the second interpretation it indicates a way of dancing (66b).

18. See De Miguel \& Fernández Lagunilla (2000) and Rodríguez Ramalle (2003) for further details regarding aspectual $s e$ in Spanish. 
(65) (Sp.)

\#Ana baila lent-o.

Ana dances slow-MSG

(66) a. (Sp.)

$\begin{array}{lll}\text { Ana baila } & \text { lent-o } \\ \text { Ana dances }\left[\varnothing_{\text {NEUTER }}\left[{ }_{\mathrm{AP}}\right.\right. & \text { slow-MSG }]]\end{array}$

Argumental

'Ana dances a slow(dance).'

b. Ana baila lent-o.

Ana $\left[_{\mathrm{vP}}\right.$ dance-s [dance] slow-MSG]

'Ana dances in a slow manner.'

In the argumental reading, the classifying adverbial adjective lento 'slow' modifies the neuter cognate object, while in (66b) lento is predicated of the relevant dimension of the mass noun that has been previously incorporated into the light verb. The fact that (65) has two different structures can explain why the two interpretations in (66a) and (66b) require two different interrogative words:

(67) a. (Sp.)

¿Qué baila Ana? ¿Lent-o o rápid-o?

Argumental

What dances Ana Slow-MSG or fast-MSG

Inherent (Manner)

'What does Ana dance? Slow (dance) or fast (dance)?'

b. ¿Cómo baila Ana? ¿Lento o rápido?

Inherent

How dances Ana Slow-Msg or fast-MSG?'

'How does Ana dance? Slowly or fast?'

The same distinction can also be seen in relative or in cleft sentences, in particular in the selection of the relative particle:

(68) a. (Sp.)

Fue lent-o lo que bailó.

Argumental

Was slow-MSG it-ACC-MSG that danced

'It was slow (dance) what (s)he danced.'

b. Fue lent-o como lo bailó.

Inherent

Was slow-MSG how it-ACC-MSG danced

'It was slow how (s)he danced it.'

(69) a. (Sp.)

Fue lent-o/*lenta-mente lo que bailó. Argumental

Was slow-MSG/slow-ly it-ACC-MSG that danced

'It was slow (dance) what (s)he danced.'

b. Fue lent-o/lenta-mente como lo bailó.

Inherent

Was slow-MSG/slow-ly how it-ACC-MSG danced

'It was slow how (s)he danced it.' 
A similar contrast is obtained in their respective agentive nominalizations. Whereas the argumental reading requires the presence of the preposition $d e$ 'of', the inherent interpretation needs an adjectival modifier.

(70) a. (Sp.)

$$
\begin{aligned}
& \text { un bailarín de lent-o } \\
& \text { a dancer of slow-MSG } \\
& \text { 'a dancer of slow music' } \\
& \text { b. un bailarín lent-o } \\
& \text { a dancer slow-MSG } \\
& \text { 'a slow dancer' }
\end{aligned}
$$

Argumental

Inherent (Manner)

Moreover, adverbial adjectives which express argumental modification can be resumed by a partitive clitic in languages that possess such anaphoric elements such as Catalan:

a. (Cat.)

Abans menjava picant però ara no en puc menjar.

Before ate $\quad$ spicy-MSG $\mathrm{M}_{\mathrm{i}}$ but now no en-PART $\mathrm{i}_{\mathrm{i}}$ can eat

'I used to eat spicy (food) but I cannot do it anymore.'

b. Abans fumava ros però ara no

Before smoked Virginian lit. blond-MSG $\mathrm{H}_{\mathrm{i}}$ but now no

en fumo.

en-PART smoke $_{i}$

'I used to smoke Virginian tobacco but I do not do it anymore.'

However, Catalan adverbial adjectives with a manner interpretation must be resumed by the adverbial clitic $h i$ 'there/like this':
a. (Cat.)
"L'Anna balla lent.
Inherent/Argumental
The Anna dances slow-MSG
'Anna dances slow.'
b. L'Anna hi balla.
The Anna hi-obl dances
Inherent (Manner)
'Anna dances (this way).'
c. L'Anna en balla.
The Anna en-PART dances
'Anna dances (this type of dance).'
Argumental

Similarly, the adverbial adjective seguido may be a source of ambiguities. As we have seen in Section 2.2, when it is predicated of the eventive argument of a telic event it expresses an iterative meaning. Instead, when it has scope over the internal 
development of an atelic activity, it conveys the meaning that the process is developed with no interruptions during the time interval in which it occurs, as shown in (73).

(73) a. (Sp.)

Trata de ayunar seguido.

'Try to fast constantly'.

b. (Sp.)

Hacer dieta seguido hace engordar más durante el embarazo.

'Following constantly a diet makes you gain weight during pregnancy.'

c. (Sp.)

Mi bebé de siete meses no duerme seguido toda la noche.

'My seven-month-old baby does not sleep all through the night.'

d. (Sp.)

Llovió seguido horas y horas.

'It rained constantly for hours and hours.'

e. (Riopl.)

La mina no labura seguido, solo unos días a la semana.

'The girl does not work constantly, only a few days a week.'

As argumental and inherent (manner) adverbial adjectives occupy different structural positions, it is expected that they can co-occur. This is what actually happens in the next sentence, where the Spanish adverbial adjective lento 'slow' is a portion of the internal object and rápido 'quick 'modifies the whole event.

(74) (Sp.)
Baila lent-o rápid-o
Argumental + Inherent
danced slow-MSG quick-MSG
'(S)he dances slow (dances) quickly'

Likewise, in (75), the adverbial adjective sano 'healthy' is predicated of the neuter cognate object while seguido 'often' is directed to the eventive argument.

(75) (Sp.)
Comemos san-o
seguid-o
Argumental + Eventive
Eat
healthy-MSG often-MSG
'(We) often eat healthy (food).'

Finally, in (76) claro 'clear' expresses the way in which the activity of hablar 'to speak' is carried out while largo $y$ tendido 'for a long time' refers to the temporal extent of the event hablar claro 'to speak clearly'. 
(76) (Sp.)

Hablaron clar-o largo $y$ tendid-o. Inherent + Durative Spoke clear-MSg long-MSg and widespread-MSG

'They spoke clearly for a long time.'

In conclusion, although most adverbial adjectives are lexically restricted to specific verbs, some of these elements may convey multiple interpretations according to differences of scope. ${ }^{19}$

\section{Adverbial adjectives and secondary predicates}

As stated above, adverbial adjectives may be directed to different portions of the sub-lexical structure of the predicate but they cannot be attributed to the subject. In this section we shall briefly discuss the behaviour of a restricted group of adverbial adjectives which can alternate with secondary predicates displaying productive gender and number agreement with the formal subject. ${ }^{20}$ Significantly, when both options are possible in the same context, speakers of Spanish identify subtle changes in meaning for each form. Consider the examples in (77).

(77) a. (Sp.)

La anciana camina rect-o.

Adverbial adjective

The old woman walks straight-MSG

'The old woman walks straight.'

b. La anciana camina rect-a.

Secondary predicate

The old woman walks erect-FsG

'The old woman walks erect.'

Notice that, whereas the masculine singular default form rect-o in (77a) is predicated of the shape of the path which can be deduced from the activity verb caminar, the secondary predicate rect- $a$ in $(77 b)$ expresses a quality attributed to the subject the old woman. ${ }^{21}$

19. This is particularly the case of elative adverbial adjectives (Sp. sensacional 'sensational', estupendo 'wonderful', horroroso 'horrific', among many others) and adverbial adjectives expressing (ine)quality, which are supposed to be lexical comparatives (Sp. igual '(a)like', parecido 'alike', distinto 'differently', diferente 'differently', among others). The structural conditions determining the adverbial use of both types of adjectives deserve further investigation.

20. In such cases, the adjectival base must be lexically compatible with both the subject and the predicate.

21. The same contrast is also found in the Italian forms dritt-o /dritt-a (Laura Brugè p.c.). 
Similar considerations apply to the contrasts in (78).

(78) a. (Sp.)

Lola camina rápid-o.

Adverbial adjective

Lola walks quick-MsG

'Lola walks quickly'.

b. Lola camina rápid-a

Secondary predicate

Lola walks quick-FSG

Lola walks prompt/efficient

'Lola is a quick walker.'

As Antrim (1994) and Ledgeway (2011:39-40) observe, some Italian Southern dialects show exactly the same alternation as the Spanish examples in (78). According to Ledgeway (2011), the distribution between agreeing and non-agreeing forms is sensitive to the active/stative split distinction ${ }^{22}$ and, consequently, discriminates between transitive/unergative subjects and unaccusative subjects. Similarly, in (78a), where the adjective fails to agree with the subject, the verbal head camina 'walks' behaves as an unergative predicate performed by an agent, while in (78b), it is interpreted as an unaccusative predicate expressing a quality/property ('to be a quick walker') that holds for an undergoer subject.

As expected, only the unergative verb + adverbial adjective is compatible with an imperative sentence which require an agentive subject (79).

(79) a. (Sp.)

Lola, camina rápid-o!

Lola, walk-IMP-2sG quick-MSG

'Lola, walk quickly!'

b. *Lola, camina rápid-a!

Lola, walk-IMP-2sG quick-FSG

'Lola, walk quickly!'

(i) a. (It.)

Laura cammina dritt-o.

Adjectival Adverb

Laura walks straight-MSG

'Laura walks straight.'

b. Laura cammina dritt-a.

Secondary Predicate

Laura walks erect-FSG

'Laura walks erect.'

22. The fact that some intransitive verbs may allow both unergative and unaccusative readings has been observed by Burzio (1986: 122-126), Sorace (2000), Bentley (2006:230-242), among many others. 
Likewise, the secondary predicate rápida 'quick' is excluded in (80b) because obligation verbs such as obligar 'to oblige', forzar 'to force', and persuadir 'to persuade' select an agentive event as internal argument. ${ }^{23}$

(80) a. (Sp.)

He obligado a caminar rápid-o a Lola.

Obliged to walk-INF quick-MSG to Lola

'(I) obliged Lola to walk quickly'.

b. ${ }^{\star}$ He obligado a caminar rápid-a a Lola.

Obliged to walk-INF quick-FSG to Lola

'(I) obliged Lola to walk quickly'.

A similar contrast is obtained by adding a subordinate clause of purpose to (81a) and $(81 \mathrm{~b})$ because this type of subordinates requires an agent in the matrix clause that could be the controller of the empty subject of the infinitive.

(81) a. (Sp.)

Lola caminó rápid-o para llegar a su casa temprano.

Lola walked quick-MSG to get to her home early

'Lola walked quickly to get to her home early'.

b. *Lola caminó rápid-a para llegar a su casa temprano.

Lola walked quick-FSG to get to her home early

'Lola walked quickly to get to her home early'.

In contrast with examples such as (77) and (78), where the alternation between adverbial adjectives and secondary predicates conveys different interpretive and structural properties, there are no significant differences between the two options when these elements are directed either to an unaccusative subject (e.g. sensorial perception verbs) as in (82) to (83), or the internal argument of a transitive verb (84)-(85).

(82) a. (Sp.)

Esta cerveza sabe rar-o.

This beer-FSG tastes strange-MSG

'This beer tastes strange.'

b. Esta cerveza sabe rar-a.

(less frequent)

This beer-FSG tastes strange-FSG

'This beer tastes strange.'

23. See Bosque \& Gutiérrez-Rexach (2009: \$ 5.6.2.2). 
(83) a. (Sp.)

Esta colonia huele divin-o.

This cologne-FsG smells divine-MsG

'This cologne smells divine.'

b. Esta colonia huele divin-a.

(less frequent)

This cologne-FSG smells divine-MSG

'This cologne smells divine.'

(84) a. (Sp.)

Pica muy fin-o la ceboll-a ${ }^{24}$

Chop very fine-MSG the onion-FMs

'(S)he finely chops the onion.'

b. Pica muy fin-a la cebolla

Chop very fine-FsG the onion-FMs

'(S)he finely chops the onion.'

(85) a. (Sp.)

Vende barat-o la fruta.

Sells cheap-MSG the fruit-FSG

'(S)he sells the fruit cheap.'

b. Vende barat-a la fruta.

Sells cheap-FSG the fruit-FSG

'(S)he sells the fruit cheap.'

24. Nevertheless, notice that the precedence of the nominal controller over the adjective, as in (i) and (ii), increases the probability of agreement, cf. (84) and (85).

(i) a. (Sp.)

?Picó la ceboll-a muy fin-o

Chopped the onion-FMs very fine-MSG

'(S)he chopped the onion very fine.'

b. Picó la ceboll-a muy fin-a

Chopped the onion-FMs very fine-FSG

'(S)he chopped the onion very fine.'

(ii) a. (Sp.)

?? una ceboll-a picad-a muy fin-o

an onion-FMs chopped-FMs very fine-MSG

'a finely chopped onion'

b. una ceboll-a picad-a muy fin-a

an onion-FMs chopped-Fms very fine-FSG

'a finely chopped onion' 
In sum, although the mentioned alternation between adverbial adjectives and secondary predicates is not always clear-cut, we can see that the distribution of agreement is sensitive to the distinction between external agentive subjects (unergatives/transitives) and derived subjects generated as internal arguments of unaccusative verbs.

\section{Conclusion}

In this paper several arguments have been provided to support the claim that adverbial adjectives should not be analysed as adverbs despite they lack productive agreement and that they can alternate with ment(e) adverbs in many contexts. Indeed, their apparent adverbial behavior must be seen as a collateral effect of the fact that they are outside of the scope of a noun with which to check their agreement features. It has also been shown that adverbial adjectives may lexicalize four types of modification according to the different portions of the lexical conceptual structure in which the event predicate is decomposed. Finally, it has been argued that the alternation between agreeing and non agreeing forms in the same context discriminates between transitive/unergative subjects and unaccusative subjects.

\section{Acknowledgements}

This article has been partially funded by the projects FFI2011-29440-C03-02 and 2014SGR1013. I would like to express my deepest gratitude to Ángela Di Tullio with whom I have studied the structural and interpretive properties of adverbial adjectives in previous works. I am also very grateful to Laura Brugè, Anna Maria Corredor and Ana Maria Martins, for their help with Italian, French and Portuguese examples respectively. Finally, special thanks must go to Laura Brugè who read the first draft of this article and made useful observations to it and to Marina Kolykhalova who corrected the English version. Needless to say, all the usual disclaimers apply.

\section{References}

Abeillé, Anne \& Godard, Danielle. 2003. The syntax of French adverbs without functional projections. In Current Studies in Comparative Romance Linguistics, Martine Coene, Gretel De Cuyper \& Yves d'Hulst (eds), 1-42. Antwerpen: University of Antwerpen

Abeillé, Anne \& Godard, Danielle. 2004. Les adjectifs invariables comme complements légers en français. In L'adjectif en français et à travers les langues, Jacques François (ed), 209-224. Caen: PUC.

Alcina, Juan \& Blecua, José Manuel. 1975. Gramática Española. Madrid: Ariel. 
Antrim, Nanacy M. 1994. Italian adverbial agreement. In Issues and theory in Romance linguistics: Selected papers from the Linguistic Symposium on Romance languages XXIII, Michael L. Mazzola (ed.), 129-140. Washington DC: Georgetown University Press.

Baker, Mark. 1988. Incorporation. A Theory of Grammatical Function Changing. Chicago Il: University of Chicago Press.

Baron, Naomi S. 1971. On defining 'cognate object'. Glossa 5: 71-98.

Bartra, Anna \& Suñer, Avel-lina. 1997. Inert agreement projections and the syntax of bare adjectives. Probus 9(1): 1-32. doi:10.1515/prbs.1997.9.1.1

Bentley, Delia. 2006. Split Intransitivity in Italian. Berlin: Mouton. doi:10.1515/9783110896053

Bertinetto, Pier Marco. 1986. Tempo aspetto e azione nel verbo italiano. Il Sistema dell'indicativo. Firenze: L’Accademia della Crusca.

Bierwish, Manfred. 1989. The semantics of gradation. In Dimensional adjectives, Manfred Bierwish \& Ewald Lang (eds), 71-261. Berlin: Springer. doi:10.1007/978-3-642-74351-1_3

Bosque, Ignacio. 1989. Las categorías gramaticales. Madrid: Síntesis.

Bosque, Ignacio \& Masullo, Pascual José. 1998. On verbal quantification in Spanish. In Studies on the syntax of Central Romance languages, Olga Fullana \& Francesc Roca (eds), 9-63. Girona: Servei de Publicacions.

Bosque, Ignacio \& Gutiérrez-Rexach, Javier. 2009. Fundamentos de sintaxis formal. Madrid: Akal. Burzio, Luigi. 1986. Italian Syntax: A Government and Binding Approach. Dordrecht: Reidel. doi:10.1007/978-94-009-4522-7

Cinque, Guglielmo. 1999. Adverbs and Functional Heads. A Cross-Linguistic Perspective. Oxford: OUP.

Company, Concepción. 2012. Condicionamientos textuales en la evolución de los adverbios en -mente. Revista de Filología Española 92: 9-42. doi:10.3989/rfe.2012.v92.11.235

Company, Concepción. 2014. Adverbios en -mente. In Sintaxis histórica de la lengua española. Tercera parte: Adverbios, preposiciones y conjunciones. Relaciones interoracionales, Concepción Company (ed.), 459-614. México: Fondo de Cultura Económica \& Universidad Nacional Autónoma de México.

Davidson, Donald. 1967. The logical form of action sentences. In Essays on Action and Events, 2nd edn, Donald Davidson (ed.), 105-121. Oxford: Clarendon Press.

doi:10.1093/0199246270.003.0006

De Miguel, Elena \& Fernández Lagunilla, Marina. 2000. El operador aspectual se. Revista Española de Lingüística 30(1): 13-43.

Demonte, Violeta. 1999. El adjetivo. Clases y usos. La posición del adjetivo en el sintagma nominal. In Gramática descriptiva de la lengua española, Vol. 1, Chapter 3, Violeta Demonte \& Ignacio Bosque (eds), 129-216. Madrid: Espasa Calpe.

Di Tullio, Ángela \& Suñer, Avel-lina. 2001. Los adjetivos desnudos y la cuantificación verbal, XI Coloquio de Gramática Generativa, Zaragoza. Ms.

Di Tullio, Ángela \& Suñer, Avel-lina. 2011. Adjetivos desnudos y sintagmas nominales sin determinación. In 60 problemas de gramática dedicados a Ignacio Bosque, Victoria Escandell, Manuel Leonetti \& Cristina Sánchez (coords), 158-162. Madrid: Akal.

Di Tullio, Ángela \& Suñer, Avel-lina. 2013. Adverbios cortos, adjetivos desnudos y SN neutros escuetos: Una amplia zona de indeterminación categorial en las lenguas románicas. 27 Congrès International de Linguistique et Philologie Romanes, Nancy. Ms.

Doetjes, Jenny. 1997. Quantifiers and selection. On the distribution of quantifying expressions in French, Dutch and English. PhD dissertation. Universiteit Leiden. 
Doetjes, Jenny. 2004. Adverbs and quantification: Degrees versus frequency. Lingua 117(4): 685-720. doi:10.1016/j.lingua.2006.04.003

Dowty, David. 1991. Thematic proto-roles and argument selection. Language 67: 547-619. doi:10.1353/lan.1991.0021

Grevisse, Maurice. 2008. Le bon usage, 14th edn. Bruxelles: De Boeck/Duculot.

Hale, Ken \& Keyser, Samuel J. 1993. On the syntax of argument structure. Lexicon Working Papers. Cambridge MA: The MIT Press.

Hale, Ken \& Keyser, Samuel J. 1997. On the complex nature of simple predicators. In Complex Predicates, Alex Alsina, Joan Bresnan \& Peter Sells (eds), 29-65. Stanford CA: CSLI.

Hale, K. \& Keyser, S. Jay. 2002. Prolegomenon to a Theory of Argument Structure. Cambridge MA: The MIT Press.

Higginbotham, James. 1985. On semantics. Linguistic Inquiry 16(4): 547-593.

Hummel, Martin. 2012. Polifuncionalidad, polisemia y estrategia retórica. Los signos discursivos con base atributiva entre oralidad y escritura. Berlin: De Gruyter. doi:10.1515/9783110281248

Hummel, Martin. 2014a. The adjective-adverb interface in Romance and English. In Adjectives in Germanic and Romance [Linguistik Aktuell/Linguistics Today 212], Petra Sleeman, Freek van de Velde \& Harry Perridon (eds), 35-71. Amsterdam: John Benjamins.

doi:10.1075/la.212.02hum

Hummel, Martin. 2014b. Los adjetivos adverbiales. In Sintaxis histórica de la lengua española. Tercera parte: Adverbios, preposiciones y conjunciones. Relaciones interoracionales, Concepción Company (ed.), 615-733. México: Fondo de Cultura Económica \& Universidad Nacional Autónoma de México.

Jones, Michael Allen. 1988. Cognate objects and the case filter. Journal of Linguistics 24: 89-110. doi:10.1017/So022226700011579

Kennedy, Christopher D. 1999. Projecting the Adjective: The Syntax and Semantics of Gradability. New York NY: Garland.

Krifka, Manfred. 1992. Thematic relations as links between nominal reference and temporal constitution. In Lexical Matters, Ivan A. Sag \& Anna Szabolcsy (eds), 29-53. Standford CA: CSLI.

Ledgeway, Adam. 2011. Adverb agreement and split intransitivity. Evidence from Southern Italy. Archivio glottologico italiano 96: 31-66.

Luján, Marta. 1980. Sintaxis y semántica del adjetivo. Madrid: Cátedra.

Massam, Diane. 1990. Cognate objects as thematic objects. Canadian Journal of Linguistics 35(2): $161-190$.

Mateu, Jaume. 2002. Argument structure. Relational construal at the syntax-semantics interface. $\mathrm{PhD}$ dissertation, Universitat Autònoma de Barcelona.

Mateu, Jaume. 2014. Structure of the verb phrase. In The Handbook of Spanish linguistics, José Ignacio Hualde, Antxon Olarrea \& Erin O’Rourke (eds), 333-353. Malden MA: Wiley \& Sons.

Mendikoetxea, Amaia. 2009. Modelos formales. In Panorama de la lexicología, Elena de Miguel (ed.), 301-336. Barcelona: Ariel.

Migliorini, Bruno. 1952. Il tipo sintattico votate socialista. Lingua Nostra 13(4): 113-118.

Mittwoch, Anita. 1998. Cognate objects as reflections of Davidsonian event arguments. In Events and Grammar, Susan Rothstein (ed.), 309-332. Dordrecht: Kluwer. doi:10.1007/978-94-011-3969-4_13

Nakajima, Heizo. 2006. Adverbial cognate objects. Linguistic Inquiry 37(4): 674-684. doi:10.1162/ling.2006.37.4.674

Noailly, Michèle. 1994. L'adjectif adverbial. Cahiers de Grammaire 19: 103-121. 
Parsons, Terence. 1990. Events in the Semantics of English. Cambridge MA: The MIT Press.

Pereltsvaig, Asya. 1999a. Two classes of cognate objects. In Proceedings of the WCCFL 17, Kimary

N. Shahin, Susan Blake \& Kim Eun-Sok (eds), 537-551. Stanford CA: CSLI.

Pereltsvaig, Asya. 1999b. Cognate objects in Russian: Is the notion cognate relevant for syntax?

Canadian Journal of Linguistics/Revue Canadienne de Linguistique 44: 267-291.

Pereltsvaig, Asya. 2001. Cognate objects in modern and biblical Hebrew. In Themes and issues in Arabic and Hebrew, Jamal Ouhalla \& Ur Shlonsky (eds), 1-31. Dordrecht: Kluwer.

RAE-ASALE. 2009. Nueva gramática de la lengua española. Madrid: Espasa Calpe.

Ramchand, Gillian C. 2008. Verb Meaning and the Lexicon: A First Phase Syntax. Cambridge:

CUP. doi:10.1017/CBO9780511486319

Real Puigdollers, Cristina. 2008. The nature of cognate objects. ConSOLE 16: 157-178.

REDES, Bosque, Ignacio (ed.). 2004. Diccionario combinatorio del español contemporáneo. Madrid: SM.

Rodríguez Ramalle, Teresa María. 2003. Los objetos cognados como expresión de la manera verbal. Verba 30: 317-340.

Sorace, Antonella. 2000. Gradients in auxiliary selection with intransitive verbs. Language 76: 859-890. doi: $10.2307 / 417202$

Suñer, Avel-lina \& Di Tullio, Ángela. 2014. Bare adjectives as syncretic forms. Borealis 3(1): 23-47. doi: 10.7557/1.3.1.2751

Tenny, Carol Lee. 1987. Grammaticalizing aspect and affectedness. PhD dissertation, MIT.

Tenny, Carol Lee. 1992. The aspectual interface hypothesis. In Lexical matters, Ivan A. Sag \& Anna Szabolcsi (eds), 1-27. Stanford CA: CSLI.

Von Stechow, Arnim. 1995. The different readings of wieder 'again'. A structural account. Journal of Semantics 13(2): 87-138. doi:10.1093/jos/13.2.87

Zubizarreta, María Luisa. 1987. Levels of Representation in the Lexicon and in the Syntax. Dordrecht: Foris. 



\section{Language index}

A

Albanian 213-214, 244

Arielli 59-60, 65, 69-70, 74-75

Aromanian 244

B

Bulgarian 211

C

Calabrian $61,72,173-174$, 176-178, 181, 186-187, 190-197, 199-200, 204

Catalan 1, 3, 9, 21, 26-27, 30, 47-48, 178, 185-188, 190-192, 204, 216-217, 236, 244, 329$330,332,336-339,354$

Catanzarese 49

Corsican 217

Cosentino 50-52, 57, 68-69

D

Danish 18

Dutch 18, 25, 174

E

English $1-6,14,16,18-19,22$, $25,27-28,32-34,39-40$, $66,81-82,84-86,92$, $95,113,174,185,187-188$, 191-192, 204, 228, 235, 241, 248-249, 264, 287

American 91

British 22

Old 18, 34

F

Finnish 187-188, 192

French 4, 16, 21, 23, 26, 28, $30-31,34-37,40,48,54,56$, $58,60,65,82,86,90,92$, 175, 212, 217, 230, 329-330, 332, 336-337

Acadian 21

Louisiana 21, 236
G

Galician 102

German 14, 18, 21, 25, 28, 32-33, $72,174,233$

Germanic 23, 33-34, 200, 244

Greek 174, 187, 211-212, 222, 230

Neo 211, 218

Ancient 19, 244

Old 27

$\mathrm{H}$

Hungarian 211, 218, 230

I

Indo-European $19,21,40$

Italian 2-4, 6-9, 19-23, 26, 28, $30,32,34-35,48-52,55-60$, $66-68,72,74-75,81-82$,

85-88, 90-95, 97-98, 100, 102, 173-176, 180-181, 183-184, 188, 191, 193, 200, 204, 212, 217, 222, 228, 244, $248,265,330-332,336-339$, 356-357, 360

Standard 176,188

see also under Romance

L

Latin $3,6,14,21-23,26-28$, $32-33,175,177,207-210$, 212-213, 216-220, 230, 239, $242,244,248,257,265,312$, 322,330

Neo 248

Classical 19, 22-23, 27-28, $30,33,39,213$

Late 19, 23, 27-28, 30, 207

Vulgar 209-210

Leccese 49, 57

M

Matinese 52,57

Mussomelese $61-65,70,74$
$\mathrm{N}$

Norwegian $\quad 187-188,190$

$P$

Polish 211, 234

Portuguese 1, 3, 9, 26-28, 31-32, $34,36-37,48,175,217,236$, $265,288,330,336,360$

American 19, 21-22, 236 Provençal 236

R

Romance 1-4, 6-7, 13-16, 18-23, 25-27, 30, 32-34, 37-38, 40, 48-51, 55-58, 6o, 65, $67-69,71-76,81-82$, 84-85, 88, 94-95, 102, 174-177, 180, 185, 187-188, 190-192, 200, 207, 210, 213, 216-218, 220, 222, 230-231, 236, 239, 244, 248, 257, 262, 265, 287-288, 290, 306, 312, 329-331

Daco 48

Ibero 265

Italo 20, 173, 176-177, 180-181, 191

Pan 1, 21, 26, 30

Romanian 2-3, 6-7, 21, 25-26, $28,30-32,36-37,49,55,72$, $75,83,88-89,94,100,102$, 174-175, 177, 204, 207-214, 216-222, 227-237, 241-246, 248-251, 265

Russian 211, 244

S

Sardinian 19, 102-104, 175, 177, 216, 236

Serbo-Croatian 211

Sicilian 3, 49, 54, 70, 83, 88-89, 94, 102-103, 175 
Slavic $\quad 6,207,211,217-218,222$, 230, 234

Slavonic

Old Church 244

Sorbian 244

Spanish 3, 4, 7-9, 14, 17-29,

$31-32,35-40,48,52-53$,

$56,60,64,76,81-82,85$,

87-88, 90-92, 94-95,

100-104, 133, 175, 190, 204,

$216-217,228,236,244,248$,

257-259, 262, 265-266,
268, 271, 275, 281, 283, 287-288, 292, 305-307, 311-312, 329-359

American 9, 19, 21-22, 37, 102, 105, 236, 264, 266, 307

Argentinian 9

Chilean 24-25, 39

European 9, 266

Medieval 271

Mexican 8-9, 87, 260, 264, 287-288, 291, 307, 309

Old $16,30-32,37,64-65,102$
Peninsular 307-309

Rioplatense 9, 90,342-344, 355

Swedish 18,28

T

Thracian 213, 244

Dacian 213

Turkish 211-213, 218, 222, 230, 243, 245 


\section{Subject index}

\section{A}

ablative $14,242,257,265$

see also case

absolutive $\quad 65,193$

see also case

acceptability $31,59,137,191$

see also grammaticality

accusative $22,55-56,60,209,214-216,221,238$, $244,257,263,265,312$

un 50-51, 53-57, 59, 61, 70, 73-75, 173, 176, $178,182,185-188,192-193,199-200,357-358$, 360

see also case

action $179-180,182-184,186-187,189,192,196$, $215,279,331,339,342$

$\sim /$ event 185

see also under event

active $56,60,65$

/stative $50-52,54-58,60-61,65,68,74-76$, $193,195,357$

see also stative

actor $68,187,193$

ragent 184

see also under agency

adjacency 232, 270, 272-274, 292, 296, 301, 338, 343

non- 272-274

adjunct $2,5,20,117-118,123,126-128,130,137,231$, 236-237, 239, 292, 295-296, 301-302, 332, 336, $342,344,348$

affixation $\quad 8,207,213,245,247-248,264-265,287$, 322

inflection 249

derivation 249, 264

see also prefixation, suffixation; see also under order

agency $34,55-56,66,117,124-125,180,183-184$, $193,195,200,216,342,354,357-358,360$ /actor 50, 55, 61, 65-66, 69, 76, 176, 195 see also under actor, orientation agreement $3-7,9,13-16,22,32,34,37-38,40$, $47-61,63-66,68-76,116-118,125-128$,
$131-133,136-137,143,149,151,153-154,160$, $162,164-167,173-200,204,227,229,232-235$, 237-240, 244, 250-251, 306, 312, 322, 330, 333 , $336,343,346-347,349,356-357,359-360$ dis 264

non- $\quad 9,51,55,57,69,114,126,129,133,150$,

$158,178,186-187,190,196,227,237,239,241$,

250-251, 264, 266, 329, 333, 347, 357, 360 see also concordance

allomorphy $173-175,216$ see also alternation

alternation $9,67,82,123,181,329,356-358,360$ see also allomorphy

ambiguity $14,23-24,26,52,54,179,181,184,232$, $263,267,280,298-301,334,352,354$

dis 14, 24, 26, 179, 181, 184, 298

analogy $31,213,217,219,312$

analysis $20,30-31,39,157,215$

see also synthesis

anaphora $96-97,99,126,229,277,346-347,354$

antecedent $96-98,105-106,229,346$

argument $9,14-15,18,34,50-52,56,59,61,65-66$, $68-70,72-76,98,103,106,118,125,128,173,175$, 179-181, 190, 192-193, 195, 199, 237-238, 274, 279, 292, 295-296, 301-302, 329, 332-334, 399-343, $346-355,358,360$

article 148

definite $116-117,234,236,322$

indefinite $114,116-118,125-127,129-133$

aspect $64,124,195,241,249,264,340,342,345$, $351-352$

attenuation 292-294

attestation $20,39,52,76,102,143,177,209,241$, $245-246,265-268,271,287$

attitude $1,14,38,95-96,104,257,290,318,320$ see also point of view

attribution $1-2,16-21,32,39-40,47-48,50-51$, $81-82,126,143,145,148,150,152,160,175$, 179-180, 191, 238, 266-267, 280, 297-299, 306, 333 see also under modification 
B

base $69-71,75-76,82,196$

lexical 28, 30-31, 41, 207, 214-216, 230-231,

$243-245,250,305-306,311,322-323,330,356$

binding 264, 270, 276-280, 336

borrowing 40, 207-208, 210-213, 216-218, 221-

223, 230-231, 248

see also loan

boundedness 276

C

canonicality $1,26,55,67,70,83,87,104-105$,

$117-118,183,188-190$

case $33-34,188,229,235,244,247,265$

see also ablative, absolutive, accusative, nominative

category $1-3,5-7,13,15,17-18,25,47,67,74,84$, 91-92, 100, 102-103, 113, 115-117, 119, 137, 143, $147,174,176-178,180-181,209,228,230,232$, 234-235, 239-240, 242, 245-246, 249-251, 257-258, 262-263, 269-270, 274-276, 291, $298,311,330,333,349$

bi $\quad 47-48,50,52,67,76$

cross- 178

mono 25-26, 47-49, 52, 242, 250, 298

re $257,264-267,270$

sub 14, 16-17, 32, 333

see also transposition, word-class

circumstance $15-17,40,323$

clause $2-4,49,66,68-69,72,81,83,87,92,97-99$, $101-104,117,123-125,128,143-146,151-152$, 173-174, 185, 188-189, 194-196 229, 290, 292, 295-296, 298-302, 320-321, 334, 350, 358

bi 90-93, 95, 104-105

mono 87, 91-92, 94

see also under root

clitic $49,56-57,59,69-70,74-75,194,232,272,354$ see also under pronoun

cognate $63,348-350,353,355$

cohesion 257, 263, 270, 273, 283, 332-333

collocation 130, 263, 292

colloquial $37,48,86,100,233$

see also informal, register

command

C- 20, 198

see also construction

communication 19, 21, 26, 40, 215, 271, 290,

293-294, 301

commutation 129,149

comparative $22,123,129,240,248,312,338,356$

see also degree, gradation, superlative competition $18-19,85,218,287,302$

complementarity $86,88,242,265-266,268,270$, 284

see also under distribution

complementation $4-5,31,50,52,63,68,72,75,98$, 101-102, 105, 116-120, 122-123, 125, 128-130, $137,143,145,148,150-152,154,160-161,174$, $185,237,239,262,279$

see also complementizer, valency

complementizer $4,81-84,87-88,91-93,96,98$, 100-106, 116-117

see also complementation; see also under phrase complexity $195,257,270,279-281,283$

composition 14, 33, 83, 104, 191, 208, 314

de $9,329,332,334$

non- 311,314

compound $6,32,122,134,193,200,208-210,240$, 264,283

concordance $152-153,157,160-161,194,200,219$, 297,300

see also agreement

conjunction $59,75,116,120,290$

connector 20, 145

construction

C- 4, 83-99, 102-106

S- 83, 86-90, 92, 94-95, 97, 104

context $8,13,18-20,48,50,89,93,95-97,130,153$, $161,175,191,228,232,234,236-241,243,246-247$, 250, 257-259, 264-271, 276-279, 281, 283, 288,

291, 293-294, 298-299, 307, 314, 317-321, 323-324, $346-347,350,356,360$

control $47,49-51,53,60,66,69,73-75,186,229$, 260-261, 294, 330, 358-359

conversion $13-14,19,31,34,126,208,217-218,228$, 231-232, 235-237, 239-240, 301

see also zero under derivation

coordination 14, 116, 118, 281, 283, 350

culture $27,38,40,48,151,212,218,294$

inter 28

Western 19, 26, 215

D

declension $22,27,312$

degree 114, 116, 119, 124-125, 130, 132, 136, 233-234, 248,338

see also comparative, gradation, intensification, superlative

deixis 101, 209-210, 316-318

derivation $6-7,13-14,18,32-33,63,68-70,81-85$, $113,122,174-175,207-208,210,212-216$, 
227-228, 230-231, 234-237, 241-250, 262, 264, $287,320,331$

zero- 232, 236, 239

see also conversion; see also under affixation

determination $36,116-117,127,144-168,312$

pre 117, 131

see also specification; see also under phrase

diachrony $3,6-8,14,19,21,23,26-28,31,33-34$,

$37-41,48,52,76,105,136,177,207-208,257$,

262, 265-271, 274-275, 279-281, 283, 305-307,

$311-312,315,320,322,324,330$

see also history, synchrony

dialect $3,6-7,19,22,28,34-35,48-50,55-56$,

$58-59,61,64,69-70,72-76,173-177,179$,

181-187, 190-200, 204, 210, 216, 236, 258-259,

262, 264-266, 357

see also variety

diamesic $48,76,85$

diastratic 48

diatopic $48,52,76$

dimension 331, 335-336, 338, 347, 353

diminutive $17,248-249,322,338$

see also evaluative

direction 30, 316-317, 323

see also locative, space

discourse $15,17,20,24-25,27-28,32,39-40,87$

$90,93,95-96,98,104,259,263,271,288-289$, 291, 346

marker $15,20,24-25,38,102,259,263,265,301$ dislocation

left- 241

see also distribution, mobility, position, order

distribution $7-8,15-18,23-24,47-48,51,53$,

$55-58,60,65,72,76,81,84,88-90,104,120$,

$133,174,204,227-228,234-235,239-241,247$,

$250-251,259,263,266,270-271,274,283,287$,

291, 309, 330, 333, 335, 352, 357, 360

complementary $82,87,246-247,302,339,343$ see also dislocation, mobility, position, order

domain $16-19,26,28,33,39,66,70,74-75,92-93$, $96,106,124,195,198,241,243,246,289,318,333$, 336,352

duration $64,124,234,334,342,344-345,351,356$ see also frequentative, time

E

educated $13,15,19,27-28,39,222-223,283,292$ see also colloquial, informal, register

ellipsis 99, 152-153, 161, 312, 317

emphasis $52,96-97,99,104,283,289,318-320$

entailment $174,179,189-190$

ergativity $47,61,65,70,74-76,193$ un $50-51,54-55,61,63-64,70,73,176,182$, $186-188,193-195,199-200,335-337,357,360$

etymology $27,30,234,242,266,269,316,320$ evaluative $9,82,93,124,243,247,249,318,324$

see also diminutive; see also under modality

event $1-2,7-9,14,51-52,66,68-71,101,131,174$, $178-182,186,189-192,195-196,233-234$, 238-239, 241, 250-251, 257, 270, 277, 279-281, $283,323,329,334,339-341,343,345,354-355$, 358,360

/action 200

see also eventive; see also under action, orientation

eventive $51,63-64,68,70,196,333-334,341-343$, $352,354-355$

see also event; see also under resultative evidentiality $82-84,91,93,95-96,98-99,101-102$, 104-106, 271

exclamative 91,96

expansion $\quad 23,27,29,38-40,178,320$

exponence $178,181,183,186,193$

extraction 263,332

F

focus $38,89,99,184,230,263,270,280,283$, 287-290, 292, 294-297, 299, 301-302, 332 frequency $4,8,20,24,27,29,32,38,48,85-86$, $124,148,219,236-237,241,264,266,270,272$, 276, 279-280, 283, 287, 292, 294, 296, 300$301,308-310,313,315,320,322,358-359$ see also token, type

frequentative 343

see also duration, time

\section{G}

gender $2,5-6,25,113-116,125-127,131-132,137$, 156-157, 160, 175, 194, 197, 199-200, 227, 229, $235,237,239,244,249,300,312,333,336,343$, $346,349,356$

feminine $14,23-24,37,49-59,61-62,64$, $67-69,73,114,116,121,124,126-136,165$, $167,173-174,176,178-180,182-186,189-194$, 196-198, 209, 215-216, 229, 231-235, 238-241, 243-244, 246-248, 250, 297, 300, 312, 317, 330, $337,346-347,350-352,356-359$

masculine $14,23,37,47-55,57-58,61-65$, $67-70,73,114,116-136,149,151,153,162$, $166,173-176,178-180,182-184,186,192-194$, 196-198, 209, 217, 228-229, 232-233, 235-244, 246-247, 250, 300, 329-331, 334, 336, 339-341, 343-359 
neuter 18, 22-23, 34, 190, 228-229, 233-234, $238,240,242-244,246,257,312,346,349-350$, 353,355

generative 4,81

genetic $5,144,147,168$

goal 117, 198-199

gradation 261,347

see also comparative, degree, intensification, superlative

grammaticality $26,177,191,264$

un 64, 177

see also acceptability

grammaticalization $4-5,9,28,33,81,83-84$, 90-92, 94, 99-100, 104-106, 233, 265, 305, $307,323-325$

semi- 100, 104-106

grammaticography 3,37

$\mathrm{H}$

head $17,70-72,74,92,98-100,117-118,123-124$, $126-127,199,235,243,302,312,333-334,336$, $341,343,357$

see also under phrase

hearsay 100, 104

heuristic $1,13,16,33$

hierarchy $9,20,71-75,145,329,333,352$

history $19,23,27,48,175,207,265,283,306,308-$ $309,311-312,324$

see also diachrony

homonymy $114,131,227-229,232-237,239,241-$ 242, 244, 249-251

see also homophony

homophony 134

see also homonymy

hyponymy 349

\section{I}

idiomatic 230-231, 246

illocutionary 92

imperative 279,357

impersonal $88,91-93,95,102,116,159,279$ see also person

incidence $144,146-147,150,161,167$

external $144,148,150,168$

internal 144

incorporation $\quad 63,334-336,338,348,353$

infinitive $5,113,115,120,122-123,125,128,133-134$, $136-137,146,240,358$

inflection $2,4-5,7,13-16,24,32-34,37-39,52-53$, $103,113,119,132-133,136,143,207,227-229$, $233,235,242,245,247-250,262,350$

see also under affixation informal $14,21-22,24,26,29,31-32,34,39-40$, $85-86,115,135-136,236,288$

semi- 24

see also colloquial, register

information structure 184,287

inherent $334-335,337-338,340,343,353-356$

instrument $15,33-34,342$

intensification $25,28,37,188,232-233,248$, 292-294, 322

see also degree, intensification

interface $1-3,5,7-8,13-16,18,20,26-27,31-32$, $39-41,175,260,271,288,291,298-301,306$

interrogative 85,321

wh- 101

isogloss 175

iteration $234,341-343,354$

J

juxtaposition $\quad 281,283$

L

Lausberg Area 6, 173, 177, 183, 185, 190-192, 195-197, 199

layer $75,92,334$

lexicalization $21,23,28,32,63,66,71,86,88$, $149-151,153,157,159,162,164-167,175,263,272$, $346,349,360$

lexicography 216

linguistic $1-2,14-15,17,21,25-26,32-33,37-41,71$, $96,161,177,208,210,269,271,273,288,291$, $302,311-312,317,319,324$

cross- $\quad 3,9,16,19-20,25,33,83,174,178,192$, 204

geo- 177

extra- 6,17

meta- 3,34

socio- $\quad 260,262,265,283,287$

literacy $24,27,48,85,266,283$

see also under orality

locative $116,122,236,241,316-318,341-342$ see also direction, space

loan $23,28,39-40$ see also borrowing

locution $8-9,31,305-309,311-316,318-324$

M

markedness 4, 8, 13-14, 18-19, 23, 25-27, 32-33, $40,55,67,72,74,84,92,98-99,101,153,156-157$, $161,175,178,181-182,184,188,196,198,213-215$, 229, 232, 234-235, 237, 270-271, 275, 277, 281, 284, 288-289, 312 
marker 15, 20, 24-25, 38, 101-102, 118, 233, 235, $248,259,263,265,289,301,312$

see also under discourse

metaphony $173,181-182$

see also under participle

minimalist 18,105

mobility 103-104

see also dislocation, distribution, position, order

modality $82,95,124,210,215,258,305-307$,

\begin{tabular}{|c|c|}
\hline & \\
\hline valuative & 243,249 \\
\hline sive & 319 \\
\hline
\end{tabular}

epistemic $14,82-84,87,89,91,93-95,98,100$, $102,104,106,265,319$

modification $1-2,4,6,9,13-17,20-28,33-34$, $36-40,50,66,70,75,81,84,87,90-92,94$, $98-99,114,124-128,131-137,154,158-159$, $165,167,174-181,183-184,186-193,195-196$, 199-200, 227-228, 231, 233-235, 238-241, 246, 250-251, 263, 276-277, 279, 297-300, 311, $313,329,333,335,337-338,341-345,347-348$, $353-355,360$

attributive $16-21,32,39-40,238$

predicative 16

quaternary 20

secondary 20

tertiary 20, 21, 35, 333

see also predication; see also under noun

$\operatorname{mood} 145,195$

subjunctive 91

morpheme $14,19,22,32-33,37,176,247-248$

morphology $1-4,7-8,13-19,23-24,26,32,34$, $39-40,81,83-85,90-91,103-104,115,144$, $173-175,177-178,180-183,189-190,192-193$, $196,198-200,216,228-229,234,237,240,244$, 250-251, 264-265, 271, 275, 298, 330, 349

- lexical 173-174, 193-194, 199

$\sim$-phonological 193, 198-199

semantic- 26

syntactic- 19, 26, 31, 71, 81-85, 113, 115, 150, $173-175,177-178,198$

motion 231-232

motivation $15,37,268,283,312,314-315,319$

un 37,314

\section{$\mathrm{N}$}

negation $15,20,40,82,86,90-92,94,116,123-125$, $131,148,150-151,153,157-158,161,163,165,167$, $217,232,319,322$

neologism $\quad 214-216,218,220-222,230,246$ nominalization $31,143,240,246,305-306,313$, $322,336,354$

see also noun

nominative $22,55-56,60,65,235,244,257$

see also case

norm 21, 24, 27-28, 37-40, 132, 175, 227, 250, 308

noun $1,6-7,14-15,18,20,24,31-34,40,47-49$, $60,63,71-72,75,100,116-117,119-120,123$, $125,128,130-131,137,141-145,148,154,156$, $168,173-175,178-179,188,190,192,199-200$, 213-215, 220-221, 227-229, 231, 233-237,

239-246, 248, 250-251, 257, 261, 263, 265, 268, 270, 276-280, 283, 297, 300, 305-306, 312-313, $317,330,334-336,338,346,349,359-360$

ad 142, 177

non- 229

pre 126-127, 179, 235

post 127, 241

bare 126, 233-234

count 350

mass $336,350,353$

modification $16-17,22,37-38,126,131,179$, 227-228, 234-235, 238-241, 246, 250, 337 see also nominalization; see also under phrase number 2, 5-6, 25, 72-74, 113-116, 125-127, 131-132, $137,156-157,160,175,194,197,199-200,227$, 229-230, 235, 237, 239, 244, 249, 333, 336, 343, $346,349-350,356$

plural $23,31,49,51-52,57-64,68-69,72,75$, $89,94,118,123,126-129,132-133,136,166,176$, $188,197,210,219,229,233-234,237-238,241$, $244,248,250,312,322,350$

singular $14,22,47-65,69-70,73,82-83,85-89$, 91-98, 100-103, 114, 116-136, 149, 151, 153, 162, $165,167,173-175,178-186,188-194,196-198$, 209-211, 214-216, 218, 220-221, 228-244, 246-248, 276, 307, 312, 329-331, 334, 336, $339-341,343-344,346-359$

$\mathrm{O}$

object $47,49-51,54-57,59-61,63-64,66,68-71$, $73-75,117-118,128,133,143-145,150-152$, $154,180,182-185,187,189-192,194-197,199$, 237-240, 243, 263, 274, 290, 296-297, 317, 332, $338-339,347-353,355$

internal $155-158$ see also under orientation onomasiology 27 operator $\quad 5,287-290,292,294-297,299,301-302$, 352 
orality $13,15,19,21-25,27-28,31,38-39,48,85-86$, $175,218,236,259,266-267,283,288,291$, 300-301

- -literacy 24,27

see also speech

order $68,83,93,184,196,241,257,263,270,274-$ $275,283,291,316,318,333,352$

affix- 245, 248

see also distribution, dislocation, mobility,

position

orientation $3,5-6,65,71,183,316$

agent- 124-125

event- 2, 7, 66, 69, 71, 195, 279-280

object- 51-52, 179-180, 183, 317

participant- 2, 7, 51

process- 66, 195

speaker- 81, 88, 93, 99, 104

subject- 14, 38, 51, 63-64, 66, 71, 179-180, 183 , $195,197,276,278-280$

orthography $83,105,132,298$

\section{$\mathbf{P}$}

paradigm $25,177,245-246$

parameter $47,49,51,66,71-73,75,200,338$

macro 71-72

meso 72,74

micro 71-72, 74

nano 72,74

paraphrase $13,16,18-19,28,38,156,189,334,346$

parenthesis $38,87,103,228,239,241$

participant $1-2,5,14,96,131,291$

see also under orientation

participle $51,55-59,69,116,125,146,148-151$,

$153,157-158,161,163,165-167,173,181-182$,

193-195, 197-200, 219-220, 231-233, 322

metaphonic 193-194,197-199

non-metaphonic $\quad 193-195,197-199$

passive 116,134

past $51,56-57,113,115-116,120-123,133-137$,

173-174, 176, 181, 193, 197-200

present 116

particle $15,20,82,97,210,213,271,353$

partitive 346,354

past $67,82,89,93-94,101,103,183,189$ see also tense; see also under participle

patient 180,183, 185, 193-194, 199

/ undergoer 192-193

see also undergoer

periphery $16-17,39,91-92,99$

periphrasis $30,272,275-276$ person $57,59,72-75,89,102,116,145,276,279$ see also impersonal

phonetics $28,121,127,181,333$

phonology $132,177,193,198-199,265$

see also under morphology

phrase $2,17,28,30,115,117,145,149-151,153,157$, $159-160,162,164-168,188,231,239,265,281$, 292, 295-296, 299, 301-302, 312, 333, 340

adjective $117,146,148-149,151,153-154,156$, $158-160,162-164,166-168,235$

adverb $117,155,177,208,212,218,220-222,235$, 299, 332

appositional 145

complementizer $\quad 84,88,91-93,96-100,105$

determinative $117,145-154,156,158-164$, 166-168

force $81,92-93,98-99,117$

noun $24,50,63,117-118,121,124-127,129-130$, $133,142,145-146,151,153-154,164,166,168$,

$177,193,250-251,257,265,270,305-306,322$, $336-338,346-347,350$

predicate $81,98-99,146,168$

prepositional $9,17-19,28-29,41,117,121,125$, $132,145,177,235,305,307,313,324-325,342$ pronominal $149,158,163,168$ quantifier $336,340,345-347$ speech act $\quad 81,93-96,99-100,105$ verb 2, 13-14, 20, 23-24, 34, 38, 50, 63, 66, 68-71, 74-75, 82, 87, 98, 114, 117, 125, 128-129, $133,145-150,152-153,161,168,189,195-197$, $199,234-235,263,283,330,333-334,336-338$, $342,352-353$

point of view $14,92,95,99,104,243,249-250$, 266, 293, 317

see also attitude

polyfunctionality $23-25,38,264,269$

polysemy $28,38,264$

position $2,5,9,14,23,25,38,50,56-57,66-71$, $74-75,82,84,87,92-93,99-100,103,117,124$, $126,128-129,131-132,148-151,153-161,163$, $165-168,176-179,184,195-197,227,228,232$, 238-241, 243, 247, 270, 274-275, 288-292, 296-297, 299-302, 319, 333, 355

see also dislocation, distribution, mobility, order predication $2,5,16-17,38,40,52,67-68,75,91,93$, $98,102,116,118,128,143-147,150-151,155,168$, $174,178-180,184-186,192,200,233,239,263$, $267,300,330,335$

intra 141-142, 148-154, 157-158, 161, 163 , $165-168$ 
non- 235

primary 145-146

secondary $38,52-53,58,145-146,151,153-156$,

$158-160,162-168,233,238-239,263,300$

see also under modification

prefixation 232

see also affixation

preposition $17,30-31,116-117,119-120,122-123$,

$137,184,210,220-221,233,236,239,241$,

243-244, 271, 305-306, 311, 323-324, 354

non- 177, 184

see also under phrase

productivity $21-22,25,28-29,31,33,39-40,76$,

$82,84,126,173-175,185,192,199-200,216$,

222, 228, 231, 235-237, 242, 244-246, 250, 306,

$330,331,333,336,346-347,349,356,360$

un $25,28,31,231,242,246,248,360$

pronoun $60,72,74,116,131,144-145,149-151$,

$153,157-158,160,162,164-168,229,236,276$,

298-299, 349-350

clitic $56,59,69,74$

see also under phrase

proposition $84,87,93,95-98,101-102,104,106$,

$124,143,146$

extra 263, 271

intra 263, 271

prosody 24, 89, 113,115,120-121, 133, 137, 291

boundary 121-123, 134

prototype $15,17,33,148,231$

Q

qualitative 24-25

quantification $25,37,116,131,261,334-336,341-$ $342,344-346$

see also under phrase

quantitative 234

quotative $81,84,99-102$

R

referential 9, 146, 152-153, 155, 158, 165, 238, 269, $276-277,292,316-317,324,348$

reflexive $59,75,185$

register $3,6,13,15,26,32,41,52,85-86,90,100$,

$121,135-136,222,233,262,265-267,288,298$, 300-301

see also colloquial, educated, informal

resultative $52,63,66-71,75,165,174,179-180$,

182-185, 187-192, 195-196, 199-200, 204, 238

non- 178

pseudo- 6, 173-174, 178, 180, 182, 187-192, 200, 204

r-eventive $68,70,196$ root $63,92,179,190,334$

clause $4,81,92,94,98-99,101-102,104$

rule $22-23,26-27,31,34,37-38,194-195,333$

S

saturation $40,148,155,168$

non- 146, 148, 153,155, 157, 159-162, 168

schema $96,107,323,325$

scope $4,14-15,20,66,70,84,88,98-100,102,104$, $148,151,153,157-158,161,163,165-167,179-183$, $186,189,196,263,266,271,274,279,289,335-$ $336,341,344,347,349,352,354,356,360$

sentence $1,2,4,14,16-17,20,23-24,28,33,38$, $40,63,66,81,83-87,90-92,94-96,99,101-106$, $120,123-124,128,137,144-149,152,156,160-162$, $165,167,178,183-184,186-187,189,195,227,232$, 235, 257, 268-271, 274-281, 283, 298, 302, 319, 333, $352-353,357$

sociolectal 266

space $1,20,30-31,38,210,230,241,316-317,320$, $324,341,344$

see also direction, locative

specification $16-17,69-71,75,92,99,117-118,127$, $129,178,185,188,317,332$

see also determination

speech $25,94,101,141,223,259-260,266-267,283$, 291, 345

act $82,102,106,121,124$

reported 100-101

see also orality; see also under orientation

Sprachausbau 19

standard 5, 19, 21-22, 24-28, 32, 38, 40-41, 47-48, $50,55,63-64,67,74,76,85-90,105,114,174$, $176,183,188,191,193,204,217-218,230,234$, $236-237,246,288$

non- 38, 174, 177, 236, 249-251, 265

sub $25,31,39,88-90$

state $184,188,190,200$

stative $55-56,60,65,76,186,343$

see also under active

style 29, 39-40, 85-86

subject $1,5,9,16,23-24,49-51,53-59,61,63-64$, $66,69-71,73-76,86,88-89,91,93-95,117-$ $118,124-126,128-129,133,136-137,143,146$, $148,152-153,160-161,176,179-180,182-187$, 192-195, 199-200, 229, 238-239, 265, 276-277, $279,290,296-297,305,333,350,356-358,360$ see also under orientation subordination $83,120,125,128,145,189,281$, 298-299, 358

in 83 
suffixation $6-7,14,17-18,26,32-33,84,113-114$, $173-175,192,204,207,210,213-216,222$, 227-228, 230-231, 235-236, 242, 244-246, $248,251,311,322,330,338$

see also affixation

superlative 248,338

see also comparative, degree, gradation

supine $231-233,240,246$

surface $\quad 6,56,70-72,74,116,178,184-185,196,346$ synchrony $3,8,19,31,33,41,76,83,85,104-105$, 230, 258, 262, 266, 269-270, 281, 305-306, 311 see also diachrony

syncretism $14,47,175,180$

synonymy $8,156,287,302$

synthesis 13, 16, 31, 209

see also analysis

\section{$\mathrm{T}$}

telicity $340-341,345,351-352,354$

$a \sim 340,345,351-352,355$

non- 340-341

time $1,20,24,30,31,38-39,64,93-94,233,241$, $263,334,339-345,351,355$

see also duration, frequentative

tense $94,120,145,195,249$

see also past

text $20,22-24,26-27,34,86,208,214,216-219$, $244,259,262,265-267,271,276-277,281,283$, 308, 318-319

co- 146, 155

thesaurus 230-231, 245-246

token $24,307-310,313,315-317,321,323-324$

see also frequency, type

topic $95-97,104,276,279,350$

transitivity $50-51,53-54,56-57,59,61,63,66$, $73-74,116,123,148,155,157,173,176,178-180$, $182,184,187-188,192-195,197,199-200,232$, $237,274,337,339,346,348,357-358,360$

di 116

in $\quad 47,54,61,66,74,76,116,122,148,155,157$,

$161-162,176,182,185,232,237,274,337,357$ non- 182

transposition $16-17,39$

see also category, word-class

type $24,307-310,313,315-316,320,322-324$

see also frequency, token

typology $16,18-20,32,38,47,76,83-84,143$

$\mathrm{U}$

undergoer $34,50,52,55-56,61,65-66,68,74-75$, $187,196,357$

$\sim /$ patient $173,176,187$ theme/ 195

see also under patient

univerbation $14,32,82,84,102$

usage $13-14,17,21-27,31,37,39-40,48,214,223$, 289, 292

utterance $16-17,96,100-102,184,279,290,298$, 324

V

valency $146-151,153,157-167,269$

bi 348

see also complementation

variability $141,227,233,237-239,250$

in $14-15,25,32,34,37-39,114,141,155-156$, $227,234,237-240,250,262,330$

variety $1-4,6,15,19-21,25,32,34,41,47-48$, $50-52,54-58,60-61,63,67-71,74-76,86,88$, 102, 173-177, 180, 184, 187, 191, 200, 211, 216, 230, 236-237, 246, 249, 251, 309

see also dialect

verb $1,5-6,14-15,17-18,20-21,24,27,31,33-34$, $50,63-64,66,68,70-71,82-83,91,98$, $100,102,105,115-120,123,128,130,133-137$, 141-167, 174-175, 177, 179-181, 184, 188-191, 193, 195-200, 215, 219, 227-228, 231-232, 234, 236-239, 241, 243, 246-247, 250, 257, 263-264, 270-274, 276-280, 284, 299, 317, 319, 322, $331-339,341-346,348-349,356-358,360$ pre $56-57,70,117,133,194,272,275$

post 56-57, 70, 117-118, 232-233, 239-241, 250, 275,333

auxiliary $5,51,55,66,72,113,115-116,120-123$, $133-135,137,148-151,153,157-158,161,163$, $165-167,176,272$

copula $90-92,94,98,104,148,160-162,167$, 247,299

light $63,195,335-336,338,348,353$ see also under phrase

vocabulary $29,178,208,210,212,244$

vowel $127,132,176-177,181,197,312,324$

W

weakening $22,48,118,193,269,279-280$ word

〜-class $1,2,13-18,20,25,32-34,38,40,144$, $178,181,236,262-263,283$

-formation 14, 26, 216, 236

see also category, transposition

writing $15,19-20,25,27-28,31,85,215,218,259$, 279, 281, 288 
Within the current discussion on grammatical interfaces, the word-classes of adjective and adverb are of particular interest because they appear to be separated or joined in manifold ways at the level of word-class or syntax, with morphology playing a prominent role, especially in Romance. The volume provides typological and theoretical insights into the common or different usage of adjectives and adverbs in Romance. Diachronic change is discussed alongside with synchronic variation and the representation in grammar. The discussion turns out to be controversial, calling into question traditional assumptions such as the dogma of the invariability and the categorial status of the adverb.

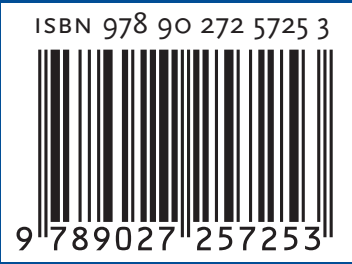

\section{John Benjamins Publishing Company}

